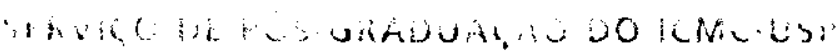

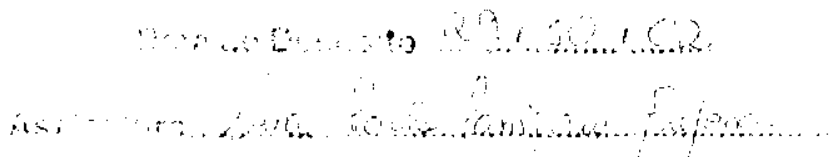

\title{
Modelagem de Ambientes Interativos Conscientes de Contexto: Uma Abordagem Baseada nos Padrões MPEG-4 e MPEG-7
}

Joăo Benedito dos Santos Júnior

Orientador

Prof. Dr. Edson dos Santos Morcira

Te'se aprese'ntada no lnstituto de' Ciencias Mutemáticas e de Computaçäo-ICMC, do Unizersidade' de Sĩo Panlo-USP, como parte dos recurisitos para obtençano do título de. Dontor e'm Ciencins - Área de Ciencins de Computnçio. 


\section{A Comissẫo Julgadora:}

Prof. Dr. Edson dos Santos Moreira

Prof. Dr. Berthier Ribeiro de Araújo Neto

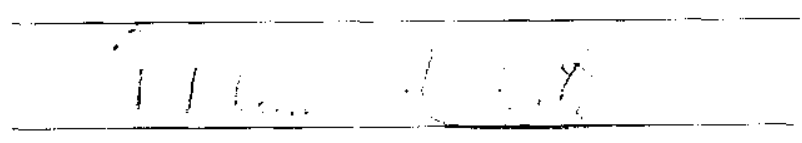

Profa. Dra. Maria da Graça Campos Pimentel

Prof. Dr. Marcelo Knörich Zuffo

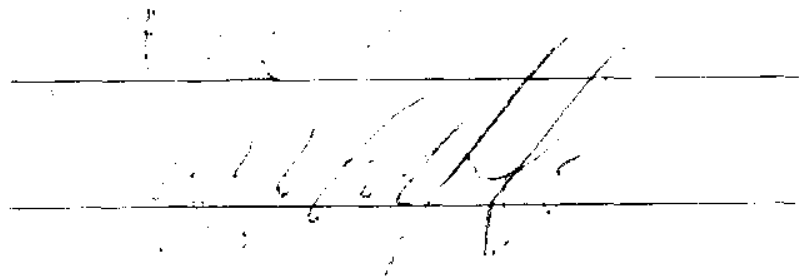

Prof. Dr. Guido Lemos de Souza lilho

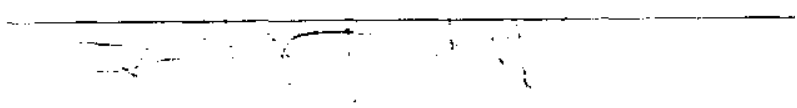




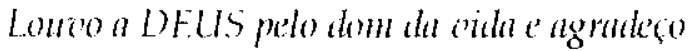
à minlun familio pela cida e'm communhöo com DFUS.

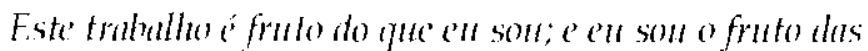
minhas origens e da minha familia.

"Vim para a cidate, tmballete e estudei

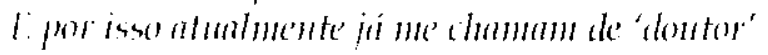

Mass o sotnouth que eu sempre carreguei

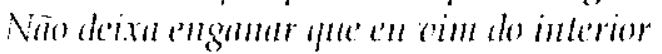

Mas nio faz mal Sou assim, ¿'u son mututo Meu 'océ nōo é fojulo Sai assim no nalurnl

Liphambo folo Metu sotaque e'utão me trui Parn surpresale espanto Se'm queterertl aligo 'tua'

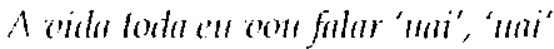
A vida toda en rou falar 'ocê'

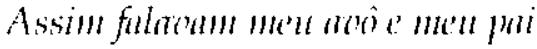
Sol caipim, logro jí se' cê..."

José Forluna e Marcelo Cosla

Dedico este trabullowas meus pis, Jỗo Bencalito dos Sanlos 'Maria de Lourdes Santos,

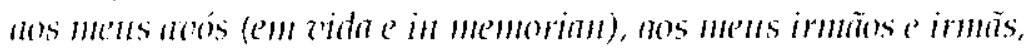
ans mens sobrinhos, especialmente ao Gabriel. 


\section{Agradecimentos}

Ao bom DFUS, por me conceder snide, por iluminar men caminhto e' por me abençon na realizaciono de? toilas as etripas de'ste traballo.

Ao me'u orientador, o Prof. Dr. Edson dos Sanlos MToreira, pelo apoio, pelo incentivo constanle é pela

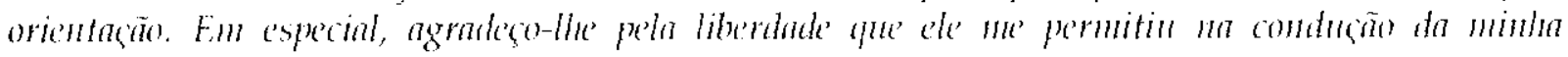
pesquisa e pelos inámeros e renocados cotos de confiança.

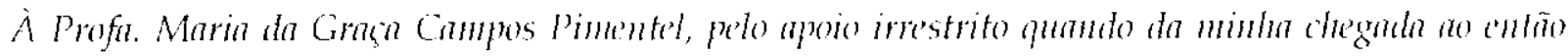
ICMSC-USP', e'm 7996 .

Aos professores lidson dos Sanlos Moreina, Thedy loño Volente, José Carlos Maldonado. Marin Cristina Ferreina de Olizeira, Maria da Grach Campos Pintentel, Sandra Marin Aluisio é Marcos José Santana por compartillarem seus conluecinentos durante o periodo de crédios, tanto no Mestrado quanto no loutorito.

Agradeco aos colegras do Inborntório Intermidia, especialmente ao Inciano Martins e ao leonarto

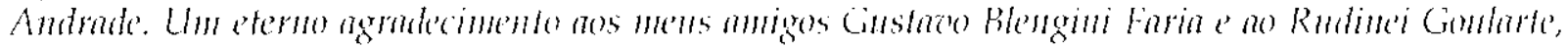
por dividirem comigo todas as responsabilidades, incertezas e conquistas da nossa pesquisa.

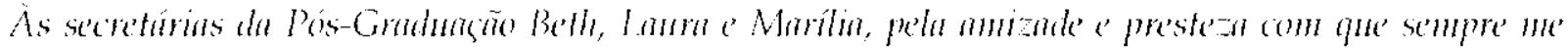
atenderam, e pelo jeilo linmuno de tratar a lodos os alunos.

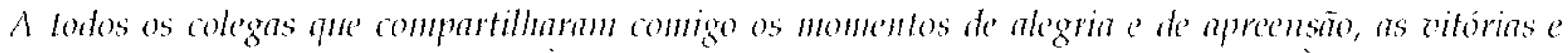
derrotas do periodo de créditos. A Mirha, pela constante amizade e incention. À Llanine, o men agradecimento especial pela sua tmizade, preocupaçōo é ajuda.

Ao Dr. Le'onardo Chinriglione, por permitir a realizaciäo de parte desta pesquisa nos laboratórios do THA AB - Telecom Inalia Lab, em Turim, Itálin. Mens sinceros agradecimentos ao Dr. Mario Guglielmo

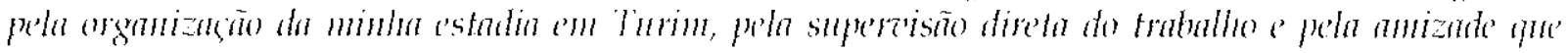
construimos no longo do tempo. Agradeço tambem no Dr. Ginhluca De. Pétris, pela orienlaçăo lécnion durante o periodo em que estive no THLAB, oferecento-me un ambiente de pesquisa extremaneme rico.

Agradecimentos especinis aos mens amigos italinues Alessandro Costa Lain e. Giondmm Cordara e a

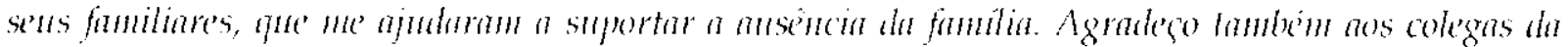
TILAB Adounced Multimedia Disision - Barbara Silano, Liego Gibellimo, Tilippo Chariglione, Barbara Negro, Stefano Dal Lago and Tiziann Tracco - que me proporcionoram um excelente ambiente de traballore incentionaram a minhar complela integraction. 
Noous formas de interaçäo têm surgido a partir da disseminação das lechologias associadas à multimidia interation. O uso de objetos multimidia apre'senta-se', mum primeiro momento, como am bônus para muitas aplicacòes, porem, no contexto no aunl este trabalho se insere, pretende-se' innestigar as possibilidales para a usuario interagir com objetos multimidia, durme a apresentacio desse's objetos, com camcteristicas que ultrapassem os limites dos tradicionais controles VCR (Video-

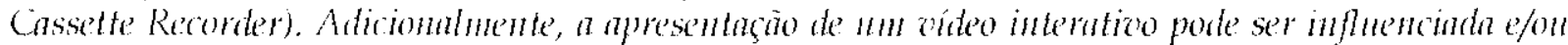

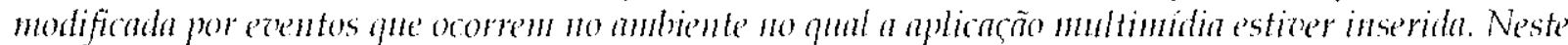
anário, o ambiente - visto Heste traballo como sendo a infra-estrutum de conumicacão, a aplicagño, as midas e us terminais para interaçöo - pode exigir adaptacóes na interface do asuário e o ajuste nos parâmetros de distribuição e consumo dos streams elementares de mídin. Técnologias, técnicas e

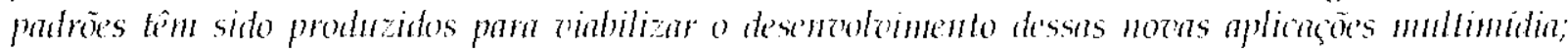
entretanto, muitas de'sias nowas formas de interaço continuam inexploradas e não formalizadas.

O principal objetiou desta tese' á apresentar uma proposta para a modelagem de ambiente's interatizos conscientes de contexto, utilizando a linguagrem UML (Lnifiad Modelling Langunge), tendo conno

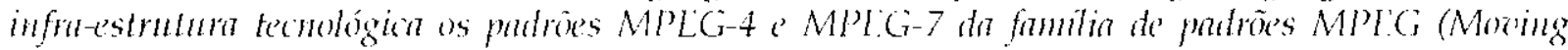
Picture Expert (iroup) e' considernulo as informaçoes contextuats como anu forma para facilitar e

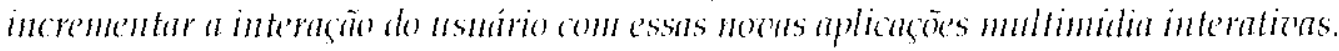

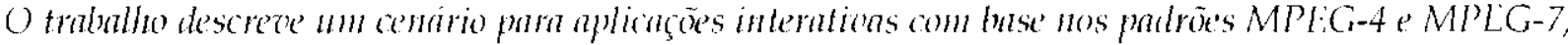
no anal seja possizel aplicar os conceitos de consciência de contex to como forma para oferecer suporte (a) desenoolvinento de noovs sistemas multimidia interations. Neste sentido, noos critérios de'

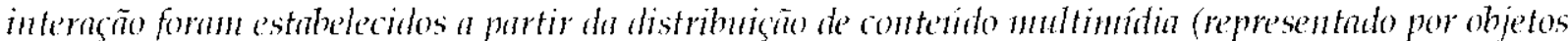
MPPG-4) e' informagäo associada ao conteudo, descrita por esquemas MPEG-7. O futuro padrão MPFG-2I esta sendo investigulo como potencial tecnologia parn represenar essés noves requisitos multimidia como itens digitnis universals. ()s principals conceitos de consciêncin de contexto fornm estendidos e adicionados is moledenge'm proposta também parn procer personalização do ambiente. ()

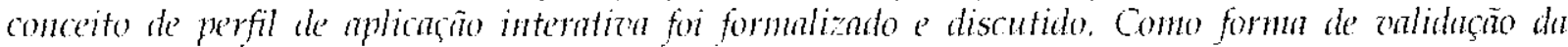

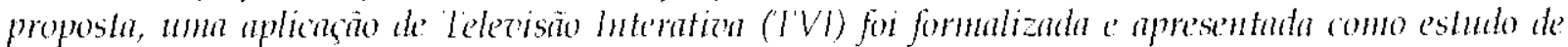
aso, possibilitando a discussĩo das limituçós presentes na modedagem proposta.

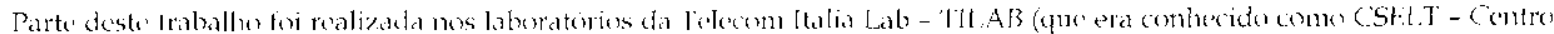

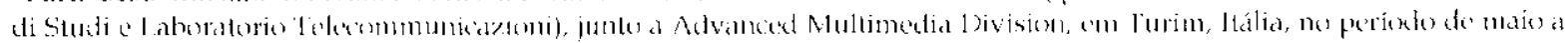
dexembro de 2001 . 


\section{Abstract}

New forms of intenction became possible from the dissemination of the interactioe video technology. The possibility for using multimedia objects in modern applications lats prowen to be a bonus and the

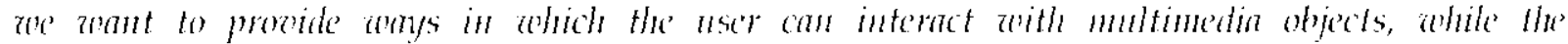
presentation is occurring, whith features flunt go beyond the regular controls of a VCR (Viteo-Cassette Recorder). Furthermore, the presentation of the zideo an be modified by events happening in the

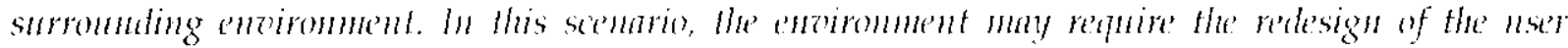
interfice and the retargeling of the elementary streams pammeters in order to match specific requirements and features of the entironment (application, media, neturork and terminals). Several new terdmiques and standards have bern produced in order to allowe for the derelopment of new applications; however, some polential nere interation forms are still mexplored.

The main objective of this thesis is to present a proposal for Modelling of Context-Aware Intermetion Encironments Based on Standards of the MPEG (Mocing Picture Expert Group) Fanily, using the UMI. (Lmified Mordelling Langrange) and considering the user actions from contextual information like a way to ease its interaction with inleractize applications.

The anoth describes a scenario for interactioe applications, based on the e'merging MPEG-4 and MPlGi-7 standards, that use's the context-nuareness concepts in order to prooide the necessary support to the deoelopment of more interaction and useful systems. At this point, newe interaction criterin have been established from distribution of MPFG-4 media objects and MPEG-7 scene descriptions on netwoork enoiromments. MPEG-21 is being studied for applying to new multimedin requiruments, considering multimedia objects as mizersal digital item. Context-anareness aspects lane be'n extended and added for proviling personalization on the interntize e'moironment. The concept of interaction application profile is formalized and presented. As zalidating mechanism, an ITV (Internctioe Television) application is presenled as a case of study, focolizing hoo and which kind of contextual information could be used in the $17 \mathrm{~V}$ entiromment, allowing the alscussion about the main problems of the proposest motelling. 


\section{Índice Geral}

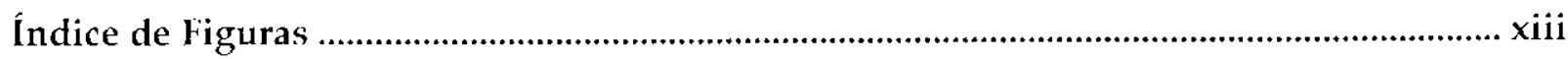

Índice de Tabelas..............................................................................................................

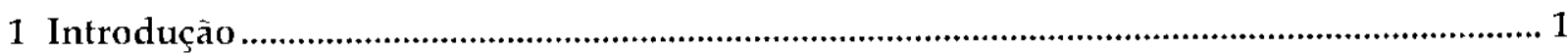

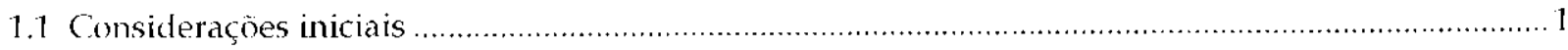

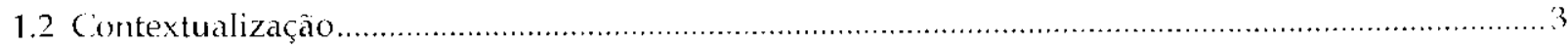

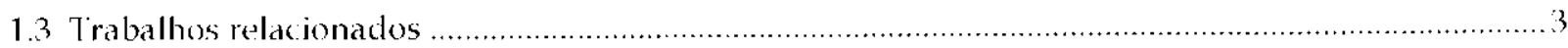

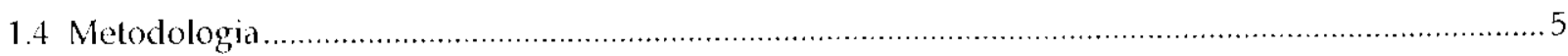

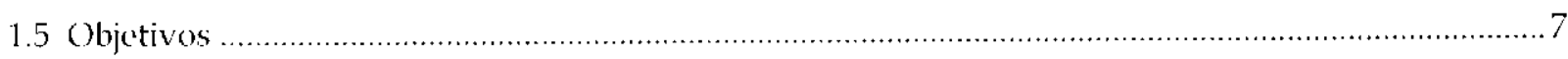

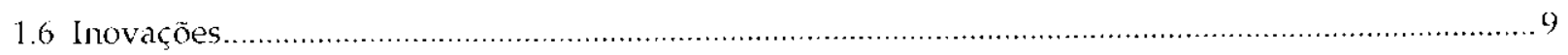

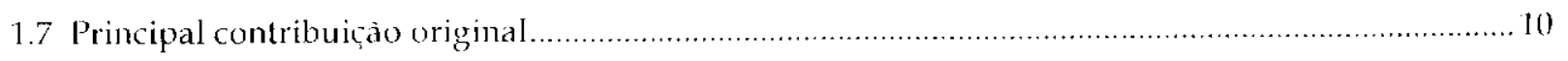

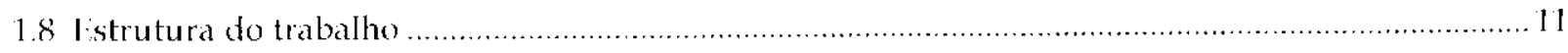

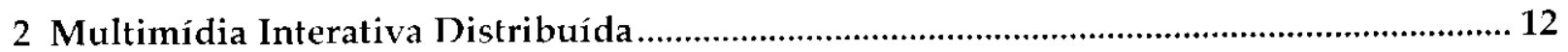

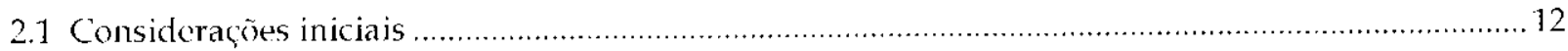

2.2 l'ecnologias associadas à multimidia interativa: uma breve apresentaçăo..................................12

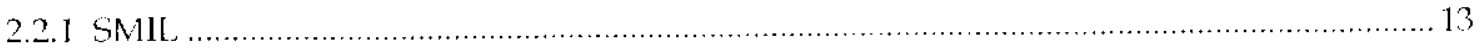

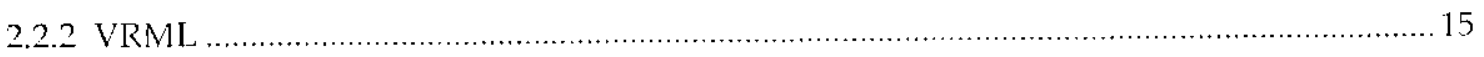

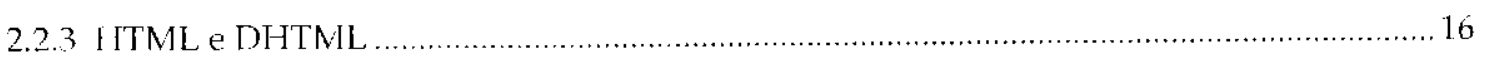

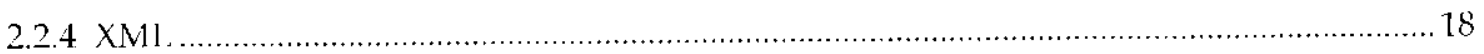

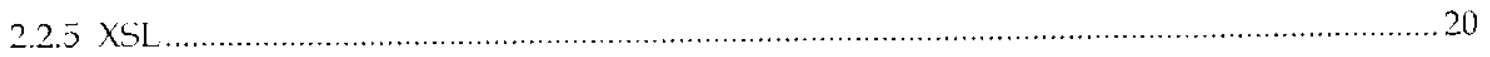

2.3 A problemática da distribuiçào de multimidia .................................................................21

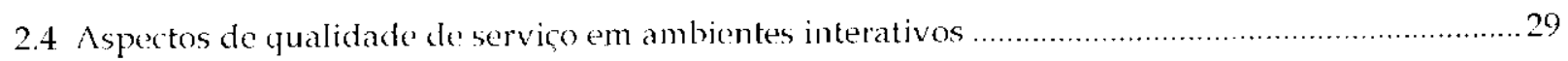

$2.5 \mathrm{~A}$ infra-estrutura de inteģração dos sistemas digitais: uma breve descrição ...................................33

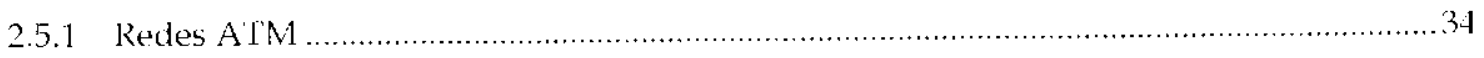

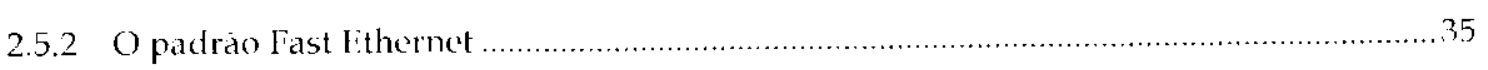

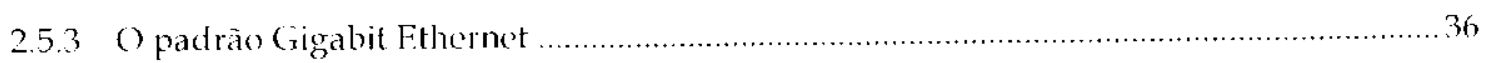

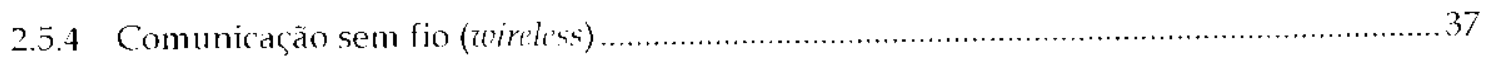

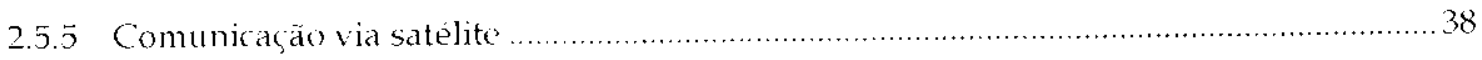

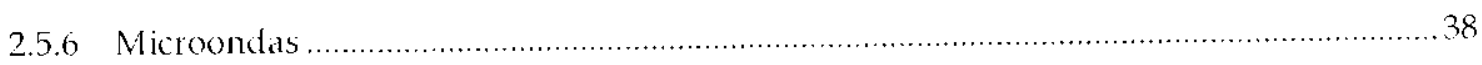


2.5.7 Telefonia celular e comunicação de dados.

2.5 .8 RDSI - Rede Digrital de Servicos lntegrados .................................................... 41

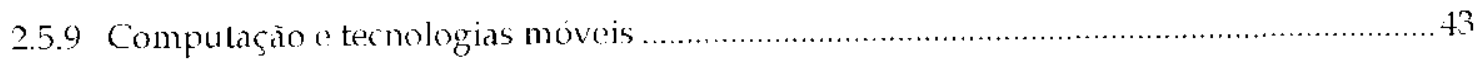

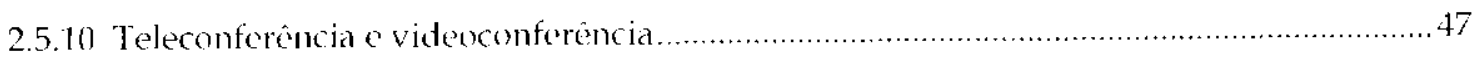

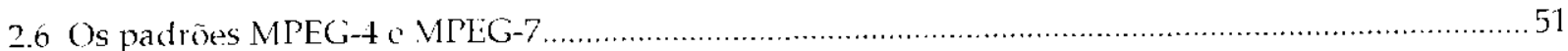

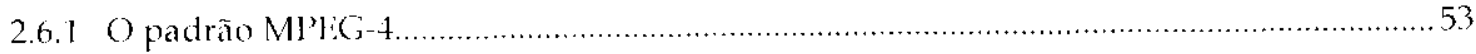

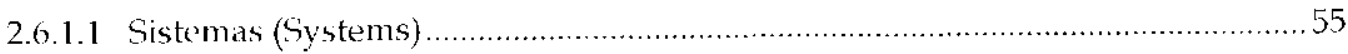

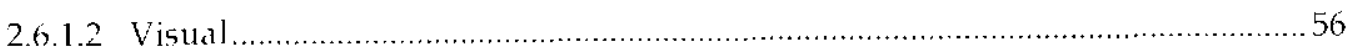

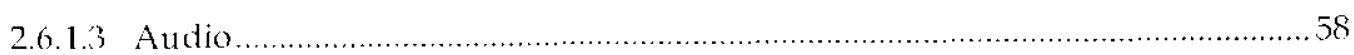

2.6.1.4 Framework para integrą̧ăo da entrega multimídia ......................................59

2.6.1.5 Soltware de referència e conformidade ..................................................... 60

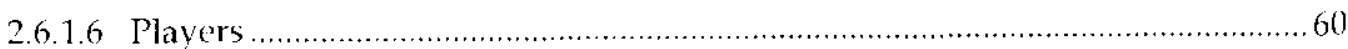

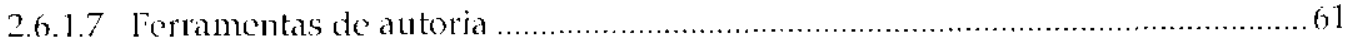

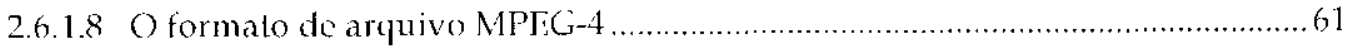

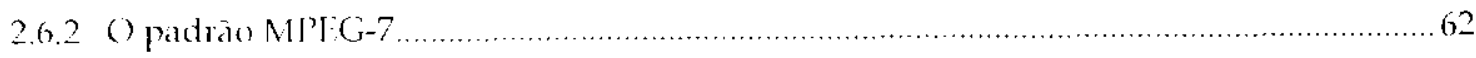

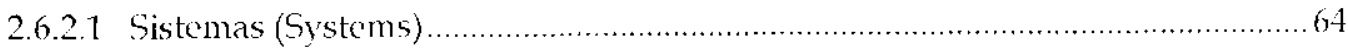

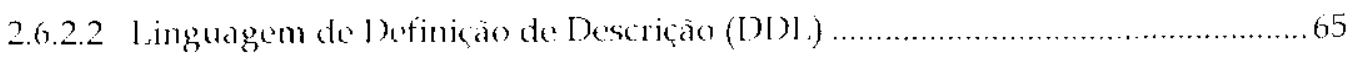

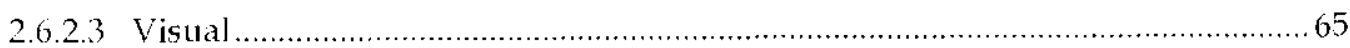

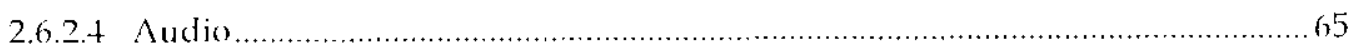

2.6.2.5 Fisquemas de Descriçäo de Multimídia (MISS) .......................................... 66

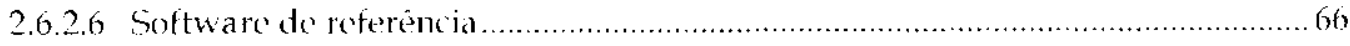

2.6.2.7 'leste de conformidade (Conformance 'T'est) ........................................67

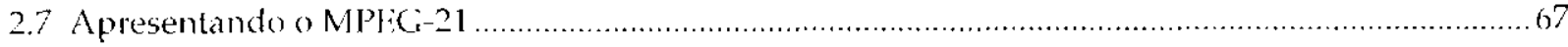

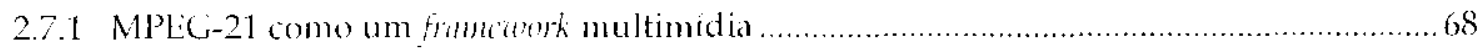

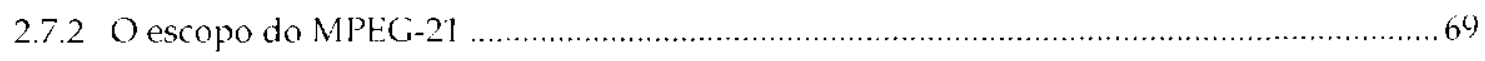

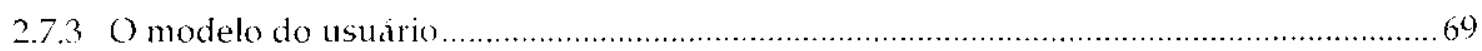

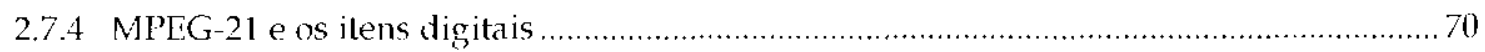

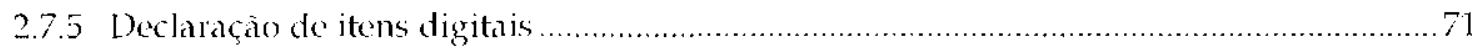

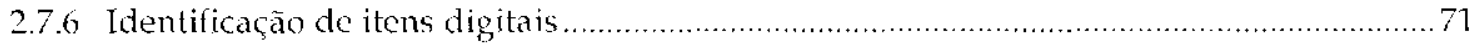

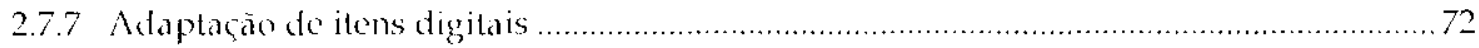

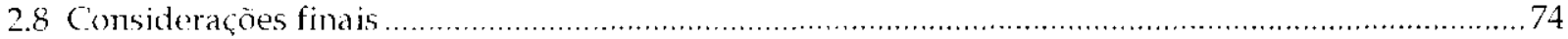

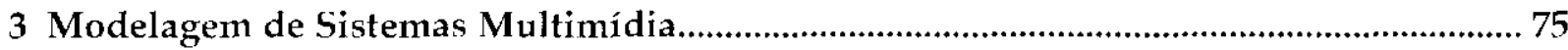

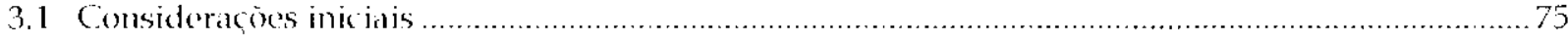

3.2 Métodos, técnicas, metodologias e modelos: uma breve apresentação .....................................76

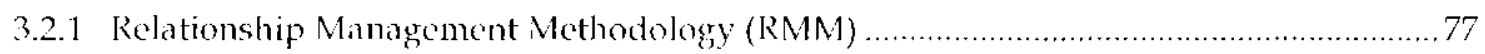

3.2.2 Object Oriented Hy permedia Design Model (OOHDM) .........................................78

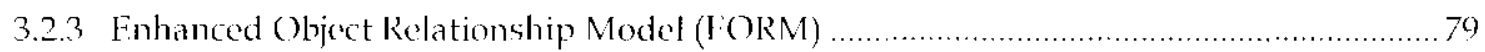




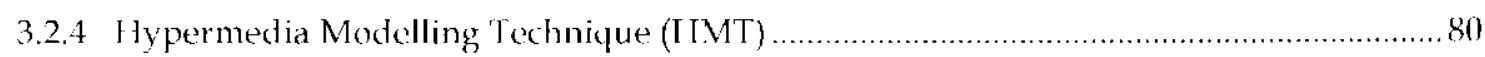

3.2.5 A Database-Oriented Approach to the Design of Educational Hyperbook ......................80

3.2.6 Analysis and Design of Web-based Information Systems ............................................... 81

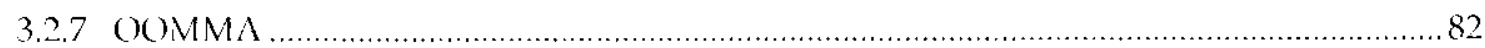

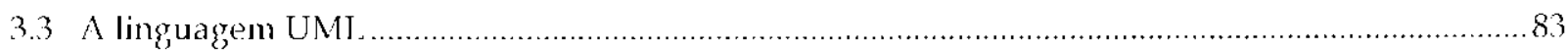

3.3.1 Os diagramas L.ML e a sua adequação a esta proposta .................................................... 85

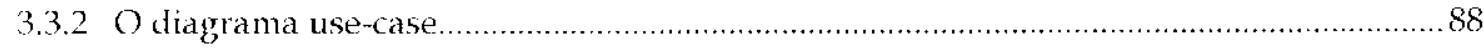

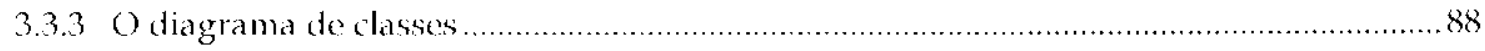

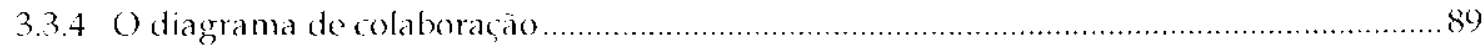

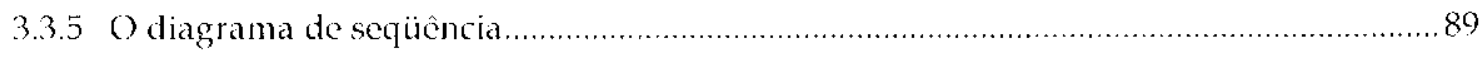

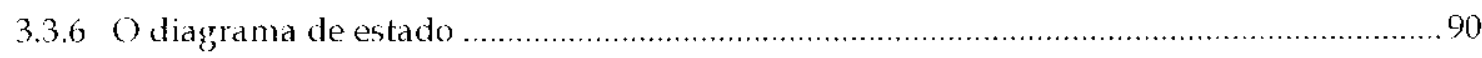

3.4 MPEG-4 e MPEG-7: justificativas para o uso desses padrôes ........................................................91

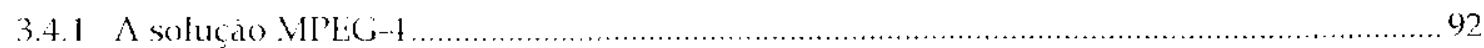

3.4.2 Diferenças entre um codificador de múdias e uma arquitetura ...........................................93

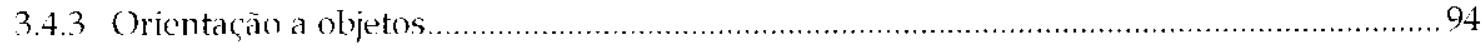

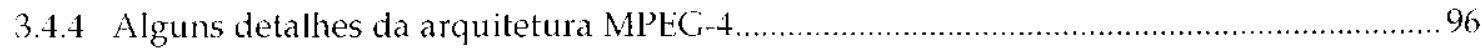

3.4.5 Algumas vantagens e desvantagens da arquitetura MPt:G-4 .....................................97

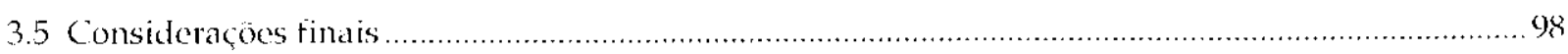

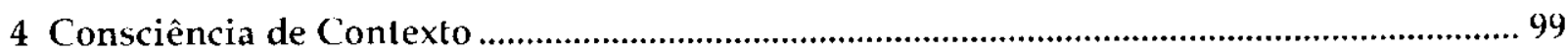

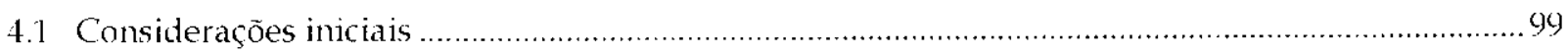

4.2 Consciência de contexto e suas relaçòes com interação do usuario ................................................99

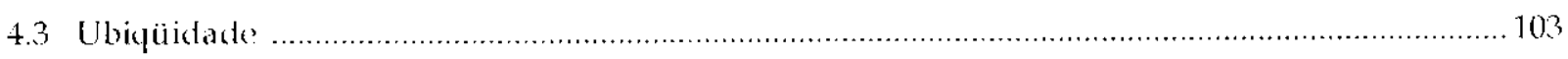

4.4 Mobilidade como infra-estrutura para consciência de contexto ..................................................... 106

4.5 Uma proposta de formalismo para consciencia de contexto ........................................................ 111

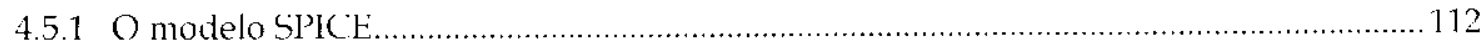

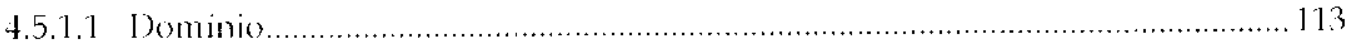

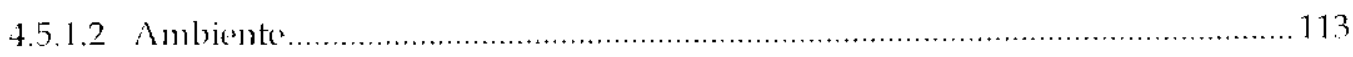

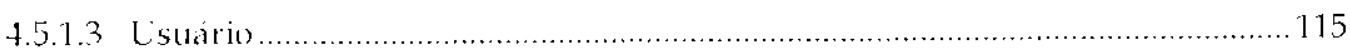

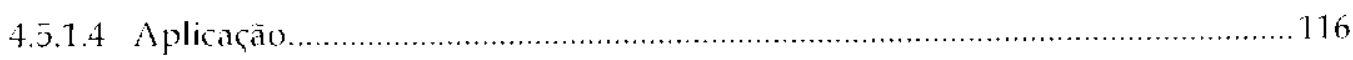

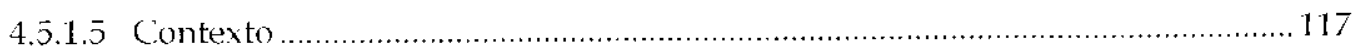

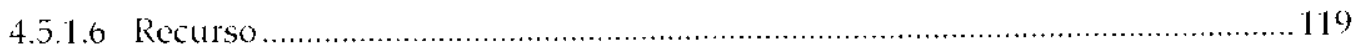

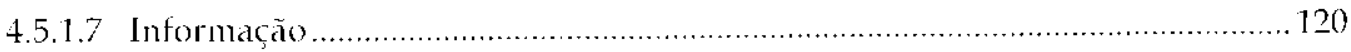

4.5.2 A proposta das regras contextuais como extensäo do modtelo de Anind ........................ 120

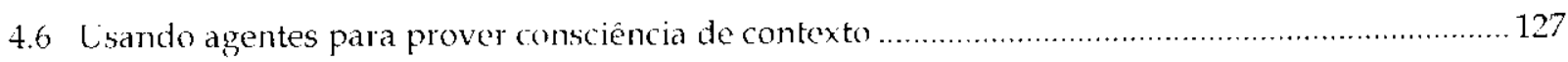

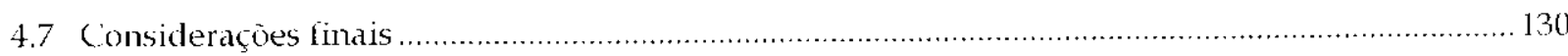




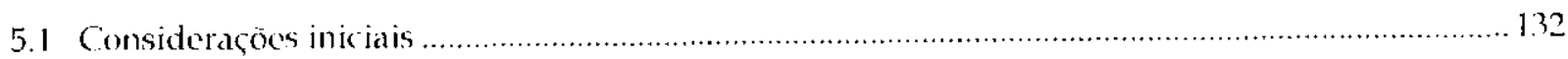

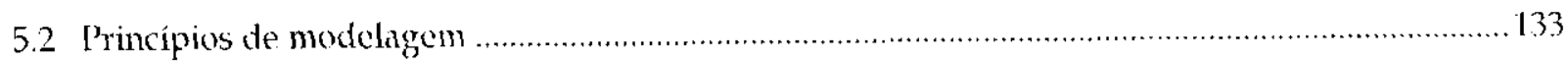

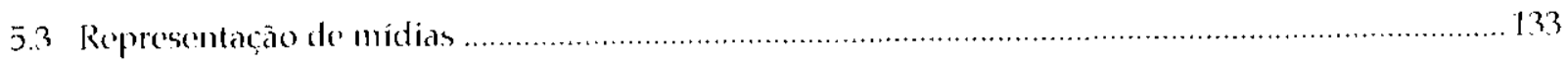

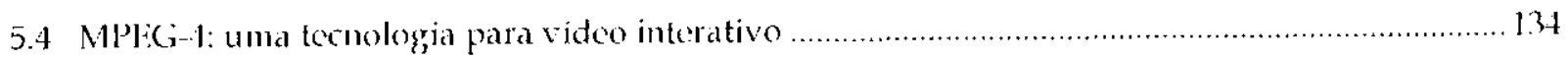

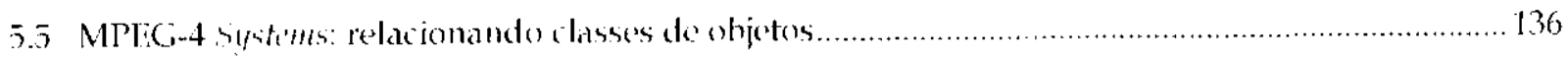

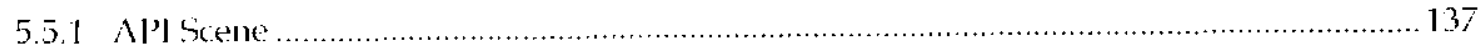

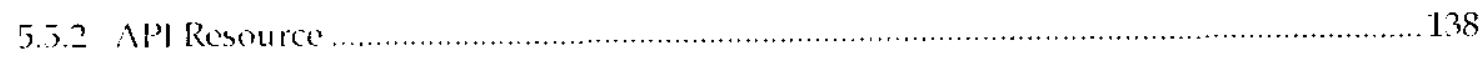

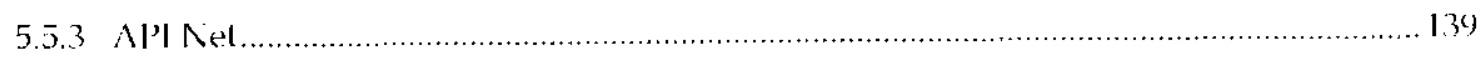

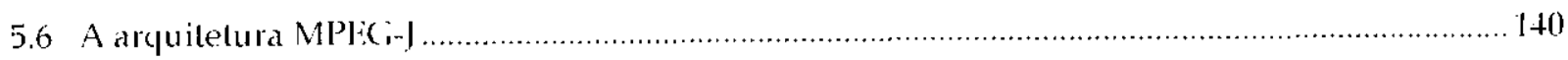

5.6.1 Lima visao geral dos recursos Vly: (j-l relevanles para esta proposta ......................... 141

5.6 .2 Fxemplos de aplicaçio do código MILG -1 ........................................................... 148

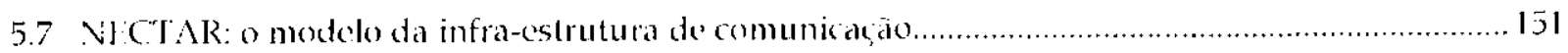

5.7 .1 Detalhando a infra-estrutura do servidor.................................................. 154

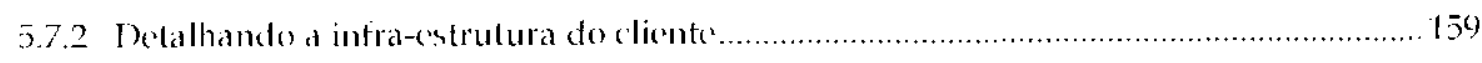

5.7 .3 Detalhando a infra-estrutura da rede de comunicaçào ........................................ 160

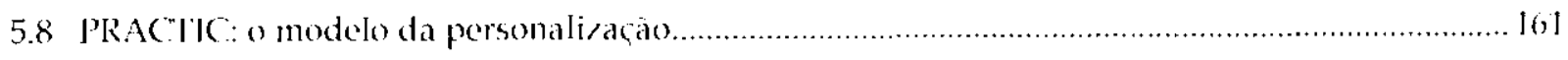

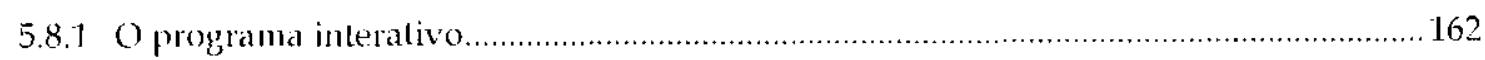

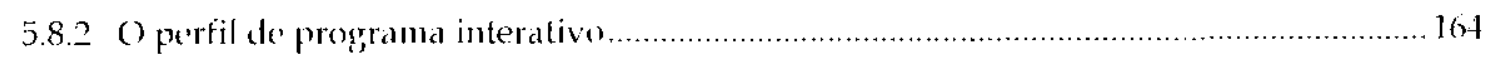

5.8 .3 Litilização dos perfis em programas interativos ................................................ 167

$5.8 . t$ P'roduzindo um progyramd interativo............................................................ 168

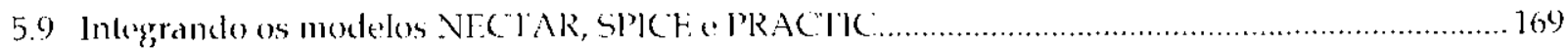

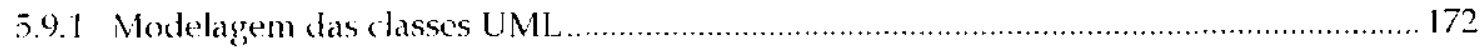

5.9.1.1 A classe l'ersoll ....................................................................... 173

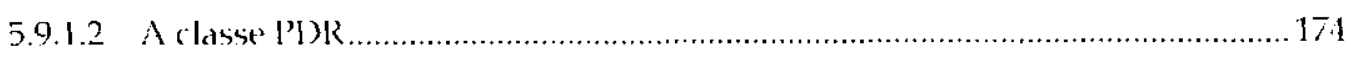

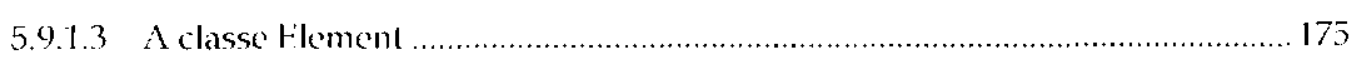

5.9.1.4 Aclasse I)

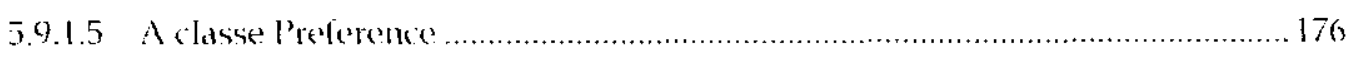

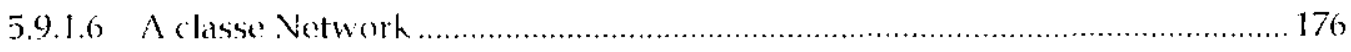

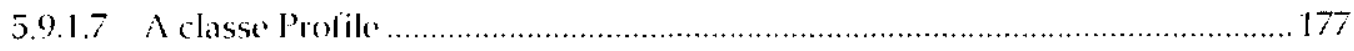

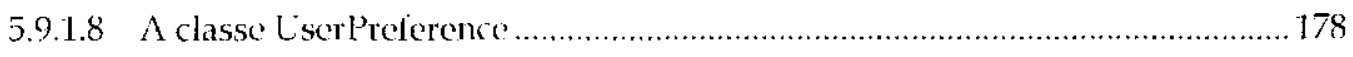

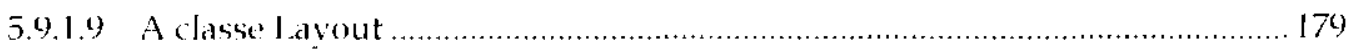

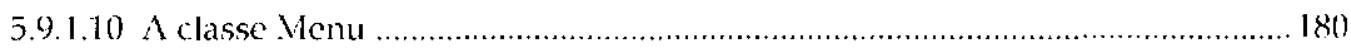

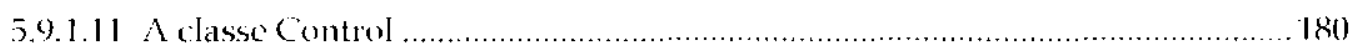

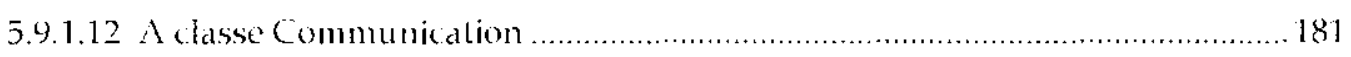

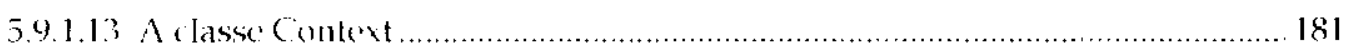

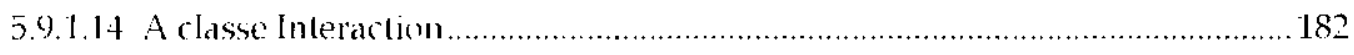

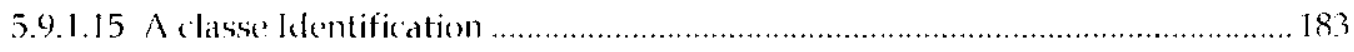


5.9.1.16 A classe Location. 184

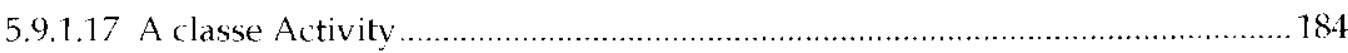

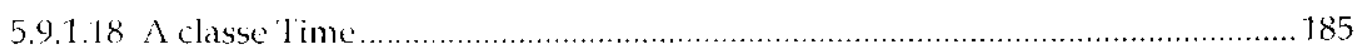

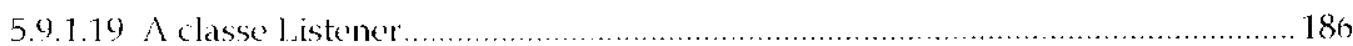

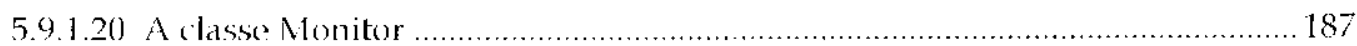

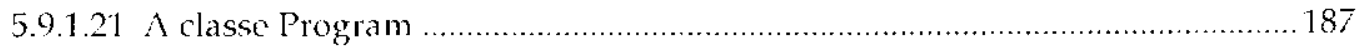

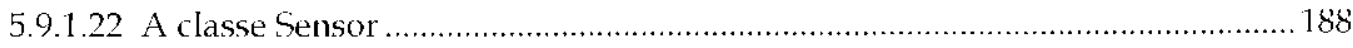

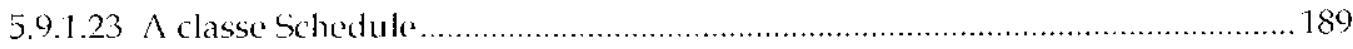

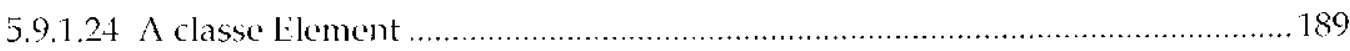

5.9.1.25 A classe InformationElement ......................................................... 190

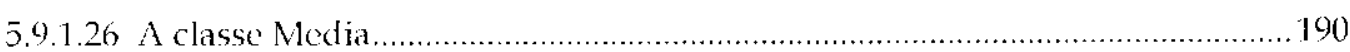

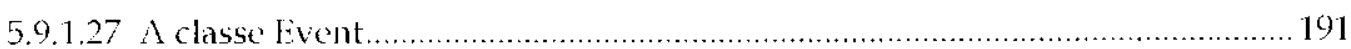

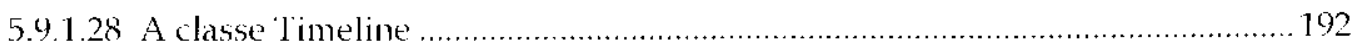

5.10 Integrando agentes des software para prover consciencia de contexto ................................. 192

5.11 Discussão das relaçōes entre esta proposta e o MPFG-21 ..............................................198

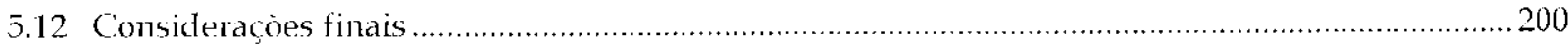

6 Estudo de Caso: Modelagem de Programas para I'elevisão Interativa .......................... 201

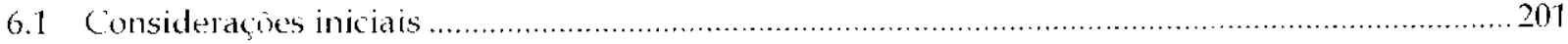

$6.2 \mathrm{Um}$ breve relato da evoluçào da interaçăo na televisăo ...................................................2201

6.3 Revisitando aspectos de consciência de contexto aplicáveis à "lV interativa .............................203

6.4 Infra-estrutura para distribuiçào de programas de TV interativa ...........................................205

6.5 Requisitos para a produçio de programas de TV interativa ................................................206

6.6 Vodelagem da aplicaçăo de TV interativa: estrutura e implementação ....................................207

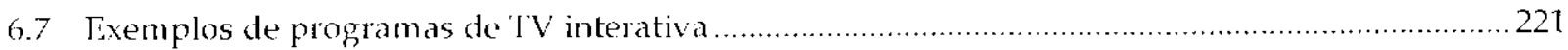

6.8 Aplicação dos conceitos de programa e perfil a um programa de evento esportivo ...................223

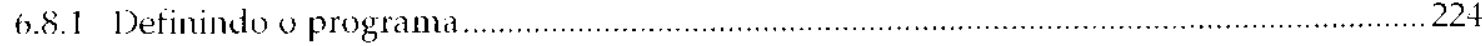

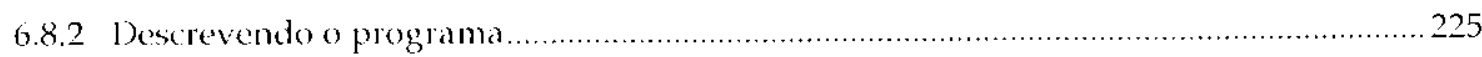

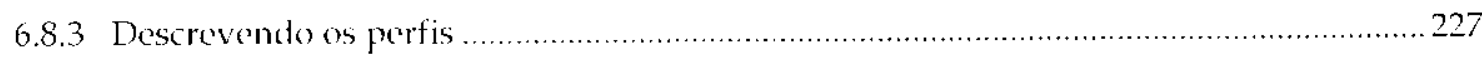

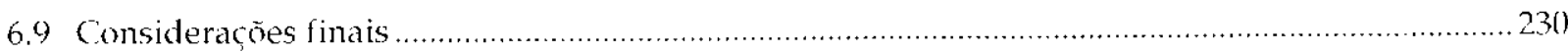

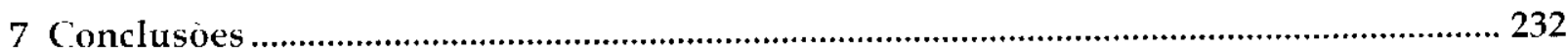

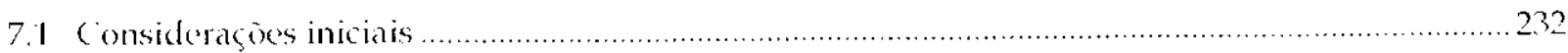

7.2 Contribuiģ

7.2.1 Contribuiçoes para o campo da modelagem de sistemas multimídia ........................235

7.2.2 Contribuiçōes para o campo dos agentes de software...........................................2235

7.2.3 Contribuiçóes para o campo da consciência de contex lo .......................................235 
7.2.4 Contribuições para o desenvolvimento de aplicaçôes multimidia interativas

7.2.5 Contribuiçóes para o estabelecimento de novos modelos de negrócios ...........................2.236

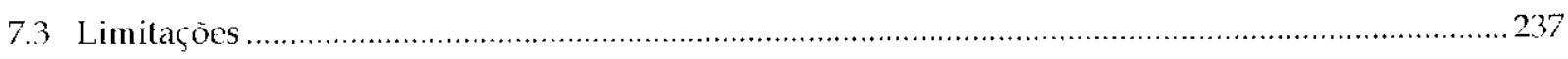

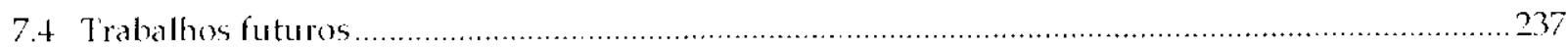

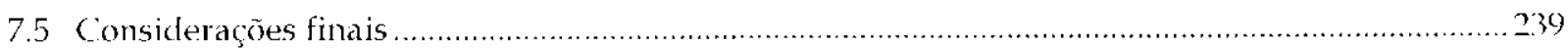

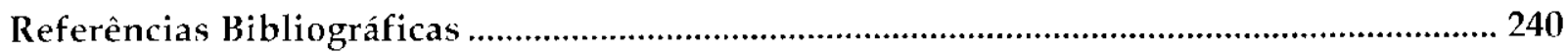

Apêndice A - Resumo do Relatório das Atividades Realizadas no Exterior ....................... 253

Apêndice B - Resumo e Abstracts dos Artigos Publicados .................................................... 265 


\section{Índice de Figuras}

Iigura 1.01 - () (scopo da modelagem - estrutura grática (Sontos J1. et al., 2001b) 8

Figura 2.01 - Uma apresentaçäo multimidic protocolada em SMII ............................................. 14

Figura $2.02-\mathrm{Lm}$ "mundo virtual" constrúdo em VRMl ....................................................... 15

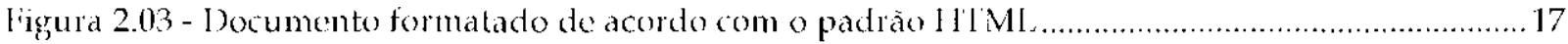

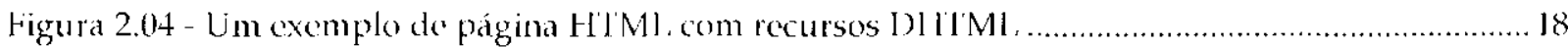

Figura 2.05 - Um exemplo de documento estruturado X.ML para o dominio ensino........................... 19

Figsura 2.06 - l'recho de documento XSil para formatar um elemento ...........................................21

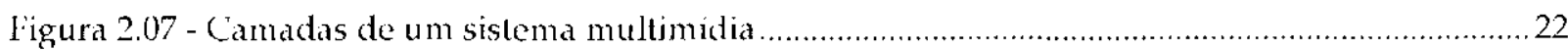

ligura 2.08 - Fistrutura genérica da arquitelura cliente-servidor para a Internet ..............................26

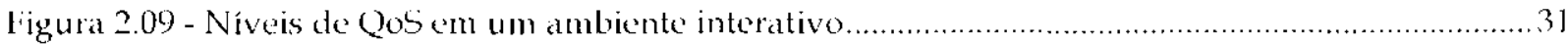

ligura 2.10- Iidemplo da estrutura de um bitstrenm MPEG-1 (Pereira \& Ebrahimi, 2002) ...................57

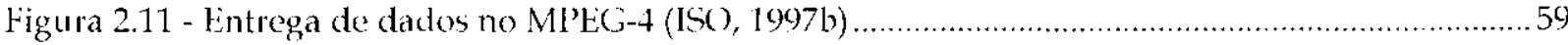

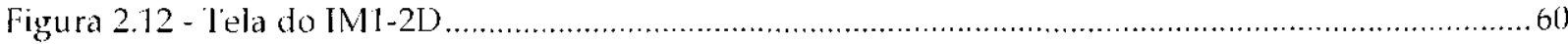

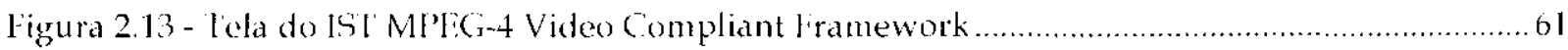

Figura 2.14 - lixemplo do formato de aryuivo MI'ic -4 para intercimbio de dados (ISO), 1999a) .........62

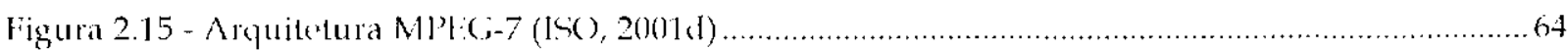

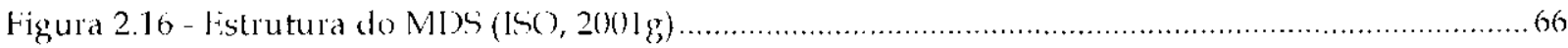

Figura 2.17 - Exemplo de uma descriçāo de um video em MPE

Figura 2.18 - Modelo de eventos e interfaces que descrevem interaçoes MPlic (i-21 (MI'l(i-21, 2001)...70

Figura 2.19- Redacionamento entre declaraçào, identificaçăo e descriçäo de um item digital ..............72

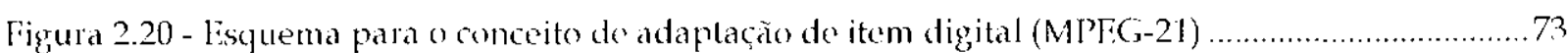

Figura 3.01 - Modelos do Database-Oriented Approach lo the Design of Lducational I lyperbook......80

Figura 3.02 - Estrutura OOMMA representada em um diagrama de classes (lingels, 200)0)................8.3

Figura 3.03 - Camadas de objelos em um ambiente com consciência de contexlo ............................87

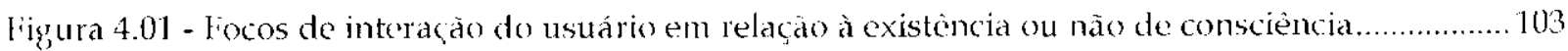

ligura 4.02 - Modelo para uso de consciencia associada a mobilidade ........................................ 109

Ligura 4.03 - O escopo da modelagem - estrutura grafica (Santos Jr. et al., 2001b) ..........................112

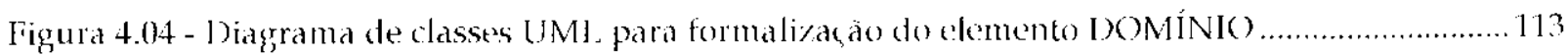

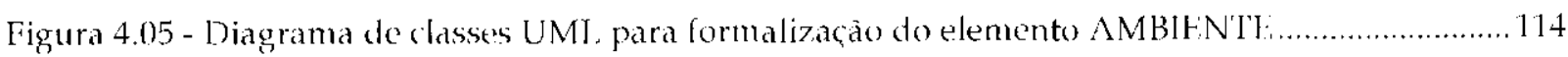




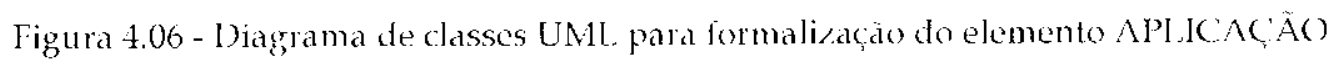
117

Figura 4.07- I iagrama de classes UMI, palrd formalizaçio do elemento CONTFXTO. 118

Figura 4.08 - Diagrama de classes UML para formalizaçào do elemento RECURSO 119

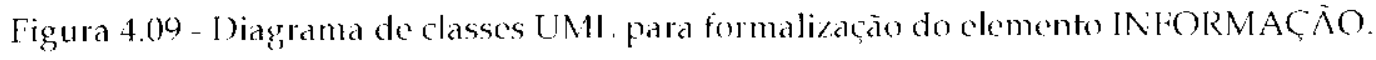
120)

Figura 4.10 - Modelo para formalizaço das regras contextuais.... 121

Figura 4.11 - Diagrama completo de tasses UNI, do modelo SPICF. ...................................12?

Figura 4.12 - Esquema de relaçòes de pertinência a um contexto ............................................124

Fişura 4.13 - Esquema de relaçoes o transições em um contexto ............................................. 124

Figura 4.14 - Exemplo de forma lismo e uso de uma regra contextual ........................................ 125

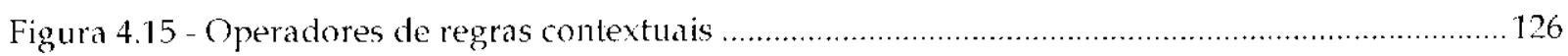

Figura 4.16 - I)iagrama de classes L.ML para os operadores de reyras contextuais ............................ 126

Figura 4.17 - Operadores de regras contextuais ............................................................. 127

liz̧rura 4.18 - Modelo para relaçoes entre contexto e elementos contextuais .................................. 127

Figura 5.01 - Arquitetura minima para o uso do .MPLG-4 em ambientes interativos ....................... 1.35

Figura 5.02 - Identificação das interfaces MPEG-J en uma arquitetura MPEG-4 (ISO, 1999a).......... 140

Figura 5.03 - Fixemplo MPJiglet para manipular os nós de um grafo de uma cena (ISO, 1999a) ........ 149

Figura 5.04 - Exemplo MPFGlet para adicionar eventos a uma cena MPEG-4 (ISO, 1999a) .............. 150

Figura 5.05 - Fxemplo MPliglel para manipular os dados de um BIFS de uma cona (ISO, 1999a) ..... 151

Figura 5.06 - Fsquema para decodificaçâo de strems. MPLG-4 (ISO, 2001a) ............................... 154

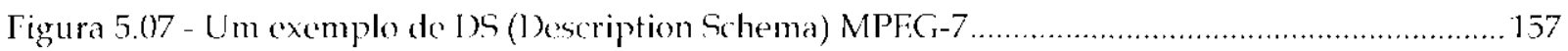

Figura 5.08 - Esquema para apresentação de objelos MPEG $-4 \mathrm{~cm}$ um terminal (ISO, 2001a)............. 159

Figura 5.09 - Estrutura proposta para um programa interativo .................................................. 162

Figura 5.10 - Lntidades que compöem um programa interativo em uma aplicaçào ........................... 162

Figura 5.11 - Schema MPFG-7 para descricăo de uma crna ................................................. 163

Figura 5.12 - Fntidades yue compoem um programa interativo em uma aplicação ........................... 16t

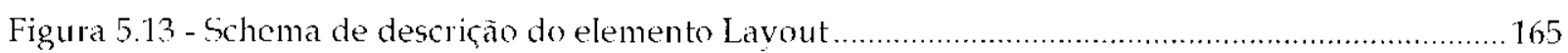

Iigura 5.14 - Schema de descricà do elemento Communication..................................................... 165

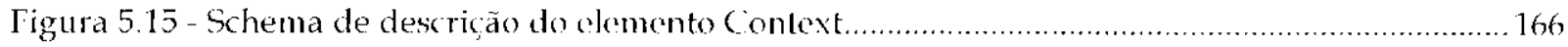

Figura 5.16 - Schema de descricäo do elemento Interaction ........................................................... 166

Figura 5.17 - Schema de descriçăo de atributos do elemento Interaction ...................................... 166

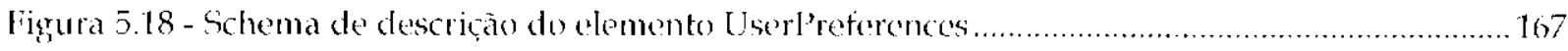

Figura 5.19 - Diagrama de seqüência UMI, para as entidades de um programa interativo.................. 168

Figura 5.20-Ropresentaçäo genérica da relaçào entre programa, perfil écond ................................... 168

Figura 5.21 - Diagrama UML $l s e^{2}-c n s e$ para o modelo de acesso aos objetos de mídia .........................170

Figura 5.22 - Diagrama de classes UMI, para o modelo de acesso ao conteúdo de mídia ................... 170

Tigura 5.23 - Diagrama UML de estados para o acesso ao conleúdo associado à mídia ..................... 171

Figura 5.24 - Diaģrama UMI, de colaboraçào entre agentes fisicos no acésso ao contéudo de midia... 171 
Figura 5.25 - I iagrama de classes UMI. de um ambiente interativo consciente de contexto 172

Figura 5.26 - Esquema das interaçoes completas em ambiente interativo consciente de contexto

liggura 5.27 - Diagrama UML de colaboraçào entre agentes em um ambiente interativo. 194

Figura 5.28 - Comportamento de um subconjunto de agentes. 195

Figura 5.29 - Fisquema baseado em agentes para coleta de informaçōes contextuais 196

Figura 5.30 - Diagrama UML de colaboração para subconjunto de agentes (Santos Jr. et al, 2001a) .... 197

Figura 6.01 - Mapeamento de entidades contextuais em elementos de perfis de TVI 204

Iigura 6.02 - Ambiente consciente de contexto para a Televisào Interativa 206

Figura 6.03 - Fixemplo de Sihem para o clemento Progrim 208

Figura 6.04 - Exemplo de cabeçalho de um programa 208

Figura 6.05 - Exemplo de Solnoma para descrever a cena 209

Figura 6.06 - lixemplo de Schmo para descrição das midias 212

Figura 6.07 - lixemplo de Sighma para os edementos da linha do tempo. 213

Figura 6.08 - Fxemplo de Schema para o elemento profile 214

Figura 6.09 - Exemplo de cabeçalho de um perfil de programa .214

Figura $6.10-$ Fxemplo do shemm para o elemento layoum. .216

Figura 6.11 - Excmplo de Schemn para o elemento Connmaication 217

Figura 6.12 - Exemplo de Schoma para os elementos de consciência de contexto 218

Figura 6.13 - Fxemplo do uso dos elementos de consciencia de contexto 218

Figura 6.14 - Fxemplo de Silkemia para os elementos de interaçào 219

Figura 6.15 - Exemplo do uso dos elementos de interaçá .220

Figura 6.16 - Extemplo de Sthem para os clementos de preferências do usuario. 220

Figura 6.17 - Fxemplo do uso dos elementos de preferências do usuário. .22]

Figura 6.18 - Exemplo de descrição de um programa de evento esportivo. .227

Figura 6.19- Exemplo do perfil Lásico 227

Figura 6.20 - Exemplo do perfil intermediário 228

Figura 6.21 - Exemplo do perfil avançado .230

Eigura 7.01 - () escopo da modelagem - estrutura gráfica (Santos Jr. et al., 2001) 233 
Tabela 2.01 - Algumas midias de distribuiçao e velocidades de transferéncia ................................... 22

T'abela 2.02 - Relação de quantidade de armazenamento para algumas mídias .................................2. 23

Tabela 2.03 - Algumas a plicacoes de serviços interativos (I lashisucd, 1996) ....................................32

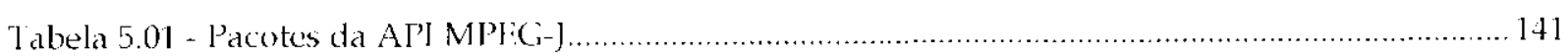

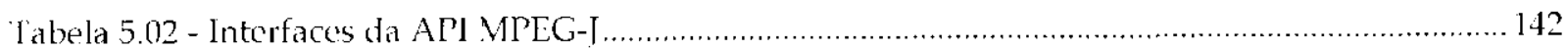

T'abela 5.03 - Mélodos da interfaces I ecoderConfig Descriptor .............................................142

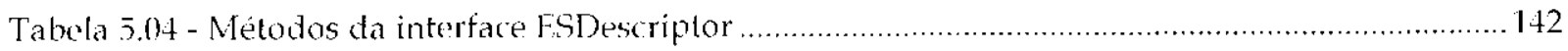

Tabela 5.05 - Metodos da classe . Mpegj l'erminal ................................................................... 14?

Tabela 5.06 - Métodos da interface ObjectDescriptor ........................................................... 144

Tabela 5.07 - Classes o interlaces do pacole Resource ....................................................... 144

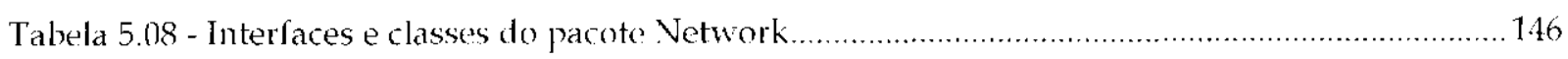

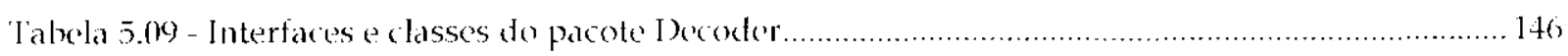

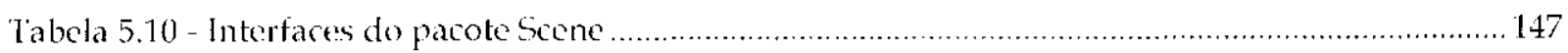

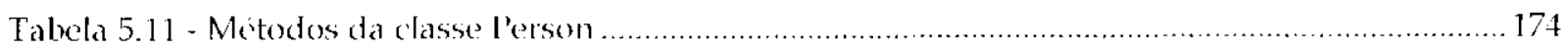

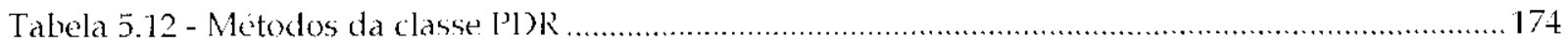

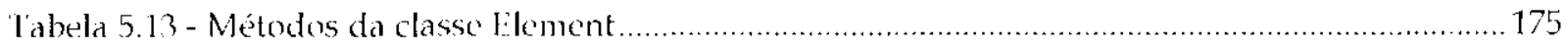

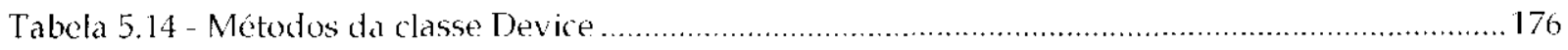

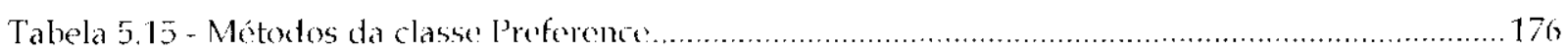

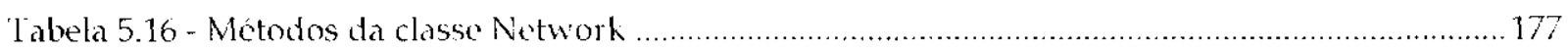

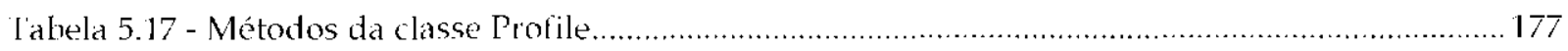

Tabela 5.18 - Métodos da classe UserPreferences ................................................................... 178

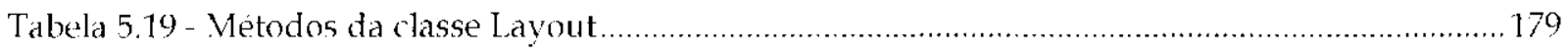

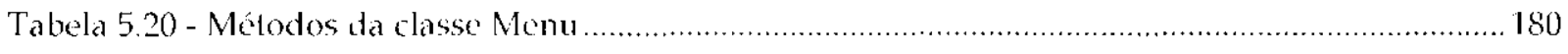

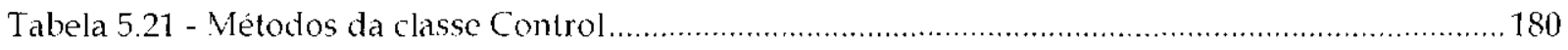

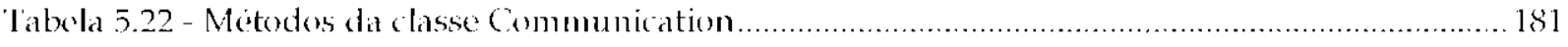

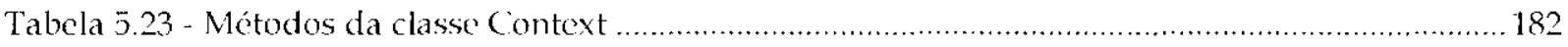

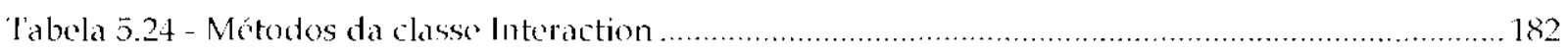

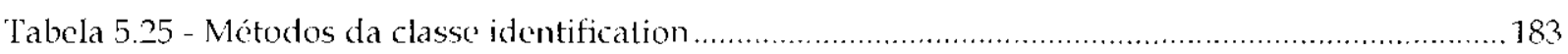

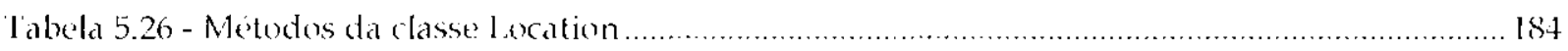

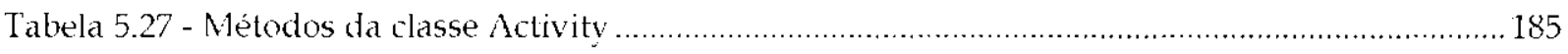

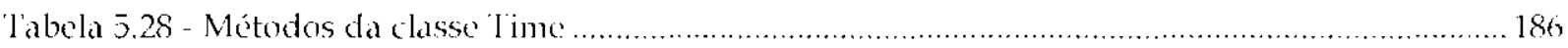


Tabela 5.29- Métodos da classe Listener 187

Tabela 5.30 - Métodos da classe Monitor 187

Tabela 5.31 - Métodos da classc P'rogram 188

Tabela 5.32 - Metodos da classe Sensor...... 188

Tabela 5.33 - Métodos da classe Schedule 189

T abela 5.34 - Métodos da classe Lilement 189

labela 5.35 - Métodos da classe Informationl lement. 190

Tabela 5.36 - Metodos da classe Media 191

labela 5.37 - Métodos da classe Fivent. 191

Tabela 5.38 - Métodos da classe 'limeline.... 192

Tabela 5.39 - Pacotes da plataforma JAISH. 197

Tabela 6.01 - Elementos do Proģrama. 207

Tabela 6.02 - Subelementos do programa. 208

labela 6.03 - Subclementos de midia 209

l'abela 6.04 - subelementos de linha do tempo.

labela 6.05 - Elementos de perfil

Tabela 6.06 - Subelementos do layout

Tabela 6.07 - Subelementos de comunicação 216

Tabela 6.08 - Subelementus de consciéncia de contexto. 217

labela 6.09 - Subelementos de interação 219

labela 6.10 - Flementos de personalizaçào do usuário 220

Tabela 6.11 - Componentes do programa 224 


\section{Introdução}

\subsection{Consideraçōes iniciais}

Com a disseminaçào das tecnologias associadas à multimídia interativa, novas aplicaçoes e? formas de interação têm se tornado possiveis. Os diferentes meios com que o usuário pode interagir com uma apresentaça multimídia (ou com objetos multimidia) demandam a adaptação das aplicaçōes (eventualmente de forma automática) a determinadas situaçoes, com o objetivo de molhorar a interajaio ('m seus diversos níveis. Além disso, a presença da computação de forma ubíqua oferece ao usuário a expectativa de que é possível acessar informaçôes e serviços em todo lugar e a qualquer momento e, para atender a essas expectativas, aspectos de consciência de contexto têm sido usados (Abowd, 1999; Pascoe et al., 1999; 1)y \& Abowd, 1999; Dey \& Abowd, 2000; Schnidt, 2000).

Um vasto número de situaçôes em que o usuário pode estar envolvido, durante uma sesssäo interativa, exiģe esforços no sentido de definir como essas interações ocorrem e quais são os melhores critérios para tratamento dessas interaçöes, oferecendo, assim, melhores condiçóes de uso para o usuário final (Dey \& Abowd, 2000; Schmidt, 2000). Uma maneira para melhorar o suporte à interaçào do usuário é melhorar a comunicaçào entre as entidades do ambiente durante todo o tempo em que essas interaçoes podem ocorrer. Isto pode ser possível através do uso de informaçōes contextuais obtidas da aplicação, da infra-estrutura de comunicaçào, das caractıristicas das midias utilizadas pela aplicaçào e das características dos dispositivos e terminais utilizados pelo usuário para ter acesso à informação.

Neste sentido, torna-se interessante formalizar um cenário para aplicaçōes interativas, considerando o estado da arte representado pela evoluço e convergencia dos sistemas digitais (computadores, televisào, telefones e telefonia, infra-estrutura de comunicaçào de dados, PDAs - Personal ligitml Assistmnt, dentre outros), e propor a utilivaçào dos padrós da família MPEG (Mocing Picture Fxperts Group) (ISO, 1997a) - MPEG-4, para representação de conteúdo multimidia na forma de objotos de mídia (ISO, 1997b; 1SO, 1999a; 150, 2001a); c MPFG-7, para descriçào de informaçào associada ao conteúdo multimídia (ISO, 1997c; ISO, 
$2000 \mathrm{a}$ - como base tecnológica para implementaçào de ambientes interativos conscientes de contexto, considerando que esses padrões MPFG apresentam potencialidades para:

- oferecer formas para estruturar conteúdo multimídia e informaçōes associadas à mídia, permitindo a implementaçào dos aspectos de consciència de contexto discutidos neste trabalho;

- possibilitar o uso es aspectos de consciencia de contexto para prover adaptaçao automática as necessidades do usuário, da aplicação é da infra-estrutura;

- permitir a extensäo dos conceitos de consciencia do contexto a todos os niveris de entidades que compõem a infra-estrutura do ambiente interativo.

Aguns estudos, encontrados na literatura, apresentam esses padroes da fanília MPEG MPLC-4 para codificaçao e stroming de mídia, o MPLG-7 para descriçào de conteúdo e indexaço - como tecnologias capazes de suportar a construçào da inf ra-estrutura necessária às novas e complexas aplicaçoes multimidia interativas e distribuálas (Chiariglione, 1999; Battista et al., 1999; Chiariglione, 2001).

Apesar da complexidade e abrangencia desses padróes, existe uma carência de modelos e modelagens para esse novo universo de aplicaçoes interativas. Adicionalmente, os trabalhos que estäo sendo desenvolvidos na area raramente consideram, como parte formal da modelagem ou modelo, aspectus como contexto consciência de contexto a adaptabilidade às necessidades do usuario como forma para methorar a interatividade (Schmidt, 2000).

Esta tese apresenta uma proposta para modelagem, utilizando a sintaxe gráfica da linguagem UMI. (Unified Modelling language) (Booch et al., 1996), do um ambiente interativo consciente de contexto bascado nos padroes MPEG-4 e MPEG-7, formalizando as situaçoes de adaptaçào da apresentaçäo de cenas multimídia de acordo com os parametros de consciencia de contexto formalizados (Santos Jr. et al., 2001b). Fissa modelagem apresenta-se

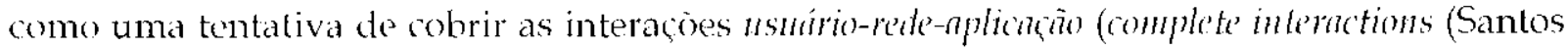
Jr. et al., 2001a)) yue ocorrem em um ambiente interativo (Rodrigues, 1998). Neste cenário, o trabalho enfoca principalmente quais os tipos de informaçoes contextuais podem ser utilizados e como devem ser manipulados en todos os niveis de interaçăo presentes no ambiente. Dessa investigaça, o trabalho também propie a formalizaçào do conceito de perfil de aplicacio interation e discute como uma aplicaça de Televisào Interativa (TVI) poderia usufruir da modelagem proposta. 


\subsection{Contextualização}

O uso de objetos multimídia - áudio, vídere, texto, imagens, gráficos, animaçóes - na construção de ambientes interativos é extremamente complexo (Battista et al., 1999). Uma ve\% que e possivel representar midias como objecos (objetos na concepcào plena presente no Paradigma da Orientação a Objetos da ONG - (Object Management Group), esta proposta oferece formas para que o usuario pussa interagir livremente com cada objeto que compoe uma ou mais cenas em uma sessào de multimídia em um ambiente interativo.

Como resultado dessa concepção, a qualidade da multimídia apresentada ao usuário passa a ser controlada não somente pela aplicaçào e pelos recursos computacionais disponíveis (computadores, players, codificadores e decodificadores, dentre outros), mas também pelas características de lodas as entidades que compóem o ambiente interativo em questào, incluindo-se a infra-estrutura de comunicação, os dispositivos sensoriais e o(s) perfil(is) do usuário. Desta forma, é possivel personalizar, em diversos niveis definidos pelo projelista, a distribuição e o consumo de multimídia interativa de forma persona lizada às caracteristicas de um determinado ambiente. Como prática descjável para o projeto desses novos ambientes, a modelagem torna-se um elemento essencial, hem como a observaça e o uso de padroes que permitam a interoperabilidade, openness e reusabilidade, dentre outras várias características descjáveis.

\subsection{Trabalhos relacionados}

A crescente evoluçào dos sistemas digitais integrados e o forte apelo que sempre existiu pela distribuição de áudio, vídeo e informacóes associadas, com boa qualidade, fizeram com que a investigação dos novos sistemas multimídia ganhasse um caráter absolutamente multidisciplinar, envolvendo, no campo das Ciências de Computaçăo, esforços de subáreas como a Multimídia/Llipermúdia (com ênfase na codificação e distribuiçào de mídias e informaçào associada, e também em esquemas de descrição e intercâmbio de dados multimídia), Engenharia de Software (com ênfase em técnicas de modelagem), Inteligência Computacional (com enfase no campo dos agentes de software), Interaçào UsuárioComputador (com ênfase em consciência de contexto) e Redes de Computadores (com ênfase na infra-estrutura de comunicaçao), dentre outras cujo potencial de integraçáo tem sido investigado. Neste sentido, ao apresentar alguns trabalhos relacionados a esta tese, é necessário categorizá-los na tentativa de identificar, com clareza, as fronteiras a partir das quais esses trabalhos impactam e/ou são impactados pelas contribuiçóes aqui reportadas. 
No campo da modelagem de sistemas multimídia, Sauer e Engels (Saucr \& Engels, 1999; Engels, 2000) propuseram um modelo U.ML para sincronizaçào de componentes multimidia, porém sem considerar aspectos de consciéncia de conlexto e sem explorar a codificaçäo das mídias como objelos. Van Setten e seus colaboradores propuseram uma modelagem do ambientes multimidia inlerativos a partir da definiçáo de calegorias de interalividade e niveis de personalizaço (Van Selten, 2001; Van Setten et al., 2001). No entanto, o trabalho ainda näo contempla as relaçoes entre a personalização a a representação de conteúdo multimídia. Consciência de contexto tem sido investigada como forma de prover personalizaçào, exclusivamente.

No campo dos agentes de software, Bellefemine e seus colaboradores (Bollefemine ot al., $2001)$ propuseram o implementaram a plataforma JADE (arn Agents Denelopme'nl Framework), que apresenta os principais recursos para desenvolvimento de aplicaçós bascadas em agentes e suporta os requisitos de mobilidade. Vo encanto, os aspectos de consciência de contexto nào são ainda ulilizados pelo francrork. Além disso, mecanismos de inlegração dos agenles JAVA com a API MPYGG-I (ISO), 1999d) nào foram especificados, o que possibilita exlensoes na plataforma IADE a partir da modelagem proposta neste trabalho.

Vo campo da consciência de contexto, Dey c Abowd (Dey \& Abowd, 1999) propuseram a representaçào de contexto a partir das entidades WIIO, WIIEN, WI IA'T, WI IERL e HOW. pesquisa de Dey e Abowd concentra-se, principalmente, no suporte ao desenvolvimento de aplicaçoes que necessitem utilizar informaçoes contextuais, sem, no entanto, mostrar esforços com a formalização des aspectos de consciência de contexlo e com a investigaçào dos diversos niveis e critérios de interaçăo que podem surgir a partir do uso de consciéncia de contexto.

Por último, no campo das aplicaçöes, mais precisamente da lelevisào interativa, iniciativas importantes foram foitos em busca de padronizaçào e modelos para distribuição, apresentaça e consumo de multimídia interativa. Dentre essas inicialivas, os traballhos do

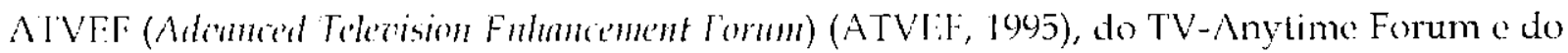
W3C Consortium merecem ser relacionados a esta tese. O W3C Consortium, observandon descjo de integraçào da ITV com a Web, criou um novo LRI (Uniform Resontere Indicator) (Bernes-Lee et al., 1998), denominado 'tv' (Finseth, 1998; Vickress, 2000). O ATVLI' especifica melhorias nas funcionalidades atuais da delevisăo convencional s propöe funcionalidades 
novas, principalmente relacionadas à interaçào. O centro dos esforços do A'IVFF é a união da TV atual com a Internet, especificando para cada padrão de TV (PAL, NTSC, DVB, dentre outros) como transmitir através do protocolo UНТТР (Unidirecional Hypertext Transfer Protocol), protocolo esse definido pelo ATVEF (ATVEF, 2000). O TV-Anytime Forum busca especificar uma nova TV, com novas funções (incluindo Internet) e novas formas de interaçăo. Esse padräo é mais completo a mais complexo que o padrào que está sencto definido pelo A'TVFF, sendo totalmente digital e buscando estruturar os programas oferecidos, fornecendo formas padronizadas para acesso a conteúdo (TVAF, 2000a; TVAI, 2000h).

Apesar da complexidade e abrangência desses padrões, nenhum deks contempla modelos e modelagens para aplicaçoes interativas. Adicionalmente, os trabalhos que estào sendo desenvolvidos na área de televisão interativa raramente levam em conta aspectos como contexto e consciência de contexto, e adaptabilidade às necessidades do usuário como forma de melhorar a interatividade.

\subsection{Metodologia}

O contexto no qual este projeto se insere é atual, tanto em termos da pesquisa em Ciência da Computaçào quanto em termos de aplicabilidade na cadeia produtiva dos complexos sistemas multimídia interativos que devem emergir. Neste ponto, é interessante e bastante razoável adotar uma estratógia do investigacào haseada $\mathrm{cm}$ uma contínua prospeção tecnológica e acompanhamento das atividades de desenvolvimento e padronização das tecnologias utilizadas neste trabalho.

Ao propor a modelagem de ambientes interativos conscientes de contexto, esta tese considera as seguintes definições:

- ambiente: pode ser visto como uma macro-entidade que contém uma aplicaçào multimídia, toda a infra-estrutura de comunicação necessária, elementos de hardware e software, dispositivos sensoriais e suporte à interação do usuário, além do próprio usuário;

- interativo: refere-se a toda e qualquer interaça entre os elementos presentes em um ambiente; 
- consciente de contexto: identifica o uso de técnicas para provimento de informaçôes contextuais que permitam adaptabilidade do ambiente às necessidades do usuário e do próprio ambiente como um todo.

Adicionalmente, termos complementares sảo considerados na composiçāo da proposta:

- sistema: pode ser visto como um conjunto de elementos do ambiente, sendo, portanto, arranjos de um ambiente;

- aplicação: uma solução de software que pode ser utilizada como um elemento componente de um ambiente ou sistema;

- multimídia: o conjunto de midias (nesta proposta, objetos de mídia) utilizáveis no desenvolvimento de uma aplicaçào de sof tware (aplicaçăo multimídia).

Ainda no campo das definiçoes, o conceito de modelagem é visto nesta proposta como sendo a especificaçào e intregraçăo de modelos para prover uma referência para prototipaçào e desenvolvimento, neste caso, de ambientes interativos conscientes de contexto.

A partir da compreensão dessas macro-definiçōes, estudos exploratórios foram realizados nos primeiros 24 (vinte e quatro) meses do prograna de doutoramento, com vistas a identificar o escopo da proposta e também as bases tecnológicas que poderiam suportar o désenvolvimento deste trabalho.

A revisão de literatura, conforme pode ser visto nos trabalhos relacionados na Seçào 1.3, evidenciou que existem modelos, técnicas e metodologias para o desenvolvimento de aplicaçōes multimúdia e hpermídia (especialmente ayuelas orientadas por hiperdocumentos), porém sem contemplar a definiçăo de ambiente defendida neste trabalho. Adicionalmente, o conceito do que é interativo estrapola o universo da interaçào usuário-compulador, uma vez que esta proposta considera a interaçào que ocorre em todos os niveis do ambiente (interação usuário-aplicaçào; interaçào aplicação-rede; interação usuário-ambiente, do ponto-de-vista de lodos os dispositivos e agentes que fazem parte do ambiente).

A partir da definiçào de que a modelagem deveria cobrir as interaçòes em lodo o ambiente, a o foco da investigaça centrou-se na consciência de contexto, considerando que o ambiente, para reagir de forma aulomatica às interaçóes, deveria ser consciente de lodos os seus dementos e de todas as interaçoes geradas por esses clementos. Da investigaçào de 
literatura, várias propostas de uso de consciência de contexto foram consideradas. No entanto, o modelo de Anind foi utilizado como referencia, uma vez que define as entidades contextuais c apresenta mecanismos para uso de consciência de contexto no desenvolvimento de aplicaçoss, enyuanto oulras propostas têm seu foco apenas na aplicaçào dos conceitos de consciência de contexto (Dey \& Abowd, 2000).

Analisado o modelo de Anind, pôde-se verificar que havia necessidade de especificar extensóes nesse modelo para contemplar o uso de consciência de contexto em ambientes interativos, considerando a definição de ambiente proposta nesta tese.

Quanto à investigaşào tecnológica, os padròes MPEG-4 e MPEG-7 foram exaustivamente estudados e analisados (ISO, 1999a; ISO, 2000a), sendo que todo o processo de padronizaça foi observado quando do uso destas tecnologias nesta tese.

Desta metodologia de investigação científica é que surgiram as duas principais contribuiçôes deste trabalho: a) um modolo de interaçoes bastado em consciência do contextor a adequado à adaptabilidade de todas as interfaces do usuário como o ambiente; b) a especificaçào de modelos de interação e a integraçà desses modelos para compor a modelagem de ambientes interativos conscientes de contexto. Lssas contribuições são apresentadas nas próximas seções e disculidas ao longo da tese. Adicionalmente, os padrões MPLG-4 e MPEG-7 forneceram as interfaces suficientes para suportar o desenvolvimento de aplicacoes multimidia e a construçào de ambientes interativos com os requisitos de interaçāo especificados pela modelagem aqui reportada.

\subsection{Objetivos}

A computação ubiqua proporciona ao usuário a expectativa de que é possível acessar informaçoes e serviços de qualquer ponto, geograficamente definido, e a qualquer momento. Os requisitos de mobilidade fazem com que o contexto do usuário seja alterado de acordo com a sua kocalizaçầ, identidade e demais entidades que estejam envolvidas num determinado ambiente. Neste sentido, os avanços nas tecnologias associadas à multimídia interativa trazem consigo novas expectativas em relaçào às tradicionais formas de interaçào multimídia. 
Conforme citado, as informaçoes contextuais podem auxiliar na definiçäo e execuçào dos ajustes necessários para uma apresentaça multimidia com um determinado grau de qualidade de serviço, provendo adaptabilidade e personalizaçào, porém conservando os niveis de interatividade esperados pelo usuário (McCanne et al., 1996; Dey \& Abowd, 2000).

Lste trabalho, ao ter propor uma modelagem para ambienles interafivos conscientes de contexto, especifica métodos para integraçào de tecnologrias como MPEG-4 (ISO, 1999a; ISO, 2001a), MPFG-7 (1SO, 2000a), XML (Connoly, 1997), dentre outras, e aponta para modelos de desenvolvimento de aplicaçoes interativas, tais como TVI, videoconferência, video-sobdemanda, dentre outras. A Figura 1.01 apresenta a estrutura gráfica do escopo coberto pela modelagem proposta. A modelagem, entào, é composta por três modelos distintos, a saber:

NECIAR (Netoork Fnironment with Context-Awarene'ss Rules): cobre a infra-estrutura de comunicacáo necessária a aplicagóses interativas conscientes de contexto, principalmente em termos dos requisitos de rede;

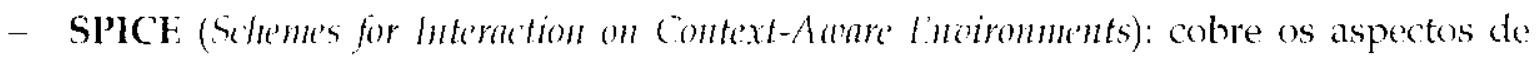
modelagem que definem esquemas e critérios de interação para o modelo de interaçoes completas (complete interiction $\rightarrow$ user-network-application);

PRACTIC (Profile for Context-Aware Interactice Applications): cobre o modelo da geração de perfis de aplicaçoes interativas, sendo composto pelo PRACTIC-E (PRACTIC l'rogram Fumples) - que cobre a especificaçäo de perfis para instâncias de aplicaçoes interativals, como é o caso de programas de TVI - e pelo PRACTIC-S (I'RACTK Schemul) - que cobre a especificação de esquemas de descriçăo para aplicaçeses interativas genéricas (Faria, Santos Ir., Goularte \& Moreira, 2001);

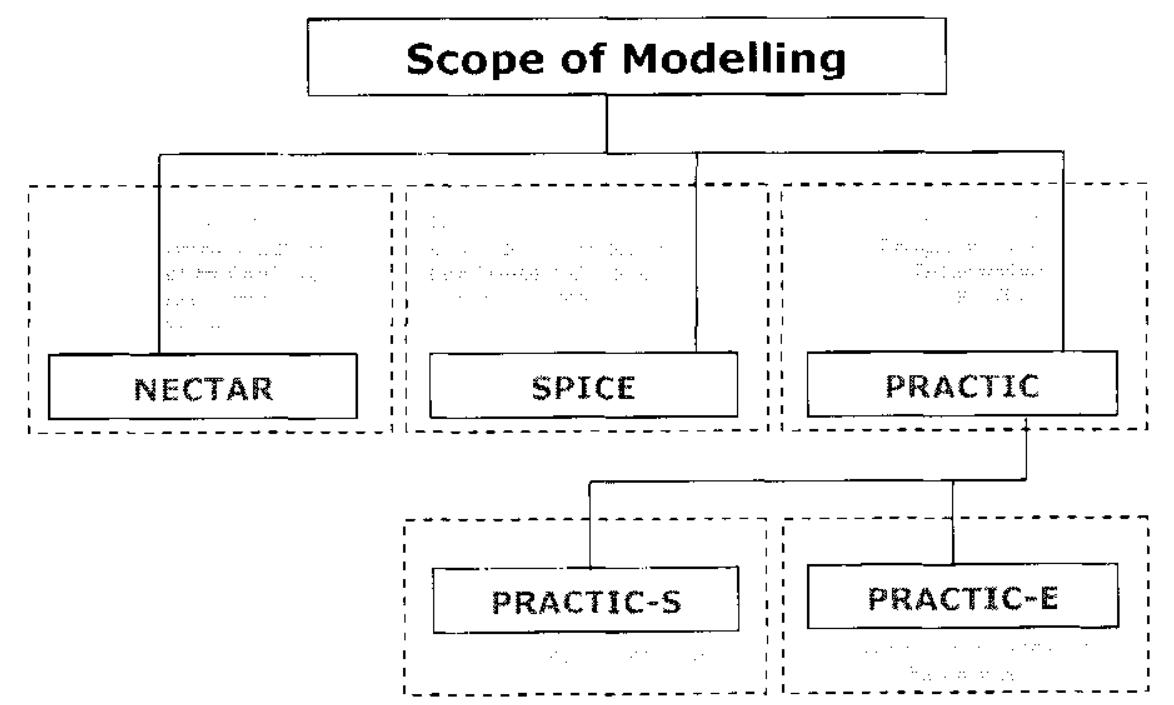

Figura 1.01: O escopo da modelagem - estrutura gráfica (Santos Jr. et al., 2001b) 
Os modelos propostos consideram que o uso de aspectos de consciência de contexto pode ser dividido em três categorias distintas:

- controle dinâmico de objetos: a tecnologia MPLG-4 permite a composição de cenas multimidia a partir de objetos de midia independentes; esses objetos apresentam, então, potencial para serem manipulados separadamente. Para que isto se torne possível, as descriçós de objetos (forma, conteúdo, açós e relacionamentos) devem incorporar semânticas de consciência de conlexto que permitam à aplicaçào estar sempre consciente do estado corrente de cada um desses olvetos;

- adaptação dinâmica da aplicação às condições da infra-estrutura: as interfaces interativas devem prover mecanismos para especificação da qualidade dos componentes de uma apresentação multimúdia; uma vez que o usuário especifica a qualidade, esses parâmetros devem permanecer aceiláveis durante toda a apresentaçào;

- adaptação dinâmica da aplicação ao contexto do usuário: existem situações nas quais a interface deve se adaptar automaticamente ao contexto do usuário; dependendo das informaçoos descritas pelas semânticas contextuais e parâmetros de consciencia de contexto, tais como identidade, localizaçào, açoes e tempo, serviços e funçôes podem ou nào ser habilitados ao usuário.

É importante observar, em termos de objetivos, que a segunda categoria auxilia o trabalho de produtores de conteudo multimidia e gerenciadores de rede. As duas outras categorias podem trazer benefícios diretamente aos usuários finais.

\subsection{Inovações}

As inovaçoes presentes neste trabalho estão concentradas no fato de que os padröes, tecnologias e modelos, propostos até então, não consideram as interaçoes existentes entre a infra-estrutura de comunicação, a aplicaçào e os objetos de midia que compòem uma ou mais cenas multimídia, uma vez que a representaçâo das mídias como objetos foi possivel somente após a padronização do MPEG-4. Desta forma, os aspectos de consciência de contexto são utilizados sempre ao nível da aplicação e näo há preocupação em formalizar os critérios de interação para uso da consciência de contexto e, nem mesno, de formalizar a semàntica dos elementos contextuais WHO, WHAT, WHERE e WHEN (D) \& Abowd, 2000). Ao formalizar os aspectos de consciência de contexto, dentro do universo das aplicaçoes interativas, este trabalho representa um avanço na diregão dos novos tipos de interaçào que são esperados para a nova geração de aplicações multimídia. Algyumas funções 
tradicionais de controle remoto, por exemplo, tendem a desaparecer e outros tipos de mecanismos de controle devem surgir muito em breve, o que reforça a importância da modelagem dos ambientes interativos conscientes de contexto, e nâo somente das aplicaçōes multimidia.

O uso de aspectos de consciência de contexto tem sido largamente pesquisado no domínio das aplicaçôes e das redes de comunicaçào de dados, porém é uma inovação na modelagem de ambientes multimídia interativos.

Este trabalho lambém inova na direçào da definiçăo dos conceitos de perfil de aplicaçào interativa e de programa interativo, que sào apresentados de forma compativel com as tecnologias MPHG-4 e MPFG-7, gerando exkensões a essas tecnoloyias de modo a possibilitar o uso integrado da aplicasăo com o ambiente.

\subsection{Principal contribuição original}

A modelagem proposta nesta tese visa definir e formalizar novos tipos de interação gerados por uma aplicacáo inserida em um ambiente interativo. Nesses ambientes, mecanismos tradicionais como VCR (Vikfo Cassette Recorder) e STB (Set-Top Box) tendem a ser substituidos por dispositivos sensoriais, o que sinaliza para a interaça usuário-ambiente ao invés da interaçäo usuário-computador. A modelagem auxilia o desenvolvimento dessas aplicaçoes interativas por apresentar um conjunto bem definido das interaçoes greradas pela comunicação entre as entidades usuário, rede, aplicação e terminal (Santos Jr. et al., 2001a; Santos Jr. et al., 2001b). A modelagem, ao contemplar a consciência de contexto, apresenta avanços para o desenvolvimento de aplicaçöes complexas, como é o caso dos ambientes classificados como wearable computing e ubiquitous computing.

Os modelos NECTAR, SPICE e PRAC"IC, em sua concepçà, consideram as potencialidades dos padroes MPEG-4 e MPEG-7. Particularmente, O MPEG-7 é utilizado para oferecer suporte à personalizaçăo do a mbiente através de esquemas de descriçăo das cenas multimídia. Como passo em direção a um futuro ainda mais promissor, a modelagem contempla o uso do mais novo padrão da lamília MPEG - o MPEG-21 - como tecnologia para a construçào de novos esquemas de representação de objetos de mídia como itens digitais universais. O novo padrão provavelmente acrescentará importantes elementos à modelagem proposta. 


\subsection{Estrutura do trabalho}

Esta tese está estruturada em sete capítulos. No Capítulo 2, é apresentada uma visão geral do campo da multimídia interativa e distribuída, com destaque para uma descriçào detalhada das caracteristicas e funcionalidades dos padroes MPFG-4, MPEG-7 e MPEG-21. No Capítulo 3, é apresentado o estado da arte em técnicas, modelos, linguagens, metodologias e framezorks que podem ser utilizados para a modelagem de aplicaçoes multimídia; uma atenção especial é dada às características da linguagem UML, escolhida como ferramenta para a construçào da modelagem proposta nesta tese. A formalizaçào dos aspectos de consciência de contexto aplicáveis a ambientes interativos é apresentada e discutida no Capítulo 4. No Capítulo 5, us modelos NECT AR, SPICE e PRACTIC, que compõem a modelagem proposta, são apresentados em detalhes. No Capítulo 6 , é discutida a construçào de uma aplicaçào de Tolevisào Interativa, servindo como estudo de caso para avaliaçầo das principais limitaçòs da modelagem proposta. No Capítulo 7, sào discutidas as principais contribuiçòes deste trabalho e apresentado um cenário para futuras pesquisas.

Vo $\Lambda$ pêndice $\Lambda$, é apresentado um resumo do Relatório das Atividades Realizadas no Exterior, mais precisamente nos laboratórios da Telecom Italia Lab - IILAB (que era conhecido como CSELT - Centro di Studi e Laboratorio Telecommunicazioni), junto à Advanced Multimedia Division, em Turim, Itália, no periodo de maio a dezembro de 2001. Esse resumo de relatório foi incorporado à tese por descrever as atividades realizadas durante a estadia no exterior, atividades essas que permitiram aprofundar os estudos sobre os padrós MPEG-4 e MPEG-7, especialmente em termos do MPEG-4 Systems, Al'l MPEG-J e inteģracào de stremis MPEG-7 em streams MIPG-4. O relatório completo encontra-se registrado e depositado nos arquivos do CSELT, mediante aprovaçăo dos supervisores da pesquisa no exterior.

No Apêndice B, são apresentados os resumos e/ou abstracts dos artigos publicados como resultado deste trabalho (Santos Jr. et al., 2001a; Santos Jr. et al., 2001b; Faria, Santos Jr., Moreira \& Goularte, 2001; Santos Jr. cet al., 2002a; Santos Jr. et al., 2002h). 


\subsection{Considerações iniciais}

En meio à revoluçâo diģital que ocorre atualmente, a distribuiçăo de multimídia é cada vez. mais um foco importante na área tecnológica, quer seja no meio acadêmico quer seja na indústria.

Os aspectos que envolvem a produçăo, a distribuição e a apresentaşão de multimídia tornam-se cada ver mais complexes e a padronizaçào apresenta-se como elemento fundamental para nortear o uso de multimidia em um mundo cada vez mais globalizado e digital.

Com o desenvolvimento contínuo das lecnologias para multimídia interativa, um vasto número de aplicaçóes tornou-se possível. As diferentes possibilidades de interação do usuario com os objetos de mídia que compoem o vídeo trazem consigo a necessidade de modelagem dessa interaçăo em direçào aos aspectos de adaptação e personalizaçào da interface. Adicionalmente, a convergència de midias e entre os meios de comunicaçáo tende a permitir a inserção do usuário em um ambiente cada vez mais interativo, passando esse usuário a fazer parte desse ambiente, juntamente com todos os componentes de hardware e software da aplicação, também inserida como componente desse ambiente (Kate, 1998).

Neste capítulo, é apresentada uma visào geral do campo da multimídia interativa e distribuída, com destaque para uma descriçăo detalhada das características e funcionalidades dos padröes MPEG-4 e MPEG-7.

\subsection{Tecnologias associadas à multimídia interativa: uma breve apresentação}

No campo da multimídia interativa, muitas são as tecnologias que podem ser utilizadas no desenvolvimento de aplicaçōes. Fm linhas gerais, essas tecnologias se aplicam às três fases de um projeto multimúdia: produçào, distribuiçào e apresentaçào. 
As tenologias de produçào e distribuição são direcionadas à composição e entrega de objetos de midia e documentos a um usuário ou grupo de usuários, usufruindo da infraestrutura das redes de comunicação. Existe uma coleção bastante rica de protocolos de distribuição, que contempla desde a distrihuiçào de midias audiovisuais simples fcomo é o caso de áudio e video) até as descriçōes de ambientes complexos (como é o caso de cenas de realidade virtual). Adicionalmente, aspectos de sincroni»açào têm sido investigados no contexto das tecnologias de distribuiçào, especialmente no caso de ambientes multimídia couperativos.

As tecnologgias de apresentaçáo contemplam us aspectos de protocolos gráficos para exibiçào de conteúdos e informaçóes de ohjetos de mídia, bem como para visualização de hiperdocumentos, especialmente no contexto da WWW.

As Subseçòes 2.2.1 a 2.2.5 apresentam uma breve descriçào de um subconjunto de tecnologias para produção, distribuiçào e apresentação de multimídia interativa.

\subsubsection{SMIL}

Un sistema multimídia é uma coleçào de componentes de hardware e software relacionados entre si e que devem ser selecionados de forma a funcionarem juntos. De modo geral, esse conjunto de componentes é formado pela placa de vídeo, barramento de dados, controladoras, software de aquisiçào, software de ediçâo, software de autoria e/ou programação e mídias de distribuiçào.

Os sistemas multimídia envolvem fortemente a captura, a transmissào e a apresentação de midias, sendo desejável em muitas aplicaçòes que técnicas de sincronizaça sejam aplicadas para temporizar a apresentaçào das múltiplas mídias em uma cena.

A linguagem SMIL, desenvolvida pelas empresas Netscape, RealNetworks, Microsoft, I'hillips, Digital Equipment, além de diversas organizaçoes de pesquisa - Columbia University, CWI e INRIA -, é uma especificaçào do W3C (World Wide Web Consortium) para criar uma maneira de enviar fluxos de mídia sincronizados através do ambiente da WWW (W3C, 1998). 
A linguagem SMIL é capaz de descrever o comportamento temporal da apresentação, o linyout da apresentação na tela, além de associar hyperlinks a objetos de mídia. Com o uso da linguagem SMII, pode-se coordenar o timing dos objetos em uma apresentação multimídia, na qual cada objeto de núdia é acessado com um único URL, o que viabiliza apresentaçoes de objetos que estào localizados remotamente em lugares distintos.

Num contexto mais amplo, deve-se observar que com o uso da linguagem S.MIL, tem-se a possibilidade de criar, por exemplo, um texto introdutório que o espectador pode ler antes do início de um video. Pode-se, também, inserir um texto publicitário sonificado acompanhando a exibiçào de um vídeo.

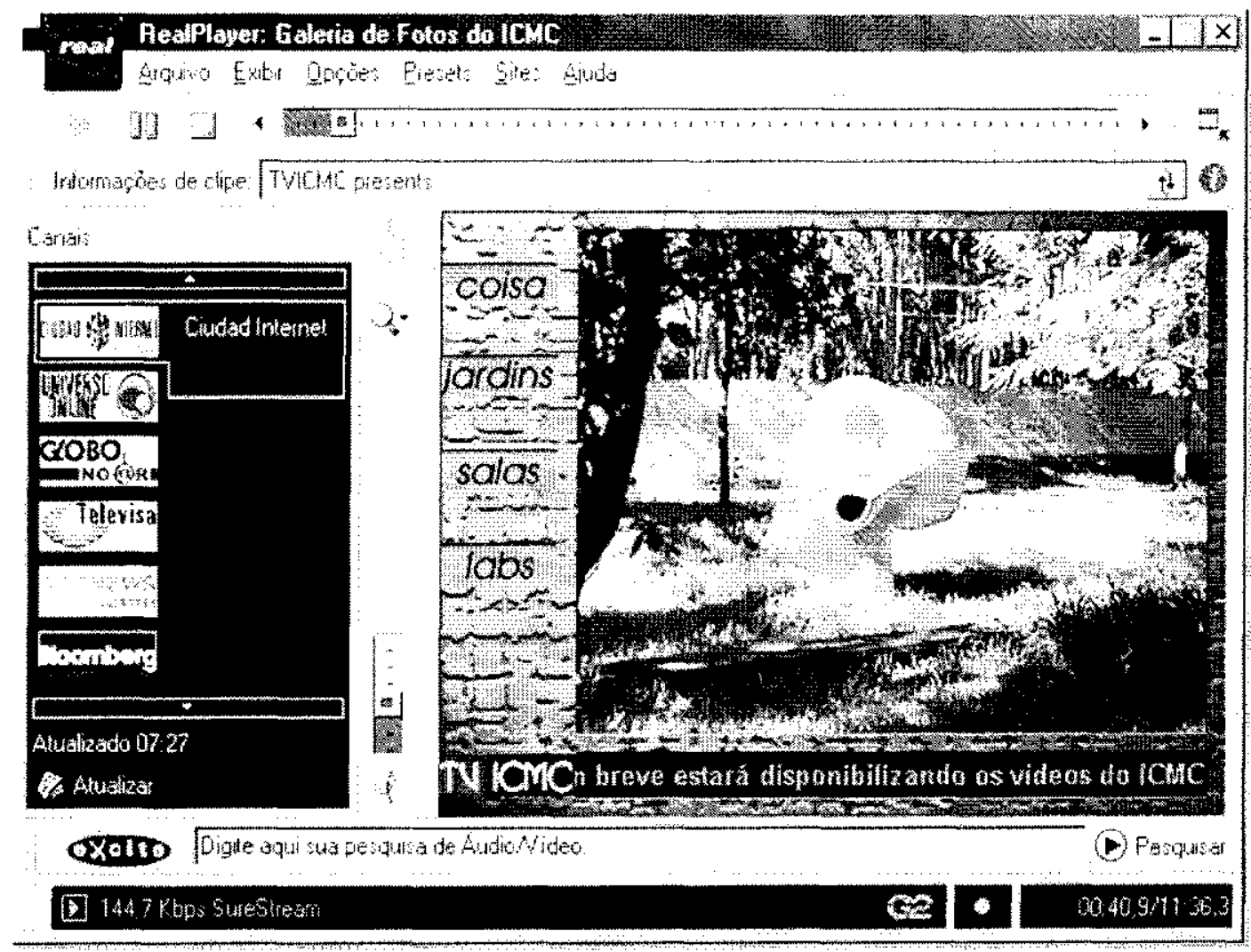

Figura 2.01 - Uma apresentação multimidia protocolada em SMIL

Atualmente, o uso da linguagem SMIL está restrito aos servidores Real, tais como Real'lext, RealAudio e RealVideo, conforme ilustra a Figura 2.01, mas espera-se que em breve os browsers de uso disseminado incorporem mecanismos interpretadores para tecnologia SMIL. Neste ponto, quanto ao uso da linguagem SMIL, pode-se produzir um texto introdutório, que será salvo como arquivo do RealText, seguido de um áudio que é manipulado pelo RealAudio. Por fim, um vídeo pode ser inserido através de um arquivo do Realvideo, e o texto final, sincronizado com o vídeo, pode ser manipulado pelo RealText. 
Uma potencialidade adicional da linģuagem SMLL reside no fato da apresentaçāo de conteúdos multimidia que necessitam de visualizaçóes seqüenciais e paralelas e que explorem, de maneira temporal, os sentidos de percepção (audição e visão) do leitor, e que contemplem, de forma associada, requisitos de consciência de contexto para identificação de propriedades de apresentaçào de uma cena e aspectus da infra-estrutura de comunicação (largura de banda, enderecos de rede que identificuem o idioma a ser utilizado), por exemplo.

\subsubsection{VRML}

A linguagem VRMI. (Virtual Réllity Modelling langhuge') é uma notaçăo baseada em scripts de texto que surgiu como um padrào para descrever formas e cenas $3 \mathrm{D}$ no ambiente da WWW. Pode ser vista, popularmente, como uma versào 3D da linguagem H'T'MI, sendo que a principal diferença reside no fato de que VRML não descreve texto ou referências gráficas, mas constrói vetorialmente objetos gráficos em três dimensióes e poligonais (VRMI, 1997).

Deve-se observar que a linguagem VRML é na realidade um formato de arquivo e não uma biblioteca de programação para aplicativos 3D, apesar da mesma dar suporte à criação de scripts.
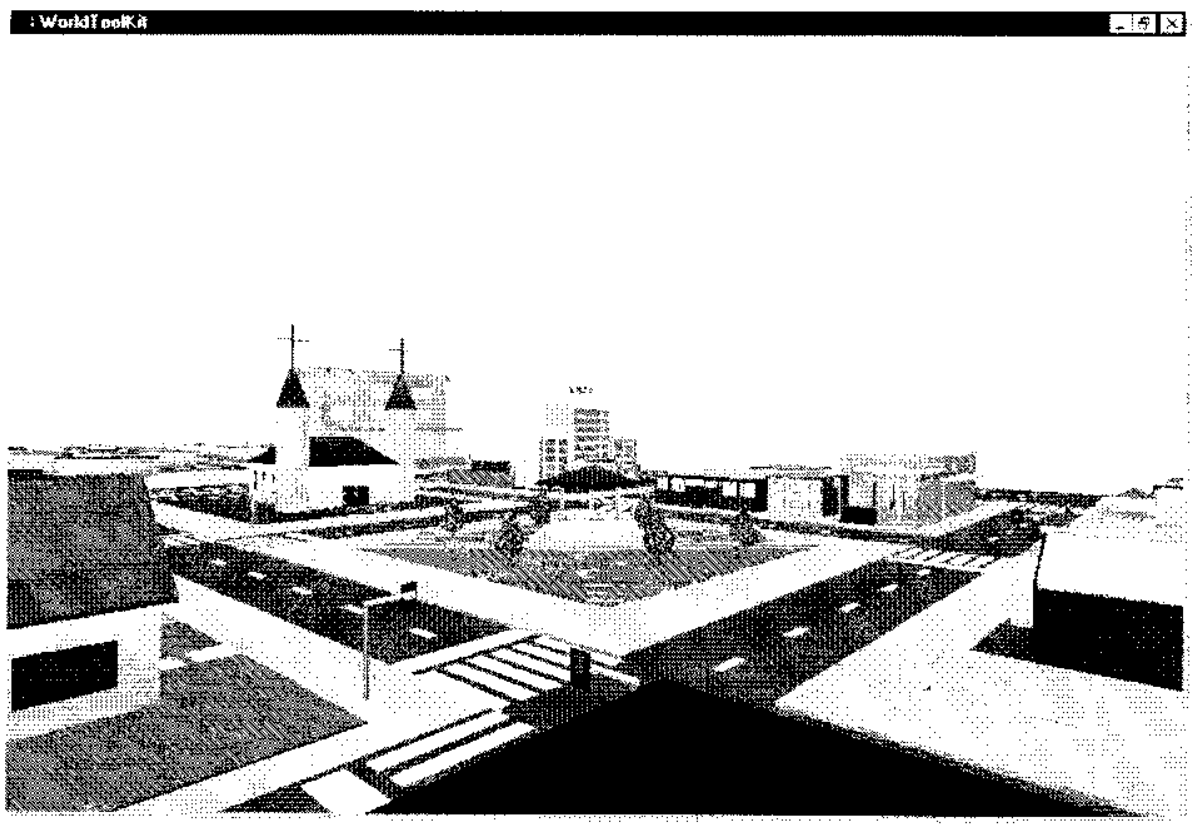

Figura 2.02 - Lm "mundo virtual" construido em VRMI.

Outra caracteristica inexistente em VRML è a capacidade de interaçào de múltiplos usuários no mesmo "mundo virtual". Este elemento básico para a fundamentação de realidade virtual 
e comunidades virtuais on-line' não se encontra implementado nas atuais versốes da linguagem, visto que exigem protocolos de comunicação e base de dados para que essas interaçōes possam ser realizadas eficientemente, apesar de ser uma característica que está sendo pesquisada e discutida, para futuras implementaçoes (VRML, 1997).

Aplicaçoes de VRML sáo amplas e incluem visualizaçato distribuida, interface 3D do usuário com recursos remotos do ambiente da WWW, ambientes 3D colaborativos, simulaçóes interativas, museus virtuais, dentre outras, conforme pode ser visto na Figura 2.02.

No caso particular dos ambientes interativos, pode-se aplicar a linguagem VRML na construçào de ambientes. 3D que permitam a interaçào simples do usuário através do motsese, estimulando a percepção do conteúdo com bom grau de realismo (Churchill, 1998).

\subsubsection{HTML e DHTML}

I ITML (Hyperlext Markup language) é uma linguagem, criada a partir da meta-linguagrem SGMI. (Standard Genernlized Markup Ianguage) (ISO, 1986a; ISO, 1986b; I lerwijnen, 1994), que se preocupa principalmente em organizar como um documento deve ser apresentado. Além disso, HTML surgiu devido à expansão da Internet è necessidade de uma linguagem simples para especificaçáo da forma de apresentaçáo dos documentos no ambiente da WWW.

A linguagem ITML possui tngs (etiquetas) pré-definidas que são utilizadas para especificar a informaçäo e a forma como esta informaçăo deve ser apresentada, tais como $\langle$ IEAD $>$, para definir o cabeçalho do hiperdocumento; $\langle\mathrm{H} 1\rangle$, para definir um tamanho de fonte; $\langle$ I'ABIE $>$, para definir uma tabela. $\triangle$ Figura 2.03 apresenta um documento formatado com o padrào HTML e o resultado da apresentaçào gráfica desse mesmo documento.

A linguagem IITML apresenta algumas caracteristicas relacionadas à sua flexibilidade, que constituem seus pontos negralivos (Bray at al., 1997; Johnson, 1999):

- HTML náo permite a especificaça de novos elementos e atributos;

- HTMr, representa a informaçăo em termos de seu layout;

- A alteração de um documento IITMI é bastante trabalhosa;

- IITML possui pouca estrutura semântica, pois seus elementos sào agrupados sem seguir uma estrutura pré-definida. 


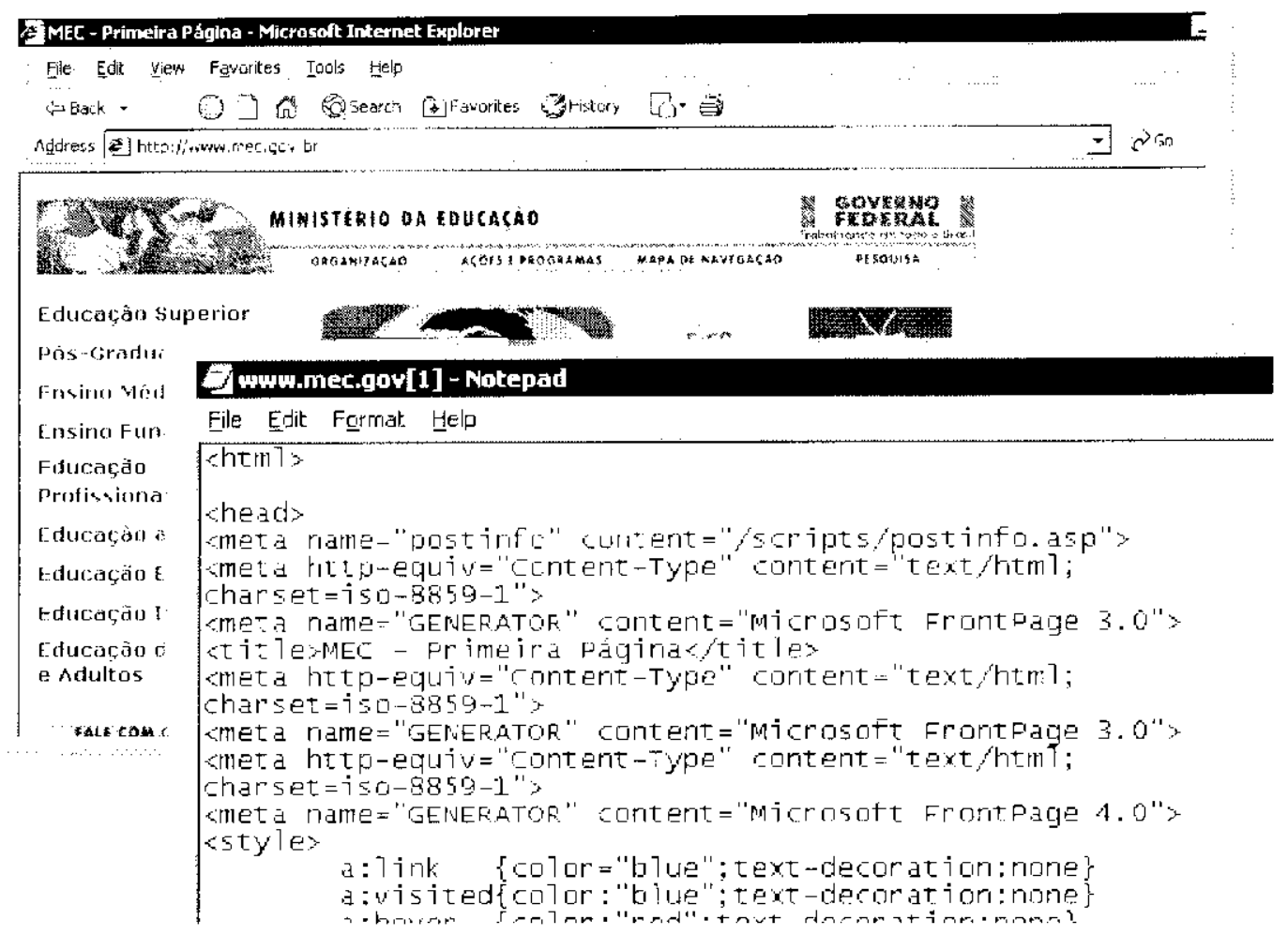

Figura 2.03 - Documento formatado de acordo com o padräo HTML

Apesar destas características, HTML é uma linguagem de singular importância, pois a simplicidade do código e a limitaçào no número de elementos que a constitui permitem que o seu uso seja extremamente simplificado e que qualquer pessoa com conhecimentos básicos de computaçăo possa implementar um hiperdocumento para ser apresentado no ambiente da WWW. Para suprir as desvantagens desta linguagem, novas tecnologias, mais poderosas, lêm sido propostas, como é o caso de DH'TiML (Dymamic HTML).

O advento do DHTML estabelece um novo ponto de referência com relaçào à interatividade no ambiente da WWW. Até então, os documentos HTML eram, em sua maioria, de uma natureza estática. Por outro lado, a inclusào de applets JAVA e controles ActiveX, por exemplo, introduz um certo nivel de interatividade; no entanto, a página em si continua a ser alg̣o estático.

Numa perspectiva inovadora, as páginas desenvolvidas com recursos DH'ML ganham "vida" com a utilização de scripts simples (por exemplo, desenvolvidos em JAVAScript), 
fáceis de desenvolver, e que tornam verdadeiramente dinâmicos os elementos de uma página, como mostra a ilustração da Figura 2.04.

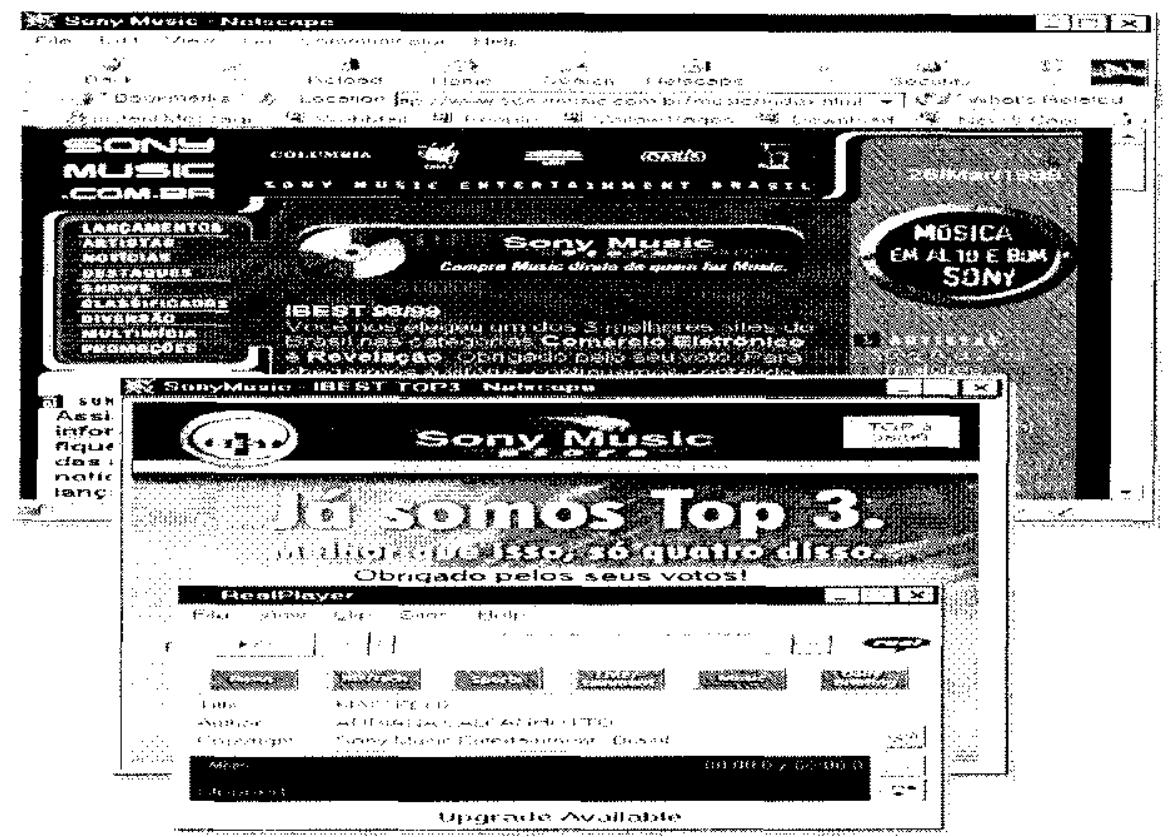

Figura 2.04 - Um exemplo de página HTML com recursos DHTMI

DHTML nào é uma extensào da linguagem HTML, nem tào pouco uma nova linguagem de programaçào. DHTML estabelece um nível superior de interatividade entre os scripts e os elementos da linguagem HTML incluidos em uma página. Nesta perspectiva, qualquer um dos elementos de uma página é modificável em tempo real, abrindo novas possibilidades de interatividade como, por exemplo, açòes de mostrar e ocultar textos como resposta à interaçào do usuário.

Dado que DHTML funciona no browser do usuário (leitor) - do lado clicnte da comunicação cliente/servidor - uma vantagem pode ser imediatamente relacionado: a reduçào drástica do tempo de resposta às açöes interativas. Finalmente, nào sendo menos importante, esta tecnologia abre novas perspectivas no que se refere ao desenvolvimento de conteúdo multimídia para aplicaçoes interativas no ambiente da WWW.

\subsubsection{XML}

A linguagem XML (Fxtensible Markup Langunge) tem por objetivo fornecer os beneficios inexistentes em HTMI, e ser mais simples que SGMI. 
A linguagem XML permite a construção de marcadores (tags) que especificam a estrutura de um determinado documento (Johnson, 1999). A lïgura 2.05 apresenta a definição de um conjunto de trags para uma aula no domínio de aplicaçào ensino, por exemplo. Pela Figura 2.05, observa-se a definiçầo de elementos que fazem parte da estrutura de uma aula, sem, no entanto, especificar como tais elementos devem ser apresentados ao leitor, no caso um estudante.

Observa-se que a modelagem é um aspeclo relevante em aplicaşöes multimídia. Percebe-se, por exemplo, que a definição de documentos estruturados permite a apresentação controlada de documentos a classes de usuários, o controle do uso do conteúdo pelo usuário, bem como o reuso de classes de documentos em mais de uma aplicação (Pimentel, Santos Jr. \& Fortes, 1998).

Como o próprio nome sugere, XML é uma linguagem extensível (meta-linguagem), com a qual os projetistas podem criar seus próprios elementos de acordo $\mathrm{com}$ a aplicação que estiver sendo modelada, dando importância ao conteúdo e à estrutura da informaçào, sem se preocupar com a apresentação (Connoly, 1997). Através desta característica, a flexibilidade da linguagem é ampla, uma vez que o projetista pode criar uma nova linguagem a partir da meta-linguagem XML.

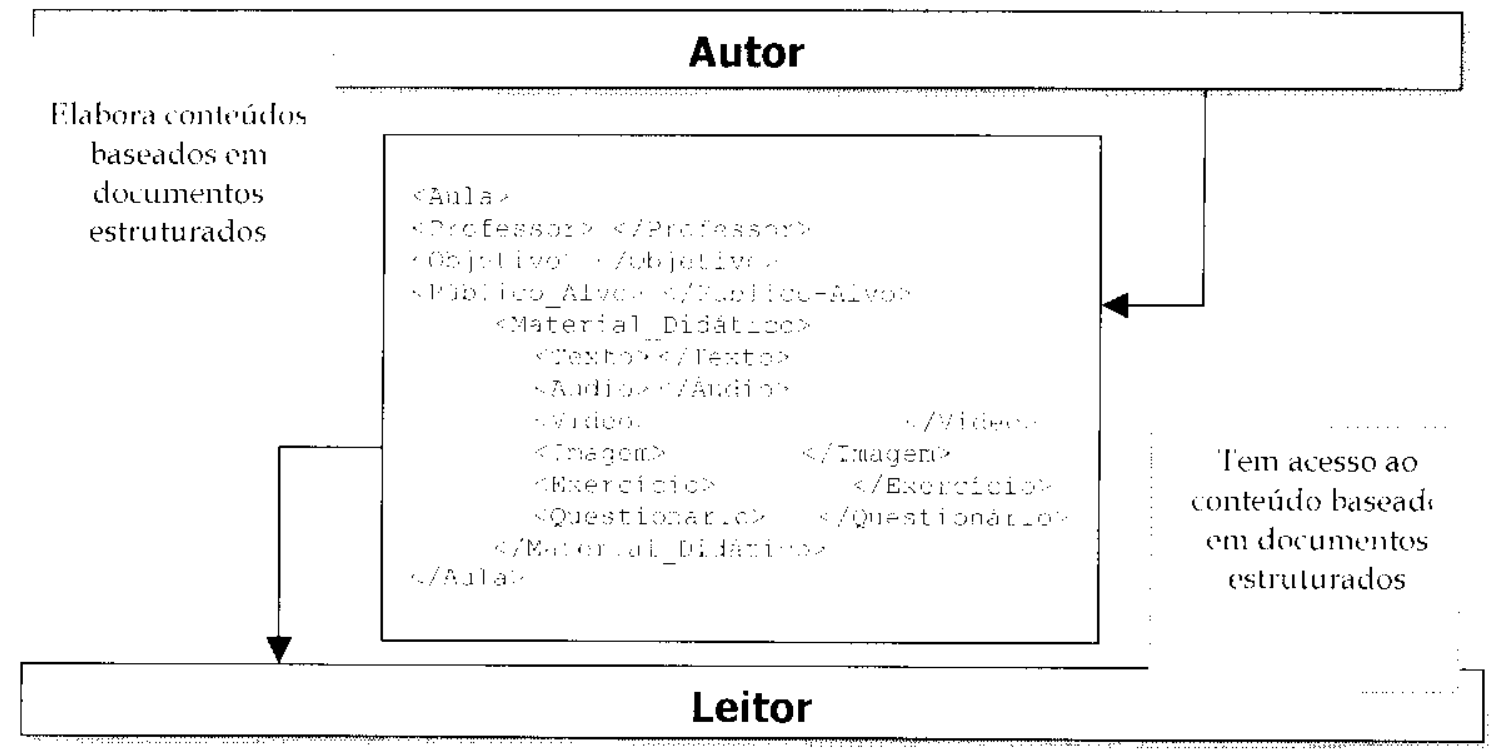

Figura 2.05 - Um exemplo de documento estruturado XMI para o domínio ensino

Através do exemplo da Figura 2.05, nota-se que nào há nenhum elemento que define como as informações contidas no documento X.ML devem ser apresentadas, diferente do que acontece em um documento formatado com a linguagem HIML. Sendo assim, pode-se dizer 
que XML considera apenas o conteúdo a ser apresentado. Portanto, existe a necessidade da utilização de outro recurso que seja responsável pelos atributos de apresentação. Esta tarefa pode ser realizada através da utilizaçào de programas específicos ou linguagens apropriadas para associar estilos ao conteúdo de um documento XML, como é o caso da tecnologia XSL, apresentada na Seção 2.2.5.

A interpretaçào de um documento X.ML ocorre através da utilizaçào de parser, que analisa o documento obtendo suas informaçòes de conteúdo para processamento. Esta função depende do tipo de purse'r implementado, do propósito da informaçäo e da estrutura semântica apresentada no documento XML. Cada documento XML pode ou não estar associado a uma linguagem especifica que define sua estrutura; essa definição é formalizada através da criaçào de um I'J'D. Genericamente, um D'l'D define regras para a especificaçào de uma classe de documentos, tais como (Halasz, 1994):

- que lipos de elementos podem existir em um documento;

- que atributos esses elementos podem ter;

- como as instâncias desses elementos estão hierarquicamente relacionadas.

A estrutura especificada em um DTD, segundo sua definiçào no padrào SGMl, possui uma propriedade importante: apenas a estrutura lógica de um documento é descrita, näo sendo fornecida informaçào sobre o conteúdo e apresentaçào dos elementos definidos.

Se o documento XML estiver associado a um DTD, o parser deve verificar se o documento XML está correto (porser de validação). Para isto o parser processa o D'l'I) que corresponde ao documento XML e obtém sua estrutura. Posteriormente, o parser ohtém as informações do documento XML realizando a validaçào com a estrutura definida no D'l'I). Por outro lado, se o documento XML nào está associado a um DID, então apenas a estrutura sintática do documento XML é verificada (parser sem validaçà)).

\subsubsection{XSL}

A manipulação de documentos formatałos através do padrão SGML envolve o uso de uma linguagem baseada em LISP, denominada DSSSL (Document Style Sennntics and Specification Language), para especificar como o documento deve ser apresentado, uma vez que caracteristicas de apresentação não estão presentes no documento SGML. O mesmo acontece con a utilizaçào de documentos formatados através da linguagem XML. Assim, o grupo 
responsável pelo desenvolvimento da linguagem XML desenvolveu também uma linguagem de apresentaçâo - XSL, que é utilizada para formatar o estilo de apresentação do conteúdo de um documento XMI (Johnson, 1999).

Lm documento XSL (Extended Style langunge) tem por objetivo "transformar" um documento XML em outros formalos de documentes, tais como HTML, TeX, Pest Soript e R'I'l (Lie, 2000). Através do uso de documentos XSL é possível criar múltiplas representaçōes (visões) de uma mesma informaçáe contida em um documente) XML. Um exemplo de sintaxe para formataçào de um documento XSL é apresentado na Figura 2.06.

Um documento XSI é formado por regras, denominadas templates. Um template é constituído de duas partes: pattern, que faz referência a um clemento; e action, que constitui o formato aplicado ao elemento referenciado pelo pattern. Os template's do documento XSL são aplicados ao documento XML e o resultado apresentado é a informação do documento XML formatada e organizada de acordo com as especificaçoes do documento XSL.

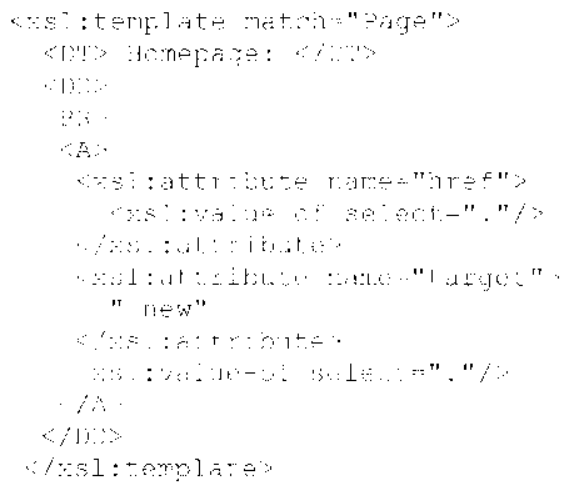

Figura 2.06 - Trecho de documento XSI, para formatar um elemento

A linguagem XSL permite a utilizaçáo de documentos formatados de acordo com a linguagem X.ML através de alguns brotesers, que são capazes de interpretar documentos XSL e XML e gerar apresentaçōes destes documentos, como é o caso do brotuser Internet Explorer versào 5 da Mícrosoft.

\subsection{A problemática da distribuição de multimídia}

Um sistema multimídia é uma coleçà de componentes de hardware e software relacionados entre si e que devem ser selecionados de forma a funcionarem juntos (Fluckiger, 1995). Fsse conjunto de componentes é formado, basicamente, pela placa de video, barramento de 
dados, controladoras, software de aquisiçào, soltware de ediçào, sof tware de autoria $\%$ ou programação e mídias de distribuiçào, conforme ilustra a Figura 2.07.

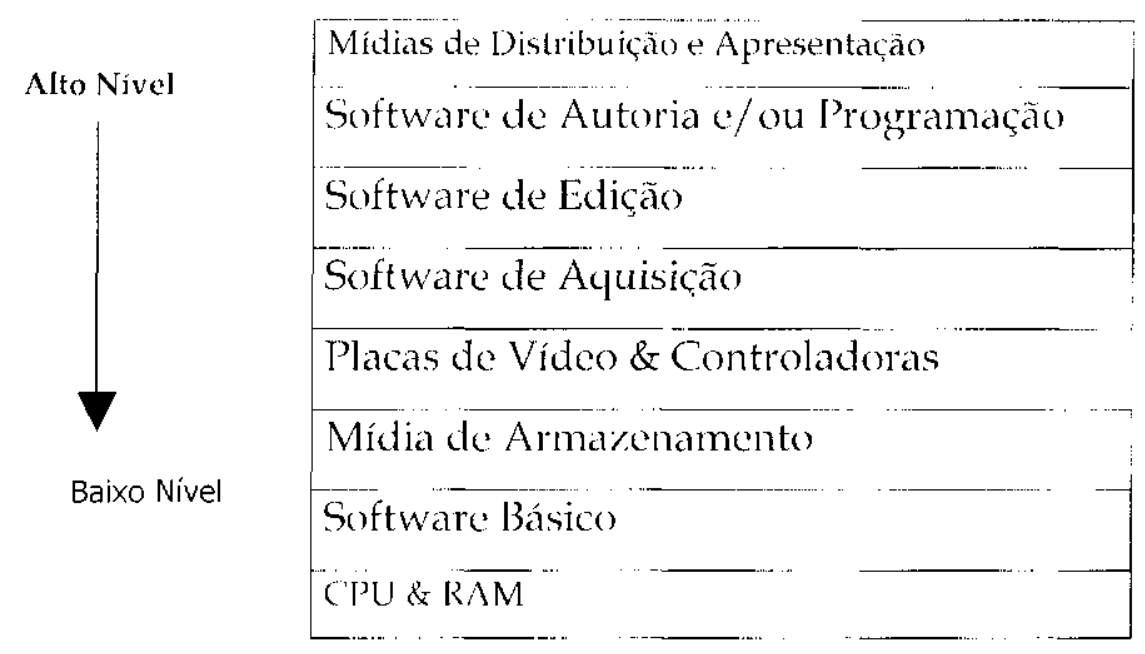

Figura 2.07 - Camadas de um sislema multimídia

O desenvolvimento de aplicaçôs multimídia comẹa com a escotha e compreensào dos principios da midia de distribuicào, uma vez yue as midias existenles possuem diferentes velocidades de transferencia, conforme apresenta a T'abela 2.01.

Tabela 2.01 - Algumas mídias de distribuiçäo e velocidades de lransferência

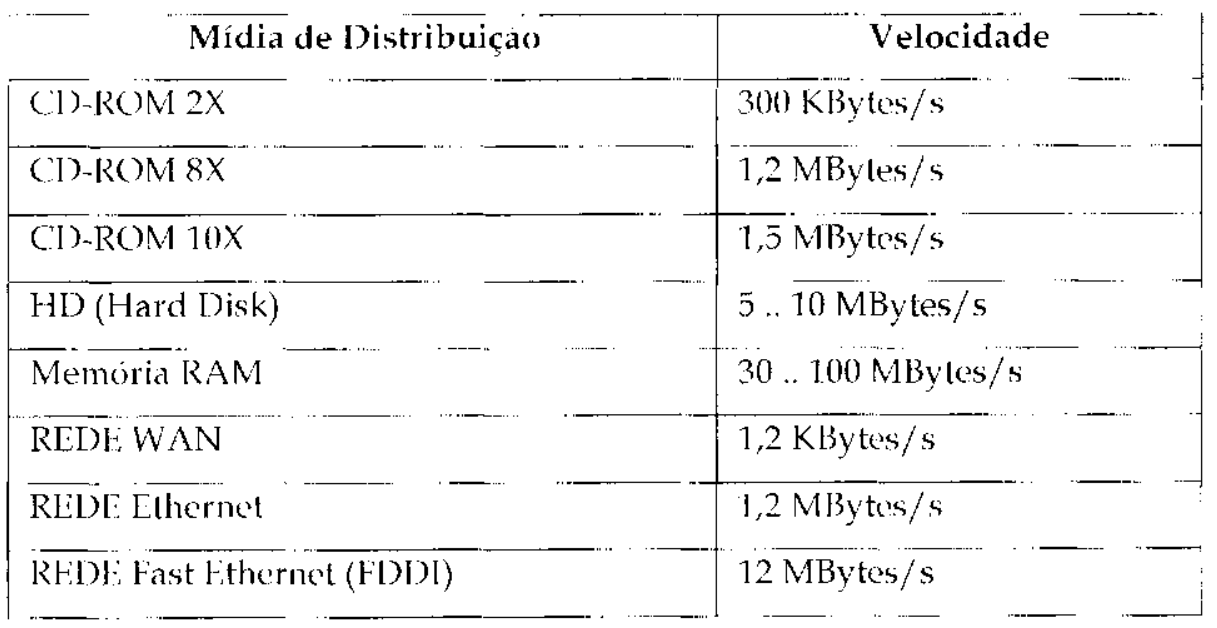

É importante, ainda, conhecer com precisào o espaço de armazenamento requisitado por um arquivo de mídia, especialmente as midias temporais como áudio e video. A Tabela 2.02 apresenta alguns exemplos de dados que indicam a quantidade de byles necessários para armazenamento de amostras de midias como audio e video digital. 
Em suma, deve-se observar dois conceitos importantes, quando do desenvolvimento de sistemas multimidia: sistema de desenvolvimento/autoria e sistema de distribuição. No sistema de desenvolvimento são necessários componentes de hardware como scanner, placas de captura de vídeo, câmera folográfica digital, unidade de CD-ROM, câmeras Cam-Corler (câmera filmadora com capacidade de gravação [recorder]), microfones e outros. Já no sistema de distribuiçäo, deve-se observar a existencia de um hardware com os acessorios essenciais à aplicação. Por exemplo, se a mídia de distribuição utilizada no desenvolvimento for um CDROM de velocidade $8 X$, então no sistema de distribuição (ao nivel do usuário) devé-se ter uma unidade de CD-ROM com velocidade $8 X$ ou superior.

Tabela 2.02 - Relaçăo das taxas de armazenamento para algumas mídias

\begin{tabular}{|l|l|l|l|}
\hline \multicolumn{1}{c|}{ Mídia } & \multicolumn{1}{c}{ Taxa de Amostragem } & \multicolumn{1}{c|}{ Número de Bits } & Armazenamento \\
\hline Sudio & 44,1 samples/s & 16 bits & 88,2 Kbytes $/ \mathrm{s}$ \\
\hline Vídeo & 8 Msamples/s & $\begin{array}{l}24 \text { bits (truc color) } \\
30 \text { frames } / \mathrm{s}\end{array}$ & $1,6 \mathrm{Mbytes} / \mathrm{s}$ \\
& & & \\
\hline
\end{tabular}

No contexto da multimidia, potencialmente, observa-se que o desenvolvedor pode usufruir de recursos que permitam a sofisticação das aplicaçoes. Neste ponto, existem algumas regras que podem ser usadas por usuários e desenvolvedores para nortear e avaliar sistemas multimídia/hipermídia, a saber (Harrisson, 1996):

- a regra da multimidia: um sistema hipermídia não deve manipular somente os tipos de dados básicos (caracteres, números e datas), mas também proporcionar sofisticacoes ao sistema sensorial do ser humano através de graficos coloridos em 2D e 3D, áudio, imagem, vîdoo, texto e widgets (objetos gráficos, como botões, ícones e outros);

- a regra do objeto: um sistema hipermídia deve empregar metáforas de objelos na interaçào, armazenamento e criaçào de aplicaçōes;

- a regra dos scripts: um sistema hipermidia deve fornecer linguagens de script acessivel que permitam a extensão c a modificação do comportamento do sistema e dos seus elementos, onde entende-se por script como sendo um programa curto que pode ser relacionado com um objeto para especificar seu comportamento sob várias condiçôes;

- a regra multi-usuário: um sistema hipermídia deve suportar a construção cooperativa de aplicaçōes por vários autores, c a execução dessas aplicações por 
vários usuários concorrentes, onde o acesso a objetos, através de redes de computadores e ambientes cliente-servidor cooperativos, deve ser de forma concorrente e transparente para os autores e usuários;

- a regra da escalabilidade: as aplicaçoes hipermídia devem executar, praticamente, com as mesmas caracteristicas de desempenho tanto no ambiente de produçào quanto no ambiente de use real;

- a regra da interoperabilidade: as aplicaçoes hipermídia devem proporcionar o intercàmbio de dados entre das, è também com aplicaçóes externas;

- a regra de hyperlink el hyperoiere: um sistema hipermidia deve permitir ao usuário estabelecer relacionamentos navegáveis entre objetos multimídia (hyperlink), explorar e navegar por esses relacionamentos de forma não-linear, determinar sua localizaçào entre eles a qualquer momento da visualizaçào/apresentaçào (hypernicu), e retornar facilmente para qualquer localizaçào anterior em um caminho navegado;

- a regra da independencia tecnológica: um sistema hipermídia deve executar em vários ambientes operacionais distintos o garantir que as aplicaços hipermídia serào executadas sem modificações à medida que a tecnologia evolui;

- a regra da extensibilidade: um sistema hipermídia deve permitir a implementação de novas funçoes ao sistema e modificar a interface com o usuário, de mancira a solucionar diversas classes de problemas e acomodar usuários de categorias distintas;

- a rerra multi-idioma: un sistema hipermídia deve suportar interaça como usuário, armazenamento e recuperaçăo de informaçào, em idiomas distintos, considerando-se os aspectos de globalizaçăo da economia, por exemplo;

- a regra do suporte ao desempenho: um sistema hipermídia deve interagir com o usuário através de uma interface gráfica amigável, empregar mídias na comunicaçào com o usuário e oferecer níveis de ajuda on-liné, acomodando usuários iniciantes, intermediários e experientes;

- a regra dos padröes: um sistema hipermidia deve suportar e obedecer os principais padroes formais e de mercado, garantindo a compatibilidade com outros produtos da árca.

No contexto dos sistemas distribúfłos, um ambiente multimídia deve suportar a construçào cooperativa de aplicaçoes por múltiplos autores e a execução dessas aplicaçoes e 
apresentaçào de informaçoes a múltiplos usuários em redes de computadores, geralmente formadas por componentes heterogêneos (Coulouris cet al., 1994).

O estado da arte revela a consolidação das redes de computadores e usuários colaborando eletronicamente $\mathrm{cm}$ ambientes cooperativos. Aplicaçôes complexas podem ser desenvolvidas por equipes isoladas fisicamente e que utilizem computadores e redes de diferentes fabricantes com diferentes sistemas operacionais e protocolos de comunicação, formando um sistema integrado via Internet.

Assim, aplicaçoes multimídia interativas devem estar potencialmente associadas a ambientes cliente-servidor, nos quais objetos de uma aplicação podem ser acessados por outros usuários, sendo que o sistema deve resolver conflitos quando dois ou mais usuários tentarem acessar e modificar um mesmo objeto. Deve-se considerar, ainda, que näo somente a aplicação e o processamento devem ser distribuidos, mas também o armazenamento e o gerenciamento, o que exige a implementação de mecanismos que garantam transparência e permitam ao ustário utilizar a rede como se fosse o seu próprio equipamento. A Internet usa o protocolo TCP/IP (Transmission Confrol Protocol - (nternet Protocol), criado em 1972, que a princípio nảo foi feito para acomodar a evoluçào tecnológica que se observa atualmente (Comer, 1995). Desta forma, a nova geração de protocolos IPng (Inlernel Profocol next genteration), em fase de consolidação, deve suportar, de forma mais adequada, as exigências de tráfego da rede mundial.

Na Internet, os pacotes trafegam da origem ao destino passando por rotcadores com tecnologias distintas no aspecto físico (Telefonia, Ethernet, RDSI, dentre outros), conforme apresentado na Seçào 2.5 , o que caracteriza a alta taxa de conectividade e a interconexão de componentes heterogêneos. A Figura 2.08 apresenta uma arquitetura cliente-servidor caracteristica da Internet.

Para que as aplicaçoes multimidia possam ser implementadas com características cooperativas e alcançar os benefícios da computação distribuida, são necessários formatos comuns para o intercâmbio de objetos. Não é suficiente padronizar apenas os formatos de mídias individuais. As relaçōes temporais, espaciais, estruturais e procedimentais entre os componentes de mídia sào uma parte importante et também devem ser representadas. 
Atualmente, sabe-se que a falta de um formato comum é um impedimento para o desenvolvimento de diversas classes de aplicaşoes multimidia (Moreira et al., 1995).

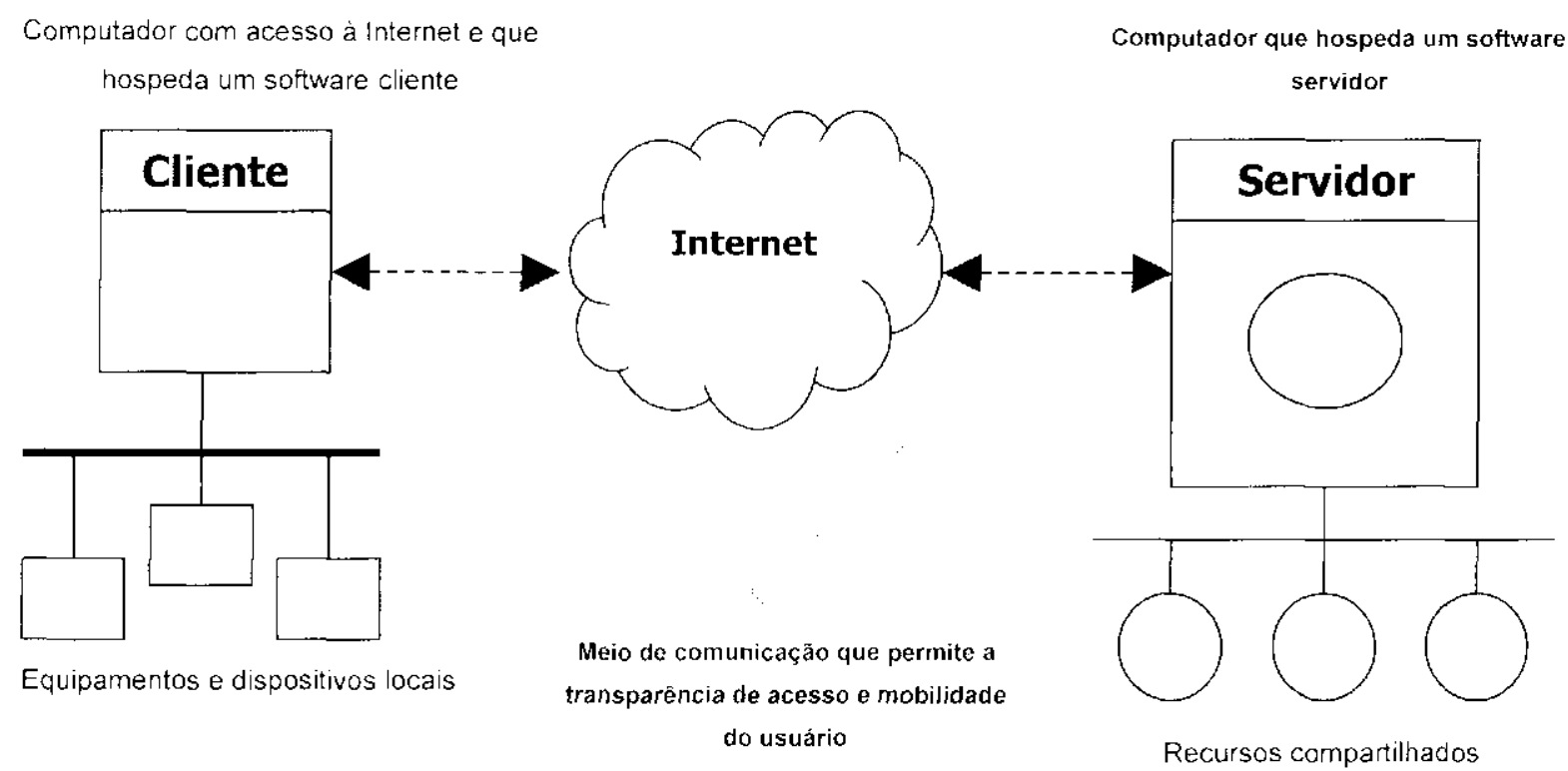

Figura 2.08 - Estrutura genérica da arquitetura cliente-servidor para a Internet

Existem diversos formatos para os objetos multimidia e que permitem o estabelecimento de intercâmbio entre as aplicaçòes e/ou ambientes de autoria e apresentaçào, especialmente na troca de documentos.

Um padrào para representaçào de documentos deve considerar, também, a possibilidade de ligação entre documentos diferentes. Exemplos destas ligaçoes são, por exemplo referências bibliograficas que levam ao documento original a palavras-chave yue levam a documentos mais específicos. Fstas ligações são chamadas de links. Quando o usuário ativa um link, ele é levado a um novo documento ou a um novo ponto dentro do documento correntemente visualizado.

Em um documento também se encontram elementos de controle, denominados markups (hags) ou etiquetas, e esses elementos devem obedecer a padròs de formataçấo de documentos, tais como o SGML, I17MLe, mais recentemente, XML.

Para o intercâmbio de imagens também existem padròes bem definidos. Uma imagem com qualidade fotográfica possui 24 bits de informaçào de cor por pixel, o que resulta em um tamanho de arquivo grande e impraticável para ser enviado por uma rede. Ĺsa-se, entào, algoritmos de compressão que podem levar a uma reduçào no tamanho de até $99 \%$. A 
aplicação desses algoritmos pode resultar em mídias com perda (lossy) ou sem perda (lossless). Um algoritmo com perdas resulta em uma imagem de pior qualidade, mas com um tamanho menor. A compressão com perdas consiste de uma troca de qualidade por tamanho. Alguns padroes de compressäo e armazenamento de inagens säo o Gif (Craplices Interchange format) e o IPEG (Joint-Photogrnph Expert Group).

Fotos, gráficos e desenhos são imagens de duas dimensōes. Uma imagem de três dimensões requer um formato completamente diferente, pois o usuário poderá visualizar os objetos representados em qualquer ângulo que desejar. Atualmente, a linģuagem VRML - uma linguagem de descriça de cenas de realidade virtual - permite o envio de objetes tridimensionais pela Internet e a interaçào do usuário com a cena apresentada em uma janela de visualizaçăo.

Para a mídia de áudio existem formatos definidos de acordo com a natureza do som. Um dos tipos de áudio é óadio em forma de onda, no qual uma onda é um sinal original de ádio convertido para o formato digital através de uma placa de som. Estas informaçoes digitais podem ser examinadas e manipuladas através dos programas de edição de áudio em forma de onda. Este tipo de audio é produzido atraves do hardware da placa de som, que transforma as informaçós digyitais novamente em sinais de áudio analógicos e os envia para um amplificador equipado com alto-falantes. Os arquivos de formas de onda possuem, nos computadores pessoais, a extensão WAV (unce' = onda).

O segundo tipo de áudio é o MID) (Musical Instruntent Digital lnterface), um padrào internacional que especifica cabos o o hardware utilizados na conexào entre computadores e instrumentos musicais eletrônicos. O padrāo MIIDI também inclui um protocolo de comunicaça para a transferencia de dados entre dispositivos. Um arquivo de $\mathrm{som} \mathrm{cm}$ formato MIDI contém informacoes que descrevem quais notas devem ser tocadas por um sintetizador MIDI de instrumentos.

O vídeo digital sempre foi um tema que atraiu muito interesse, pois reúne qualidade de imagem com facilidade de ediçäo. Há anos, as principais companhias do mercado de sistemas iniciaram a produção de extensöes multimídia que incorporavam o vídeo digital. Os formatos criados por estas companhias, entrotanto, eram proprietários a os vídeos so rodavam na sua própria plataforma. Para resolver isto, os fabricantes desenvolveram aideo 
plnyers para as demais plataformas. Neste ponto, tornaram amplamente utilizados os formatos QuickTime da Apple Computers e o AVI (Audio Video Interchange) da Microsoft, tanto para gravaçảo de vídeo em CD-ROM quanto para disponibilizaçào na Internet, apesar de serem inferiores quando comparados às imagens de televisäo. 1)evido ao alto volume de dados que um vídeo digital contem e às altas taxas de largura de banda exigidas para transferência em redes de computadores, pesquisadores procuraram, então, um novo algoritmo de compressão yue pudesse trazer a yualidade dos VCRs para os computadores, sendo que o trabalho desses pesquisadores resultou no padrăo MPEG, que será apresentado, em suas releases 4 e $\vec{i}$, na Seçäo 2.6

No contexto do intercâmbio de objetos multimídia, um modelo de composiçào é uma lista que define a ordem em que os objetos multimídia serào acessados e visualizados, sendo usados para transportar estes objetos pela rede. É importante ressaltar que um modelo de composiçào nào fornece formatos para armazenar uma imagem ou um vídeo, mas formatos para transportar estes objetos.

Os modelos de composiçào fornecem recursos para a estruturaçào de mídias interativas representando os relacionamentos temporais, sincronizaçào, formatos de midias e acesso aos objetos de mídia. Alguns modelos também permitem a integraçao de scripls aos objetos. Isto lhes dá características dinamicas. Um bom modelo de composiçào deve ser eficiente em relaçào ao armazenamento c acesso aos objetos.

Lm linhas gerais, existem dois modelos básicos: modelo de trilhas e modelo de objetos. No modelo de trilhas, a seqüencia de acesso primário é temporal e a apresentaçào multimídia é vista como uma sequienncia de trilhas. No modelo de objetos, a seqüência de acesso primário é hierárquica e a apresentaçào multimidia é vista como ligaçòes entre objetos. Como principais representantes do modelo de trilhas existem o QuickTime te o OMFI (Open Media Frnmereork Interchange). Já como modelo de objetos, o principal representante é o MIIEG (Mullimedia Hypermedin Lipert Group) (Buford et al., 1994; ISO, 1995).

Ainda no contexto do intercàmbio de objetos multimidia, devem ser abordados os aspectos referentes a relacionamentos temporais entre objetos multimídia e distribuiçào dos mesmos numa apresentaçào. 
Quando se integra as múdias numa apresentaçầ, deve-se criar relacionamentos temporais entre essas mídias, fazendo com que sejam apresentadas seqüencialmente ou simultaneamente (em paralclo).

Para representar estes relacionamentos, utiliza-se de modelos que representam todas as possibilidades de combinaçôes (seyüenciais ou paralelas) de objetos multimídia. Além disso, existem técnicas para combinar tais objetos visando a melhor qualidade da apresentaçào, principalmente no aspecto sincronizaçào. A representação de relacionamentos pode ser feita tanto graficamente, através de timelines ou Redes de Petri, como por meio de scripts, representando combinaçes seyüenciais, paralelas e loops, através de linguagens de soripts, por exemplo.

As operaçòes que um sistema multimídia deve suportar também são relevantes. Tais operaçóes são avanço, retrocesso (apresentação reversa), pausa, retomada da apresentação, acesso aleatório, looping e hrozusing. Fstas operaçōes são o resultado da interação do usuário com o sistema multimídia. Uma atençào especial é dada para a operaçào de browsingr onde a interação com o usuário leva a uma apresentação nâo-seqüencial dos dados, na qual o usuário decide sohre o próximo trecho a ser apresentado.

Em ambientes distribuidos, o problema da distribuição dos objetos multimídia consiste em assegurar que os objetos multimidia de uma apresentação, que podem estar fisicamente em diferentes lugares, sejam apresentados com sincronismo. Assim, tecnologias podem ser combinadas e integradas de modo a assegurar que os objetos sejam apresentados no instante de tempo previsto, de modo que haja continuidade na apresentaçào.

\subsection{Aspectos de qualidade de serviço em ambientes interativos}

Sistemas multimidia utilizam tanto mítias discretas (como texto e gráficos) quanto mídias contínuas (como áudio e vídeo). Os dados de mídia contínua (ou dados baseados no tempo) sào gerados em uma determinada taxa c devem ser reproduzidos nessa mesma taxa, sendo que existe um prazo (deadline) para que o dado seja exibido sem perda na qualidade (Buford, 1994). Como exemplo, se uma aplicaçào descja exibir frantes a uma taxa de 30fps (frames por segundo) e em algum momento da transmissão (imaginando que a exibição é remota) essa taxa diminui, ocorreräo tremores na imagem (iifter) que estiver sendo exibida. As tecnologias atuais encontram algumas dificuldades em suportar essas caracteristicas de tempo real dos 
dados de midia contínua, de forma que muitas pesquisas têm sido feitas no sentido de superar essas dificuldades.

Servidores de dados multimídia devem suportar transmissão a clientes heterogêneos e garantir que o vídeo seja apresentado com a mesma qualidade com a qual foi gerado, e isto requer paràmetros de qualidade de serviço (QoS - (unality of Serrice) (Hashisuca, 1996).

Fntende-se por qualidade de serviço como sendo à parametrização, para o sistema, da vontade ou necessidade do usuário. Por exemplo, se um cliente descja transmitir um video no formato NISC, a taxa de frames deve ser de 30fps, e os sistemas devem garantir que essa taxa seja mantida. Os parâmetros de QoS podem estar relacionados com a aplicação, com o sistema operacional, com a rede ou com o disposilivo (Hachisuca, 1996).

Num estágio mais atual, observa-se que us aspectos de consciencia de contexto também podem influenciar a qualidade de serviço, especialmente em termos do controle eficiente das ações do usuário e das reaçoes do ambiente em face das mídias válidas nesse ambiente.

O gerenciamento de QoS para aplicaçoes de mídia contínua pode ser subdividido em dois esquemas de controle: estático e dinimnico (Buford, 1994). No esquema de controle estático, o usuário simplesmente especifica o nível de QoS no momento da criaçào de uma determinada sessão, sendo que esse nível será mantido até o final déssa séssào.

Por outro lado, o esquema de controle dinâmico permite yue o sistema ou o programa de usuário modificue o nivel de QoS durante o andamento da sessão, o que é relevante para aplicações com consciência de contexto. A Figura 2.09 apresenta as camadas de QoS em um ambiente interativo.

Quanto à qualidade de serviços, as aplicaçoes VoD (Video-on-Demand) apresentam-se como importanles representantes dos sistemas interativos, sendo divididas, genericamente, em categorias que incluem televisāo interativa c aplicaçòes corporativas/educacionais. O foco da TVI é a apresentação de vídeo a partir de uma pequena coleção. O foco das aplicações corporativas/educacionais é a apresentaçào aleatória de dados de video, selecionados a partir de uma coleção de vídeos de tamanhos variados. Lim sistema VoD para TVI pode armazenar dados de vídeo economicamente em discos magnéticos. Contudo, devido ao grande volume: de dados de video armazenados para uma aplicação 
corporativa/educacional, um sistema VoD para esse tipo de aplicaçăo tipicamente usa uma combinaçao de discos magnétios com outros moios de armazenamento (Berger, 1995).

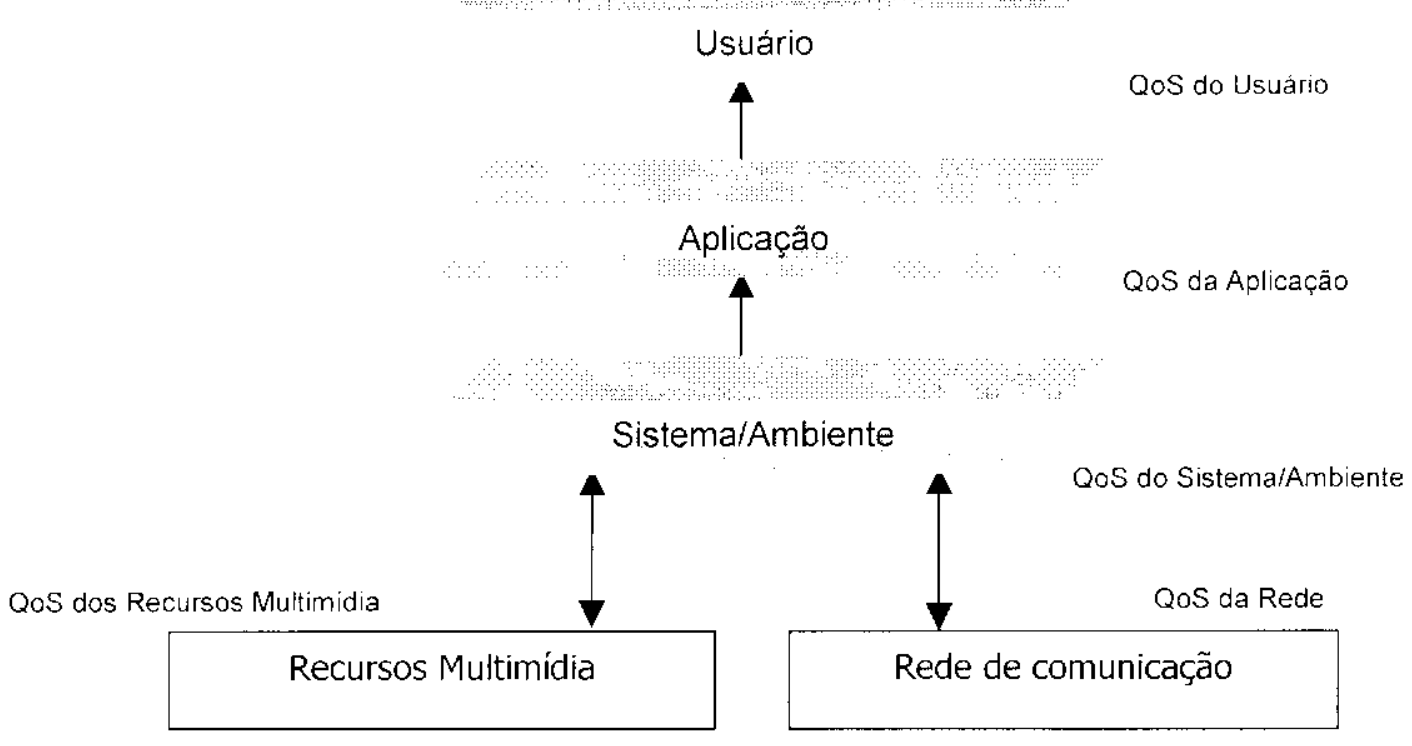

Figura 2.09 - Níveis de QoS em um ambiente interativo

No desenvolvimento de um sistema VoD, pesquisadores têm que resolver muitos problemas. Primeiro, o sistema deve estar apto a localizar um vídeo desejado. Segundo, o sistema deve armazenar e gerenciar coleçoes de dados de víderos estruturados. Terceiro, o sistema deve transportar um vídeo selecionado e apresentá-lo ao usuário final (Berger, 1995).

Para localizar um vídeo desejado, uma interface amigável deve ser criada, permitindo que se realize pesquisas em uma hase de metadados com vistas à localização de um vídeo em um repositório. O projeto da interface de pesquisa deve considerar quais tipos de pesquisas devem ser suportadas e como as pesquisas devem ser especificadas. Adicionalmente, aspectos de consciência do contexto do usuário podem ser considerados durante o processo de pesquisa e seleçào do um vídeo.

Serviços de vídeo interativos sào similares ao serviço de difusâo de IV. A diferença é que a interface da TV foi projetada para suportar muitos canais simultâneos sobre um mesmo banco de dados. No sistema de IV tradicional, cala estaço realiza a sua programaçào simultaneamente com outras estacoòes, e o usuário seleciona um canal específico. Em contraste, um sistema interativo faz com que toda a programação seja apresentadia ao usuário sem nenhuma restrição. O usuário pode selecionar qualquer parte da programação a qualquer hora (Little \& Venkatesh, 1994). 
De acordo com o nivel de interatividade, os serviços de vídeo podem ser classificados em (Hachisuca, 1996):

- serviços hrontcast (No-VoD): similar aos canais de televisão, em que o usuário é um participante passivo e não possui nenhum controle sobre a sessào;

- serviço pay-per-diéw (PPV): o usuário paga por uma programaça específica, similar ao serviço existente em CATV (Cuble TV);

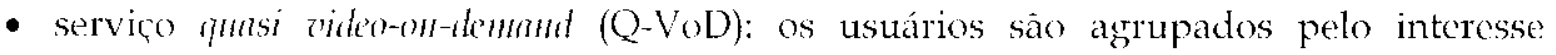
comum que possuem; os usuários possuem um controle rudimentar, ativado por chaveamento para os diferentes grupos;

- serviços near zidélo-on-demand (N-VoD): funções de avançar e voltar são simuladas por transiçōes em um intervalo de tempo discreto (da ordem de 5 minutos); isto é feito utilizando-se vários canais yue possuem a mesma programaçāo, porem em tempos diferentes;

- serviço trate video-on-demand (T-VoD): o usuário possui total controle sobre a apresentaçào, manipulando todas as funçoes de VCR, incluindo avançar, voltar, congelar e posicionar diretamente, dentre outras; é alocado um canal para cada usuário, o que limila o número de usuários do serviço.

Os serviços interativos podem ser usados nas mais diversas aplicaçòes, como visto na Tabela 2.03. Um sistema VoD pode ser acessado simultaneamente por vários usuários com diferentes preferencias. O sistema deve ser capaz de garantir uma qualidade de serviço Satisfatória a todos os clientes. Um cenário típico de um VoL) consiste em um banco de dados local, conectado a uma residencia de um usuário por uma rede de comunicação. Na residencia do usuário, há uma interface de rede e um monitor.

Tabela 2.03 - AIgumas aplicaçōes de serviços interativos (Hachisuca, 1996)

\begin{tabular}{|l|l|}
\hline \multicolumn{1}{|c|}{ Aplicação } & \multicolumn{1}{|c|}{ Descriçâo } \\
\hline $\begin{array}{l}\text { Mothes-on-Demand } \\
\text { (Filmes sob Demanda) }\end{array}$ & $\begin{array}{l}\text { O consumidor pode selecionar e ver o vídeo com } \\
\text { total capacidade de interaçào }\end{array}$ \\
\hline Video-Game Interativo & $\begin{array}{l}\text { Pode-se jogar sem ter que adquirir uma cópia do } \\
\text { jogo }\end{array}$ \\
\hline Noticiário de TV interativo & $\begin{array}{l}\text { O consumidor é capaz de selecionar uma noticia } \\
\text { bem como seu nível de detalhe }\end{array}$ \\
\hline Catálogos inlerativos & $\begin{array}{l}\text { O consumidor pode examinar e comprar } \\
\text { produtos }\end{array}$ \\
\hline Educação a distância & $\begin{array}{l}\text { Um estudante se inscreve em um curso, } \\
\text { remotamente. O estudante pode ter preferências } \\
\text { e horários individuais }\end{array}$ \\
\hline
\end{tabular}


A interação do usuário com o sistema pode ser feita através de um controle remoto ou um teclado de computador. Fsse sistema consiste da informaçào/arquivo de programação armazenada em um servidor central. Essa informaçào é transmitida a servidores regionais através de uma rede de comunicaçăo de alta velocidade, ficando à disposiçào dos usuários.

Sessoes VoD são geralmente longas e requerem alta banda passante para transmissão, necessitando, então, de técnicas de compressào de vídeo, tais como MPEG, MJPEG (MotionJoint Photographic Lxpert Ciromp), H.26, dentre outras, para diminuir o numero de bits a serem transmitidos (Berger, 1995).

\subsection{A infra-estrutura da integração de sistemas digitais: uma breve descrição}

Assim como existem especificaçoes para um computador e/ou equipamento local (desktop), existem especificaçò (requisitos) para aplicaçōes em redes de comunicação. Dentre esses requisitos encontram-se a largura de banda adequada, a pouca variação de atraso, o pouco atraso máximo, a conexão ponto-a-ponto ou multiponto e a escolha de comutaçào por circuit switching ou packet switching.

O padrão LAN Ethernet é packet switching, permitindo a comunicação bidirecional nàodeterminística en relação ao tempo do trajeto dos pacotes. O padrão ATM (Asynhlironous Transfer Mode) pode ser usado em LANis (Iocal Are'l Netcork), MANs (Metropollitan Aren Neturork) e WANs (Wide Arer Netrork), e atualmente sua aplicaçào em AANs (All Aren Netuork) está em expansão, sendo do tipo circuit saitching e deterministico (Tanenbaun, 1998). Observa-se, entào, que padröes como AT:M apresentam características interessantes para suportar o tráfego de objetos multimidia cm ambientes interativos.

A comunicação de dados apresenta-se como um avanço tecnológico de grande importância para a humanidade, uma vez que permite a interligacaio de computadores, dispositivos e equipamentos diversos, possibilitando às pessoas se comunicarem de forma abrangente $\mathrm{e}$ transparente em termos das complexidades tecnológicas exigidas.

A base para a implantação e difusào das redes de comunicação sào as redes locais de computadores. Entende-se por rede local como um suporte de comunicação para interconexăo de equipamentes numa área restrita, sendo que a interconexăo de 
equipamentos é desejada para viabilizar o compartilhamento dos recursos computacionais de hardware, software e de informaço.

A organização básica de una rede local consiste de um número de equipamentos, tais como computadores, impressoras, terminais, servidores especializados (impressào e de disco, por exemplo) que sào interligaders de diversas maneiras, tais como por cabo coaxial, par trancado, fibra otica ou mesmo por sinais de rádio (redes sem fio), permitindo o acesso por um determinado número de usuários.

Com o crescimento do número de usuários nas redes e também o com aumento de aplicativos gráficos, multimídia a cooperativos, a performano das redes locais com tecnologia Ethernel a IOMbps (megabits por segundo) está sendo abalada. Para quebrar a barreira dos $10 \mathrm{Mbps}$, surgiram as tecnologias de redes de alta velocidade como o ATM e o padrais IEEE 100 Basi-T Fast Fithernel.

Nas Subseções 2.5.1 a 2.5.11 säo apresentadas as caracteristicas principais de alguns padrōes para comunicação de dados e yue formam a infra-estrutura básica de comunicaçào em uso.

\subsubsection{Redes ATM}

O ATM é uma forma de lecnologia baseada na transmissào de pequenos pacotes de tamanho fixo e estrutura definida denominackos colulas. Estas celulas sào transmitidas alravés de? conexòes de circuitos virtuais estabelecidos, senclo sua entrega e comulaço feitas pela rede de comunicaço, com hase na informaçào de seu cabceçlho.

A tecnologia ATM se adapta facilmente à exigencias de uma vasta gama de trálegos, suportando com isto diferente tipos de serviços, o que propiciou sua escolha para oferecer suporte à implantaça da Rede Digital de Serviços Integrados - Faixa larga RDSI-I'L

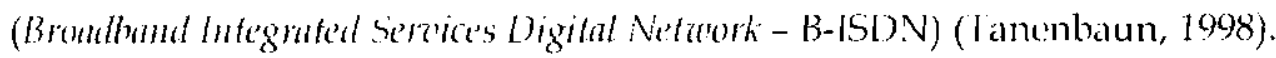

Numa rede ATM, um canal é identificado pela posiçá lixa de seus shots dentro dos frames, sendo que a banda passante ó dividida em segmentos fixos de informaçào (cólulas). Cada célula possui um cabeçalho de informaçào para que o receptor possa idenlificar o canal ao qual uma célula pertence, e tomar as medidas cabiveis. Un canal nào é mais identificado de maneira estática por uma posiçào no tempo, mas de maneira dinámica através das 
informaçōes contidas nos cabeçalhos. Assim, não é necessário definir um mapeamento entre as posiçoes no tempo e os canais envolvidos na transmissão, pois esta informação de mapeamento está contida no cabeçalho. Os pontos comutadores da rede podem também lidar de maneira homogênea com o chaveamento de todos os serviços.

Observa-ses, então, que o fato de se poder alocar dinamicamente uma determinada quantidade de banda passante é de grande valia para a transmissão de informações cujo tráfego pode ser caracterizado por pacotes de dados distribuídos no tempo, evitando-se o desperdício de banda nos períodos de latência da fonte geradora.

\subsubsection{O padrão Fast Ethernet}

Com o crescimento do número de usuários nas redes e também com o aumento de aplicativos gráficos, multimídia e cooperativos, a performance das redes locais com tecnologia Lthernet a $10 \mathrm{Mbps}$ está sofrendo abalos.

Para quebrar a harreira dos $10 \mathrm{Mbps}$, surgiram as tecnologias de redes de alta velocidade como o ATM e o padrão IEEE 100 Base-T Fast Ethernet (Tanenbaun, 1998). O padrão 100 Base-T de Ethernet a $100 \mathrm{Mbps}$ mantém as principais características do padrão Ethernet 10Mbs, tais como o formato do fromh', a quantidade de dados que um frame pode transportar, e o mecanismo de controle de acesso ao meio, diferenciando do padräo original apenas na velocidade de transmissào dos pacotes, que no padrão 100 Base-Té 10 vezes maior que no original.

Os meios físicos padräo 100Base-l'X e 100Base-FX, usados no Fast Fthernet, foram originalmente desenvolvidos pelo A.VSI para o padrão FDDI, e são amplamente utilizados em redes locais FDDI. A conexão ao meio físico é feita através da interface dependente do meio, que consiste de um conector de par trançado ou de fibra ótica de oito pinos.

A Interface Independente do Meio (Media Independe'nl Interface) è um conjunto de eletrónicos opcionais que provê uma maneira de ligar as funçòes de controle de acesso ao meio do dispositivo de rede com o dispositivo da camada física (PHY), o qual envia os sinais para o meio fisico. A MII pode, opcionalmente, suportar tanto operaçōes a $10 \mathrm{Mbps}$ como a 100 Mbps, permitindo que dispositivos de rede possam conectar tanlo segmentos 10 Base-T como 100 Base- $\mathrm{I}$. 
E importante notar que as portas Ethernet dos repetidores não usam uma interface Fthernet. Uma porta do repetidor conecta-se ao sistema do meio FastEthernet usando os mesmos equipamentos PHY e MDI. No entanto, as portas dos repetidores operam ao nivel de bit individual para sinais Ethernet, movendo os sinais diretamente de segmento para segmento. tintretanto, as porlas dos repetidores nào contêm interfaces Fthernet já que clas não operam ao nivel de frimes lithornet.

\subsubsection{O padrão Gigabit Ethernet}

En novembro de 1995, a comissão IFEE 802.3 encarregou o Spet Study Group para viabilizar um incremento na capacidade das redes Fast Ethernet, buscando o que foi denominado de rede Gigabit ('Tanenbaun, 1998).

Iim meados de 1996, o IELLi aprovou a solicitasào do projeto de desenvolvimento para o Gigabit Ethernet, e formou o $802.3 z$ Cigratht Fthermet Task force, com alguns objetivos iniciais, a saber:

- alcançar a velocidade de $1000 \mathrm{Mbps}$;

- usar o formato de frame's do padräo Ethernet 802.3;

- alcangar os requisitos funcionais do padrào 802;

- possibilitar a comunicaçäo entre $10 \mathrm{Mbps}$, $100 \mathrm{Mbps}$ e $1000 \mathrm{Mbps}$;

- manter o tamanho mínimo e máximo de frames dos padroes anteriores;

- prover operaçoes halfe full-duplex;

- suportar a topologia estrela;

- utilizar o método de acesso CSMA/CD com suporte para ao menos um repetidor por subrede;

- suportar o canal de fibra $\triangle N S I F C-1$ e FC-0e, se possivel, cabo de cobre;

- fornecer uma família de especificaçoes de nível físico;

- permitir controle de fluxo;

- especificar uma Interface Independente de Mídia Lógica (GMII).

Assim, tem-se uma tecnologia derivada do padrào tithernet, que oferece uma largura de banda de 1000 Mhps (1 Gops), sendo 100 (cem) veres mais rapida que o padrào Ethernet, mas compativel com esté último e usando os protocolos CSMA/CD e MAC. 


\subsubsection{Comunicação sem fio (zvireless)}

Muitos sistemas de comunicaça fazem a transmissio dos dados utilizando fios de cobre (como par trançado e cabo coaxial) ou fibra ótica. Outros, entretanto, transmitem os dados pelo ar, näo utilizando qualquer tipo de meio físico, como é o caso da transmissāo por raios infravermelhos, laser, microondas e rádio. Cada uma destas técnicas é adequada a certas aplicaçoes, que podem ser empregadas em l.ANs e WANs (Tanenbaun, 1998).

Na realidade, o ar (ou espaço livre) constitui-se de um meio natural para a propaģaçào de sinais eletromagnéticos, podendo, em muitos casos, ser considerado o melhor suporte de transmissão, no que se refere à conectividade. Tal afirmaçào bascia-se no fato de que o ar provê uma interconexầ completa e permite maior flexibilidade na kocalização das estaçōes.

Existem também alguns inconvenientes com relação ao sistema de comunicação sem fio, sendo que os principais são o custo dos equipamentos e a regulamentação pública.

A escolha de canais de radiofrequiencia para sistemas de comunicação, de uma forma geral, é bastante complexa, pois vários fatores devem ser observados, dentre os quais pode-se citar:

- banda passante descjada;

- área de cobertura;

- disponibilidade do espectro;

- interferencias e fontes de ruido;

- regulamentação pública;

- custos dos equipamentos.

Como se pode observar atualmente, o cabo já é uma alternativa concreta à TV por radiodifusào; o celular está ganhando o espaço dos telefones convencionais e, em alguns casos, o cabeamento da LAN está cedendo sua posiçäo para ondas de rádio e infravermelho.

Muitos fabricantes competem em um mercado impulsionado pela necessictade de substitutos para sistemas com fio em instalaçôes de redes de comunicação, e uma gama extensa de produtos tem sido desenvolvida e colocada à disposiçáo do usuario. 


\subsubsection{Comunicação via satélite}

Os satélites artificiais são largamente empregados em lelecomunicações, podendo ser classificados em geo-estacionários ou não geo-estacionários, de acordo com sua órbita, podendo prover meios de comunicaçăo nas seguintes categorias:

- ponto a ponto;

- ponto a multiponto;

- multiponto a ponto;

- multiponto a multiponto.

A comunicaçào via satélite apresenta algumas vantagens em relaçào aos meios tradicionais, principalmente no que diz respeito à largura de banda disponivel, mas também apresenta limitaçoes, sendo a maior delas a vida útil relativamente curta ( 8 a 10 anos).

Os clementos básicos do serviço de comunicaçăo por satélite são divididos entre o segemento espacial e o segmento terrestre, e este serviço pode se dar nas bandas C e KU de frejüencia (Tanenbaun, 1998).

A Banda C é uma faixa de freqüencia utilizada na comunicação com satélite no espectro de freqüência de $3.9 \mathrm{GHz}$ até $6.2 \mathrm{GHz}$ - segundo o IEEF - e espectro de freqüência comercial de $3.7 \mathrm{GIl}$ l até $6.425 \mathrm{GH} z$, sendo utilizado um sinal de freqüencia $6 \mathrm{GHz}$ para comunicação no sentido terra-satélite e $4 \mathrm{GH} /$ no sentido satélite-terra.

A Banda KU é uma faixa de freqüência utilizada na comunicação com satélite no espectro de freyüência de $15.35 \mathrm{GJ}$ l $z$ até $17.25 \mathrm{GHz}$ - segundo o IEEE - e espectro de freqüência comercial de $10.7 \mathrm{GH} z$ até $18 \mathrm{GH} z$, sendo utilizado um sinal de freqüência $14 \mathrm{GHz}$ para comunicaçâo no sentido terra-satélite e $12 \mathrm{GHz}$ no sentido satélite-terra.

\subsubsection{Microondas}

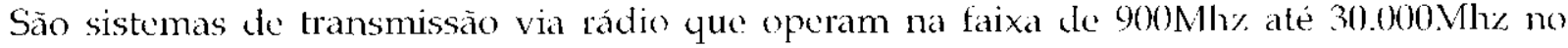
espectro de frequiencia, sendo também conhecidos como "line-of-sight microwaze systems" (Tanenbaun, 1998). Estes sistemas sào usados para transportar sinais analógicos ou digitais de voz e dados. 
Nestas freqüências, as ondas de rádio se comportam praticamente como ondas de luz e sua propagaça segue uma linha reta, de onde se conclui que näo devem existir obstáculos sólidos em meio a esta linha.

Uma caracteristica importante destes sistemas é a possibilidade de se prever o nível do sinal que é recebido pelo receptor distante com uma precisäo conhecida.

Em linhas gerais, a transmissĩo de rádio em freyüências de microondas é uma alternativa interessante, sendo que sua aplicação pode ser observada em tronos para lelefonia (antigamente estes mesmos troncus serviam para transmissäo de TV), em links ponto a ponto para um backhone de uma rede WAN ou L.AN, em sistemas multiponto para telefonia ou dados, e no transporte de sinais de vídeo, tais como C N'V (televisão a cabo).

\subsubsection{Telefonia celular e comunicação de dados}

Nos últimos vinte anos, tecnologias de comunicaçào móvel evoluíram de protótipos experimentais ao sucesso comercial.

A telefonia colular é um sistema de telecomunicação que permite a conexào de assinantes (fixos ou móveis) através de um enlace de rádio, enquanto que na telefonia clássica os assinantes sáo conectados à central de comutaça através da dispendiosa instalaçào de cabos para composiçào da rede telefonica.

As redes de telefonia celular existentes foram olimizadas para tráfego de voz, com taxa de transmissào de até $4,8 \mathrm{Kbps}$, tipicamente. Redes digitais, destinadas ao transporte de dados e voz digitalizada, estäo em desenvolvimento na Europa e EUA, podendo elevar a taxa típica de transmissão para 9,6 Kbps (1'erkins, 1997).

Existem diversas infra-estruturas de WWAN (Wireless Wide Aren Neturork) disponiveis para suportar comunicaçào de dados. Muitas delas foram desenvolvidas inicialmente para suportar comunicaçào de voz e depois foram adaptadas para suportar dados. Infraestruturas para transmissào sem fios apresentam diversals limitaçoos en relaçăo à infralestrutura convencional. A taxa de erros em links de rádio limita o desempenho a $10 \mathrm{Kbps}$. Esses canais nào oferecem estabilidade da qualidade de transmissão, podendo a mesma variar em funçào de "sombras de rádio" causadas por obstruçöes tais como edifícios, 
acidentes geográficos, chuva, neblina, neve, dentre outros. Assim, a taxa efetiva de transmissão pode cair a 1 Kbps.

Na telefonia celular, os problemas de transmissäo de dados tipicamente ocorrem nas fronteiras das células e quando os sinais sào comutados de uma célula para outra, instante em que a transmissào pode ser interrompida por cerca de 100 milissegundos (brenk-beforemake swithing). Os protocolos da camada de enlace dos modems foram adaptados especificamente para poderem lidar com a qualidade variável na transnissão de dados.

Hoje o mercado de transmissão de dados sem fios é dominado por produtos que são inseridos diretamente em microcomputadores pessoais (desktop) de forma similar a outros perifericos tipo EISA ou adaptadores externos que utilizam as interfaces serial ou paralela. Alem disso, interfaces portáteis com adaptadores do tamanho de um cartao de crédito, conhecidas como PCMCLA (Personal Computer Memory Cind International Associntion), tornamse cada ve\% mais populares utilizadas.

Cada terminal móvel celular de assinante (telefone celular) é acoplado a uma antena de rádio que transmite na banda de $800 \mathrm{MH} \%$ (padrào americano) ou 900 Ml lz (padräo europeu). No Brasil foi instalado um sistema de telefonia movel analógica, basicamente para transmissão de voz, baseato no padräo europeu. Recentemente, esforços foram feitos para implantaçăo da telefonia celular digital, que já se tornou uma realidade no país, a exemplo do que aconteceu nos Estados Unidos da América e em países curopeus, nos quais esforços de padronização de sistemas de telefonia colular digital foram feitos para suportar a transmissão de vo\% c dados.

Para a implantação da telefonia móvel celular, subdivide-se a área geográfica em pequenas células hexagonais, ada uma dispondo de uma estaçào de rádio-base e de conjuntos de antenas direcionais para supervisào a controle das suas radiofreqüencias disponíveis. Estaçóes ràdio-base säo conectiadas ao terminal de controle, e estes säo conectados entre si c com a "Rede. Vacional e Internacional de Telefonia".

Cada telefone colular, em trânsito por determinada área, quando deseja fazer uma chamada, envia uma mensagem ao rádio-base. Essa mensagem, após ser processada e aceita pelo Terminal de Controle, implica a conexäo do telefone relular à estaça telefonica colular 
através da concessão de uma radiofrequència disponível. lodas as transmissões são fullduplex, com um canal de! transmissäo e outro de recepçás.

A passagem de um assinante de um setor para outro, dentro da mesma célula, fica a cargo dos equipamentos de controle internos à célula. Quando o assinante move-se de uma célula para outra, o procedimento é diferente. Ao verificar a apresentação de um nivel mínimo de recepção do sinal na célula de origem, o terminal de controle comuta o assinante para uma radiof reqüencia disponível em uma cólula vizinha. A radiofreqüência utilizada na célula de origem é desalocada e torna-se disponível para nova alocação. Muitos sistemas celulares esperam em torno de 100 milissegundos, após a liberação da radiofreqüência de origem, antes de alocar nova radiofreqüência na célula vizinha. Este atraso nâo causa descontinuidade na comunicagão de voz, mas causa problemas na transmissào de dados.

\subsubsection{RDSI - Rede Digital de Serviços Integrados}

A introduçào da RDSIBE (Rede l)ighital de Serriģos Inlegrados de Ranta Fstreita), que possibilita a comunicaçào inclusive via Internet a $128 \mathrm{~K}$ bps e/ou $2 \mathrm{Mbps}$, já é um avanço em termos de transmissão digital, apesar de estar disponivel nos países industrializados desde o início da década de 80 (Soares et al., 1995; Tanenbaun, 1996; Tanenbaun, 1998).

Com o advento, entretanto, da fibra ótica, dos multiplexadores óticos e da tecnologia ATM, a taxa de transmissão já cheģa a dezenas de Gbps. I evando-se em consideração que a fibra ótica tem como matéria-prima a sílica, que é muito mais abundante em nosso planeta do que o cobre, é evidente que a fibra ótica deverá se tornar muito mais barata do que os atuais cabos de pares de cobre usados pelas concessionárias de serviços públicos de telefonia, das centrais telefonicas até o terminal do cliente. Além disto inúmeras vantagens técnicas levaram os países industrializados a utilizar fibra ótica até o terminal do cliente e foi criada a

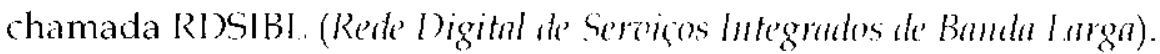

A partir do ano 2000 a comunicacăo multimídia (voz, dados em alta velocidade, áudio, vídeo em alta definiçào, gráficos, telemedicina, dentre outros) em banda larga estará disponivel para um vasto número de clientes, e a previsăo é as telecomunicaçòes interativas e vídeo 3D sejam realidade até o ano de 2010.

No Brasil, a RDSIBF ainda é uma tecnologia em consolidaçào e a utilização extensiva de 
RISSIBI ainda é um objetivo a ser atingido. Neste ponto, ao invés de realizar investimentos na instalaçào de cabos óticos que alcancem o cliente, apenas para a transmissão de sinais de TV a cabo e persistir nas baixas taxas de transmissão na Internet, principalmente nos enlaces intererestaduais e internacionais, pode-se investir em infra-estrutura que acompanhe o desenvolvimento das técnicas de telecomunicaçós.

Tradicionalmente, sistemas de comunicaçào foram desenvolvidos para o transporte de tipos específicos de informação - o sistema lelefônico para o tráfego de voz, as redes de comunicação de pacotes para dados textuais, vídeo e televisào em redes de radiodifusão ou a cabo. Essas redes foram claramente projetadas para aplicaçōes especílicas, o que gera problemas de adaptaçäo a outros tipos de serviço. O ideal de uma única rede capaz de atender a todos esses serviços, de forma a obter uma economia devido ao compartilhamento dos recursos, veio a motivar o conceito das Redes de Serviço Integrado.

Pela primeira vez, em 1972, o CCITT (atual ITU-T), emitiu, em sua recomendaçăo G.702, a seguinte definição para essa nova rede: "uma rede digital integrada, na qual os mesmos comutadores e caminhos digitais sào usados para os diferentes serviços, por exemplo, telefonia e dados".

Nos periodos subseqüentes de estudo, o CCITT continuou a elaborar as especificaçoes sobre a RDSI, que culminaram em $1984 \mathrm{com}$ as recomendaçöes da Série I do Livro Vermelho. Surģiu entào a seguinte definição de RDSI: "uma rede, em geral evoluida da rede digital de telefonia, que proporciona conectividade digital fim-a-fim, para suportar uma variedade de serviços vocais e năo vocais, aos quais os usuários têm acesso a partir de um conjunto limitado de interfaces padronizadas.

O investimento no sistema telefonico existente é alto, exigindo que a RDSI seja concretizada por etapas ao longo de décadas, fazendo com que a RDSI coxxista com o sistema analógico atual por muitos anos. Esses requisitos têm uma influência importante sobre a forma final que a RLSI assumirá e sobre a forma como o sistema corrente evoluirá gradativamente em direção à RISSI.

Lim fato importante é o crescimento das redes comerciais comutadas por pacotes, crescimento esse observado descle meados dos anos setenta. Outro fator importante reside na 
decisão de aproveitar a base telefônica instalada, considerando-se que é inviável substituir uma vasta malha de cabeamento por fibra ótica somente para satisfazer os requisitos da RDSI. Por outro lado, substituir troncos entre centrais por fibra ótica é factível, porque são em menor número e podem ser atualizados com maior facilidade.

Esses fatos indicam que a RDSI foi projetada, deste o início, para conviver com as limitaçoes existentes das malhas de assinantes a das redes de voz, além das redes de comutação de pacotes.

Um novo conjunto de interfaces, que utiliza a tecnologia ADSI. (Iinlu de Assimmtes Assimétrica Digital) sobre linhas comuns de telefone, promete abrir canais de até $6312 \mathrm{Kbps}$ A velocidade de envio dos dados seria de até quatro vezes maior que uma linha Tl e cerca de 400 vezes mais veloz que um modem de $14.4 \mathrm{Kbps}$.

Outra tecnologia que pode ser combinada com a ADSL é o HDSL, a linha digital de assinante de alta taxa de bits. O ADSL utiliza um fio de par trançado de mais de $5 \mathrm{~km}$. O HDSL, por sua vez, usa dois pares completos de par trançado de quase $4 \mathrm{Km}$.

A linha de assinante digital simétrica (SDSL), segundo alguns analistas, pode até ser mais atraente para alguns usuarios. O 5051. permite duas larguras de banda em sentido bidirecional, o que viabiliza, por exemplo, videoconferencias ao vivo em ambientes domésticos.

\subsubsection{Computação e tecnologias móveis}

A computaçào móvel é o último estágio do desenvolvimento da computacào pessoal. Eim 1946, a Illinois Bell Ielephone Company introduziu um serviço de telefonia móvel, que permitia a usuários que estivessem conduzindo veículos, comunicar-se com o sistema telefônico. Foi a primeira iniciativa de pormitir comunicação bidirecional sem fio. Atualmente, observa-se a expansão e a popularizaça do telefone colular, que garante mobilidade aos usuários do sistema telefónico (Bates \& Gregory, 1997).

São muitos os argumentos que formam a base para o desenvolvimento de um ambiente de computaçăo móvel. Inicialmente', deve-se pensar que nem todas as pessoas yue necessitam do computador estão presentes em um determinado local físico, tal como um escritório, uma sala 
de aula, dentre outros. Vendedores são exemplos de trabalhadores com alta mobilidade que necessitam acessar bases de dados remotas e executarem operaçōes diversas, tais como a emissão de pedidos, requisiçào de mercadorias, dentre outras.

É possivel relacionar vantagens de um sistıma móvel, tais como conforto para utilizaçào em qualquer ambiente, flexibilidade para utilizaçào $\mathrm{cm}$ diversas aplicaçoes que exijam movimento, disponibilidade independente da localizaçào do usuário. Além disso, algumas exigèncias também podem ser relacionadas, tais como a portahilidade para facilitar o transporte, autonomia de energia para garantir o funcionamento onde nào existe disponibilidade de energia e desempenho comparável a estaçoes fixas.

A exemplo dos computadores fixos, deseja-se garantir características de comunicaçào aos computadores móveis, de uma forma sem fio (arreless). Esta comunicação deve ser feita através de sistema de ondas de rádio, utilizando antenas para transmissào e recepcào. Pela portabilidade do sistema, espera-se que as antenas näo sejam grandes e nem mesmo muito potentes, para não ferir a autonomia de energia do sistema.

Lm ambiente de computaçào móvel envolve computadores portáteis interligados em rede através de sistema de ondas de rádio, no yual denomina-se unidade móvel (UM) o elemento de rede (computador portátil conectado à rade de computaçào móvel). As unidades móveis são agrupadas e ligadas em rede, divididas em subredes, cada qual mantida por um grupo de antenas, as quais săo chamadas ponto de acesso (PA). Um ambiente de computaçào móvel pode ser desenvolvido de forma independente de infra-estrutura fixa, caracterizando as redes ad-hoc, que são interligadas diretamente através das antenas.

A mobilidade porém, sempre implica algumas condiçoes, típicas do ambiente, que devem ser consideradas, independente do sistema de acesso (Perkins, 1997):

- capacidade de comunicaşo limitada com largura de banda variável e alta taxa de erros;

- autonomia de energia limitada por baterias com limite de consumo, de forma que deve-se despender o minimo de energia com processamento e dispositivos de apoio ao sistema;

- limites físicos de hardware para garantia de portabilidade, limitando também o poder de processamento e disposilivos; 
- problemas de roteamento de pacotes, yuando há variaçào da subrede onde está presente a UM;

- perda temporária de comunicação, quando do deslocamento entre áreas mantidas por diferentes estaçós de rádio e renegociação de características de acesso.

Para contornar estes problemas, diversas soluçoes têm sido propostas, algumas das quais já em operação, outras em pesquisa.

A princípio, pode-se utilizar o próprio sistema de telefonia celular para fazer a interconexāo destes computadores em rode, porém, alyumas timitaços estào presentes neste tipo de accsso, especialmente no que diz respeito à baixa velocidade de acesso obtida neste sistema. Para este sistema, a unidade móvel é um computador portátil que utiliza um modem e um telefone celular para se conectar a um servidor de acesso remoto. As estaçōes de rádio sào as estaçōes dos sistemas de telefonia celular e todas as operaçoes de mobilidade são gerenciadas pela camada física deste sistema, provida pelo sistema de telefonia celular.

Outras formas de comunicaçăo podem também ser usadas, como é o caso da Wavelan, que permite a utilização de taxas de transmissào mais satisfatorias, entre 1 e 2Mbps. Fste sistema deve resolver problemas de roteamento, que são resolvidos naturalmente pelo sistema celular.

Como ponto importante, após o estabelecimento de mecanismos nas camadas inferiores que possibilitam o uso de computação móvel, deve-se observar as necessidades de adaptação para as camadas superiores para permitir o seu uso de forma mais ampla, caracterizando e permitindo o uso de computaça móvel na Internet (a Internet móvel).

Espera-se que uma unidade móvel seja reconherida na Internet independente da subrede em que cla se encontre. Sabe-se, porém, que o endereço de uma estação depende de sua subrede, o que exige modificaçòes de configuração para que o acesso mantenha-se transparente ao usuário.

Para servidores móveis o problema é mais critico ainda, pois deve ser reconhecido na Internet com um endereço fixo, independente da subrede em que se encontra. Espera-se, 
ainda, que a estaçào fixa em comunicação com a unidade móvel não observe diferenças entre esta unidade c outra estação qualquer.

Uma unidade móvel deve ser capar de acessar todos os recursos disponiveis em uma estação ligada a uma rede atravís de cabeamento, contornando todos os problemas deste ambiente. Lança-se mão, entāo, de técnicas para melhor aproveitamento do canal de comunicạ̧ao, da energia do sistema e do processamento, de forma a limitar as tarefas executadas na unidade móvel.

Deve-se adaptar a aplicação, o protocolo utilizado ou mesmo a pilha de protocolos utilizados no ambiente de computação móvel para garantir os mesmos parâmetros de QoS que seriam garantidos em uma aplicaçào semelhante em uma rede fixa. Pode-se alterar a pilha de protocolos entre a unidade móvel e a estaçào fixa, de forma a criar uma camada intermediária que agregue as características necessárias, como por exemplo em requisiçôes feitas ao protocolo HTTP (Hypertext Transfer Protocol). Assim, uma camada middlezere (agente) pode ser responsável por fazer uma adaptaçäo do protocolo I ITTP para o meio, de forma a economizar a banda e, possivelmente, o processamento. O resultado pode ser transparente para o usuário ou nào, dependendo dos aspectos de contexto desse mesmo usuário (andereness). Vesste caso, uma abordagyem poderia ser a realizaçăo de um tratamento previo sobre serviços oferecidos ao usuário, como por exemplo, as figuras poderiam ser inicialmente transmitidas e mostradas em preto-e-branco e, somente as figuras necessárias e requisitadas sob a açäo do usuário seriam entào transmitidas em cores.

Ainda no contexto da mobilidade, ao vislumbrar o serviço de telefonia IP (Internet Protocol), deseja-se adaptá-lo de forma a possibilitar seu uso en um ambiente de computação móvel. Neste ponto, o uso de diversos algoritmos de codificação de voz influi na largura de banda necessária para o serviço e na qualidade da reproduçào da voz no outro extremo da conversação, de forma a ter possivelmente uma reproduçào de voz mais mecanizada, com perda de alguns sons da fala.

A adaptabilidade a ser trabalhada para telefonia IP pode ser feita sobre estes algoritmos de codificação e decodificaçào, definidos pela I'lU- $[$, além da possibilidade de compactaçào e supressào de silêncio. Assim, a estaçào fixa pode alterar dinamicamente estes métodos, atuando diretamente na voz, de acordo com a disponibilidade de largura de banda. 
As tecnologias que permitem a implementaça de sistemas móveis abrem uma perspectiva ampla para o desenvolvimento de aplicaçoes com requisitos de consciência de contexto, especialmente em termos da interação do usuário com ambientes nos quais essas aplicaçôes estiverem inseridas.

\subsubsection{Teleconferência e videoconferência}

Diversas situaçōes de trabalho exigem que as pessoas estejam geograficamente dispersas apesar de formarem uma equipe. Isto é muito comum em grandes empresas, como as multinacionais, por exemplo. Nestes casos, a realizaçào de reuniōes para discussão de problemas pode se tornar um fator de alto custo. O transporte de pessoal, a acomodaçäo, enfim, toda a infra-estrutura que precisa ser criada para realizar os encontros acarreta altos gastos. Além dos gaslos diretos, o desperdício de tempo com o transporte para locais distantes também representa uma perda significativa. Na tentativa de melhorar este quadro, vários grupos de pesquisa direcionaram seus enfoques sobre o conjunto de serviços denominado, genericamente, teleconferência (Lemair \& Shae, 1997).

As aplicaçôes atuais para as teleconferencias incluem principalmente as reuniões de negócios, os grupos de discussão e a educação a distância.

O ambiente de teleconferência é um ambiente multimídia, que torna possível o compartilhamento de diversos espaços acústicos e visuais. Nas teleconferencias, os diversos participantes são capazes de compartilhar mídias estáticas como textos, diagramas e figuras e também mídias dinâmicas como áudio e vídeo. Logricamente, o fato de se utilizar canais de comunicaçăo e equipamentos de aquisição de dados, que são limitados, cria um fator de limitaçào na qualidade e na interatividade das conferências (Galbreath, 1995).

Existem diversos serviços normalizados para teleonferéncia. Uma teleconferência pode ser definida como um conjunto de facilidades de comunicaçāo através de meios eletrônicos para possibilitar comunicages bidirecionais entre dois ou mais usuarios ou grupos de usuátrios. Para ser interoperável, o sistema deve seguir os padròes estabelecidos para transmissão das diversas mídias. Os organismos de padronizaçào internacional (ISO e ITU-T) indicam a utilização da norma I 1.200, definindo diferentes níveis de teleconferência:

- andioconferincia - serviço em que somente sinais de áudio e controle sảo transmitidos cntre os participantes; 
- conferência ándio-documentacional - similar à sessão de audioconferência, havendo entretanto o tratamento de documentos textuais;

- conferência audiogrifica - serviço com suporte à transmissão de áudio, sinais de controle, documentos e imagens estáticas;

- freeze-frame zidteoconferêncin - serviço similar à conferência audiogeráfica acrescida do envio periódico de imagens estáticas aos participantes;

- teleseminário - serviço que consiste da distribuiçào dos eventos ocorridos num local (audio e vídeo) para todos os demais participantes, sendo o áudio o único sinal de retorno;

- virleoconferêncin - serviço similar à conferência audiográfica acrescida do envio online e em tempo real de sinais de vídeo entre os vários participantes.

Lm linhas gerais, uma aplicaçào deve utilizar um conjunto mínimo de serviços de teleconferência. Um serviço de videoconferencia que queira facilitar a realização de reuniōes deve, entretanto, incluir outras ferramentas. Tais facilidades devem incluir todo um sistema denominado de pré-conferência, que deve permitir o agendamento da conferência e sua divulgação aos seus componentes. Além disto, na pré-conferência deve-se configurar o ambiente para a sessão a ser realizada.

Já durante uma sessäo de videoconferència, os participantes devem se sentir o mais próximo possível de uma conferencia clássica. Para isso eles deven dispor, por exemplo, de ferramentas que permitam a fácil e eficiente manipulaçio dos documentos compartilhados. Os usuários devem também ter oportunidade de comunicaçào, tanto em modo privado como em grupos. Diferentes sistemas de votaçăo também podem ser implementados para facilitar o andamento de reuniòes. Um ponto de extrema importância em uma videoconferência é sua privacidade. Deste modo, mecanismos robustos de segurança devem proteger as conferencias de espionagens, impedindo a entrada de componentes näo desejados. Estes itens são essenciais para uma boa aceitação dos sistemas de videoconferencia pelos usuários. Adicionalmente, deve haver um limite de tempo na utilizaça do canal de voz por cada um dos participantes, por exemplo. Este controle de acesso pode ser realizado por um coordenador ou de modo automálico pelo ambiente, o que caracteriza o uso da consciéncia de contexto. 
Uma das maiores preocupaçôs nos sistemas de videoconferência é a inundação de redes com o volume de dados gerado (voz e, principalmente, video). Mecanismos de controle de fluxo devem ser implementados para evitar tais inundaçoes. Os principais elementos de um sistema de videoconferência incluem (Bates \& Grogory, 1997):

- participante: usuário da conferência com direitos, controlados pelo coordenador, à fala e demais recursos da conferência;

- organizador: indivíduo que tem como tarefa agendar a conferência e, se necessário, divulgar aos participantes a existência da conferencia (pode ser um participante ou não);

- coordenador: participante com dircitos especiais sobre todo o controle da conferência (uma conferência pode ser realizada sem a presença deste indivíduo, quando o controle de acessos for realizado pelo próprio sistema);

- interlocutor: participante que detém, em um dado instante, o dircito à fala e à alteraçào dos documentos multimídia/hipermídia (o dircito de alteraçào de documentos pode ser delegado a um secretário);

- secretário: usuário da conferencia para quem se delega o direito de escrita nos documentos multimidia/hipermídia da base compartilhada (pode ser um participante ou năo);

- assento: dispositivo lógico que pode ser preenchido por um participante ou secretário;

- base privada: sessão de trabalho de um usuário, de acesso e controle restrito a este usuário;

- hiperbase ou hiperbase pública: depósito de documentos persistentes de acesso a todos os usuários da conferência, de acordo com seus direitos;

- base compartilhada: depósito volátil de documentos que possibilita o trabalho cooperativo entre os participantes da conferência (é visivel por todos os participantes, mas com controle de alteracào realizado pelo sistema).

Observa-se, aproveitand(o-se dos conceitos de agentes apresentados no Capitulo 4, que os elementos de um sistema de videoconferência podem ser mapeados em agentes computacionais habilitados para a realizaçào das tarefas de cada elemento e também para tarefas de cooperação, sendo essa implementação relevante para o cenário dos ambientes com consciência de contexto. 
Ao nível tecnológico, as primeiras soluçoes de videoconferência apareceram com um contexto de controle centralizado, tendo sido uma soluçào natural para as conferências baseadas em comulaçòes de circuitos, como ocorre com as linhas telefônicas públicas e na $\mathrm{N}$ ISDN, por exemplo.

O crescimento da Internet vem atraindo os mais diversos tipos de aplicaçào, que tentam explorar ao máximo o potencial da rede mundial. Como nào podia deixar de ser, os sistemas de videoconferência também passaram a se integrar neste universo. Os sistemas de videoconferência em redes de comulação de pacoles apareceram como solução para o desperdicio de recursos que ocorrem nos sistemas de comutação de circuitos. Uma das soluçōes, adotada para otimizar o uso da rede, foi a utilização de sistemas distribuídos.

Numa arquitetura distribuída, as estaçóes dos usuários se responsabilizam pelo tratamento dos dados. A confiabilidade do sistema é muito melhor do que na arquitetura centralizada. Os usuários se conectam em uma estrutura multicast que os interconecta, permitindo a troca de informaçoes entre eles. Una das maiores dificuldades dos sistemas distribuídos é a garantia da qualidade de serviço (QoS), causada, principalmente, pelo congestionamento nos canais de comunicaçào, e que gera, como conseqüencia, sérios problemas de sincronismo e descontinuidade nas midias de áudio e video.

Para superar problemas de sincronismo, algumas técnicas sào utilizadas. Inicialmente, as fontes de áudio e vídeo são tratadas independentemente. Na geração de cada mídia, existe um esquema de marcação dos pacotes com "time stamps" que permitirão a recuperação do sincronismo no destino. Ao serem reproduzidas, as mídias são re-sincronizadas, tendo como mestre o sinal de áudio. Desta forma, se for necessário, o sinal de vídeo descarta alguns quadros se o sinal de áudio estiver um pouco atrasado. Da mesma forma o sinal de vídeo pode repetir alguns quadros antigos se o sinal de áudio estiver adiantado em relação a tele.

Outra preocupaçáo é a implementaçào de mecanismos de controle de congestionamento da rede multiponto utilizada. Deve-se lembrar que o tráfego de mídias de áudio e vídeo ocupa uma porcentagem alta da banda passante disponivel. No caso da Internet, o backbone multiponto disponivel, o MBONE, funciona com o protocolo UI)P (User Datagram Protocol), que năo apresenta mecanismos de controle de fluxo e de congestionamento. Desta forma este controle deve ser realizado em camadas superiort's ao UDP. As soluçöes procuram sempre 
diminuir as perdas de dados decorrentes do congestionamento da rede. Em geral técnicas de estimação do estado atual das redes são empregadas para a obtenção de suas capacidades instantâneas de transmissào.

Mesmo com a implementação de mecanismos de controle de congestionamento e de fluxo, a ocorrência de perdas em alguns instantes é praticamente inevitável. Um bom sistema de videoconferencia deve ser o mais imune possivel a essas perdas. Desta forma, os participantes de uma conferência devem notar o mínimo possivel de degradaçăo de serviços. Para tanto, é interessante a utilizaçào de codificadores e decodificadores (CODECS) robustos a perdas.

Fim geral, a videoconferência tradicional requer interconexào especial através do telefone com alta taxa de largura de banda. Atualmente estào sendo utilizadas redes ISDN e ATM, e com os avanços da tecnologia, proporcionando processadores mais rapidos e melhor esquemas de compressâo de dados, um novo tipo de videoconferência, a conferência desktop, tornou-se viável. Ao contrário das videoconferências em salas especiais, exigindo equipamentos especiais e caros, a videoconferência em desktop pode ser realizada através da inclusão de software e hardware em computadores originariamente para uso pessoal.

\subsection{Os padrões MPEG-4 e MPEG-7}

O crescente número de aplicaçós multimídia torna complexa a representação dos dados audiovisuais, uma vez que a maioria das aplicaçōes utiliza multimidia como característica comum para interatividade com usuário. As aplicaçoes impoiem conjuntos de especificaçós que variam muito de uma aplicaçào para outra. A diversidade de aplicaçôes implica em diferentes conjuntos de especificações, sendo que cada aplicaça pode ser caracterizada pelo de dado a ser processado (vídeo, imagem, texto), natureza do dado (natural, sintética, médica, gráfica), taxa de bits (haixa, média e alta), atraso admissível máximo, tipo de comunicação (ponto-a-ponto, multiponto), e por um conjunto de funcionalidades oferecidas (escalabilidade, manipulaçào de objetos, ediçào).

Tanto a indústria eletrônica como as operadoras de TV a cabo, companhias de telecomunicações e empresas de software c hardware têm mostrado um interesse crescente em multimídia. Esta tendência tem acelerado o crescimento da utilizaçào de CD-ROMs, do ambiente da WWW e, mais recentemente, do DVD. Assim, os padrões que atualmente 
existem para multimídia nào conseguem atender adequadamente às novas expectativas e requisitos do usuário e das novas e complexas aplicaçōes (Ebrahimi \& Horne, 2000). Dentro deste contexto, dois novos grupos de trabalho MPEG foram criados para desenvolver padrós com o objetivo de atender os requisitos das aplicaçòes multimidia atuais e futuras, sendo denominados MPEG-4 (1SO, 1997b) e MPEG-7 (1SO, 1997c).

Conforme apresentado, diversas tecnologias podem ser utilizadas para a construçäo de aplicações multimídia interativas. No contexto do grupo MPEG, o padrão MPEG-2 é o mais indicado para a codificação de imagens, porém, à medida que os requisitos de interatividade estào se tornando mais complexos, a demanda por tecnologias mais adequadas tem crescido (ISO, 1997d; ISO, 1997e).

O grupo MPEG, desde 1980, tem trabalhado na padronizaçào de informaçào audiovisual (áudio e vídeo), tendo como resultado dois padroes mundialmente conhecidos: o MPEG-1 (IS-11172) e MIPGG-2 (IS-13818). O primeiro especifica o armazenamento de áudio e vídeo a taxas de 1,5Mbps; o segundo manipula a codificação genérica de TV digital e sinais de HDTV (high Lefinition Television). Estes padrōes têm, ao longo do tempo, gerado forte impacto na indústria eletrônica.

Em linhas gerais, o padrão MPEG-4 visa altender as áreas de televisào digital, aplicaçöes gráficas interativas e WWW, além de fornecer requisitos para integrar a produçào, distribuição e acesso ao conteúdo basedo em informaçào audiovisual. O padrão MPEG-7 tem como nome formal "Interface de Descrição do Conteúdo Multimídia" e oferece um conjunto padrão de descritores e esquemas de descriçăo usados para especificar o conteúdo da informação, com a finalidade de tornar a busca da informação multimídia mais rápida e eficiente.

O padräo MPEG-4 é o sucessor natural do MPEG-2, tendo sido desenvolvido para ser um padrăo multimídia e não somente audiovisual (como o MPVG-2), e já existem estudos para o encapsulamento de stremms MPEG-4 em MPLG-2, o que é utilizado pelos padròes da TV Digital.

O padrão MI'EG-7, ao contrário dos demais padròes $\mathrm{MPEG}$, nào é relacionado à codificaçào de áudio e vídeo; sua funçào é criar um padrăo para a descrição de uma cena audiovisual, 
uma imagem ou sons, que não precisam estar armazenados digitalmente. O MPEG-7 pretende disponibilizar ferramentas (nesse caso, as ferramentas säo os descritores, que permitem a criaçào das descrições) para que a busca em imagens, videos c arquivos sonoros seja tão fácil quanto é a busca em lexlos.

As Subseçōes 2.6 .1 e 2.6.2 descrevem as principais características destes dois padrōes da família MPFG.

\subsubsection{O padrão MPEG-4}

O padrào MPEG-4 tem como objetivo construir uma cena audiovisual, tratando os dados como objetos de mídia. Esses objetos podem ser vídeo, áudio, objetos sintéticos (imagens e áudio gerados por computador) e objetos Web (documentos na WWW), além de sua relação com o tempo e o espaço.

As informaçóes dos objetos, que serão especificados posteriormente, são organizadas em árvores. Outro aspecto do MPEG-4 é permitir a integraçào da produçào, distribuiçào e do acesso a conteúdo (ISO, 2001a; ISO, 2001b; Battista et al., 1999). A primeira versão MPEG-4 atingiu o nível de padräo intemacional em abril de 1999 (ISO, 1999a) e a segunda versão tornou-se padrào no início de 2001 (1SO, 2001a), porém, alģumas extensōes ainda estào em progresso.

Uma cena audiovisual MPEG-4 é descrita como a composição de objetos de mídia primitivos. Um objeto de mídia primitivo é, por exemplo, um vídeo da face de uma pessoa ou um áudio de uma voz, e correspondem às folhas em uma árvore descritiva. Já um objeto composto associa esses objetos em subárvores, de modo que sc pode ter, dentro de um objeto composto, um vídeo de um rosto e o áudio relacionado a uma voz, facilitando a manipulação de vários objetos relacionadus. Dentre as suas características, o MPLG-4 permite (ISO, 2001a):

- colocar objetos de mídia em qualquer posiçào espacial, dadas as suas coordenadas;

- aplicar transformaçoes a objetos, mudando sua geometria ou acústica;

- criar objetos compostos, agrupando objetos primitivos;

- mudar interativamente a visualização e o som de conas.

Assim como o MPEG-2, o MPEG-4 possui diversos profiles, sendo 8 para vídeo natural, 7 para vídeos sintéticos e híbridos (sintéticos + naturais), 8 para áudio, 3 para gráficos, 4 para 
descritores de cena, 2 para o MPEG-J e um para a descrição de objetos (ISO, 2001a). Além destes, outros profiles estão sendo estudados (15O, 2000b).

Algumas das aplicaçoes para as quais o MI'FG-4 foi desenvolvido sào (ISO, 2001a; Pereira \& Fbrahimi, 2002):

- brondcast: o MPLG-4, pelo fato de suportar uma compressão de dados muito alta, permite um uso muito bom da largura de handa disponivel; lambém, por esse motivo, permite que diversos strenms de vídeo scjam transmitidos em paralelo; o padrào MPEG-4 trata o vídeo como um conjunto de objetos inter-relacionados e essa característica é bastante interessante para a televisào interativa, uma vez que pode-se associar diferentes objetos a diferentes açoes; o ISDB (TV Digital japonesa) prevê o uso do MPEG-4 em sua implementação;

- visualizaça de conas de modo colaborativo: o MPEG-4 e bastante apropriado para a organizacão de cenas envolvendo objetos reais e virtuais, yue devem ser transmilidos para participantes dispersos; isso faz do MPEG $\mathrm{M}^{-4}$ uma poderosa ferramenta para a construçào de aplicaçōes de trabalho colaborativo, aplicações de realidade virtual e de realidade aumentada (minguented renlity);

- armazenamento e recuperação baseada em conteúdo: pelo fato do MPEG-4 permitir uma descriçáo dos objetos, a busca por palavras-chave fica bastante facilitada. Essa característica é táo importante que o uso adequado de metadados (comumente chamados de dados sobre os dados) é o objetivo principal do MPEG-7, que será descrito na Seção 2.6.2;

- Se'-fop box da Televisão I)igital: a 'J'V Digital, como foi dito anteriormente, irá mudar o modo das pessoas assistirem televisão, uma vez que ella possuirá um ambiente mais interativo; algumas das características que o MPLG-4 possui, que podem ser hastante interessantes para a 'IV Digital são: a) criaçāo de links entre os comerciais apresentados e suas páģinas na Internet; b) acesso à informaçào na Internet; c) jogos interativos e video on de mund;

- jogos: é inegável a popularidade dos jogos de computador nos dias de hoje. A maioria dos jogos utiliza gráficos 3D tanto para o ambiente quanto para os objetos controlados pelo usuário; o uso de $\mathrm{MPEG}-4$ nos jogos abre novas possibilidades com integração dos objetos sintéticos com os naturais e a animação facial;

- computação móvel: com a popularização dos Personal Digital Assistants (PDAs) e dos telefones celulares, fica evidente a importância da computaçào móvel nos próximos 
anos; o MPEG-4, pelo fato de conseguir transmitir vídeo em redes com pequena largura de banda, mostra-se uma boa soluçào para a futura transmissào de vídeos para dispositivos móveis;

- produção de TV: o MPEG-4 apresenta-so como uma interessante evolução en relação ao chroma keying (técnica da TV analógica com a qual é possível colocar um vídeo sobre uma área de outro yue possui uma cor bem definida, normalmente verde ou azul), permitindo a gravação dos objetos separadamente e com diferentes níveis de qualidade.

O padräo MPEG-4 é dividido en sete partes: Sistemas, Visual, Audio, Teste de Conformidade, Software de Referência, DMIF e Software Otimizado para as ferramentas MPEG-7 (codificadores de video), que serão apresentadas a seguir.

\subsubsection{Sistemas (Systems)}

A parte Systems do padrão define a descrição do relacionamento entre os componentes audiovisuais que formam a cena. Esse relacionamento é descrito em dois niveis principais.

O primeiro descritor é o BIFS (Binary format for Scenes) (ISO, 2001a), que descreve o relacionamento espacial o temporal entre os componentes da cena. O BIFS ó baseado no conceito do VRMI, tanto na estrutura quanto na funcionalidade da composição de nós de objetos. O outro descritor é o OD) (Object l)escriptor), que define o relacionamento entre os Flementary Streams de cada objeto da cena.

Outros aspectos relacionados à parte Systems do MPEG-4 são a interação, a multiplexação, o armazenamento, interfaces com redes e outros equipamentos, representação textual, sincronização e direitos autorais. A interaçào com e entre os objetos é possível no MPEG-4 de duas formas.

O primeiro tipo de interaçào é o previsto pelo padrão, como o posicionamento espacial éa retirada de objetos da cena. Para que seja possível a interação não prevista pelo MPEG-4, com e entre os objetos, a API MPLG-I, que é derivada da linguagem Java (Cornell, 1997; SLN, 1999; SLN, 2000), pode ser amplamente utilizada. MPFG-J é um sistema de controle flexível e programável que representa uma sessào audiovisual de modo a permitir que a sessão se adapte às características do terminal onde ela será apresentada. MPEG-J possui 
duas importantes características: a) a capacidade de permitir uma pequena degradação quando os recursos sào limitados ou variam de acordo com o tempo; b) a habilidade de responder à interaçăo do usuário e prover funcionalidades multimídia (ISO, 1999d). Na Seçào 5.5, o MPEG-4 Systems é descrito em delalhés e suas relaçoes com esta proposta são discutidas; o mesmo ocorre com a $\triangle P 1 M P \mathrm{MG}_{\mathrm{j}} \mathrm{J}$, na Seção 5.6.

\subsubsection{Visual}

O padrão de vídeo natural do MPEG-4 (ISO, 1998a; P'ereira \& Fbrahimi, 2002) consiste de uma coleça de ferramentas para as áreas de shape coding (codificação de forma), estimativa e compensaçào de movimento, codificação de textura, recuperação de erro, sprite coding e escalabilidade.

O shupe coding pode ser feito de duas maneiras: a) em modo binario, onde a forma de cada objeto e dada por uma máscara binária; b) pelo modo de grayscale (tons de cinza), onde a forma do ohjeto é dada de modo similar ao dos canais alpha, permitindo transparência e diminuindo o alinsingr (diferença nas bordas das figuras). $\Lambda$ estimativa e a compensaçào de movimento é baseada em blecos, que podem ser de 8X8 ou $16 \times 16$ pixels. A codificaçào da textura é baseada no $8 \times 8$ LCI (Discrete Cosine I hmsform). Com algumas modificaçoses, a codificaçäo de texturas estáticas pode ser feita ulilizando transformadas whrele't (Daubechies, $1990)$.

As mais importantes características do padrào de codificaçáo visual do MPEG-4 são (Pereira \& Ebrahimi, 2002; Battista et al., 1999):

- eficiência na compressào: a compressão eficiente foi um dos principais objetivos tanto do MPEG-1 quanto do MPEG-2. O MPEG-4 pretende, a partir de uma codificação melhorada e da codificaçào de múltiplos streans de mídia concorrentes, molhorar ainda mais essa compressäo e, com isso, aumentar o número de aplicaçöes e produtos yue utilizam esse padrăo;

- interaçáo bascada em conteúdo: codificando e representando objetos de vídeo ao invés de quadros de vídeo, o MPEG-4 permite a criaçào de aplicaçoos bascadas em contéúdo;

- acesso universal: as duas últimas funcionalidades do $\mathrm{MPHG}^{-4}$ são a robustez e a escalabilidade permitindo, assim, a transmissào de videos, de acordo com a largura de banda disponivel; O padrào definiu très faixas de bitrates: abaixo de $64 \mathrm{~Kb} / \mathrm{s}$, entre 
64 e $384 \mathrm{~Kb} / \mathrm{s}$ c entre 384 e $4 \mathrm{Mh} / \mathrm{s}$, cobrindo, assim, as necessidades de diferentes aplicaçòes.

Uma cena visual do MPEG-4 é composta por um ou mais objetos de vídeo. Cada objeto de vídeo possui informação temporal e espacial através de sua forma, movimento e textura.

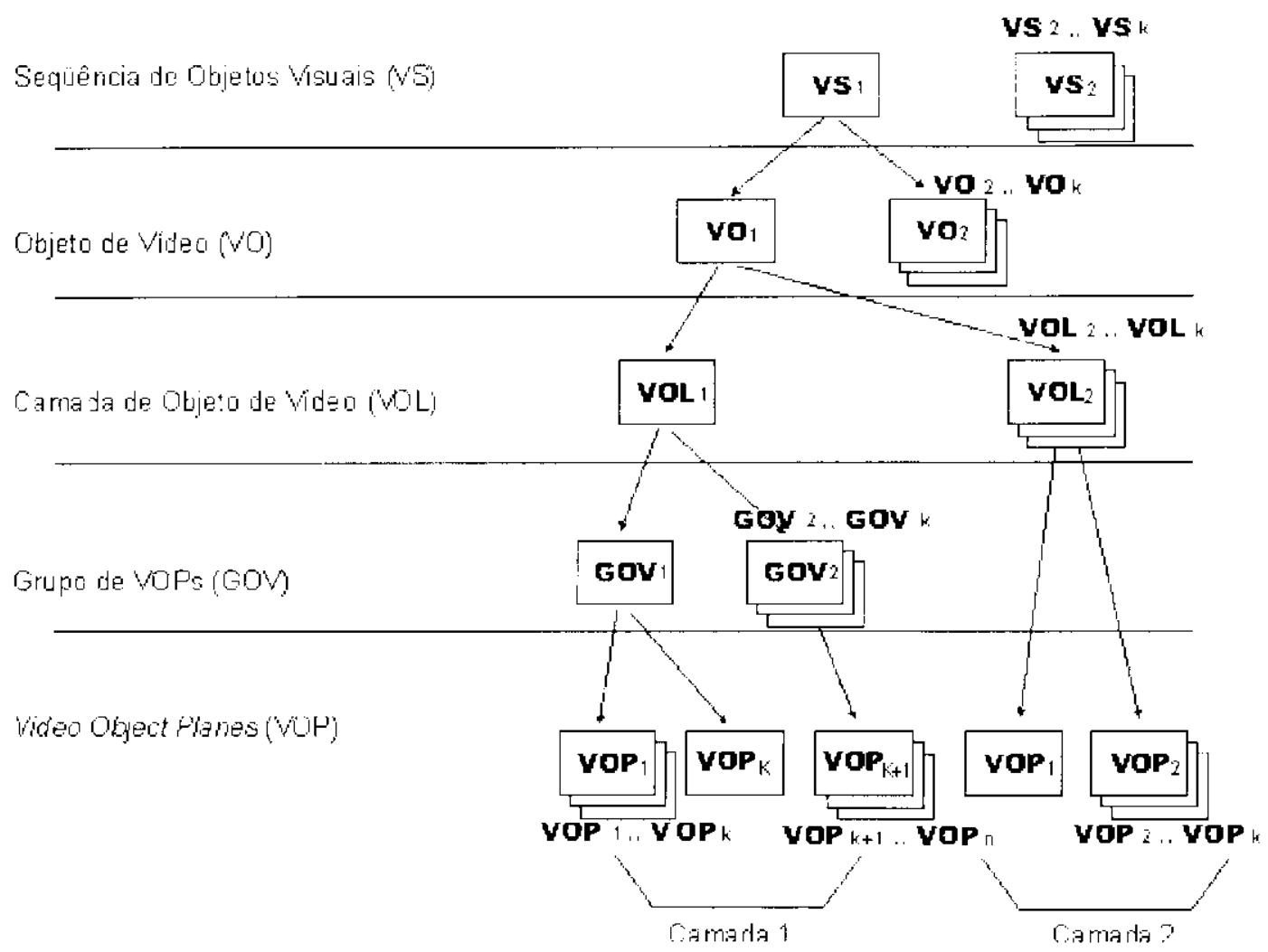

Figura 2.10 - Exemplo da estrutura de um bitstream MPEG-4 (Pereira \& Ebrahimi, 2002)

Um bitstram MPEG-4 tem uma divisão hierárquica (Figura 2.10), sendo dividido em:

- Següiencia de Objetos Visuais (VS): a cena completa, que pode conter objetos 2D e 3D;

- Objeto de Vídeo (VO): um objeto de vídeo é necessariamente 2D, e ele pode ter um formato retangular ou, utilizando máscaras, irregular;

- Camada do Objeto de Vídeo (VOL): um objeto de vídeo pode ser composto por diversas camadas, por exemplo, com diferentes niveis de compressào e quantizaçăo.

Cada objeto de vídeo é dividido em frame's, chamados Video object Plane (VOP), que podem ser agrupados em Gromps of Video Object Planes (GOV). 


\subsubsection{Audio}

A parte de áudio do MPEG-4 é referente tanto à codificação de áudio, com diversos Profiles e Learels, quanto à apresentação de voz sintética, incluindo a sincronizaçào labial c a informação sobre os fonemas.

$O$ áudio MPEG-4 permite o desenvolvimento de uma variedade de aplicaçèes, que vào desde a conversão automática entre fala e texto (text-fo-speéch) até a definição de multicanais e sons tridimensionais. O áudio, assim como ocorre com os objetos visuais, é representado como um objeto de mídia e suas propriedades podem ser manipuladas pelas interfaces definidas pelo MPEG-4 systems. Algumas possibilidades de codificação estão presentes na especificação MPEG-4 Audio.

A primeira possibilidade é a codificação de sinais de áudio genéricos. Neste caso, o objetivo e a codificação de sinais de audio com alta compressâo e destinados a compor stremms de mídia para distribuiçâo em canais com baixa largura de banda. A cobertura, neste caso, iniciase aos $6 \mathrm{kbits} / \mathrm{s}$ num espectro de freqüência de $4 \mathrm{KHz}$. Parâmetros de codificação e a representação orientada a objetos permilem a manipulação de características do sinal de áudio e sua adequação a outros níveis de QoS.

A segunda possibilidade é a codificação de sinais de áudio baseados na fala. Neste caso, a codificaçào é voltada a aplicaşòes em que o áudio leve ser capturado e reproduzido cm tempo real. A codificaçao é gerada para transmissão a taxas que variam de $2 \mathrm{kbits} / \mathrm{s}$ a 24 kbits/s. A codificaçào é bascada em alyoritmos HVXC, permitindo todos os controles de interação do usuário. F́ possível, ainda, durante a codificação, gerar ajustes de velocidade e produzir efeitos nos sinais de áudio.

A terceira possibilidade é a codificaçāo de sinais de áudio sintéticos. O áudio MPEG-4 é estruturado de forma a permitir também a descriçào de sons de instrumentos musicais, assim como ocorre com o formato MIDI. Teste caso, vale observar que os algoritmos não são baseados diretamente nos sons dos instrumentos musicais, mas em descriçôes matemáticas que permitem a codificação de escalas de notas musicais. 
Por fim, é possivel ainda a codificaçào de sinais escaláveis de áudio baseados na fala. () MPEG-4 Audio possui codificadores TTS que operam em taxas que variam de $200 \mathrm{bits} / \mathrm{s}$ a 1,2 Kbits/s, possibilitando a codificação de fonemas e parâmetros de descrição da fala.

\subsubsection{Framework para a Integração da Entrega Multimídia}

Outro componente importante do MPLG-4 é o DMIF (Delinery Multimedia Integration Frametoork) (ISO, 2001a). O DMIF é um protocolo para o gerenciamento de streams multimidia sobre tecnologias de transporte. Fle ó semelhante ao FTP, sendo que a principal diferença é que enquanto o FIT' retorna dados, o IDMIF retorna ponteiros para onde obter os streams de dados, ajustando a QoS do objeto às condiçóes da rede (ISO, 2001a).

Uma vez que os objetos de midia podem ser entregues separadamente, deve haver um mecanismo para integrar estes dados e sincronizá-los. Este mecanismo é composto por duas camadas: a camada DMIF e a camada de Sincronizaçào, conforme ilustra a Figura 2.11. A primeira camada recebe os streams de dados da camada de transmissão de dados (chamada de camada Transmux) por meio dos canais TransMux, implementados na Interface DMII/Network (1SO, 1997b). Listes stremms podem ser compostos por streans independentes, mas com algum tipo de afinidade (normalmente a mesma QuS), e são decompostos em strerms elementares por meio dos FlexMuxes.

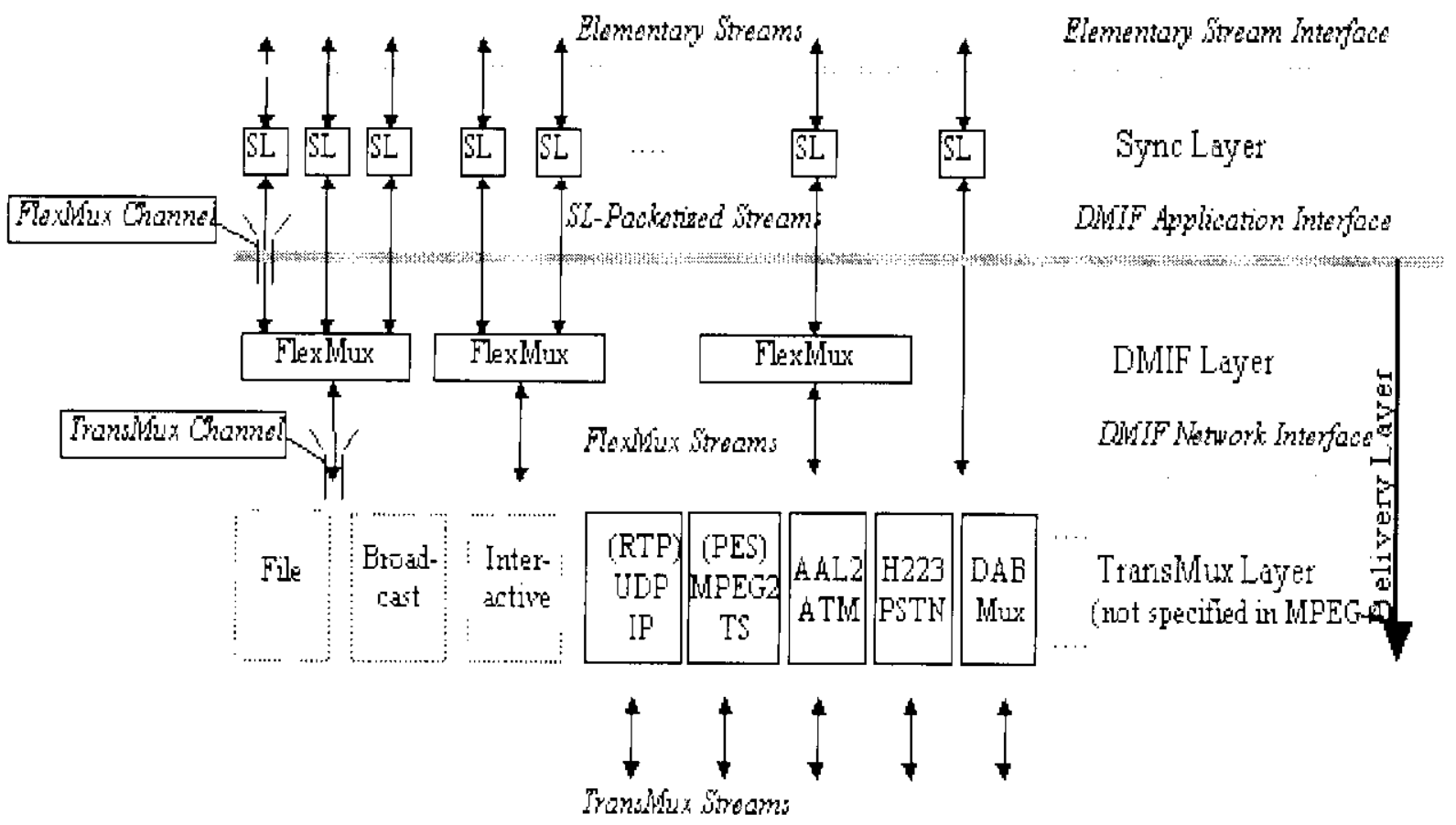

Figura 2.11 - Entrega de dados no MPEG-4 (ISO, 1997b) 
A camada DMIF não é utilizada se a funcionalidade dos FlexMuxes nào é requerida. Estes strem sans são entào entregues à camada de sincronizaçào, que efetua a sincronizaçào dos streams, além de testes de consistência. Após a sincronizaçâo, os streams são entregues à camada de Decodificaçào. Nesta camada, cada stream de dados é tratada pela ferramenta de descompressào adequada, ou utilizado para compor a descrição da cena. Finalmente, os objetos de midia são compostos pelo compusitor de cemal utilizando informações de descrição de cena processadas anteriormente, de modo a reconstituir a informaçào multimídia.

\subsubsection{Software de Referência e Conformidade}

O softzure de referência é um softzorre que deve ser utilizado para o teste de strenms $\mathrm{MP} \mathrm{HG}_{\mathrm{G}}-4$. O softurare desenvolvido se chama IM1-2D e pode ser encontrado no site do CSELT (www.cselt.it).

O teste de conformidade visa estahelecer regras para que futuros softwares que utilizem o padrào MPEG-4 possam ser lestados.

A sétima parte do padrão pretende suportar a construção de um softzare que se utilize das ferramentas MPEG-7, possibilitando a integração completa entre os dois padröes.

\subsubsection{Players}

Vão existem muitus players de MPlGG-4 disponiveis. O mais conhecido é o IM1-2D) feito pelo CSELT (atual Telecom Italia Lab). O IMI-2D foi feito para ser o softanre de referencia, relativo à parte $\bar{y}$ do padrào. A última versâo disponivel para dozuload é a versão 2.7. Ela apresenta os streams MPEG-4 e vem con un codificador. No entanto, não foi possivel implementar um exemplo de TV Interativa, pois foram encontrados problemas para realizar a codificação do vídeo. A ligura 2.12 apresenta a tela do player [M1-2D.

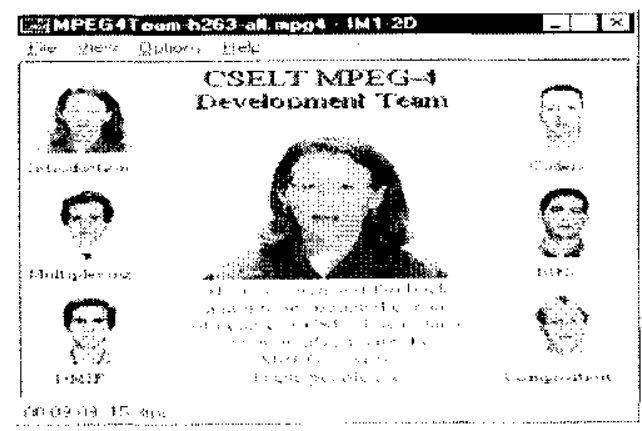

Figura 2.12 - Tela do IM1- 2D 
Existem codecs que implementaram somente a codificaçào do video MPFG-4, no entanto, eles nào são compative is como IM1-2D. Essés codecs são o MPFGG-4 video codec da Microsoft e o da DivX. Os vídeos codificados dessa forma podem ser visualizados no Windows Media Player ou no The Playa, player de video teito pela equipe que desenvolveu o DivX.

\subsubsection{Ferramentas de autoria}

Ainda não existem muitas ferramentas de autoria para o MPEG-4. Uma ferramenta avaliada foi a desenvolvida pelo Instituto Superior Técnico de Portugal. O IST MPFG-4 Video Compliant Framerork implementou diversas funcionalidades do padrão, entre elas a codificaçào separada dos ohjetos. A Figura 2.13 apresenta uma tela do softuerre na qual pode ser notada a presença da árvore de objetos, à esquerda, e da Timeline, abaixo.

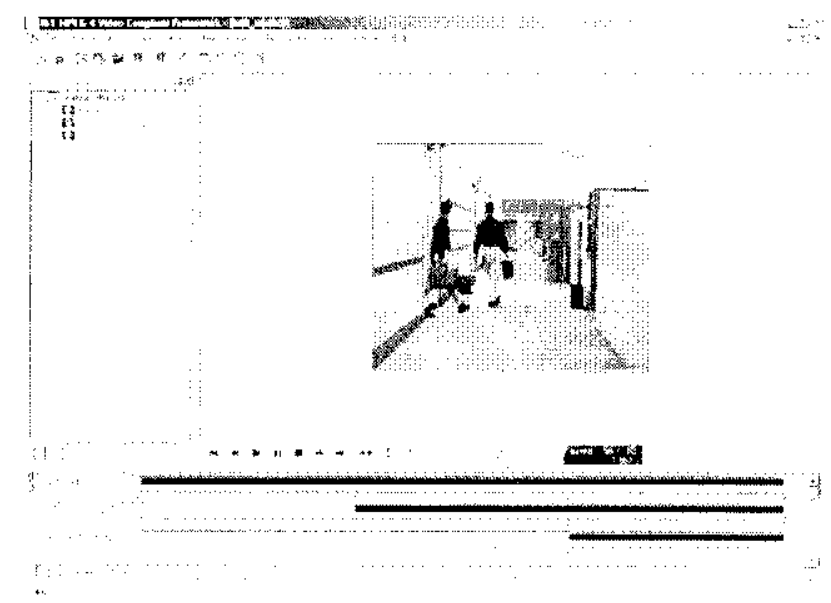

Figura 2.13 - Tela do IST MPEG-4 Video Compliant Framework

O softrare foi testado, porém, ele só trabalha com objetos já codificałos, e os codificadores disponiveis não eram compativeis com ele, bem como os strenms gerados por cle näo eram compativeis com os players.

O CSELT está en fase final de desenvolvimento do Sinfonia, um softuare que compreenderá um player, uma ferramenta de autoria e um servidor de streams.

\subsubsection{O formato de arquivo MPEG-4}

O formato de arquivo do PPEG $_{3}-4$ (cuja extensão é MP4) foi projetado para conter informaçōes, na forma de objetos, de todas as mídias que compõem uma apresentação mullimídia. Trata-se de um formato flexivel, extensivel e que permite o intercambio, o gerenciamento, a edição e apresentação dos objetos de mídia. O formato permite, ainda, a reprodução local ou distribuida em uma rede de comunicagào. Neste segundo caso, a 
apresentação é baseada nas interfaces entre o formato de arquivo e os mecanismos de entrega de stremms (Transivux).

O formato de arquivo loi projetado para ser independente da aryuitetura de codificaçào, distribuição e apresentaçào, lendo sido o projelo baseado no formato de Quick Time (R) da Apple Inc (ISO, 1999a). A ligura 2.14 apresenta o esquenta genérico de um aryuivo MPEG-4.

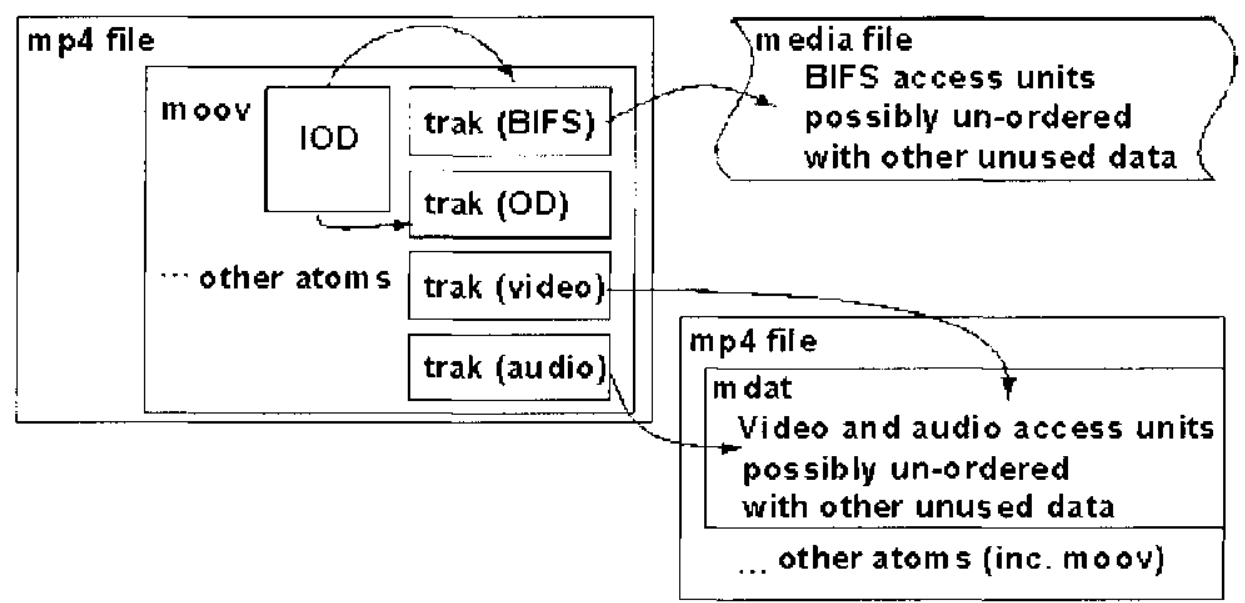

Figure 2.14 - Fxemplo do formato de arquivo MPEG-4 para intercâmbio de dados (ISO, 1999a)

O lormato de aryuivo MPIG-4 é pode ser definido como stremmble, una vez que não define um protocolo de transporte, mas contím informaçoes sobre como os strerams de milia devem ser transportados a apresentados. Desta forma, uma aplicação pode interagir com o formato de arquivo e obter informaçoes para personalizaçào de todo o ambiente (hardware, software, dispositivos) no qual o arquivo esliver sendo manipulado.

\subsubsection{O padrão MPEG-7}

Com o uso crescente de informaçà audiovisual, um modo de descrever o conteúdo dessas informaçòes fez-se necessário, uma vez que as buscas nesses dados näo eram "eficientes". Para isso, foi utilizado o conceito de metadados, também conhecido como "dados sobre os dados".

Diversos trabalhos nessa linha de pesquisa já foram feitos no grupo Intermidia do $\mathrm{IC} M \mathrm{MC}$, como, por exemplo, " trabalho de Goularte (Goularte, 1998). O uso de metadados em conteúdo audiovisual tornará possivel a busca minuciosa em grandes bases de dados, em um tempo baslante curto, semelhante à busca em texto. No entanto, para que seja possível essa busca, o conteúdo audiovisual deve ser descrito de uma forma padronizada. 
O MPLG-7 (ISO, 1999c; ISO, 2000a), formalmente conhecido como "Interface de Descriçào do Conteúdo Multimídia", tem como objetivo especificar um conjunto padrão de descritores de vários tipos de informaçōes multimidia. Fssa descrição será associada ao conteúdo permitindo, assim, um modo de procura eficiente para o material de interesse do usuário.

İm termos de padronizaçăo, pretender-se definir com o MPEG-7:

- T'ipos de Dados (Ditratypes): elementos de descrição não específicos ao dominio audiovisual, que correspondem ao reuso de tipos hásicos ou estruturas, utilizados por múltiplos Descritores e Esquemas de Descrição;

Descritores (D): representam as caracteristicas e definem a sintaxe c a semântica de cada representaçào de características;

- Esquemas de Descriçar (DS): especificaçào da estrutura e da semântica dos relacionamentos entre seus componentes, que podem ser Ds ou DSs;

- Uma Linguagem de Definiçăo de Descriçào (Definition Description Language) (DDL) (ISO, 1999b): para permitir a criação de novos DSs (ou mesmo novos Ds) e permitir a extensão e modificação dos mesmos.

O MPFG-7 não especifica como é feita a extração das descriçôes/(aracteristicas do objeto, hem como nào especifica um mecanismo de busca que faça uso das descrições (ISO, 2001c).

O MPEG-7 tem como principais áreas de aplicação (Nack \& Lindasy, 1999):

- Liducação;

- Jornalismo;

- Informaçào turística;

- Serviços culturais (museus, galerias de arte e exposiços);

- Entretenimento (jogos);

- Sistemas geográficos;

- Aplicações biomédicas;

- Home-Shopping (busca por palavras-chave);

- Arquivos de filmes, vídeo e rádio (permitindo, assim, uma busca por assunto).

O ISDB (TV Digital Japonesa) já prevê o uso do MPEG-7 como modo de descrever seus programas e, com isso, tem trabalhado em conjunto com o TV-Anytime Forum na especificaçào de como utilizar o MPEG-7 na TV Interativa ('IVAF, 2000c). 
O padrão MPEG-7 é dividido em sete partes: Sistemas, Linguagem de Definição de Descriçào, Visual, Áudio, Fsquemas de Descriçăo Multimídia, Softurare de Referência e Teste de Conformidade, que serão apresentadas a seguir.

\subsubsection{Sistemas (Systems)}

A primeira parte do padrào MPEG-7 é o Systemts (ISO, 2001b). É a arquitctura padrào do sistema, que especifica as funcionalidades para a comunicaçào das descriçöes do conteúdo multimídia.

O objetivo do MPt.(j-7-Sy.stems é criar uma especificação não ambigua que permita aos desenvolvedores e usuários de MPEG-7 o desenvolvimento de decodificadores MPEG-7 e o preparo de Descriçóes MPEG-7 para o transporte e armazenamento.

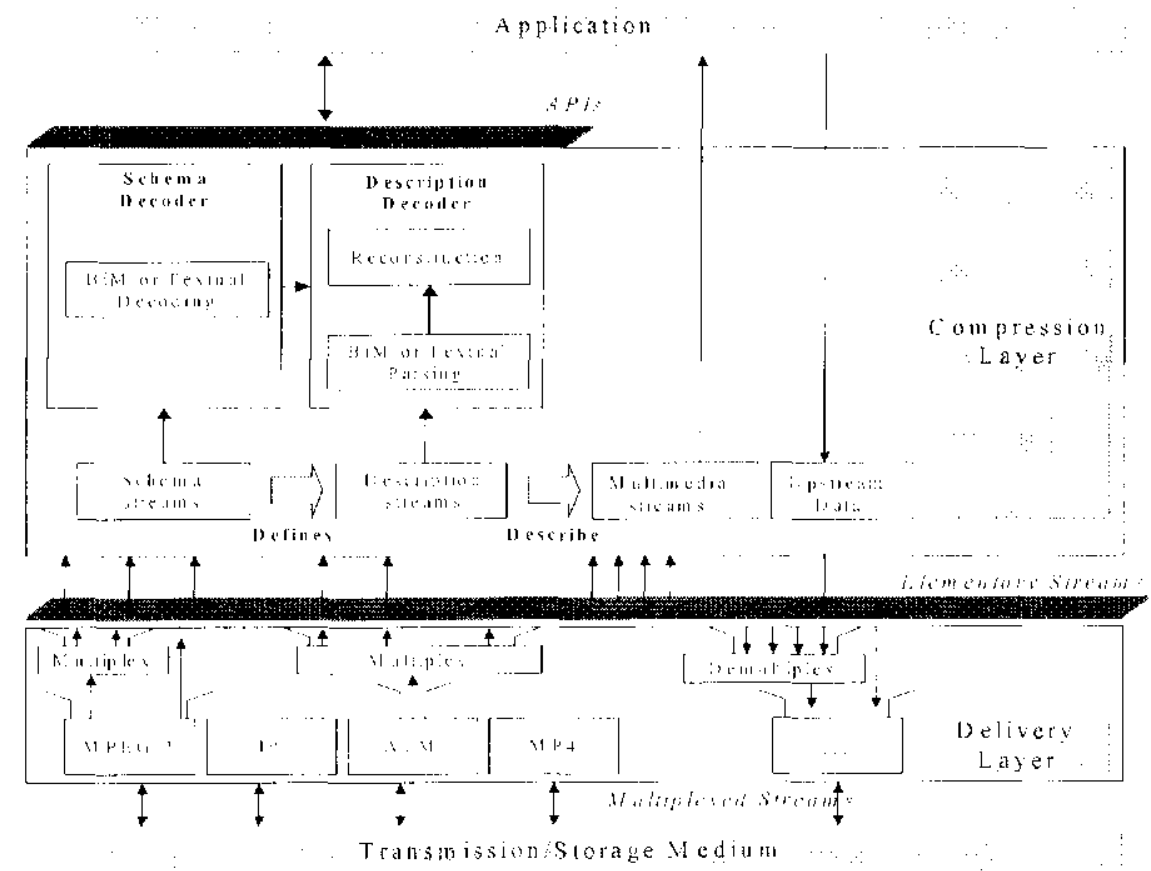

Figura 2.15 - Arquitetura MPEG-7 (ISO, 2001d)

A Figura 2.15 apresenta a arquitetura do MPEG-7. A camada mais baixa é o meio de transmissäo/armazenamento (Thumsmission/Storgore Medium), referente às camadas de distribuçóses da infra-estrutura.

O strenm MPEG-7 pode ser transportado de diversas maneiras, como MPEG-2, ATM, IP ou MPEG-4, sendo que na Camada de Transmissão (1)elinery Layer) é especificado como isso ocorrerá. 
A Camada de 'Transmissäo entregará stremms clementares de MP'EG-7 para a Camada de Compressäo (Compression layler). Esses strems dementares podem ser compostos por Esquemas de Descriçào ou por Descriçoes, que podem estar representados ou no formato textual ou no formato binário (BiM - Binary Format for MPEG-7), dependendo da aplicação que o utilizará.

\subsubsection{Linguagem de Definição de Descrição (DDL)}

Para que as Descriçōes e Esquemas de Descriçăo sejam feitos, é necessária a definição de uma linguagem para a criaçào dessas descriçōes. O MPEG Group decidiu recentemente pela adoção da linguagem XM1, Schema (W3C, 2001a; W3C, 2001b; W3C, 2001c), por ser um padrão hastante difundido no mundo. Porém, como o XML Schema não foi feito especificamente para o conteúdo audiovisual, foram criadas extensòes para o MPEG-7. Essás extensões são relativas à representação de matrizes e vetores e a tipos de dados relativos a tempo. Com isso, a DDL do MPEG-7 foi dividida em três partes: a linguagem estrutural do XMI. Schema, os tipos de dados do XMI. Schemn e as extensöes feitas, que podem ser encontradas no documento que especifica a DDL MPLG-7 (ISO, 2001c).

\subsubsection{Visual}

A terceira parte do padrāo (ISO, 2001d) especifica ferramentas (descritores) para a descrição do conteúdo visual, como imagens, vídeo e imagens em 3D.

As ferramentas säo definidas a parlir de sua sintaxe cm DDL e representaçào binária (BiM) e permitem a descriçào das características visuais, como cor, textura, formato e movimento, assim como permitem a descrição da localizaçào dos objetos descritos em uma imagem ou seqüencia de vídeo.

\subsubsection{4 Áudio}

Esta parte do padräo MPEG-7 (ISO, 2001e) especifica ferramentas para a descrição do contéudo sonoro.

O formato de codificaçào ou o meio de transmissào nào sào fatores limitantes, bem cono não é limitado à descrição de músicas, discursos, efeitos especiais e trilhas sonoras. Também foram descritos os timbres de instrumentos e as saúdas de mecanismos de reconhecimento de 
voz. Através desses descritores pretende-se que seja possível a localizaçào de áudio por semelhança.

\subsubsection{Esquemas de Descrição de Multimídia (MDS)}

A quinta parte do padrảo MPEG-7 especifica as ferramentas para a descrição de informaçòes multimídia.

As ferramentas podem ser divididas em elementos básicos (Basic Llements), dementos de descriçào de conteúdo (Content Description), elementos de gerenciamento (Content Manngentent), organização de conteúdo (Content Organization), navegaçăo e acesso (Navigation \& Access) e interação do usuário (User Interaction), como mostrado na Figura 2.16.

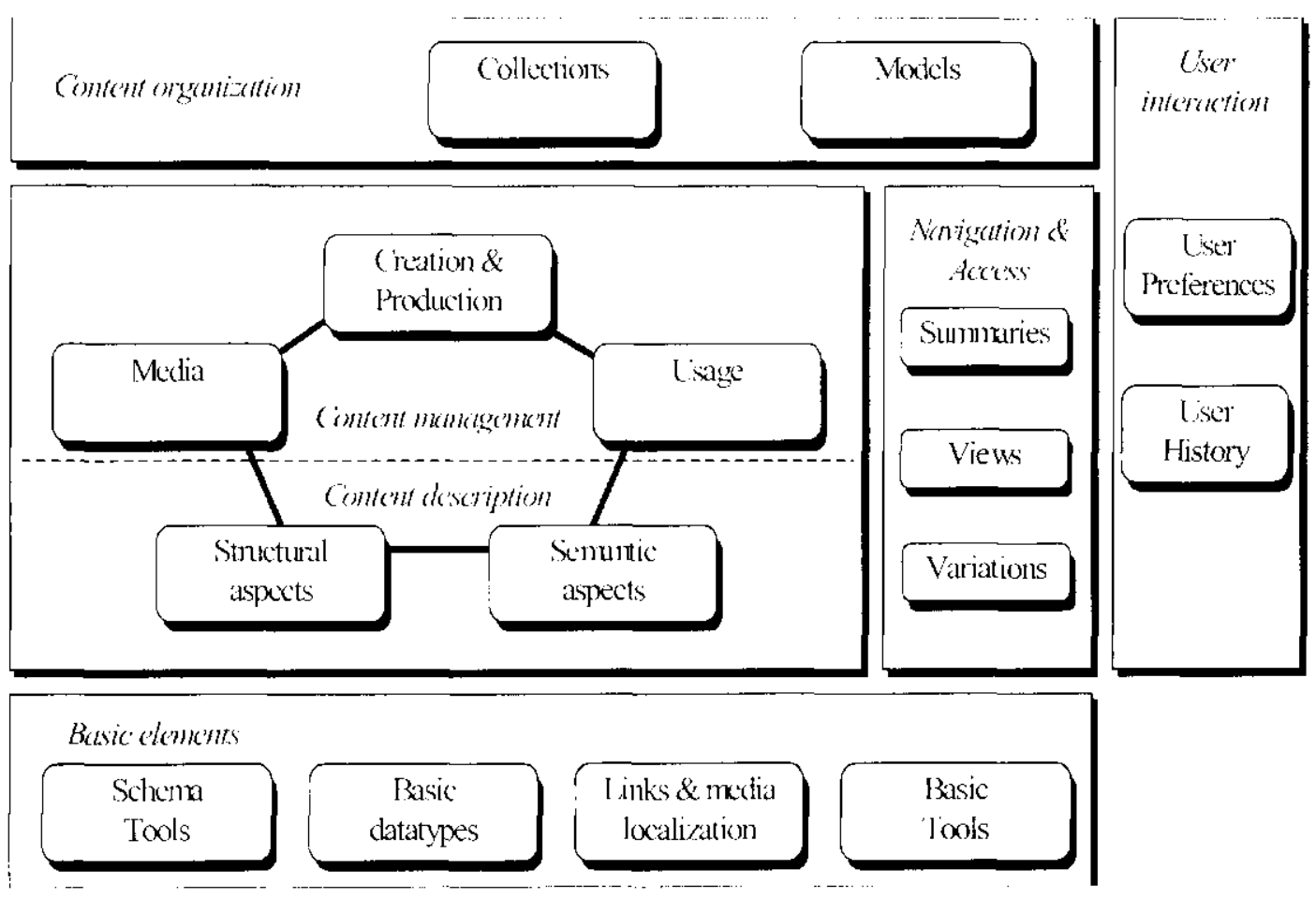

Figura 2.16 - Estrutura do MDS (ISO, 2001f)

\subsubsection{Software de Referência}

A sexta parte do padrão é a criação de um softume de referência. Esse softrmme é dividido em quatro partes:

- Um parsier de DDL;

- Descritores visuais - o software deve criar descriçoes padröes do conteúdo visual;

- Descritores sonoros - o softzmare deve criar descriçoes padróes do conteúdo sonoro;

- Fsquemas de Descriçăo Multimídia - o suftrone deve possuir esquemas de descrição multimídia padrōes. 
No entanto, ainda não foi otimizada a aquisiçào automática de características sonoras, visuais ou multimídia $(\mathrm{ISO}, 2001 \mathrm{~g})$.

\subsubsection{Teste de Conformidade (Conformance Test)}

A última parte do padrão definirá guias e procedimentos para o teste de conformidade com o padrào das implementaçós. Un exemplo da descriçào de um video utilizando o MPEG-7 MDS é apresentado na Figura 2.17.

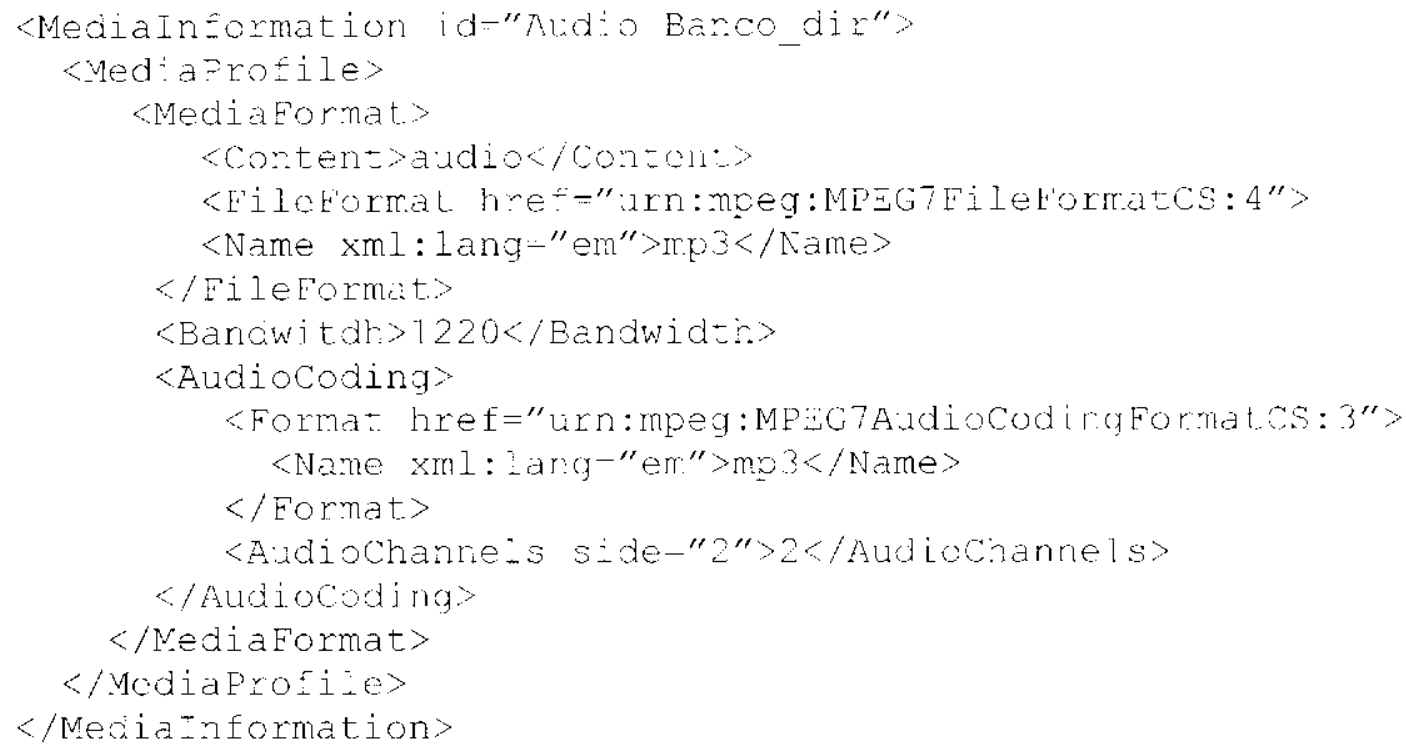

Figura 2.17 - Exemplo de uma descriçāo de um vídeo em MPEG-7

\subsection{Apresentando o MPEG-21}

Atualmente, existem muitas tecnologias, formatos e tipos de mídia que podem ser utilizados na construção, distribuição e consumo de conteúdo multimídia. Năo há, entretanto, nenhum frmacurork para descrever como esses elementos, já existentes ou em desenvolvimento, se relacionam.

O foco principal do MPEG-21 - padrão cm fase inicial de desenvolvimento pelo grupo MPEG - é descrever como esses vários elementos de mídia podem ser utilizados de forma conjunta. Como resultado, espera-se que o MPEG-21 forneça uma estrutura aberta para a distribuição e consumo de conteúdo multimidia, preservando tanto os direitos do autor quanto do consumidor. Espera-se, também, que o padrão MPEG-21, enquanto framéork, possa fornecer mecanismos padronizados para interoperabilidade de sistemas multimídia, 
permitindo o uso transparente de objetos multimidia através de redes de comunicaçăo que interliguem comunidades distintas ao redor do mundo (MPEG-21, 200l; Koenen, 200L).

\subsubsection{MPEG-21 como um framezeork multimídia}

Atualmente, as tecnologias multimidia suportam o uso de dilerentes tipos de players para visualizacáo de conteúdo. Lissas tecnologyias estaio também asseciadas a mecanismos de rede, permitindo o acesso a inlormaçäe e aes serviços a qualquer momento e de qualquer luggar. Veste ponto, terminais ubíquos têm sido desenvolvidos em conjunto com as tecnologias de comunicaçào. Entretanto, nenhuma soluçà pode ser considerada completa, uma vez que cada soluçàn utiliza seus próprios modelos, procedimentos, formatos de midia, gerando diferentes possibilidades de arquitelura e composiça da infra-estrulura. De qualquer forma, pode-se dizer que os ambientes multimidia tendem a se tornar cada vez mais complexos e inlegrados.

Neste cenário, desenvolver uma estrutura comum para uso de multimídia facilitará a cooperaçâo entre os diversos clementos da cadeia produtiva, yue envolve es produtores de conteúdo, os provedores de acesso à rede de comunicacáo (geralmente a Internet), os produtores de interface, os administradores de redes de comunicaçào e os usuários finais.

Para contemplar us interesses desses diversos elementos, os objetos de midia, yue compóm uma aplicaçäo multimídia, devem ser identilicades, descritos, controlades e protegides. O transporte e a entrega de um objeto de midia deve respeitar parâmetros pré-estabelecidos durante a produçán $\%$ ou durante as negociaçoes entre os terminais e as redes de comunicaçao, considerando-se os eventos que podem ocorrer durante uma sessäo de interação. Adicionalmenle, os aspectos de gerencia de informaçous do usuário, tais como suas prelerências, podem influenciar diretamente o consumo dos objelos de mídia e as questöes que envolvem a propriedade intelectual, por exemplo. Lsta abordayem permite a adapatabilidade ao nivel da infra-estrutura e a controle de itens como personalizacáo, seģurança, tarifaçao, dentre outros.

Dentro do escopo do .MPEG-21, a sintaxe e a semántica dos objetos de midia passam a ser referenciadas no contexto dos itens digitais. Neste sentido, o MPLG-2l prevé a definiçào de sete subgrupos de recomendaçôes: a) Schema de declaraçào do item digital (uma abstração de LRI com potencial de interoperabilidade) l; b) identificaça do item digital (natureza, 
granularidade, tipo); c) manipulaçào de protocolos de acesso ao item digital; d) gerência da propriedade intelectual e proteçào de direitos; c) interoperabilidade entre terminais e entre as redes de comunicação; f) formatos de representação de itens digitais; f) controle de ('ventos.

Observa-se que as recomendaçós MPEG-21 estào diretamente relacionadas com as questōes de interoperabilidade, o que tem influenciado as propostas de contribuiçào durante o processo de padronização do MI'EG-21.

\subsubsection{O escopo do MPEG-21}

O escopo do MPEG-21 pode ser definido como a integração das tecnologias e recursos para permitir a autoria, distribuiçào e consumo de conteúdo multimídia, além de suportar o gerenciamento da propriedade intelectual.

Do ponto de vista tecnológico, definir um framenork exiģe contribuiçoes de diversos segmentos da cadeia produtiva. Lima proposta de estrutura de aplicaçós multimidia é o passo inicial do MPEG-21, identificando aspectos de integração de tecnologias e sistemas, bem como novos critérios de interaçâo em todos os níveis (ou camadas) de uma aplicaçào, sendo que esses níveis estào relacionados com o usuário, com a infra-estrutura de comunicação, com os dispositivos de apresentaçáo e com a aplicação multimídia propriamente dita.

\subsubsection{O modelo do usuário}

No contexto do MPEG-21, um usuário é toda e qualquer entidade que interage num ambiente MPEG-21, manipulando itens digitais de mídia.

Os usuários são identificados através de seus relacionamentos com outros usuários ou por alguma interaçào no ambiente como um todo. Todo e qualquer tipo de usuário (produtor, distribuidor, consumidor) é identificado da mesma forma no MPlig-21, uma vez que, independente da ação do usuário, este se relaciona com itens digitais de mídia, que são o foco central da proposta do padrào. 


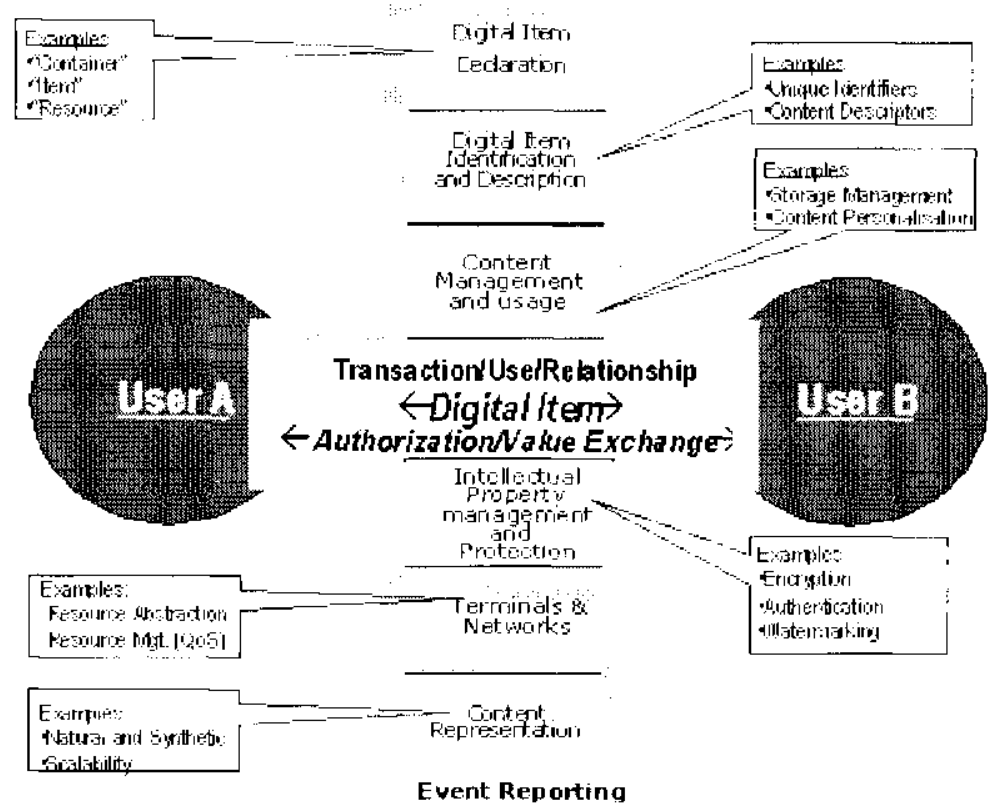

Figura 2.18 - Modelo de eventos e interfaces que descrevem interaçòes MPEG-21 (MPEG-21, 2001)

Em seu nível mais básico, o MPEG-21 oferece uma estrutura a partir da qual um usuário interage com os itens digitais de mídia e participa da geração de interaçóes no ambiente como um todo. Neste ponto, as interaçoes säo baseadas nos itens digitais e as restrições de interaçóes no ambiente estão definidas na estrutura desses itens digitais, conforme ilustra a Figura 2.18.

\subsubsection{MPEG-21 e os itens digitais}

Ĺm padrào, tal como MPEG-21, que propöe estruturar a integraçăo de tecnologias em larya escala, deve descrever, de forma precisa, como os itens digitais de mídia devem ser formados, gerenciados e utilizados por todas as entidades pertencentes ao sistema.

Existem muitas maneiras para descrever um item digital de mídia. Desta forma, um desafio adicional do MPEG-21 é configurar modelos de descriçào que scjam suficientemente flexíveis quanto à interoperabilidade. Tais modelos serão considerados úteis se produzirem formatos capazes de representar todo e qualquer item digital de mídia.

A especificação da declaração de um item digital (MPVG-21, 2001) consiste do uso de um dos modelos disponíveis e que seja suficientemente completo para permitir o gerenciamento desse item digital. L'm exemplo pode ser visto a seguir. 
Supondo a declaraçào de uma zeeb page como um item digital. Uma 'web page consiste lipicamente de um documento HTML e seus links para outros documentos (hiperdocumentos). Adicionalmente, uma weh page pode conter também elementos de mídia, tais como imagens (JPEGs e GIFs), vídeo (AVI, MOV, MPG), audio (WAV, MIDI, MP3) e animações (VRMI., Flash). Neste exemplo simples, pode-se declarar o item digital como sendo a areb proge acrescida de toda a árvore de elementos formadores. Aplicaçoes como Java applets e scripts podem modificar a wet page para determinar, por exemplo, qual o idioma do ustário que estiver visualizando o hiperdocumento. O ponto-chave é que a interação pode modificar o conteúdo do item digital. Desta forma, mecanismos devem permitir a separação dos elementos que comporm a estrutura do item digital de outros elementos que, potencialmente, manipulam éventos e/ou geram interaçōes no ambiente. Observa-se, então, que algumas interaçoes podem ser permitidas em algumas plataformas e nào serem possíveis e/ou permitidas em outras plataformas. No entanto, a estrutura do item digilal deve ser universal (independente da plataforma).

\subsubsection{Declaração de itens digitais}

O objetivo da declaração de um item digital é descrever um conjunto de operaçoes e conceitos abstratos que instanciem esse item a um dos modelos de itens digitais disponiveis no escopo do MPFG-21.

Dentro de um modelo, um item digital passa a ser a representação digital de um objeto de mídia e suas operaçòes que geram interaçöes no ambiente. O modelo, por sua vez, deve ser tào flexível e genórico quanto possivel, fornecendo todas as primitivas necessárias para compor a luncionalidade de uma instancia desse modelo (item digital). Adicionalmente, o modelo deve fornecer concsitos comuns que permitam o mapeamento (mapping) entre esquemas que descrevem itens digitais de mídia de modelos diferentes.

\subsubsection{Identificação de itens digitais}

O escopo da identificaça de um item digital inclui: a) como identificar um item digital e os recursos associados ao item; b) como identificar se um endereço de rede (por exemplo, o IP address) está relacionado a um ou mais itens diritais; c) como identificar esquemas de descriçâo relativos a modelos que instanciam itens digitais; d) como usar identificadores para associar itens digitais a informaçóes e/ ou metadados do ambiente. 
A especificaçào de identificaçào de itens diģitais nào cobre açoes que nào estejam relacionadas no modelo de item digital. Os identificadores cobertos por uma identificação de item digital devem ser incluídos diretamente na identificaçào e relacionados aos itens permitidos pelo modelo em uso. A Figura 2.19 apresenta as possibilidades de identificadores para os itens digitais e seus relacionamentos em um modelo de item digital.

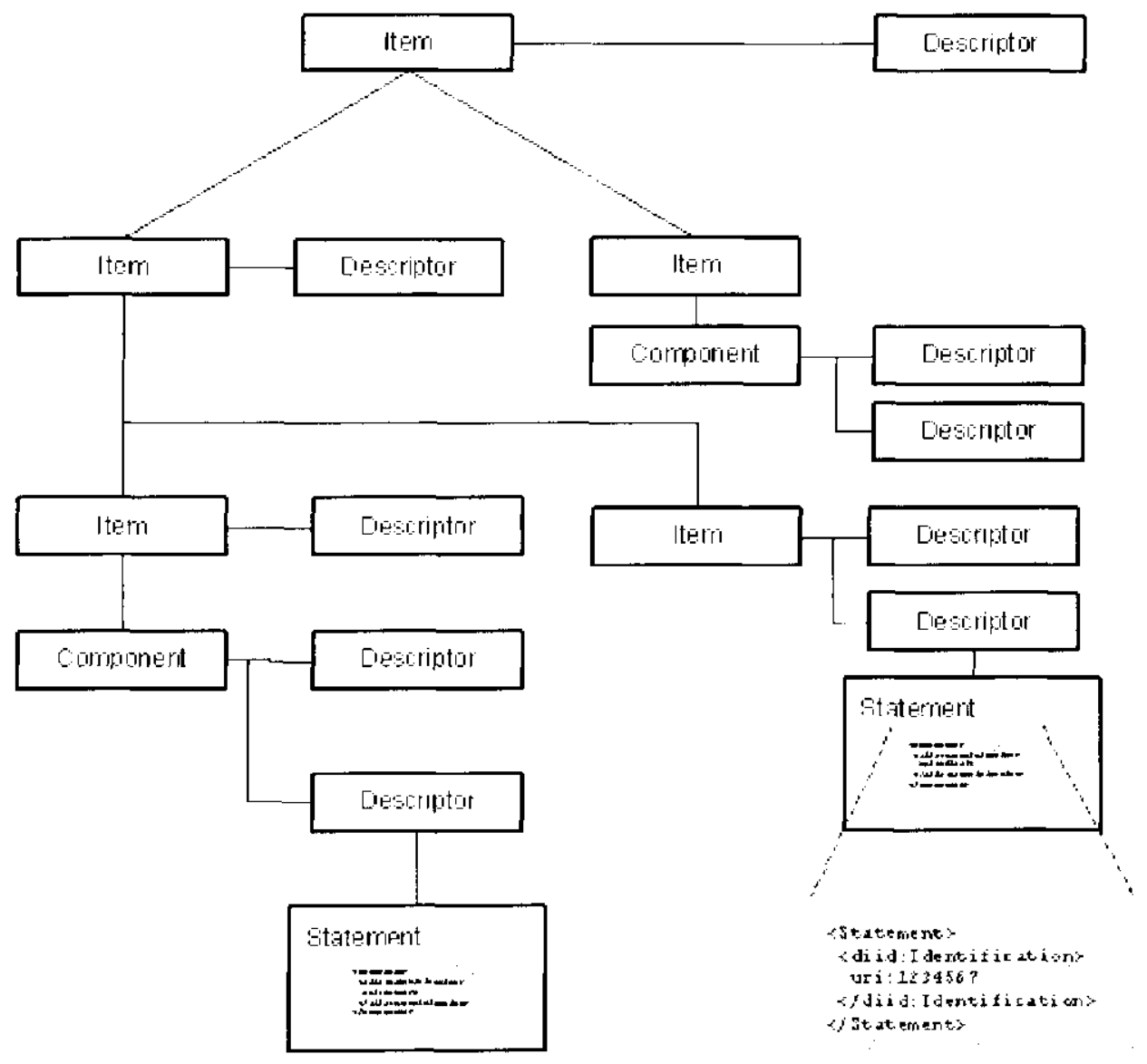

Figura 2.19 - Relacionamento entre a declaração, identificaçäo e descriçāo de um item digital

\subsubsection{Adaptação de itens digitais}

O objetivo dos elementos associados aos terminais a a rede de comunicação é permitir o acesso transparente aos itens digitais de midia. Isto permite a personalização do acesso a esses itens de mídia e o desenvolvimento de aplicaçoes yue utilizem informaçoes para controle automático de açòes. Para se atingir esse objetivo, é necessário o desenvolvimento de modelos de adaptação dos itens digitais ao ambiente em que estiverem sendo referenciados.

O MPEG-21 propóe o desenvolvimento de um motor de adaptação de itens digilais, que é composto por mecanismos e descriçoes que analisam as relaçoes descritas entre os items 
digitais e os recursos associados. A Figura 2.20 apresenta um esquema para adaptaçào de um item digital a ambientes distintos.

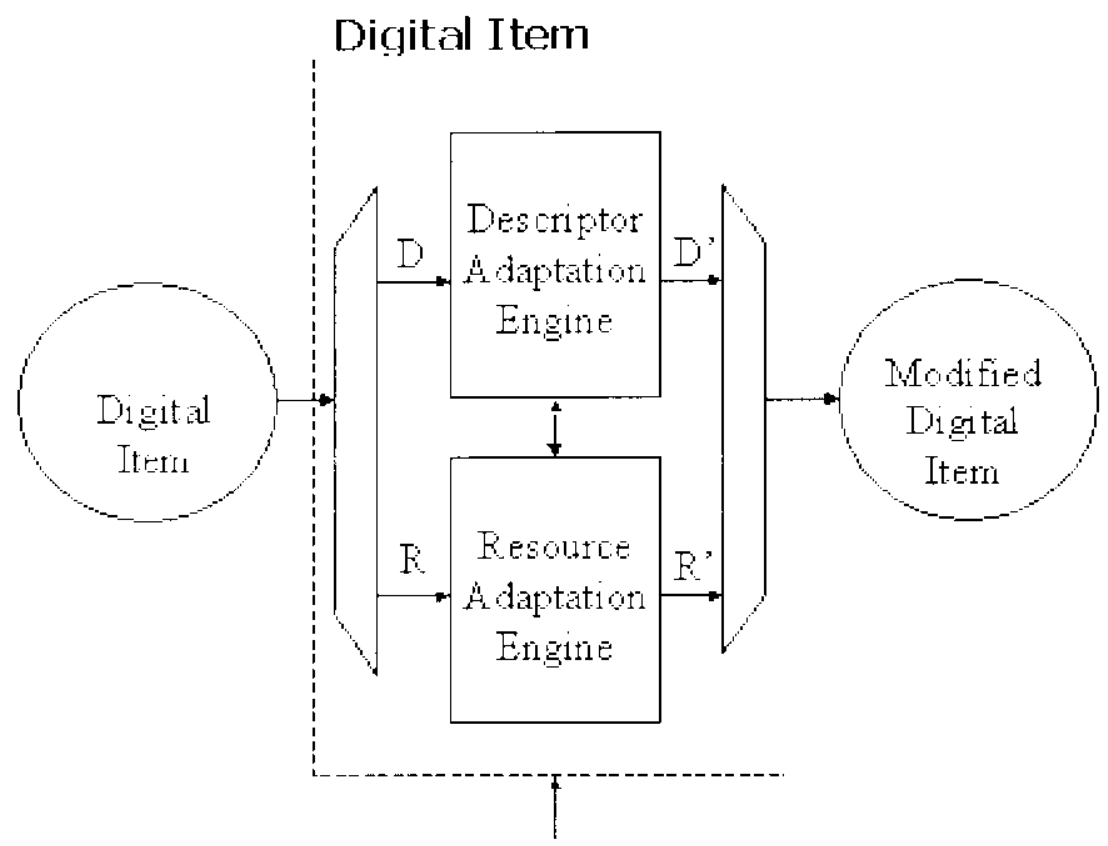

Digital Item Adaptation Descriptions

Figura 2.20 - Fsquema para o conceito de adaptação de item digitalm(MPEG-21, 2001)

O estágio atual de desenvolvimento do MPEG-21 contempla seis categorias de investiģaçào, para as quais novas propostas têm sido encaminhadas ao grupo MPEG, a saber:

- características do usuírio: propostas yue especifiquem ferramentasde descricão das características de um usuário, incluindo suas preferências em relaçào à interação e também as preferéncias em relação à infra-estrutura disponivel; aspectos de mobilidade devem ser considerados em relação ao acesso ao item digital;

- potencialidades dos terminais: propostas que especificuem ferramentas de descrição que identifiquem a potencialidade de uso de diversos tipos e configuraçōes de terminas de exibição/interaçăo multimídia, incluindo aspectos de decodificação, composição, protocolos de comunicaçào, software e demais sistemas relacionados;

- características da rede: propostas que especifiquem ferramentas de descriçăo das potencialidades para adaptabilidade de uma infra-estrutura de comunicaçāo às necessidades de uma aplicaçào, considerando-se as características dos itens digitais envolvidos; 
- características naturais do ambiente: propostas que especifiquem ferramentas de descrição que permitam personalizaçào das interfaces em relação às propriedades (iluminaçäo, ruídos, área, objetos) e ao contexto de um determinado ambiente;

- adaptability dos recursos: propostas que especifiquem lerramentas que auxiliem a manipulaçäo de recursos através de metadados que descrevam esses recursos; adicionalmente, essas ferramentas devem permitir ajustes nas propriodades dos recursos para os casos em que os parâmetros de qualidade de serviço (QoS) devam ser ajustáveis;

- mobilidade da sessão: propostas de ferramentas que especifiquem como transportar o estado de um item digital de um ponto a outro; ao nível técnico, essas propostas devem cobrir a captura do estado corrente no ponto de origem, a transferencia e a reconstrução do estado no ponto de destino, envolvendo, portanto, técnicas clássicas e modernas de migraçào de processos em sistemas distribuídos (Coulouris et al., 1994).

\subsection{Considerações finais}

Vo contexto da multimídia interativa, novas tecnoloģias têm sido criadas e, gradativamente, vão sendo incorporadas às aplicaçoos.

Ao contemplar as alternativas tecnologicas para o desenvolvimento de uma aplicação, devese ressaltar a importância de uma análise de requisitos para que se possa escolher as tecnologias mais adequadas a um determinado domínio de aplicação.

No contexto no yual este trabalho está inserido, uma importante contribuiçào reside na investigação na apresentaçăo de uma modelagem orientada a objetos e baseada nos padrōes MPEG-4 e MPIG-7, contemplando aspectos de compartilhamento, armazenamento e recuperação, distribuiçào e apresentaçào de conteúdo multimidia em aplicações associadas a ambientes interativos. A partir da apresentaçào tecnológica feita nesste capítulo, uma visão geral das técnicas, metodologias, métodos e linguagens de modelagem, que podem ser utilizadas no desenvolvimento de aplicaçòes multimídia, é apresentada no Capítulo 3. 


\section{Modelagem de Sistemas Multimídia}

\subsection{Considerações iniciais}

Devido à demanda do mercado por aplicaçóes multimídia e interativas, com requisitos funcionais, elegantes e flexíveis, organizações de padronizaçăo como a ISO (International Standardization Organization) e W.C (World Wale Web Consortium) produziram padròes, tecnologias e recomendações para a área, tais como HTML, XML e DOM (Document Object Model). Devido à sua simplicidade, o padrâo IITML foi rapidamente absorvido pelo mercado. Conforme as aplicacoes foram se tornando mais complexas e exigindo mais recursos, outros padróes e recomendaçoes foram se juntando ao HTML para atender à demanda. Tais tecnologias, contucto, nào contemplam metodologias de desenvolvimento para aplicaçoes.

A modelagem, projeto e desenvolvimento de aplicaçöes e sistemas computacionais é suportada por ferramentas e técnicas, advindas geralmente da Engrenharia de Software, que garantem qualidade, produtividade e baixo custo de produçäo. Muito do que se dispóe tecnologicamente no mercado para a produçào de sistemas multimídia é centrado em apresentaçäo, demonstrando uma grande preocupaçào com a interface e pouca com a estrutura da informação. Isto lica evidenciado pelo número de ferramentas como HTML, DHTML, SMIL, Flash, dentre outras, que permitem a construçào de visuais impressionantes e bons niveis de interaçâo (principalmente quando utilizados em conjunto com linguagens como Java ou Java-Suript), porém, nào contemplam uma representaçào estruturada da informaçao, o que seria de grande valia para a o desenvolvimento de aplicaçoes personalizadas e conscientes de contexto, por exemplo.

Do ponto de vista conceitual, cada formato de mídia pode requerer ferramentas próprias para seu manuseio, dificultando o processo de produçà) de uma apresentaçào. Como conseqüencia, a sincronizaçăo dessas midias torna-se um problema. Como exemplo, pode-se imaginar um vídeo de uma propaganda de um produto, onde alguém fala das características do mesmo enquanto imagens, texto e algumas animações (desenhos animados inseridos no vídeo) sào apresentados. É desejável que o áudio, descrevendo a cor do produto, deve ser 
tocado sincronamente com as imagens que mostram características desse mesmo produto. Da mesma forma, as animaçòes devem ser inseridas em posiçoes específicas e com tempos muito bem determinados. Conseguir sincronizar estas midias pode ser um trabalho penoso. A abordagem usual utiliza todas as midias juntas em um mesmo arquivo (garantindo a sincronizaçâo) para a transmissào em rede, porém, existem vanlagens em transmitir essas midias separadamente. Pexde-se consegruir niveis diferentes de controle da apresentaçäo durante a exihiçào de cada mídia individualmente, podendo-se escolher, por exemplo, se um determinado objeto iri ou nao aparecer na cena e do que forma. Contudo, transmitir as mídias individualmente reyuer novas medidas de sincronizaçăo, uma ve que a rede não fornece garantia de tempo de entrega. Nota-se, portanto, que o processo de modelagem é decisivo na construçáo dos novos a complexos ambientes interativos, considerando a aplicaçào multimídia como parte desse ambiente, conforme propoe este trabalho.

\subsection{Métodos, técnicas, metodologias e modelos: uma breve apresentação}

O projeto de aplicaçóes multimídia difere do projeto e desenvolvimento de software tradicionais em vários aspectos criticos, uma vez que aplicaçoes multimídia apresentam dificuldades em sua modelagem e em seu projelo que náo são encontradas no projeto de sistemas tradicionais. Como conseqüência, métodes especificos para modelagem e projelo deste tipo de aplicaçấo säo necessírios, mélodos estes que precisam alender as diferentes necessidades dos vários lipos de aplicaçoes multimidia que lêm surgido.

Diversos métodos para modelagem e projeto de aplicações multimídia têm sido pesquisados e propostos. Dentre esses métodos, destacam-se o I IDM (Hypernedia Desion Metho) (Garzotto et al., 1993), o RMM (Relationship Manngement Methodology) (Isakovitz et al., 1995; Isakovitz ot al., 1998), OOOHDM (()bject Oriented Hypemedia Lesign Model) (Schwabe, 1995), o Analysis and Design of Web-Based Information Systems (Takahashi et al., 1997), O EORM (Fnhaced Object Relutionship Mortel) e o Malabase-Oriented Approch to the losign of liduational Hyperbooks (Fröhlich, 1997) to o HBMS (H fypertexl Model Based on Statedarts) (Turine et al., 1997).

Alguns dos métodos para modelagem e projeto de aplicaçoes multimídia, propostos na literatura, utilizam o paradigma da orientaçào a objetos e, conseqüentemente, permitem a construçăo de novos sistemas multimidia explorando o "reuso" de componentes já modelados em sistemas anteriores (Nemetz, 1997; Rossi et al., 1995; Schwabe, 1995). ['orém, nenhum destes mélodos para projeto e modelagem de sistemas multimídia, propostos na 
literatura, é baseado em um padrão 150 para especificaçào do comportamento do conteúdo multimídia. Além disso, a maioria desse métodos nào faz parte de uma metodologia completa de desenvolvimento que contemple os padröes, tecnologias e recomendaçoes, tais como XML, SGML, SMIL, XSL, DOM e es padroes da familia MPEG, por exemplo. Observase, ainda, que esses métodos concentram-se na modelagem da aplicação multimídia ao nível da estrutura e da interface, porém no contexto único da aplicação encuanto software. Nesses métodos, não há ferramentas para modelagem do ambiente interativo como um todo, visão essa que é cliscutida neste trabalho; o ambiente interativo passa a ser formado pela infraestrutura de comunicaçào, pela aplicação em si, pelo(s) usuário(s) e pelos objetos de mídia que compoim as cenas em apresentaçăo. As Subseçóes 3.2.1 a 3.2.8 apresentam uma breve descrição de cada um dos principais métodos, metodologias e técnicas de que podem ser aplicados à modelagem de sistemas multimídia.

\subsubsection{Relationship Management Methodology (RMM)}

O RMM é uma metodologia para projeto estruturado de hipermídia e seu nome é derivado da visão de hipermidia como um véculo para gerenciar relacionamentos entre objetos de informação. O método é descrito em (Isakovitz et al., 1995), dentro do contexto do ciclo de desenvolvimento de software completo e especifica os passos para um projeto de um sistema hipermídia clesde a fase de análise e projeto até a fase de teste, focalizando os aspectos de projeto e implementaçào da aplicação, principalmente as etapas destinadas a especificaçào do domínio e dos mecanismos de naveģaçào da aplicação.

O núcleo do RMM é um modelo de dados chamado RMDM (Relationship Manugement Datro Model). O RMDM é a primeira lase do RMM, sendo composto de três passos: F-R Design, Fntity Design, Nonignalon lesign. Eis as principais características de um desses três passos:

- E-R Design, primeiro passo do RMDM e do próprio RMM, consiste em representar as informaçós do domínio da aplicaçào utilizando um diagrama de EntidadesRelacionamento; esta forma de representaçào foi escolhida por ser familiar aos desenvolvedores;

- Entity Design, segundo passo do RMM, é exclusivo de sistemas hipermídia e determina como as informaçoes sobre as entidades, definidas no passo anterior, serăo apresentadas aos usuários e como esses usuários poderão ter acesso às informaçoes; 
- Natigation Design, lerceiro passo do R.MM, permite o modelo e o projeto caminhos pelos quais o usuário podera navegar no hipertexto; no RMDM, a representagào da navegaçào é suportada através de diferentes primitivas, tais com ginited tour, index e indexed guided tonr.

A segunda parte da metodologia R.MM näo está diretamente relacionada com a modelagem c projeto de estruturas de acesso, o consisto de 4 passos: Concersion Prolocol Design, Userinterfuce Desigh, Rum-tinfe Beluniur Design e Construction and Testing. Desses passos, os dois primeiros säo os mais importantes:

- Coniversion Protocol Desigh: transforma cada ckemento do diagrama RMDM em um elemento da plataforma destino, na qual será implementado o sistema;

- User-interfiter Desigh: consiste do projeto das interfaces (telas) para todos os objetos que aparecen no diagrama RMDM, resultado final do terceiro passo.

Isakowit\% propoe uma nova versào do R.MM, chamada de RMM extented (Isakovity et al., 1998. Issa nova versão da metodologia possui como objetivo cobrir falhas do RMM pactrâo (Isakovitz el al., 1995). O RMM extended introdus um novo elemento, denominado M-Slice, que possibilita maior reusabilidade de projeto.

\subsubsection{Object Oriented Hypermedia Design Model (OOHDM)}

Fiste método utiliza os mecanismos de abstraçáo c composicăo para permitir a descriçào concisa de itens de informaçà complexos (comuns em sistemas flipermídia) e para possibilitar a especificação de padróes de navegaçào e transformaçoes de interlace (Schwabe, 1995). No OOHDM, um sistema Hipermídia é construído em quatro passos:

- Conceptual Design (Modelo do Dominio da Aplicacàn);

- Narigntional Design (Modelo de Navegaçà);

- Abstrict Interface Design (J'rojeto de lnterface);

- Implementalion.

O OOHDM, durante o Comcephal Iesign, faz uso dos principios de modelaygem orientada a objetos do OMT (Schwabe, 1995) e difere do RMM em dois pontos principais: a) pela ênfase no projete do modelo de navegaca ào e no projeto da interface abstrata que o (OOHDM possui; b) pelo uso do paradigma de orientacio a objetos. Neste primeiro passo, classes conceituais podem ser construidas a partir de relacionamentos de agregaçá e 
generalizaçào/especializaçào. A principal preocupaçào, durante o Conceptunl Design, é modelar a semântica da aplicaçào, sem considerar os tipos de usuários e tarefas que realizarão.

O modelo de navegação é uma "visăo", em termos de base de dados, do modelo concuitual da aplicação e é expressado em dois esquemas: Nazigational Class Schema e Navigration Context Schema. No primeiro esquema, são definidos os objetos navegáveis da aplicaçào. Similar ao IIDM, existe um conjunto pré-definido de classes navegacionais, tais como nós, links e estruturas de acesso (como indexes e guided tour). No OOHDM, o projeto do modelo de navegraça considera os tipos de usuários e o conjunto de tarefas que realizarào durante o uso da aplicação. Diferentes modelos de navegação podem ser construídos para um mesmo modelo conceitual, uma vez que uma mesma aplicação pode possuir diversos conjuntos diferentes de usuários e tarefas.

No terceiro passo, Abstract Interface Design, o OOHDM define quais os objetos de interface que o usuário irá perceber, quais os ohjetos de interface irão ativar a navegação, a forma como os objetos multimídia da interface serào sincronizados e como as transformações de interface iräo ocorrer. F́ possivel a construção de diferentes interfaces para um mesmo modelo de navegação. O último passo, Implenentation, consiste do mapeamento dos modelos de navegaçào e de interface abstrata em objetos concretos disponiveis para o ambiente de implementaçào escolhido.

\subsubsection{Enhaced Object Relationship Model (EORM)}

Este modelo, assim como o OOHDM, utiliza o OMT para definir as primitivas do modelo conceitual do sistema (Millet ot al., 1996). O EORM é composto de três etapas:

- especificação da estrutura de classes da aplicação (Class Framerork);

- definição da relaçào entre as classes que compoe a aplicação (Composition traméwork);

- definição dos aspectos de interface.

O modelo do domínio da aplicação é descrito através de classes e de relacionamentos de generalização e associaçào em um esquema conceitual, construido a partir das primitivas do OMT. 
O modelo FORM estende o modelo ORM, incluindo semântica nas relaçóes de classes, de forma que as relaçoes sào mapeadas nas classes de ligação, que possuem uma estrutura e um comportamento proprio. Uma classe de liģaça pode representar uma ou mais relaçòes da aplicaçào e estas classes podem ser agrupadas em uma hicrarquia, com o objetivo de indicar herança entre elas. O modelo LOR.M nảo separa de forma explícita o projeto conceitual do projeto de navegação do sistema.

\subsubsection{Hypermedia Modelling Technique (HMT)}

O HMT utiliza quatro modelos para descrever uma aplicaçâo: o Object Model, o Hyperobject Motel, o Narigalion Motel e Interface Model. O primciro modelo descreve os objetos do domínio do sistema e seus relacionamentos, utilizando os conceitos e notações do modelo de objetos OMT (Rumbaugh, 1991).

O Hyperobject Model refina o (Object Modkl, associando semântica aos relacionamentos entre os objetos do dominio. O Nanigation Model define os objetos de navegaçào e os contextos de navegração da aplicaçào. Através do Interfrice Model do I IMT', descreve-se como a informação será apresentada ao usuário. Essas definiçōes são baseadas no Navigation Motel e no Hyperobject Model.

\subsubsection{A Database-Oriented Approach to the Design of Educational Hyperbook}

A Database-Orienled Appronch to the lesign of Filucational Hyperbooks é um método voltado para modelagem e projeto de sistemas educacionais "adaptativos". Este método utiliza a linguagem de modelagem orientada a objetos O-Telos, que combina conceitos de orientação a objetos com regras de deduçăo e restriçöes. Segundo o método, o modelo de um sistena é composto por quatro submodelos: Donnin Motel, Nacigational Model, Visualization Model e User Model. A Figura 3.01 ilustra o relacionamento entre esses modelos.

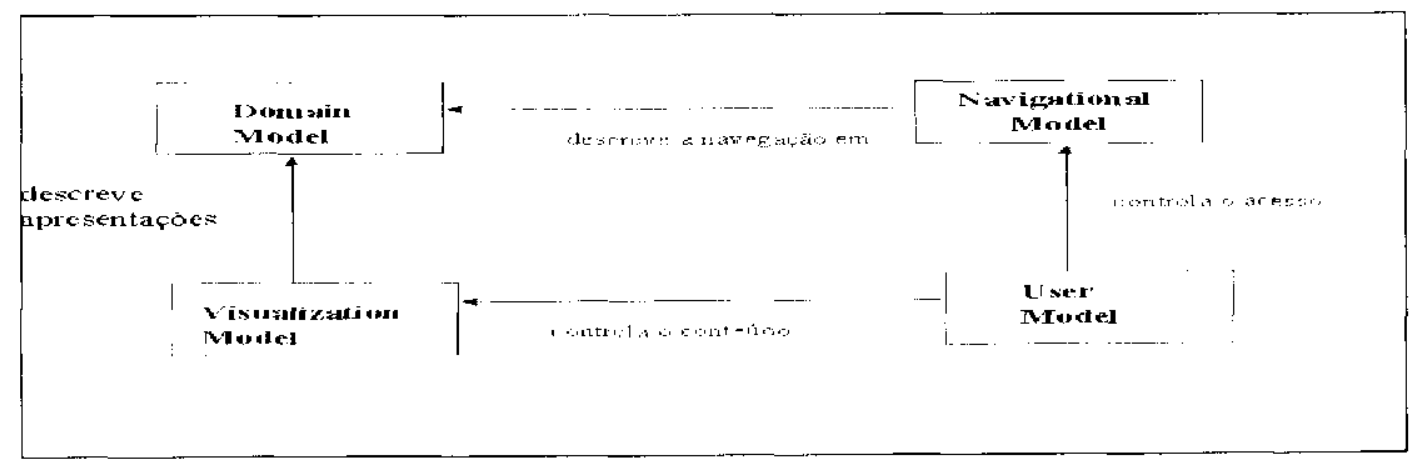

Figura 3.01: Modelos do Database-Oriented Approach to the Design of Edacalional Hyperbook 
O primeiro submodelo, Dontain Motel, descreve as entidades do domínio do sistema, tratadas cono classes, o os seus relacionamentos. Para isto, o método mescla conceitos e notaçós de orientaçào a objetos e de diagramas E-R (Entidade-Relacionamento).

As classes de uma aplicação em um sistema podem ser organizadas em uma hierarquia simples com relacionamentos de heranģa únicos entre elas. Lim modelo de domínio pode possuir superclasses, subclasses, classes, instâncias e relacionamentos entre as entidades (entre classes e instàncias de classes). Este modelo de domínio é similar ao RMM, porém estende-o através de conceitos de classe e herança.

A navegaçào, neste modelo, deve ser suportada de duas formas:

- Data Mordel Nazigration: baseado no modelo de domínio es similar à modelagem no OOHDM; no Domain Model, este tipo de navegação permite uma leitura seletiva e acesso rápido à informaçào através dos hypertinks;

- Sequential Naregalion: apresenta páginas em uma seqüência.

O terceiro submodelo, denominado Visulization Model, especifica como a informaçào será apresentada. O User Model adapta o conteúdo e a estrutura de naveģação de hypertooks. Este modelo de usuário possui suas limitaçoes, uma vez que é baseado no fato do usuário visitar ou nào as páginas, nào descrevendo o quanto ele realmente absorveu do conteúdo de cada página que visitou. Entre os métodos descritos nesta breve revisão, este é o úmico método que possui recursos específicos para a modelagem e projeto de aplicações Ilipermídia educacionais adaptativas.

\subsubsection{Analysis and Design of Web-based Information Systems}

Métodos para modelagem e projeto de sistemas Hipermídia como o RMM mostram-se bastante eficientes para aplicaçoess do tipo "quiosque de informaçoes", nas quais o usuário navega pelas informaçōes de uma maneira sistemática. Mas para alguuns sistemas Hipermídia, o acesso a uma parte específica da informacào é apenas parte dos objetivos do usuário, que também necessita de processar dados, comunicar-se e colaborar com seus colegas através da aplicaçao (WB/Ss-Web-bused luformation Systems). O) método Analysis and Design of Web-based Information Systems (Takahashi et al., 1997) foi desenvolvido para suprir as necessidades deste tipo de aplicações Hipermídia, onde usuários necessitam processar 
dados além de possuir acesso a informaçoes. Em conjunto com este método estão sendo desenvolvidas ferramentas para suportá-lo.

Este método consiste de duas abordagens: estática e dinâmica. O modelo EntidadeRelacionamento (L-R) é utilizado para descrever a modelagem e projeto estático de WBISs. Para o modelo e projeto dinâmico, o método utiliza conários. O modelo estático, baseato em diagramas F- $R$, define quais são as entidades e cono clas estão relacionadas. Os cenários definem quais os recursos da Web que săo utilizados e acessados e a quem estão relacionados.

Os passos do método Annlysis and Design of Wéb-based lnformation Systems são: E-R Analysis (E-R), Scenario Analysis (cenário), Ardhtecture Design (diagramas RMIDMW), Auribute Definition, Construction, Test. Os diagramas RMDMW (Relationship Manngement Data Model for IVBISs) são uma extensaio dos diagramas R.VDM da metodologia RMM (Isakovitz et al., $1995)$.

\section{2 .7 OOMM}

Conforme discutido, aplicaçōes multimidia podem ser definidas como aquelas que combinam elementos de hardware e software para prover interatividade a cenas compostas por objetos de mídia independentes s que se relacionam no tempo e no espaço. Adicionalmente, a sincronizaçăo entre esses objetos pode ser organizada de forma hierarquica e através de um modelo que descreva a interação e a navegação. O modelo OOMMA (Ohject Orienterl Modellingr of Multimedir Applications) é uma extensão à linguagem de modelagem UML e que permite modelar aspectos de uma aplicação multimídia, gerando um modelo coerente e integrado e observando os seguintes aspectos: a) a estrutura das cenas, incluindo a arquitetura da aplicação e o cenário de uso dos objetos multimídia; b) a apresentaçầo dos objetos no tempo e no espaço; c) o comportamento temporal dos objetos de mídia; d) a interaçäo bascada em eventos (F.ngels, 2000).

Em relaçăo às extensões LMI, o modelo OOMMA provê uma linguagem (OOMMA-L) para descrever as relações temporais entre os diversos tipos de mídia. A construção de interfaces é suportada por uma notação gráfica que permite especificar o posicionamento de objetos em uma cena e sua hierarquia de apresentaçâo. Por fim, säo oferecidas guidelines para integrar os 
diversos diagramas UML na construçáo de aplicaçoes multimídia complexas (Sauer \& Fngels, 1999).

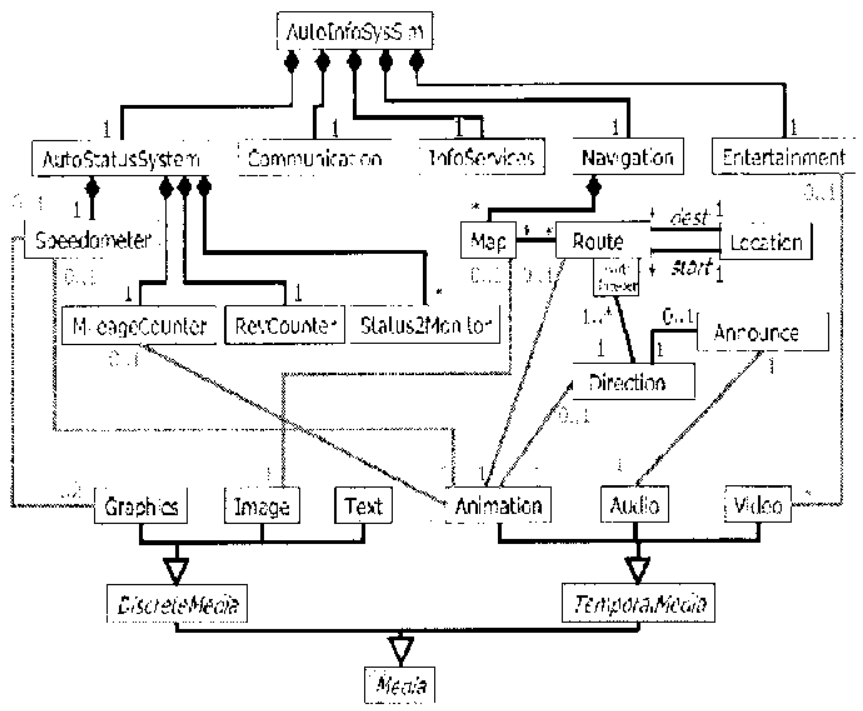

Figura 3.02 - Fstrutura OOMMA representada em um diagrama de classes (Engels, 2000)

Pelo método OOMMA, a estrutura de uma aplicação multimídia por ser representada em um diagrama de classes, que descreve logicamente a hierarquia das classes que compöem a aplicação, conforme ilustrado na Figura 3.02. As relaçôes temporais são descritas em um diagrama de seqüencia, que possui algumas sintaxes graficas estendidas da linguagem UMT. padrào. O diagrama de apresentaçào é usado para projetar a interface do usuário, contemplando objetos de visualizaçào e objetos de interaçäo. As interaçoes são descritas através de statecharts (diagramas de estados).

\subsection{A linguagem UML}

Um dos principais problemas no desenvolvimento de novos sistemas utilizando a orientaçào a objetos nas fases de análise de requisitos, análise de sistemas e design é que não existe uma notação padronizada e realmente eficaz que abranja qualquer tipo de aplicaçăo que se descje. Cada simbologia existente possui seus próprios conceitos, gráficos e terminologias.

O surgimento da UML apresentuu-se como uma possibilidade concreta para uma metodologia de modelagem. UML é mais que a padronizaçào de una notaçào. É também o desenvolvimento de novos conceitos não normalmente usados. I'or isso e muitas outras razòes, é que UMI, representa um passo na direçào do estado da arte em modelagem de objetos. 
UML permite abordar o caráter estático e dinâmico do sistema a ser analisado levando em consideração, já no período de modelagem, todas as futuras caracteristicas do sistema em relação a utilizaçào de semânticas próprias da linguagem a ser utilizada, utilização de banco de dados bem como as diversas especificaçóes do sistema a ser desenvolvido de acordo com as métricas finais do sistema.

Os conccitos da orientaçào a objetos têm sido discutidos há muito tempo, desce o lançamento da primeira linguagem orientada a objetos, a SIMULA. No entanto, a literatura demonstra a dificuldade de se encontrar linguagens que possibilitem o desenvolvimento de qualquer tipo de aplicação.

Alguns conceitos foram discutidos e/ou definidos por nomes como Coad, Yourdon e Pressman, e reportam aus seguintes itens:

- a orientaçào a objetos é uma tecnologia para a produçào de modelos que especificuem o domínio do problema de um sistema;

- quando construidos corretamente, sistemas orientados a objetos sào flexíveis a mudanças, possuem estruturas bem conhecidas e provêm a oportunidade de criar e implementar componentess totalmente reutilizáveis;

- modelos orientado a objetos sá implementados convenientemente utilizando uma linguagem de programação orientada a objetos;

- a orientaçào a objetos não é só teoria, mas uma tecnolugia de eficiência e qualidade comprovadas, usada em inúmeros projetos e para construção de diferentes tipo de sistemas.

A UML é uma tentativa de padronizar a modelagem orientada a objetos de uma forma que qualquer sistema, seja qual for o tipo, possa ser modelado corretamente, com consistência e potencial para se comunicar com outras aplicaçóes.

Existem varias metodologias de modelagem orientada a objetos que precedem o surgimento de. UML, a saber:

- Booch - o método de Grady Booch para desenvolvimento orientado a objetos está disponivel em muitas versões; Booch definiu a noçăo de que um sistema é analisado a partir de um número de visoees, onde cada visào é descrita por um número de modelos e diagramas; 
- OMT - Técnica de Modelagem de Objetos (Object Modelling Technique) é um método desenvolvido pela GE (Ge'neral Flectric), onde James Rumbaugh trabalhava; o metodo é especialmente voltado para o teste dos modelos, bascado nas especificaçôes da análise de requisitos do sistema, sendo que o modelo total do sistema baseado no método OMT é composto pela junção dos modelos de objetos, funcional e use-cases;

- OOSF/Objectory - Os métudos OCSE e o Objectory foram desenvolvidos com base no mesmo ponto de vista formado por Ivar Jacobson; O método OOSE é a visão de Jacobson de um método orientado a objetos; já o Objectory é usado para a construção de sistemas diversos, sem restrições quanto à natureza; ambos os métodos são

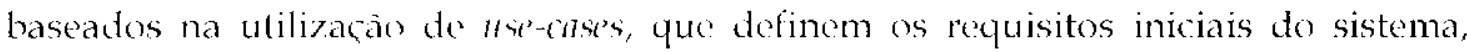
vistos por um ator externo.

Cada um destes métodos possui sua própria notaçào (seus próprios símbolos para representar modelos orientado a objetos), processos (que atividades são desenvolvidas em diferentes partes do desenvolvimento), e ferramentas (as ferramentas CASE que suportam cada uma destas notaçôes e processos).

UMI tem potencial para dominar o campo da modelagem de sistemas e ambientes ao nivel da indústria, sendo uma linguagem baseada em conceitos e padroes consolidados e que apresenta recursos para especificaçào de construçôes semânticas genéricas.

\subsubsection{Os diagramas UML e sua adequação a esta proposta}

Um dos principais problemas do desenvolvimento de novos sistemas utilizando a orientaçao a objetos nas fases de análise de requisitos, análise de sistemas e désign é que não existe uma notaçào padronizada ? realmente eficaz que abranja qualquer tipo de aplicação que se descje construir.

Cada simbolugia existente possui seus próprios conceitos, gráficos e terminologias, resultando, muitas vezes, em modelos confusos, especialmente para aqueles que querem utilizar a orientaçào a objetos não somente para visualizar o sentido de um fluxo em um relacionamento entre entidades, mas para criar modelos de qualidacte para ajudá-los a construir e manter sistemas e ambientes cada vez mais eficazes. Nesle contexto, metodologias como a LML surgiram para suportar a modelagem de sistemas e ambientes computacionais (Jacobson et al, 1999). 
Em linhas gerais, um sistema é composto por diversos aspectos: funcional que é sua estrutura estática e suas interaçoes dinâmicas), nào luncional (requisitos de tempo, confiabilidade, desenvolvimento) e aspectos organizacionais (organização do trabalho, mapeamento dos módulos de código). Assim, um sistema é descrito em um certo número de viscies, cada uma representande uma projeça da descriça completa e mostrando aspectos particulares do sistema. Cada visào é descrita por um número de diagramas que contém informacóos que dào ênfase aos aspectos particulares do sistema. Em alguns asos, pode haver sobreposiço entre os diagramas, o yue indica que o diagrama pode fazer de duas ou mais visoes.

Genericamente, as visoes que compoem um sistema sảo:

- visáo "nse-case": descreve a funcionalidade do sistema desempenhada pelos atores externos do sistema (usuários);

- visăo lógica: descreve como a funcionalidade do sistema será implementada;

- visão de componentes: é uma descriçáo da implementação dos módulos e suas dependências;

- visão de concorrência: trata a divisâo do sistema em processos e processadores;

- visão de organização: mostra a organização física do sistema, os computadores, os periléricos e como eles se conectam entre si.

No contexto do desenvolvimento de aplicaçoes distribuídas, o ambiente da WWW oferece a infra-estrutura basica para suportar tanto a criaça quanto o gerenciamento de sessoes de trabalho cooperativo (Bernes-Lee of al., 1994). Neste ponto, é importante considerar as propriedades do ambiente no qual a aplicaçào está inserida. Essas propriedades roferem-se às operaçōes associadas ao sensoriamento e a descoberta de informaşôes contextuais, permitindo o controle da apresentação de informaçoes é serviços ao usuário a a execuçào automática de açóes no ambiente.

Considerando a existência de objetos de midia em um ambiente com consciencia de contexto, a manipulação eficiente dessess objelos torna-se necessária, especialmente em termos do armazenamento e recuperação de stromis e dados associados. Desta forma, tecnologias devem ser associadatas às tarefas de manipulação de mídias e ao controle do conlexto do usuário, da aplicaçào e do ambiente. 
Essas tecnologias podem ser mapeadas com base no paradigma da orientaçào a objetos, considerando a existência de três camadas, conforme ilustra a Figura 3.03.

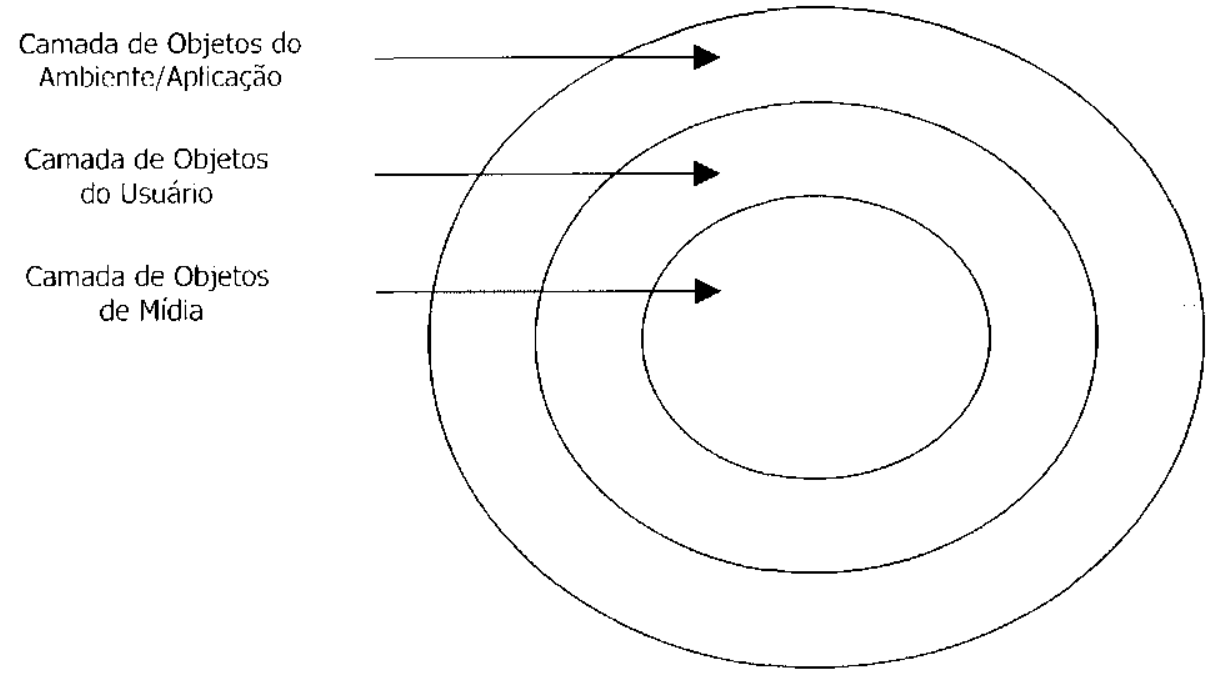

Figura 3.03 - Camadas de objetos em um ambiente com consciência de contexto

A Figura 3.03 mostra que a camada de objetos do ambiente é a mais externa cafeta as outras duas camadas. Neste ponto, é importante observar que uma classe genérica de objetos deve ser definida nesta camada e mapeada para classes específicas de objetos, gerando instâncias em termos de tecnologias que podem ser utilizadas na implementaçào de aplicaçoes para o ambiente.

Neste contexto, uma linguagem de modelagem, como é o caso da UML, permite a especificaçào formal dessas classes de objetos e seus relacionamentos em termos das atividades (açóes) que são geradas quando o usuário interage com o ambiente.

Analisando os aspectos de consciência de contexto, é relevante verificar que propriedades como atributos, comportamento e relacionamentos (agregação, especializaçăo e herança, por exemplo) podem ser mapeadas para o paradigma da orientação a objetos. Desta forma, é possível que classes de objetos de um ambiente com consciência de contexto sejam passíveis de mapeamento para tecnologias, protocolos, esquemas de armazenamento/recuperaçào e linguagens, tais como XML, MPEG-4, MPEG-7, MPFG-J, JAVA, dentre outros.

Genericamente, elementos da simbologia LML podem ser transformados em açós, atributos, condiçoes, eventos, métodos (operaçoes) código, a partir do uso de um conjunto de diagramas de modelagem. 
Na modelagem de um ambiente com a linguagem UML, pode-se utilizar uma seqüencia de nove diagramas: diagrama de use-case; diagrama de classes; diagrama de objetos; diagrama de estados; diagrama de seqüência; diagrama de colaboração; diagrama de atividade; diagrama de componentes; e o diagrama de execução.

Nas Subseçôes 3.3 .2 a 3.3.7 e apresentada uma breve descriçăo de cada um dos diagramas UML aplicáveis a esta proposta.

\subsubsection{O diagrama use-case}

O diagrama $u s^{2}-c a s e$ é uma técnica usada para descrever e definir os requisitos funcionais de um sistema, sendo que um requisito funcional engloba os atores externos ao sistema modelado. Os atores representam o papel de uma entidade externa ao sistema, como é o caso de un usuário ou um outro sistema que interage com o sistema modelado. Os atores iniciam a comunicaça com o sistema através de use-cawes (casos de uso), que representam uma seqüência de açoes executadas pelo sistema a partir da necessidado do ator.

Genericamente, atores e use-case's são classes. Um ator é conectado a um ou mais use-crises através de associações, e tanto atores quanto use-inse's podem possuir relacionamentos de generalização que definem um comportamento comum de herança.

O uso de us'-case's em tarefas colaborativas é muito importante, por apresentar as interaçoes necessárias para a execução de uma tarefa especifica no sistema. Uma colaboração é descrita por diagramas de atividades e um diagrama de colaboraçào.

\subsubsection{O diagrama de classes}

O diagrama de classes demonstra a estrutura estática das classes de um sistema, no qual essas representam as "coisas" que são gerenciadas pela aplicação modelada.

Uma classes pode se relacionar com outras classes através de diversas maneiras:

- através de associagão (conecladas entre si);

- através de dependencia (uma classe depende ou usa outra classe);

- pela especialização (uma classe é uma especialização de outra classe);

- em pacotes (classes agrupadas por caracteristicas similares). 
Todos estes relacionamentos são mostrados no diagrama de classes juntamente com as suas estruturas internas, que são os atributos e operaçós. O diagrama de classes é considerado estático, uma vez que a estrutura descrita é sempre válida em qualquer ponto do ciclo de vida do sistema.

Uma classe presente em um diagrama pode ser implementada utilizando-se uma determinada tecnologia que suporte a orientação a objetos de forma direta ou indireta.

\subsubsection{O diagrama de colaboração}

Um diagrama de colaboraça mostra, de maneira semelhante ao diarsrama de seqüuencia, a colaboração dinâmica entre os objetos. Normalmente, pode-se escolher entre utilizar o diagrama de colaboração ou o diagrama de seqüência.

No diagrama de colaboração, além de mostrar a troca de mensagens entre os objetos, porcebe-se também os ohjetos com os seus relacionamentos. Se a ênfase do diagrama for bascada na linha do tempo, é melhor escolher o diagrama de seyüencia; mas se a ênfase for o contexto do sistema, é melhor dar prioridade ao diagrama de colaboração.

O diagrama de colaboraçào é desenhado como um diagrama de objeto, no qual os diversos objetos săo mostrados juntamente com seus relacionamentos. As setas de mensagens são desenhadas entre os objetos para mostrar ofluxo de mensagens entre eles. As mensagens são nomeadas e, dentre outras propriedades, mostram a ordem en que as mensagens são enviadas. Também podem mostrar condiçōes, interações, valores de resposta, dentre outros.

\subsubsection{O diagrama de seqüência}

Um diagrama de seqüencia mostra a colaboração dinâmica entre os vários objetos de um sistema, sendo que o mais importante aspecto deste diagrama é que a partir dele percebe-se a seqüência de mensagens enviadas entre os objetos.

O diagrama de seqüencia consiste de um número de objetos apresentados em linhas verticais, que representam uma linha do tempo. As mensagens enviadas por cada objeto sāo simbolizadas por setas entre os objetos que se relacionam. Os diagramas de seqüencia possuem dois rixos: o eixo vertical, que mostra o tempo; co o eixo horizontal, que mostra os objetos envolvidos na seqüência de uma certa atividade. No cixo horizontal estão os objetos 
envolvidos na scuüência. Cada objeto é representado por um retângulo (similar ao diagrama de objetos) e uma linha vertical pontilhada chamada de linha de vida do objeto, indicando a execução do objeto durante a seqüência.

A comunicaçào entre os objelos é representada com uma linha com setas horizontais, simbolizando as mensagens entre as linhas de vida dos objetos. A seta especifica se a mensagem é síncrona, assíncrona ou simples. As mensagens podem possuir também números seyüenciais para tornar mais explícita a seqüência no diagrama. Em alguns sistemas, objetos agem de forma concorrente, cada un com sua linha de execução $($ thread $)$.

\subsubsection{O diagrama de estado}

O diagrama de estado é tipicamente um complemento para a descriçào das classes, mostrando todos as estados possiveis em que objetos de una certa classe podem se encontrar, além de apresentar os eventos do sistema que provocam tais mudanças de estado.

Os diagramas de estado nào são escrilos para todas as classes de um sistema, mas apenas para aquelas que possuem un número definido de estados conhecidos e onde o comportamento das classes é afetado e modificado pelos diferentes estados.

Diagramas de estado capluram o ciclo de vida dos objetos, subsistemas e sistemas. Eles mostram os estados yue um objeto pode possuir e como os eventos (mensayens recebidas, time', erros, condiçoes) afetam estes estades ao passar do tempo.

Ao nível da notaçào, os diagramas de estado possuem um ponto de início e vários pontos de finalização. Lim ponto de início (estado inicial) é mostrado como um círculo todo preenchido, e um ponto de finalizaçāo (estado final) é mostrado como um círculo em volta de um outro círculo menor preenchido. L'm estado é mostrado como um retângulo com cantos arredondados. Entre os estados estào as transiçoes, mostradas como uma linha com uma seta no final de um dos estados. A transiçào pode ser nomeada com o seu evento causador. Quando o evento acontece, a transiçăo de um estado para outro é executada ou disparada.

Lma transição de estado normalmente possui um evento associado a cla. Se um evento é anexado a uma transiçăo, esta será exccutada quando o evento ocorrer. Se uma transição nào possuir um evento associado a ela, a mesna ocorrerá quando a açāo interna do código do 
estado for executada (se existirem açöes internas como entrar, sair ou outras açoes definidas pelo desenvolvedor). Entäo, quando todas as açoes forem executadas pelo estado, a transiçà será disparada e serāo iniciadas as atividades do próximo estado no diagrama de cstados.

\subsection{MPEG-4 e MPEG-7: justificativas para o uso desses padrões}

Conforme citado, ć crescente a interesse por novas tecnologias de rideo strom, principalmente ao nível das grandes indústrias provedoras de tecnologias multimídia, como é o caso da Apple (QuickTime), da Microsoft (Windows Media) e da Real Networks (RealMedia).

Por outro lado, os ambientes de brondonsting ainda necessitam de um padrão que seja capaz de unificar a programaçào e a difusào de multimídia, por exemplo via Internet (Finseth, 1998).

Muitos editores de conteúdo multimídia têm considerado os usuários de PDA, telefones celulares, dispositivos móveis de acesso à Internet e set-top boxés como um novo e vasto mercado a ser explorado. No entanto, as múltiplas tecnolog̣ias multimídia existentes e as múltiplas especificaçôes para vários tipos de dispositivos constituem um obstáculo para o desenvolvimento e suporte as aplicaçöes. Adicionalmente, é interessante pensar que um mecanismo simplificado e adaptável para produção e distribuição de conteuddo multimídia poderá ser interessante para uma comunidade tăo diversamente configurada, permitindo que se atinja aspectos como escalabilidade e adaptabilidade, por exemplo em relação à largura de banda disponivel e à qualidade das mídias utilizadas. Neste sentido, MPEG-4 surge como uma possibilidade para integração dos processos de produção e distribuiçăo, constituindo-se no mais recente esforço do Mooing Picture Experts Croup.

Recentemente, acreditava-se que propostas como Windows Media Technologies, QuickTime c RealMedia seriam suficientes para cobrir a produção e distribuição de multimídia. No entanto, o pensamento da indústria era voltado somente para o contexto da Internet. Atualmente, existe um crescente interesse por HDIV (High Digital TeleVision) e, conseqüentemente, pela convergência entre Internet a televisão digital (Kate, 1998). Neste contexto, as potencialidades de padroes como MPEG-2 e MPEG-1 Layer-3 (MP3) foram revistas (ISO, 1994), permitindo que os padröes MPEG-4 e MIPKI-7 fossem também potencializados quanto ao uso num cenário de televisão digital e Internet, por exemplo. 
Em decorrência da revisăo de pensamento, indústrias como a Apple, Cisco, Ihilips e Sun iniciaram altos investimentos no campo da televisào digital, sendo que o primeiro obstáculo enfrentado foi escolher um padrá que suportasse os requisitos para straning de áudio e video em redes IP. Neste ponto, o padräo MPEG-4 foi identificado como a melhor soluçào existente, devido, principalmente, ao modelo de orientaça a objetos.

Fundamentalmente, observa-se que os serviços haseades em stronming ultrapassam os limites do "mundo $\mathrm{IP}^{\prime}$, atingindo territórios como a comunicasào zireless, broadcasting e as comunicaçóes via cabo e satélite. Adicionalmente, com avanço dos trabalhos em nivel cientílico e industrial, e também com a evoluçao dos requisitos em torno do cenário de integraçào da televisão com a Internet, observou a necessidade de uso de um protocolo capaz de fornecer possibilidades de negociaçao entre as diversas camadas e midias que compoem uma determinada aplicasăo. Fssess requisitos identificados vào de concontro as caracteristicas de projeto do .MPEG-4, contrapondo-se ao uso de tecnologias proprictárias para stremming. Por outro lado, ainda existem os problemas relativos a qualidade do processo de strenming e também em relaçà̃o ao processo de licenciamento para uso, visto que o referido padrão é relativamente novo.

\subsubsection{A solução MPEG-4}

Para compresnder o escopo da solucäo $\mathrm{MPEG}-4$ é interessante conhecer os principios a partir dos quais a solucáo foi proposta. Para tal, pode-se considerar um exemplo baseado no problema da produçào e distribuiçáo de contécido por uma rede de televisào, que deseja também distribuir esse mesmo conteúdo multimúdia via Internet. Neste sentido, alguns argumentos devem ser consideratos:

- a rede de televisão tem um público que recebe a programação através de meios de comunicaçào de banda larģa, como de caso do sislema de antenas, cabos e satélite, nos quais a qualidade de transmissáo co considerada ótima e/ ou excelente;

- a rede de televisào fornece também o mesmo conteudo em um zél site, através de streaming em tempo real via Internet; neste caso, a qualidade da transmissão é razoável ou mesmo inaceitável em muitos casos, dependendo diretamente das características da conexão do usuário, especialmente em termos da velocidade;

- uma conexão a 28,8 Kbps nào oferece possibilidades para uma boa transmissão de video e apenas uma yualidade razoável para a transmissão de áudio. 
Neste cenário, pode-se pensar também que na programaçăo da emissora existem programas como aqueles que apresentam cotaçào das bolsas de valores e classificaçào de equipes em eventos esportivos, tais como campconatos de futebol, corridas de fórmula 1, dentre outros. Para esses casos, a informaçào que se deseja transmitir é basicamente textual, que pode ser visto com boa qualidade tanto no ambiente televisivo quanto na Internet. No entanto, também esse tipo de informação pode sofrer alteraçóes na qualidade da apresentação, visto que os vários tipos separados de mídia (áudio, vídeo e texto) são misturados em um único fluxo de informaçào, antes de serem enviados. Assim, tem-se a degradaçào de todo o conteúdo transmitido quando se usa uma conexäo com pouca largura de banda.

Ao nível das aplicações, observa-se que o problema reportado impede a implementação de serviços como o e-commerce, visto que nào existe um modo para transformar um elemento de mídia c um hyperlink, por exemplo. Adicionalmente, seria interessante, em termos da programação da emissora, adicionar um arquivo de informaçōes das empresas às cotaçóes da bolsa, por exemplo; ou, ainda, permitir ao usuário saltar as tahelas de classificação dos eventos esportivos e acessar diretamente os detalhes sobre as equipes e/ ou atletas. Observase que o impedimento para o desenvolvimento dessas aplicaçoes reside justamente no fato de yue os elementos de mídia nào sào transmitidos como elementos individuais (Elementury Streams). Adicionalmente, nào é possível também atingir a distribuição para dispositivos zoireless, celulares, set-top boxes, dentre outros, sem ao menos produzir um stream específico para cada um desses terminais de recepcào e interaçầo. Porém, neste caso, conforme citado, cada proprietário dessas soluçóes deveria ter a liberdade para acessar um URI e manipular o conteúdo de acordo com os seus próprios procedimentos de gerenciamento do conteúdo multimúdia (Bernes-Lee et al., 1998).

Veste sentido, uma soluçāo é orģanizar um processo produtivo que permita a criação de um único strenm padrão que possal ser adaptável ao maior número possivel de usuários e alendendo aos requisitos de qualidade especificados. Esta foi, em suma, a proposta de projeto que deu origem ao MГГG $\mathrm{r}-4$.

\subsubsection{Diferenças entre um codificador de mídias e uma arquitetura}

Para medir a potencialidade da tecnologia MPEG-4 é importante compreender as diferenças que existem entre um codificador de midias (codec) e uma arquitetura. 
O termo colec (acronismo para compressão/descompressão) se refere a qualquer algorilmo utilizado para comprimir e descomprimir fluxos de dados que formam uma mídia digital, visando obter maior eficiência no armazenamento (por exemplo, em discos como o CDROM), e também na transmissão em rades de comunicaçào. Vale ressaltar que existe um outro tipo de codec que se refere aos mecanismos utilizades para converter sinais analógicos em digitais e vice-versa, porém näo è o foro dessa abordagem.

Por outro lado, uma arquitetura é um conceito muito mais amplo, identificando os formatos das mídias suportadas e definindo os mecanismos de sincronização $\mathrm{em} \mathrm{um} \mathrm{stream.}$ Adicionalmente, é responsável por descrever a estrutura dos arquivos comprimidos, as regras para transmissão dos strém e os protocolos de comunicaçào entre o servidor e o terminal do usuário.

Assim como para a arquitetura proposta para o MPEG-4, as tecnologias QuickTime, RealMedia e Windows Media suportam vários colecs, porém essas arquileturas proprietárias focalizam principalmente as mídias utilizadas, a rede IP' e o computador (enquanto elemento processador e terminal de exibição). Por oulro lado, a arquitelura MPEG-4 suporta uma vasta gama de meios de transmissäo e dispositivos de recepção. Adicionalmente, visto que MPEG4 foi criado a partir do trabalho de um organismo internacional de padronizaçào, no caso a ISO, envolvendo representantes de todos os setores interessados da indústria, o padrão é isento dos problemas decorrentes do desenvolvimento de uma solução proprietária.

Do ponto de vista do usuário, no entanto, o codéc é mais importante que a arquitetura. Podese dizer que nenhum usuário vê ou escuta a arquitetura. Neste sentido, os algoritmos cołté para vídeo do MPEG-4 näo estão ainda ao nível dos algoritmos utilizados por soluçöes como da Real Networks e Microsolt Windows. Adicionalmente, a Apple também está trabalhando no desenvolvimento de um novo cotec QuickTime, denominado On2, que promete significativas melhorias em relaçăo ao coder atualmente utilizado. Assim, a arquitetura MI'EG-4 é muito promissora, porém os aspectos relativos aos codecs necessitam ainda de aprimoramento.

\subsubsection{Orientação a objetos}

Em um strenm MPEG-4, todos os elementos de midia, como é o caso dos conteúdos de áudio e vídeo, imagens estáticas e informaçoes textuais (como no exemplo das cotaçòes das bolsas 
de valores e competiçoes esportivas) são mantidos como objetos independenles uns dos outros.

Em linhas mais avançadas, os componentes de um stréal de vídeo também podem ser tratados separadamente.

Considerando o exemplo da emissora de televisão, um programa para apresentação da previsão do tempo pode ser gerado e representado como diversos objetos de vídeo. Assim, pode-se gerar as cenas da previsão do tempo com um determinado objeto que represente o fundo (backgrom objeto que represente, por exemplo, um mapa de uma determinada região, com animaçōes e outras personalizaçōes apropriadas ao caso. Lm um strenm MPEG-4, todos esses elementos de mídia podem ser representados como objetos independentes.

De forma análoga, durante os programas esportivos e de informaçóes financeiras, exemplificados anteriormente, o apresentador e os textos informalivos podem ser representados como objetos distintos e independentes. Fsta abordagem da orientaçào a objetos apresenta dois benefícios fundamentais:

- primeiro, é que cada clemento pode ser tão interativo quanto necessário, permitindo ao usuário, por exemplo, acionar controles de pausa ou acclerar a apresentação, selecionar links de interesse, eliminar o objeto apresentador de uma determinada cena, c outras ilimitadas possibilidades de interação;

- segundo, é cada strenm pode ser personalizado para vários tipos de conexão e dispositivos de recepção.

Neste contexto, um usuário conectado via LSL, por exemplo, poderia receber todos os elementos de um conteúdo multimídia, enquanto um usuário que verifica as condiçóes meteorológicas usando um PDA poderia receber somente os ohjetos referentes ao mapa da previsão do tempo, alguma animaçào das condiçoes climáticas e algumas faixas de áudio adequadas a condições de pouca largura de banda.

Ainda em termos de aplicaçào e interatividade, um usuário interessado nos dados das cotaçoes das bolsas de valores poderia ouvir em seu celular o conteúdo das informaçoòs 


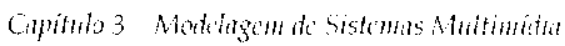

textuais, isto após um processo de conversão dos objetos de texto em objetos de áudio, usando um dos componentes da arquitetura MPEG-4.

Em linhas gerais, observa-se que essas possibilidades de interaçào contribuem para colocaro MPEG-4 em contraste com as limitaçoes das lecnologias de streaming oferecidas pelas soluçòes proprietárias e existentes atualmente. Essas tecnologias, por exemplo, se limilam a eliminar fromes de vídeo ou a utilizar um colec de áudio de baixa qualidade para alingir alguns requisitos de transmissão em uma rede de comunicaçào.

Fm termos de produçào, usando MPEG-4, a indústria de brondcasting e os profissionais broadansters podem reduzir sensivelmente os custos de produção e de armazenamento, uma vez que é possível criar apenas um único stream de dados multimídia e aplicar mecanismos inteligentes sobre esse strean para personalizar a distribuiçào e a apresentaçào.

\subsubsection{Alguns detalhes da arquitetura MPEG-4}

MPEG-4 e o primeiro padrão da família MPEG definido a partir do paradigma da orientação a objetos. Desta forma, novas tecnologias e mecanismos foram definidos para compor a arquitetura MPEG-4.

O primeiro desses mecanismos e tecnologias sào os BIFS (Binary Format For Scentes) que é a linguagem especificata para descrever como os diversos objetos fazem parte de um cena. A linguagem BIFS foi inspirada em VRMI., porém os arquivos BIFS podem ser binários ou texluais, enquanto arquivos VR.MI. são essencialmente textuais. Neste ponto, usando BIFS é possível a reprodução e apresentação durante o processo de streaning de uma cena, o que é uma necessidade absoluta para o ambiente da Internet. Por outro lado, usando VRML, a reprodução e apresentação da cena ocorre somente depois que se completa todo o dozmlond dos componentes da cena.

Na arquitetura MPEG-4, cada objeto é encapsulado no seu respectivo stream ou em diferentes strenms, dependendo das necessidades da aplicaçào. Cada stream individual é denominado Elementary Stream. Cada clementury strenm contém as informaçoes necesssárias sobre o decoder requisitado e também detalhes sobre a qualidade de serviço especificada, tais como o bit rate mínimo necessário para transmissão. Um outro elementary stream contém as informações no 
formato BIFS, que descrevem as relaçōes temporais para garantir o sincronismo entre os objetos durante a apresentaçàs.

Do ponto de vista da transmissào, a arquitetura MPLG-4 inclui dois tipos de multiplexadores que permitem a transmissāo dos strenms usando os mecanismos de transporte existentes, tais como R'IP (Real Time Protocol) - usado na Internet ou ATM - e. MPEG-2 - usado na difusảo via cabo ou via satélite, por exemplo. O primeiro multiplexador, denominado Flex.Mux e definido no D.MIF (Ielizery Multimedia Integration Framerork), define a comunicaçăo entre o servidor MPEG-4 e o terminal capaz de reproduzir as cenas MPEG-4, negociando os níveis de QoS e ajustando os elementury stremms para as condiçóes de transmissão. O segundo multiplexador, denominado TransMux, é responsável pela interface com o stream que transporta o contédo multimídia e pela transmissào correta dos dados, permitindo que strams MPEG-4 possam ser transportatas via brondcast, wireless e Internet, ampliando, significativamente, a cobertura da arquitetura em termos de mercado.

Neste sentido, os mecanismos derivados dos multiplexadores oferecem ao MPEG-4 significativas vantagens sobre tecnologias como QuickTime (que foi o ponto de partida para a constru(ào do formato MPFG-4) e SMIL. (Synchronized Multimedin Integration langunge), padronizado pela W3C. Em linhas gerais, observa-se nenhum desses dois formatos oferece os níveis de negociaçăo presentes na arquitelura MPEG-4, o que não permite o uso de seus recursos em outros meios que näo a Internet.

\subsubsection{Algumas vantagens e desvantagens da arquitetura MPEG-4}

Além dos fundamentos principais do MPEG-4, a arquitetura oferece também possibilidades para funçoes de animação facial que, quando combinada com interfaces de texto e voz, permitem a construção de cenas baseadas em "imagens falantes", que abrem um interessante espectro de aplicaçoes no "mundo virtual", principalmente por utilizar pouca bandat passante.

Outro ponto importante da arquitetura MPFG-4 é que os algoritmos para compressão de imagens estáticas sào extremamente otimizados e apresentam resultados semelhantes aos algoritmos JPEG. Por outro lado, ainda persiste o problema com o coler de vídeo MPEG-4, que nào tem produzido resultados satisfatórios, sendo muito inferior às soluçóes proprietárias da Microsoft e Real Networks. No caso específico de vídeo, a Real Networks, ao 
apresentar o codec Real Video 8 (que demonstrou alto desempenho), propôs que o produlo fosse inserido integralmente como parte do padrào de vídeo MPEG-4 e nas futuras extensoies.

\subsection{Considerações finais}

De forma genirica, os ambientes interativos sáo considerados "ambientes enriquecidos" por ulilizarem objetos de mídia de diferentes natureyas. Muitas podem ser as formas de composiçăo das cenas multimídia a partir desses objetos de mídia. Em termos de infraestrutura de comunicaçăo, pode-se definir varios níveis de qualidade de serviço. Ao nivel do usuário, muilas são as formas de interação com as cenas em apresentaçào, inclusive explorando recursos sensoriais e informaçóes contextuais.

Neste capitulo, foi disculida a necessidade da modelagem de ambientes interativos e foram apresentados alguns dos mélodos, técnicas e melodologias que podem ser aplicados à modelagem de aplicaçoes multimidia interativas. A linguagem U.MI. foi delalhada em seus diagramas e justificada quanto ao uso na modelagem proposta por este trabalho. L'ma reflexào sobre o uso de padróes, no contexto da modelagem, foi apresentada e discuticla, especialmente em termos dos padrós MPLG-4 c MPEG-7.

No proximo capilulo, inicia-se a discussão da modelayen proposta por este trabalho para o caso dos ambientes interativos conscientes de contexto. Fssa discussão parte da definiça do que is contexto, consciencia de contexto e suas relaçoss com aplicacooes multimídia em ambientes interativos. 


\section{Consciência de Contexto}

\subsection{Considerações iniciais}

Em meio à revoluçào diģital que scorre atualmente, a distribuiçào de multimídia é cada vez mais um foco importante na área tecnológica, quer seja no meio acadêmico quer seja na indústria.

Com o surgimento das tecnologias para multimídia interativa, um vasto número de aplicaçòes tornou-se possivel. As diferentes possibilidades de interação do usuário com os objetos de midia que compoem o vídeo trazem consigo a necessidade de modelagem dessa interação em direção aos aspectos de adaptação e personalização da interface. Adicionalmente, a convergencia de núdias e entre os meios de comunicação tende a inserir o usuário em um ambiente cada vez mais interativo e esse usuário passa a fazer parte desse ambiente, juntamente com todos os componentes de hardware e software da aplicaçào, também inserida como componente desser ambiente.

Neste capítulo, discute-se uma possibilidade para formalização de aspectos de consciencia de contexto, como parte da modelagem proposta por este trabalho, considerando que informaçôes contextuais podem ser extremamente úteis para a oferta de serviços personalizados nesse novo e potencial universo de aplicaçōes multimídia interativas.

\subsection{Consciência de contexto e suas relações com interação do usuário}

Reconhecidamente, a interface com o usuário é um ponto cada ve mais importante a medida que o uso da tecnologia, especialmente do computador, cresce consideravelmente.

O desenvolvimento de interfaces usuário-computador ć altamente criativo e diferentes projetistas usam diferentes técnicas. J'or cnvolver um projeto multidisciplinar, várias formas de "enxergar o mundo" são aplicadas, sendo de extrema importância o foco centrado nas tarefas do usuário - "como o usuário trabalha e? o que è importante para ele" (P'ressman, 1995). 
O ser humano possui um sistema perceptivo sensorial e paralelo. Uma especificação adequada da comunicação visual é um elemento chave de uma interface anigável. De forma geral, as informaçōes sào armazenadas no cérebro em una memória STM (Short Time' Menory) - que podem ser reusadas imediatamente - ou em uma memória LTM (lone Time Ménory), onde é formado o conhecimento (Preece, 1994). Além disso, um usuário utiliza heurísticas (diretrizes, regras e estratígias) que influenciam una informaçào ou conhecimento em um certo contexto da interaçào.

A abordagem cognitiva tradicional enfoca a utilização de cenários de execução de tarefas, nos quais deve-se enxergar o ser humano como um ator capaz de controlar as tarefas e o ambiente no qual essas tarefas estäo inseridas (Shneiderman, 1998). Um sistema baseado em computador é usado para automatizar tarefas que, em suma, são formadas por eventos e relacionamentos, existindo tarefas genéricas, tais como tarofas de comunicaçăo, tarefas de diálogo, tarefas cognitivas e tarefas de controle, que devem ser consideradas no projeto de quaisquer interaçoes usuário-computador (Preece, 1994).

No atual estado da arte, observa-se que a interação usuário-compulador tem se tornado cada vez mais complexa, em termos de análise de requisitos, e transparente e natural para os usuários.

Tecnologias e técnicas avançadas de interaçào tèm sido criadas para minimizar o uso de dispositivos tradicionais de interaçào como mouse e o techado, permitindo que o usuário interaja diretamente com o ambiente no qual a aplicação está inserida. No entanto, na criação de ambientes computacionais nos quais a aplicaçào possa ter a "liberdade" de sugerir ou tomar certas decisòes, é necessário o uso de informaçoes contextuais do usuário, da aplicaçào e do ambiente como um todo.

Segundo Abowd, um sistema co consciente de contexto se utiliza o contexto para oferecer informaçōes relevantes c/ou serviços ao usuário, sendo que a relevância depende das tarefas que o usuário realiza (Abowd, 1999).

Em linhas gerais, entende-se por contexto como sendo qualquer informação que possa ser usada para caracterizar a situação de uma entidade. Uma entidade, por sua vez, pode ser uma pessoa, um lugar ou objeto relevante para a interaçào entre um usuário e uma aplicaçáo, 
incluindo-se também o usuário e a própria aplicaçāo (Dey \& Abowd, 1999). Adicionalmente, parâmetros do comportamento humane podem caracterizar a consciencia de contexto, especialmente quanto à definição das visòes de contexto (superficial ou abrangente) que se deseja extrair de um ambiente.

Ao nível da aplicaçăo, pode-se citar duas maneiras de se obter informaçoes de contexto. Na primeira, um usuário fornece informaçoes explicitamente, tais como um nome de usuário e uma senha em um procedimento de autenticaçào/autorizaçào. Na segunda, mais complexa, o usuário informa implicitamente as informaçōes de contexto para a aplicaçào, sendo função da aplicação a captura dessas informaçóes de contexto geradas por açóes do usuário.

A criaçăo de ambientes que utilizem as informaçoes de contexto para fornecer informaçoes relevantes c/ou açóes específicas para cada usuário, conforme o grau de liberdade definido pelo projetista, é uma tarefa que precisa ser parametrizada pela aplicação. Esta parametrização é obtida com base em cinco yuestionamentos:

- onde o usturitio éstí?

- queméo tusmírio?

- quais recursos estño em 11 so?

- quando se pote renlizar doteminada operaciõo?

- o que o usuário éstá fazento?

A partir dos yuestionamentos citados, pode-se obter as seguintes categorias de contexto:

- Iocalizaçàn;

- identidade;

- atividade;

- tempo.

Observa-se, entào, que através da categorização é possivel caracterizar a situação de uma entidade, bem como obter informaçes sobre o comportamento dessa entidade no tempo (Dey \& Abowd, 1999). Assim, a partir das informações de contexto, uma aplicação pode realizar açoes/reaçoes como as seguintes:

- a apresentação de informaçōes e serviços para o usuário, como por exemplo a apresentaçào de mídias disponíveis e yue estão relacionadas com o contexto do usuário; 
- a execuçáo automática de serviços, como por exemplo o disparo de eventos relacionados com a localizaçào corrente de uma entidade;

- a associaçăo do contexto com a informação para posterior recuperação, como por exemplo o armazenamento de informaçòes contextuais durante uma sessāo de chat em uma sala de aula virtual, relacionando observaçoes de alunos e professores (tutores) com o assunto discutido em uma aula.

As definiçōes de consciência de contexto oferecem condiçōes para o desenvolvimento de aplicações altamente adaptativas, o que é relevante em ambientes multimídia distribuídos, especialmente em termos das açōes e reaçōes, tanto ao nível do usuário quanto ao nível da aplicação e do ambiente. Neste ponto, o uso de dispositivos sensoriais, o uso de mecanismos e recursos para descoberta de informaçoes e associaçáo de dados digitais ao contexto do usuário são extremamente importantes em ambientes com consciência de contexto, viabilizando a apresentaçào personalizada de conteúdos, a execuçào automática de serviços e o armazenamento/recuperaçăo de informaçòes contextuais em diversos níveis de interesse.

O grau de consciência (aznreness) de um objeto em relaçào a outro quantifica a importância subjetiva ou relevância do objeto para um determinado ambiente ou mesmo para uma determinada mídia utilizada em uma aplicaçào. Como exemplo, pode-sc observar que o grau de consciência pode ser mapeado para o volume de um canal de áudio ou para o nível de detalhe de um rentering de uma imagem, sendo que, em linhas gerias, espera-se maior dedicação de processamento aos objetos que possuam valores de consciéncia mais altos.

Outro ponto importante reside no fato de que um objeto, em uma interação, pode afetar os níveis de consciência de outro objeto, exigindo, portanto, procedimentos de negociaçào. $\mathrm{O}$ objeto que observa (ou receptor) pode focar sua atenção em areas ou objetos específicos, enquanto o objeto observado (ou transmissor) pode controlar sua "visibilidade" de forma que objetos em algyumas áreas sejam mais conscientes que em outras áreas. Un bom exemplo pode ser reportado ao acesso a mídias distintas em uma determinada cena multimidia.

$\Lambda$ criaçäo de ambientes interativos com consciência de contexto é um desafio devido aos muitos fatores inerentes à criaçào de ambientes virtuais, especialmente quando se trata de interaçào multiusuário em ambientes distribuidos, como é o caso considerado nesta proposta. 


\subsection{Ubiqüidade}

A computaçào ubíqua (Libiquitons Computing's) tem sido vista como a próxima era da computação (nge of calm techmology) - ć a ciência objetivando a invisibilidade dos recursos computacionais para as pessoas. Neste contexo, invisibilidade não significa desaparecer com os computadores, mas que os recursos computacionais irào, cada vez mais, ser embutidos em objetos do mundo real, permitindo que as pessoas interajam com computadores de uma forma natural.
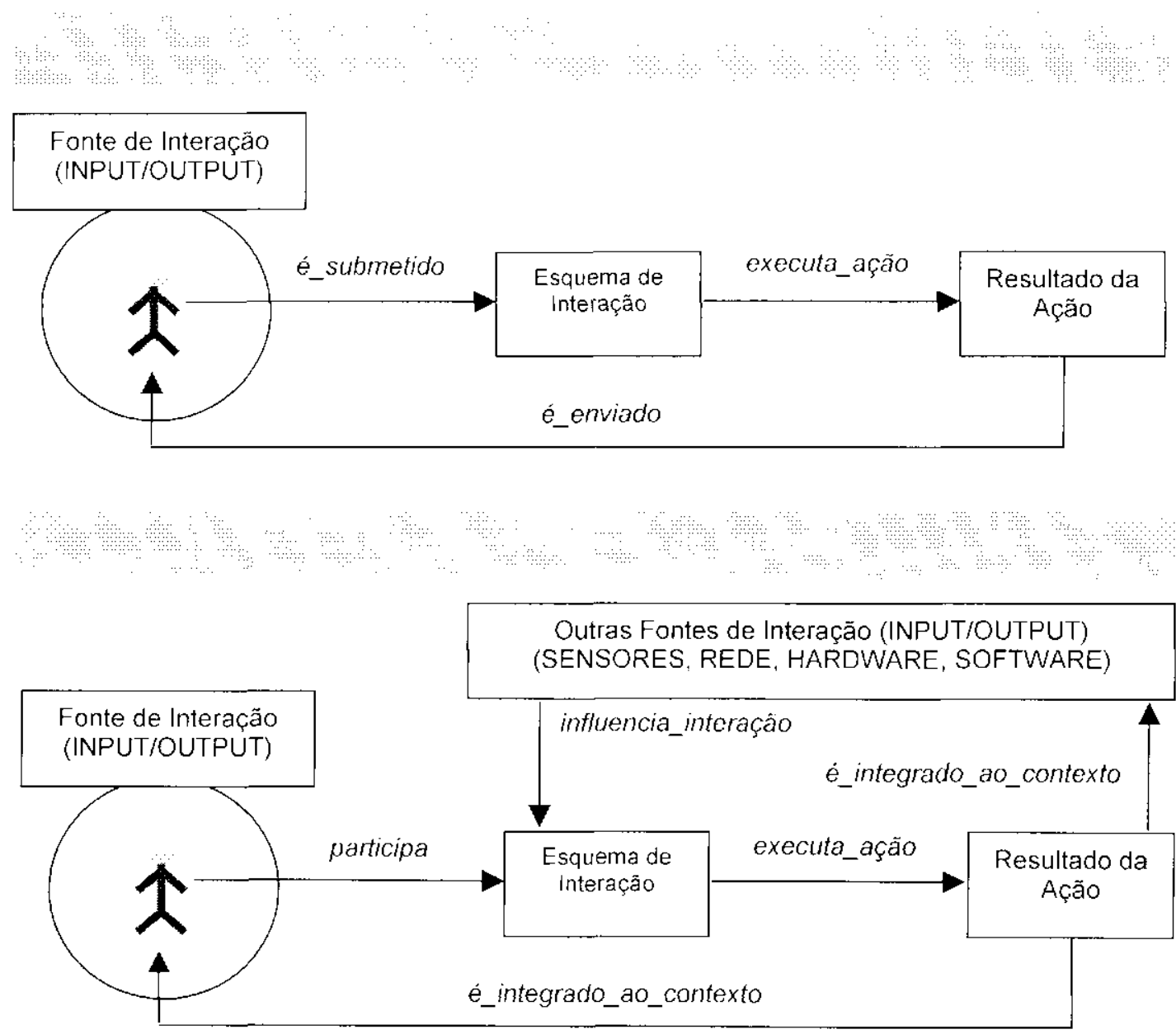

Figura 4.01: Focos de interaçāo do usuário em relação à existência de consciência

É fato que um dos principais fundamentos da tecnologia é auxiliar o ser humano nas suas tarefas do cotidiano (écryduy tasks), porén, ao longo do tempo, tom-se observado as dificuldades que o homem tem encontrado para se adaptar aos requisitos que determinada tecnologia impoe (psychopatologies of ererydryj), o que, de certa forma, tende a distanciá-lo do mundo real (Cooper, 1997). 
A computação ubíqua provê várias das possibilidades para inserção do usuário como componente de um ambiente mais amplo, oferecendo-lhe formas para experimentar o acesso à informação independente da localização geográfica e das formas de produção dessa informaçào. Além disso, os elementus da computaçào móvel oferecem formas para captura de alguns dos dados referentes ao contexto no yual o usuário está inserido, tais como a localizaçào geográfica, pessoats e objotos que se encontram próximos ao usuário, abrindo possibilidades concretas para melhoria na interaşäo do usuário com o ambiente.

O vasto número de situaçòes em que o usuário pode estar envolvido acrescenta a necessidade da adaptação a cada uma dessas situações e/ ou a grupos formados por algumas dessas situaçòes. Os requisitos de adaptabilidade, portanto, também oferecem possibilidades concretas para melhoria da interaçăo do usuário com o ambiente (McCanne et al., 1996; 1)ey \& Abowd, 2000).

Genericamente, uma forma para melhorar a interação do usuário é através da melhoria da comunicação entre o usuário e o ambiente durante o processo de interação, usando, por exemplo, informações contextuais.

A Figura 4.01 apresenta um esquema que ilustra a posiçäo do foco de interaça do usuário em um ambiente consciente de contexto, em relaçào a um ambiente não consciente de! contexto.

Observa-se que aplicaçoes conscientes de contexto usam os aspectos associados ao contexto para fornecer informaçóes e/ ou habilitar serviços ao usuário (Salber, 1999). Adicionalmente, informaçôes podem ser fornecidas ao ambiente como um todo, considerando que também a rede, sensores, hardware e soltware podem usufruir do grau de consciência de contexto do ambiente. Isto permite o desenvolvimento de adaptabilidade em diversos níveis, e o grau de automatismo pode ser definido de acordo com a aplicação, considerando, por exemplo, as condiçes de infra-estrutura de cada aplicaçào.

No caso das aplicaçōes interativas, de forma simplificada, o suporte à consciência de contexto pode ser usado de três formas distintas: a) para controle dos objetos de mídia de uma cena; b) para adaptaçăo dinâmica da aplicação às condiçós da rede de comunicaçào; c) para adaptaçăo dinâmica da aplicaçào ao contexto do usuário. 
O controle sobre os objetos de mídia é um aspecto fundamental para aplicaçoes interativas, considerando que novas tecnologias de midias interativas (video interativo) permitem a composição de cenas multimídia formadas por diferentes objetos e originados de diferentes fontes. Lsses objetos têm, naturalmente, o potencial para serem manipulados individualmente e de forma independente em uma cena. Para este caso, esquemas de descriçăo oferecem a semântica necessária para a construção de cada objeto e também as formas possíveis e permitidas para acesso e manipulação desses objetos. Neste sentido, observando-se as descriçoes semânticas, é pussivel obter as açoes que podem ser realizadas sobre um determinado objeto e/ ou grupo de objetos, e associar essas ações a requisitos de consciência de contexto.

A adaptaçáo dinâmica da aplicaçăo às condiçóes da rede de comunicaçào e ao servidor de multimídia acrescenta aspectos de adaptabilidade que são muito importantes em aplicaçōes interativas distribuidas. As interfaces de comunicaçào em rede aplicadas a serviços interativos devem fornecer mecanismos para que o ustário especifique, por exemplo, os parâmetros de qualidade da apresentaçào das cenas multimídia. Uma vez que o usuário tenha especificado o nível de qualidade desejado, as interfaces de comunicação devem se adaptar a esses novos parâmetros e assegurar que a qualidade desejada seja mantida durante toda a apresentaçào. Caso algum parâmetro precise ser reajustado, isto deve ocorrer de uma forma transparente ao usuário e também ao contexto do ambiente no qual o usuário está inserido.

A adaptação dinâmica da aplicação ao contexto do usuário é um dos pontos-chave para os serviços personalizados às necessidades do usuário. Existem muitas situaçoes nas quais as interfaces existentes no ambiente podem se auto-adaptar ao contexto do usuário, de forma transparente. Essa adaptação pode usar, por exemplo, informações contexluais, tais como identificaçâo do usuário, localizaçăo geográfica, ação ou açoes em curso e os parâmetros de tempo (time._stamp). De acordo com esses parâmetros, serviços podem ser habilitados e/ou desabilitados a um determinado usuário ou grupo de usuários.

Em termos da cadeia produtiva de aplicaçoes interativas, observa que a adaplação dinâmica da aplicação às condiçōes da rede de comunicação e ao servidor de multimídia pode auxiliar sobremancira aos provedores de rede e de contédo. Por outro lado, o usuário final será o maior beneficiado se o ambiente oferecer condiçôes de adaptação da aplicação ao contexto 
do próprio usuário e também um controle eficiente dos objetos que componem uma aplicaçào interativa.

\subsection{Mobilidade como infra-estrutura para consciência de contexto}

No escopo deste trabalho, o conceito de mobilidade pode ser definido como sendo o elemento que fornece suporte a implementaça de aplicaçoes que podem ser utilizadas de qualquer ponto geograficamente definido. Num contexto mais restrito, pode-se pensar num exemplo de mobilidade com o uso de protocolos WAP (Vireless Application l'rotocol), através do qual é possivel implementar aplicaçós para acesso a conteúdo de servidores wet de qualquer ponto geográfico.

Nos últimos anos, diversos equipamentes surgiram (e estao surgindo) com o objetivo de ampliar as fronteiras da mobilidade do usuário, tais como o celular, o PDA (Pt'rsonal Digital Assistani), weamble compuler, dentre outros. En adiçăo, existem vários recursos e sistemas que têm por objetivo suportar a mobilidade do usuário, dentre os quais pode-se citar aplicaçōes do lipo Mylowsonline, que permite ao usuário, através de qualquer tipo de conexào com a Internet, acessar os scus documentos e, inclusive, imprimi-los em um terminal de I:AX. Outro exemplo é a tecnologia java que', juntamente com a leconologia X.ML, possibilitam a criação de sistemas que usulruem da mobilidade do usuário

Observa-se que o conceito de ubiqüidade está ligado ao conceito de mobilidade, e prelendese, neste trabalho, apresentar uma visão de como a mobilidade por ser modelada para oferecer suporte à ubiyüidade. Em linhas gerais, tem-se o seguinte problema: so a compulaçao ubiqua parte do princípio que os computadores podem estar espalhados por todas as partes e em diferentes formas de objelos, por que nào aproveitar estes recursos para permitir a mobilidade?

Com intuito de responder a essa questào, no enfoque deste trabalho, o modelo de mobilidade passa pelo uso dos reyuisitos de consciência de contexto (context-ninreness), que, em suma, referem-se ao uso do dados contextuais (who, where, when, what, how) para prover informaçöes relevanles de tarclas ou serviços para um usuário. Conforme visto, entende-se por contexto como sendo yualquer informaçao que pode ser utilizada para caracterizar umk entidade, onde uma entidade pode ser uma pessoa, um lugar ou um ambiente lísico ou computacional (Dey \& Abowd, 2000). 
Observa-se, portanto, que os requisitos de consciência de contexto podem ser aplicados num cenário de uhiqüidade a mobilidade na forma de um agente observador do ambiente (context) de forma sistêmica, analisando todos os objetos do ambiente tanto de forma independente como em conjunto (relacionamentos). Mudanças no ambiente podem ocorrer a partir da ocorrência de eventos, c us agentes de context-armeness (CnA) devem estar habilitados a percebê-las é, desta forma, auxiliar na tomada de decisóes. Algumas mudanças são significativas e importantes e fazem com que o proprio CaA acione um evento. Como exemplo, pode-se imaginar o seguinte cenário: uma pessoa está assistindo a um programa com cenas de violência na televisào (contexto inicial); uma criança adentra o recinto (mudança no contexto inicial); um Ca $\triangle$ automaticamente dispara um evento para a mudança da programaçăo na televisão, visto que não é recomendável para uma criança assistir a programas violentos. Outras mudanças no contexto näo geram grandes transformaçoes e, portanto, o CaA pode gerar recomendaçôes ou mesmo manter o ambiente inalterado.

Em linhas gerais, para que um CaA reconheça mudanças significativas no contexto, é importante estabelecer paràmetros para quantificar e qualificar os requisitos contextuais, hem como as suas mudanças. Estes parâmetros podem ser obtidos alravés de cinco argumentos:

- WHERE - determina onde uma entidade se encontra dentro do contexto (exemplo: onde estí o usuário?); pode-se quantificar este argumento utilizando-se da posição geográfica $(X, Y$ ou $X, Y, Z)$ de uma entidade; um novo nivel de interaçào pode ser estabelecido e pode-se pensar na divisào de uma entidade em subentidades (exemplo: onde éstá o pró do usmário?);

- WHO - identifica qual a entidade que está realizando uma determinada açào (exemplo: que'm é esse usmário?); pode-se obter dados a respeito do ustário através do uso de sensores (íris, altura, temperatura) ou através de processos que identifiquem $\log \mathrm{em}$ um sistema;

- WHEN - identifica, a parlir de uma unidade de tempo conhecida, o horário em que una determinada entidade do contexto realizou uma determinada açao (exemplo: quando o usuário ligon a entidade telerisiono?); pode-se quantificar este argumento através do armazenamento dos dados de tempo (fiml'stamp) associados com a açào;

- WHAT - retorna informaçoes sobre as açoes que uma determinada entidade está realizando em um determinado momento (exemplo: o que o usuário estrí assistindo 
mo televisino?); pode-se quantificar este argumento através dos resultados obtidos por outros argumentos de contexto, tais como WHERE/WHO/WHEN (conhecendo a posiçào geográfica de duas entidades distintas, pode-se descobrir as relaçòes entre essas entidades; ainda, se uma entidade está se deslocando de um ponto geográfico para outro, e reconhecendo que essa entidade pertence a uma categoria pesson, pode-se listar as atividades permitidas naquele contexto para ayuela pessoa);

- HOW - identifica como uma determinada entidade está realizando uma ação, apresentando elementos complementares a essa ação e permitindo a descoberta de relaçòes implicitas ao contexto (exemplo: como o usuátio traballar?).

Observa-se que o uso de requisitos de consciência de contexto pode gerar impactos diretos na qualidade de serviço (QOS) em um ambiente. I) um ambiente dotado de CaA, pode-se extrair dados que auxiliem a quantificaçào do grau da qualidade de um serviço, em seus diversos niveis de avaliaşao. O grau obtido näo deve ser visto com um valor fixo, uma vez que variáveis de diferentes naturezas podem influenciar a sua medida, tais como o trafego da rede, software, o número de usuários, o conteúdo em distribuiçăo, dentre outras.

Num cenário mais abrangente, a expectativa de uso da mobilidade, da consciência de contexto e da ubiqüidade tem seu foro central na possibilidade de um usuário ter acesso qualitativo a serviços, independente da sua localizaçào geográfica, usufruindo das regras de transição de contexto (quando ocorrer) que permitam a manutenção de níveis aceitáveis da qualidade de serviço e mecanismos de adaptação natural e gradativa aos meios de comunicaçà utilizados e aos dispositivos terminais de informaçào.

Neste sentido, se é possivel quantificar e qualificar um contexto, pode-se determinar quais mudanças sào realmente significativas. Vale ressaltar que o conceito de mudanģa significativa é subjetivo, devendo haver mecanismos que permitam a sua configuraçào para um determinado ambiente $\mathrm{e} / \mathrm{ou}$ cenário. Por exemplo, para um determinado usuário (WHO), o fato de uma criança entrar em um ambiente que esteja apresentando um filme com cenas de artes marciais pode ser uma mudança de contexto significativa, porém, para outras pessoas isso pode nào ser significativo. Ao ocorrer uma mudança significativa no contexto, os CaA podem disparar eventos que promovam ajustes à realidade de cada entidade envolvida no contexto. Por exemplo, quando a criança adentra o recinto, automaticamente o) 
sistema começa a passar cenas de um desenho animado na entidade televisào, enquanto dispara um evento que continue apresentando o filme em um PDA do adulto. Neste caso, a mudança de contexto pode causar sensíveis modificaçòes nos níveis de QoS, considerando-se as diferenças de propriedades e caracteristicas entre os terminais envolvidos (terminal de televisăo e PDA, por exemplo).

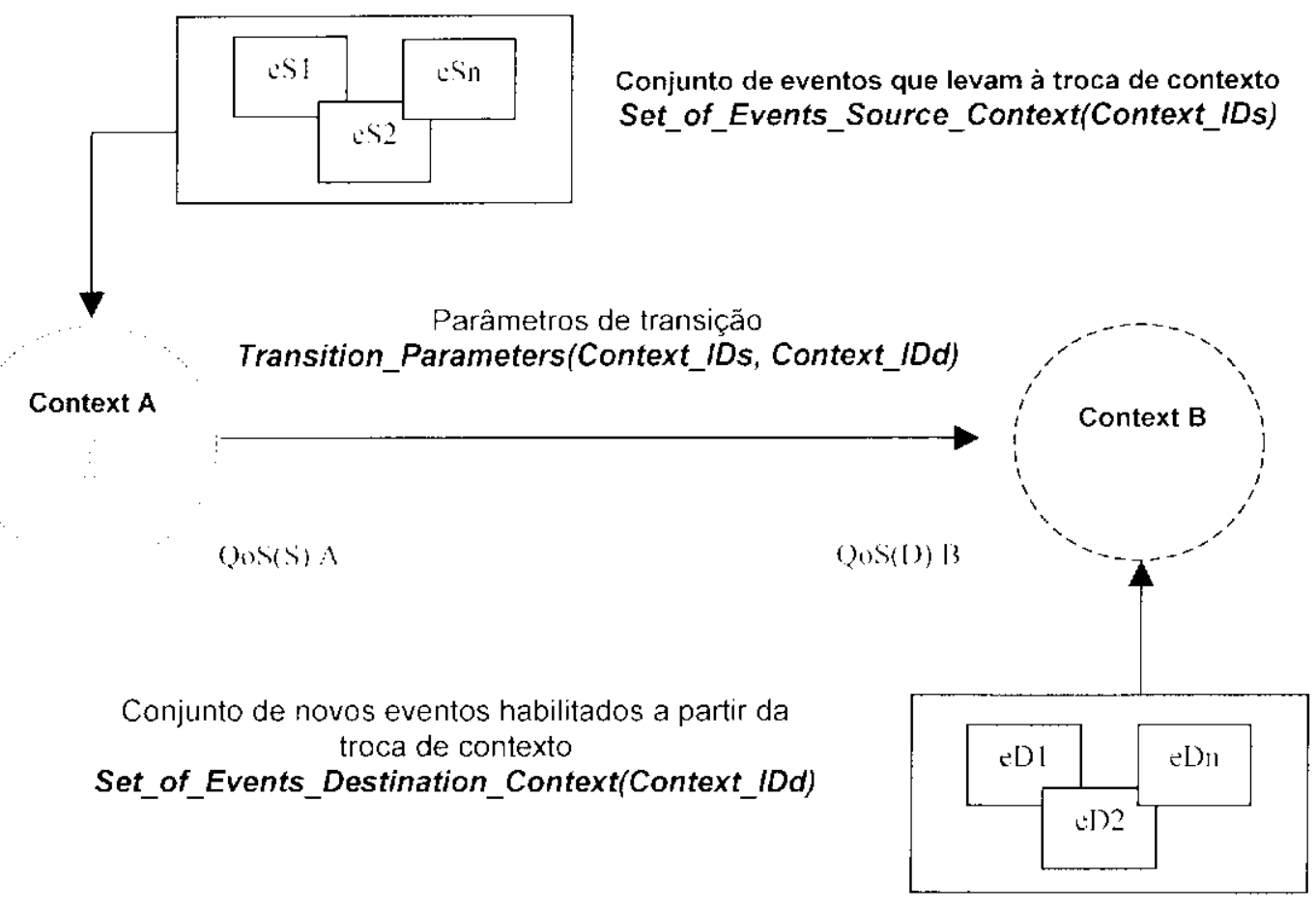

Figura 4.02 - Modelo para uso de consciência associada à mobilidade

Analisando os paràmetros de QoS, quando da troca de contexto, pode-se atingir diversos níveis de avaliaçào do ambiente como um todo. Com os dois valores de QoS (QoS(S) e o QoS(D)), pode-se obter um valor que representa a diferença de qualidade de serviço entre os contextos. Este valor é chamado de sc e é calculado pela diferença parametrizada entre o QOS(S) e o QoS(D). Pode-se, com isso, estabelecer regras de contexto que levem a situações de melhor qualidade. Por conseqüência, critérios de interação sistematizados podem sè definidos a partir das regras de contexto, estabelecendo formas de incrementar a interação, em todos os seus niveis, sem prejuizos aos níveis de QoS classificatos como aceitáveis.

Com esta proposta, pode-sè verificar yuando coorre uma alteraçăo no QoS de um ambiente: e, a partir do calculo do $\Delta c$, pode-se saber como executar as ações associadas a essa alteraçào da forma mais natural e gradativa para o usuário, conforme ilustra a Figura 4.02. Assim, 
apesar das possibilidades de queda na Qualidade de Serviço, o usuário continuará realizando a(s) tarefa(s) em curso.

No àmbito tecnológico, os padroes MPEG-4 e MPHG-7 têm sido vistos como potenciais soluçoes para aplicaçóes no (ampo da televisáo, do radio, da Internet, dentre outros. Em adiça, os estes padröes MPEG oferecem recursos para suportar a arquitetura proposta neste trabalho. Conforme visto, o padrào MPEG-4 possui diversas formas de compactaçáo (imagem, som, texto) e representação de mídias como objetos. O MPEG-4 permite, então, a apresentaçâo de uma mesma cena multimidia cm uma variedade de equipamentos e infraestrutura de comunicaçāo. Desta forma, quando ocorrer uma mudança de contexto, uma apresentaçäo pode continuar sendo apresentada sem dependências com o equipamento utilizado. Em adiçäo, no instante em que o agente CA perceber uma variação de qualidade de Serviço no contexto, o ambiente pode alterar o grau de compactação de uma apresentaçáo MPEG-4 de forma gradativa. Assim, o usuário pode assistir a uma apresentação multimídia independente de sua localizaçāo geográfica.

Neste cenário, poderá ocorrer uma mudança na qualidade da apresentação, mas será assegurada a continuidade da apresentaçäo multimídia. De forma complementar, mecanismos de pesquisa e busca podem ser implementados e/ou aprimorados de acordo com os itens de consciéncia de contexto, e o padrào MP'EG-7 oferece suporte semàntica para a construção desses mesanismos.

Como análise da arquitetura proposta pela Figura 4.02, pode-se desenvolver uma reflexão sobre o seguinte caso: "O senhor Silva está assistindo o seu filme preferido em sua confortável sala de estar. O filme é codificado e apresentado no padrào MPEG-4 e com uma qualidade excepcional ( $64 \mathrm{Kbit} / \mathrm{s}$ de áudio, por exemplo), uma vez que o ambiente possui bons equipamentos e boa conexäo de rede. Num delerminado instante, a filha do Sr. Silva the telefona e the pede para que a busque na escola. Sr. Silva se levanta rapidamente o vai buscar a sua filha. OS agentes CA verificam uma mudança significativa no contexto e imediatamente param de transmitir o filme na televisão e armazenam num servidor o momento exato em que o Sr. Silva parou de assistir o filme. No seu percurso até a escola, Sr. Silva é surpreendido por um congestionamento. Neste instante, o sistema analisa o contexto e verifica que o Sr. Silva está apto para continuar vendo o filme $\mathrm{cm}$ seu PDA. O sistema, entào, envia uma mensagem para o Sr. Silva perguntando se ele deseja dar prosseguimento 
ao filme. Sr. Silva responde que sim e volta a assistir o seu filme. Como o PIDA näo possui alto poder de processamento e a infra-estrutura de transmissão de dados näo é baseda em banda larga, o sistema sabe que deve reduzir a qualidade do filme (por exemplo, reduzindo o áudio para 2 Kbits). Mesmo assim, o Sr. Silva pôde continuar assistindo o filme".

\subsection{Una proposta de formalismo para consciência de contexto}

No Capítulo 5, é apresentada e discutida a modelagem completa para a proposta aqui reportada. Nesta seçao, conforme ilustra a Figura 4.03, apresenta-se o escopo completo da modelagem e discute-se o a formalizaçäo do modelo de consciência de contexto (SPICF), conforme ilustra o diagrama estrutural da modolagem (Figura 4.03, que é uma reapresentação da Figura 1.01).

A modelagem completa é composta por três modelos distintos, porém integrados, tendo cada um deles as seguintes funçoes de cobertura em relaçào à modelagem como um todo:

- SPICE (Schema for Intraction on Context-Aware Enviromments): este modelo cobre a modelagem da interaçao do usuário para o caso específico dos ambientes conscientes de contexto, especificando os métedes para interação e considerando também o tipo de aplicação a ser desenvolvida; neste caso, a interação do usuário em uma aplicaçio de videoconferencia pode ser especificada a partir dos requisitos identificados para uma aplicaçào de 'J'elevisăo Interativa, por exemplo;

- NECTAR (Network Lnoiromment with ConText-Awromess Rules): este modelo cobre a infra-estrutura necessária para aplicaçōes interativas conscientes de contexto, especialmente em termos dos requisitos de rede de comunicaçào;

- PRACTIC (Profile for Context-Aware Interactioe Applications): este modelo cobre a greracăo de profiles (perfis) especificos para aplicaçoes interativas conscientes de: contexto, sendo composto por dois submodelos distintos: a) PRACTIC-S (PRACTIC) Schema), que cobre a especificaçào de esquemas genéricos de descrição para programas interativos (Practic, 2001a); b) PRACTIC-E (PRACITC Progrom Examples), que cobre a especificaçào de profiles para instâncias de programas de televisáo interativa (Practic, 2001b).

Conforme apresentado, os agentes de software são vistos como componentes do ambiente e estăo presentes nos três modelos propostos (NECIAR, SPICE o PRACTIC), servindo, portanto, como elemento integrador desses modelos. Neste sentido, a modelagem proposta 
explora os recursos da plataforma JADE (Jicn Agents I)ezelopment Framework), que está em desenvolvimento nos laboratórios TTI, AB (Bellefemine et al., 2001).

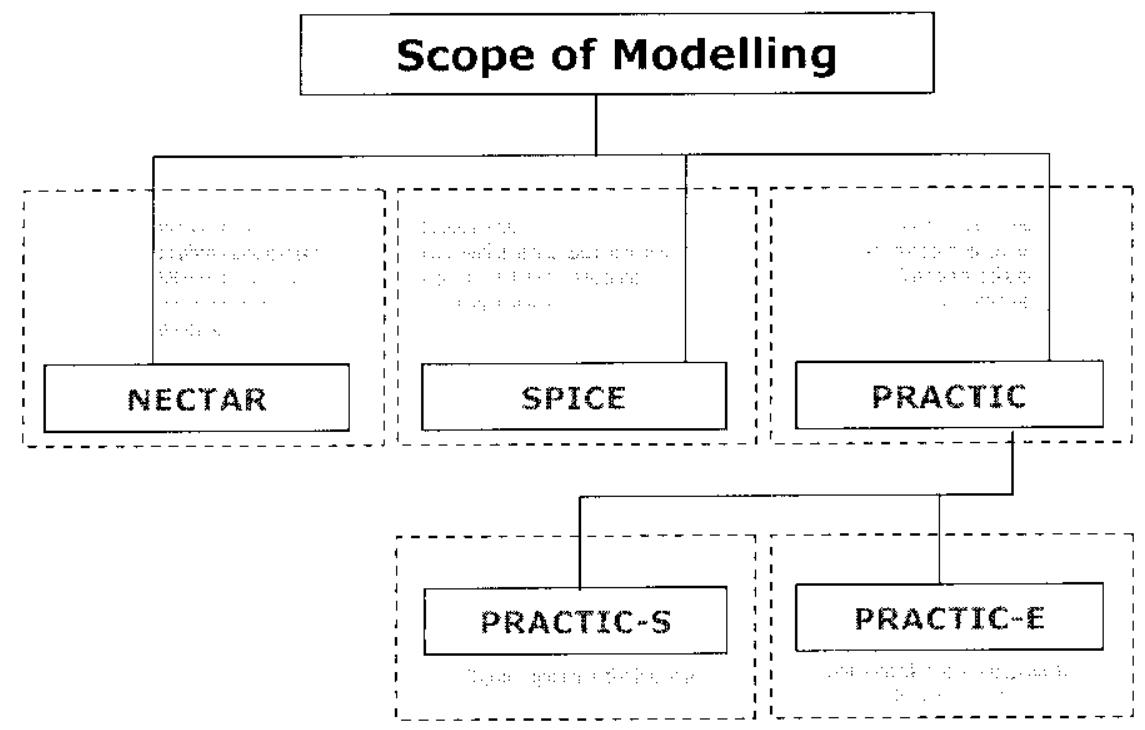

Figura 4.03: O escopo da modelagem - estrutura gráfica (Santos Jr. et al., 2001b)

Um dos focos deste trabalho está centrado em como modelar interaçóes em ambientes interativos conscientes de contexto. Para tal, o uso de consciência de contexto, no modelo SPICE, é proposto como uma macro-definiçăo que impacta todos os demais modelos da modelagem. Essa visäo estende as propostas de Anind, Schmidt e Morse, que se limitam a oferecer os elementos fundamentais de consciencia de contex to e a apresentar formas de uso desses elementos em aplicaçoes (Dey \& Abowd, 2000; Schmidt, 2001; Morse, 1998).

\subsubsection{O modelo SPICE}

O modelo SPICE cobre a modelagem da interaçáo do usuário para o caso específico dos ambientes interativos conscientes de contexto, especificando os métodos para interação e habilitando novos critérios de interação. Tal abordagem influencia a produção, a distribuição e a apresentação de aplicaçôes interativas, usufruindo do suporte tecnológico oferecido pelos padrōes MPEG-4 e MPEG-7 (ISO, 1998b; ISO, 1999a; ISO, 2000a).

Do ponto de vista estrutural, a modelagem do modelo SPICE consiste dos elementos necessários para formalizar consciência de contexto e direcionar o seu uso em aplicaçôs multimídia interativas. Fsses elementos - Contexto, Usuário, Ambiente, Domínio, Recurso, Informação e Aplicação - foram identificados a partir da proposta de ambiente interativo defendida neste trabalho, que considera a aplicação como parte do ambiente. O conjunto 
completo desses componentes é denominado CUADRIA, sendo referenciado nas seçōes desta tese, nas quais serão apresentadas as relaçoos descobertas ao longo do desenvolvimento da modelagem. Nas Seções 4.5.1.1 a 4.5.1.7, são descritas as características de cada componente do modelo SPICI e sua formalizaçäo.

\subsubsection{Domínio}

Um determinado contexto existe e/ou pode existir a partir da existência de um determinado dominio de aplicaçao. A informaçà produzida em um contexto possui uma semántica associada ao domínio de aplicação ao qual pertencem as relações e entidades que definem o contexto, conforme ilustra a Figura 4.04 .

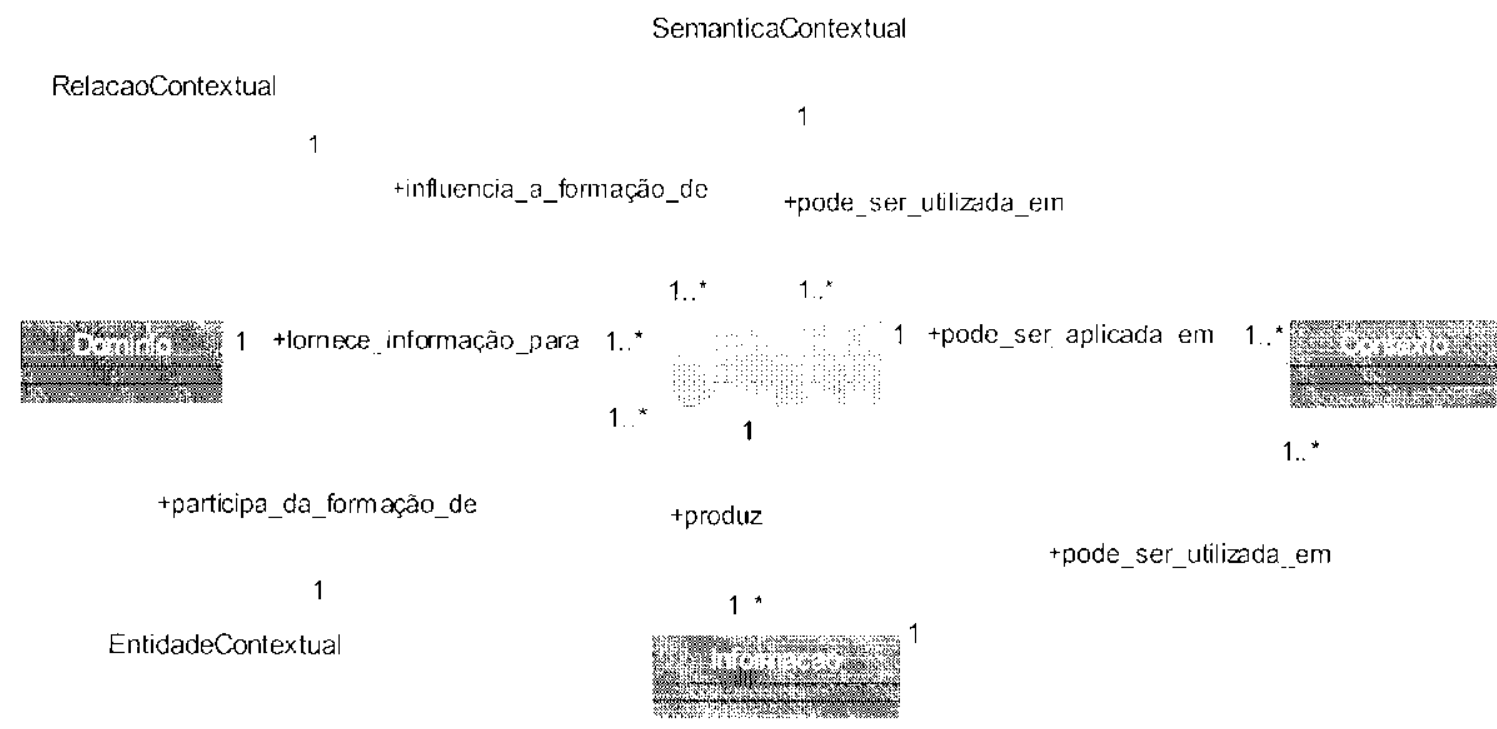

Figura 4.04 - Diagrama de classes UMl para formalização do elemento DOMíNIO

A comunicaşão entre domínios de aplicações se faz através de agentes que conheçam as regras de contexto de ambos os dominios e as informaçóes que sào produzidas em cada um deles. Adicionalmente, esses agentes são capazes de inserir novas semânticas aos domínios de aplicạăo e também modificar as semánticas existentes. Observa-se, portanto, que a qualidade da informação em um domínio de aplicação depende da qualidade das semânticas e. da qualidade dos processos que executam as regras de contexto. Educaçào, comércio eletrônico e entretenimento são exemplos de domínios de aplicação.

\subsubsection{Ambiente}

Oambiente é formado por todas as entidades (elementos) que influenciam o usuário também durante o uso de uma aplicação em um determinado domínio. 
Uma entidade, por sua ve\%, pode ser uma pessoa, um lugar ou objeto relevante para a interação entre um usuário e uma aplicaşào inscrida nesse ambiente (Dey \& Abowd, 2000).

Uma entidade pode ser nativa (FNIIDADE INTERNA) a um domínio ou ser inserida (ENTIDADE EXI'ER.VA) nesse domínio a partir de uma necessidade, requisito ou evento. Desta forma, as relaçose que produz'm as regras de contexto devem considerar também a natureza da entidade em relaça ao domínio, conforme ilustra a Figura 4.05.

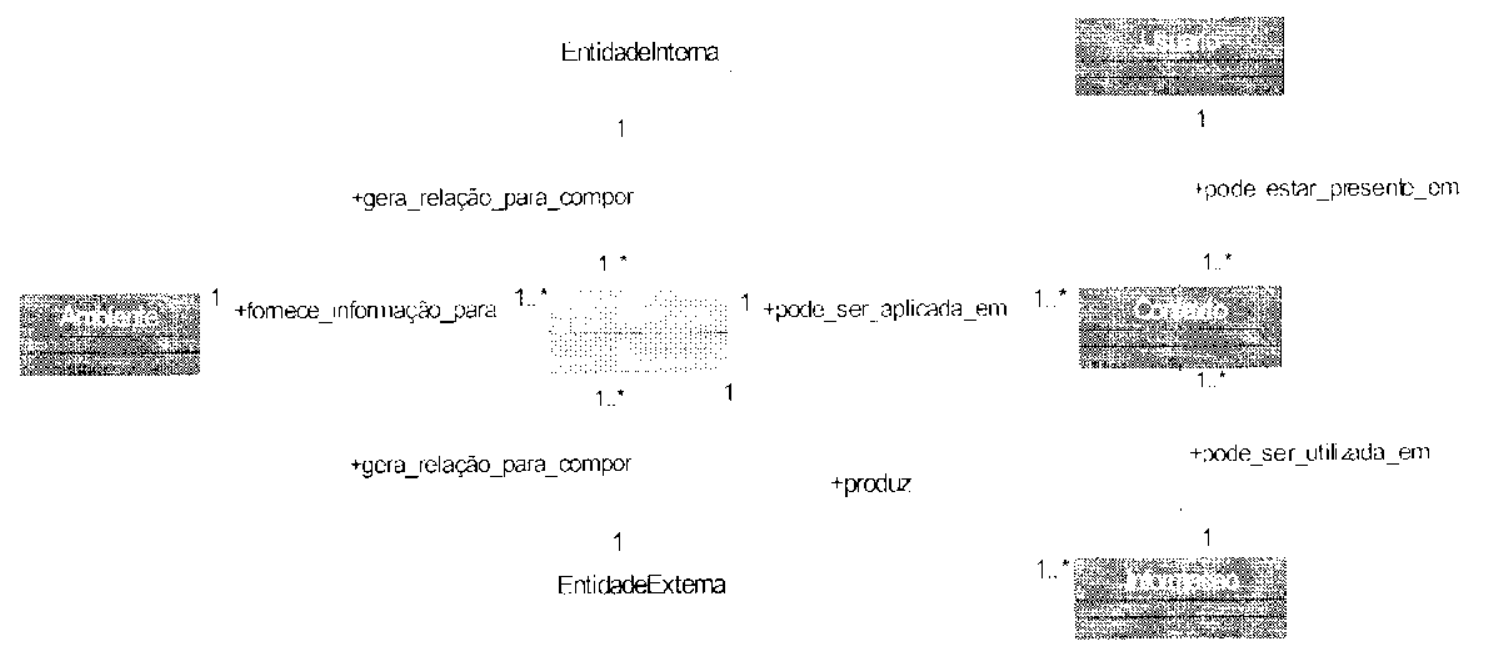

Figura 4.05 - Diagrama de classes UML para formalização do elemento AMBIFNTE

Um ambiente é, portanto, uma instância de um domínio de aplicação, instância essa configurada de acordo $\mathrm{com}$ as entidades de ambiente disponíveis em um determinado momento. Quanto maior a flexibilidade de configuraçào do ambiente, maiores serào as possibilidades de uso das informaçós contextuais.

Assim, um ambiente é consciente de contexto se utiliza o contexto para oferecer informaçoes relevantes $\% /$ ou serviços ao usuário, sendo que a relevância depende das tarefas que o usuário realiza (Abowd, 1999).

A criaçào de ambientes que utilizem as informaçöes de contexto para fornecer informaçóes relevantes e/ou açoes específicas para cada usuário, conforme o grau de liberdade definido pelo projetista, é uma tarefa que precisa ser parametrizada para cada aplicaçáo e considerando também o domínio de aplicação.

Esta parametrizaçấo é obtida com base em cinco questionamentos: a) onde o usuário está (WHERE); b) quem é o usuário (WHO); c) cono o usuário está utilizando os recursos 


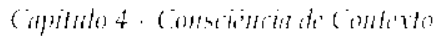

(HOW); d) quando se pode realizar determinada operação (WI IEN); e) o que o usuário está fazendo (WHAT).

No contexto da execução automática de tarelas e açoes, pode-se considerar as quatro entidades de consciência definidas por Dey (Dey \& Abowd, 2000), a partir dos questionamentos citados: a) localizaçào (WI IERE); b) identidade (WHO); c) atividade (WHAT + HOW); d) tempo (WI IEN).

Lma sala de aula, uma sala de trabalho, um ambiente doméstico, um salão de convenções e um automóvel, são exemplos de ambiente.

\subsubsection{Usuário}

A presença do usuário é uma premissa básica na relaçăo domínio-ambiente, justificando a necessidade das aplicaçoes. Neste sentido, também a modelagem de um ambiente consciente de contexto deve ser centrada no usuário.

Fm linhas gerais, existem cinco grupos de características que permitem identificar o usuário, quando este utiliza uma ou mais aplicaçoes em um ambiente:

- características de identificação do próprio usuário: são as características do usuário enquanto inctividuo, tais como nome, idade, data de nascimento, dentre outras;

- características dos interesses do usuário: essas características formam a base para definir o porquê do interesse de uma pessoa por uma determinada informação ou parte dessa informaçào; por exemplo, a caracteristica de interesse por videos sobre Geografia do Brasil pode fazer parte dos interesses de um usuário;

- características das preferencias do usuário: formam o conjunto explícito das informaçóes de maior relevância para o usuário; por exemplo, a preferência por uma mídia de áudio ou de vídeo, ou por uma mídia de texto, durante uma apresentaçäo multimídia;

- características dos objetivos do usuário: as características dos objetivos do usuário permitem especificar melhor os elementos mais importantes de seus interesses e preferencias; por exemplo, o usuário tem interesse em informacoes sobre Geografia do Brasil e preferências por receber informações em formato de áudio e vídeo, como objetivo de estudar especificamente o nível de pluviosidade na Floresta Amazônica; 
- características das tarefas do usuário: as características das tarefas do usuário permitem, juntamente com as caracteristicas dos objetivos, especificar a granularidade dos interesses do usuário; neste sentido, uma lista das tarefas auxilia na definiçào da ordem dos processos necessários para se atingir o maior grau possivel de satisfação em relação aos interesses do usuário; por exemplo: lista lde tarcfas [a) enviar e-mail ao IBGE visando receber dados, em formato de áudio e vídeo, sobre a pluviosidade na Floresta Amazonica; b) esperar por resposta do IBGt; c) analisar os dados recebidos; d) selecionar os dados de interesse] ou lista 2 de tarefas [a) pesquisar sobre pluviosidade na Floresta Amazonica nos siles de busca da Internet; b) selecionar links de interesse; c) enviar aos destinatários selecionados a partir dos links, uma solicitação de dados em formato de áudio e vídeo; d) esperar por respostas dos destinatários; c) analisar os dados recebidos; f) selecionar os dados de interesse].

O usuário, ao utilizar uma aplicaçäo inserida em um ambiente consciente de contexto, recebe diretamente os resultados produzidos pelas regras de contexto, que são geradas pelas relações domínio-ambiente-aplicaçào e pelas semânticas de ambiente. Neste sentido, melhorando a produçào das regras de contexto pode-se ampliar os níveis de informações contextuais e, por conseqüência, fornecer mecanismos elaborados para tlaboração da lista de tarefas do usuario. Assim, yuanto maior o grau de otimização da lista de características das tarefas do usuário, maior será a possibilidade de melhoria nos processos de interação com o ambiente, contribuindo para o incremento do grau de satisfaçào do usuário.

\subsubsection{Aplicação}

Uma aplicação é toda e qualquer interface entre o usuário e o ambiente, em um determinado domínio, constituindo-se, essencialmente, dos elementos de software necessários para produção e consumo de informaçôes nesse a mbiente.

As aplicaçoes também sào responsáveis pelo estabelecimento de comunicação entre domínios diferentes, provendo mecanismos de suporte à troca de contexto, conforme apresentado pela Figura 4.06. Neste sentido, as regras de contexto podem ser incrementadas por semânticas mais complexas derivadas, por exemplo, do uso da tecnologia de agentes (Jenningss \& Wooldrige, 1995), com base em descriçôes de ontologias (Blásquè, 1998; Sowa, 2000). 


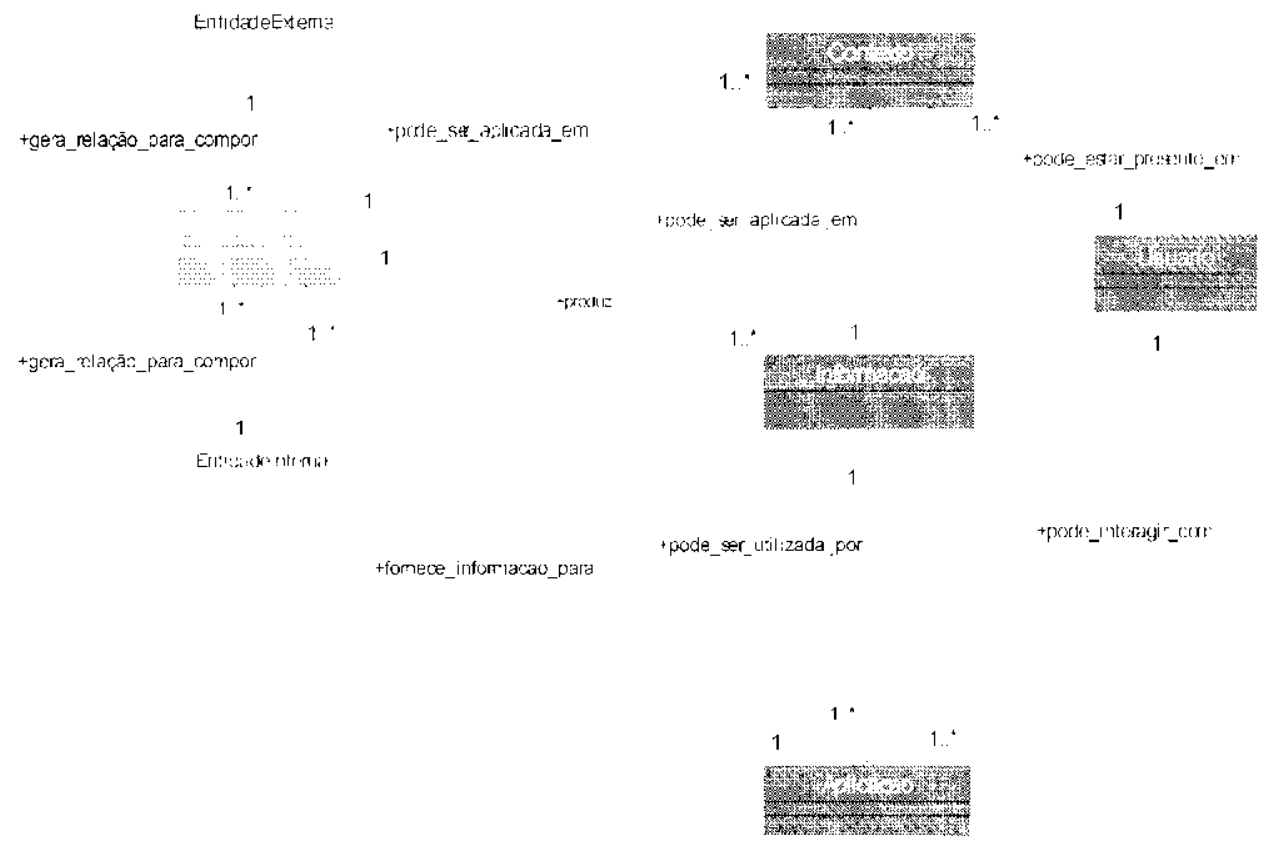

Figura 4.06 - Diagrama de classes UMI para formalizaçào do elemento APLICAÇĀO

Uma interface gráfica para interação do usuário com um computador é um exemplo de aplicação, assim como um software que recebe dados de um dispositivo de rede e configura automaticamente os requisitos de comunicaçà a partir dos dados recebidos.

\subsubsection{Contexto}

O contexto de uma aplicacào consiste de todos os elementos associados direta ou indiretamente ao ambiente da aplicação e às informaçoes que essa aplicação usa e/ou produz.

O conlexto está diretamente associado ao domínio de aplicação no qual uma aplicação está inserida. De maneira geral, pode-se reconhecer o contexto através das relaçōes entre o domínio de aplicaçào es recurses disponíveis no ambiente, conforme ilustra a Figura 4.07.

Dentro de um determinado contexto, uma regra de contexto é responsável por associar um recurso a um processo baseado nos operadores INPUT (I), RUN.VIG (R) e OUTPUT (O), produzindo uma informação. Lm operador $I R O$ define a natureza de um recurso dentro de um ambiente. Assim, quando um operador INPLT é associado a um recurso, define-se que aquele recurso tem a natureza de gerar informaçoes para INPUT no ambiente; se o operador associado for RUNNING, então o recurso tem a função de processamento dentro do 
ambiente; por fim, se o operador associado for OLTPU', o recurso tem natureza apropriada ao fornecimento de informaçoes. Com esta formalizaçâo, estruturas pipe podem ser construidas a partir dos operadores IRO.

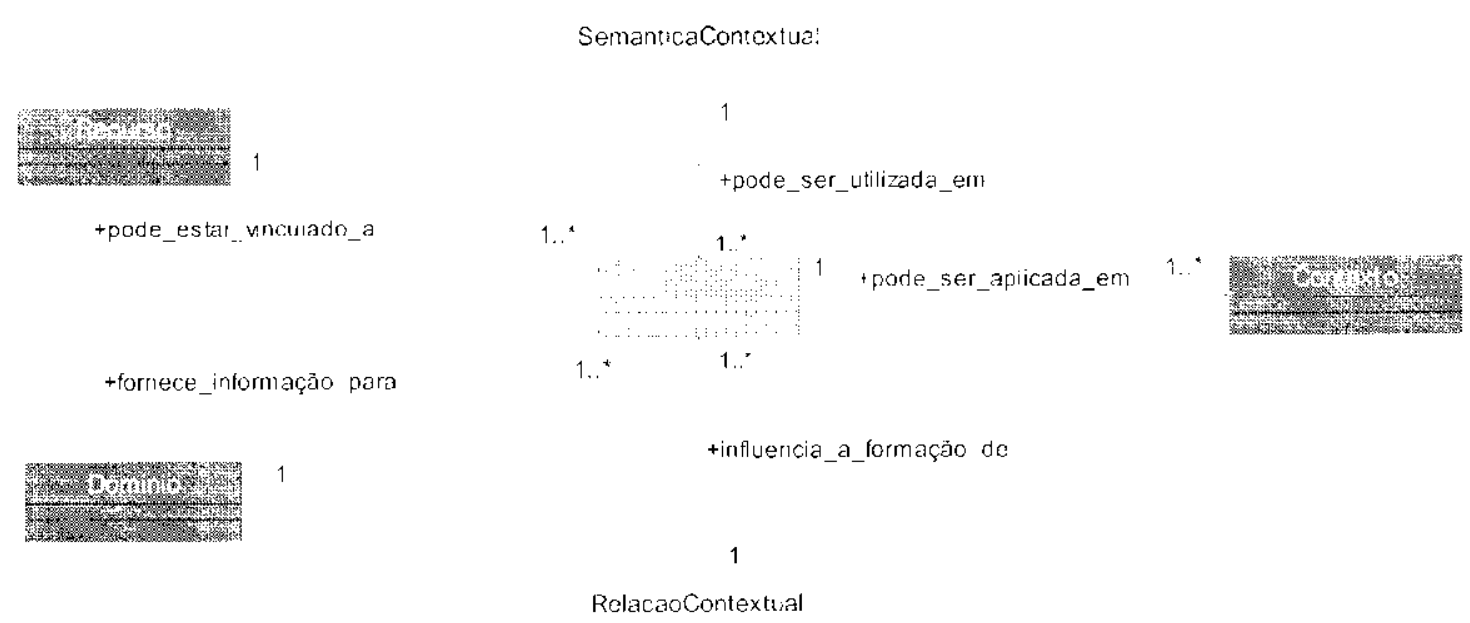

Figura 4.07 - Diagrama de classes UML para formalizaçào do elemento CONTEXTO

Os operadores IRO são independentes do domínio de aplicação, mas herdam as relaçōes geradas a partir da associação DOMINIO-RECURSO. Desta forma, um recurso pode estar associado a um mesmo operador em diversos domínios diferentes, realizando a mesma operaçào. No entanto, a semântica associada à regra de contexto pode influenciar na informação produzida pelo recurso/operador em um determinado domínio.

A troca de contexto pode ocorrer quando uma relaçào DOMINIO-RECURSO faz referência a outras relaçoes que năo conduzem ao conjunto de regras de contexto que forma o domínio de aplicaçào corrente.

Um grupo de vinte estudantes e um professor, em uma sala de aula na cidade de Sảo Carlos, no estado de Sào Paulo, Brasil, usando projetor de recursos audiovisuais e um computador para acesso à Internet, em uma aula de Geografia, é um exemplo simplificado de descricào de um contexto. O dia da semana en que a aula está sendo realizada é um exemplo simples de semântica de ambiente capaz de mudar o contexto c/ ou associá-lo a outros contextos. 


\subsubsection{Recurso}

Um recurso é qualquer elemento de hardware ou software utilizado em um ambiente e, a partir do qual, se pode obter uma informação. Todo recurso precisa de um operador IRO para entrar em operaçào, como apresentado na Figura 4.08.

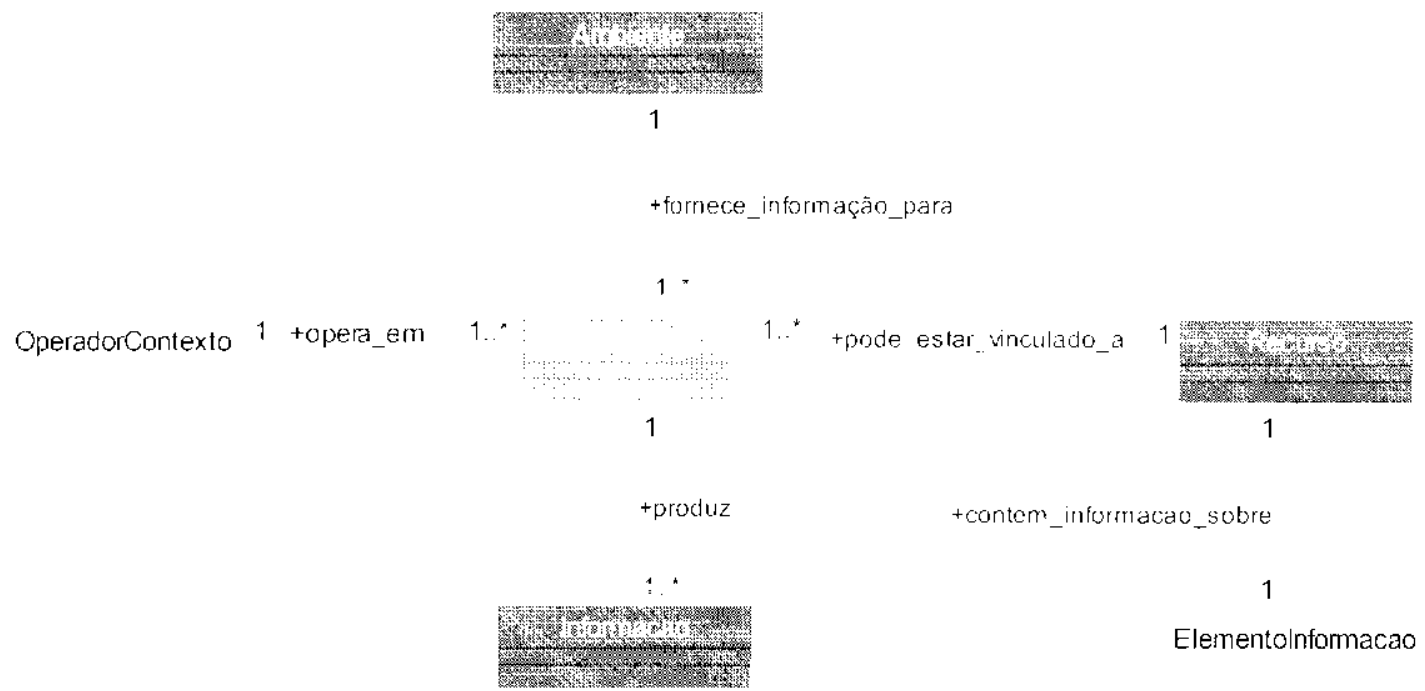

Figura 4.08 - Diagrama de classes UMI para formalização do elemento RECURSO

Neste sentido, pode-se definir cinco estados básicos para um recurso: a) associação; b) ativaçâo; c) operação; d) suspensăo; e) reativação; e) desativação.

Genericamente, o recurso começa a operar quando se procede a sua associação a um operador IRO. O estado de ativaçào ocorre, por exemplo, a partir de um evento disparado no ambiente. O estado de operaçăo é atingido respeitando-se a nature\%a do recurso e as regras de contexto que definem as relaçōes no domínio de aplicação. $\mathrm{O}$ próprio ambiente e/ou outro recurso podem provocar um estado de suspensão; neste caso, o estado de reativaçào pode ser atingido disparando-se um novo evento. Por fim, o estado de desativaçào pode ser atingido a partir do estado de suspensão ou quando o recurso for considerado completo em termos das relaçóes que definem as regras de contexto a ele associadas.

A desativaçâo de um recurso pode ser definiliva ou temporária. No primeiro caso, todas as relaçōes que definem as reģras de contexto associadas ao recurso deixam de alimentar esse recurso. No segundo caso, uma semântica específica pode reativar o recurso quando necessário, promovendo a reatimentaçào das relaçoes que delinem as regras de contexto. 


\subsubsection{Informação}

A informação é o elemento produzido por um determinado recurso em um determinado contexto de um determinado ambiente.

O motor de execuçào de cada recurso é abastecido com dados de entrada (INPUT) e é responsável por algum tipo de processamento. Neste ponto, as semànticas de contexto e as relaçoes contextuais são responsáveis por instruir ao recurso sobre as formas mais adequadas para processamento dos daclos contextuais e geração das informaçỏes contextuais. Observa-se que o grau de consciência de contexto de um ambiente depende, diretamente, da granularidade dos dados de INPUT e da qualidade das regras contextuais aplicadas para produzir a informaçào, conforme ilustrado na Figura 4.09.

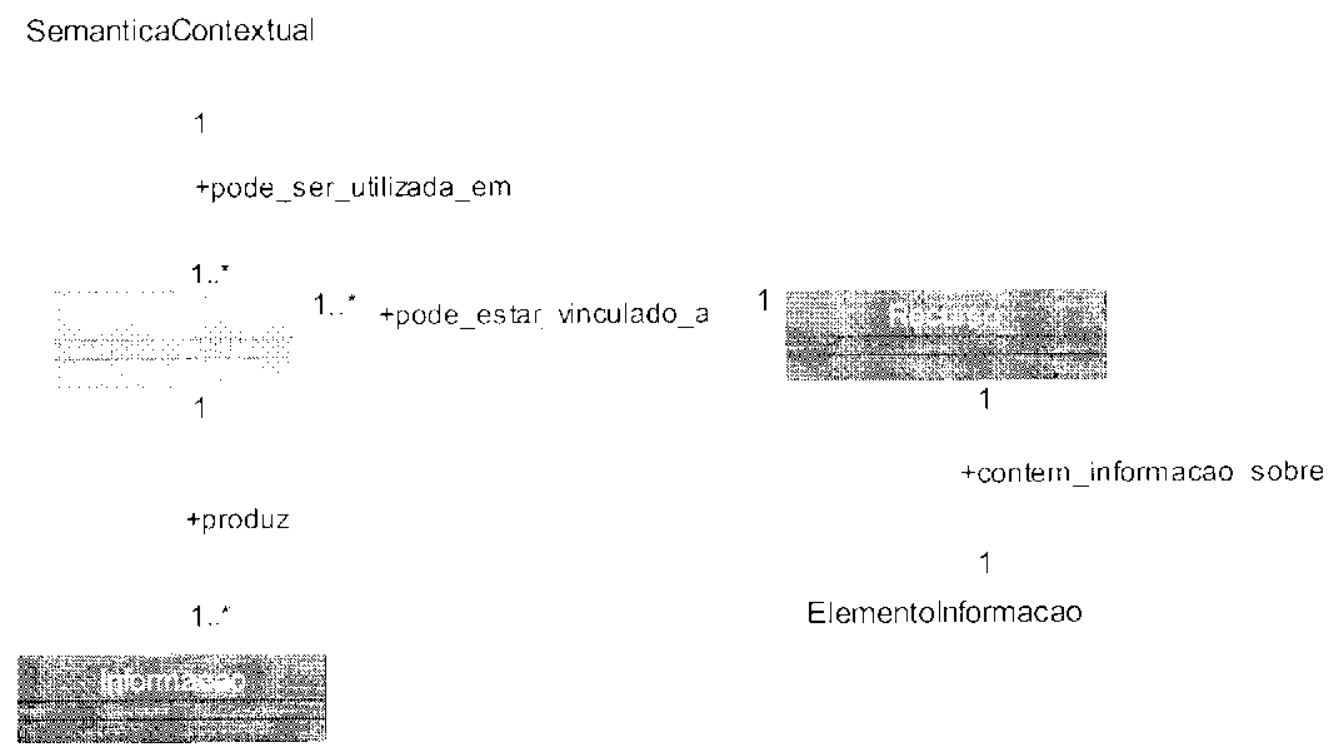

Figura 4.09 - Diagrama de classes LML para formalizaçào do elemento INIORMAÇĀO

Considerando que um processo está associado a um recurso, pode-se dizer que uma informação é o resultado do trabalho realizado por esse recurso.

\subsubsection{A proposta das regras contextuais como extensão do modelo de Anind}

A formalizaçào das relaçōes contextuais depende diretamente da definiçăo de très elementos: a) entidade contextual (EC), semàntica contextual (SC) e regra contextual (RC). Esses alementos devem ser associados a um Motor de Contexto (MC), que é o agente responsável pela greraçäo das relaçoes contextuais, conforme ilustra a Figura 4.10. 
A formalização das relaçöes contextuais depende diretamente da definiçào de três elementos: a) entidade contextual (EC), semântica contextual (SC) e regra contextual (RC). Esses elementos devem ser associados a um Motor de Contexto (MC), que é o agente responsável pela geraçào das relaçoes contextuais.

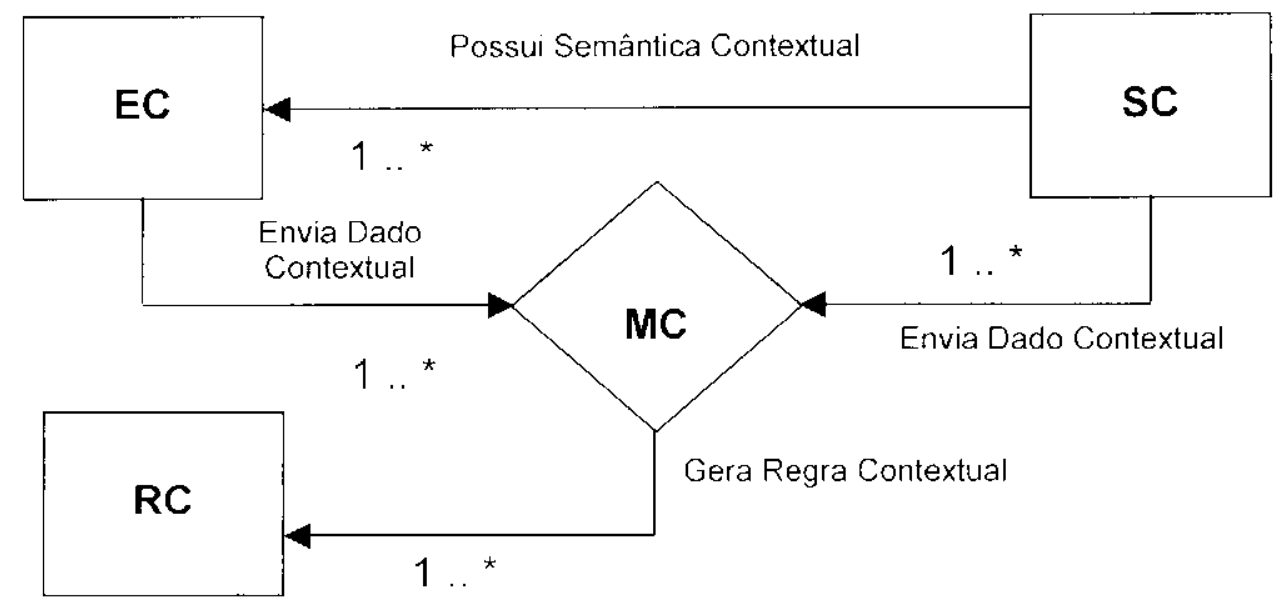

Figura 4.10 - Modelo para formalizaçảo das regras contextuais

Em termos de consciência de contexto, a modelagem proposta estende o modelo proposto por Anind (Dey \& Abowd, 2000), acrescentando novos elementos formadores. Esses novos dementos são genéricos e agregam funcionalidades conceituais, independentes do domínio de aplicaşào e do ambiente.

Genericamente, três questionamentos conduzcm a uma reflexão sobre os requisitos essenciais para o uso de consciência de contexto, por exemplo, em ambientes interativos:

a) Quando (WHEN) se descja produzir uma midia (WHAT), em que (WHO + WHAI' + I JOW) se deve pensar?

b) quando (WHLN) de deseja distribuir essa midia produzida, quais (WHAT + HOW + WHERE) são os requisitos de distribuição?

c) quando (WHEN) se descja apresentar essa midia, quais (WHAT) são as opçoes de visualizaçà disponiveis em um determinado momento (WHEN + WHERE) ?

No contexto deste trabalho, uma proposta para responder os questionamentos é elaborada com base no escopo CUADRIA. A Figura 4.11 apresenta o diagrama de classes UML que relaciona todas as classes do modelo SPICE. 


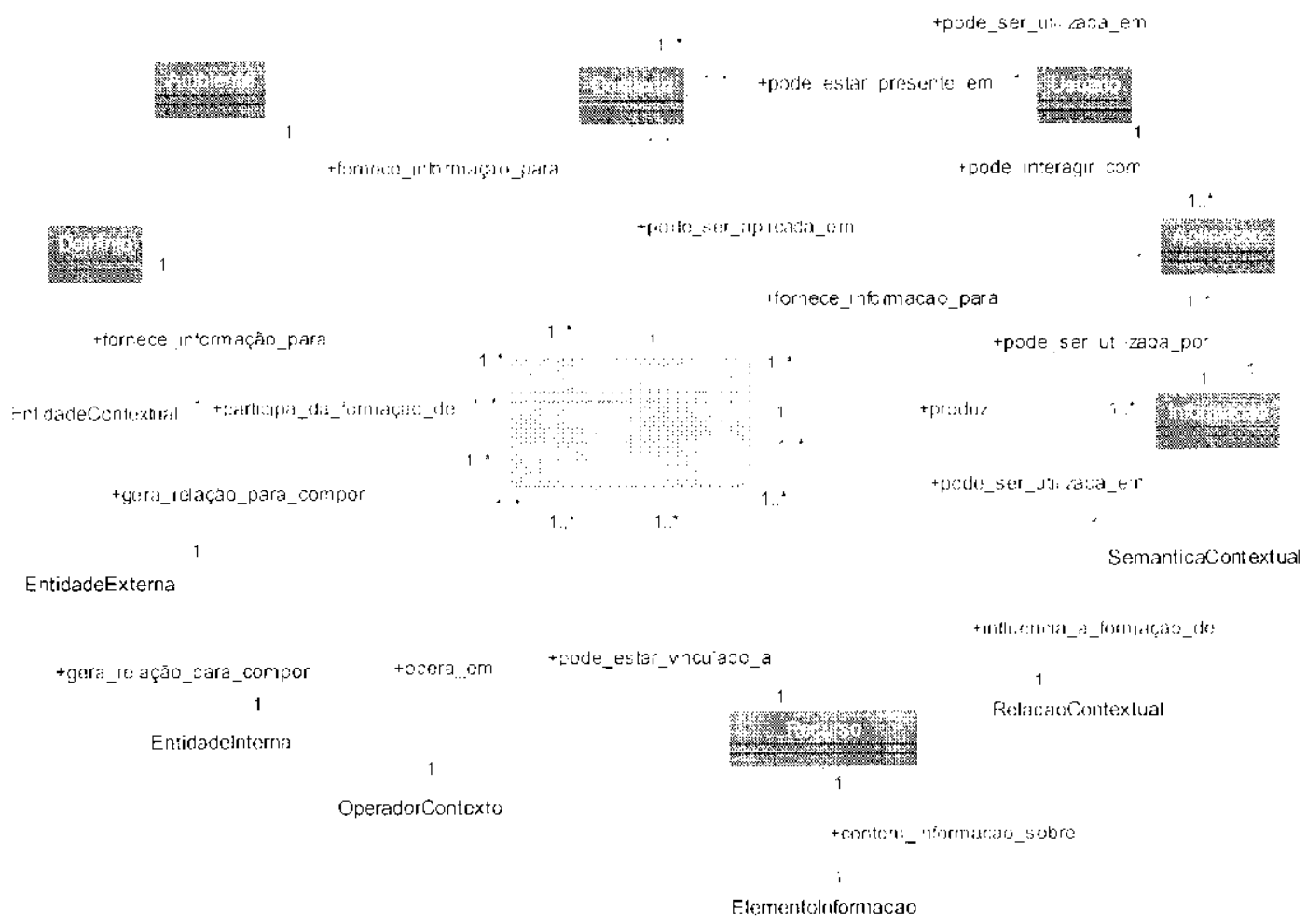

Figura 4.11 - Diagrama completo de classes UML do modelo SPICF.

Para o primeiro questionamento, o elemento <WHAT> conduz a uma reflexao sobre o Conteúdo e Usuário. Para o segrundo questionamento, o foco do elemento <WHAT> concentra-se sobre Recurso, Ambiente e Aplicação. No terceiro questionamento, o elemento $<$ WHAT $>$ refere-se ao Ambiente e L suário.

Percebe-se, portanto, que o Contexto é um componente de ligaçào entre os demais componentes do escopo CUADRIA. Adicionalmente, o grau de consciência é responsável pelo nível de resposta para cada um dos yuestionamentos. Quanto maior o grau de consciência, mais completa será a lista de elementos que formarào cada uma das respostas. Definir mecanismos para aumentar o grau de consciência de contexto em um ambiente é a principal motivação deste trabaho. Neste sentido, estender o modelo de Anind (Dey \& Abowd, 2000), muito mais do que definir novos elementos formadores de consciência de contexto implica em apresentar alternativas para construçào de relaços que gerem novas regras de contexto. 


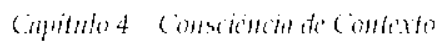

\section{O modelo de Anind}

O modelo de consciência de contexto proposto por Anind concentra-se no nivel da interaçào usuário-aplicação, enfocando, principalmente, a execução automática de tarefas e açoes.

O modelo é baseado em quatro entidades de consciência, geradas a partir dos cinco questionamentos fundamentais; a) localização (WHFRE); b) identidade (WHO); c) atividade (WHAT + HOW); d) tempo (WIJEN).

Na relação usuário-aplicaçào, os níveis de consciência de contexto são simplificados, uma véz que näo sào consideradas as relaçòes usuário-ambiente e ambiente-aplicação, que produzem regras de contexto mais complexas.

Neste sentido, no modelo proposto por Anind näo é necessário definir operadores que definam as relaçoes para produção de regras de contexto. Usando o modelo, o projetista pode partir diretamente dos dados que sào gerados pela interaçào usuário-aplicação e extrair o grau de consciência de contexto a partir dos cinco questionamentos básicos. A existência de relaçòes ao nível do ambiente, da aplicação e do usuário, conduz à extensäo das relaçôes que produzem as regras de contexto. Nesta proposta, essa extensào inicia-se com a definiçäo de

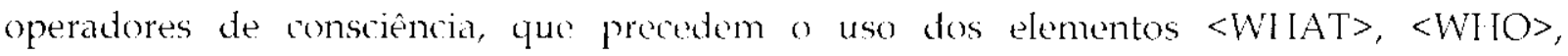
$<$ WHEN $>,<$ WHERE $>$ e $<$ HOW $>$.

O primeiro grupo de operadores (operatores de pertinêncin ao contexto-OPC) são dedicados às operaçós que verificam se uma determinada entidade ou informaçào é pertinente a um determinado domínio. Adicionalmente, us operadores de pertinência podem se comunicar, através de agentes, com operadores de pertinência de outros domínios, gerando mecanismos de busca por pertinencia a um contexto.

Em termos das opcraçóes, os OPC podem verificar se um elemento pertence a um determinado contexto ( $<$ INCONTEXT>) ou, então, definir/configurar que um determinado elemento deve deixar de pertencer a um determinado contexto (<OUTCONTEXT>). Genericamente definidos, os OPC sào aplicados as reliçoes usuário-ambiente, aplicaçàoambiente e recurso-aplicação, conforme ilustra a Figura 4.12. 


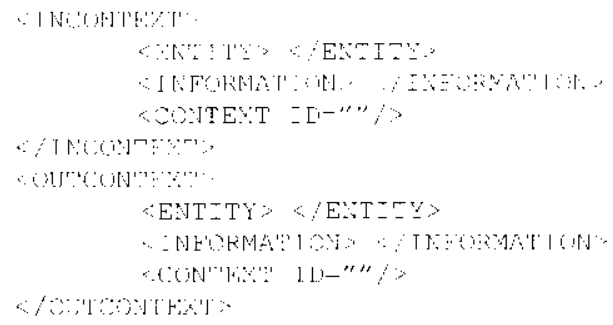

Figura 4.12 - Esquema de relaçòes de pertinência a um contexto

O segundo grupo de operadores (operatores para troca de contexto - OTC) são dedicados às operaçòes que verificam e executam a troca entre contextos diferentes em um ambiente. Operadores OTC consideram as regras de contexto para auxiliar nas decisoes que envolvam troca de contexto, identificando a(s) entidade(s) que solicita(m) uma operaçáa de troca (context clangye) e os dados que seräo necessários para essa troca, bem como a(s) entidade(s) que será(äo) responsável(is) por receber os dados no contexto destinatario.

Em termos das operaçòes, os OTC podem verificar se um elemento pertence a um determinado contexto ( $<$ INCON TEXT $>$ ) ou, então, definir/configurar que um determinado elemento deve deixar de pertencer a um determinado contexto ( $\angle$ OLTCONTEXT>). Genericamente delinidos, os OTC sào aplicados às relaçöes usuário-contexto, contextoambiente contexto-contexto, conforme mostra a Figura 4.13.

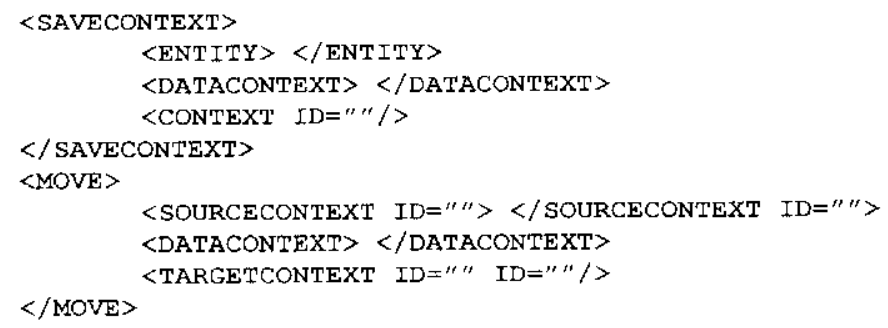

Figura 4.13 - Esquema relações e transiçòes em um contexto

O) terceiro grupo de operadores (operntores de vecursos - OR) säo dedicados às operaçóes de associaçăo de recursos a entidades do ambiente, a partir das regras de contexto válidas para as entidades e recursos envolvidos na operação. De forma complementar, os operadores OR também são responsáveis pela liberação dos recursos associados às entidades. 
Operadores OR consideram os seguintes estados de um recurso realizar as operaçoes de associaçào e liberação: a) associação; b) ativaçào; c) operação; d) suspensão; c) reativaçào; c) desativaçào.

$\mathrm{O}$ estado de associaçăo (operadores $\langle\mathrm{GET}\rangle$ e $\langle\mathrm{SET}>$ ) consiste $\mathrm{em}$ indicar um recurso mais apropriado para uma entidade em um determinado instante do contexto. O estado de ativação ( $\angle$ SEND $>\mathrm{e}<\mathrm{USE}>$ ) consiste em enviar os dados contextuais que ativam o motor de contexto (MC) para um determinado recurso. O estado de operaçào (operador <RUN>) consiste em manter o motor de contexto (MC) em estado de execuçăo. O estado de suspensão (operador $\left\langle S I^{\prime O P}\right\rangle$ ) é atingido quando ocorre um evento no contexto ao qual pertence o recurso ou, ainda, quando o ambiente, usando as regras de contexto apropriadas, decide intervir no estado de operação de um recurso. Uma vez suspenso, um recurso pode voltar ao estado de operação através de uma nova ativação, que pode ser automática, através das regras de contexto, ou gerada por um evento. Por fim, o estado de desativação (operadores $<$ LEAVE $>$ e $<$ FREE $>$ ) é atingido quando o recurso é liberado pela entidade a que estava associado. Essa liberação pode ocorrer quando se atinge o final do estado de operação ou, ainda, quando ocorre algum evento que gere estados nâo-recuperáveis no ambiente.

A proposta de extensão apresentada neste trabalho encapsula os elementos <WHAT>, $\langle$ WHIO $\rangle,\langle$ WHEN $\rangle,\langle$ WHERE $\rangle$ e $\langle$ HOW $\rangle$, à luz dos operatores especificados, gerando classes que contém as regras de contexto.

Por exemplo, considerando o modelo proposto por Anind, a relaçào "Usuário_Pode Usar_-_Recurso" pode ser formalizada de acordo com a Figura 4.14. $\Lambda$ figura mostra também exemplo de uso da relação contextual.

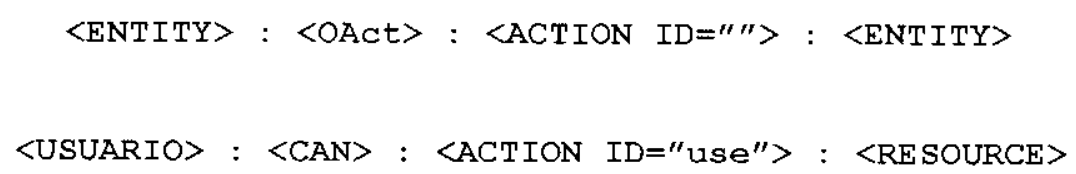

Figura 4.14 - Fxemplo de formalismo e uso de uma regra contextual

A formalização de uma relação contextual recebe como parâmetros as entidades válidas para definiçào dessas relaçós em ambientes conscientes de contexto. Um operador de ação (OAct), representado por verbos, é usado para conectar as entidades que se descja relacionar. 
A Figura 4.15 mostra como os operadores Oact podem ser definidos e utilizados em regras contextuais.

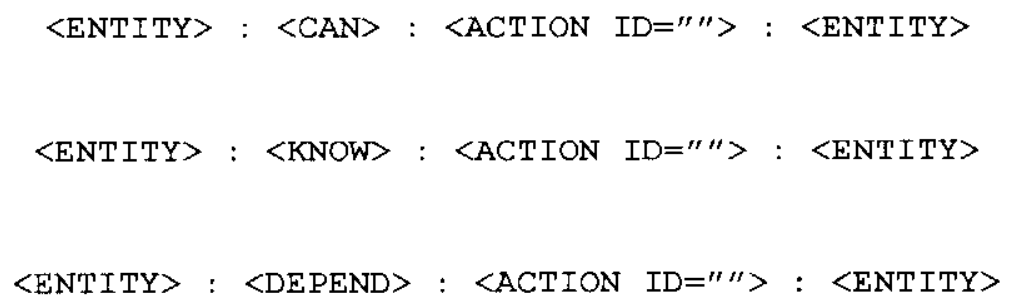

Figura 4.15 - Operadores de regras contextuais

Adicionalmente, as açoes permitidas em $<A C I I O N>$ podem ser configuradas de acordo com as semanticas habilitadas para o ambiente e que produzem as regras de contexto. $\Lambda$ Figura 4.16 ilustra o diagrama U.ML de classes que integra o uso de operadores de regras contextuais ao modelo SPICF.

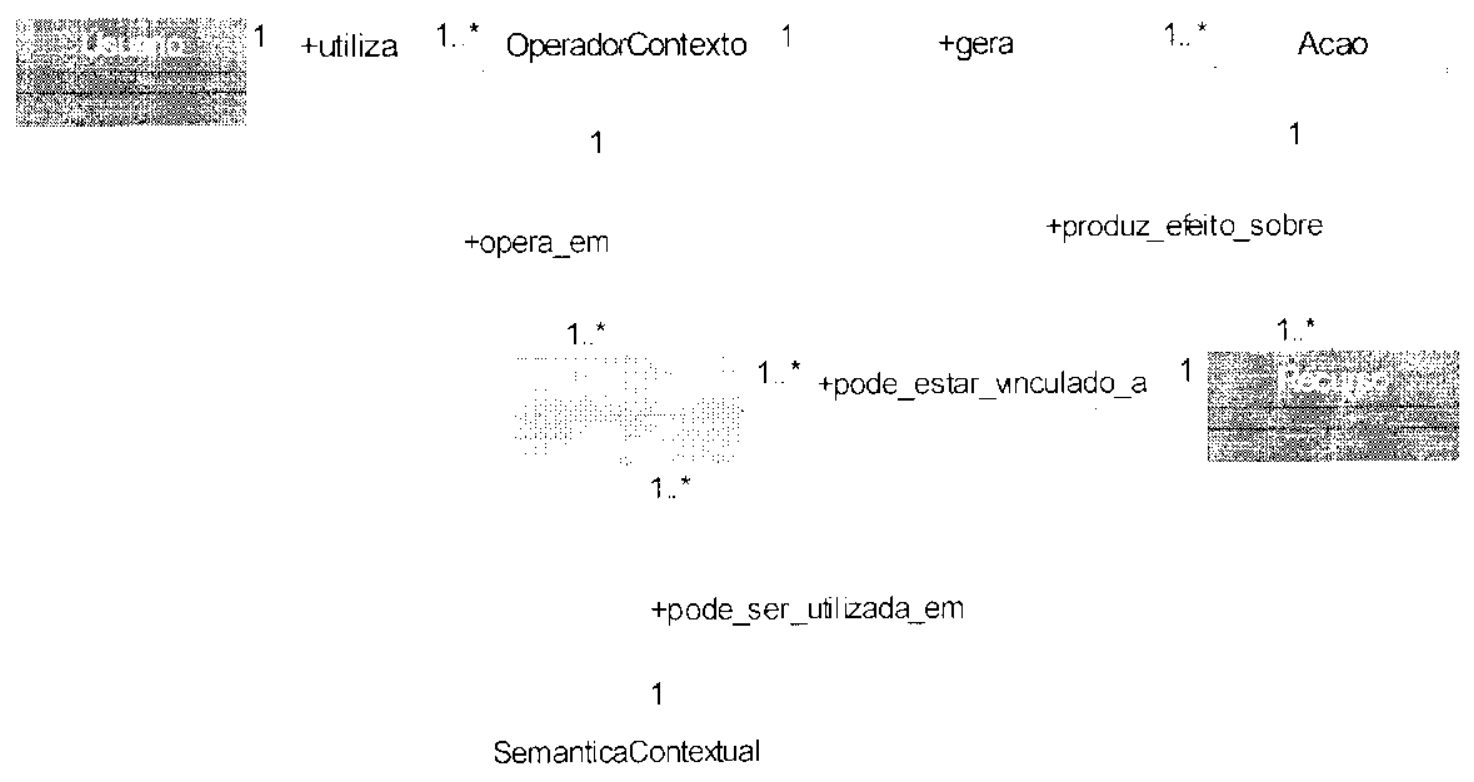

Figura 4.16 - Diagrama classes LML para os operadores de regras contextuais

A partir da formalizaçăo da relaçào de contexto, as regras contextuais podem ser geradas como extensöes e combinaçós das entidades propostas no modelo de Anind. A Figura 4.17 apresenta possibilidades do regra de contexto para a relaçăo "Lisuario_Pode Lsar_Recurso". 


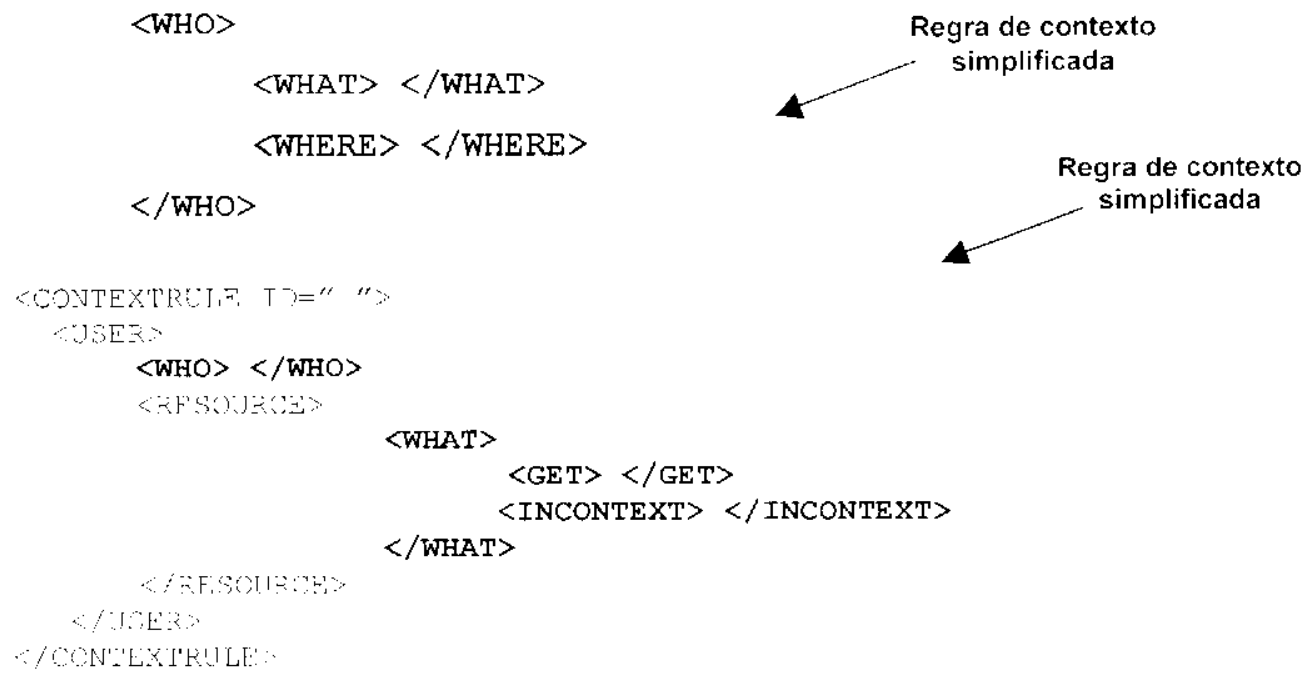

Figura 4.17 - Operadores de regras contextuais

Observa-se que a representacäo acima gera uma hierarquia entre as classes RESOLRCE, USER c CONTEXTRLLE, e sugere uma forma de encapsulamento, conforme ilustrado na Figura 4.18. Esta abordagem é coerente com a proposta teórica apresenta no escopo CUADRIA, da qual se extrai as relaçòes entre as entictades contextuais.

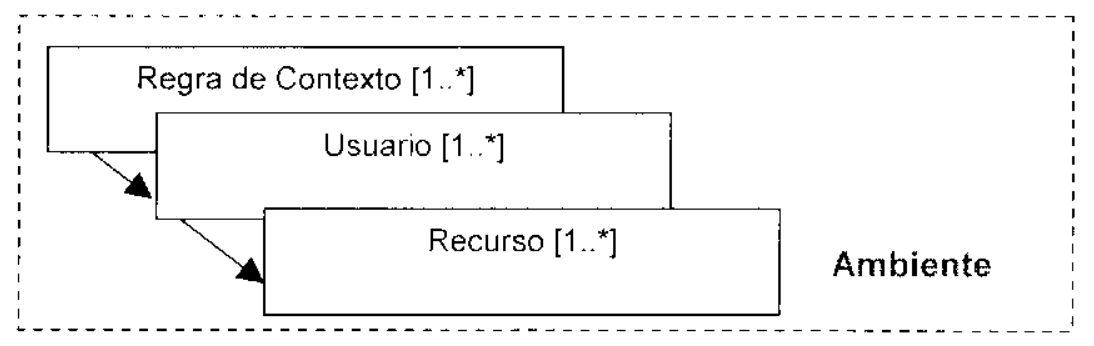

Figura 4.18 - Modelo para relaçöes entre contexto e elementos contextuais

\subsection{Usando agentes para prover consciência de contexto}

Tradicionalmente, eventos e relacionamentos são analisados e modelados no desenvolvimento de interface's para aplicaçoes em ambientes computacionais. No entanto, ao serem considerados aspectos como a ubiyüidade, o projeto de interface exige requisitos que vão além dos eventos e relacionamentos, uma ve\% que a interface deve ser dotada de capacidades reativas, tanto ao nível do usuário quanto em termos da infra-estrutura formada pela própria aplicaçào e pela rede de comunicação, por exemplo. Adicionalmente, aspectos de consciência de contexto acrescentam novas possibilidades de interação aos usuários, aplicaçoes e inf ra-estrutura. 
Em linhas gerais, entende-se por contexto como sendo qualquer informação que possa ser usada para caracterizar a situação de uma entidade. Uma entidade, por sua vez, pode ser uma pessoa, um lugar ou objeto relevante para a interaçào entre um usuário e uma aplicação, incluindo-se também o usuário e a aplicaçao em si. Assim, um sistema é consciente de contexto se utiliza o contexto para oferecer informaçòes relevantes e/ ou serviços ao usuário, sendo que a relevancia depende das tarefas que o usuário realiza (Abowd, 1999).

A criaçầo de ambientes que utilizem as informaçoes de contexto para fornecer informaçōes relevantes e/ou açós especíticas para cada usuário, conforme o grau de liberdade definido pelo projetista, é uma larefa que precisa ser parametrizada pela aplicação. Esta parametrizaçào é obtida com base em cinco questionamentos: a) onde o usuário está (WHLRL); b) quem é o usuário (WHO); c) como o usuário está utilizando os recursos (I IOW); d) quando se pode realizar determinada operaçào (WHEN); e) o que o usuário está fazcondo (WHAT).

No contexto da execuçăo automática de tarefas e açōes, pode-se considerar as quatro entidades de consciência definidas por Dey (Dey \& Abowd, 2000), a partir dos questionamentos citados: a) localização (WHERF); b) identidade (WHO); c) atividade (WHAT + HOW); d) tempo (WHEN).

Aspectos de consciencia de contexto podem ser importantes quando associados ao ambiente no qual uma aplicação está inserida, oferecendo a informaçoes do contexto em que o usuário se encontra, as possibilidades de adaptaçào e informações sobre recursos disponíveis em um determinado momento. Este é o ponto-chave para a definiçào do conceito de perfilde aplicaçăo interntion apresentado e discutido neste trabalho, e que se encontra detalhado no Capítulo 5.

Um ponto importante é que palavras como HOW, WHERE, WHAT, WHO e WHEN expressam semânticas que podem ser tão complexas quanto seja necessário a uma aplicaçào. Assim, a semântica HOW, por exemplo, ao se referir a "quais recursos estão em uso", expressa implicitamente "como o usuário está utilizando esses recursos". Neste ponto, implementando um mecanismo avaliador (agente + filtros, por exemplo) que apresente e/ou monitore uma lista dos recursos em uso, pode-se ter uma indicaçào de como o usuário está se sentindo no ambiente (contribuiçâo para c'motional interfaces). De forma complementar, a proposta de junção das semânticas HOW e WHAT oferece suporte à formação da entidade 
"atizidade" que, em suma, é um elemento lormador do conceito de perfil, visto que para se ter atividade é necessário ter recursos em uso, quer seja ao nível do usuário quer seja ao nível da infra-estrutura.

Na proposta apresentada por este trabalho, a execuçào automática de tarefas c açōes é de extrema importancia. Neste sentido, agentes podem ser usados para permitir a implementaçào dos aspectos de consciência de contexto, considerando-se, por exemplo, as quatro entidades de consciência definidas por Dey (Dey \& Abowd, 2000).

A definiçào fundamental de agente, obtida da literatura, diz que am aģente d' capaz de colaborar, atrazés da troca de dados com outros agentes e programas, para a resoluciano de problemas complexos (Moreira \& Walczowski, 1997). Complementando, pode-se dizer que um agente computricional é um componente de software capaz de se comunicar e cooperar com outros agentes usando uma linguagem de comunicação (Maes, 1994).

Observa-se que dispositivos como STB (Set Top Boxes) acrescentam novas possibilidades de interaçào que vão além dos dispositivos tradicionais de interação como mouse e o teclado, e a interaçâo com o ambiente (consciência de contexto) no qual a aplicaçào está inserida passa a ser tão importante yuanto a interação direta do usuário com uma aplicação.

O desenvolvimento de perfis para aplicaçoes interativas é, então, uma forma de categorizaçâo que caracterize a situaçào de uma entidade em uma aplicaçào, bem como uma forma de se obter informaçōes sobre o comportamento dessa entidade no tempo. Assim, com o uso de perfis em conjunto com informaçöes de contexto, uma aplicaçào pode realizar açöes e reaçoes como as seguintes:

- a apresentação de informaçòes e serviços para o usuário, como por exemplo a apresentação de mídias disponiveis e que estão relacionadas com o contexto do usuário;

- a execução automática de serviços, como por exemplo o disparo de eventos relacionados com a localização corrente de uma entidade;

- a associaça do contexto com a informação para posterior recuperação, como por exemplo o armazenamento de informaçòes contextuais durante uma sessão multimídia interativa, relacionando observaçoes do(s) usuário(s) com o(s) assunto(s)chave que faz(em) parte da descriçào de uma ou mais cenas desse vídeo. 
As definiçôes de consciência de contexto olerecem condiçoes para o desenvolvimento de aplicaçóes altamente adaptativas, o que é relevante em ambientes interalivos, como é o caso da TVl, por exemplo.

O grau de conscienncia (abmeness) de um objeto em relaçà a outro quantifica a importância subjetiva ou relevância do objeto para um determinado ambiente ou mesmo para uma determinada mídia utilizada em uma aplicação. Como exemplo, no contexto das aplicaçōes interativas, o grau de consciência pode ser mapeado para o volume de um canal de áudio ou para o nível de detalhe de imagem de uma seqüencia de objetos formadores de uma cena em um vídeo.

Outro ponto importante reside no fato de que um objeto, em una interaçäo, pode afetar os níveis de consciència de outro objeto, exigindo, portanto, procedimentos de negociaçäo. $O$ objeto que observa (ou receptor) pode focar sua atençào em áreas ou objetos específicos, enquanto o objete observado (ou transmissor) pode controlar sua "visibilidade" de forma que objetos em algumas áreas sejam mais conscientes que em outras áreas. Este aspecto é relevante no acesso a conteudo de mídias em uma determinada cena, representada com tecnologias como MPEG-4 e MPEG- 7 , por exemplo.

\subsection{Consideraçōes finais}

Conforme discutido, entende-se por contexto como sendo qualquer informaçào que possa ser usada para caracterizar a situaçào de uma entidade. Parâmetros do comportamento humano podem caracterizar a consciência de contexto (context-awareness), especialmente quanto à definição das visões de contexto (superficial ou abrangente) que se descja extrair de um ambiente. Ao nível do usuário, muitas sào as formas de interaçào com as cenas em uma apresentação multimídia, inclusive explorando recursos sensoriais e informaçōes contextuais.

Neste capitulo, foram apresentados os principais argumentos para definiçào de consciência de contex to e discutidas alỵumas visòn de contexto e consciencia reportadas na literatura. Como contribuição, apresentou-se um modelo para formalização de contexto e uma proposta para construção e formalizaçào de regras contextuais. Aspectos dos ambientes interativos, c de seus objetos de mídia, foram considerados para a definiçăo dos novos esquemas e 
critérios de interaçào do usuário, considerando que essa interaçào acontece entre o usuário e o ambiente, e não somente ao nível da interação usuário-computador.

No próximo capítulo, discute-se a modelagem completa proposta por este trabalho para o caso dos ambientes interativos conscientes de contexto. 


\section{Ambientes Interativos Conscientes de Contexto}

\subsection{Considerações iniciais}

Conforme discutido, tecnologias, técnicas e padrōes têm sido produzidos para viabilizar o desenvolvimento de novas e complexas aplicaçoes multimidia, especialmente aquelas inseridas no contexto da convergência de mídias e sistemas.

Nos capítulos anteriores, procurou-se justificar o uso de informaçós contextuais como uma importante fonte para oferecer suporte ao desenvolvimento de aplicaçoes personalizadas às caracteristicas e preferencias do usuário, além de permitir diversos níveis de adaptabilidade para a infra-estrutura do a mbiente no qual as aplicaçôes estão inseridas.

Neste sentido, a modelagem de ambientes interativos conscientes de contexto apresenta-se como uma propostá capaz de servir como referencia para o desenvolvimento de novas aplicaçoes multimidia interativas e auxiliar a loda a cadeia produtiva - emjssoras de brontasting, Intemet Service Providers, produtores de conteudo, designers e usuário finais - na compreensào desse novo universo de aplicaçoes. Os padroes MPEG-4 e MPEG-7 foram investigados e escolhidos como referencia tecnológica, apesar de que a modelagem aqui reportada possui características de opemness e pode ser utilizada para a construção de ambientes com outras bases tecnológicas.

Neste capitulo, são apresentados detalhes da arquitetura MPEG-4, especialmente do MPEG-4 Systems e da API MPEG-J, e disculidos os modelos NECTAR e PRACTIC, que compóem, juntamente com o modelo SPICE, a modelagem proposta. Detalhes complementares do modelo SPICE são também discutidos, uma vez yue a formalização desse modelo foi apresentada no Capítulo 4. Aspectos integradores da arquitetura, representados pelos agentes de software, são também discutidos, especialmente em tormos da implementação desses agentes com a plataforma JADE e com a API MPEG-J. 


\subsection{Princípios da modelagem}

Para o desenvolvimento da modelagem de ambientes interativos conscientes de contexto, esta proposta considera o contexto dividido em duas categorias: a) o contexto do ambiente; b) o contexto do usuario. A linguagem LMI. fornece recursos adequados para modelagem do classes dos objetos, permitindo a especificação formal dessas classes e de seus relacionamentos em termos das açoes que ocorrem em um ambiente (Booch et al., 1996). Em linhas gerais, aspectos tais como atributos, comportamento e relacionamentos (agregação, especialização e herança) podem ser representados como objetos, evidenciando as virtudes da linguagem UML. As classes de objetos podem ser mapeadas em tecnologias como XML, MPEG-4, MPEG-7, JAVA e MPLG-J, dentre outras.

O ambiente, e suas informaçóes contextuais, pode ser modelado em diagramas UMI, tais como o diagrama da classe, o diagrama da colaboração e o diagrama de seqüencia. O estabelecimento de relaçoes entre as classes de objetos do ambiente e as classes de objetos das aplicaçôes inseridas nesse ambiente, é especificado nos diagramas UML, e essa modelagrem pode ser implementada em uma linguagem de programaçào.

\subsection{Representação de mídias}

$\Lambda$ modelagem UMI permite descrever os eventos e os relacionamentos no ambiente em que uma aplicação está inserida. Por outro lado, a tecnologia MPEG-7 é usada para descrever objetos de mídia do ambiente.

O padrão MPEG-7, em desenvolvimento no grupo MPEG descle outubro de 1996, oferece recursos para a descrição dos dados associados a objetos de mídia em una cena multimídia (ISO, 1998b; Nack \& lindsay, 1999). Conforme apresentado, o padrão MPEG-7 utiliza descritores, esquemas de descrição e uma linguagem de definição de descrição (DDL), permitindo a descrição de todos os tipos de objetos multimídia (ISO, 2001c). Neste sentido, o MPEG-7 tem características importantes para permitir a associação de informaçōes contextuais aos objetos de mídia que compoom uma aplicaçào em um determinado ambiente.

As categorias de informaçăo contextual identificadas por Dey (Dey \& Abowd, 1999) podem ser mapeadas para os recuros do padrăo MPEG-7 da seguinte forma: 
- Localização: pode ser mapeada através de descritores e tipos primilivos de dados MPEG-7, tais como string, flont, $\|$ ll, dentre outros; adicionalmente, esta informação contextual pode ser associada diretamente ao ID (identificador) de um objeto de mídia, descrito em MPEG-4, por exemplo;

- Identidade: o padräo MPEG-7 oferece suporte à definiçào de tipos como ENTITY e NAME através da associação de identificadores formatados como números inteiros; atém disso, as entidades podem ser utilizadas em diferentes esquemas de descrição;

- Atividade: os tipos de dados MPEG-7 podem ser utilizados para descrever informaçóes sobre os estados de um objeto em uma cena multimidia, utilizando-se, por exemplo, strings de caracteres;

- Tempo: o padrào MPEG-7 oferece dois tipos primitivos de dados para manipulaçáo de informaçós de tempo: date e time; estes tipos primitivos sào úteis na associaçào de dados cronológicos as informaçoes contextuais do ambiente; esquemas de descriçáo estendidos podem ser definidos pela combinaşào dos tipos primitivos de dados, o que acrescenta possibilidades semánticas em uma cena multimídia.

Vale a pena observar que os esquemas de descriçào MPEG-7 podem ser utilizados para definir hierarquia entre informaçòes contextuais, tanto em um mesmo ambiente quanto entre ambientes distintos.

\subsection{MPEG-4: uma tecnologia para vídeo interativo}

Conforme apresentado, o padräo MPEG-4 (ISO, 1999a; Battista et al., 1999) foi desenvolvido pelo grupo MPFG com o objetivo principal de fornecer suporte à codificação, transmissäo, apresentaçào e gerenciamento de objetos multimídia (áudio, vídeo, imaģens, animaçōes 2D e 3D, textos), bem como o controle da sincronizaçâo eda recuperaçào desses objetos em um stream de midia que estiver sendo transmitido.

Outras características como o gerenciamento da interatividade e a descrição das cenas, em termos do comportamento temporal e espacial, também sào suportadas pelo padrão.

Em um strenm de mídia representado em MPEG-4 é pessivel a busca alcatória por seqüencias áudio ou video, bem como localizar e interagir com quaisquer objetos da cena. A infraestrutura mínima para uso da tecnologia MPEG-4 em um ambiente interativo pode ser vista na Figura 5.01. 


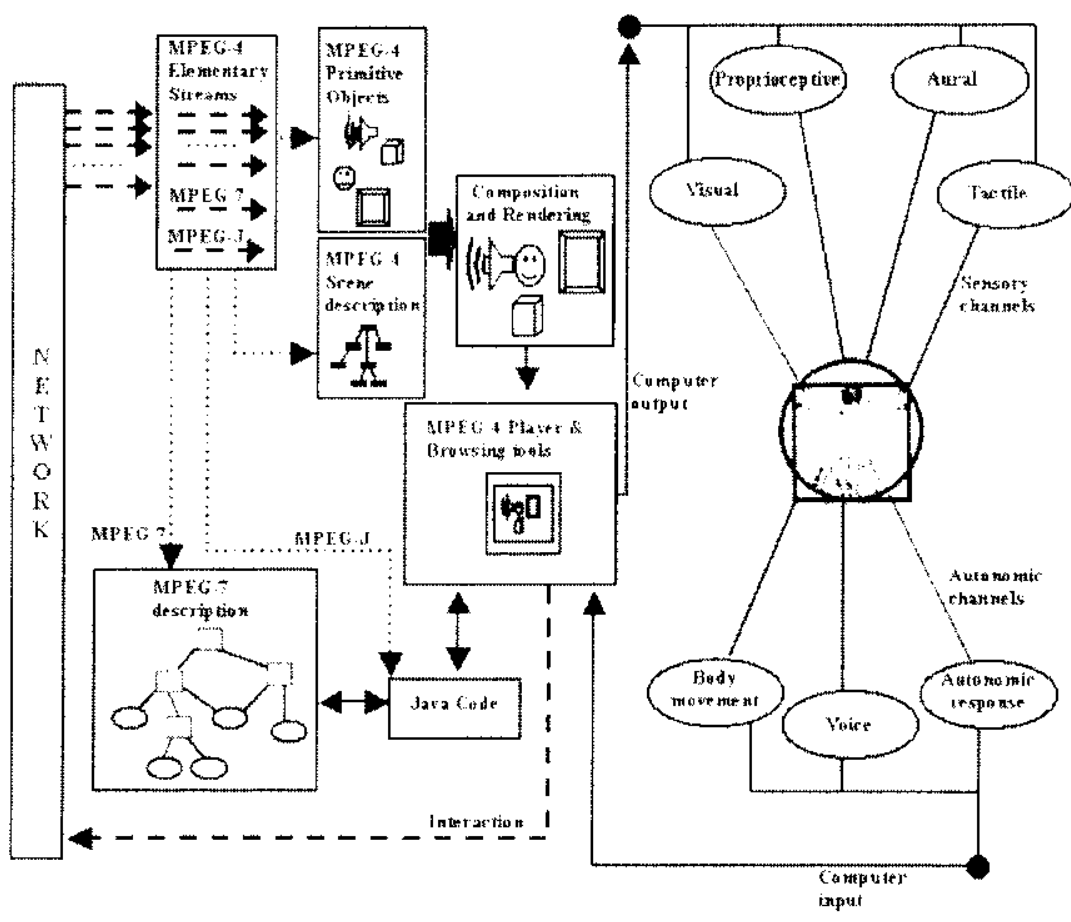

Figura 5.01 - Arquitetura mínima para uso do MPEG-4 em ambientes interativos

No cenário apresentado pela Figura 5.01, uma apresentaçào multimidia consiste de um conjunto de objetos de mídia e seus relacionamentos. A apresentaçào MPEG-4 é codificada e distribuída (cada objeto MPEG-4 é um strém de mídia elementar) através da rede (ou em um sistema local). Uma descrição MPEG-7 dos objetos de mídia e do contexto da aplicação/usuário/ambiente pode ser codificada também como um stréan elementar em um fluxo MPEG -4 .

Conforme citado, um recurso interessante do padrão MPEG-4 é a API MPEG-J (ISO, 1999d), que consiste de um conjunto de classes de objetos que permite a programação da interação entre os usuários e a aplicaçăo multimídia. Como a API MPEG-J é inteiramente baseada em JAVA, é possível usufruir de todos os recursos da programação JAVA na construção de uma aplicação, que é denominada MPEGlet. A Seçäo 5.6 apresenta os detalhes da $\triangle P$ P MPEG-J e que são importantes para esta proposta.

Observa-se que o desenvolvimento de interlaces MPEG-J acrescenta novas possibilidades de controle das informaçoes contextuais e representa um caminho natural para a integraçào de agentes de software nesta proposta. 


\subsection{MPEG-4 Systems: relacionando classes de objetos}

Como apresentado no Capítulo 2, o MPEG-4 systems define um conjunto de algoritmos avançcados para codificaçào/decodificaçào da informaçăo audiovisual.

Os streams de' midin (Elementary Strenm - LS) codificados podem ser transmitictos ou armazenados como objetos, e os sistemas MPFG-4 apresentam descriçōes e interfaces para estabelecimento de relacionamentos entre esses objetos de midia na composição de cenas audiovisuais.

Um BIFS (Binary Information for Scenes) descreve os arranjos espaciais e temporais entre os objetos de mídia de uma cena. Os usuários, através de um player MPEG-4 podem interagir com cada um dos objetos de: mídia de uma cena e gerar açóes que alterem propriedades e o comportamento desses objetos. Em um nível mais baixo, os descriptors do objeto (ODs) definem o relacionamento entre os strums elementares de mídia associados a cada objeto (por exemplo, o strenm de áudio e o strram de video para um usuário em uma aplicação de videoconferência). Um OD fornece também informações adicionais para a decodificação de um strenm de mídia, tais como a URL, dados de propriedade intelectual e esquemas de descrição da mídia, que podem ser especificados em MPLG-7.

Num contexto mais amplo, o MPEG-4 Systems contém as seguintes especificaçoes:

- um formato padrào de arquivo para suportar o armazenamento e o intercâmbio de informaçào audiovisual;

- um modelo para programação de níveis de interatividade;

- um modelo geral de eventos para as cenas;

- uma API programável - MPEG-j - para desenvolvimento de controles do terminal, da aplicação e da infra-estrutura de comunicação;

Nas relaçōes entre os terminais e a rede de comunicaçào, o MPEG-4 Systems define primitivas de mapeamento entre protocolos, tais como RTP, UDP e II', além de esquemas para encapsulamento em nível de transporte, como é o caso de strenms MPEG-4 em fluxos MPEG-2.

Lim termos de implementação de aplicaçôes, O MPEG-4 Systems oferece três APIs para o controle de todos os elementos envolvidos na apresentaçào de uma cena audiovisual: Scene 
(controle de cenas), Resource (controle de recursos do ambiente) e Net (controle da rede de comunicaçâo). Diversas interfaces e classes encontram-se especificadas nessas APIs e a programação pode ser desenvolvida inteiramente com MPEG-J, conforme apresentado na Seçào 5.6.

\subsubsection{API Scene}

A API Scene fornece mecanismos para que aplicaçōes MPEG-J possam acessar e manipular os elementos de uma cena audiovisual que estiver sendo r'nderiznda em um player. Os BIFS fornecem os dados dos objetos de mídia e a interface BIFS-Scene é definida.

As classes e interfaces para controle de cenas encontram-se definidas na biblioteca org.iso.mpeg.mpegj.scene e pode-se selecionar as classes mais apropriadas para uma determinada arquitetura aplicação-rede-terminal.

O controle de eventos nos BIFS de um grafo de cenas pode ser feito através das interfaces de classes EventIn e EventOut. Adicionalmente, pode-se acrescentar monitores de eventos utilizando a classe EventOutI istener.

A classe EventIn contém os métodos para associação de eventos a cada nó em um grafo de cenas MIPE-4. Lsssa associação é feita com base nas relações temporais e espaciais entre os objetos de mídia da cena. Do mesmo modo, a classe EventOut contém métodos para desabilitar eventos associados a um nó do grafo de cenas. Adicionalmente, a Al'l oferece possibilidades de inserçăo de monitores de eventos através da classe IventOutListener, que verificam as transiçoes entre os objetos da cena.

A interface SceneManager contém métodos para adicionar e remover um monitor para toda a cena (SceneI istener). Este conceito é diferente do conceito de evento, uma ver que um ScencListener é capaz de gerar informações de controle de todo o comportamento da cena e nāo somente de um nó do grafo. A interface SceneListener, por sua vez, monitora diretamente o BIFS de uma cena e notifica (notify()) uma aplicaçào (por exemplo, MPEG-J) nos momentos em que houver yualquer tipo de alteraçào no BIFS.

A interface Scene funciona como um agente que se relaciona com o BIFS de uma cena. Um método getNode() retorna um descritor para um nó descjado em uma cena. Desta forma, uma segunda interface - Node - ag̣e para controlar diretamente as propriedades de um nó 
no grafo de uma cena (getEventOut(), EventOutListener, sendEventIn, getNodélype(), NodeType).

\subsubsection{API Resource}

A Al’ Resource fornece mecanismos para que aplicaçós MPEG-J possam acessar e manipular informaçóes de todos os recursos associados a um terminal (MpegjTerminal) que? interage com uma aplicação multimídia MPEG-4.

As classes e interfaces para controle de cenas encontram-se definidas na biblioteca org.iso.mpeg.mpegj.resource e pode-se selecionar as classes mais apropriadas para uma determinada arquitetura aplicaçáo-rede-terminal.

O gerenciamento eficiente de recursos auxilia o controle de uma sessão MPEG-4 e permite a personalizaçào de componentes do ambiente associados a esses recursos.

O principal componente da APl Resource é o pacote ResourceManager, que é baseado no modelo de eventos MPEG-4 e é responsável pelo monitoramento dinâmico e estático de todos os profiles associados aos recursos de um terminal, inclusive aqueles que têm interaçōes com a rede de comunicaçào (neste caso, existem interfaces entre a API Resource c a API Net). Uma coleção de classes pode ser utilizada no desenvolvimento de mecanismos de controle dos recursos. Dentre essas classes, pode-se citar a classe Renderer, a classe MPDecoderMediaEvents a a classe MPRendererMediaEvents.

Para cada decodificador, o ResourceManager gerencia os eventos associados e relaciona esses eventos com o restante dos componentes da cena. Desta forma, o gerenciamento do recurso considera o contexto da cena como um todo, e nào somente as propriedades dacuele recurso. Uma vez que é conhecido um nó em um grafo de nós de uma cena, as interfaces acessam os decodificadores associados a esse nó (usando o OD ou ESID), determinando, por exemplo, as prioridades entre os decodificadores.

Para manipular as potencialidades de cada recurso, a API Resource possui um outro conjunto de classes - CapabilityManager - que fornece métodos que trabalham com abstraçoes de recursos em relaçào à arquitetura de hardware e software em uso. Diferentes plataformas e cenários podem fazer parte de um ambiente interativo, e os recursos 
associados a um terminal devem garantir parâmetros de QoS pré-estabelecidos. Como exemplo, pode-se citar algumas premissas:

- uma aplicacăo multimedia em uma infra-estrutura wireless pode usufruir de diferentes capacidades de comunicaçà e conexóes;

- um computador pode estar envolvido no processamento de aplicações que não fazem parte do ambiente interativo;

- sessões audiovisuais utilizam múltiplas fonts de mídia.

Em termos do terminal em si, a API Resource possui um conjunto de classes TerminalProfileManager - que permite a uma aplicaçào selecionar o melhor profile, com hase nas especificações MPEG-4 Syste'ms para uma determinada situação em que o terminal estiver envolvido. As classes oferecem avançados mecanismos de busca para seleçào automática de um profile; neste ponto, aspectos de consciência de contexto, conforme discutido no Capítulo 4, podem ser associados aos recursos dos terminais.

\subsubsection{API Net}

$\triangle A P I$ Net oferece recursos para permitir o controle de todos os componentes da rede que se relacionam com um playjer MPEG-4. Isto é possivel pelo fato de que as especificaçöes DMIF contém abstrações de componentes de rede em todos os níveis de uma arquitetura. Desta forma, as aplicaçôes podem ser conscientes dos detalhes de conexões de rede que estão sendo usadas (LAN, WAN, MAN) e ter acesso às propriedades dos serviços que estão sendo oferecidos. As funcionalidades da $\Lambda$ PI Net podem ser divididas em dois grandes grupos:

- Network anery: oferece recursos que habilitam a execucão de podidos de informaçôes estatísticas sobre os components da rede; essas informações são negociadas com as interfaces DMIF e deven ser pedidos que estejam em conformidade com o MPEG-4 Systems;

- Channels control: oferece mecanismos para o controle de cacla canal de transmissảo de dados audiovisuais que estiver em uso pelo player MPEG-4; desta forma, uma aplicação MPEG-J pode habilitar/desabilitar a transmissāo de um stream de mídia (elementary strenm), adicionando requisitos para personalização de um ambiente.

Observa-se que as APIs Scene, Resource e Net constituem o núcleo principal das especificações MPEG-4 Systems, no que tange à parte programável das aplicações. 


\subsection{A arquitetura MPEG-J}

MPEG-J é um subsistema MI’EG-4 programável yue especifica uma API (Application Progranming Interface) que oferece classes Java para permitir a interoperabilidade entre um player MPEG-4 e um código Java. Combinando us objetos de mídia MPEG-4 e o código Java, é possivel desenvolver mecanismos complexos de manipulaçào dos dados associados a esses objetos de mídia e controlar, de forma inteligente e/ou automática, a interaçâo com esses objetos em uma sessão multimídia. A Figura 5.02 ilustra o funcionamento de um código MPEG-J em uma aplicação baseada em MPEG-4 Systoms.

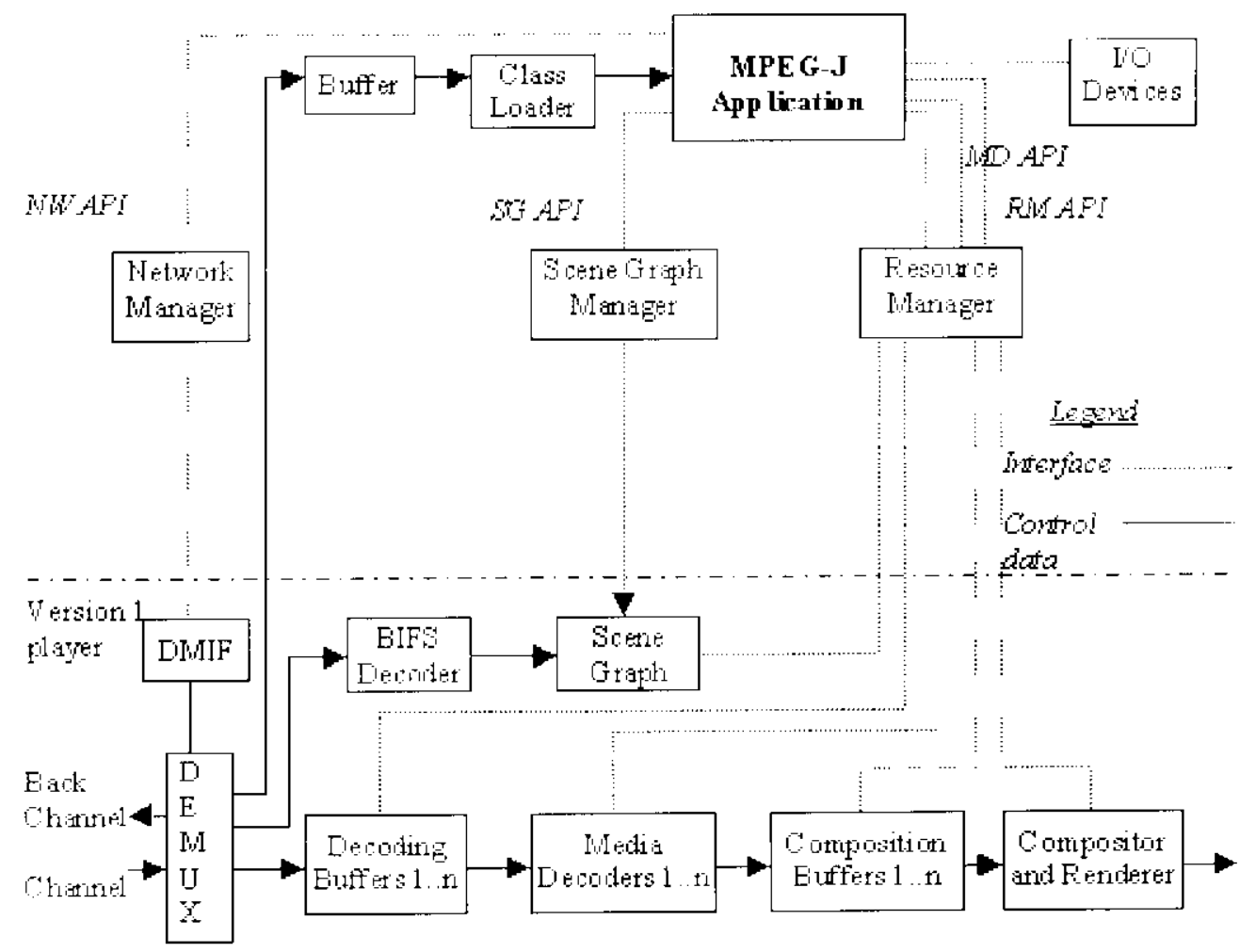

Figura 5.02 - Identificação das interfaces MPEG-J em uma arquitetura

MPEG-4 System (ISO, 1999a)

Observa-se, na parte inferior da Figura 5.02, que existe um motor de apresentaçào de objetos audiovisuais, conforme prevè a MPEG-4 Systems. O subsistema MPEG-J pode controlar o motor da apresentaçào, influenciando diretamente a forma de apresentação e interaçào com os objetos de mídia.

A aplicaşão Java, desenvolvida com a API MPEG-J, é distribuido como um elementar stream (fluxo elementar), da mesma forma que ocorre com o áudio, com o vídeo e com todos os demais objetos audiovisuais. 
Em um player MPEG-4, o código MPEG-J é decodificado como um objeto de mídia. Fm termos funcionais, o código MPFG-J tem acesso ao grafo do objetos de mídia de uma cena MPEG-4, tendo permissão para consultar dados do grafo, alterar a hierarquia dos nós do grafo, remover nós do grafo e gerenciar recursos associados aos objetos de mídia representados no grafo.

O gerenciador de recursos da API MPEG-J (ResourceManager) oferece primitivas para acesso e controle dos terminais associados ao player e também dos recursos da infra-estrutura de comunicaçào (Netrorkmanager) associada aos terminais. A API MPEG-J permite, ainda, o controle sobre os decodificadores (Decoder Mannger) de objetos de mídia. Vale ressaltar que todas as formas de interaçào com a rede de comunicação são compatíveis com as especificações DMIF do MPEG-4.

Vas Subseçöes 5.6.1 e 5.6.2, säo apresentadas as classes MPEG-J que estäo diretamente relacionadas com as classes modeladas nesta proposta, especialmente em termos do gerenciamento das interaçoes, com suporte dos agentes software, que ocorrem em um ambiente interativo consciente de contexto. Alguns exemplos de aplicação MPEG-J são também apresentados.

\subsubsection{Uma visão geral dos recursos MPEG-J relevantes para esta proposta}

Genericamente, a API MPEG-J e composta de cinco macro-pacotes especificados de acordo com a sintaxe padrão da linguagem Java, conforme pode ser visto na Tabela 5.01.

Tabela 5.01 - Pacotes da API MPFG-J

\begin{tabular}{|c|c|}
\hline Pacotes & Descriçāo \\
\hline org.iso.mpeg.mpegj & $\begin{array}{l}\text { Oferece classes para acesso ao } \\
\text { Mpegj'lerminal que fornece métodos para } \\
\text { para manipulaça de diferentes classes de } \\
\text { gerenciadores, tais como ResourceManager, } \\
\text { SceneManager e NetworkManager }\end{array}$ \\
\hline org - iso mpeg - mpegj decoder & $\begin{array}{l}\text { Oferece classes para acesso e controle dos } \\
\text { decodificadores de objetos audiovisuais }\end{array}$ \\
\hline org. iso.mpeg. mpegj.net & $\begin{array}{l}\text { Oferece classes para acesso e controle dos } \\
\text { components de rede associados a um player } \\
\text { MPEG-4 }\end{array}$ \\
\hline org.iso mpeg.mpegj resource & $\begin{array}{l}\text { Oferece classes para permitir o gerenciamento } \\
\text { das propriedades de um recurso presente em } \\
\text { uma aplicacao haseada no MPEG-4 Systems }\end{array}$ \\
\hline org. iso.mpeg mpeg j. scene & $\begin{array}{l}\text { Oferece classes para manipular o grafo de } \\
\text { uma cena MPEG-4 }\end{array}$ \\
\hline
\end{tabular}


A partir dos pacotes-padrão, a API MPEG-J também especifica interfaces e a classe pública para implementação de MPEGlets, conforme pode ser visto na Tabela 5.02.

Tabela 5.02 - Interfaces da API MPEG-J

\begin{tabular}{|c|c|}
\hline Interfaces & Descrição \\
\hline DecoderConfigDescriptor & $\begin{array}{l}\text { Uma interface para implementação de classes que } \\
\text { acessem IecoderConfigDescriptor }\end{array}$ \\
\hline objectDescriptor & $\begin{array}{l}\text { Uma interface para descritores de objetos de mídia } \\
\text { ObjectDescriptor }\end{array}$ \\
\hline MPEG let & $\begin{array}{l}\text { Interface padrão que deve ser implementada pela } \\
\text { aplicação MPEG-J }\end{array}$ \\
\hline ÉSDescriptor & $\begin{array}{l}\text { Lima interface para descritores de strams dementures } \\
\text { de mídia } \mathrm{SSD} \text { Soscriptor }\end{array}$ \\
\hline \multicolumn{2}{|l|}{ Classes } \\
\hline Mpegj'erminai & $\begin{array}{l}\text { Uma classe padrão para interação com um terminal } \\
\text { MPEG-J Mpegj Terminal }\end{array}$ \\
\hline \multicolumn{2}{|l|}{ Exceções } \\
\hline MPFGJException & $\begin{array}{l}\text { Uma classe para tratamento de exceções MPEG-J com } \\
\text { base no modelo de exceçoes da language Java. }\end{array}$ \\
\hline \multirow{2}{*}{$\begin{array}{l}\text { NetworkMaragerNot.FoundException } \\
\text { SceneManagerNotFoundException }\end{array}$} & \\
\hline & \\
\hline
\end{tabular}

A interface DecoderConfigDescriptor possui métodos que manipulam o tipo e as propricdades de um descritor de objeto de mídia, conforme pode ser visto na Tabela 5.03 .

Tabela 5.03 - Métodos da interface DecoderConfigDescriptor

\begin{tabular}{|c|c|}
\hline Métodos & Descriçāo \\
\hline int getstreamType(); & $\begin{array}{l}\text { Retorna o tipo de um elementmy strenm de acordo } \\
\text { com os tipos especilicados no MPLG-4 Systems }\end{array}$ \\
\hline int getbuffersizeDB(); & $\begin{array}{l}\text { Retorna o tamanho do buffer de decodificaçà para } \\
\text { um elementary stream }\end{array}$ \\
\hline int getmaxBitrate(); & $\begin{array}{l}\text { Retorna o máximo bitrate (bits por segundo) de un } \\
\text { elementury strenm }\end{array}$ \\
\hline int getobjectTypelndication(); & $\begin{array}{l}\text { Retorna uma indicação de um objeto de mídia ou } \\
\text { cena com vínculos com um decodificador }\end{array}$ \\
\hline
\end{tabular}

A interface ISDescriptor possui métodos que manipulam as propriedades de um descritor de elemenlary strem, conforme pode ser visto na Tabela 5.04 .

Tabela 5.04 - Métodos da interface ESDescriptor

\begin{tabular}{|l|l|}
\hline Métodos & Descrição \\
\hline int getESID(); & Retorna o ID associado a um ESDescriptor \\
\hline Boolean isStreambepenaent (); & $\begin{array}{l}\text { Retorna TRUE se há dependência cutre dois ou } \\
\text { mais elemtentary stremus. }\end{array}$ \\
\hline
\end{tabular}




\begin{tabular}{|c|c|}
\hline int getdependson_ESJD(); & $\begin{array}{l}\text { Retorna o ID (ESID) de un elenentary strean que } \\
\text { dependa de um outro elementary strenm }\end{array}$ \\
\hline int getstreampriority(); & $\begin{array}{l}\text { Retorna a prioridade relativa de um elementary } \\
\text { stream em uma cena }\end{array}$ \\
\hline $\begin{array}{l}\text { DecoderConfigDescriplor } \\
\text { getDecoderconfiguescriptor(): }\end{array}$ & $\begin{array}{l}\text { Retorna um objeto de propriedades de um } \\
\text { descritor de decodificador }\end{array}$ \\
\hline
\end{tabular}

O tratamento de exceçós na API MPEG-J segue o modelo de exceçōes da linguagem Java, e existem formas de tratar exceçóes em relação à rede, aos decodificadores, aos recursos e às cenas, observando-se as seruintes bibliotecas de classes:

- org.iso.mpeg.mpegj . net. AccesstayerException;

- org.iso.mpeg.mpegj.scene. BadNodefxception;

- org. iso.mpeg mpegj.scene. BadparameterException;

- org.iso.mpeg mpegj.resource CapabilitymanagerNotfoundexcept ion;

- org iso.mpeg. mpegj resource. Tl iegal DecoderMediaEvents Exception;

- org. iso.mpeg.mpegj.rcsource. Il legal.RendererMediaEvents Exception;

- org. iso.mpeg.mpegj . resource. Il legalstreammediaEventsexception;

- org.iso.mpeg.mpegi.scene. InvalidNode Exception;

- org.iso.mpeg.mpegj.scene. InvalidsceneException;

- org.iso.mpeg.mpegj.decoder. MediaDecoderException;

- org. iso.mpeg.mpegj.resource . RendererNotFoundException;

- org.iso.mpeg.mpegj. resource. ResourceManagerNotFoundException.

A classe MpegjTerminal possui construtores e métodos para o gerenciamento do terminal ao qual um player MPEG-4 está associado e também para gerenciamento dos recursos e da rede que suportam o terminal, conforme pode ser visto na Tabela 5.05 .

Tabela 5.05 - Métodos da classe MpegjTerminal

\begin{tabular}{|c|c|}
\hline Método & Descrição \\
\hline MpeqjTerminal(); & $\begin{array}{l}\text { Málodo que constrói um objesto } \\
\text { MpegjTerminal }\end{array}$ \\
\hline Mpeg j Terminal (MPEGlet); & $\begin{array}{l}\text { Método que constroi um objeto } \\
\text { MpegjTerminal }\end{array}$ \\
\hline Resourcemanager getResourcemanager (); & $\begin{array}{l}\text { Método que obtém um gerenciador de } \\
\text { recursos para o terminal selecionado }\end{array}$ \\
\hline SceneManager getscenemanager(); & $\begin{array}{l}\text { Método que obtém um gerenciador de cenas } \\
\text { para o terminal sclecionado }\end{array}$ \\
\hline NetworkManager getNetworkManager(): & $\begin{array}{l}\text { Método yue obtém um gerenciador de rede } \\
\text { para o terminal selecionado }\end{array}$ \\
\hline ObjectDescriptor getinitoD(); & $\begin{array}{l}\text { Retorna o descritor do primeiro objeto de } \\
\text { mídia (raíz) de uma cena }\end{array}$ \\
\hline Vector getoDs (int); & $\begin{array}{l}\text { Retorna um vetor de objetos de descritores de } \\
\text { objetos de mídia (OD) presentes em uma cena }\end{array}$ \\
\hline
\end{tabular}


A interface ObjectDescriptor possui métodos que manipulam as propriedades de um objeto de mídia que é descrito como elementrny stream, conforme pode ser visto na Tabela 5.06.

Tabela 5.06 - Métodos da interface ObjectDescriptor

\begin{tabular}{|c|c|}
\hline Método & Descrição \\
\hline int getobjectDescriptortD(); & Retorna o ID associado a um ObjectDescriptor \\
\hline Vector getesDescriptors(); & $\begin{array}{l}\text { Retorna um vetor de elenentary sfremms } \\
\text { associados com um ObjectDescriptor. }\end{array}$ \\
\hline ESDescriptor geteSDescriptor(int); & $\begin{array}{l}\text { Retorna um descritor de elementary strean } \\
\text { associado a um HSID }\end{array}$ \\
\hline String getURt (); & \begin{tabular}{|l} 
Retorna uma URI, associada a um \\
ObjectDescriptor
\end{tabular} \\
\hline
\end{tabular}

O pacote Resource possui classes e interfaces para suportar a manipulaçáo de todos os recursos presentes em terminal que esteja associado a um pliyer MPEG-4. Dentro do pacote Resource, é importante apresentar os métodos da classe Capability, que descrevem as propriedades mais importantes de um terminal, permitindo a implementaçào de diversos niveis de personalização, conforme pode ser visto na Tabela 5.07.

Tabela 5.07 - Classes e interfaces do pacote Resource

\begin{tabular}{|c|c|}
\hline Construtores & Descrição \\
\hline \multicolumn{2}{|l|}{ CapabilityManager (); } \\
\hline \multicolumn{2}{|l|}{ Métodos } \\
\hline \multicolumn{2}{|l|}{ void not ifyApplicat ionsreememory (lory, onserver); } \\
\hline \multicolumn{2}{|l|}{ void notifyTerminaifreememory (long, observer); } \\
\hline \multicolumn{2}{|l|}{ void not:fyTerminalload (long, observer); } \\
\hline \multicolumn{2}{|l|}{ void notifyTerminalNetworkload (long, observer); } \\
\hline \multicolumn{2}{|l|}{ void deleteobserver (observer); } \\
\hline \multicolumn{2}{|l|}{ int getNumCPUs (); } \\
\hline \multicolumn{2}{|l|}{ int getCPUSpeed (int); } \\
\hline \multicolumn{2}{|l|}{ String getcpu'Type (int); } \\
\hline \multirow{2}{*}{\multicolumn{2}{|c|}{ String getMouse T'ype (); }} \\
\hline int getDisplayColorDepth(); & \\
\hline \multicolumn{2}{|l|}{ String getDisplayType! i } \\
\hline \multirow{2}{*}{\multicolumn{2}{|c|}{ String get keyboardType(); }} \\
\hline & \\
\hline \multirow{2}{*}{\multicolumn{2}{|c|}{ int getNumParallel Ports (; ; }} \\
\hline int getNumserial Ports (); & \\
\hline \multicolumn{2}{|l|}{ Dimension getscreensize(); } \\
\hline \multicolumn{2}{|l|}{ short getscreenDepth(); } \\
\hline \multicolumn{2}{|l|}{ short getscreenResolution (); } \\
\hline \multicolumn{2}{|l|}{ String getosLanguage ()$;$} \\
\hline \multicolumn{2}{|l|}{ Strirg getosType (); } \\
\hline String getlerminalArchiteceure(); & \\
\hline String [] ge & \\
\hline
\end{tabular}




\begin{tabular}{|c|c|}
\hline Stringli getmididrivers (); & \\
\hline String [] getvideoDrivers (); & \\
\hline String getModemType(); & \\
\hline long getFreeTerminalMemory(); & \\
\hline long getTotalTerminalMemory(); & \\
\hline long get TotalApplicationMemory(); & \\
\hline Iong get FreeApplicationMemory (); & \\
\hline long getTerminal Load (); & \\
\hline Long getNetworkLoad (); & \\
\hline short getscenedescriptionProfile(); & \\
\hline short getvisualProfile(); & $\begin{array}{l}\text { Retorna um profile objetos } \\
\text { visuais de acordo com as } \\
\text { especificaçoes do } \\
\text { Visual Profile }\end{array}$ \\
\hline short getaudioprofile(); & $\begin{array}{l}\text { Retorna um profile de áudio de } \\
\text { acordo com as especificaços } \\
\text { do MPEG-4 Audio Profile }\end{array}$ \\
\hline short getsceneDescriptionfrofize(); & $\begin{array}{l}\text { Retorna um profile de descrição } \\
\text { de cena, por exemplo, } \\
\text { utilizando esquemas MPLG-7, } \\
\text { de acordo com as asces do MPEG-4 } \\
\text { especificaçes } \\
\text { Scene Description I'rofile }\end{array}$ \\
\hline short getodprofile(); & $\begin{array}{l}\text { Retorna um profile de descritor } \\
\text { de objeto de midia, de acordo } \\
\text { com o MPEG-4 Object } \\
\text { Descriptor definido em } \\
\text { ODProfileLevellndication }\end{array}$ \\
\hline short getGraphicsprofile(); & $\begin{array}{l}\text { Retorna um profile apresentação } \\
\text { gráfica de acordo com as } \\
\text { especificaçoes do MPEG-4 } \\
\text { Visual Profile definido em } \\
\text { graphicsProfileLevelIndication }\end{array}$ \\
\hline short getmPEGuprofile(); & $\begin{array}{l}\text { Retorna um profile do Ml'EG-J } \\
\text { de acordo com as } \\
\text { especificaçoes da API MPEG-J } \\
\text { no MPEG-4 Systems e definido } \\
\text { em JProfilet evellndication }\end{array}$ \\
\hline
\end{tabular}

O pacote Network (net) possui classes e interfaces para suportar a manipulação de todos us recursos de redes de comunicaçào vinculados a um pluyer. MPEG-4, conforme pode ser visto na Tabela 5.08. As questōes de QoS são especialmente tratadas neste pacole, principalmente em termos do controle dos canais de transmissäo de elementary strenms. 
Tabela 5.08 - Interfaces e classes do pacote Network

\begin{tabular}{|c|c|}
\hline Interfaces & Descrição \\
\hline \multicolumn{2}{|l|}{ NetworkManager } \\
\hline ChannelDescriptor & $\begin{array}{l}\text { Interface que permite recuperar todas as informaçōes sobre } \\
\text { um determinado canal especificado em uma sessão } \\
\text { audiovisual }\end{array}$ \\
\hline \multicolumn{2}{|l|}{ DMIFMonitor } \\
\hline \multicolumn{2}{|l|}{ ChannelController } \\
\hline Servicesessiondescriptor & $\begin{array}{l}\text { Interface que permite recuperar todas as informações sobre } \\
\text { una sessào audiovisual }\end{array}$ \\
\hline \multicolumn{2}{|l|}{ QosDescriptor } \\
\hline \multicolumn{2}{|l|}{ Classes } \\
\hline \multicolumn{2}{|l|}{ Qualifier } \\
\hline \multicolumn{2}{|l|}{ ChannelsDescriptor } \\
\hline \multicolumn{2}{|l|}{ QosData } \\
\hline QualifierTag & $\begin{array}{l}\text { Classe que contém as constants que definem as métricas de } \\
\text { QuS em uma sessáo audiovisual, de acordo com as } \\
\text { especificaçoes DMIF MPEG-4 }\end{array}$ \\
\hline
\end{tabular}

O pacote Decoder possui classes para a manipulação de decodificadores de mídia reconhecidos por um player MPEG-4, conforme pode ser visto na Tabela 5.09. Cada tipo de objeto de mídia (ictentificados por um Objectl)escriptor) pode estar associado a um conjunto (vetor de decodificadores) de decodificadores válides, o que permite a personalizaçào a partir de ajustes nos parâmetros de QoS.

Tabela 5.09 - Interfaces e classes do pacote Decoder

\begin{tabular}{|c|c|}
\hline Interfaces & Descrição \\
\hline MPDecoder & $\begin{array}{l}\text { Interface que é a base para instanciação de um } \\
\text { lecoder a um ou mais objetos de mídia. }\end{array}$ \\
\hline DccoderType & $\begin{array}{l}\text { Interface para acesso aos tipos de decoler válidos } \\
\text { para um determinado objeto de mídia em relaçào } \\
\text { ao contexto de uma cena }\end{array}$ \\
\hline \multicolumn{2}{|l|}{ Exceções } \\
\hline $\begin{array}{l}\text { MediaDecoder:Exception } \\
\text { InvalidDecoderLevelException } \\
\text { DecoderNotFoundException } \\
\text { TnvalidDecoderPriority } \text { nxception } \\
\text { Inval idDecoderSpeedException } \\
\text { TnvalidDecoderModeException } \\
\text { DecoderNotRunn ngException } \\
\text { DecoderAlreadyAttachedException } \\
\text { DecoderNotAttachedException } \\
\text { DecoderAlreadyRunningException } \\
\text { InvalidDecoderTypeException }\end{array}$ & \\
\hline
\end{tabular}

O pacote Scene possui interfaces para descrever todas as interaçoes possíveis em uma cena MPEG-4. Essas interaçòes são suportadas pelo controle de eventos (event_in c erent_out), 
inserção e controle de sensores de cena, e monitoramento dos objetos de midia da cena, conforme pode ser visto na 'I'abela 5.10 .

Tabela 5.10 - Interfaces do pacote Scene

\begin{tabular}{|c|c|}
\hline Interfaces & Descrição \\
\hline Scene & $\begin{array}{l}\text { Interface que atua como um proxy para um l3I fs de } \\
\text { uma cena }\end{array}$ \\
\hline Node & $\begin{array}{l}\text { Interlace que atua como um proxy para um nó de um } \\
\text { BIts no grafo de nós da cena }\end{array}$ \\
\hline Scenelistener & $\begin{array}{l}\text { Interlace que primite o monitoramento das mudanças } \\
\text { no BIIS de uma cena }\end{array}$ \\
\hline NodeType & $\begin{array}{l}\text { Interface que define constantes para os tipos de nós } \\
\text { permitidos peto MPLG-4 systems }\end{array}$ \\
\hline Nodevalue & $\begin{array}{l}\text { Interface que definic um valor para um nó de um } \\
\text { liss de uma cena ou especifica um novo valor } \\
\text { yuando da criaça de um novo no }\end{array}$ \\
\hline Fiejdvalue & $\begin{array}{l}\text { Controlador que verifica se um objelo de midia pode } \\
\text { retomar valores de suas propricdades }\end{array}$ \\
\hline Eicld & $\begin{array}{l}\text { Interface que controla o acesso a campos de dados } \\
\text { associados às propriedades de um nó }\end{array}$ \\
\hline Field.Anchor & Define constantes para o defII) Anchor em um nó \\
\hline Field.Proximitysensor $2 \mathrm{D}$ & $\begin{array}{l}\text { Define constantes para o defiD ProximitySensor2D } \\
\text { em um nó }\end{array}$ \\
\hline Field.Proximitysensor & $\begin{array}{l}\text { Define constantes para o defID ProximitySensor em } \\
\text { um nó }\end{array}$ \\
\hline Fiela.Timesensor & $\begin{array}{l}\text { Define constantes para o deflI) TimeSensor (m um } \\
\text { nó }\end{array}$ \\
\hline Field. Touchsensor & $\begin{array}{l}\text { Define constantes para o defID TouchSensor em um } \\
\text { nó }\end{array}$ \\
\hline Eventout & $\begin{array}{l}\text { Interface que controla a desativação de um } \\
\text { controlador de evento em uma cena }\end{array}$ \\
\hline Eventout. Anchor & \\
\hline Eventout. Timesensor & \\
\hline Eventout. Touchsensor & \\
\hline EventoutListener & $\begin{array}{l}\text { Interface yue implementa a notificação de desativaçao } \\
\text { de eventos }\end{array}$ \\
\hline EventIn & $\begin{array}{l}\text { Interface que controla a ativação de um controlador } \\
\text { de evento em uma cena }\end{array}$ \\
\hline Event In. Anchor & \\
\hline Event in. Proximitysensor $2 \mathrm{D}$ & \\
\hline EventIn. Proximitysensor & \\
\hline Eventin. Timesensor & \\
\hline EventIn. Touchsensor & \\
\hline EventIn.visibilitySensor & \\
\hline EventIn. WorldInfo & \\
\hline Exceçōes & \\
\hline $\begin{array}{l}\text { Tual idscene } \mathrm{Except} \text { ion } \\
\text { BadNodeException } \\
\text { BadparameterExcept ion } \\
\text { TrvalidnodeException. }\end{array}$ & \\
\hline
\end{tabular}




\subsubsection{Exemplos de aplicação do código MPEG-J}

Um primeiro exemplo de aplicaçấo do código Ml’EG-J permite visualiðar as potencialidades para controle do grafo de uma cena composta por objetos de mídia MPLG-4. Pelo exemplo, ilustrado na Figura 5.03, observa-se que o MPFGlet pode acessar, modificar e criar nós no grafo de descriçào da cena.

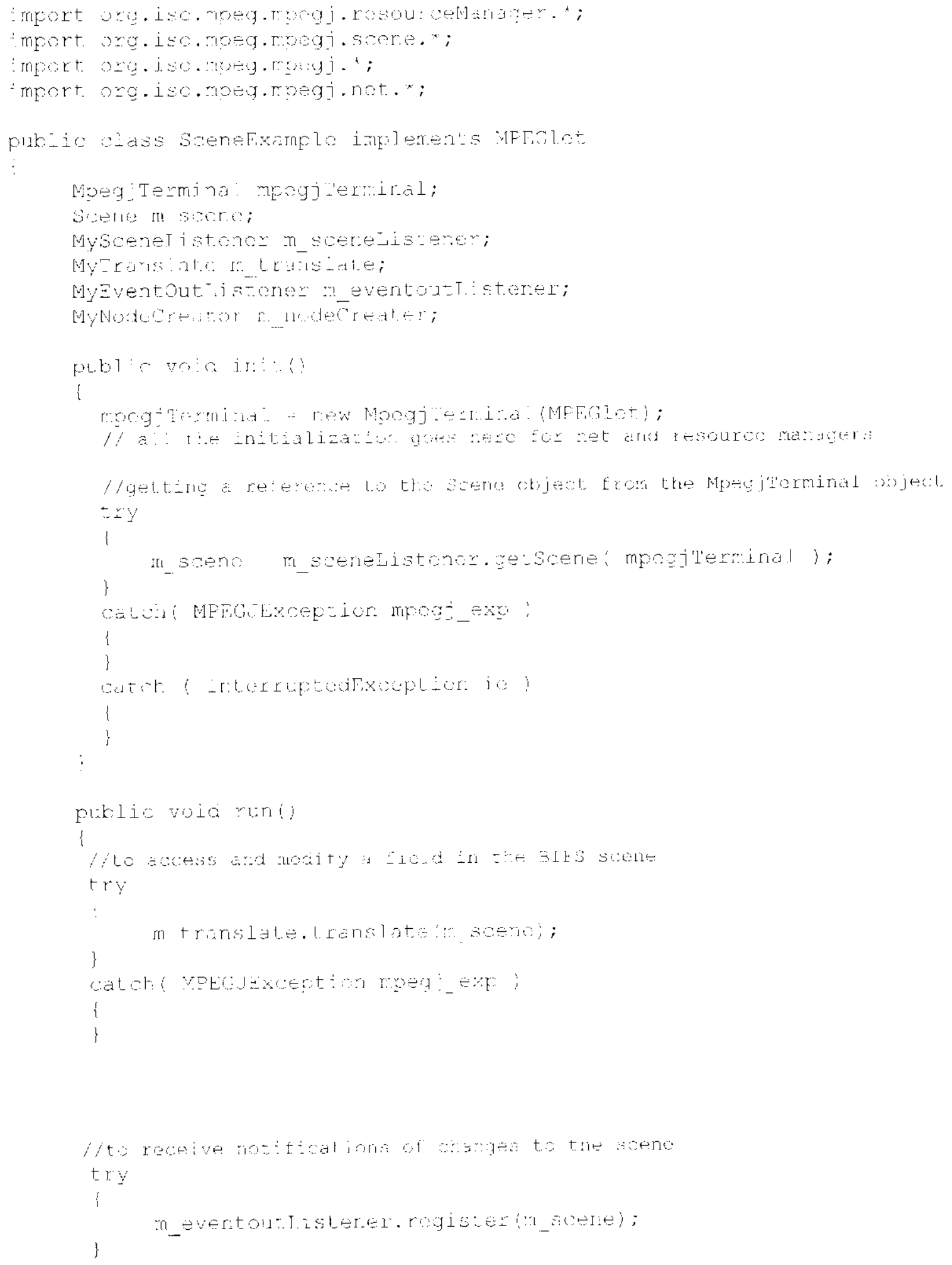




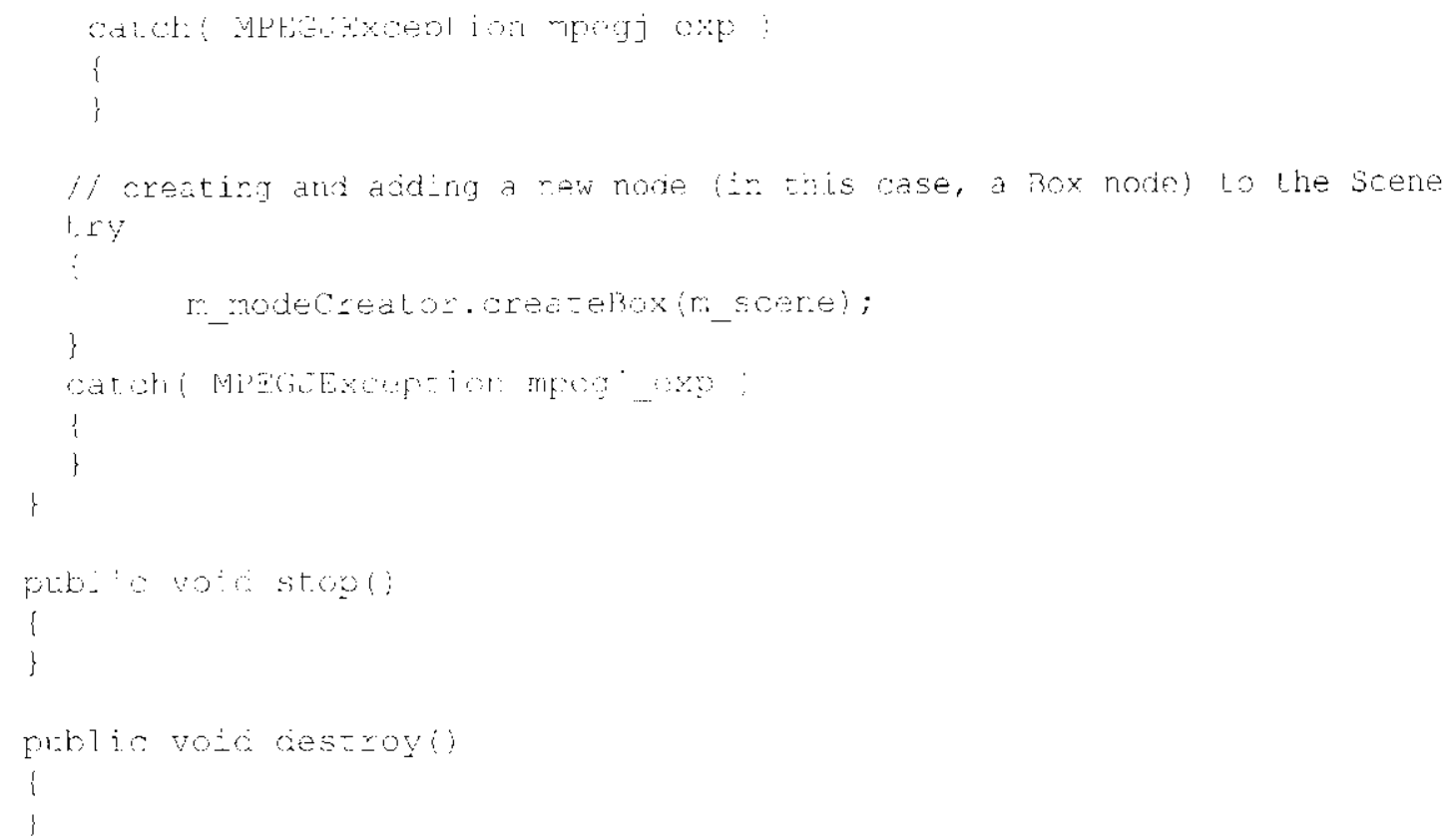

Um segundo exemplo de aplicação do código MPEG-J permite compreender a implementacão de sensores de eventos (listeruers). Esses sensores podem ser acoplados aos Touch Sensors descritos no MPFG-4 Systems. Pelo exemplo, ilustrado na Iigura 5.04, observaSe que o MPEGlet apresenta um mecanismo para se obter uma referencia a um objeto de mídia em uma cena MPEG-4, considerando-se também as propriedades do objeto MpegjTerminal. Neste ponto, é relevante observar que essa abordagem permite estabelecer eventos de acordo com as potencialidades do terminal em uso.

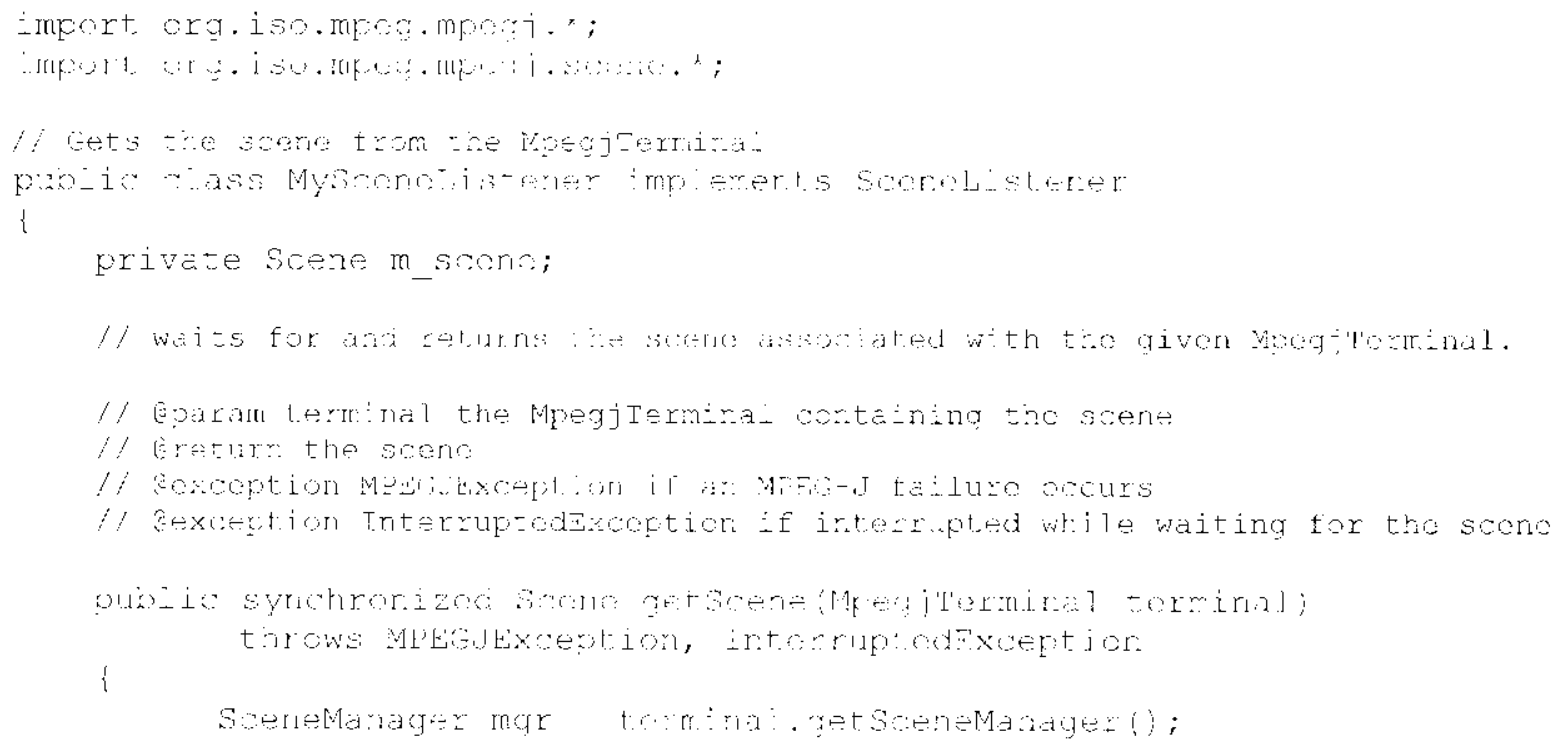




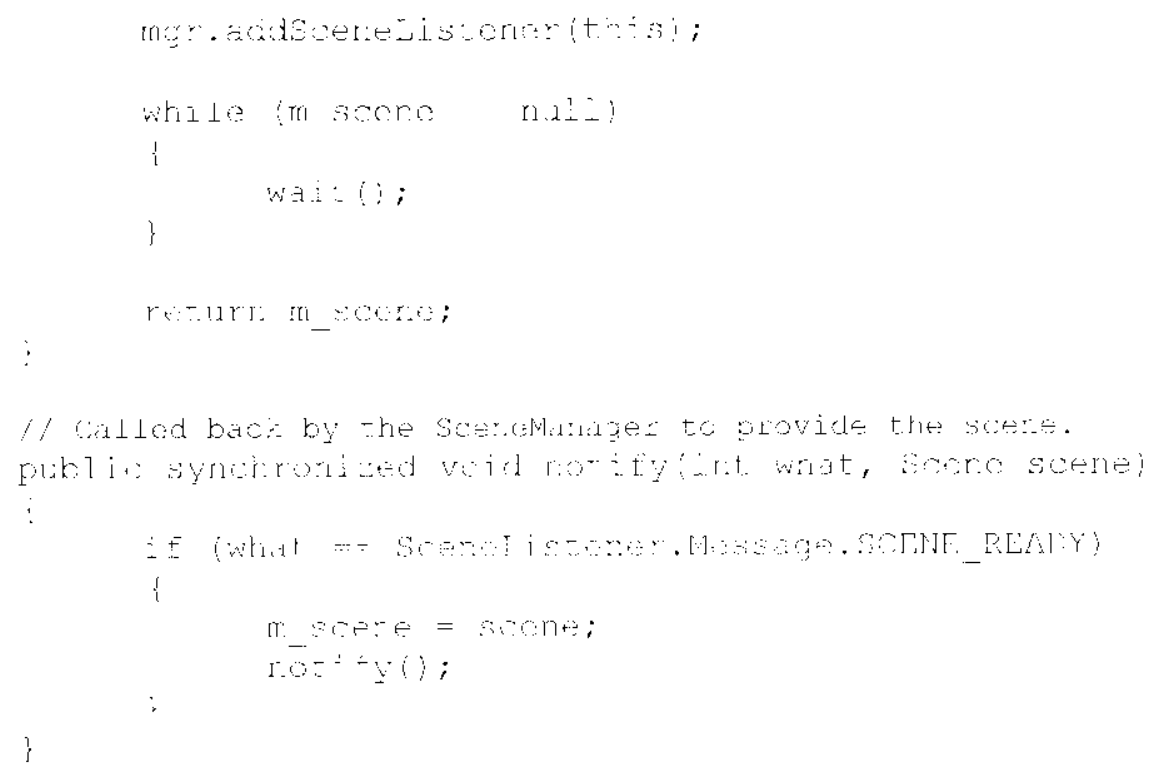

Figura 5.04 - Exemplo MPLGlet para adicionar eventos a uma cena MPEG-4 (ISO, 1999a)

Lim terceiro exemplo de aplicação do código MPEG-J mostra como acessar e manipular um campo de dado descrito no BlFS de uma cena $\mathrm{MPEG}$-4. Neste caso, a proposta é modificar o parâmetro de translaçào de um nó Transform2I no ỵafo da cena. A modificaçào do valor é feita através do envio de uma mensagem ao controlador eventIn, que aciona o método scene.getNode() com um argumento 1, yue corresponde ao campo DEF 1D do nó Transform2D em uma cena MI'EG-4. A Figura 5.05 apresenta o MPEGlet para manipulação de BIFS.

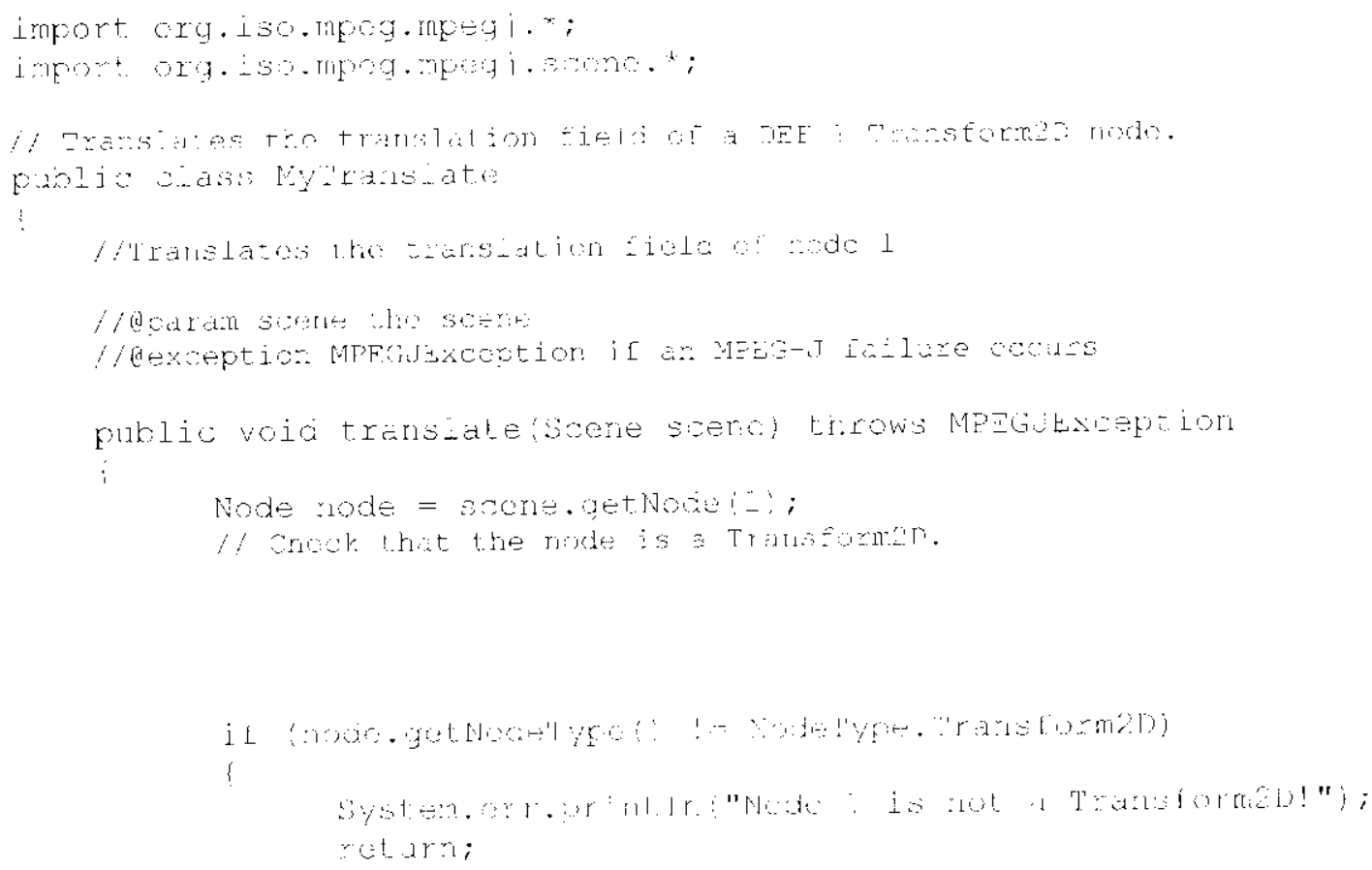




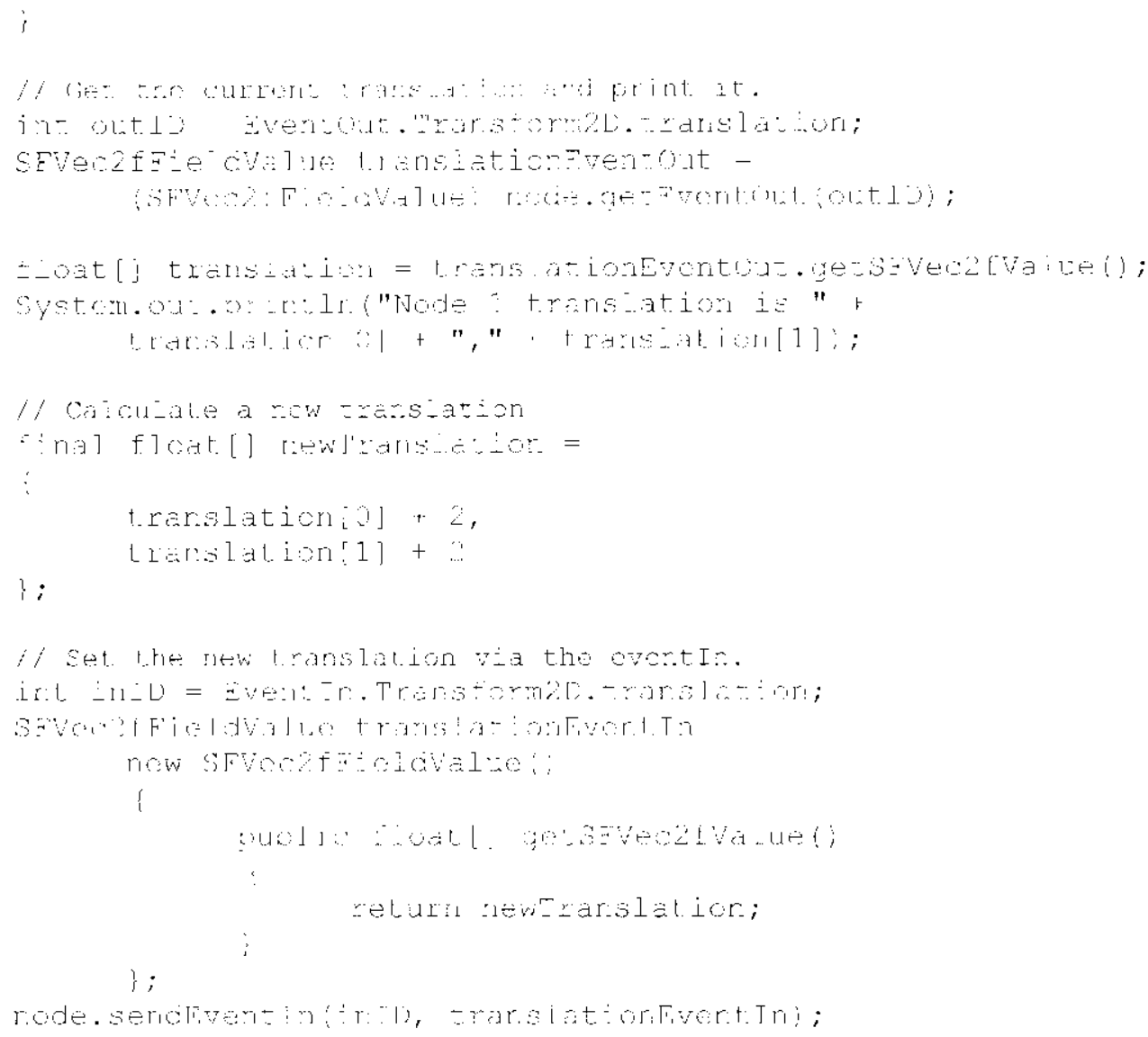

Figura 5.05 - Exemplo MPEGlet para manipular os dados de um BIFS de uma cena MPFC.4 (ISO), 1999a)

Apresentados e discutidos os principais recursos do MPEG-4 Systems e da API MPEG-J, as próximas seçòes apresentam os dois modelos - NECTAR e PRACTIC - que compóem a modelagem de ambientes interativos conscientes de contexto, juntamente com o modelo SPICE apresentado no Capítulo 4. Adicionalmente, o uso de agentes de software é discutido, usufruindo-se, conforme citado, dos recursos da plataforma JADE (Bellefemine et al., 2001).

\subsection{NHCTAR: o modelo da infra-estrutura de comunicaçäo}

O modelo NECTAR (Network Emrironment with Conlext-Awneness Rules) propõe a modelagem da infra-estrutura de comunicação e oferece suporte às três formas distintas para uso de consciência de contexto em aplicaçoes interativas: a) para controle dos objetos de mídia de uma cena; b) para adaptação dinâmica da aplicaçào às condições da rede de comunicação; c) para adaptação dinâmica da aplicação ao contexto do usuário. 
Em linhas gerais, a infra-estrutura de comunicaçăo proposta pelo modelo pelo NECTAR visa melhorar o suporte à interatividade entre o usuário e a aplicaçào como um todo, considerando o fato de que a aplicaçào interativa é parte integrante de um ambiente consciente de contexto. Essa infra-estrutura é composta por três componentes distintos: o seridor, a rede de commancacion e o termimal.

O sernidor cobre as operaçoes de armazenamento envio de informaçoes multimídia. Além disso, o servidor também realiza operaçōes que permitem enviar objetos multimídia diferentes a usuários com preferências e interesses diferentes. Em termos conceituais, o seridor deve armazenar os objetos multimídia que compoem a um programa interativo e a estrutura desse programa, no que diz respeito aos objetos das cenas, as informaçoes temporais e espaciais, e os relacionamentos entre os objetos. Nesta proposta, um programa interativo é definido como sendo o conjunto completo dos componentes de midia esuas relaçoes como o ambiente e com o usuário, sendo que o programa interativo $\dot{2}$, então, parte integrante de uma aplicação multimídia interativa. Essa aplicaçào, por sua vez, é parte integrante do ambiente.

No contexto deste trabalho, o conteúdo multimídia é baseado em objetos MPEG-4 (Pascoe et al., 1999). Por outro lado, a estrutura dos programas interativos é representada por descriçoes MPEG-7 (Wu et al., 1997; DeRose \& Durand, 1994), gerando instancias da modelagem. Neste sentido, as descriçoes MPEG-7 oferecem as semânticas necessárias ao contédo codificado em MPEG-4, permitindo novas formas de interatividade e o uso eficiente das informaçōes contextuais para adaptação do programa interativo às condições do servidor, por exemplo (Ebrahimi \& Horne, 2000).

A rede de commnichção, e configurada de forma a oferecer un suporte flexível as condiçoes de tráfego e permitir o gerenciamento da qualidade da apresentaçào ao usuário. Iradicionalmente, a qualidade de serviço (QOS) em uma rede de comunicaçào é limitada pelos esquemas de roteamento e controle da qualidade dos dados yue trafegam nessa rede.

Este trabalho sugere o uso de consciência de contexto também ao nível das redes comunicaçăo (Context-Aware Netiorks), apresentando mecanismos para uso de regras de contexto entre as entidades que compoem a rede de comunicaçào e oferecendo novos esquemas de controle de Q0S em duas formas diferentes: a) para descobrir entidades de rede 
que sejam capazes de melhorar o processamento sobre os dados que trafegam em direçào ao usuário; b) para que a aplicaçào do ustário possa interferir nas confiģuraçóes da rede de comunicação, oferecendo, por exemplo, dados contextuais que possam melhorar o desempenho da própria rede (Li et al., 1998).

O uso de regras de consciência de contexto em nivel de rede de comunicação apresenta-se como uma nova perspectiva para os esquemas de interação usuário-rede e aplicação-réde, sendo, portanto, uma inovaçào para a construção de aplicaçós interativas conscientes de contexto.

Aspectos de consciencia de contexto podem ser potencialmente usados no processamento de informaçoes contextuais sobre a rede de comunicaçâo, sobre o servidor e sobre as aplicaçües, permitindo a tomada de decisōes de forma dinâmica sobre as condições mais adequadas à distribuição e apresentação de programas interativos, considerando, por exemplo, o tráfego, a largura de banda, a qualidade necessária para a apresentação, o nível de interatividade exigido, as caracteristicas e necessidades do programa e do usuário. Fssas decisóes podem ser tomadas no momento em que ocorrerem eventos relevantes ao contexto, sem necessidade de intervençào ou consulta ao servidor. Desta forma, pode-se dizer que a rede de comunicaçào passa a ser consciente do contexto da aplicação interativa.

O componente temminal é responsável por todas as interfaces diretas entre o usuário e a aplicação interativa. Em linhas gerais, as principais funções concentram-se em receber e processar as informaçoes contextuais e negociar dinamicamente, com o servidor e com a rede de comunicação, os reyuisitos e stıtus da aplicação.

O terminal é também responsável por exibir as cenas que formam o programa interativo, cenas essas compostas por objetos MPFG-4. Desta forma, o lerminal possui um player MPEG-4, implementado segundo as recomendaçoes MPEG-4 Syslems, conforme visto na Seção 5.5 .

Conforme discutido, a API MPEG-J pode ser usada como interface entre o player MpeG-4 e programas JAVA (Nack \& Lindsay, 1999), acrescentando possibilidades de manipulação das informaçöes contextuais, por exemplo. 
Observa-se que a infra-estrutura proposta para aplicaçóes interativas gera um complexo universo de novas possibilidades de interaçăo entre os componentes dessa infra-estrutura. Os relacionamentos representados pelas setas em vermelho indicam os pontos nos quais se faz necessaria a comunicaçào entre agentes de software; por outro lado, as setas em preto indicam os relacionamentos entre clementos de hardware e software que compeom o ambiente interativo consciente de contexto.

Observando-se a infra-estrutura proposta, a comunicação entre agentes pode ser aplicada a dois propósitos distintos: a) para coletar informaçoes contextuais dos diversos componentes da infra-estrutura; b) para operaçoòs de personalização das interfaces com o usuário.

\subsubsection{Detalhando a infra-estrutura do servidor}

Fm linhas gerais, o servidor é responsável por armazenar e distribuir os programas interativos. Esses programas são compostos por objetos multimídia, tais como vídeo, áudio, imagens, animaçoos, gráficos c textos, dentre outros. Além disso, um programa interativo possui também scripls que especificam a estrutura do programa e as relaçóes espaciais e temporais entre os objetos que formam as cenas desse programa. Generalizando, um programa interativo é composto por conteúdo multimidia e descriçào da estrutura do conteúdo multimídia.

O servidor também deve ser capaz de distribuir objetos multimídia distintos para usuários com preferencias e necessidades distintas.

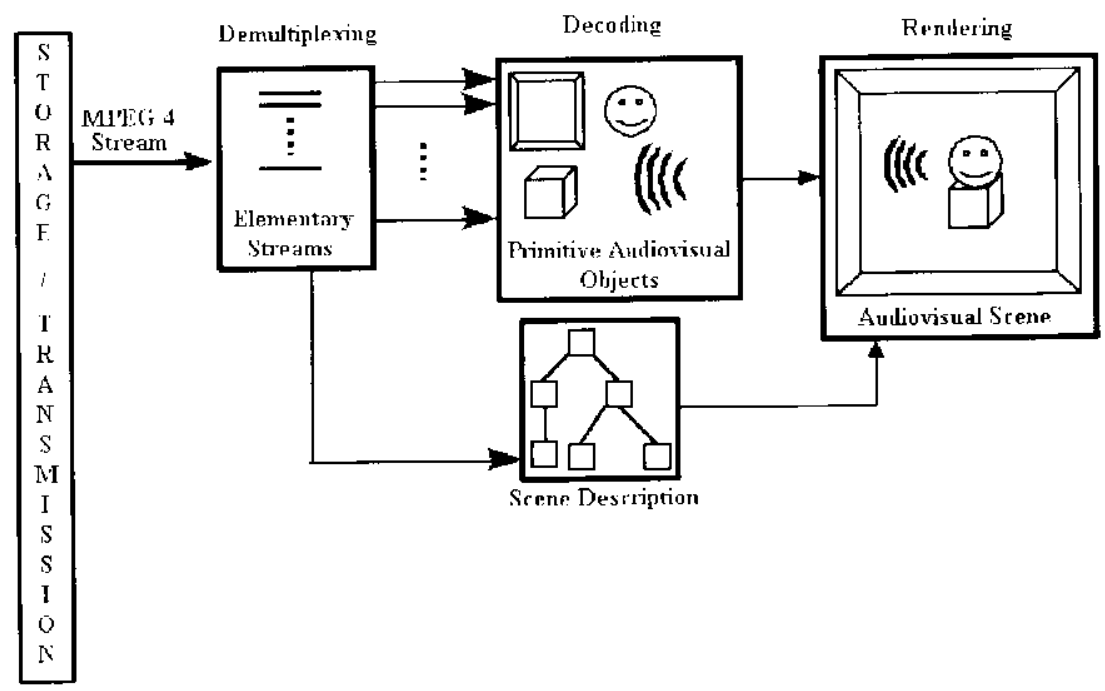

Figura 5.06: Fsquema para decodificação de streams MPEG-4 (ISO, 2001a) 
O padräo MPEG-4 oferece o suporte necessário para o conteúdo dos objetos multimídia, tendo sido desenvolvido para prover soluçóes aos novos tipos de aplicaçoes interativas (Battista et al., 1999). O potencial e a funcionalidade do MPEG-4 são baseados na manipulaçăo - codificaçào, decodificação e interacào - de mídias como ohjetos, conforme é possível observar na Figura 5.06.

Uma apresentaçâo MPEG-4 é baseada em cenas. Cada cena é composta por diversos objetos de mídia (vídeo, áudio, gráficos 2D e.3D, animaçoes 2D e 3D, texto, imaģens, dentre outros) e esses objetos são codificados em strenms (Hlementary Streams - ES). Streams MPEG-4 são decodificadas, permitindo a separaçào e reonstruçáo dos objetos, tornando possivel a interação com cada objeto que compòe a cena, conforme ilustra a Figura 5.06. Neste sentido, uma possivel lista de interaçoes contém operaçôes como alteração da posição e forma dos objetos na cena; operaçôes de escala e rotação; alteraçăo da velocidade de apresentação dos objetos; adiçào e remoçào de objetos de uma cena (ISO, 2001a).

Fim termos de codificação, o padräo MPEG-4 suporta diversos tipos de algoritmos e taxas de compressão. Os objetos passam por um processo de compressão e podem se multiplexados em um ou mais stréms, tanto para armazenamento quanto para transmissào em uma rede de comunicaçào.

O processo de composição de cenas é bastante flexível com o uso de MPEG-4, permitindo a criação de apresentaçôes multimídia (naturais ou sintéticos) com base em um grafo das cenas que compōem essa apresentaçào. Os objotos de mídia, por sua vez, são organizados hicrarquicamente, permitindo que objetos de tipos mais complexos sejam formados a partir de objetos dos tipos primários.

Cada objeto de mídia é uma entidade independente, e pode ser sincronizado com outros objetos que compóem a cena. A sincronização em MPEG-4 é feita em nível de frames para todos os objetos. Isto é uma vantagè em relação aos mecanismos de sincronização usados por tecnologias como SMIL. (W3C, 1998) e HyTime (ISO, 1992; DeRose \& Durand, 1994), que geram sincronizaçào ao nível de strenms ou grupos de frames. Os mecanismos de sincronização são extremamente importantes em proyramas interativos, como é o caso dos programas de TVI, visto que esta proposta considera que os usuários possam manipular os 
objetos durante a exibiçâo das conas. Além disso, o suporte automático da consciência de contexto também envolve diretamente os mecanismos de sincronização.

Outra caracteristica interessante do padrào MPLG-4 é que os objetos de video são compostos por camadas (layers) (Ebrahimi \& Horne, 2000). Fxiste uma camada básica e várias camadas complementares que permitem escalabilidade temporal e espacial. As camadas complementares visam melhorar a qualidade da camada básica em termos da resolução e da taxa de transmissão de frame's. Neste sentido, MPEG-4 permite a composição de cenas como objetos estruturados e relacionados entre si. Adicionalmente, características como facilidades de streaming, alto potencial de compressão, sincronizaçào, dentre outras, fazem com que o MPEG-4 apresente-se como potencial candidato para implementaçào de programas de TVI. Adicionalmente, a estrutura do conteúdo MPEG-4 pode ser descrita com o uso de descriçóes MPLG-7 (Nack \& Lindsay, 1999); ISO, 2000a), que representam instancias de um modelo de ambiente interativo. Neste ponto, descriçoes MPEG-7 podem ser codificadas no mesmo stream que contém o conteúdo multimúdia, permitindo o estabelecimento de diversos de níveis de interação, especialmente aqueles associados aos mecanismos de consciência de contexto.

MPLG-7 tem por objetivo padronizar as descriçīes de dados referentes ao conteúdo multimídia, representado, por exemplo, em MPEG-4. Fssa padronizaçào é feita através de um conjunte de "Descritores" (Descriptor - D), que podem ser usados para descrever qualquer tipo de ohjeto de mídia. O padrão MPEG-7 especifica também estruturas de descritores pré-definidas e seus relacionamentos na descrição de cenas, oferencendo suporte também para que o usuário possa definir suas próprias estruturas. Tais estruturas são denominadas "Esquemas de Descriçào" (Descriptors Schemes - DS).

Para a definição de um novo DS, deve-se utilizar uma linguagem específica para esse propósito, denominada "Linguagem de Definição de Descrição" (Description Definition Language - DDL) (ISO, 2001c). Lsando uma DDL, DSs e Ds, o padrão MPEG-7 pode acrescentar ao conteúdo multimídia as mesmas características que XML (W3C, 2000) acrescenta ao conteúdo textual.

Conforme citado, os objetos MPEG-4 podem ser descritos com o uso do MPEG-7. Esta possibilidade abre um cenário interessante para o conteúdo de programa de TVI, uma ve\%. 
que olerece todas as semânticas necessárias para o gerenciamento eficiente do contcúdo, para a construçào de mecanismos de pesquisa e para o desenvolvimento de novos níveis de interatividade. Deve-se observar também que MPEG-7 não é limitado à descrição de conteúdo de objetos multimídia, podendo ser aplicado também para construção de níveis mais abstratos, como é o caso de um programa interativo (um programa de TVI, por exemplo). Um exemplo dessa aplicacáo pode ser visto no código seguinte na Figura 5.07.

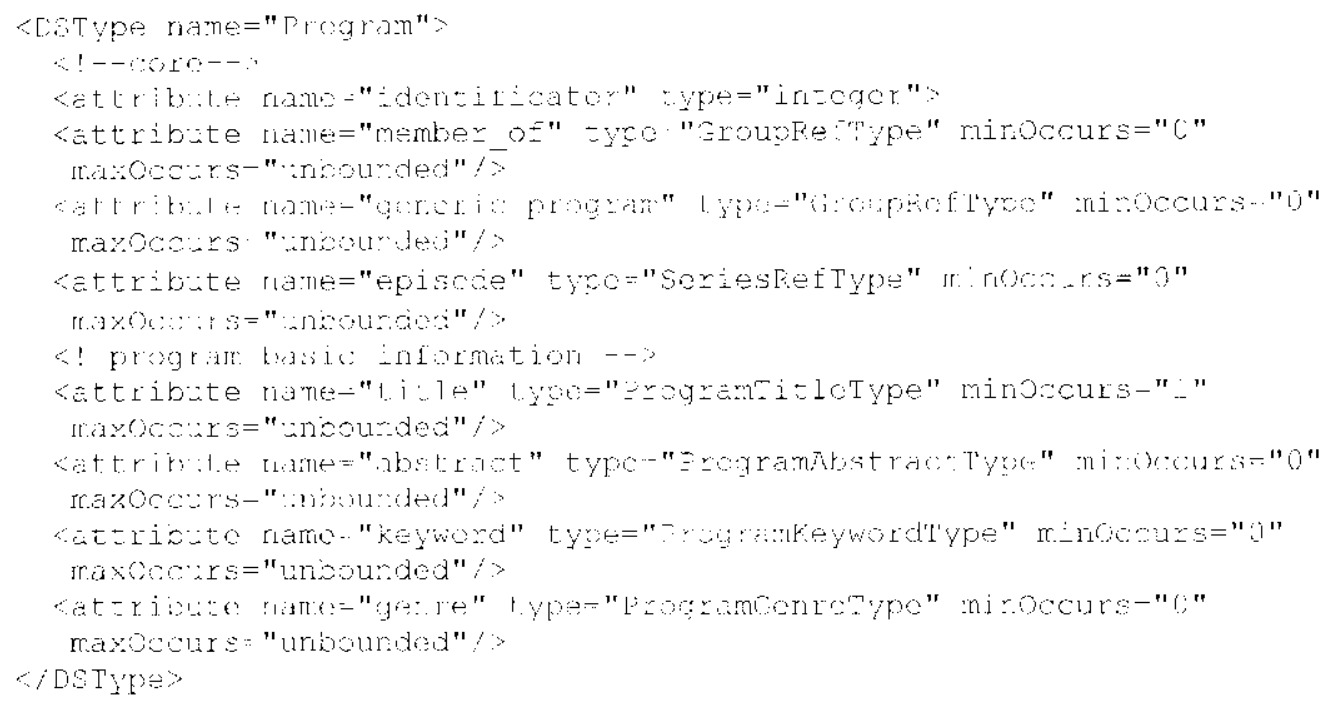

Figura 5.07 - Um exemplo de DS (Description Schema) MPEG-7

Observa-se que o DS apresenta uma forma para estruturar um programa de TVI e quais os elementos, em mais alto nível, que compōem esse programa. A composiçào é determinada pela identificação do programa, pela associação de elementos (grupo, epsódio) e pelo índice de informaçoes (título, palavras-chave, dentre outros). Nota-se, ainda, que no DS existe um atributo memler_of que é capaz de estabelecer um link com outros DS.

No cenário dos ambientes interativos conscientes de contexto, é interessante que o servidor possa se adaptar às necessidades dos serviços sob demanda. Essess serviços, tanto para um usuário quanto para um grupo de usuários, deve possuir, dentre muitas características, as seguintes:

- permitir a distribuição via streanes;

- realizar a multiplexaçào de dados;

- permitir ajustes nos streams durante a distribuição;

- possibilitar o armazonamento e a recuperaçào de programas;

- realizar pesquisas com base nas descriçoes de conteúdo. 
Os parâmetros de informação, necessários aos procedimentos de adaptação e personalização, devem ser fornecidos pela aplicação do cliente, tais como o nível de qualidade desejado, por exemplo; pela rede, tais como as condiçoes de tráfego, banda disponivel, dentre outros; e pelo servidor, tais como os dados disponíveis em determinado momento e as descriçoes associadas a usses dados.

O modelo de ambientes interativos conscientes de contexto apresenta as situaģoes em que os parämetros de personalizaçäo sâo necessários, especialmente em termos dos elementos de informaçōes presentes no Terminal Mode. Neste ponto, esses elementos de informação são também instanciados como descriçoes MPEG-7, mantendo a compatibilidade com as descriçōes de conteúdo presentes para os objetos de mídia. Adicionalmente, os elementos de informaçào sào usados para representar informaçòes contextuais (context-anderness), tais como identidade, localizaçà, atividade o tempo, informaçōes essas que podem ser mapeadas por descrilores cesquemas de descriçào do $M P E G-7$.

Num cenário de l'VI, diferentes usuários podem possuir diferentes tipos de preferência e. niveis de qualidade para uma mesma apresentaçào. Desta forma, o servidor deve ser capaz de distribuir diferentes streams de um mesmo programa interativo. No caso particular de vídeo, a tecnologia utilizada deve ser baseada em codificaçào em camadas, como é o caso do MPEG-4, en que o sinal de vídeo é codificado em una ou mais camadas com diferentes niveis de prioridade (Wu ct al., 1997; McCanne et al., 1996; I, et al., 1998; Fbrahimi \& Horne, 200(0). Assim, o servidor pode usar codificadores MPEG-4 para oferecer as funcionalidades baseadas en camadas para os objetos de video.

Completando a infra-estrutura do servidor, agentes de software podem ser usados para controlar e monitorar os processos de distribuiçán dos programas interativos. Esses agentes podem acessar as descriçoes de programa, os requisitos de interaça do usuário e os parámetros do servidor é da rede de comunicaçáa, usufruindo dos recursos da API MPFC-G, por exemplo. De posse desses dados, os agentes podem executar operaçoes de personalização em todo o ambiente. Como exemplo, pode-se pensar no caso de balanceamento da carga do servidor, em que agentes podem monitorar a execuça das tarefas de entrega dos programas interativos e indicar possibilidades de interrupçáo no serviço. Nesta situaçáo, os agentes podem consultar as descriçōes do programa interativo para tentar encontrar alternativas para os objetos que compoem o programa, como, por 
exemplo, selecionar um novo codificador de video que seja capaz de codificar um número menor de camadas, reduzindo assim o fluxo de dados na rede de comunicaçáo, porém conservando a qualidade da apresentação ao nivel do usuário.

\subsubsection{Detalhando a infra-estrutura do cliente}

O modelo do cliente é composto pelos agentes de terminais. O terminal é composto por um computador pessoal, conectado a uma rede, e deve exibir programas interativos, contendo um player MPEG-4 como a base para essa exibição.

A Figura 5.08 mostra os componentes envolvidos no processo de exibição de uma apresentação MPEG-4 pelo terminal do cliente (como é o caso de um programa de TVI). Os stremms de mídia codificados em MPEG-4 sào enviados ao terminal. Através de um demultiplexador, esses strentms Mpeg-4 são identificados e separados como streams elementares. Cada stream elementar é descodificado em objetos de mídia e enviado ao player para sua renderização. O player utiliza a descrição da cena e as descriçóes dos objetos de mídia e verifica que lipos de controle podem ser aplicados a cada objeto.

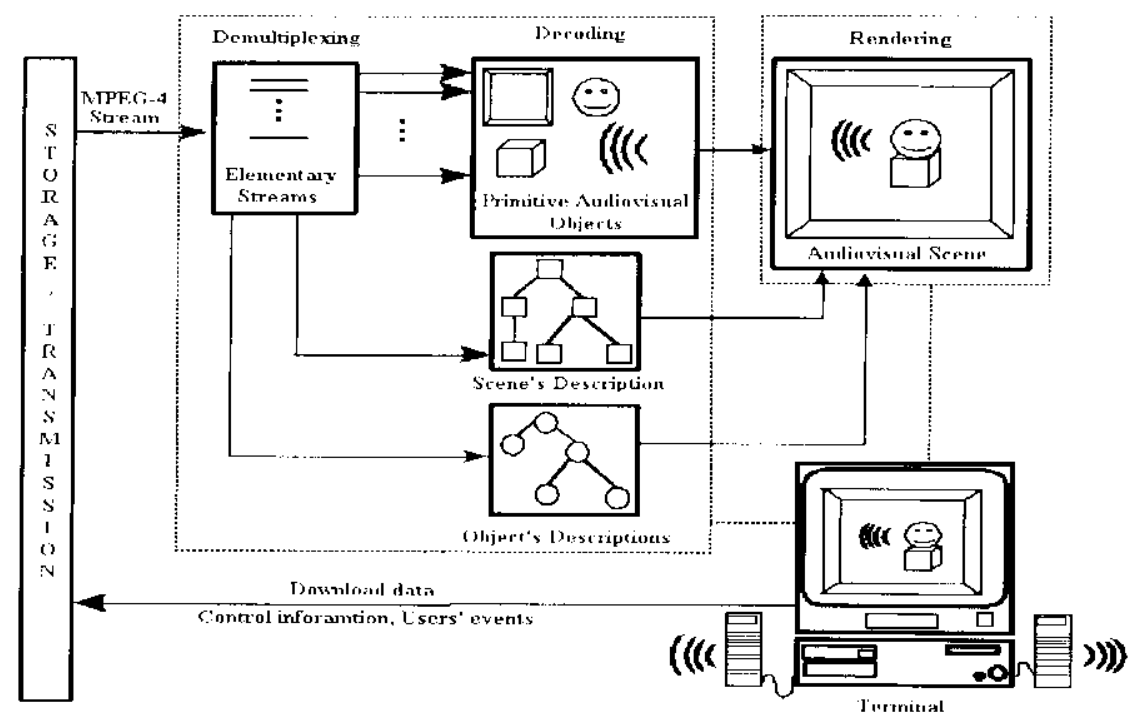

Figura 5.08: Esquema para apresentação de objetos MPEG-4 em um terminal (ISO, 2001a)

O autor de uma apresentação multimídia é quem determina esses controles que podem ser aplicados aos objetos de mídia. Cada objeto tem una lista de controles padrão, além dos controles adicionados durante a autoria. Os tipos mais complexos de controle podem ser conseguidos usando MPEGl'ts desenvolvidos com o uso da API MPEG-J (ISO, 1999d), que 
age como uma interface entre entre o player, os objetos de mídia e a aplicação como um todo, que pode ser desenvolvida em Java.

Os usuários podem interagir com a apresentaşa de diversas formas, partindo-se do principio do controle de objetos na cena e das possibilidades de searching de características de cada objeto. Neste cenário, as interaçóes dos usuários geram eventos. Alguns eventos têm um efeito local, como a amplificaçào de uma imagem, e são fáceis de processar. Outros podem afetar a rede ou os serviços do usuário, como é o caso de uma requisição por uma taxa de compressão de fromés, por exemplo.

Os terminais podem ser conectados também a dispositivos como VCRs, estaçōes de trabalho, terminais de TV, cameras, dentre outros. Estes dispositivos podem possuir sensores, que capturam algum tipo da informaçào contextual e fornecem suporte à ubiquidade e à consciência de contexto. Noste sentido, um sensor comunica-se com os dispositivos que são controlados pelos terminais.

\subsubsection{Detalhando a infra-estrutura da rede de comunicação}

Lm dos focus desta proposta é centrado no fato de que a rede de comunicaçào deve estar consciente do contexto da aplicaçäo interativa e do ambiente como um todo (usuários, programa interativo e interaçoes usuário-rede-aplicação), oferecendo novas possibilidades de gerenciamento das aplicaçòes. Essas possihilidades são relacionadas as interaçóes entre os três componentes da infra-estrutura. Para se atingir esse novo nivel de gerenciamento da rede, são necussários protocolos e algoritmos que forneçam informaçōes gerenciáveis, como é o caso do MPEG-4.

Tradicionalmente, o processamento de informaçōes da redé é limitado à distribuição, ao controle de congestionamento e a qualidade de serviço (QOS). As novas arquiteturas de rede, como é o caso das redes ativas, permitem a mudança dinámica de comportamento da aplicaçào. Neste sentido, os roteadores podem processar dados contextuais do usuário e da aplicação (Tennenhouse \& Wetherall, 1996; Calvert et al., 1998).

O trabalho de doutorado de Goularte investiģa o uso de diferentes tecnologias de rede para implementar os requisitos definidos por esta proposta, especialmente em termos do uso de informaçōes contextuais (Goularte, 2001). O foco da proposta de Goularte é permitir que a rede tome decisões dinâmicas, baseadas em informaçoes contextuais e regras de contexto 
modeladas nesta proposta, visando melhorar a distribuiçào de programas interativos, sobretudo em termos do tráfego, da largura de banda, da qualidade da apresentaçäo, do nível de interatividade, das necessidades dos programas interativos e das interações do usuário. Lssas decisóes podem ser tomadas no momento em que determinados eventos ocorrem, sem necessidade da intervenção do usuário ou de respostas do usuário. Neste sentido, este trabalho contribui com a proposta de Goularte quando oferece requisitos necessários para determinar que informaçôes contextuais são relevantes às decisôes da rede e que decisòes contribuem realmente para a adaptação da aplicaçăo.

Atualmente, o toolkit AN'IS tem oferecido suporte a experimentos com redes ativas (Wetherall et al., 1998), permitindo o desenvolvimento de aplicaçóes JAVA para o monitoramente da rede, o que é interessante para esta proposta, que considera o uso da plataforma JADE e da API MPEG-J, tecnologias bascadas em Java.

\subsection{PRACTIC: o modelo da personalização}

A abordagem atual para o desenvolvimento de aplicaçoes interativas, em nivel mundial (ATVEF, 2001; DVB, 2000; TVAF, 2001a), prevê somente a adiçâo de alguns aspectos de interatividade aos tradicionais programas interativos. No entanto, com a mesma tecnologia que esses modelos utilizam, é possível obter um resultado com maior grau de adaptabilidade ao consumidor e que também permita uma melhor definiçào do público-alvo pelos desenvolvedores de aplicaçào.

Neste ponto, observa-se que é possivel adaptar um mesmo programa interativo, com pequenas modificaçoes, a espectadores com diferentes interesses, conforme ilustra a Figura 5.09 .

Na Figura 5.09 é apresentado um programa interativo com seus diversos objetos, porém para cada usuário ele será mostrado de uma forma diferente, dependendo dos perfis que esse usuário tem à disposição. No Capítulo 6, será descrita uma aplicaçào de TVI como exemplo dos conceitos aqui discutidos. 


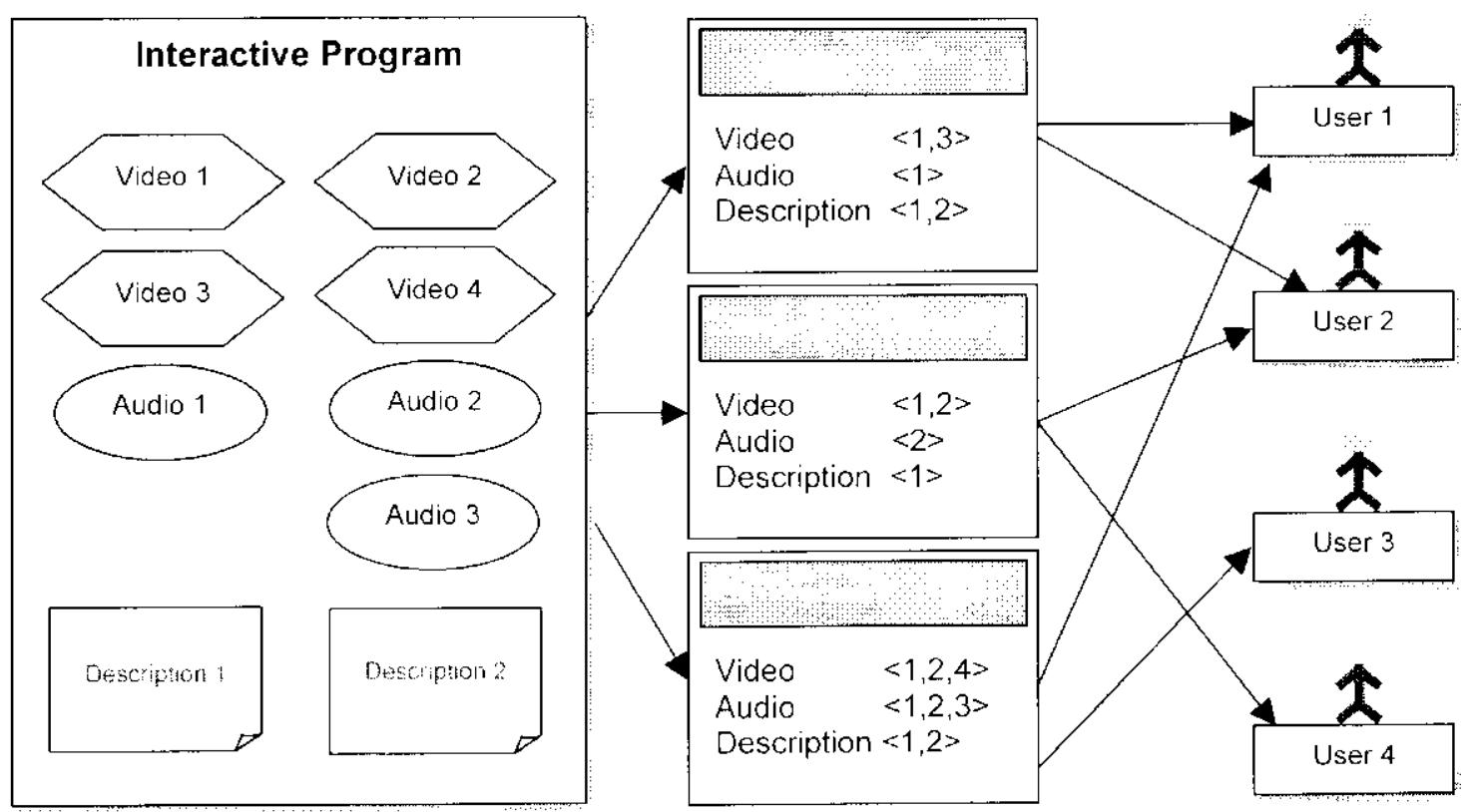

Figura 5.09: Estrutura proposta para um programa interativo

Neste contexto, a importante ressaltar que esse tipo de adaptação, considerando-se uma estrutura particular para um programa interativo, pode ser feito com o uso de aspectos de consciência de contexto. As Seções 5.8 .1 e 5.8 .2 apresentam descriçōes de programa e de perfil, respectivamente.

\subsubsection{O programa interativo}

Nesta proposta, o programa é o elemento central de uma aplicaçào interativa. O programa interativo pode ser definido como o conjunto de todas as mídias (e suas descriçoes), cenas (e suas descriçóes), um sumário (ou sinopsè) é sua programação, conforme mostra a Figura 5.10 .

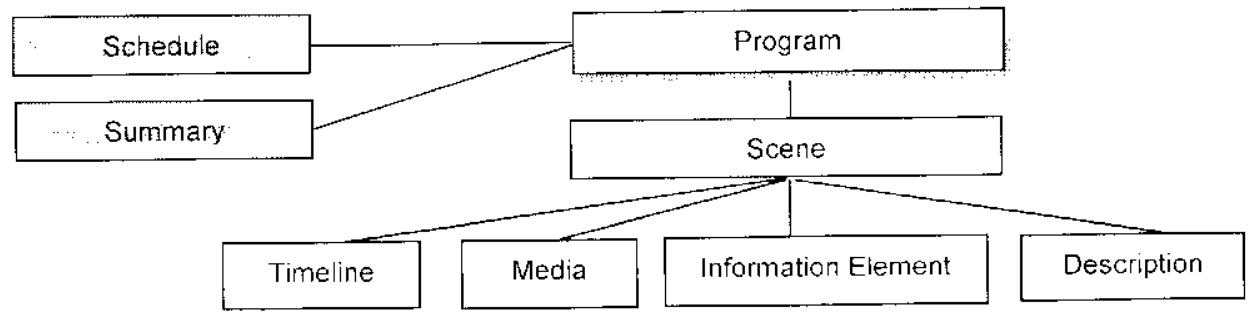

Figura 5.10: Entidades que compòem um programa interatico em uma aplicaçào 
O programa interativo é estruturado usando a DI)I. MPEG-7 (ISO, 2001b) e utiliza as descricoes nultimidia definidas pelo MPEG-7 (ISO, 20010). As entidades Schedule e Summary são definidas pelo TV-Anytime Forum (TVAF, 2001b; 'I'VAF, 2001c). A seguir, uma versão simplificada do Schema de descriça de uma cena é apresentada na Figura 5.11. A versào completa para cenas (e programas) é encontrada em (PRACTIC, 2001b) e também no Capítulo 6.

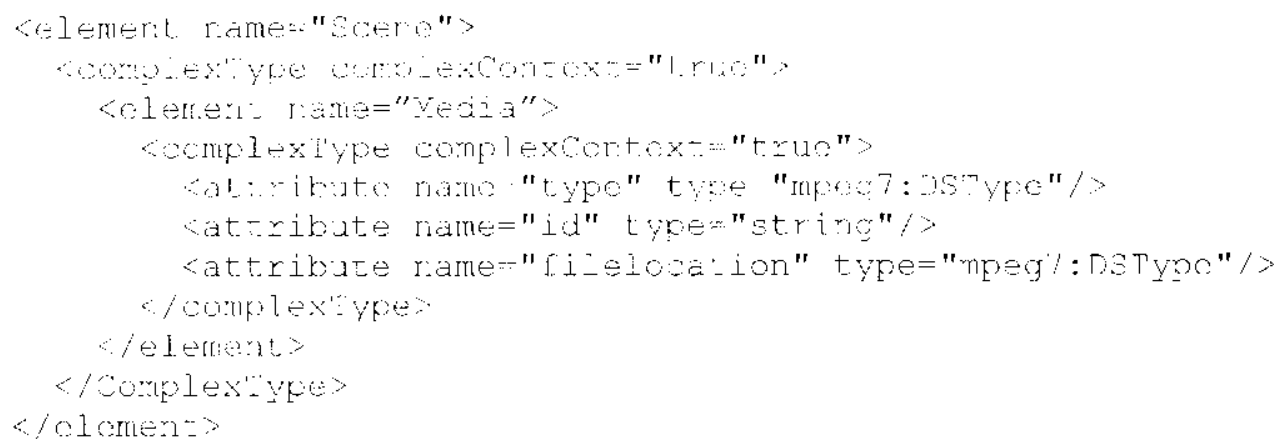

Figura 5.11 - Schema MPEG-7 para descriçāo de uma cena

A partir das mídias e suas descriçòes, é possivel construir diferentes interfaces, ou modos de apresentação, para um programa interativo. $\Lambda$ esta possibilidade, dá-se a denominação de perfil (profile). Para a codificaçào das mídias e das cenas, esta proposta considera o uso da tecnologia MPEG-4, que é bastante flexivel e eficiente para a compactação de vídeo e de áudio. Como característica fundamental do $\mathrm{MPLC}^{\mathrm{P}}-4$ pode-se citar o fato dos componentes de uma cena estarem separados como ohjetos, permitindo assim incrementos nas formas de manipulaçào desses componentes. Essa característicá é bastante significativa para o caso da implementação de diferentes perfis de programas interativos. É importante salientar que apesar deste trabalho considerar o uso de MPEG-4 para a apresentação e transmissão do programa, a estrutura apresentada é independente do mecanismo de transporte, podendo utilizar us padroes da TV Digital (A'TSC, 2001; DVB, 1999; ARIB, 2000), bem como pode utilizar o Multimidia Home Plataform (DVB, 2000) para a apresentaçào do conteúdo multimidia.

As descriçōes das cenas e das mídias permitem a criação de ferramentas de busca em vídeos, áudio e nas cenas. Pelo fato deste trabalho utilizar o padräo MPEG-7 para a descriçào destas, deve-se observar que ferramentas de busca para MPEG-7 poderão ser utilizadas. 
Por outro lado, o sumário e o schedule têm uma destacada importância para aplicaçóes do tipo EPG (Fletronic Program Guides), uma vez que é a partir do uso de EPGs que o usuário escolherá o que assistir e o que pretende gravar. Com as informaçoes do sumário, o usuário pode escolher exatamente os programas a serem assistidos/gravados; com a informação do schedulte, o usuário não precisa se preocupar com o horário de início do programa, uma vez que seu STB fara isso de forma transparente. Outro relevante uso do schedule reside no fato de que em um ambiente consciente de contexto o ubíquo o STB pode informar um equipamento telefônico ou PDA o horário de início de um determinado programa ao vivo.

\subsubsection{O perfil de programa interativo}

Um programa interativo precisa de uma especificação de modo de apresentação. Pelo fato de existir uma vasta quantidade de mídias disponiveis, o número de diferentes formas de apresentaçoes desse programa lende a ser igrualmente grande. Quem disponibiliza os perfis sajo as emissoras geradoras de programas, porem estes perfis podem ser personalizados pelos usuários. Ao fazer com que as produtoras disponibilizem os perfis, impede-se a incompatibilidade entre um perfil e um programa, além de permitir que diferentes perfis possam ser disponibilizados de acordo com o tipo e/ ou categoria de usuário (por exemplo, o plano de canais interativos que um determinado usuário possui).

Para a descriçào dos perfis, este trabalho utiliza o padrào MI’EG-7 e a criaçăo de novos elementos, acessivel em (PRAC'IIC, 2001b), para descrever alguns aspectos de layout, requisitos econtexto, relevantes a esse perfil e suas interaçoes, conforme ilustra a Figura 5.12. As informaçoes relativas a um perfil estão dentro de um clemento <profile>. lisse elemento, por sua vez, é composto por outros elementos, que terào suas funcionalidades apresentadas a seguir.

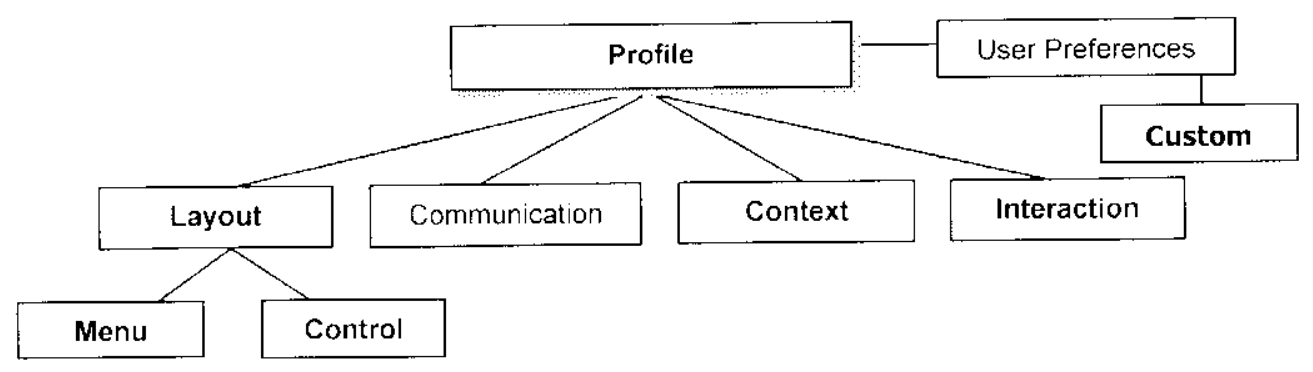

Figura 5.12: Entidades que compõem um programa interativo em uma aplicaçäo 
Os aspectos de apresentaçäo definidos, que fazem parte do elemento <Layout>, são relativos às cores de fundo, das fontes e posiçoes das midias. Ientro do laymont ainda, tem-se os controles de mídia possíveis para um determinado perfil, o tipo de menu e seu conteúdo. Uma versão simplificada do Schema de descrição do elemento <layout $>$ é apresentadia na Figura 5.13. A versão completa do Schema pode ser encontrada em (PRACTIC, 2001b) c também no Capítulo 6, quando é discutida uma instância de aplicaçào interativa, no caso a TVI.

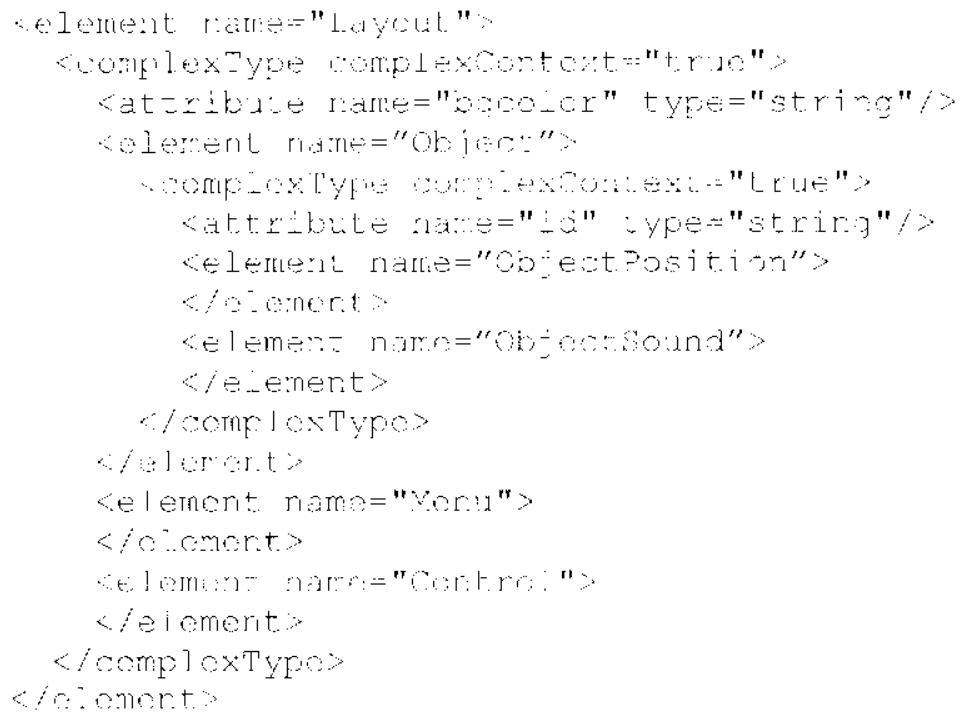

ligura 5.13 - Schenta de descrição do elemento Layout

Os requisitos do perfil ficam especificados e armazenados dentro do elemento <Communication>, onde estào os requisitos de comunicação de cada múdia, os decodificadores necessários para cada uma dessas mídias e requisitos do STB. Na Figura 5.14, é apresentada uma versão simplificada o Schema de descriçào do elemento $<$ communication>.

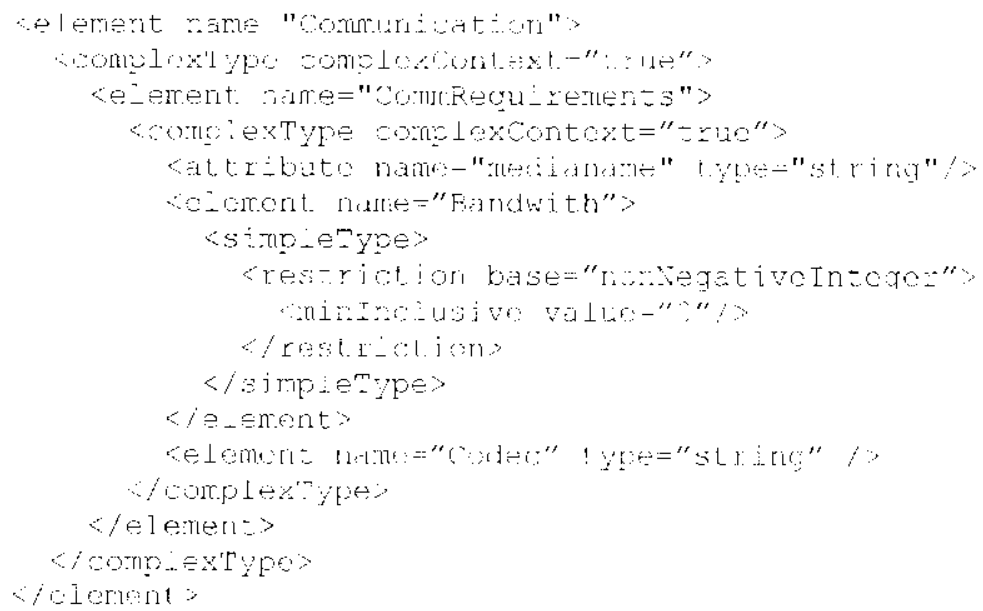

Figura 5.14 - Schema de descrição do elemento Comnnunication 
Dentro do elemento $<$ Context $>$, insere-se todo o tipo de informação de contexto que pode ser relevante para um determinado perfil. Esse clemento foi definido a partir de variáveis relevantes em consciência de contexto, tais como $\langle$ who $\rangle$, $\langle$ where $\rangle$, $<$ when $\rangle$ e $<$ what $\rangle$ (Dey \& Abowd, 2000). Fsse elemento possui as açoes que devem ser realizadas em determinadas situaçoes. Na Iigura 5.15, é apresentado um exemplo de como utilizar o Schema para a utilizaçào em consciência de contexto.

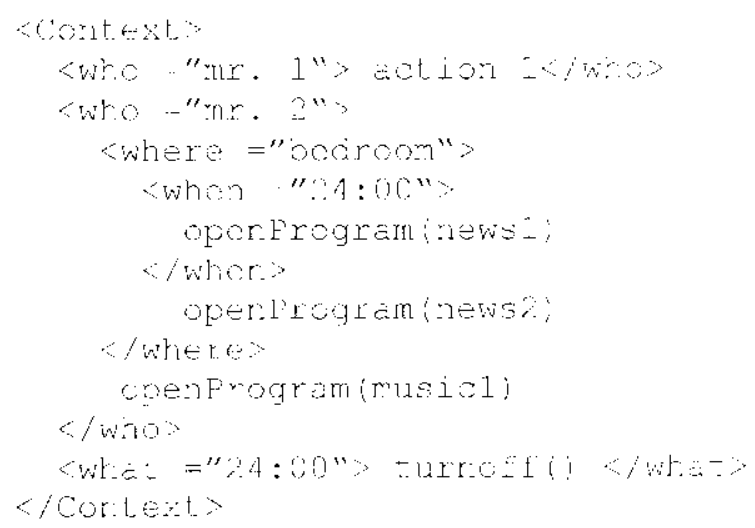

Figura 5.15 - Schoma de descrição do elemento Context

O último grande clemento é o <lnteraction>, no qual estaräo todas as ações que devem ser realizadas para cada interaçào definida para um perfil. Essas interaçoess são descritas na Figura 5.16.

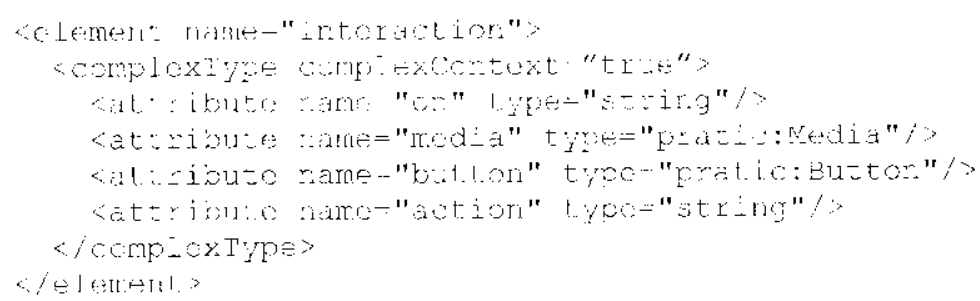

Figura 5.16 - Schema de descrição do elemento Interaction

No exemplo da Figura 5.17, o atributo moe e uma descrição MPEG-7, o atributo rideo3 foi apresentado no programa e descrito cm MPEG-7 e a ação movedMedin(zideo3) representa um comando yue será dado ao STB para realizar a tarefa. Percebe-se que esse comando depende do Sistema Operacional presente no STB e das aplicaçòes que estāo presentes no mesmo, tais como MHP (Evain, 1998) ou JavaTV (SUN, 2001).

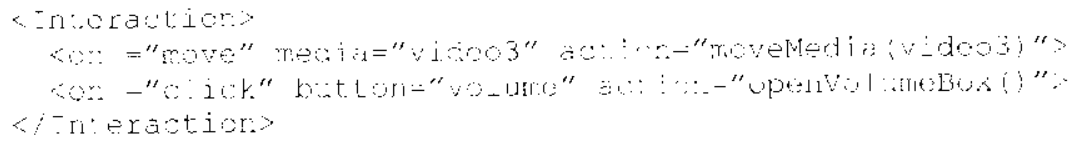

Figura 5.17 - Schema de descrição de atributos do elemento Interaction 
Além desses elementos, existe mais um elemento que segue a sintaxe dos perfis, denominado <UserPreferences>. O elemento <UserPreferences>, diferentemente dos outros elementos, fica armazenado no STB, nele estão armazenadas algumas personalizaçòes feitas pelos usuários para um determinado perfil de um determinado programa. L'm exemplo de uso desse elemento é apresentado na Figura 5.18.

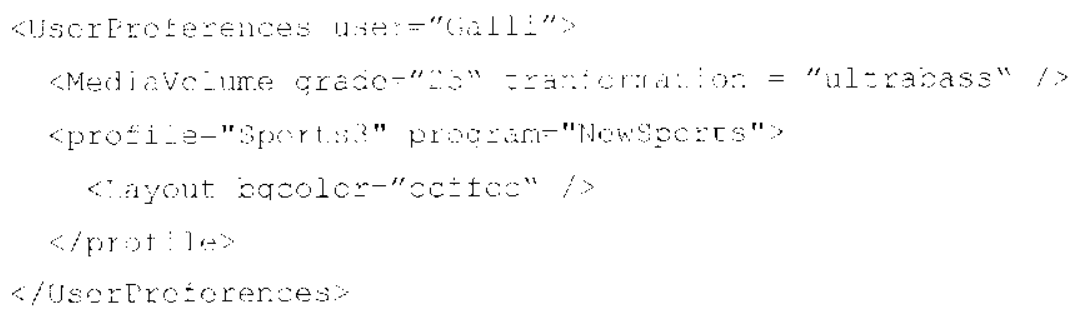

Figura 5.18 - Schema de descriçäo do elemento UserPreference's

Com os elementos apresentados e: utilizando as descriçoes do MIPGG-7 (1SO, 2001c) e do TVAnytime forum (TVAF, 2001b; TVAF, 2001c), pode-se especificar um amplo conjunto de características singulares, além de personalizaçoes para os perfis e programas.

\subsubsection{Utilização dos perfis em programas interativos}

A utilização de perfis permite, inicialmente, uma melhor adequação de um determinado programa ao seu espectador. A Figura 5.19 apresenta um diagrama de seqüencia, em sintaxe gráfica baseada em UML (Booch et al., 1996), que mostra o funcionamento básico da açào dos perfis para a apresentação de um programa em um ambiente não consciente de contexto.

Observando-se a Figura 5.19, percebe-se que a scyuência de eventos tem início quando o usturirio (user) decide qual programa interativo irá assistir; escolhido o programa, o \$ \$7B (STB) requisita ao distribuidor (sender) quais são os perfis possiveis e permitidos para aquele usuririo; o distribuidor, entào, retorna esses perfis para o STB que apresenta as opçōes para o usuário; o ustuario escolhe o perfil e suas modificaçoes, e entào o STB faz a requisiçào, junto ao distribuidor, dos streams de vídeo, áudio, dos metadados e do stream de controle da cena; por fim, o distribuidor enviará o programa e o perfil desejados para o usuário.

Lima outra utilização do conceito de perfis é em um ambiente consciente de contexto. Observando-se a Figura 5.19, percebe-ste que a seqüencia de eventos tem início quando o usuirio (user) decide qual programa interativo irá assistir; escolhido o programa, o STB (STB) requisita ao distribuidor (sender) quais sào as perfis possiveis e permitidos para 
aquele ustário; o distribuidor, então, retorna esses perfis para o $5 T B$ que apresenta as opçoes para o usuário; o usuário escolhe o perfil e suas modificaçōes, e então o STB faz a requisição, junto ao distribuidor, dos streams de vídeo, áudio, dos metadados e do stream de controle da cena; por fim, o distribuidor enviará o programa e o perfil desejados para o ustúrio.

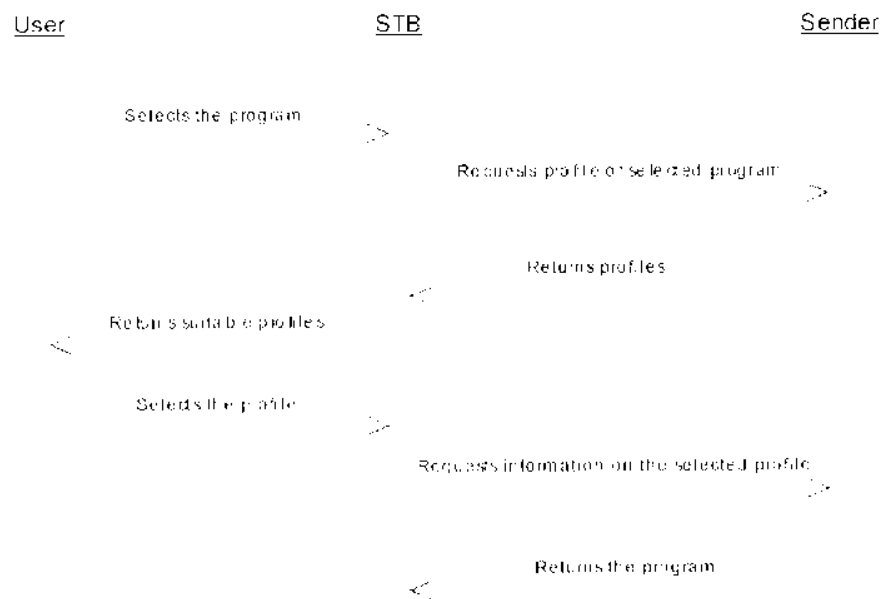

Figura 5.19: Diagrama de seqüência UMI para as entidades de um programa interativo

Nesse tipo de ambiente, agentes fornecem ao STB as informaçoes que podem ser relevantes ao perfil. O STB, por sua vez, utiliza essas informaçoes, descritas no elemento <Contexl>, para a adaptaçàn do perfil do programa.

\subsubsection{Produzindo um programa interativo}

Um programa pode possuir vários de perfis, que representam a forma e é composto por várias cenas, que representam o conteúdo, conforme ilustra a Figura 5.20.

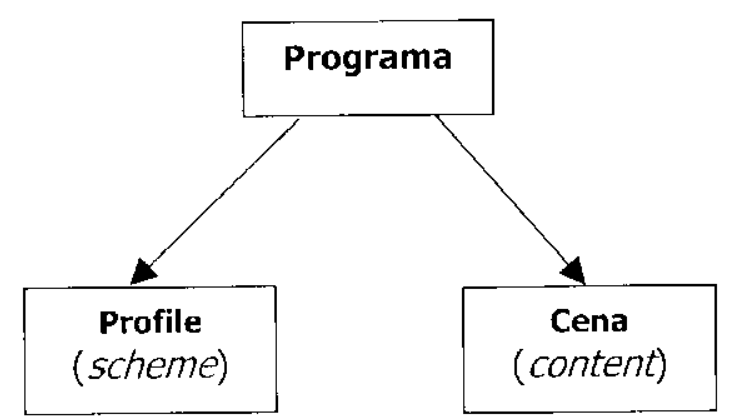

Figura 5.20 - Representaçào genérica da relaçào entre programa, perfil e cena 
Um perfil de programa interativo é composto por atores, que podem ser: produtor, diretor, produtor de contéúdo, produtor de conteúdo aeb, e usuário final. Todos esses atores realizam ações (uste-cases) e a partir dos atores e das ações de cada perfil pode-se determinar os recursos necessários. Cada perfil de programa interativo pode ser analisado e identificado a partir do uso de três parâmetros:

- necessidade de interação, que é o fato da interação ser necessária ou nào para que o programa interativo seja assistido (pode ser CN - com necessidade ou SN - sem necessidade);

- nível de interação, que é a medida quantitativa da interaçăo média esperada, e pode ser dividida em 6 nivcis : alto(6), médio-alto(5), médio(4), médio-baixo(3), baixo(2) e sem interação(1);

- acesso a conteúdo, que corresponde à quantidacle de contéudo que pode ser acessado, podendo ser restrito (R) ou amplo $(\Lambda)$.

No universo desta proposta, o programa interativo é incrementado com características de consciencia de contexto e computação ubiqua.

Inicialmente, o autor (PRODUTOR) deve preparar a o conteúdo multimidia, através de objetos de mídia MPEG-4, inserindo-os em uma TIMELINE. Nessa TIMELINE, podem ser inseridos os ELEMENTOS (objetos de uma cena), os ELEMENTOS DE INFORMAÇĀO ("objetos abstratos") e as PESSO $\triangle S$ que farão parte da programação.

Em termos de apresentaça, o conteúdo multimídia a pode ser realizado de duas formas:

1. em tempo-real de programação (CONTEUDO_AO_VIVO);

2. como revisão do conteúdo (CONTEÚDO_REGISTRADO).

Com relação ao CONTEÚDO, na produção de um programa interativo, o PRODUTOR pode inserir referências a OBJETOS DE MÍDIA, DOCUMENTOS, HIPERDOCUMENTOS e SITES WWW, alem de poder conectar, atraves de um LINK externo, a programação de dois ou mais ambientes distintos.

\subsection{Integrando os modelos NECTAR, SPICE e PRACTIC}

A modelagem das classes dos modelos NECTAR, SPICE e PRACTIC apresenta-se como uma referencia para o desenvolvimento de aplicaçoes multimidia que tenham como cenário 
um ambiente interativo consciente de conlexto. A Figura 5.21 apresenta um diagrama UML usé-rise que descreve o cenário das macro-interaçōes que devem ocorrer entre as entidades em um ambiente dessa natureza.

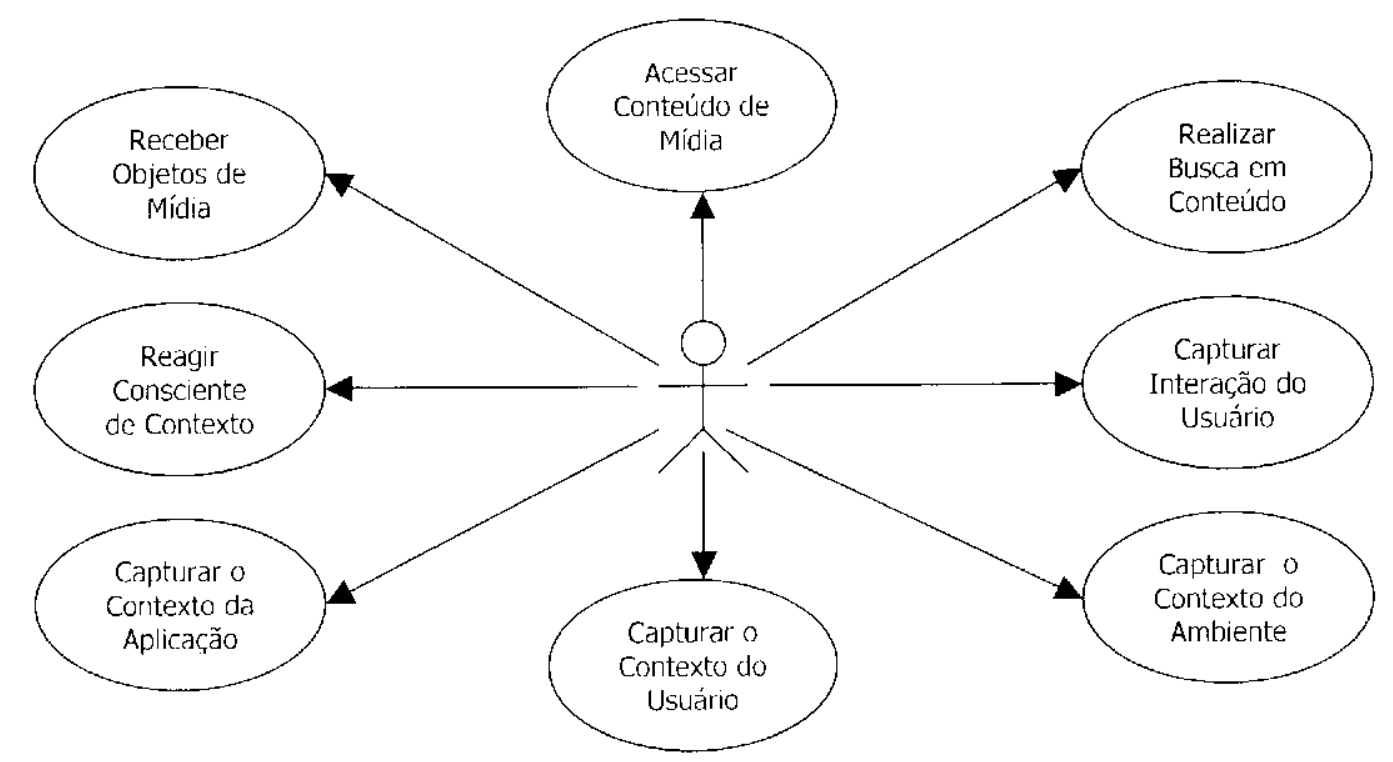

Figura 5.21: Diagrama U.ML use-case para o modelo de acesso aos objetos de mídia

A Figura 5.22 apresenta um diagrama LML de classes que descreve as relaçose entre as classes envolvidas em um dos esquemas de interaçào possiveis no ambiente. Ohserva-se que a relação entre o objoto de mídia e o restante do ambiente passa pela definiçào dos esquemas de descriçâo de conteúdo, impactando diretamente o comportamento dos objelos na cena, o que é compativel com as especificaçôes do MPEG-4 Systems.

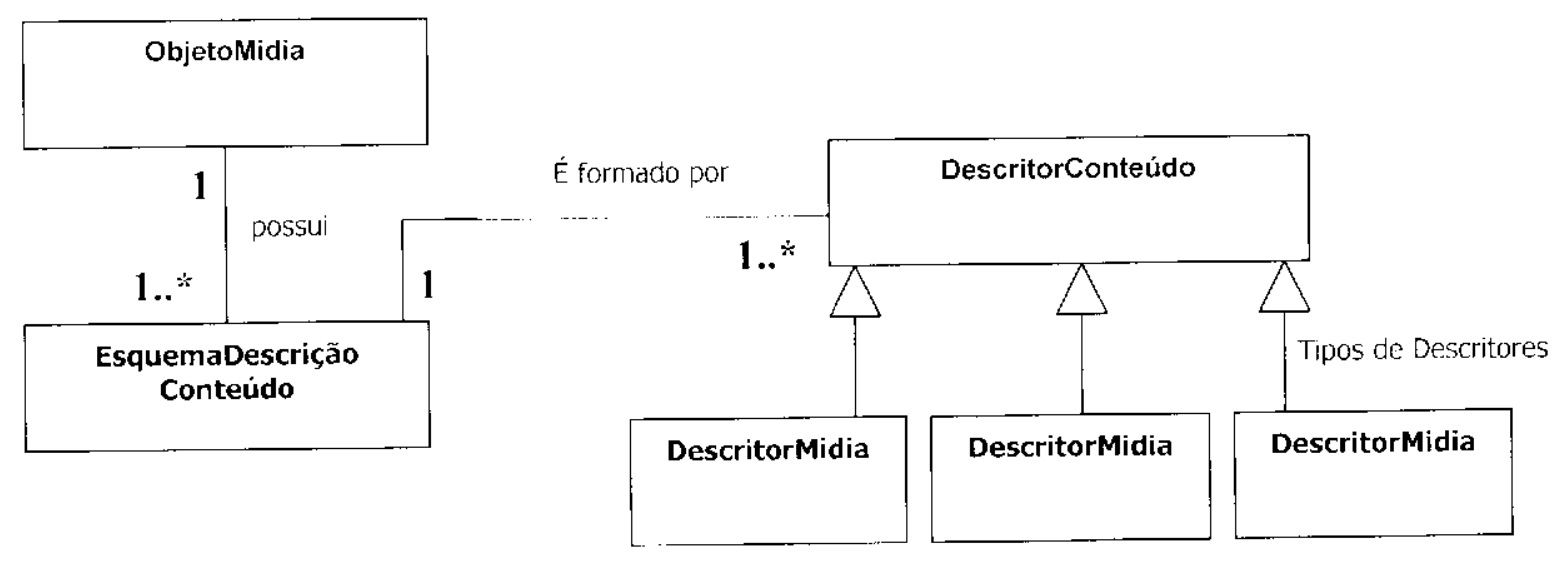

Figura 5.22: Diagrama de classes para o modelo de acesso ao conteúdo de mídia

O diagrama UML de estados apresentado pela Figura 5.23 ilustra as açōes (representadas por verbos) que geram interaçós entre componentes do ambiente. Essas interaçōes 
correspondem às transiçôes entre estados e estào relacionadas aos monitores de eventos associados ao BIFS de uma cena, conforme especificações do MPEG-Systems.

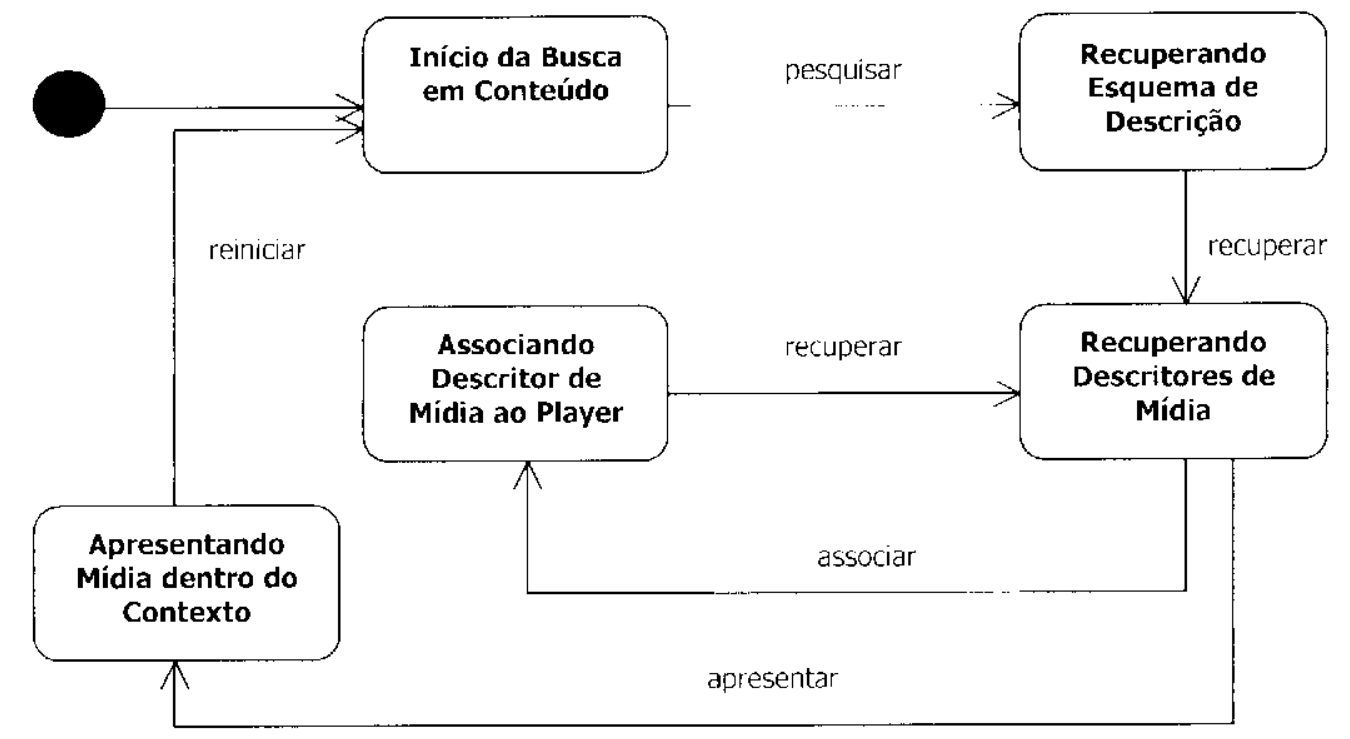

Figura 5.23: Diagrama UML de estados para o acesso ao conteúdo associado à mídia

Complementando a apresentaçào do cenário, a Figura 5.24 mostra um diagrama UML de colaboração entre os componentes de hardware e software necessários para gerar as interaçoes apresentadas na Figura 5.21.

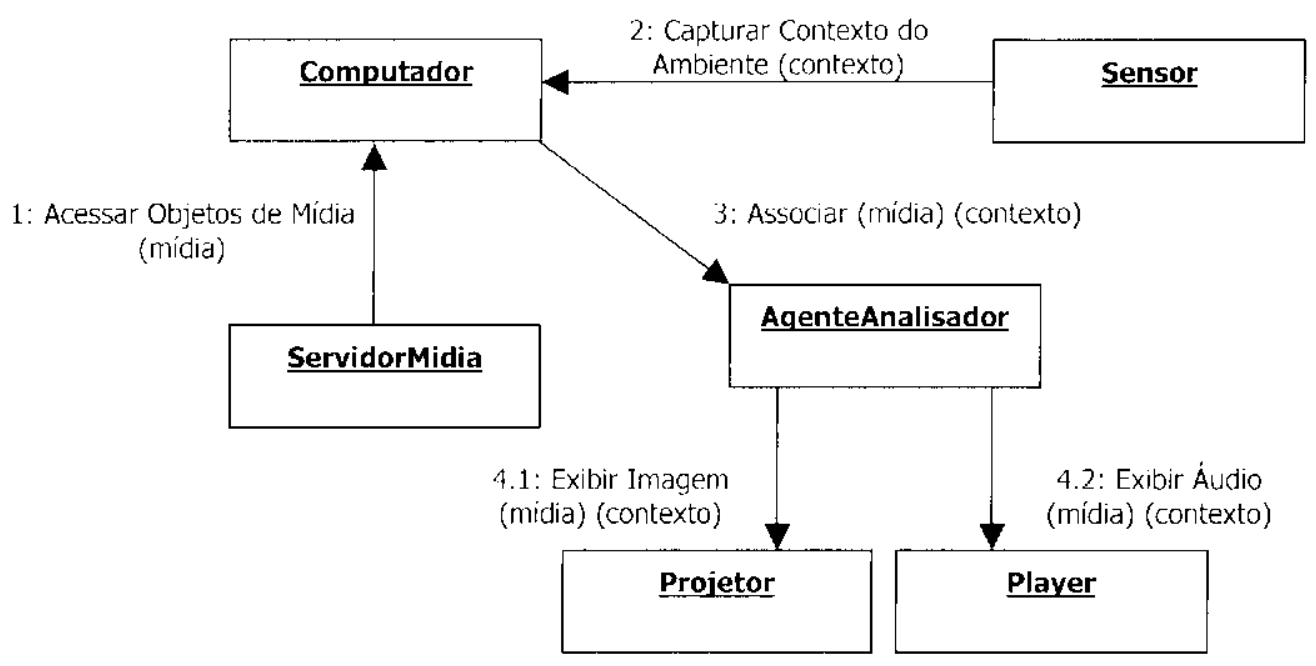

Figura 5.24: Diagrama UML de colaboraçào entre agentes físicos para o acesso ao conteúdo de mídia

Identificado o cenário de aplicaçào dos modelos NECIAR, SPICL e PRACTIC, as próximas subseçōes discutem, em detalhes, todas as classes de objetos, modeladas em UML, necessárias para suportar o desenvolvimento de aplicaçoes multimídia para ambientes interativos conscientes de contexto. 


\subsubsection{Modelagem das classes UML}

Na modelagem proposta por este trabalho, uma aplicação interativa é o elemento do ambiente interativo que integra os très modelos especificados: NICTAR, SPICE e PRACTIC. Adicionalmente, a aplicaçào interativa encontra-se dividida em três grandes componentes; outros dois componentes säo relacionados a todas as partes do processo.

A modelagem, apresentada na Figura 5.25, é baseada em UML., permitindo a especificaçäo formal das classes e seus relacionamentos, em termos das interaçós que são geradas durante o uso da aplicação pelo usuário.

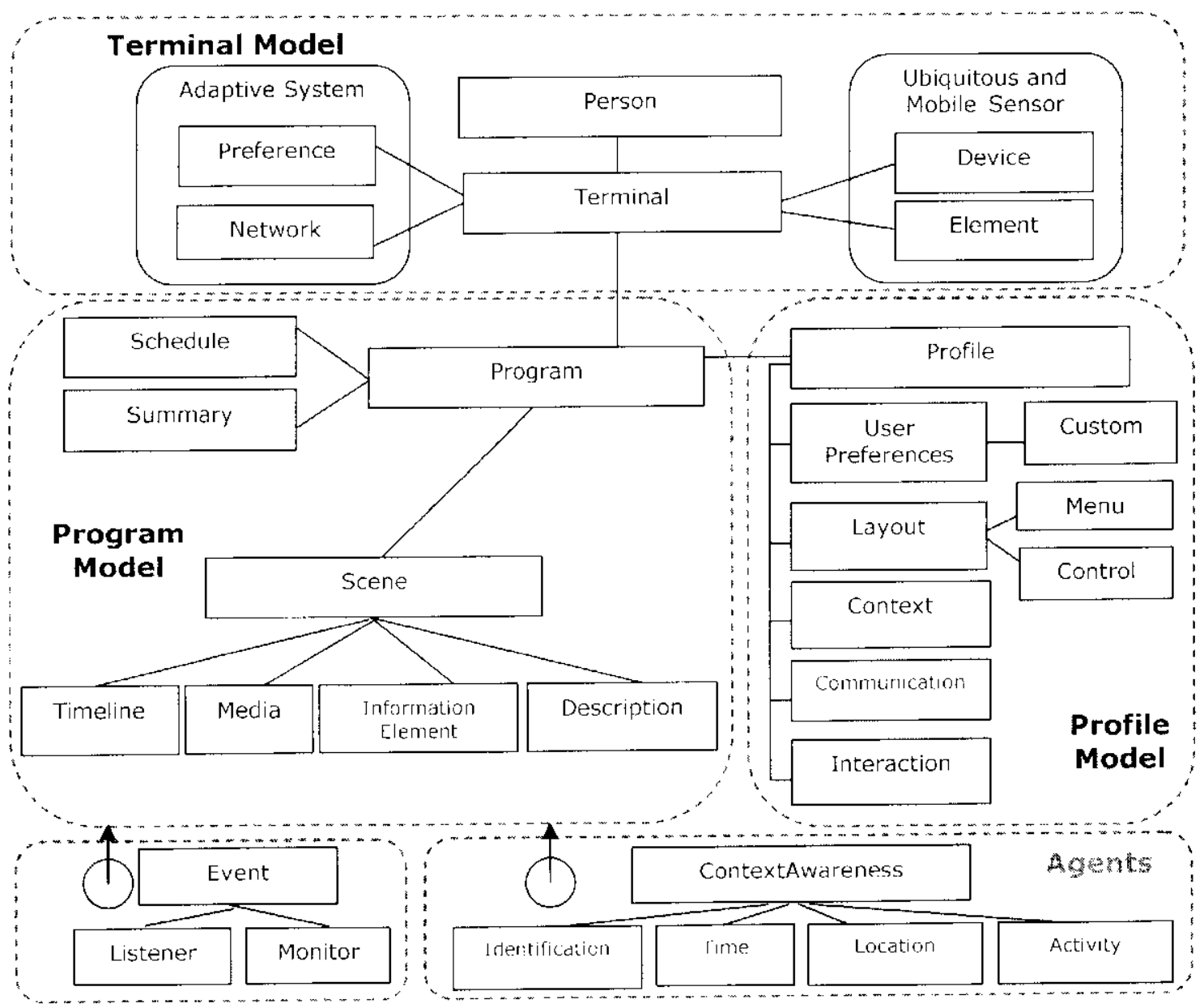

Figura 5.25 - Diagrama de classes UMI para um ambiente interativo consciente de contexto

(Santos Jr., 2001a)

O modelo de interaçăo, descrito pelo SPICE, ć composto por três principais componentes. O primeiro componente é o Proggrom Model. O objelo central de uma aplicação interativa é o programa interativo (internctioe programl), que é associado às principais partes dos outros modelos (internctive profile e terminal); essas associaçoses existem porque o terminal recebe informaçòes de um perfil de programa (program profile), porém, como loda essa informaçào 
está no program motel, ele se comunica com o objeto progrram (a Seção 5.8.1 apresentará o motelo de progrann interation em detalhes).

O segundo componente é o Profile Mold. Cada programa é composto (e apresentado) por um ou mais perfis; um perfil pode ser visto como uma "face" diferente de um programa (a Seçào 5.8.2 apresentará o conceito de perfil de programa interatiou com mais detalhes).

O terceiro componente é o lerminal Model. O objeto central desse componente é o terminal, que está conectado ao Sistema Adaptativo (Aduptive System) e aos sensores de movimento e equipamentos ubiquos (Uhiquitors ant Mobile Sensor), que incluem todos os sensores e equipamentos que podem prover informação contextual útil; o terminal pode possuir equipamentos embutidos, como decodificadores (de vídeo e de audio) e acessórios para a interação (por exemplo, teclados e joysticks); outro objeto que está presente no Terminal Modol é a pessoa (person), que é o objeto que armazena toda a informação relevante sobre todos os usuários do sistema; exemplos de informaçōes relevantes podem ser idade, gênero, salário, canais e programas favoritos, restriçōes de acesso, volume do som e ajustes da imagem; o Aduptize System é referente às informações relacionadas à rede, enquanto o Ubiquitous/ Mobile' Sensor é composto por objetos (derices) que representam os equipamentos que tornam possível a associação de consciência de contexto à ubiqüidade, como sensores e suas características.

Os outros componentes são os referentes à consciência de contexto e aos eventos que ocorrem durante o programa, conforme o modelo SPICE apresentado no Capítulo 4.

Com base no diagrama LML de classes da Figura 5.25, as próximas subseçôes descrevem os detalhes de todas as classes especificadas para suportar o desenvolvimento de aplicaçòes interativas baseadas nos modelos NICCTAR, SPICE e PRACTIC e yue serào inscridas em ambientes interativos conscientes de contexto.

\subsubsection{A classe Person}

A classe Person contém a especificaçào de informaçoes das pessoas que irăo interagir com um PDR (Personal I)igital Recorder) em um ambiente interativo consciente de contexto. Um PDR deve ser especificado e visto como elemento central da interaçăo do usuário com um programa interativo. A classe Person, portanto, deve possuir interfaces com a classe Profile e 
com a lista de atividades de uma instância da classe Program, conforme pode ser observado no diagrama UMI de classes apresentado pela Figura 5.25. Em termos de definição, a classe Person é formada pelos métodos e propriedades descritos na Tabela 5.11.

Tabela 5.11 - Métodos da classe Person

\begin{tabular}{|c|c|}
\hline Métodos & Definição \\
\hline Set IDPerson (Identification); & $\begin{array}{l}\text { Método que define uma identificação (ID) } \\
\text { ánica para uma pessoa em um programa }\end{array}$ \\
\hline setprofileperson(Profile); & $\begin{array}{l}\text { Metodo que associa um profile a uma } \\
\text { pessoa, considerando o contexto em que a } \\
\text { pessoa estiver inserida }\end{array}$ \\
\hline Activity [] getvalidactionsList(); & $\begin{array}{l}\text { Método que retorna a lista das agoes válidas } \\
\text { para uma pessoa, considerando-se o perfil } \\
\text { associado a pessoa. }\end{array}$ \\
\hline Identification get IDPerson(); & $\begin{array}{l}\text { Mátodo que retorna um objeto de } \\
\text { identificaça (ID) para uma pessoa em um } \\
\text { programa }\end{array}$ \\
\hline setActivityperson(Person, Activity); & $\begin{array}{l}\text { Método que associa uma atividade como } \\
\text { sendo válida para uma pessoa em um } \\
\text { programa }\end{array}$ \\
\hline Location getLocationPerson(); & $\begin{array}{l}\text { Método que retorna um objeto de } \\
\text { localizaçào yue representa a posição } \\
\text { geográfica de una pessoa em relação ao } \\
\text { ambiente em que um programa estal } \\
\text { inserido }\end{array}$ \\
\hline
\end{tabular}

\subsubsection{A classe PDR}

A classe PDR contém as propriedades de um equipamento do ambiente, as propriedades de personalização de um PDR e as descriçöes sobre a interaçäo desse PDR com outros dispositivos do ambiente, tais como os sensores, por exemplo. Ressalta-se, novamente, que um PDR deve ser especificado e visto como elemento central da interaçào do usuário com um programa interalivo. As interações da classe PDR podem ser vistas no diagrama UML de classes apresentado pela Figura 5.25. Em termos de definição, a classe PDR é formada pelos métodos e propriedades descritos pela Tabela 5.12 .

Tabela 5.12 - Métodos da classe PDK

\begin{tabular}{|c|c|}
\hline Métodos & Definição \\
\hline PDR getDeviceProperties (); & $\begin{array}{l}\text { Método que retorna as propriedades } \\
\text { físicas de } u m \text { dispositivo do ambiente, } \\
\text { especialmente em termos da } \\
\text { associaçarocom um PIOR }\end{array}$ \\
\hline$\overline{\text { Control [] }}$ GetDevicecontrols(); & $\begin{array}{l}\text { Método que retorna a lista dos } \\
\text { controles válidos para } u \text { dispositivo } \\
\text { do ambiente }\end{array}$ \\
\hline
\end{tabular}




\begin{tabular}{|c|c|}
\hline Ldentification get IDDevice(); & $\begin{array}{l}\text { Método que retorna a identificação } \\
\text { única de um dispositivo em relação ao } \\
\text { contexto cm que estiver inserido }\end{array}$ \\
\hline SendCommand (Command); & $\begin{array}{l}\text { Método que envia comandos para um } \\
\text { receptor em um programa }\end{array}$ \\
\hline Informationelement getelementproperties $(; ;$ & $\begin{array}{l}\text { Método que retorna a lista de } \\
\text { propriedades de um elemento } \\
\text { associado a um programa }\end{array}$ \\
\hline Identification getIDElement(); & $\begin{array}{l}\text { Método que retorna a identificaçào } \\
\text { unica de um elemento associado a um } \\
\text { programa }\end{array}$ \\
\hline Identification getIDPerson(PDR); & $\begin{array}{l}\text { Método yue retorna a identificaça de } \\
\text { uma pessoa que estiver utilizando um } \\
\text { determinado PDR }\end{array}$ \\
\hline Profile getProfileperson(PDR); & $\begin{array}{l}\text { Método que retorna o profile associado } \\
\text { a unia pessod que estiver utilizando } \\
\text { um determinado PDR }\end{array}$ \\
\hline Network getNetworkProperties (); & $\begin{array}{l}\text { Metodo que retorna um registro de } \\
\text { propriedades (bitrnte, protocolo de } \\
\text { comunicação, dentre outros) de uma } \\
\text { rede de comunicação à qual um PDR } \\
\text { estiver associado }\end{array}$ \\
\hline PDR getPDRPreferences(); & $\begin{array}{l}\text { Método que retorna as propriedades } \\
\text { preferenciais pard o funcionamento de } \\
\text { um PDR em um ambiente }\end{array}$ \\
\hline SendRequest Tnteract on (Tnteraction); & $\begin{array}{l}\text { Método que envia uma requisição do } \\
\text { interaça para um PIJR, habilitando o } \\
\text { l'DR a essa interação de acordo com o } \\
\text { contexto }\end{array}$ \\
\hline
\end{tabular}

\subsubsection{A classe Element}

A classe Element contém a especificação de informaşões e propriedades de elementos de um programa interativo que podem interagir com um PDR. Deve-se observar que agentes podem utilizar elementos para interagir com um PDR. As interaçöes da classe Element podem ser vistas no diagrama UML de classes apresentado pela Figura 5.25. Em termos de definiçăo, a classe Element é formada pelos metodos e propriedades descritos pela Tabela 5.13.

Tabela 5.13 - Métodos da classe Element

\begin{tabular}{|c|c|}
\hline Métodos & Definição \\
\hline PDR set LDELlement (); & $\begin{array}{l}\text { Nétodo que define um ID para um } \\
\text { clemento do ambiente }\end{array}$ \\
\hline Events [] getvalideventsList (); & $\begin{array}{l}\text { Nétodo que retorna a lista de eventos } \\
\text { válidos para um elemento }\end{array}$ \\
\hline setElement Properties (Properties []); & $\begin{array}{l}\text { Mólodo que define propriedades para um } \\
\text { elemento }\end{array}$ \\
\hline String receivemessage (); & $\begin{array}{l}\text { Wetodo que retorna uma mensagem } \\
\text { rocehida por um elemento durante cuma } \\
\text { sessao interativa }\end{array}$ \\
\hline
\end{tabular}




\subsubsection{A classe Device}

A classe Device contém as propriedades de equipamentos que podem ser utilizados/acessados por um PDR. A classe Device gera subclasses que podem estar relacionadas com mobile computing devices, sensoring, ubiquitous computing e demais meios eletrônicos que permitam algum tipo de interação com o ambiente. As interaçoes da classe Device podem ser vistas no diagrama LML de classes apresentado pela Figura 5.25. Em termos de definiçào, a classe Device é formada pelos mitodos é propriedades descritos pela

Tabela 5.14

Tabela 5.14 - Métodos da classe Device

\begin{tabular}{|l|l|}
\hline Métodos & Definição \\
\hline setDeviceproperties (Properties []; & $\begin{array}{l}\text { Método que define as propriedades de } \\
\text { um dispositivo do ambiente }\end{array}$ \\
\hline setIDDevice (Identification); & $\begin{array}{l}\text { Método que define os controles } \\
\text { validos para ummdispositivo }\end{array}$ \\
\hline Command receivecommand (); & $\begin{array}{l}\text { Metodo que define um ID para um } \\
\text { dispositivo }\end{array}$ \\
\hline
\end{tabular}

\subsubsection{A classe Preference}

A classe Preference contém a descrição das propriedades de personalização de uma interaçà com um PDR. As interaçoes da classe Preference podem ser vistas no diagrama UML de classes apresentado pela Figura 5.25. Em termos de definiçào, a classe Preference é formada pelos métodos a propriedades descritos pela Tabela 5.15.

Tabela 5.15 - Métodos da classe Preference

\begin{tabular}{|c|c|}
\hline Método & Definição \\
\hline setPDRPreferences (Preference []); & $\begin{array}{l}\text { Método que define as propriedades de } \\
\text { preferências para um PIOR }\end{array}$ \\
\hline setvalidinteractions(Interaction l]); & $\begin{array}{l}\text { Metodo que define a lista do } \\
\text { interaçoes válidas em relaçào às } \\
\text { preferências de um dispositivo }\end{array}$ \\
\hline Lnteraction $[j \overline{g e t v a l i d}$ nteractions $)$; & $\begin{array}{l}\text { Método que retorna a lista de } \\
\text { interaçoes válidas em relaçäo as } \\
\text { preferencias de um dispositivo }\end{array}$ \\
\hline
\end{tabular}

\subsubsection{A classe Network}

A classe Network contém as especificaçoon das características de uma rede de comunicação que estiver associada a um PDR. Adicionalmente, classe Network suporta a especificação dos recursos do ambiente associados ao terminal que contém um PDR. As interaçōes da 
classe Network podem ser vistas no diagrama LML de classes apresentado pela Figura 5.25. Lm termos de definição, a classe Network é formada pelos métodos e propricdades descritos pela Tabela 5.16.

Tabela 5.16 - Métodos da classe Network

\begin{tabular}{|c|c|}
\hline Método & Definiçāo \\
\hline setNetworkRaLe(short) & $\begin{array}{l}\text { Método que define a taxa de } \\
\text { transmissão em uma rede }\end{array}$ \\
\hline NetworkProperties verifyNetworkstatus (); & $\begin{array}{l}\text { Método que retorna as } \\
\text { propriedades de status de uma rede }\end{array}$ \\
\hline setCompliterinformation (Device); & $\begin{array}{l}\text { Método que define as informaçoes de } \\
\text { configuraçào de um computador como } \\
\text { um dispositivo do ambiente }\end{array}$ \\
\hline Preferences get NetworkRequirements (\rangle ; & $\begin{array}{l}\text { Método que retorna os requisitos } \\
\text { de uma rede de comunicaçào } \mathrm{cm} \\
\text { relaçào ao contexto }\end{array}$ \\
\hline \multicolumn{2}{|l|}{ String get.NetworkName (); } \\
\hline Identification getNetworkID(); & $\begin{array}{l}\text { Método que retorna a identificaçào } \\
\text { de uma rede como sendo um } \\
\text { elemento do ambiente }\end{array}$ \\
\hline \multicolumn{2}{|l|}{$\begin{array}{l}\text { String getprotocol Name (); } \\
\text { stort getNetworkRate }() ;\end{array}$} \\
\hline Device[] getNetworkAssociatedDevicelist (); & $\begin{array}{l}\text { Método que retorna a lista de } \\
\text { dispositivos associados a uma rede }\end{array}$ \\
\hline
\end{tabular}

\subsubsection{A classe Profile}

A classe Profile contém mélodos e atributos que fornecem informações sobre as características de um perfil de um elemento do ambiente, bem como a lista das interaçóes possíveis c yuais os tipos de busca disponíveis. As interaçoes da classe Profile podem ser vistas no diagrama UML de classes apresentado pela Figura 5.25. Em termos de definição, a classe Profile é formada pelos métodos e propriedades descritos pela Tabela 5.17.

Tabela 5.17 - Métodos da classe Profile

\begin{tabular}{|c|c|}
\hline Atributos & \\
\hline String name; & Nome do perfil \\
\hline String program; & $\begin{array}{l}\text { Nome do programa que originou } \\
\text { um perfil }\end{array}$ \\
\hline boolean searchwww; & $\begin{array}{l}\text { Informa se é permitida a busca de } \\
\text { informaçoes no ambiente da } \\
\text { WWW }\end{array}$ \\
\hline boolean searchscene; & $\begin{array}{l}\text { Informa se é permilida a busca de } \\
\text { informacoes êm uma cena }\end{array}$ \\
\hline boolean intrascenetree; & $\begin{array}{l}\text { Informa se é possivel a interação } \\
\text { com o grafo de objetos da cena }\end{array}$ \\
\hline
\end{tabular}




\begin{tabular}{|c|c|}
\hline & \\
\hline boolean interscenetree: & $\begin{array}{l}\text { Informa se há conexão entro } \\
\text { grafos de conasa diferentes, } \\
\text { permitindo a interaçào entro } \\
\text { cenas }\end{array}$ \\
\hline Métodos & Definição \\
\hline setProfileName (string): & $\begin{array}{l}\text { Método que define um nome para } \\
\text { un profile }\end{array}$ \\
\hline setProgramName (string); & $\begin{array}{l}\text { Método que define um nome para } \\
\text { um programa que originou um } \\
\text { profile }\end{array}$ \\
\hline Identification getTDPerson(); & $\begin{array}{l}\text { Metodo que retorna a identificaçào } \\
\text { de un usuario que pode ser } \\
\text { associado a um profile }\end{array}$ \\
\hline setsearchInwwis (boolean); & $\begin{array}{l}\text { Mátodo que define o estado } \\
\text { (TRUE ou FALSE) para a busca } \\
\text { no ambiente da WWW }\end{array}$ \\
\hline setSearchInScene (boolean); & $\begin{array}{l}\text { Vétodo yue define o estado } \\
\text { (lRUE ou FALSE) para a buscáa } \\
\text { dentro de uma cena }\end{array}$ \\
\hline setsearchInterscene (Scene [], boolean); & $\begin{array}{l}\text { Método que define o estado } \\
\text { (TRUE ou FAISE) parat a busca } \\
\text { entre cenas }\end{array}$ \\
\hline SetInteract i onwithsceneTree (sccne, booleari); & $\begin{array}{l}\text { Método que define a } \\
\text { possibilidacle de interaçào com o } \\
\text { grafo de objetos de uma cena }\end{array}$ \\
\hline Interaction [. get InteractionList (Scene); & $\begin{array}{l}\text { Método yue retorna a lista de } \\
\text { interaçoes possíveis em unia cena } \\
\text { en rolaşao a um prolile? }\end{array}$ \\
\hline
\end{tabular}

\subsubsection{A classe UserPreference}

A classe UserPreference armazena as preferências do usuário para um determinada profile de programa interativo, incluindo as mudanças em relaçáo ap menu, controles de interaçao, layout e o profile como um todo. As interaçóes da classe UserPreference podem ser vistas no diaģrama UML de classes apresentado pela Figura 5.25. Em termos de definição, a classe UserPreference é formada pelos métodos e propricdades clescritos pela Tabela 5.18.

Tabela 5.18 - Métodos da classe UserPreference

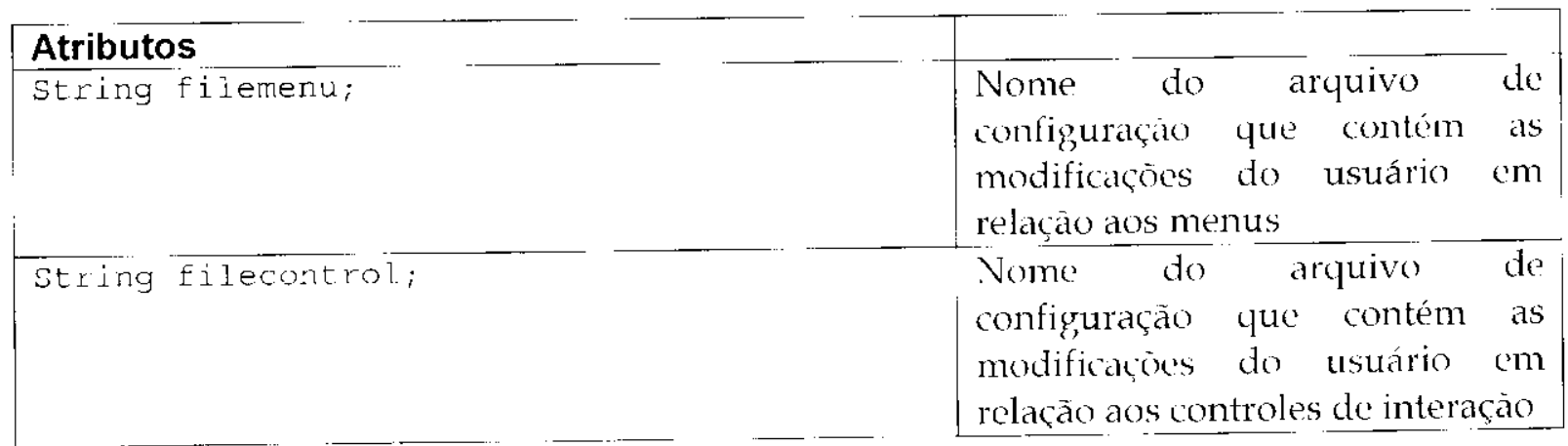




\begin{tabular}{|c|c|}
\hline String filelayout; & $\begin{array}{l}\text { Nome do arquivo } \\
\text { configuraça que contém as } \\
\text { modificaçes do usuário em } \\
\text { relação ao layout das interfaces } \\
\text { gráficas }\end{array}$ \\
\hline String fileprofile & $\begin{array}{l}\text { Nome do arquivo do } \\
\text { configuração que contém as } \\
\text { modificaçóes do usuário em } \\
\text { relação ao profile como um todo }\end{array}$ \\
\hline Métodos & Definição \\
\hline Media [] getAvailableMedia(Profile); & $\begin{array}{l}\text { Metodo que retorna uma lista das } \\
\text { mídias disponiveis para uso em um } \\
\text { delerminado perfil de programa } \\
\text { interativo }\end{array}$ \\
\hline $\begin{array}{c}\text { setcustompiles (Profile, string, string, } \\
\text { String, string); }\end{array}$ & $\begin{array}{l}\text { Método que define os arquivos de } \\
\text { personalização contendo as } \\
\text { preferências do usuário }\end{array}$ \\
\hline
\end{tabular}

\subsubsection{A classe Layout}

A classe Layout contém as propriedades de um layout gráfico para um profile de um programa interativo. As interaçöes da classe Layout podem ser vistas no diagrama LMI. de classes apresentacto pela Figura 5.25. Em termos de definiçâo, a classe Layout é formada pelos métodos e propriedades descritos pela Tabela 5.19.

Tabela 5.19 - Métodos da classe Layout

\begin{tabular}{|c|c|}
\hline Atributos & \\
\hline vector [] mediaposition; & $\begin{array}{l}\text { Um vetor com yuatro campos: o } \\
\text { primeiro deve conter o ID de um } \\
\text { objeto de mídia; o segundo deve } \\
\text { conter a posiçào da mídia no eixo } \\
\text { cartesiano } X \text {; o terceiro deve } \\
\text { conter a posição da mídia no cixo } \\
\text { cartesiano } Y \text {; o quarto deve conter } \\
\text { a posiçào da mídia no eixo } \\
\text { cartesiamo } 7 \text {, quando o layout for } \\
\text { no plano 3D. }\end{array}$ \\
\hline long int bgcolor; & $\begin{array}{l}\text { Valor da cor de fundo do layoul } \\
\text { de um programa }\end{array}$ \\
\hline Métodos & Definição \\
\hline setmediaposition(Identification, vector); & $\begin{array}{l}\text { Método que define a posição de uma } \\
\text { mídia em uma interface yráfica }\end{array}$ \\
\hline SetBackgroundColor(lont int); & $\begin{array}{l}\text { Método que define a cor de fundo } \\
\text { do layout de um programa }\end{array}$ \\
\hline
\end{tabular}




\subsubsection{A classe Menu}

A classe Menu contém as propriedades de un menu gráfico para um profile de um programa interativo. As interaçòes da classe Menu podem ser vistas no diagrama UML de classes apresentado pela Figura 5.25. Em termos de definiçào, a classe Menu é formada pelos métodos e propriedades descritos pela Tabela 5.20.

Tabela 5.20 - Métodos da classe Menu

\begin{tabular}{|c|c|}
\hline \multicolumn{2}{|l|}{ Atributos } \\
\hline string tontname; & $\begin{array}{l}\text { O nome da fonle padrào utilizada } \\
\text { nos controles do menu }\end{array}$ \\
\hline long int fortcolor; & $\begin{array}{l}\text { Valor da cor da fonte dos controles } \\
\text { do menu }\end{array}$ \\
\hline$\overline{\text { short fontsize; }}$ & $\begin{array}{l}\text { Valor do tamanho da fonte padräo } \\
\text { utilizada nos controles do menu }\end{array}$ \\
\hline vector elements; & $\begin{array}{l}\text { Um vetor contendo todos os } \\
\text { clementos que compóem o menu }\end{array}$ \\
\hline Métodos & Definição \\
\hline setFontName (string); & \\
\hline setFontColor (long int); & \\
\hline setFont Name $($ string); & \\
\hline setFontsize (short); & \\
\hline addelement (Esement); & $\begin{array}{l}\text { Método que adiciona um elemento } \\
\text { a um menu }\end{array}$ \\
\hline setelement Index(int); & $\begin{array}{l}\text { Método yue define a posiça do } \\
\text { elemento no vetor de elementos do } \\
\text { menu }\end{array}$ \\
\hline vector getelementsofmenu(); & $\begin{array}{l}\text { Metodo que retorna um vetor de } \\
\text { elementos que compoem um menu }\end{array}$ \\
\hline
\end{tabular}

\subsubsection{A classe Control}

$\Lambda$ classe Control contém as propriedales de todos os controles associantos a um profile de um programa interativo. As interaçöes da classe Control podem ser vistas no diagrama UML de classes apresentado pela Figura 5.25. En termos de definiçào, a classe Control é formada pejos métodos e propriedades descritos pela Tabela 5.21 .

labela 5.21 - Métodos da classe Control

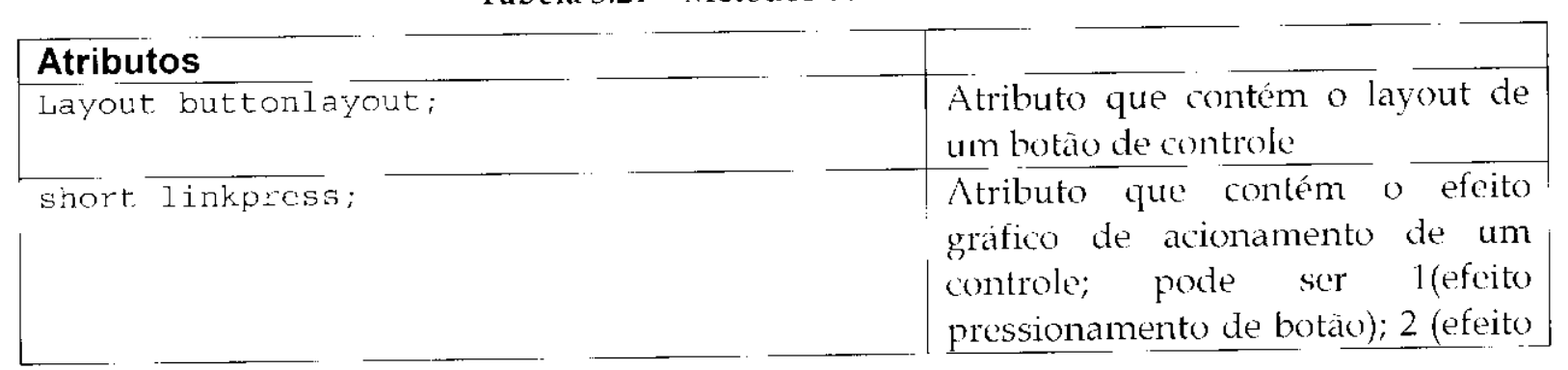




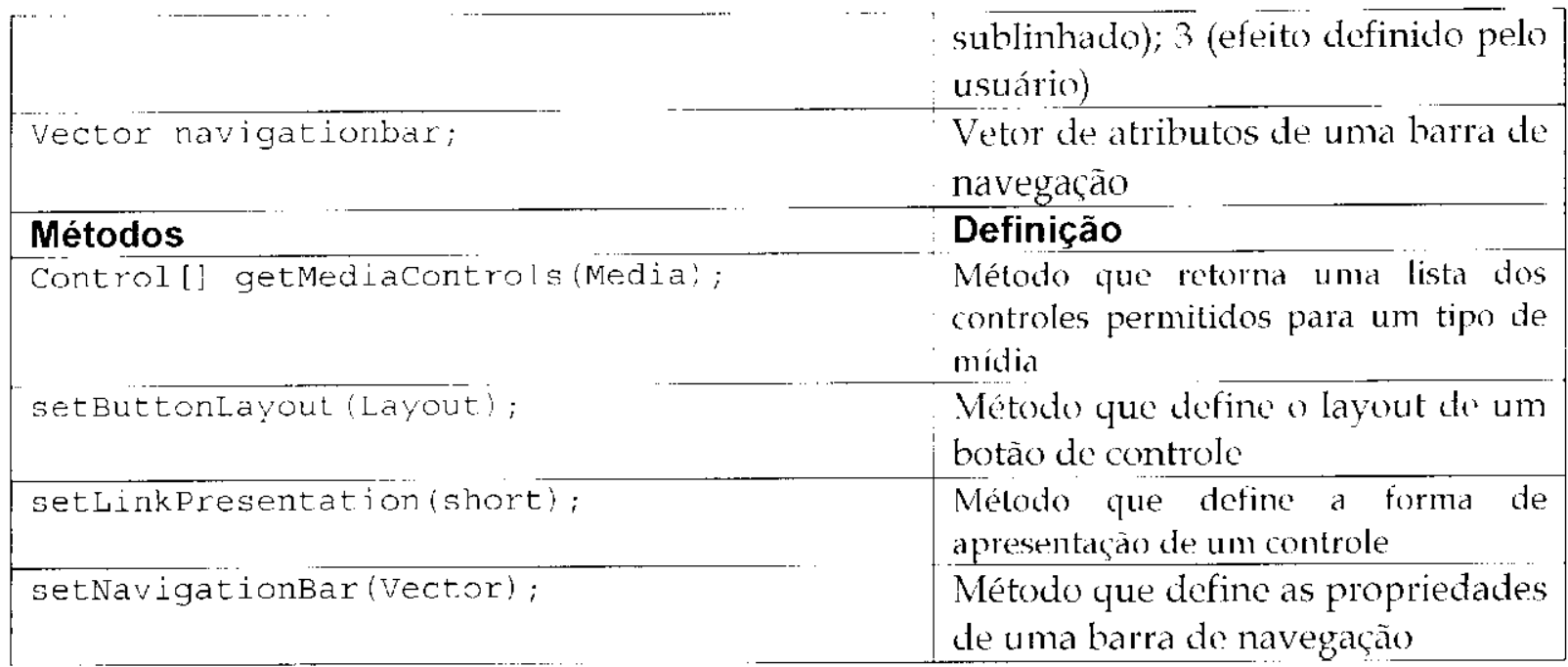

\subsubsection{A classe Communication}

A classe Communication contém as características necessárias tanto ao nível da rede quanto ao nível dos recursos de hardware locais para a apresentaçào de cada mídia è do profile como um todo. As interaçôes da classe Communication podem ser vistas no diagrama UML de classes apresentado pela Figura 5.25. Em termos de definiçăo, a classe Communication é formada pelos métodos e propriedades descritos pela Tabela 5.22.

Tabela 5.22 - Métodos da classe Communication

\begin{tabular}{|c|c|}
\hline Atributos & \\
\hline Vector profileband; & $\begin{array}{l}\text { Lm vetor de propriedades da } \\
\text { banda passante necessária para um } \\
\text { determinado profile }\end{array}$ \\
\hline Vector profilerequirements; & $\begin{array}{l}\text { Um vetor de requisitos de um } \\
\text { recurso formado por dois campos: } \\
\text { o primciro deve conter o ID de um } \\
\text { recurso; o segundo, uma lista das } \\
\text { características desse recurso }\end{array}$ \\
\hline Método & Definição \\
\hline setFrofi:eBard(vector); & $\begin{array}{l}\text { Método que define as propriedades da } \\
\text { banda passante para um determinado } \\
\text { profile }\end{array}$ \\
\hline setProfileRequirements (Vector); & $\begin{array}{l}\text { Método que define os requisitos } \\
\text { computacionais necessários para } \\
\text { uso de um recurso em um profile } \\
\text { (por exemplo, codificadores, } \\
\text { decodificadores, processadores) }\end{array}$ \\
\hline
\end{tabular}

\subsubsection{A classe Context}

A classe Context relaciona as características contextuais necessárias para um profile de programa interativo. Vale ressaltar que as classes de contexto (Identification, Time, Activity 
e Location) usufurem das informaçoes capturadas pela classe Context. Desta forma, a classe? Context funciona como uma coletora de informaçöes contextuais, construindo listas (vetores) com essas informaçōes coletadas do ambiente. As interaçòes da classe Context podem ser vistas no diagrama UMI, de classes apresentado pela Figura 5.25. Em termos de definiçào, a classe Context é formada pelos métodos e propriedades descritos pela Tabela 5.23.

Tabela 5.23 - Métodos da classe Context

\begin{tabular}{|c|c|}
\hline \\
\hline Atributos & \\
\hline Vector ndevice; & $\begin{array}{l}\text { Um vetor dos dispositivos } \\
\text { pertinentes a um determinado } \\
\text { profile }\end{array}$ \\
\hline vector nmedia; & $\begin{array}{l}\text { Um vetor das midias pertinenles a } \\
\text { um determinado profile }\end{array}$ \\
\hline Vector nperson; & $\begin{array}{l}\text { Um vetor das pessoas pertinentes a } \\
\text { um determinado profile }\end{array}$ \\
\hline Método & Definição \\
\hline setNecessaryDevice (Device); & \\
\hline setNecessaryperson (Person); & \\
\hline setNecessaryMedia (Media); & \\
\hline Vector getNecessaryDevice (); & \\
\hline Vector get NecessaryPerson(); & \\
\hline Vector getNecessarymedia(); & \\
\hline
\end{tabular}

\subsubsection{A classe Interaction}

A classe Interaction contém as propriedades yue definem uma interaçào entre todos os dementos do ambiente. Cada interaçào deve ser identificada e relacionar duas ou mais entidades do ambiente interativo consciente de contexto. Observa-se, então, que as interaçōes estão diretamente relacionadas com as classes contextuais. As interaçōes da classe Interaction podem ser vistas no diagrama LMI de classes apresentado pela Figura 5.25. Em termos de definição, a classe Interaction é formada pelos métodos e propricdades descritos pela Tabela 5.24 .

Tabela 5.24 - Méfodos da classe Interaction

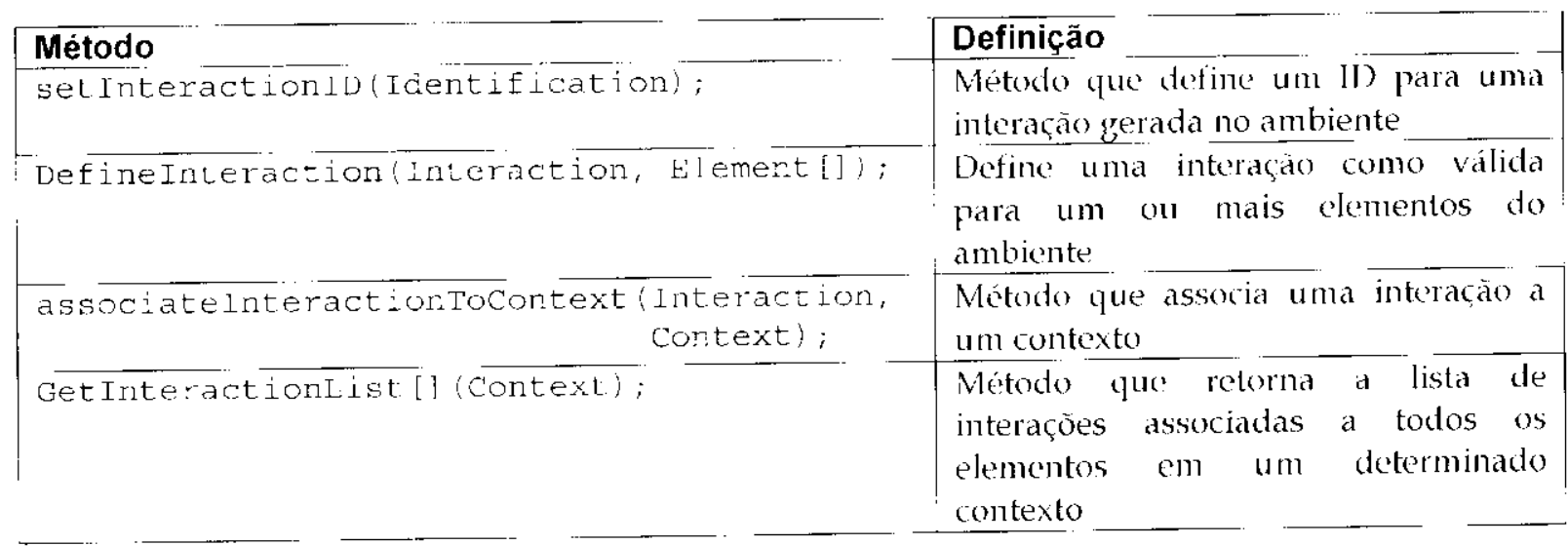




\subsubsection{A classe Identification}

A classe Identification é responsável pelas operaçoes de identificaça de pessoas e elementos que fazem parte de um programa interativo insericto em um ambiente consciente de contexto. Neste sentido, a classe Identification provê mecanismos que identificam sumariamente esses elementos, permitindo a execução de açôes associadas a uma lista de atividades e considerando as condiçōes de localizaçăo e tempo. As interaçóes da classe Identification podem ser vistas no diagrama UML de classes apresentado pela Figura 5.25. Em termos de definição, a classe Identification é formada pelos métodos e propriedades descritos pela Tabela 5.25 .

'Tabela 5.25 - Métodos da classe Identification

\begin{tabular}{|c|c|}
\hline Método & Definição \\
\hline Identification get 1 DPerson(Person); & $\begin{array}{l}\text { Método que retorna a } \\
\text { identificaça única de uma } \\
\text { pessoa em um programa, a } \\
\text { partir da interasao com um PDR }\end{array}$ \\
\hline Identification get [DF] ement (Element); & $\begin{array}{l}\text { Método que retorna a } \\
\text { identificaça unica de um } \\
\text { elemento en uma cena, } \\
\text { permitindo a associação com } \\
\text { descriçoes de cena e modelos de } \\
\text { eventos }\end{array}$ \\
\hline $\begin{array}{l}\text { Identification } \\
\text { getIDInformationElement (InformationElement); }\end{array}$ & $\begin{array}{l}\text { Método que retorna a } \\
\text { identificaça única do um } \\
\text { elemento de informação em } \\
\text { uma cena, permitindo a } \\
\text { associação com modelos de } \\
\text { eventos. }\end{array}$ \\
\hline Tdentification get TDIJevice () ; & $\begin{array}{l}\text { Método que retorna a } \\
\text { identificaçao unica de um device } \\
\text { que permite iNPUT/OUTPUT } \\
\text { em um programa. }\end{array}$ \\
\hline associaterDLocation (Tdentification, Location); & $\begin{array}{l}\text { Método que permite a } \\
\text { associaçà de dados de } \\
\text { identificação a um mapa de } \\
\text { localização de pessoas, } \\
\text { clementosedevices. }\end{array}$ \\
\hline associate? DActivity (Identification, Activity); & $\begin{array}{l}\text { Método que permite a } \\
\text { associação de uma identificação } \\
\text { a uma atividade ou lista de } \\
\text { atividades. }\end{array}$ \\
\hline Identification[] getListlDTime(Time, Timeline); & $\begin{array}{l}\text { Método que retorna uma lista de } \\
\text { identificadores de elementos } \\
\text { que realizam alguma atividade } \\
\text { em um instante de tempo Tem } \\
\text { uma timelime }\end{array}$ \\
\hline
\end{tabular}




\subsubsection{A classe Location}

A classe Location é responsável pelas operaçòes de localizaçào de pessoas e elementos que fazem parte de um programa interativo inserido em um ambiente consciente de contexto. A classe Identification manipula, conceitualmente, um mapa de localizaçào, que contém os elementos diretamente associados ao programa e também os elementos do ambiente como um todo, como é o caso da localização de devices que permitem a interaçào com o programa através de um PDR. As interaçoes da classe Location podem ser vistas no diagrama U.ML de classes apresentado pela Figura 5.25. Em termos de definição, a classe Location é formada pelos métodos e propriedades descritos pela Tabela 5.26 .

Tabela 5.26 - Métodos da classe I ocation

\begin{tabular}{|c|c|}
\hline Método & Definição \\
\hline Location GetPositionPersonscere (Person); & $\begin{array}{l}\text { Método que permite obter a } \\
\text { posiça corrente de uma pessoa } \\
\text { em uma cena de um programa. }\end{array}$ \\
\hline Location GetPositionelementscene (Element); & $\begin{array}{l}\text { Método que permite oliter a } \\
\text { posiça corrente de um elemento } \\
\text { em uma cona de um programa. }\end{array}$ \\
\hline Location GetpositionDevice(Device): & $\begin{array}{l}\text { Método que permite obter a } \\
\text { posição corrente de um device } \\
\text { associado a um programa através } \\
\text { de um PDR. }\end{array}$ \\
\hline EnablepersonbocationMonitor (Person, booiean); & $\begin{array}{l}\text { Metodo que habilita/desabilita a } \\
\text { associaçăo de um monitor de } \\
\text { presença para uma pessoa em um } \\
\text { programa. }\end{array}$ \\
\hline $\begin{array}{l}\text { EnableElementLocationmonitor(Monitor, } \\
\text { Doolean); }\end{array}$ & $\begin{array}{l}\text { Método que habilita/desabilita a } \\
\text { associaça de um monitor de } \\
\text { presença para um elemento em } \\
\text { um programa. }\end{array}$ \\
\hline EnabledeviceLocationMonitor(Device, boolean); & $\begin{array}{l}\text { Método yue habilita/desabilita a } \\
\text { associaçào de um monitor de } \\
\text { presença para um device em um } \\
\text { programa. }\end{array}$ \\
\hline Location getLocationdataSensor(Sensor); & $\begin{array}{l}\text { Mctodo que permite obter a } \\
\text { posiçăo corrente de um sensor de } \\
\text { dados no ambiente }\end{array}$ \\
\hline
\end{tabular}

\subsubsection{A classe Activity}

A classe Activity é responsável por operaçóes que permitem o acesso às atividades de um programa. Entende-se por atividade como sendo um item de programação em execução, a partir do dispara de eventos ou açöes pré-programadas. A classe Activity relaciona-se diretamente com as classes Identification, Location e Time, resultando em operaços conjugadas, quanto da definição dos niveis de consciência de contexto associados a uma 
atividade ou lista de atividades. As interaçoes da classe Activity podem ser vistas no diagrama UMI. de classes apresentado pela Figura 5.25. Em termos de definiçäo, a classe Activity é formada pelos métodos e propriedades descritos pela Tabela 5.27.

Tabela 5.27 - Métodos da classe Activity

\begin{tabular}{|c|c|}
\hline & \\
\hline Método & Definição \\
\hline Identification getactivityID(); & $\begin{array}{l}\text { Método que retorna a identificaçào } \\
\text { sumária de uma atividade em uma } \\
\text { cena de um programa. }\end{array}$ \\
\hline Activity [] getActivitiestistPerson(Person); & $\begin{array}{l}\text { Método que retorna a lista de } \\
\text { atividades associadas a uma pessoa } \\
\text { em uma cena de um programa. }\end{array}$ \\
\hline Activity[] getActiviticsistscene(); & $\begin{array}{l}\text { Método yue retorna o schedule de } \\
\text { todas as atividades programadas } \\
\text { para uma cena em um programa. }\end{array}$ \\
\hline Activity getcurrentActivityperson(); & $\begin{array}{l}\text { Método que retorna a identificaçào } \\
\text { e as propriedades da atividade } \\
\text { correntemente associada a uma } \\
\text { pessoa. }\end{array}$ \\
\hline Vector getTimedateActivity(); & $\begin{array}{l}\text { Método que retorna os dados } \\
\text { temporais (tempo e data) } \\
\text { associados a uma atividade, } \\
\text { especialmente em termos de } \\
\text { cronometragem. }\end{array}$ \\
\hline updateActivityperson (Persor, Activity); & $\begin{array}{l}\text { Método que permite atualizar a } \\
\text { associaçào de uma atividacte a uma } \\
\text { pessoa, considerando-se aspectos } \\
\text { de consciência de contexto como a } \\
\text { localizaça, a identificaça e o } \\
\text { tempo. }\end{array}$ \\
\hline $\begin{array}{r}\text { updateEventListForActivity (Event [], } \\
\text { Activity); }\end{array}$ & $\begin{array}{l}\text { Método que permite atualizar a } \\
\text { lista de eventos válidos para uma } \\
\text { atividade, considerando-se aspectos } \\
\text { de consciência de contexto como a } \\
\text { localizaça, a identificaçăo e o } \\
\text { tempo. }\end{array}$ \\
\hline Person [] selectPersonsforActivity(); & $\begin{array}{l}\text { Método que retorna a lista de } \\
\text { pessods associaclas a uma } \\
\text { atividade. }\end{array}$ \\
\hline associateActivityElement (Element, Activity); & $\begin{array}{l}\text { Metodo que associa uma atividade } \\
\text { a uma pessod ou telemento do } \\
\text { ambiente }\end{array}$ \\
\hline
\end{tabular}

\subsubsection{A classe Time}

A classe Time é responsável por operaçōes que permitem o acesso aos dados temporais de uma cena em um programa. Entende-se por dados temporais como sendo os valores definidos na pré-programaçăo de uma timeline', e também os valores de tempo associados à execuçà de atividades, localização de pessoas, elementos e devices. Observa-se que a classe Time tem relacionamento direto com a pré-programação baseada na timeline e também com 
as preferências associadas a um PDR. As interaçóes da classe Time podem ser vistas no diagrama UML de classes apresentado pela Figura 5.25. Em termos de definição, a classe Time é formada pelos métodos e propriedades descritos pela Tabela 5.28.

Tabela 5.28 - Métodos da classe Time

\begin{tabular}{|c|c|}
\hline Método & Definição \\
\hline getTime(); & $\begin{array}{l}\text { Método que retorna a hora corrente, } \\
\text { considerando-se um padrão de } \\
\text { referencia previamente definido no } \\
\text { prosrama, como por exemplo o cinli. }\end{array}$ \\
\hline get Temporaldata(); & $\begin{array}{l}\text { Metodo que retorna os dados } \\
\text { temporais associados a qualquer } \\
\text { pessoa (como por exemplo, o tempo } \\
\text { total de interaça contre uma pessoa e } \\
\text { um device), elemento, agente ou } \\
\text { device ('m um programa. }\end{array}$ \\
\hline \multicolumn{2}{|l|}{ setrime(); } \\
\hline set'i'emporaldata(); & $\begin{array}{l}\text { Método que retorna os dados } \\
\text { associados a pré-programaçăo de datas } \\
\text { para ocorréncia de eventos } \mathrm{c} / \mathrm{ou} \\
\text { execuçăo de atividades em um } \\
\text { programa. }\end{array}$ \\
\hline \multicolumn{2}{|l|}{ getDate () ; } \\
\hline \multicolumn{2}{|l|}{ setDate ()$;$} \\
\hline getTimeDateListPerson(); & $\begin{array}{l}\text { Método yue retorna a lista de todos os } \\
\text { dados temporais (time e date) } \\
\text { associados a uma pessoa. }\end{array}$ \\
\hline getTimeDateListElement (); & $\begin{array}{l}\text { Método yue retorna a lista de todos os } \\
\text { dados temporais (time e date) } \\
\text { associados a um elemento }\end{array}$ \\
\hline getTimedateI,ist Device(); & $\begin{array}{l}\text { Metodo yue retorna a lista de todos } \\
\text { os dados temporais (time c date) } \\
\text { associados a um device. }\end{array}$ \\
\hline
\end{tabular}

\subsubsection{A classe Listener}

A classe Listener é uma interface que pode ser associada a qualquer atividade programada para uma cena, permitindo a notificaçào de ocorrência de eventos. As interaçòes da classe Listener podem ser vistas no diagrama U.ML de classes apresentado pela Figura 5.25. Em termos de definiçào, a classe Listener é formada pelos métodos e propriedades descritos pela

Tabela 5.29.

Tabela 5.29 - Métodos da classe Listener

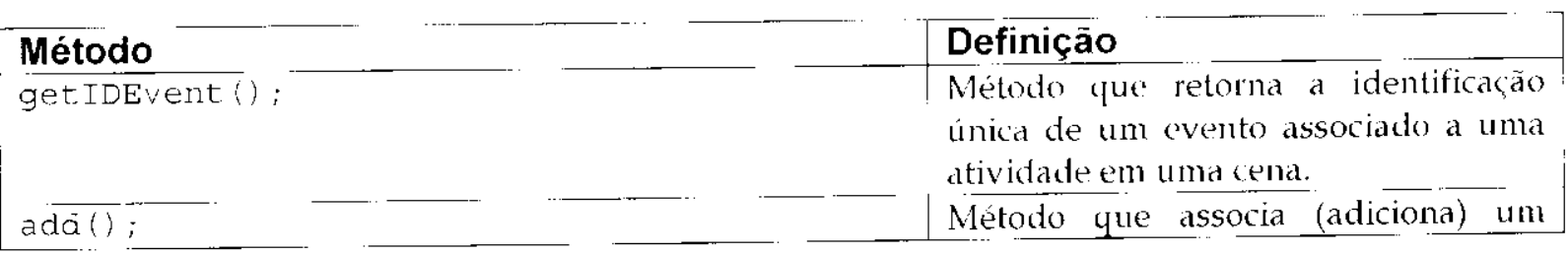


remove ()$^{\prime}$;

equals () listencr (notificador de eventos) a uma atividade em uma cena.

Método que remove um listencr (notificador de eventos) de uma atividade em uma cena.

Metodo que verifica se um listener é igual a outro listener presente em uma cena.

\subsubsection{A classe Monitor}

A classe Monitor é uma interface que pode monitorar qualquer ator (pessoas, elementos, agentes e devices) em um programa interativo inserido em um ambiente consciente de contexto e notificar dados e propriedades desses atores, seja em estado de inércia ou quando em estado de execuçào de alguma atividade. As interaçōes da classe Monitor podem ser vistas no diagrama UML de classess apresentado pela Figura 5.25. Em termos de definiçào, a classe Monitor é formada pelos métodos e propriedades descritos pela Tabela 5.30.

Tabela 5.30 - Métodos da classe Monitor

\begin{tabular}{|c|c|}
\hline Método & Definição \\
\hline getActorAssociatedToMonitor (); & $\begin{array}{l}\text { Método que retorna a identificaçào do ator } \\
\text { ao qual um monitor esta associado. }\end{array}$ \\
\hline $\operatorname{ada}()$ & $\begin{array}{l}\text { Método que associa (adiciona) um monilor a } \\
\text { um ator em um programa. }\end{array}$ \\
\hline remove (); & $\begin{array}{l}\text { Método que remove um monitor de um } \\
\text { programa. }\end{array}$ \\
\hline getListMonitorFunctions (); & $\begin{array}{l}\text { Método que retorna a lista de funçós de } \\
\text { um monitor. }\end{array}$ \\
\hline
\end{tabular}

\subsubsection{A classe Program}

A classe Program contém as propriedades mais genéricas de um programa interativo, identificando as características que catalogam um programa. As interações da classe Program podem ser vistas no diagrama UML de classes apresentado pela Figura 5.25. Em termos de definição, a classe Program é formada pelos métodos e propriedades descritos pela Tabela 5.31 .

Tabela 5.31 - Métodos da classe Program

\begin{tabular}{|c|c|}
\hline Método & Definição \\
\hline Time getDuration(); & $\begin{array}{l}\text { Método que retorna dados de tempo } \\
\text { de duração de um programa }\end{array}$ \\
\hline Time getEndTime(); & $\begin{array}{l}\text { Método que retorna dados de tempo } \\
\text { quando do encerramento de um } \\
\text { programa }\end{array}$ \\
\hline string getProgram Name (); & $\begin{array}{l}\text { Método que retorna o nome de um } \\
\text { programa }\end{array}$ \\
\hline Scene [] getscenestolist (); & Método que retorna uma lista de \\
\hline
\end{tabular}




\begin{tabular}{|c|c|}
\hline & $\begin{array}{l}\text { identificadores das cenas de um } \\
\text { programa }\end{array}$ \\
\hline Time getstartTime(); & $\begin{array}{l}\text { Método yue retorna dados de tempo } \\
\text { quando do início de um programa }\end{array}$ \\
\hline Person[] getpersonsList (); & $\begin{array}{l}\text { Método yue retorna uma lista de } \\
\text { pessoas yue interagem com um } \\
\text { programa }\end{array}$ \\
\hline Element! getElementsloList (); & $\begin{array}{l}\text { Método que retorma uma lista de } \\
\text { identificadores dos elementos } \\
\text { associados a un programa }\end{array}$ \\
\hline Vector getmetaInformationnulnors () ; & $\begin{array}{l}\text { Método yue restoma as propricdades, } \\
\text { na forma de lista de meta-informaçào, } \\
\text { dos autores des un programa }\end{array}$ \\
\hline
\end{tabular}

\subsubsection{A classe Sensor}

A classe Sensor contém as propriedades de um sensor, que é identificado como um elemento do ambiente. Um sensor fornece dados do ambiente o auxilia no controle desse ambiente através dos aspectos de consciência de contexto. As interaçoes da classe Sensor podem ser vistas no diagrama UML de classes apresentado pela Figura 5.25. Em termos de definiçào, a classe Sensor é formada pelos métodos e propriedades descritos pela Tabela 5.32.

Tabela 5.32 - Métodos da classe Sensor

\begin{tabular}{|c|c|}
\hline & \\
\hline Método & Definição \\
\hline short getsensorlype(); & $\begin{array}{l}\text { Método que retorna o tipo de sensor; } 1 \text {, } \\
\text { para sensores contextuais; } 2 \text {, para } \\
\text { sensores embuticlos em dispositivos do } \\
\text { ambiente }\end{array}$ \\
\hline Identification getsensorfD(); & $\begin{array}{l}\text { Método que retorna o II) de um } \\
\text { sensor }\end{array}$ \\
\hline Context [] getsensorRange(); & $\begin{array}{l}\text { Método que retorna o contexto no qual } \\
\text { a atuação de um sensor é válida }\end{array}$ \\
\hline enablesensor(); & $\begin{array}{l}\text { Método que habilita o uso de um } \\
\text { sensor no ambiente }\end{array}$ \\
\hline disablesensor(); & $\begin{array}{l}\text { Método que desabilita o uso de um } \\
\text { sensor no ambiente }\end{array}$ \\
\hline associatesensormonitor(Monitor); & $\begin{array}{l}\text { Método que associa um sensor a } \\
\text { um monitor de eventos }\end{array}$ \\
\hline
\end{tabular}

\subsubsection{A classe Schedule}

A classe Schedule fornece métodos para acesso às propriedades de controle de uma programação, que contém um programa interativo. As interaçoes da classe Schedule podem ser vistas no diagrama UML de classes apresentado pela Figura 5.25. Em termos de definição, a classe Schedule é formada pelos métodos e propriedades descritos pela Tabela 5.33 . 
Tabela 5.33 - Métodos da classe Schedule

\begin{tabular}{|c|c|}
\hline Método & Definição \\
\hline addActivity (Activity); & $\begin{array}{l}\text { Método que adiciona uma atividade ao } \\
\text { schedule de um programa }\end{array}$ \\
\hline Control [] get.DeviceControls(); & $\begin{array}{l}\text { Método que reforna a lista dos } \\
\text { controles presentes em um programa }\end{array}$ \\
\hline Identification [] getTDDevice(); & $\begin{array}{l}\text { Método que retorna a lista do } \\
\text { identificadores do dispositivos } \\
\text { presentes em um programa }\end{array}$ \\
\hline addListenerforActivity (Listener): & $\begin{array}{l}\text { Método que adiciona um listener para } \\
\text { uma atividade em um programa }\end{array}$ \\
\hline Event [] get Programevenes (); & $\begin{array}{l}\text { Metodo que retorna uma lista dos } \\
\text { eventos associados a um programa }\end{array}$ \\
\hline Activity[l getProgramActivitiesl:; & $\begin{array}{l}\text { Método que retorna uma lista de } \\
\text { atividades associadas a um programa }\end{array}$ \\
\hline
\end{tabular}

\subsubsection{A classe Element}

A classe Element contém as propriedades singulares de um elemento do ambiente, sendo, que o clemento é definido como sendo qualyuer entidade do ambiente. As interaçoes da classe Element podem ser vistas no diagrama L.ML de classes apresentado pela Figura 5.25. Em termos de definição, a classe Llement é formada pelos métodos e propriedades descritos pela Tabela 5.34 .

Tabela 5.34 - Métodos da classe Element

\begin{tabular}{|c|c|}
\hline Método & Definição \\
\hline Idertification getIDElement (); & $\begin{array}{l}\text { Método que retorna o ID de um } \\
\text { elemento }\end{array}$ \\
\hline setIDElement (Idencification); & $\begin{array}{l}\text { Método que define um ID para um } \\
\text { elemento }\end{array}$ \\
\hline Location getLocationelement (); & $\begin{array}{l}\text { Método que retorma a Jocalização de } \\
\text { um clemento no ambiente }\end{array}$ \\
\hline Event [] getvalideventsisst (); & $\begin{array}{l}\text { Metodo que relorna a lista de } \\
\text { eventos associados a um elemento } \\
\text { do ambiente }\end{array}$ \\
\hline Properties getProperties (); & $\begin{array}{l}\text { Método que retorna as } \\
\text { propriedades de um elemento }\end{array}$ \\
\hline booiean equalsto(Elcment); & $\begin{array}{l}\text { Método que verifica se um } \\
\text { elemento é igual a outro elemento }\end{array}$ \\
\hline
\end{tabular}

\subsubsection{A classe InformationElement}

A classe InformationElement contém informaçôes de controle de todos os elementos de um ambiente. Vale ressaltar que um elemento de informaçăo (InformationElement) difere-se de um element (Element) cm termos conceituais, uma vez que um elemento refere-se diretamente a uma entidade do ambiente. As interaçoes da classe InformationElement podem ser vistas no diagrama LML de classes apresentado pela Figura 5.25. Hm termos de 
definiçào, a classe Informationtlement é formada pelos métodos e propriedades descritos pela Tabela 5.35 .

Tabela 5.35 - Métodos da classe InformationElement

\begin{tabular}{|c|c|}
\hline Método & Definição \\
\hline get TDTnformationElement (); & $\begin{array}{l}\text { Método que retorna o } \\
\text { identificador de um elemento de } \\
\text { informasão }\end{array}$ \\
\hline setidinformationelement (Identification); & $\begin{array}{l}\text { Método que define um II) para } \\
\text { um elemento de informaçăo }\end{array}$ \\
\hline Informationelement get InformationType (); & $\begin{array}{l}\text { Método que retorna as } \\
\text { informaçóes de ambiente } \\
\text { associadas a um elemonto de } \\
\text { informação }\end{array}$ \\
\hline Properties getProperties(); & $\begin{array}{l}\text { Método que retorna as } \\
\text { propriedades de um elemento de } \\
\text { informação }\end{array}$ \\
\hline Equajs'o( Tnformat ionelement); & $\begin{array}{l}\text { Método que verifica se um } \\
\text { elemento de informação è igual a } \\
\text { outro }\end{array}$ \\
\hline associate informationElement ToPerson(Person); & $\begin{array}{l}\text { Método que associa um elemento } \\
\text { de informlção a uma pessoa }\end{array}$ \\
\hline associateInformatiorElementToEiement (Element); & $\begin{array}{l}\text { Método yue associa um elemento } \\
\text { de informaçào a } \mathrm{um} \text { elemento do } \\
\text { ambiente }\end{array}$ \\
\hline associate Tnformationelement ToDevice (Device) & $\begin{array}{l}\text { Metodo que associa um elemento } \\
\text { de informacão a um dispositivo } \\
\text { do ambiente }\end{array}$ \\
\hline associateInformationElement ToMed & $\begin{array}{l}\text { Método que associa um clemento } \\
\text { de informação a uma midia em } \\
\text { uma cena }\end{array}$ \\
\hline
\end{tabular}

\subsubsection{A classe Media}

A classe Media permite o acesso às macro-informaçōes de uma mídia (objeto de múdia) em uma cena multimídia. Essas macro-informaçöes nào se referem às características técnicas de uma múdia, mas descrevem quais são as relaçoes de uma midia em uma cena e quais interaçòes são permitidas. As interaçoes da classe Media podem ser vistas no diagrama UML de classes apresentado pela Figura 5.25. Em termos de definição, a classe Media é formada pelos métodos é propriedades descritos pela Tabela 5.36 .

Tabela 5.36 - Métodos da classe Media

\section{Método} definemediatype (short) ; monitoringAddMediascene();

\section{Definição}

Método que define um tipo (Object l)escriptor) para uma mícia

Método que monitora a inserca de uma mídia a uma 


\begin{tabular}{|c|c|}
\hline & cena \\
\hline $\begin{array}{l}\text { Media } \\
\quad \text { get MediaTarget. Interaction (Interaction); }\end{array}$ & $\begin{array}{l}\text { Método que retorna yual mídia } \\
\text { está sendo alvo de una } \\
\text { interaçäo }\end{array}$ \\
\hline monitoringRemovemediascene(); & $\begin{array}{l}\text { Método que monitora a } \\
\text { remoçào de una mídia de } \\
\text { uma cena }\end{array}$ \\
\hline Media[] selectMediaListofscene(); & $\begin{array}{l}\text { Método que retorna uma lista } \\
\text { de todas as mídias inseridas } \\
\text { em uma cena }\end{array}$ \\
\hline addEventListForMedia (Event!]); & $\begin{array}{l}\text { Método que adiciona uma } \\
\text { lista de eventos a uma mídia }\end{array}$ \\
\hline addInformationforMedia (InformationElement); & $\begin{array}{l}\text { Método que adiciona um } \\
\text { elemento de informaçào a } \\
\text { uma mídia }\end{array}$ \\
\hline Control[] getContro]s(); & $\begin{array}{l}\text { Método que retorna uma lista } \\
\text { de todos os controles } \\
\text { permitidos sobre uma mídia }\end{array}$ \\
\hline $\begin{array}{l}\text { InformationElement [] } \\
\text { capturetnformationofMedia(); }\end{array}$ & $\begin{array}{l}\text { Mćtodo que captura todas as } \\
\text { informaçoes de uma mídia } \\
\text { como elemento de um } \\
\text { ambiente }\end{array}$ \\
\hline Properties get Properties(); & $\begin{array}{l}\text { Método que retorna as } \\
\text { propriedades físicas de uma } \\
\text { midia }\end{array}$ \\
\hline
\end{tabular}

\subsubsection{A classe Event}

A classe Event permite o acesso às informações sobre os eventos que ocorrem no ambiente interativo consciente de contexto. Desta forma, os eventos não são simplesmente disparadores de açós geradas a partir da interaçào do usuário, mas açóes que dependem das variáveis de contexto. As interaçôes da classe Event podem ser vistas no diagrama UML. de classes apresentado pela Figura 5.25. Em termos de definiçào, a classe Event é formada pelos métodos e propriedades descritos pela l'abela 5.37 .

Tabela 5.37 - Métodos da classe Event

\begin{tabular}{|c|c|}
\hline Método & Definiçāo \\
\hline Identification get IDEvent (); & $\begin{array}{l}\text { Metodo que relorna um identificador } \\
\text { de um evento }\end{array}$ \\
\hline setEvent ToActivity (Event [j, Activity[l); & $\begin{array}{l}\text { Método que define um evento ou } \\
\text { lista do eventos permitidos para } \\
\text { uma atividade ou lista de } \\
\text { atividades }\end{array}$ \\
\hline SetEvent ToMedia(Event [], Media []); & $\begin{array}{l}\text { Método que define um evento ou } \\
\text { lista de eventos permitidos para } \\
\text { uma mídia ou lista de midias }\end{array}$ \\
\hline boolear equalsto (Fvent); & $\begin{array}{l}\text { Método que verifica se um evento é } \\
\text { igual a outro evento }\end{array}$ \\
\hline Event getLastevent (); & Método yue retorna o ultimo \\
\hline
\end{tabular}




\begin{tabular}{|l|l|}
\hline & $\begin{array}{l}\text { evento que ocorreu no ambiente } \\
\text { como um todo }\end{array}$ \\
\hline Event [] getEventTime (Time); & $\begin{array}{l}\text { Método que retorna o cvento (ou } \\
\text { lista de eventos) associado a um } \\
\text { elemento de tempo no ambiente }\end{array}$ \\
\hline Event [] getEventList $(E$ lement); & $\begin{array}{l}\text { Metodo que retorna a lista de todos } \\
\text { os eventos ocorridos em um } \\
\text { elemento do ambiente }\end{array}$ \\
\hline
\end{tabular}

\subsubsection{A classe Timeline}

A classe Timeline contém as propriedades de um equipamento do ambiente, as propriedades de personalizaçào de um PDR e as descriçoes sobre a interação desse PDR com outros dispositivos do ambiente, tais como os sensores, por exemplo. Ressalta-se, novamente, que um PDR deve ser especificado e visto como elemento central da interaçāo do usuário com um programa interativo. As interaçoes da classe Timeline podem ser vistas no diagrama UML de classes apresentado pela Figura 5.25. Em termos de delinição, a classe Timeline é formada pelos métodos e propriedades descritos pela Tabela 5.38.

Tabela 5.38 - Métodos da classe Timeline

\begin{tabular}{|c|c|}
\hline & \\
\hline Método & Definição \\
\hline Time getDuration(); & $\begin{array}{l}\text { Metodo que retorna o tempo total } \\
\text { de duração de uma timeline para } \\
\text { uma cena }\end{array}$ \\
\hline Time setDuration(); & $\begin{array}{l}\text { Método qua define o lempo total } \\
\text { de duração de uma timeline para } \\
\text { uma cena }\end{array}$ \\
\hline Element [] get ParallelElementList (Time); & $\begin{array}{l}\text { Mélodo que retorna a lista de } \\
\text { todos os elementos que se } \\
\text { relacionam no ambiente em um } \\
\text { determinado instante de tempo } \% \\
\text { de uma timeline }\end{array}$ \\
\hline Element [] getsequentialelementlist $($; & $\begin{array}{l}\text { Metodo que retorna a lista de } \\
\text { todos os clementos relacionados } \\
\text { em uma timeline }\end{array}$ \\
\hline monitoringAddelement () ; & $\begin{array}{l}\text { Meitodo que monitora a inserção } \\
\text { de um clemento a uma timeline }\end{array}$ \\
\hline monitoringRemoveComponent (); & $\begin{array}{l}\text { Método que monitora a remogà } \\
\text { de um elemento de uma timeline }\end{array}$ \\
\hline addMonitorTorime (Time) $\overline{\text {; }}$ & $\begin{array}{l}\text { Método que adiciona um monitor } \\
\text { de eventos para uma unidade de } \\
\text { tempo em uma timeline }\end{array}$ \\
\hline
\end{tabular}

\subsection{Integrando agentes de software para prover consciência de contexto}

Os agentes de software podem ser utilizados para prover consciencia de contexto ao ambiente interativo, considerando-se as tefiniçoes de aģentes reportadas na literatura (Moreira \& Walczowski, 1997; Ketchpel \& Genesereth, 1994). Os relacionamentos entre 
agentes caracterizam as interaçóes que ocorrem entre Usuário-Rede-Aplicaçào, conforme ilustrado na Figura 5.26.

A Figura 5.26 apresenta um esquema para representar as interaçōes entre entidades em uma aplicação inserida em um ambiente interativo consciente de contexto. No esquema, é possível observar a existência de interaçoes bem definidas entre Usuário-Rede, AplicaçàoRede, e Usuário-Aplicação.

As interaçōes entre a rede e o usuário ocorrem quando as açōes do usuário disparam eventos sobre componentes de software nativos da infra-estrutura de comunicaçăo. As interaçōes entre a aplicação e a rede cobrem o relacionamento entre todas as aplicaçōes (agentes, programas, dhemons, drioers, dentre outras) e a rede de comunicação (especialmente ao nivel dos protocolos de comunicação). As interaçōes entre o usuário e a aplicação ocorrem sempre que o usuário manipular, através da aplicaçào, um elemento do terminal que gera um evento no ambiente como um todo. Complementando, denomina-se interação completa quando houver relacionamentos entre as três entidades de interação.

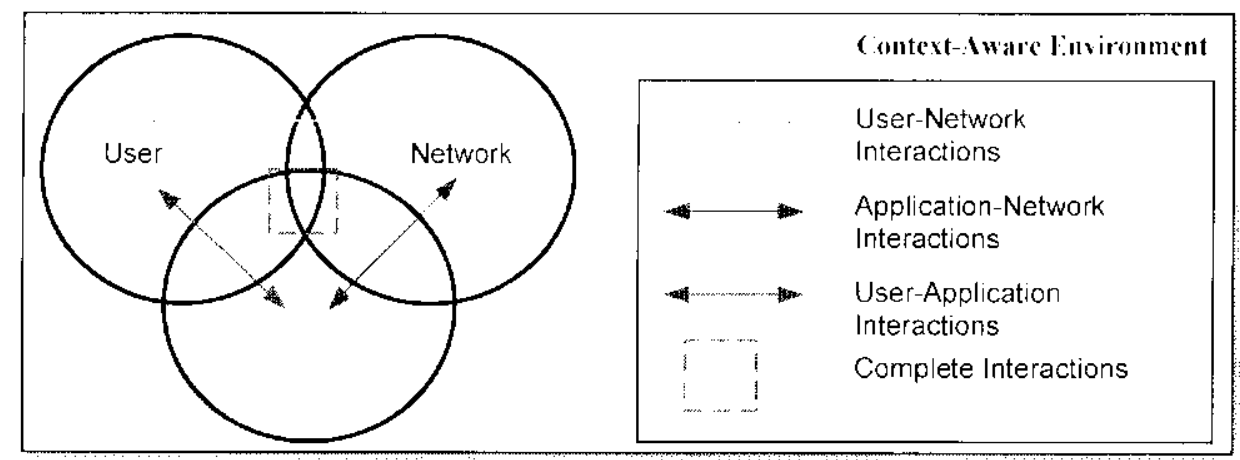

Figura 5.26: Esquema de interação completas em um ambiente consciente de contexto

Essas interaçoes completas podem ser vistas no modelo de integraçăo de agentes apresentado na Figura 5.27.

A seqüencia de transiçòes apresentada na Figura 5.27 inicia-se com o usuário ligando o terminal e escolhendo um programa (1); em seguida, o terminal fará, simultaneamente, a captura de informaçăo sobre o ambiente, começando por informaçòes sobre os dispositivos ligados e suas propriedades (2.1), seguindo com a captura das informações dadas pelos sensores (2.2) e as informaçóes contextuais, como dia, horário e eventos relacionados (2.3). Depois disso, com as informaçôes capturadas, o terminal recebe o perfil do programa 
adequado para aquele contexto (3). Lntão, as informaçồs sào passadas para a aplicaçâo de I'V Interativa, que configurará o programa de 'I'VI para ser recebido (4). Em seguida, as descriçōes do programa sầo recebidas (5), seguidas pelo estado atual da rede (6); entào, serào definidas as melhores características para a transmissào do programa na rede (7) e o estado do servidor é recebido. Finalizando, a aplicaçào envia o programa para o terminal apresentar. Existem ainda os agentes de eventos, que têm a função de capturar eventos durante a transmissão e que podem mudar algumas características do programa (10).

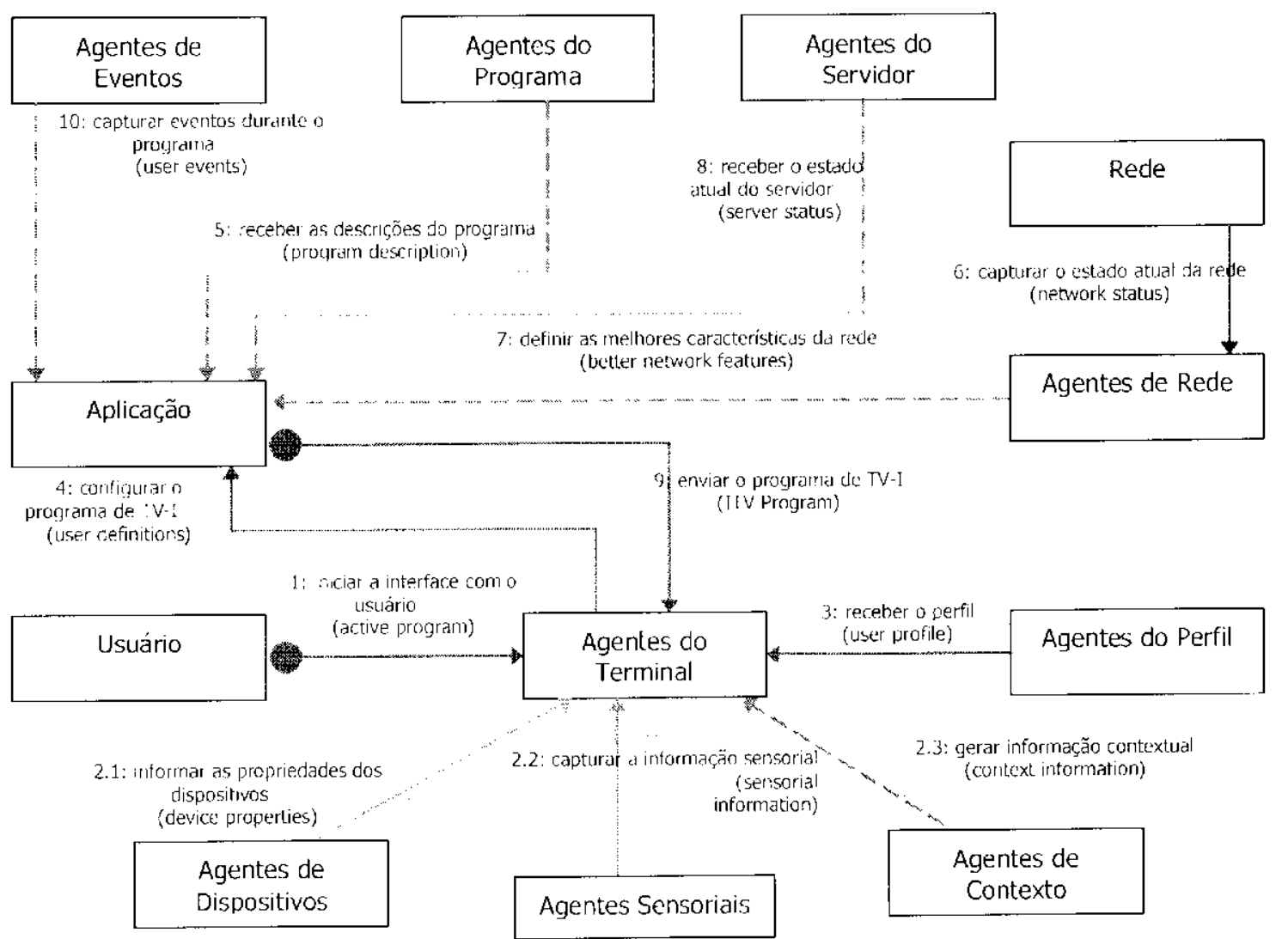

Figura 5.27 - Diagrama de colaboração UMI, entre agentes $\mathrm{em}$ um ambiente consciente de contexto

Ao nível do desenvolvimento de aplicaçoes para ambientes interativos conscientes de contexto, conforme discutido no Capítulo 4, as relaçoes contextuais surgem das interaçōes que ocorrem entre as entidades do ambiente e descrevem, de modo geral, os eventos e as açoos que ocorrem no ambiente.

Considerando que agentes do sofware podem ser utilizados para prover informaços contextuais em todo o ambiente, essas relaçoes contextuais podem ser mapeadas em um esquema de descrição de eventos baseado em agentes, conforme ilustra a Figura 5.27. 
O uso de um agente de software em um ambiente interativo consciente de contexto pode ser mapeado através de um diagrama UML da, como mostrado na Figura 5.27. No diagrama, os relacionamentos entre agentes caracterizam as interações que ocorrem entre as entidades Usuário-Aplicaçào-Rede, evidenciando que os agentes podem ser distribuídos por todo o ambiente e colctar informaçōes contextuais, especialmente aquclas que permitam adaptação automática do conteúdo multimídia em relação ao contexto e interesses (mapeados de acordo com o perfil e preferências) do usuário.

A capacidade social dos agentes computacionais é usada para o estabelecimento da cooperaçào na soluçào de problenas complexos, como é o caso das interaçóes completas em ambientes interativos conscientes de contexto.

O comportamento de um aggente de software deve ser descrito com base em uma ontologia, conforme prevê o padrào a AC.L (Agent Communication langunge) do padrão FIPA (Foundation for Intelligent Plysical Agenls) (Bellifemine et al., 2001).

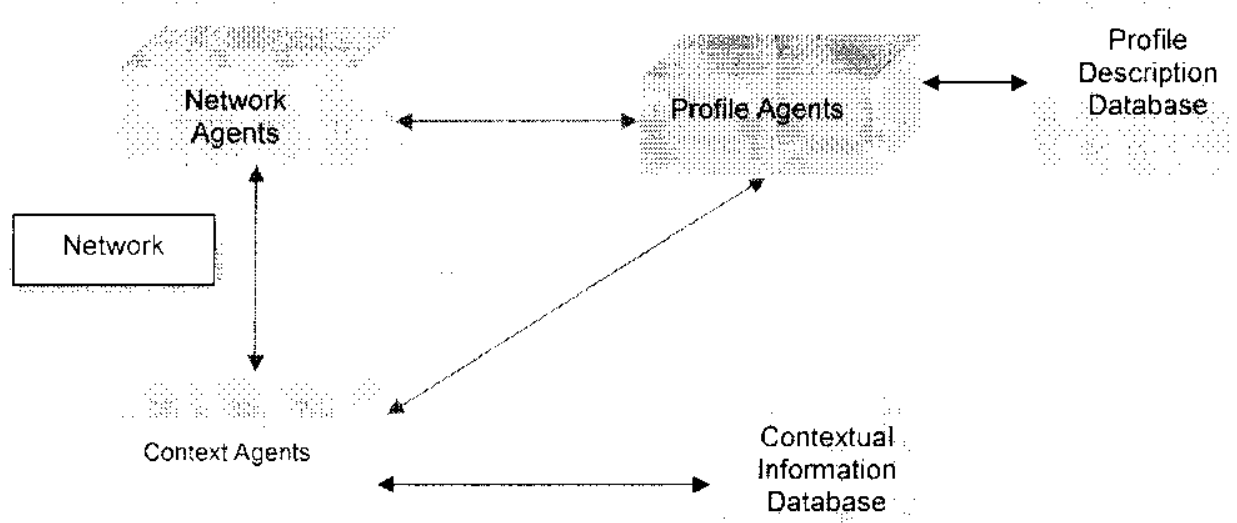

Figura 5.28: Comportamento de um subconjunto de agentes

A Figura 5.28 mostra um subconjunto dos agentes que compoem o diagrama completo apresentado na Figura 5.27, enquanto a Figura 5.29 apresenta um esquema para definiçào de uma ontologia em um ambiente interativo consciente de contexto (Santos Jr. et al., 2001b). 


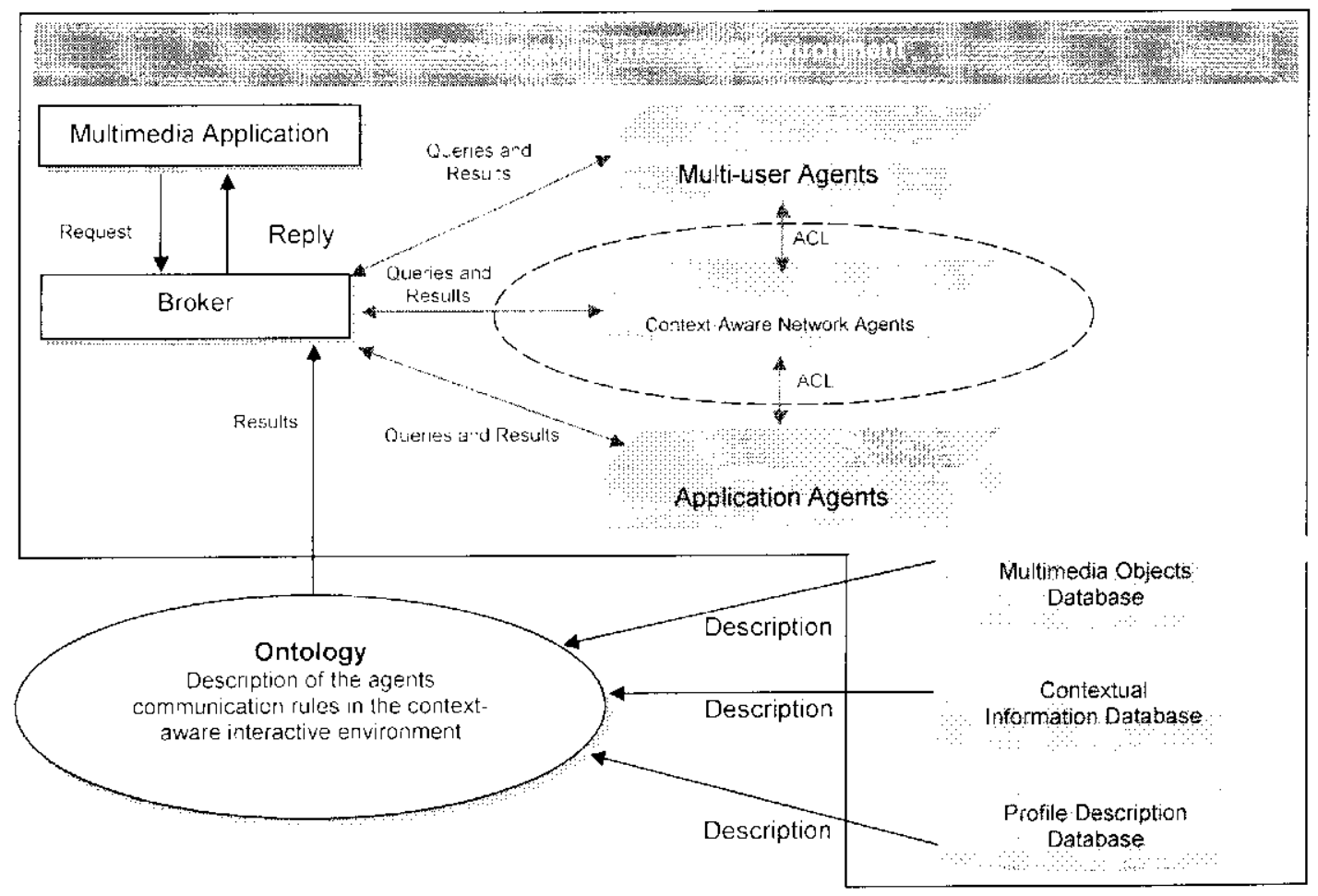

Figura 5.29: Esquema baseado em agentes para coleta de informaçöes contextuais (Santos Jr. et al., 2001b)

Conforme ilustra a Figura 5.29, a ontologia descreve como organizar as açöes dos agentes. A ontologia utiliza esquemas de descrição basedos um XML (ou MPEG-7), que informam como extrair informação das bases de dados; os resultados produzidos pela cooperaçáo entro os agentes podem ser utilizados como parâmetro de entrada para a negeciaçào entre um broker (midlle'r(rre) e a aplicaça multimidia.

O diaģrama UML de colaboraçàc, apresentado pela Figura 5.30, mostra o comportamento dos agentes da rede, agentes do contexto e agentes do perfil em relaçăo à ontologia definida. Os agentes da rede são ativados com um pedido do usuário de um programa interativo; os agentes da rede estabelecem comunicaçào com os agentes do contexto e com os agentes do perfil; com agentes de contexto, os agentes da rede negociam sobre as características contextuais que impactam a qualidade de serviço da aplicaçào; com agentes do perfil, os aģentes da rede negociam sobre as características do perfil de usuário que são relevantes para a adaptabilidade dos aspectos de QoS na rede; os agentes de contexto negociam com os agentes de perfil sobre as características do perfil de usuário que são relevantes para o contexto em que a aplicação está inserida. 


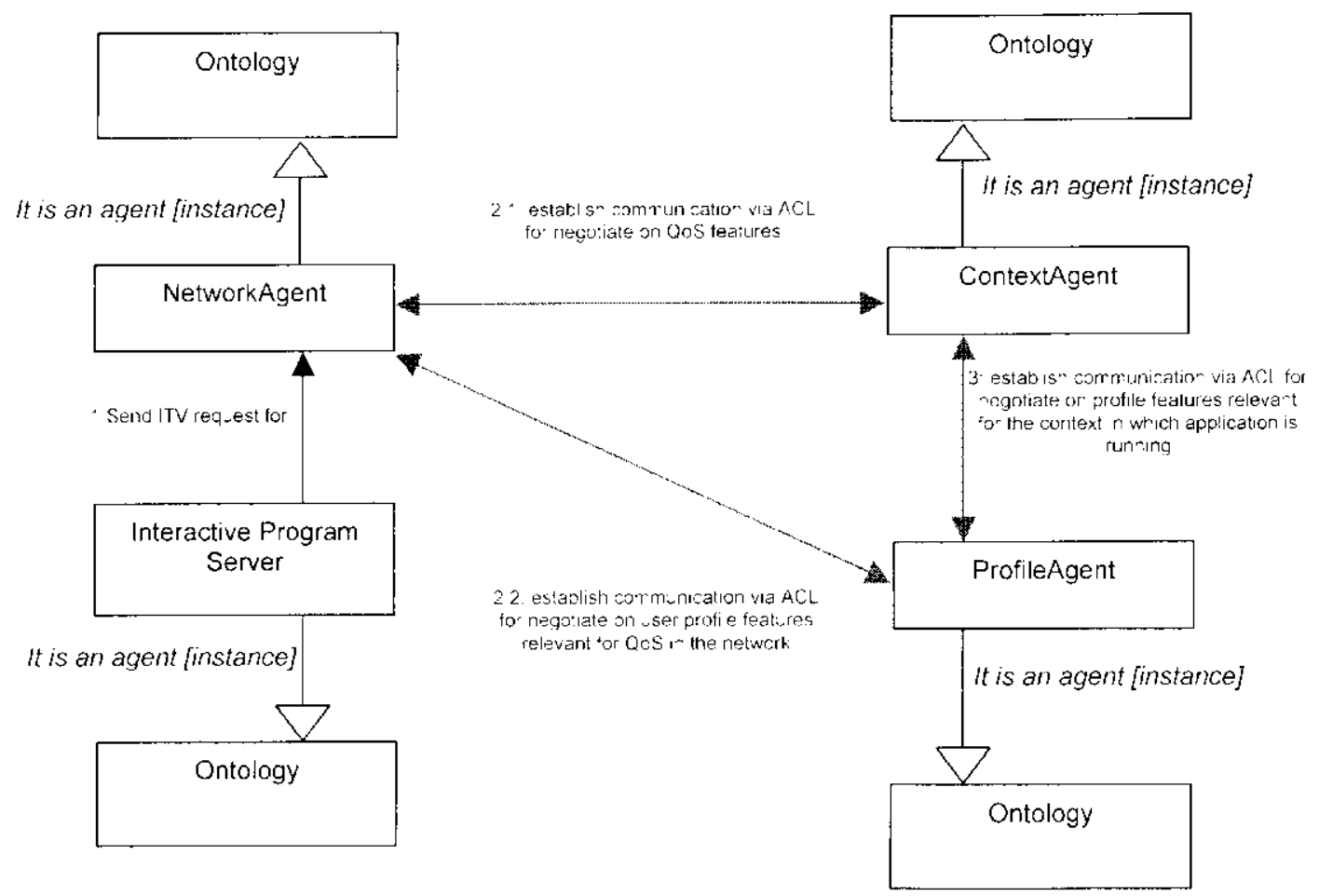

Figura 5.30: Um diagrama UML de colaboraçāo para um subconjunto de agentes

(Figura 5.25) (Santos Jr. et al., 2001a)

Para o escopo desta tese, diversas plataformas de desenvolvimento de agentes oferecem suporte à implementação. A plataforma JADE, também desenvolvida pelo grupo MPEG, oferece todos os recursos necessários para definição de ontologias, criaçào de agentes (móveis ou não) e para o estabelecimento da comunicaçăo entre agentes. Adicionalmente, o) fato da plataforma JADE ser inteiramente desenvolvida em JAVA permite a sua integraçào com aplicações MPEGlet desenvolvidas com a API MPEG-J. A Tabela 5.39 apresenta uma visão geral dos pacotes das classes da plataforma JADE.

Tabela 5.39 - Pacotes da plataforma JADE

\begin{tabular}{|c|c|}
\hline Pacote & Descriçāo \\
\hline jace.content.acl & $\begin{array}{l}\text { Contém classés para estabelecimento de } \\
\text { comunicaçào entre agentes }\end{array}$ \\
\hline -ade.cortent. Iar.g & $\begin{array}{l}\text { Contém classes que especificam a } \\
\text { linguagem do comunicação entre os } \\
\text { agentes }\end{array}$ \\
\hline jade.contert.onto & $\begin{array}{l}\text { Contém classes para definição de uma } \\
\text { ontologia }\end{array}$ \\
\hline jacde. content. schema & $\begin{array}{l}\text { Contém classes para definição de } \\
\text { esquemas de descrevam o conteúdo a ser } \\
\text { manipulado por um agente }\end{array}$ \\
\hline iade. core & Contém o microkemel da plataforma JADE \\
\hline jade.core.behaviours & Contém classes para definir \\
\hline
\end{tabular}




\begin{tabular}{|c|c|}
\hline & cumportamento de agentes \\
\hline jade. core. event & $\begin{array}{l}\text { Contém classes para manipular eventos } \\
\text { gerados por agentes }\end{array}$ \\
\hline jade. domain & $\begin{array}{l}\text { Contém classes para especificaçào do } \\
\text { escopo de uma ontologia }\end{array}$ \\
\hline jade.domain. FIPAAgentManagement. & $\begin{array}{l}\text { Contém a definiçäo da ontologia FIPA- } \\
\text { Agent-Management de acordo com o } \\
\text { padrào FIPA, apresentado como deve ser } \\
\text { o monitoramento dos agentes na } \\
\text { plataforma JAISE. }\end{array}$ \\
\hline jade.domain.mobility & $\begin{array}{l}\text { Contém classes que permitem clefinir a } \\
\text { ontologia JADE-mobility, utilizada no } \\
\text { desenvolvimento de agentes móveis }\end{array}$ \\
\hline jade.gui & $\begin{array}{l}\text { Contém classes para o desenvolvimento } \\
\text { de interfaces graficas baseadas no modelo } \\
\text { swing da linguagem Java }\end{array}$ \\
\hline jade.proto & $\begin{array}{l}\text { Contém as regras dos protocolos que } \\
\text { regulam o comportamento dos agentes, de } \\
\text { acordo com o padräo FIPA }\end{array}$ \\
\hline jade.util & $\begin{array}{l}\text { Contém classes que permitem a } \\
\text { manipulaçào das propriedades dos } \\
\text { agentes }\end{array}$ \\
\hline jade.wrapper & $\begin{array}{l}\text { Oferece suporte ao desenvolvimento de } \\
\text { aplicaçóes Java externas ao mumb dos } \\
\text { agentes, como é o caso das aplicaçóes } \\
\text { MPEG-J }\end{array}$ \\
\hline
\end{tabular}

\subsection{Discussão de relações entre esta proposta e o MPEG-21}

Na seçào 2.7, o MPLG-21 foi apresentado como sendo o novo projeto de padráo do grupo MPEG, tendo sido iniciado no final do ano de 2001. As principais características do MPEG-21 foram apresentadas e relacionadas à definiçâo dos itens digitais universais (Koenen, 2001).

Uma vez apresentada a modelagem proposta por este trabalho, é importante discutir algumas relaçōes que existem entre esta proposta e aquilo que está sendo especificado nos cenários do MI’EG-21.

A essência de todos os esforços do grupo Ml'EG é a interoperabilidade, especialmente para o consumidor de multimídia. A interoperabilidade, neste caso, significa que os consumidores podem usufruir de conteúdo multimídia sem qualquer preocupaçào com formatos de arquivo, codecs, modelos de meta-informação, arquiteturas de hardware e software, dentre outros elementos envolvidos na apresentação multimídia. 
De acordo com a proposta lécnica, o objetivo do MPEG-21.s é descrever um framerwork que referencie como diferentes elementos de hardware e software, no contexto do conteúdo multimídia, podem ser utilizados na construção de uma infra-estrutura para a distribuição e o consumo desse conteúdo multimidia. Neste cenário, o grupo do MPFG-21 absorve esforços de representantes da incústria fonográfica (música), da indústria de produção de múdias c dos fornecedores de tecnologia multimidia. O aspecto integraçăo é o elemento-chave da proposta do MPEG-21 e, segundo estimativas do grupo MPEG, há 6 (seis) bilhòes de potenciais usuários para a propesta MPFG-21 (Kuenen, 2001).

O projeto do MPEG-21 procura usar padroes existentes, quando possivel, e apresentar mecanismos para facilitar sua integração em uma infra-estrutura. Essa integração é a base para a primeira parte do MPEG-21: a declaraçâo de item digital, conforme visto na Seçào 2.7.5. Fssa declaração é baseada em um XML-Sche'ma, considerando que XML é um poderoso padrăo para intercâmbio de dados. No entanto, a parte mais complexa do MPEG-21 é a identificação e a descrição dos itens digitais. Para este caso, o foco do MPEG-21 é desenvolver mecanismos que permitam a adaptaçào do conteúdo ao ambiente. Vale observar que para o grupo MPEG o conceito de ambiente é o mesmo desenvolvido nesta tese. Neste caso, o conteúdo multimídia será visto como uma coleçào de itens digitais associada a um ambiente, sendo que o ambiente inclui as redes de comunicaçào, os terminais de exibiçào e as aplicaçoes para acesso ao conteudo.

Neste contexto, o grupo MPEG-21 tem sinalizado a necessidade de pesquisas e propostas que incluam: a) a representacão de conteúdo multimídia como coleção de itens digitais, observando-se as representaçoes já existentes em outros padrōes MPEG, como é o caso dos objetos de mídia do padrão MI'li-4; b) os modelos de interaçào que descrevam o comportamento desses itens digitais no ambiente; c) os modelos que conceituem e caracterizem os novos ambientes interativos; d) os modelos yue controlem eventos e monitores para personalização nesses novos a mbientes interativos.

Cronologicamente, esta tese teve inicio em 1998, atingindo um estágio de maturidade no ano de 2001. Observa-se pelos argumentos descritos, que a proposta, aqui reportada, tem relaçóes com as expectativas de projeto do MPEG-21. 


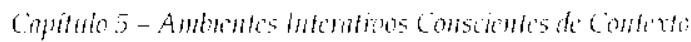

O conceito interativo, ao se referir a tedas as interaçies que ocorrem entre os mais diversos elementos de uma infra-estrutura, pode ser aplicado aos requisitos do MPEG-21. Adicionalmente, o conceito de ambiente, ao se referir à composiçăo da infra-estrutura de rede, terminais, aplicaçòes e usuários, também se enquadra na proposta do MPEG-21.

Ao nível do conteúdo multimídia, a proposta de personalizaçào de conteúdo, através de profiles, é dirctamente aplicavel as MPEG-21, sendo que os aspectos de consciencia de contexto, formalizados nesta tese, representaçăo uma nova contribuiçầo para o projeto do novo padrão. De forma complementar, as classes UML propostas nesta tese formalizam os requisitos das interaçốs completas (rede-aplicação-usuário), e esse requisitos podem ser mapeados e/ou configurados para auxiliar a descrição de itens digitais, que é um dos pontos de investigaçào recomendados para futuras propostas de contribuiçoes ao MPEG-21.

\subsection{Considerações finais}

As tecnolog̣ias MPEG-4 e MPEG-7, desenvolvidas para serem padròes internacionais, são potenciais para o desenvolvimento de aplicaçoes interativas nesse novo e complexo universo de sistemas digitais integrados.

Enyuanto tecnologias, as características desses padróes evidenciam sua aplicabilidade na cordificação, distribuição e apresentaçào de multimídia. Por representarem mídias como objetos e permitirem a descrição de conteúdo multimídia em uma cena, essas tecnologias se relacionam diretamente com o paradigma da orientaçào a objetos. Neste sentido, a proposta de modelagem de ambientes interatives conscientes de contexto apresenta-se como uma forma de orientação para a cadeia produtiva dos novos programas interativos, como é o caso dos programas de TVI.

Neste capitulo, foram apresentados e discutidos os modelos que compoem a modelagem de ambientes interativos conscientes de contexto. Como contribuiçào, foram apresentadas as formas de integração dos modelos propostos com as tecnologias MPEG-4 e MPEG-7, identificadas como base tecnológica para sustentar esta proposta.

No próximo capítulo, discute-se a modelagen de uma aplicaçăo de TVI como forma de validaçāo da modelagem proposta neste capilulo. 


\section{Estudo de Caso: Modelagem de Programas para Televisão Interativa}

\subsection{Considerações iniciais}

A televisăo é um meio de comunicaçăo extremamente popular e que possui linguagem e funcionalidades próprias. Atualmente, a lelevisão passa por um período de revoluçào; a primeira grande mudança está sendo a digitalizaçào do sinal e a segunda é o novo universo de possibilidades de interação que se pretende criar.

Essas duas mudanças tendem a impactar diretamente o modo como as pessoas assistem a um programa de TV. A Televisào Interativa (I'VI) é uma aplicação multimídia que insere novas funcionalidades em um ambiente anteriormente não interativo (Backer et al., 1998). Um grande número de tecnologias pode ser usado em sua implementação e, devido ao crescente interesse da indústria, diversos esforços têm sido leitos para sua padronização (Anatel, 2001).

Neste capítulo, é apresentado e discutido um novo conceito para criar e distribuir programas interativos, representando um avanço na adaptaçăo dos programas às necessidades ou expectativas dos usuários. Na próxima seção, será apresentada uma breve descrição sobre TVI. Na seqüencia, scrão revisitados os principais aspectos de consciência de contexto relevantes a aplicaçōes de TVI e discutidos us aspectus da infra-estrutura necessária para a distribuição, os requisitos para a produçäo, a modelagem do ambiente de TVI consciente de contexto, e a modelagem e implementação de uma aplicação de TVI, como é o caso de um evento esportivo.

\subsection{Um breve relato da evolução da interação na televisão}

A possibilidade da interação com um programa de televisão é um desejo antigo. Diversos programas incentivam a interacăo dos espectadores, na maioria das vezes por telefone, e essa interaçào ocorre tanto em game shores quanto para fazer pesquisa de opiniảo, como é o caso da escolha do desfocho de um programa. Um aspecto inconveniente é que essa interação é hastante limilada, uma vez que a TV e o telefone são aparelhos que não se comunicam de forma integrada. Com a evoluçào da tecnoloģia e o aparecimento das URD)s (Umidade 
Receptom-Iecodificndom), a ligação do aparelho de TV com o telefone tornou-se possivel, possibilitando o lançamento de diversos modelos e produtos de TV Interativa.

$\Lambda$ transmissão da TV Interativa pode ser feita de três modos: a) via broadcast, em que todos os usuários recebem toda a informaçào possivel, porém as LRISs só apresentam o necessário; b) via unicast, que permite a entrega individual da informaçào para o usuário (tem a vantagem de que só a informação que interessa ao usuário é disponibilizada, porém tem a desvantagem no caso da transmissão de vídeo de vários lltrends, necessitando muitos recursos computacionais dos servidores); c) via multicast, em que a transmissào de cada objeto exige um thread do servidor, independente do número de receptores (nesse modo, cada receptor entra num grupo para receber o objeto). Martins mostra uma comparaçào de desempenho entre um servidor de vídeo mincast e um multicast, na qual fica evidente a melhor utilização da banda e o menor processamento necessário no servidor mullicast (Martins, 2001).

O canal de retomo é um outro fator que categroriza a TV Interativa em três grupos. O primeiro grupo é o que não possui canal de retorno, sendo que toda a informação com a qual o usuário pode interagir sempre é entregue ao usuário. Esse tipo de interaçào apresenta alto custo em termos de transmissão e apresenta limitaçoes para o usuário. O segundo grupo possui canal de retorno năo-dedicado; a linha telefónica é utilizada como o canal de retomo. A interaçâo fica mais "rica" e menos limitada. A maioria dos modelos de Enhomed TV pode ser inserida nesse grupo. Como parte do último grupo estão as T'Vs Interativas com canal de retorno dedicado. Desse grupo fazem parte as TVs Interativas por Cabo ou que utilizam linhas IDSL para o retorno. A existência de um canal dedicado permite uma interação completa, uma vez que a possibilidade de interação está sempre presente e o tempo de resposta, normalmente, é menor.

Atualmente, existem diversas soluçoes de TV Interativa disponiveis. Lssas soluçöes, apesar de permitirem alguma interação do usuário, são bastante limitadas em relaçăo às expectativas dos usuários, acostumados à interaçào existente na WWW, por exemplo (Abert, 2000). Existem nomenclaturas diferentes para diferentes implementações de TV Interativa em relação à sua funcionalidade, a saber:

- Enhanced TV: os programas podem possuir conteúdo relacionado que, normalmente, é acessado através de um clique em um ícone; 
- Indiondualized 'TV: o usuário possui opcōes de câmera e ádudio, semelhante às funcionalidades de um DVD, por exemplo;

- Intemet TV: permite o acesso à Internet via televisor, utilizando a linha telefônica como meio de comunicarà;

- On demand TV: é a TV que permite o Video on Demand (ou a sua variação Near Video on De'mand);

- Personal TV: é o tipo de TV que permite an usuário o controle do vídeo, sendo bastante conhecida e funciona a partir dos ['I)Rs (Personal Data Recorters).

Uma das aplicaçóes mais conhecidas e úteis da TV Interativa é o Guia Fletrônico de Programação (EPG - Eletronic Program Gilide'), que é uma aplicação presente tanto nos modelos de Fnlunced TV quanto em Inleractize TV. Tamanha importancia deve-se ao fato de que o EPG é o programa centralizador de toda a informação sobre a programação dos canais de TV. Os LPGs sảo aplicaçoes que diferenciam as funcionalidades entre motelos de 'IV Interativa, podendo ser simples indicadores da programaçào atual (como os utilizados nas IVs por satélite), como controladores da gravaçăo de programas (como os usados nos ['VRs), ou para fazer recomendaçōes de programaçào (Barbieri, 2001; Kurapati et al., 2001).

Como foi apresentado, existem diversas implementaçōes e definiçōes de TV Interativa. Neste trabalho, considera-se como TV Interativa a TV que possui as seguintes características:

- recepão digital dos sinais de áudio e de vídeo;

- canal de retorno dedicado;

- possibilidade de transmissão e recepção de dados;

- possibilidade de comunicação com outros equipamentos eletronicos;

- possibilidade de interação na rede e na aplicação através do uso de agentes de software.

A partir dessas características e dos modelos apresentados e discutidos no Capítulo 5, uma aplicaçào de TV Interativa foi modelada e implementada, sendo yue os detalhes dessa modelagem e implementação serão discutidos nas próximas seçōes.

\subsection{Revisitando aspectos de consciência de contexto aplicáveis à TV Interativa}

Conforme discutido no Capítulo 4, aspectos de consciência de contexto podem ser importantes quando associados ao ambiente no qual uma aplicação está inserida, oferecendo 
as informaçòes do contexto em que o usuário se encontra, as possibilidades de adaptaçào e informaçōes sobre recursos disponiveis em um determinado momento.

Ainda em relaçāo ao Capítulo 4, observou-se que palavras como HOW, WHERE, WHAT, WHO e WHEN expressam semânticas que podem ser tão complexas quanto seja necessário a uma aplicaçào. Conforme exposto, uma semântica HOW, por exemplo, ao se referir a "quais recursos estäo em uso", expressa implicitamente "como o usuário está utilizando esses recursos". A implementaçà de um mecanismo avaliador (agente + filtros, por exemplo) que: apresente e/ ou monitore uma lista dos recursos em uso pode indicar como o usuário está se sentindo no ambiente.

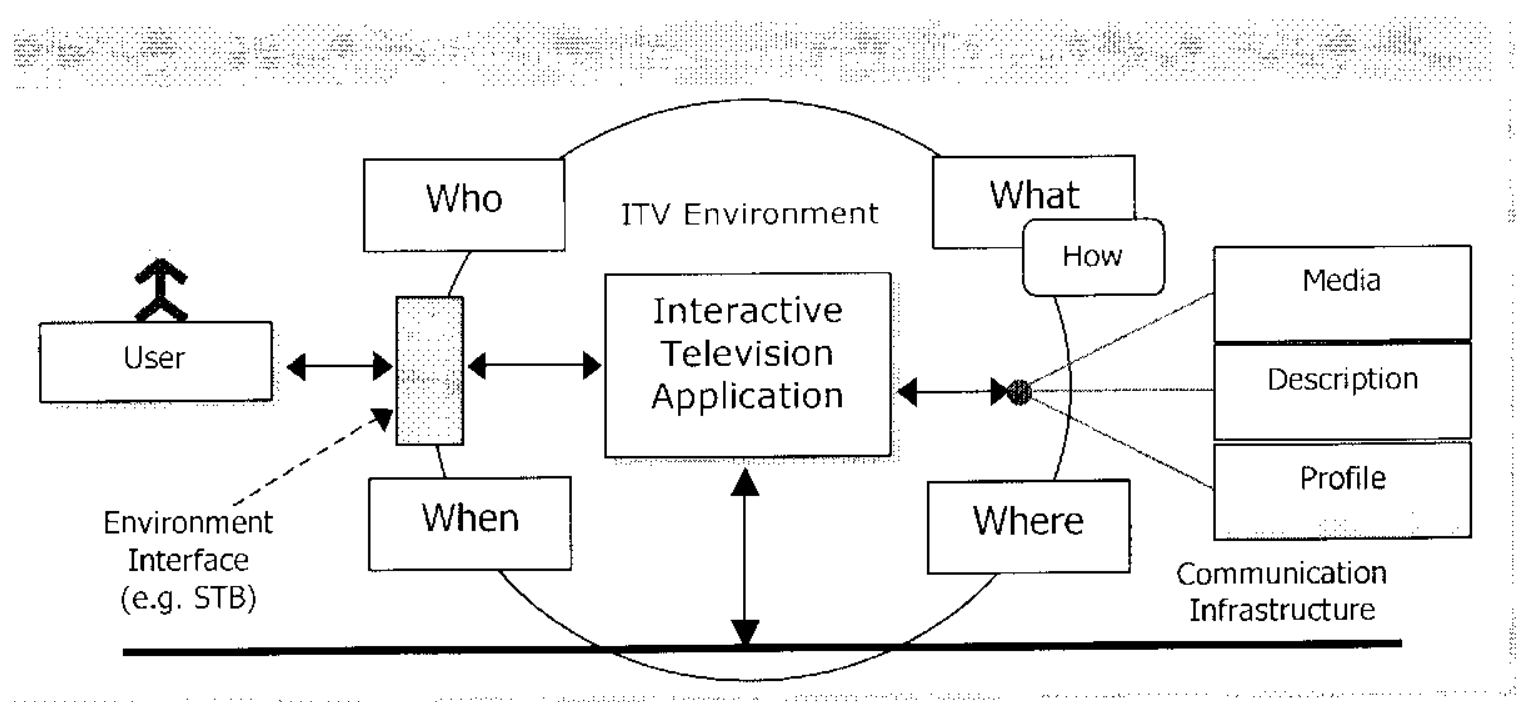

Figura 6.01 - Mapeamento de entidades de consciência de contexto em elementos de perfis de aplicações de TVI

De forma complementar, a proposta de junçăo das semânticas HOW e WHAT oferece suporte à formaçào da entidade "atividade" que, em suma, é um elemento formador do conceito de perfil, conforme ilustrado na ligura 6.01 .

No contexto proposto por este trabalho para as aplicaçōes de TVI, a execução automática de tarcfas e açós é de extrema imporlância. Nesse sentido, agentes podem ser usados para permitir a implementaçäo dos aspectos de consciência de contexto, considerando-se, por exemplo, as quatro entidades de consciência definidas por Dey e $\Lambda$ bowd (Dey \& Abowd, 2000).

Conforme discutido, o desenvolvimento de perlis para aplicaços de TVI é, entäo, uma forma de categorizaçào que caracteriza a situaçào de uma entidade en una aplicação, bem 
como uma forma de se obter informaçoes sobre o comportamento dessa entidade no tempo. Assim, com o uso de perfis em conjunto com informaçóes de contexto, uma aplicaçào podt: realizar açōes e reaçôes, como as seguintes:

- a apresentação de informaçóes e serviços para o usuário, como, por exemplo, a apresentação de mídias disponíveis e que estàn relacionadas com o contexto do usuário;

- a execução automática de serviços, como, por exemplo, o disparo de eventos relacionados com a localizaçào corrente de uma entidadı;

- a associação do contexto com a informação para posterior recuperação, como, por exemplo, o armazenamento de informaçoes contextuais durante uma sessão de multimídia interaliva, relacionando ohservaçôes do(s) usuário(s) com o(s) assunto(s)chave que faz(em) parte da descrição de uma ou mais cenas desse vídeo.

Outro ponto importante reside no fato de que um objeto, em uma interaçăo, pode afetar os níveis de consciência de outro objeto, exigindo, portanto, procedimentos de negociação. Esse aspecto é relevante no acesso a conteúdo de mídias em uma determinada cena, representada com tecnologias como MPEG-4, por exemplo.

\subsection{Infra-estrutura para distribuição de programas de TV Interativa}

A aplicação de TVl modelada neste trabalho tem como base uma infra-estrutura para a distribuiçāo desenvolvida especialmente para a I'VI. Essa arquitetura segue o modelo cliente-servidor e contempla requisitos de consciência de contexto. A Figura 6.02 apresenta essa infra-estrutura, yue encontra-se dividida em:

- Server: o servidor tem como função armazenar e distribuir programas de TVI; esses programas são compostos por objetos multimídia, como vídeo, áudio, imagens, animações, gráficos e textos, dentre outros; além disso, um programa deve possuir um script indicando como esse programa deve ser apresentado, sua estrutura e as relaçòes espaciais a temporais entre seus objetos (conteúdo e estrutura);

- Netarork: existem duas redes no ambiente apresentado; a rede yue faz a ligação entre o servidor e a rede "caseira" (home network), e a própria rede "caseira". A primeira rede deve ser capa\% de mudar seu comportamento de modo a transmitir os dados eficientemente, mudando dinamicamente seus protocolos e algoritmos; já a rede "caseira" deve ser capaz de realizar a comunicacáa entre os diferentes equipamentos (e sensores) e o terminal de exibição; 
- Client: o cliente é composto pelo terminal eseus agentes; o terminal é composto por um computador pessoal conectado à rede e deve exibir os programas de TVI; esse lerminal também deve executar um player compatível com o padrào MPEG-4.

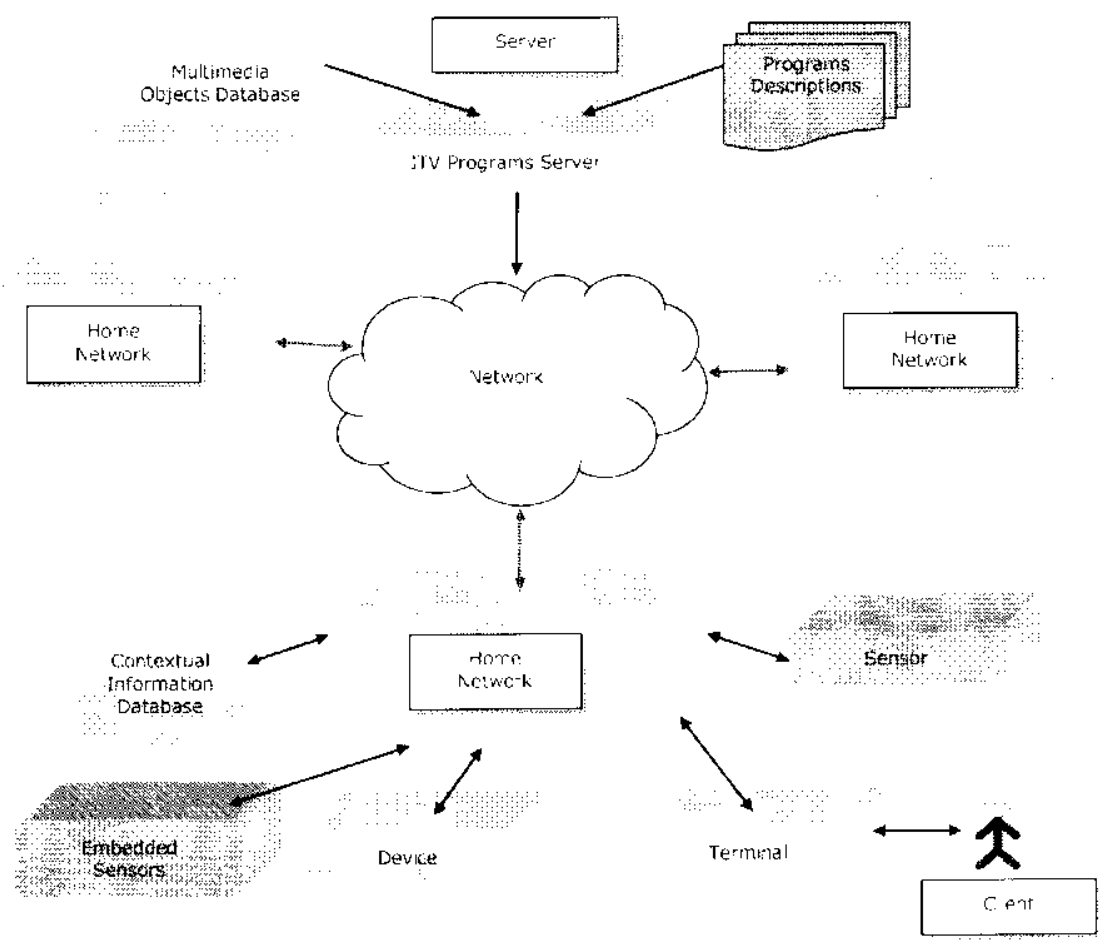

Figura 6.02 - Ambiente consciente de contexto para a TV Interativa

\subsection{Requisitos necessários para a produção de programas de TV Interativa}

Uma preocupaçào adicional deste trabalho é minimizar as mudanças na infra-estrutura, necessárias para a produçào de um programa de IVI em relaçào a um programa para a TV Digital. Com isso, além dos equipamentos presentes em um estudio de TV Digital, como câmeras e VTRs digitais, é necessário acrescentar somente dois novos softroures.

O primeiro é uma ferramenta para a edição dos streams MPEG-4; essa ferramenta deve possuir funcionalidades para manipular vários objetos de mídia. O segundo softzurtre necessário é um editor de metadados que suporte o padrão MPEG-7 e os clementos especificados pelo IV-Anytime Formm e por este trabalho (que serão discutidos a partir da Seção 6.7). Esse segundo softerom, preferencialmente, deve estar integrado a um editor ou ployer de strenms MPEG-4, de modo a facilitar a inserçào de metadados.

A mudança mais significativa está no modo de criar os programas, já que na TVl, além da produçào do conteúdo audiovisual tradicional, é necessária a produçào de conteúdo audiovisual alternativo, dos metadados e de como será a interação do usuário. 


\subsection{Modelagem da aplicação de TV Interativa: estrutura e implementação}

A abordagem atual da TV Interativa, em nível mundial, prevê somente a adição de alģuns aspectos de interatividade aos tradicionais programas de televisão (ATVEF, 2000; DVB, 2000; ARIB, 2000; TVAF, 2001a). No entanto, com a mesma tecnologia yue esses modelos utilizam, é possivel obter um resultado com maior grau de adaptabilidade ao consumidor e que também permita uma melhor definiçâo do público-alvo pela emissora de televisào.

A aplicaçăo de TVI, apresentada nas próximas seçòes, é especificada a partir da modelagem proposta no Capítulo 5, e considera a integração dos modelos NECTAR, SPICE e PRACTIC. conforme discutido na Seção 5.9 .

Conforme visto na Seçào 5.8.1, o programa interativo é o elemento central de uma aplicação de TVI, sendo estruturado de acordo com as especificaçoes da DDL MPEG-7 (ISO, 2001c) e as descriçoes multimidia definidas pelo MPEG-7 (ISO, 2000a). As entidades Schtedule e Summary sào definidas pelo 'T'V-Amytime formm ('TVAI', 2001b; 'TVAF, 2001d) e, por isso, não serão apresentadas aqui com maior detalhamento. A Tabela 6.01 apresenta os elementos de um programa.

Tabela 6.01 - Elementos do Programa

\begin{tabular}{|c|c|}
\hline Nome & Definição \\
\hline Program & $\begin{array}{l}\text { F o principal elemento de um programa, sendo do tipo } \\
\text { ProgramType }\end{array}$ \\
\hline ProgramType & $\begin{array}{l}\text { É um complextype, dentro do qual estào a cena, a } \\
\text { proyramação (schedule) c a sinopse (Summary) }\end{array}$ \\
\hline Information & Apresenta informasoes sobre o prograna \\
\hline ProgramInformationType & $\begin{array}{l}\text { É um simpletype que contém informaçōes sobre o } \\
\text { programa }\end{array}$ \\
\hline name & Nome do programa, sendo do tipo mpeg $7:$ TitleType \\
\hline id & $\begin{array}{l}\text { Identificação única do programa - é utilizado o } \\
\text { identificador de programas do l'V Anytime Forum } \\
\text { CRIDType }\end{array}$ \\
\hline Scene & $\begin{array}{l}\text { Descreve os objetos presentes na cena, sendo to tipo } \\
\text { scenetype }\end{array}$ \\
\hline Summary & $\begin{array}{l}\text { Apresenta a sinopse do programa - foi definido pelo TV } \\
\text { Anytime Forum como o tipo Synopsis Type }\end{array}$ \\
\hline Schedule & $\begin{array}{l}\text { É um elemento yue apresenta a programaça do } \\
\text { programa, sendo do tipo tva : Schedul eEventType }\end{array}$ \\
\hline
\end{tabular}

A Figura 6.03 apresenta um exemplo de Sohema MPEG-7 para descriçõo do programa. 


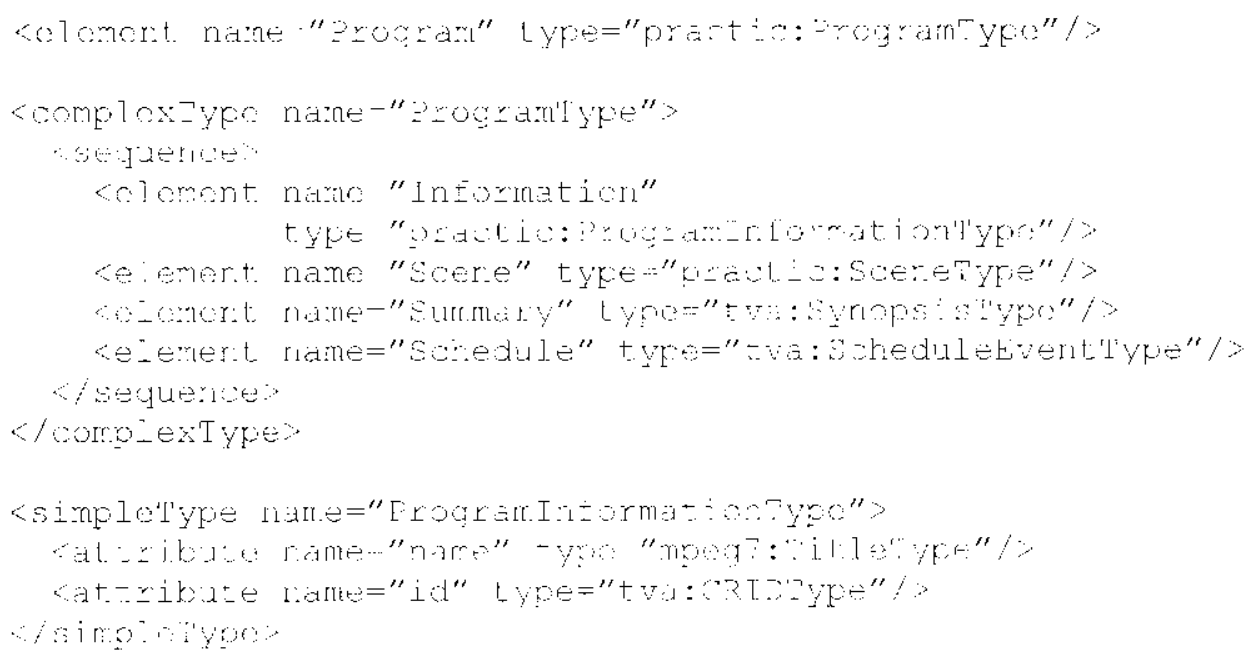

Figura 6.03 - Exemplo de Scho'ma para o elemento Program

O programa deve ser definido e disponibilizado pela emissora, de modo que seja possivel sua apresentação de diferentes maneiras. No programa, estão presentes as informaçoes fundamentais para o funcionamento do mesmo, bem como a sua composiçào por midias, que podem ser descritas em MPEG-7. Um exemplo do uso do cabegalho é apresentado na Figura 6.04 .

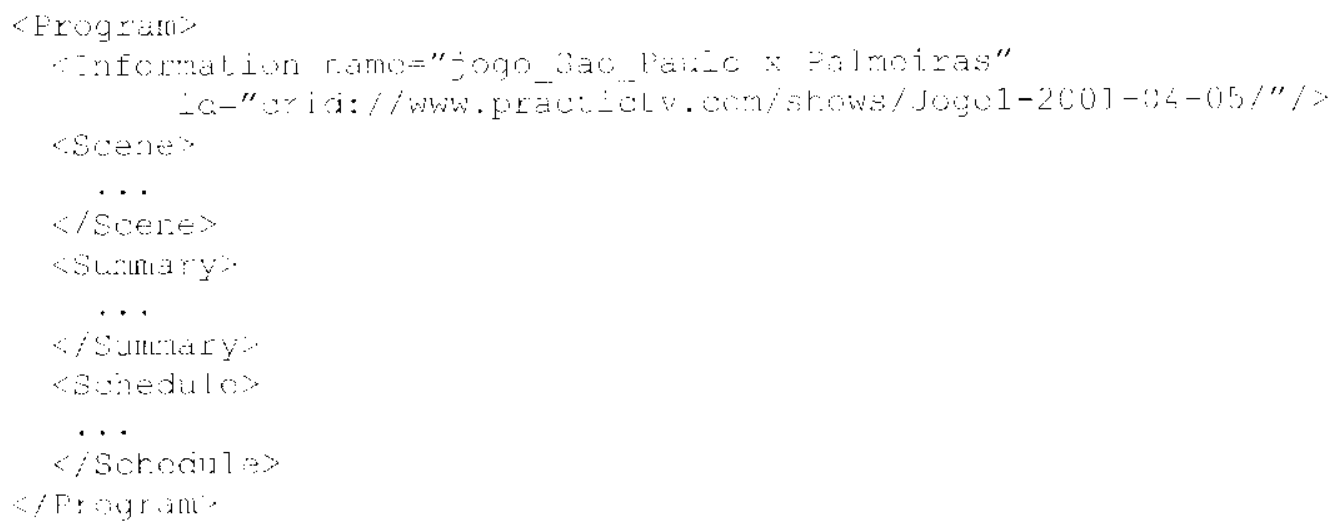

Figura 6.04- Exemplo de cabeçalho de um programa

Como foi discutido na Seçào 5.8.1, um programa é composto por diversos subelementos, cuja definição, bem como de seus atributos, ć apresentada na Tabela 6.02 .

Tabela 6.02 - Subelementos do programa

\begin{tabular}{|l|l|}
\hline Nome & Definição \\
\hline SceneType & $\begin{array}{l}\text { É tipo de dado que possui as informaçóes sobre a cena } \\
\text { Media }\end{array}$ \\
$\begin{array}{l}\text { É um elemento que indica o tipo de mídia existente na cena e } \\
\text { sua localizaçào, sendo do tipo MediaType }\end{array}$ \\
\hline
\end{tabular}




\begin{tabular}{|c|c|}
\hline Timeline & E um clemento que indica a localizaça da descriçào da linha do \\
\hline Ielement & $\begin{array}{l}\text { É elemento responsável pela interação via } \\
\text { InformationElement, e é nesse elemento que estão as ações } \\
\text { que devom ser feitas de acordo com o contexto; esse elemento, } \\
\text { bem como seus subclementos, é do tipo Ielement Type }\end{array}$ \\
\hline Description & 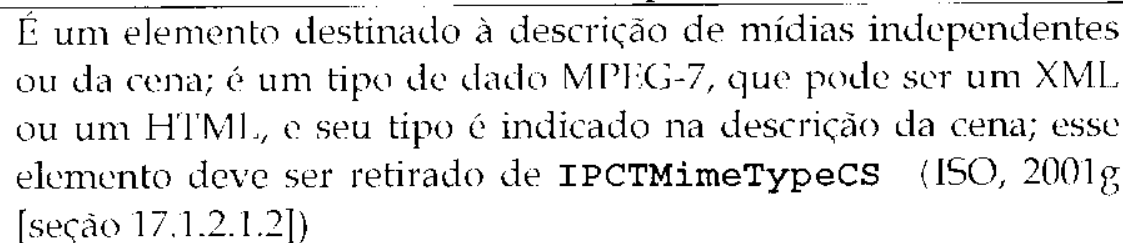 \\
\hline
\end{tabular}

A ligura 6.05 apresenta um exemplo de Schema MPEG-7 para descricão de cena.

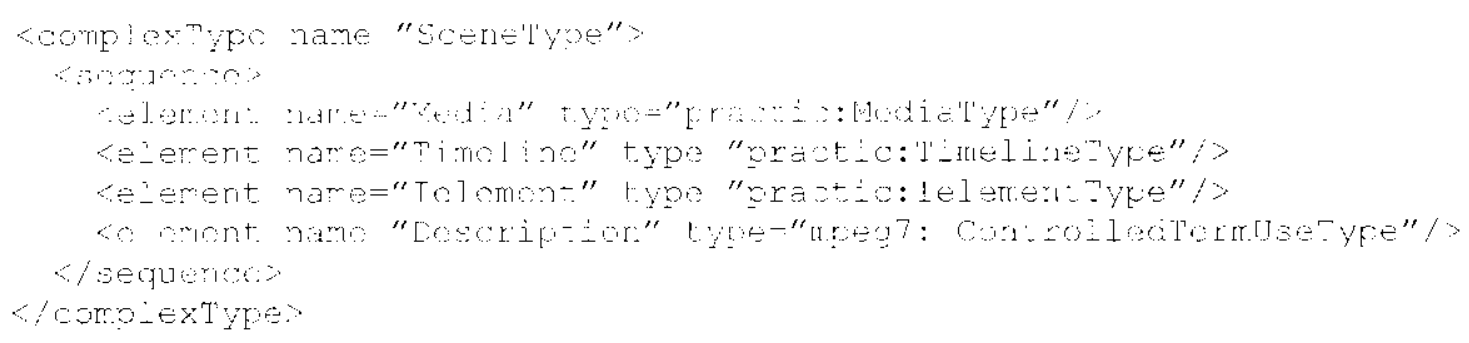

Figura 6.05 - Fxemplo do Schema para descrever a cena

O programa pode ser composto por vários objetos de mídia, que devem ser descritos. A descriçào desses objolos de mídia é apresentada na Tabela 6.03, e o seu Schemn de representação é apresentado na ligura $\mathbf{6 . 0 6}$.

Tabela 6.03 - Subelementos de mídia

\begin{tabular}{|c|c|}
\hline Nome & Definição \\
\hline MediaType & É o lipo de dado que descreve as características da mídia \\
\hline MediaID & $\begin{array}{l}\text { É o identificador do objeto de mídia, sendo do lipo } \\
\text { mpeg7 : UniqueIDType.; é utilizado para a ligaçào a dados } \\
\text { relacionados à mídia descritos em MPEG-7 }\end{array}$ \\
\hline objectID & $\begin{array}{l}\text { É o identificador do objeto de mídia, sendo do tipo } \\
\text { PracticIDType; é utilizado para a manipulaçào do objeto mídia } \\
\text { no layout }\end{array}$ \\
\hline Fileformat & $\begin{array}{l}\text { F. um elemento que indica o formato da mídia, sendo do lipo de } \\
\text { dado MPEG-7 que deve ser retirado de MPEG7FileFormatcs } \\
\text { (ISO, 2001g [seção 17.1.2.1.1]) }\end{array}$ \\
\hline Location & $\begin{array}{l}\text { Informa a localizaçào do arquivo, sendo do tipo } \\
\text { mpeg7: MedialocatorType }\end{array}$ \\
\hline Filesize & Informa o tamanho do arquivo \\
\hline System: & $\begin{array}{l}\text { Informa o lipo de sistema de cores utilizado, por exemplo, PAL, } \\
\text { N'ISC e DVB, sendo de um tipo de dado MPEG-7 que deve ser } \\
\text { retirado de MPEG7SystemCs (ISO, 2001g [secaão 17.1.2.3.1]) }\end{array}$ \\
\hline Bandwiath & Informa a largura de banda necessária para a múdia ser \\
\hline
\end{tabular}




\begin{tabular}{|c|c|}
\hline & apresentada \\
\hline Bitrate & Informa a taxa de bits necessária para a apresentação da midia \\
\hline variable & Ltilizado se a laxa de bits é variável \\
\hline minimum & $\begin{array}{l}\text { Indica a laxa de bits mínima necessária para a apresentação da } \\
\text { mídia }\end{array}$ \\
\hline average & Indica a laxa de bits média para a apresentação da mídia \\
\hline maximurn & $\begin{array}{l}\text { Indica a taxa de bits máxima necessaria para a apresentaça da } \\
\text { midia }\end{array}$ \\
\hline AudioAttributes & Descreve as características sonoras da mídia \\
\hline Coding & $\begin{array}{l}\text { Indica o tipo de codificaçà utilizado na mídia, sendo de um tipo } \\
\text { de dado MPEG-7 que deve ser retirado de } \\
\text { MPEG7AudioCodingFormatCS (ISO, 2001g [seçào 17.1.2.6.1]) }\end{array}$ \\
\hline Chanrels & Indica o número de canais sonoros da midia em cada posiçăo \\
\hline front & Número de canais de áudio frontais \\
\hline rear & Número de canais de audio traseiros \\
\hline side & Número de canais de áudio laterais \\
\hline lfe & Número de canais de audio de baixa trequêencia \\
\hline track & Número de faixas nas quais o som está gravado \\
\hline MixType & $\begin{array}{l}\text { Indica o tipo de mixagem utilizado pela mídia, sendo de um tipo } \\
\text { de dado MPLG-7 que deve ser retirado de } \\
\text { MPEG7AudiopresentationCS (ISO, 2001g [seção 17.1.2.5.1]) }\end{array}$ \\
\hline VideoAttributes & Descreve as características visuais da midia \\
\hline Codirig & $\begin{array}{l}\text { Indica o tipo de codificaço utilizado na mídia, sendo de um tipo } \\
\text { de dado MPEG-7 que deve ser retirado de } \\
\text { MPEG7VideoCodingFormatCS (ISO, 2001g [seçâo } 17.1 .2 .41])\end{array}$ \\
\hline Scan & $\begin{array}{l}\text { Indica o tipo de "scan" utilizado pela mídia (por exemplo, } \\
\text { progressivo, entrelaçado), sendo do tipo de dado tva : ScanType }\end{array}$ \\
\hline Horizontalsize & Indica a tamanho horizontal (em pixels) da mídia \\
\hline Verticalsize & Indica a tamanho vertical (em pixels) da midia \\
\hline AspectRatio & $\begin{array}{l}\text { Indica o aspecto da imagem (a proporçà) do tamanho horizontal } \\
\text { e do vertical), sendo do tipo de dado tva : Aspectratiotype }\end{array}$ \\
\hline Color & $\begin{array}{l}\text { Indica como é a coloraçào da mídia (branco e preta, colorida } \\
\text { artificialmente...), sendo do tipo de dado tva: ColorType }\end{array}$ \\
\hline
\end{tabular}

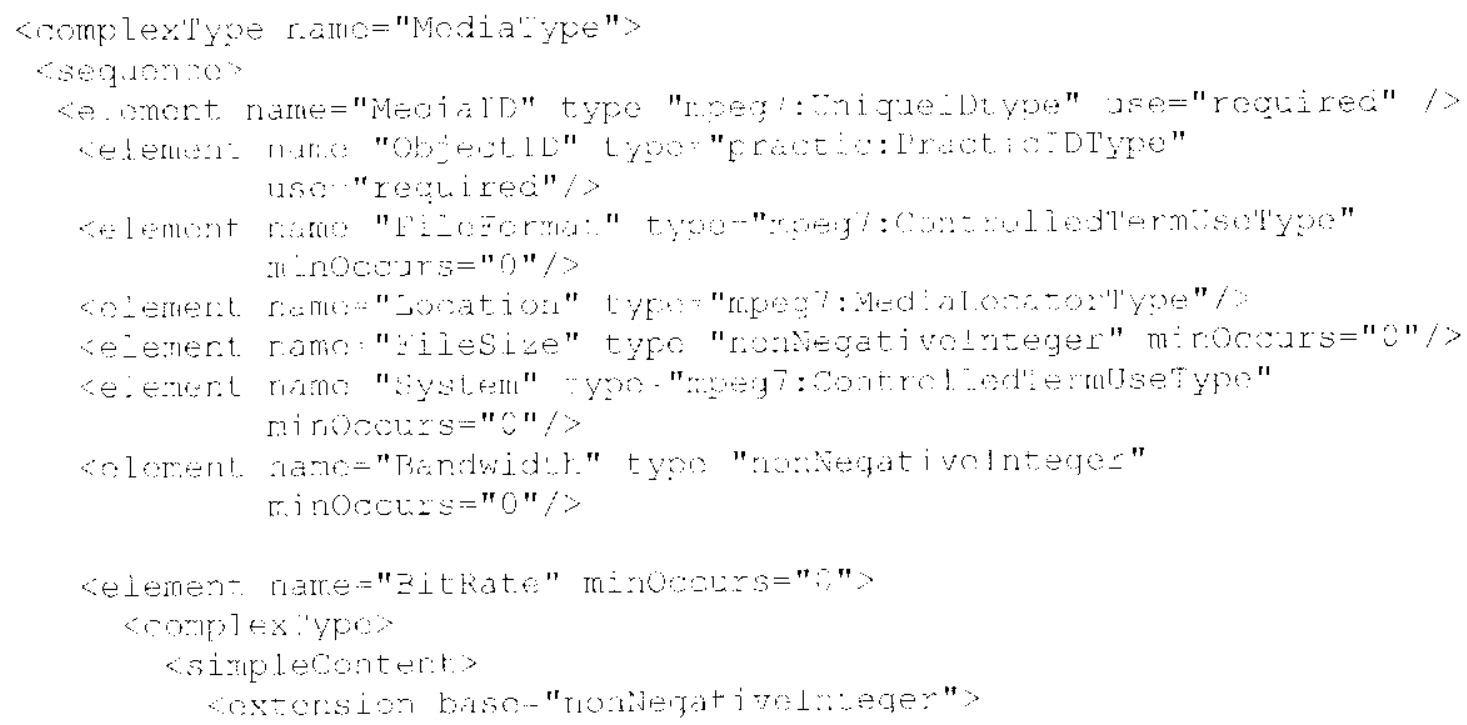




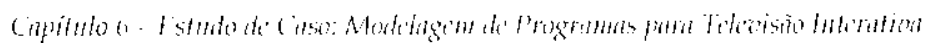

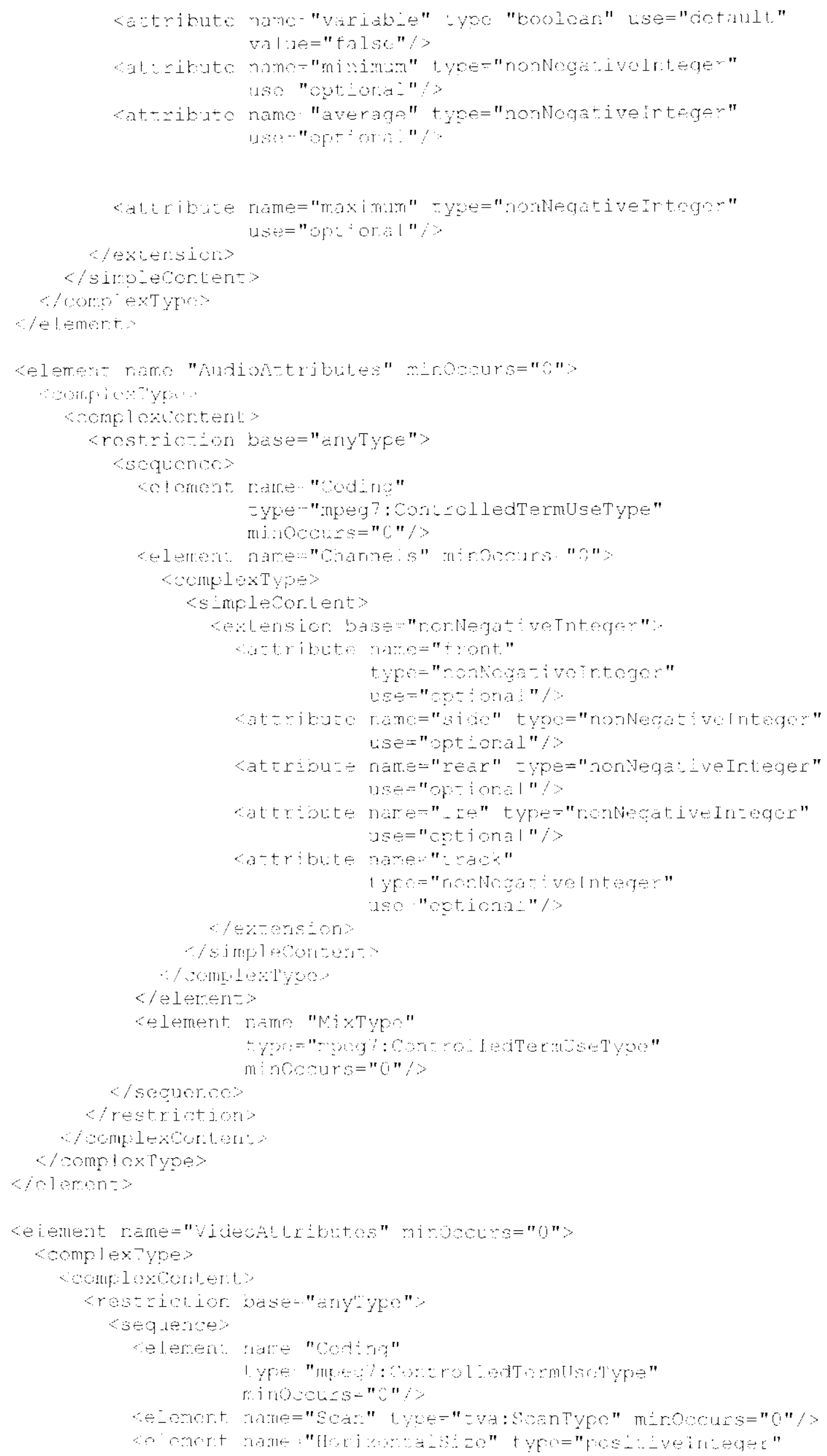




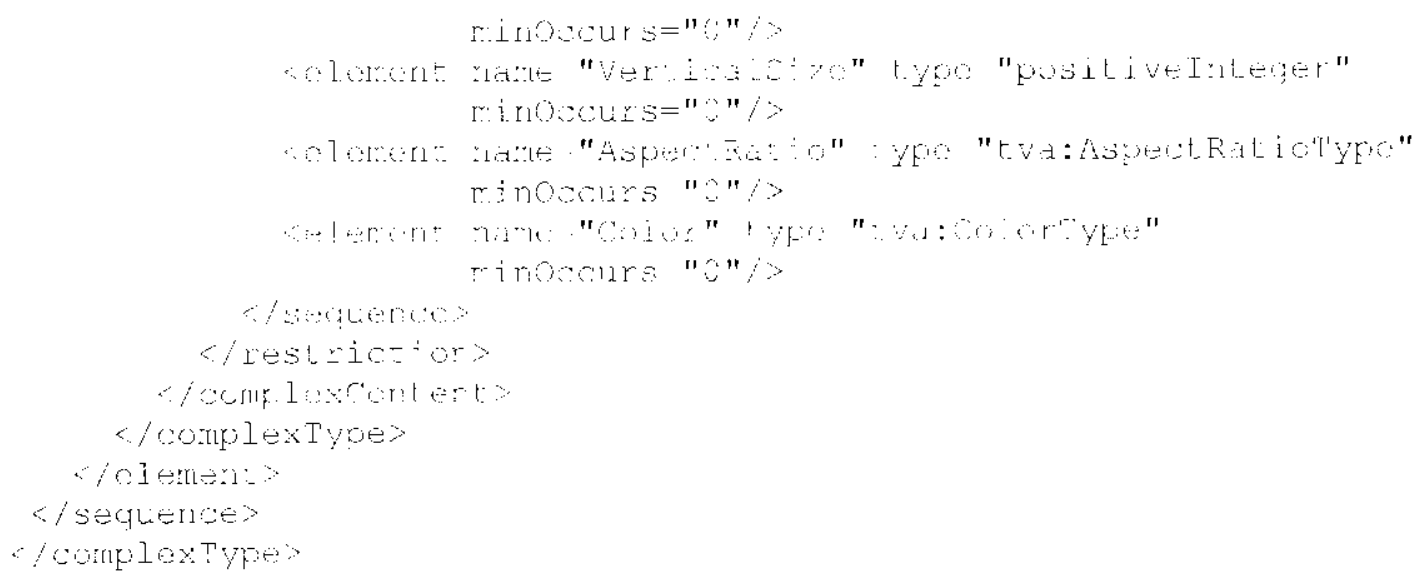

Figura 6.06 - Exemplo do Schenna para a descrição das mídias

A partir das midias e suas descriçōes, é possível construir diferentes interfaces (ou modos de? apresentação) para um programa. A essa possibilidade dá-se a denominação de perfil. Para a codificaçào das mídias e das cenas, essa proposta considera o uso da tecnologia MPEG-4, que é bastante flexível e eficiente para a compactação de vídeo e de áudio. Como caracteristica fundamental do MPEG-4, pode-se citar o fato dos componentes de uma cena estarem separados como objetos, permitindo, assim, incrementos nas formas de manipulaçăo desses componentes. Essa característica é bastante significativa para o caso da implementação de diferentes perfis de programas de TVl.

É importante salientar que apesar deste trabalho considerar o uso de MPEG-4 para a apresentação e transmissão do programa, a estrutura apresentada é independente do mecanismo de transporte, podendo utilizar os padroes da TV Digital (ATSC, 2001; DVB, 1999; ARIB, 2000), bem como o MHP (Multimedia Home Platuform) para a apresentação do conteúdo multimídia (DVB, 2000). As descriçôes das cenas e das mídias permitem a criação de ferramentas de busca em vídeos, em áudio e nas cenas.

Outro elemento importante da cena é o timeline (linha do tempo), que informa a posiçào temporal das mídias na cena. Esse elemento é do tipo Timeline Type, que tem seus elementos apresentados na Tabela 6.04 e seu Srhemm, na Figura 6.07.

Tabela 6.04 - Subelementos de linha do tempo

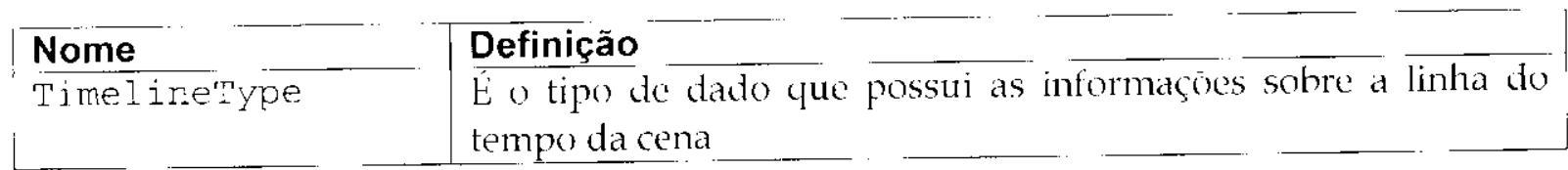




\begin{tabular}{|c|c|}
\hline Tobject & $\begin{array}{l}\text { E um elemento que indica o objeto que terá sua açào temporal } \\
\text { descrita }\end{array}$ \\
\hline ID & É um identificador do objeto, sendo do tipo PracticIDType \\
\hline Mediatime & $\begin{array}{l}\text { É um elemento que informa o ponto em que a mídia deve } \\
\text { começar e sta duraçấ, sendo um elemento MPEG-7 do tipo } \\
\text { mpeg7 : MediaTimeType }\end{array}$ \\
\hline Scenetimepoint & $\begin{array}{l}\text { É um elemento que indica o instante da cena em que o objeto } \\
\text { deve ser inserido, sendo um elemento MPEG-7 do tipo } \\
\text { mpeg7:TimePointType }\end{array}$ \\
\hline
\end{tabular}

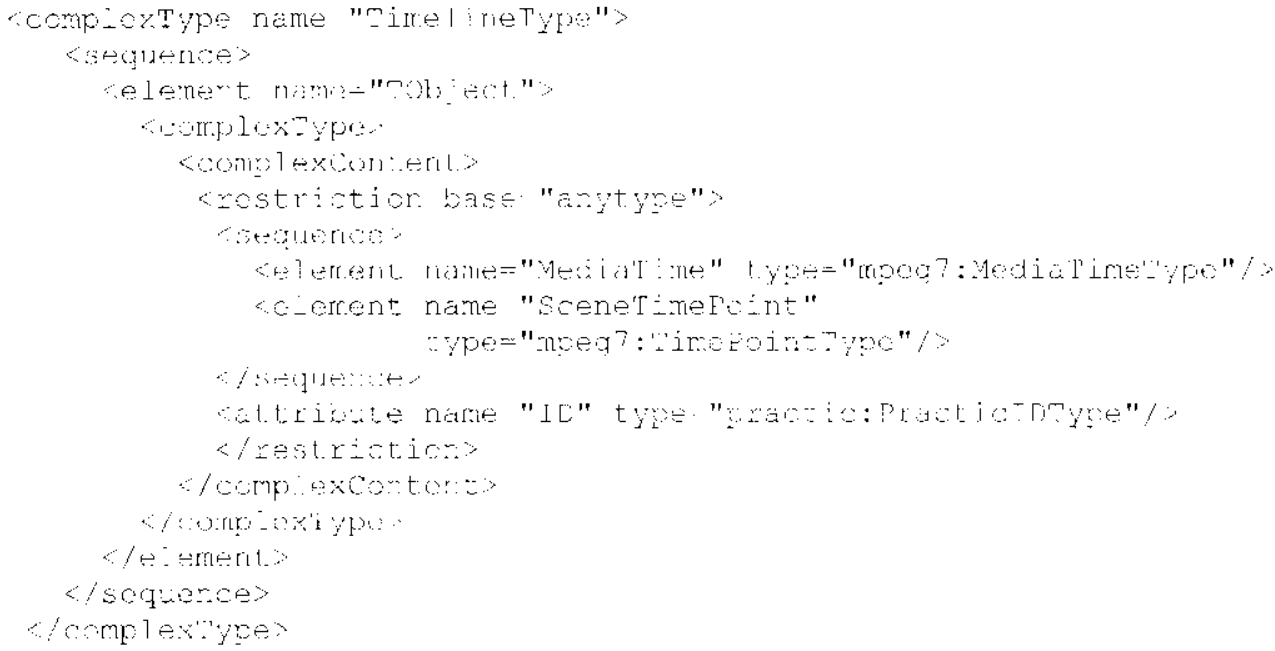

Figura 6.07 - Exemplo do Schema para os elementos da linha do tempo

O sumário e o schedule têm uma destacada importância para aplicaçoes do tipo EPG (Electronic Program Guides), uma vez que é a partir do uso de EPGs que o usuário escolherá o que assistir e o que pretende gravar. Com as informaçóes do sumário, o usuário pode escolher exatamente os programas a serem assistidos/gravados; com a informaçào do schédule, o usuário não precisa se preocupar com o horário de início do programa, uma vez que sua URI) fará isso de forma transparente.

Outro uso relevante do schedule reside no fato de que, em um ambiente consciente de contexto e ubique, a URD pode informar, automaticamente, a um equipamento telefônico ou PDA (Personal Digital Assistant) o horário de início de um determinado programa.

Na Seção 5.8.2, disculiu-se a integração de um ou mais perfis de programa interativo ao desenvolvimento de programas interativos. Este trabalho utiliza o padrão MPEG-7 para a criaçào de novos elementos e para descrever alguns aspectos de layout, requisitos e contexto, 
relevantes a esse perfil e suas interaçoes. $\Lambda$ s informaçōes relativas a um perfil estào dentro de um elemento profile. Esse elemento, por sua vez, ć composto por outros elementos, que terão suas funcionalidades apresentadas na Tabela $6.05 \mathrm{e}$ seu Soltema, na Figura 6.08. A Figura 6.09 apresenta um exemplo de uso do cabeçalho.

Tabela 6.05 - Elementos de perfil

\begin{tabular}{|c|c|}
\hline Nome & Definição \\
\hline Profile & $\begin{array}{l}\text { É o elemento que descreve as características do perfil do programa, } \\
\text { sendo do tipo Profiletype }\end{array}$ \\
\hline Profiletype & $\begin{array}{l}\text { F́ um complextype, dentro do qual estäo todos os elementos do } \\
\text { perfil. }\end{array}$ \\
\hline Layout & $\begin{array}{l}\text { E um elemento, dentro do qual sstará especificada a disposiçáco dos } \\
\text { clementos na tela, sendo do tipo Layout Type }\end{array}$ \\
\hline Communication & $\begin{array}{l}\text { E um elemento que informa as características necessárias para a } \\
\text { transmissão e visualizaçăo do perfil, sendo do tipo } \\
\text { CommunicationType }\end{array}$ \\
\hline Context & $\begin{array}{l}\text { E um elemento que informa como devem ser tratadas informaçóes de } \\
\text { contexto relevantes }\end{array}$ \\
\hline name & Identifica o nome do perfil \\
\hline id & Identificador único do programa, sencto do PracticIDType \\
\hline prograr & $\begin{array}{l}\text { Indica o id do programa ao qual aquele perfil pertence, sendo do tipo } \\
\text { tva: CRIDTYpe }\end{array}$ \\
\hline
\end{tabular}

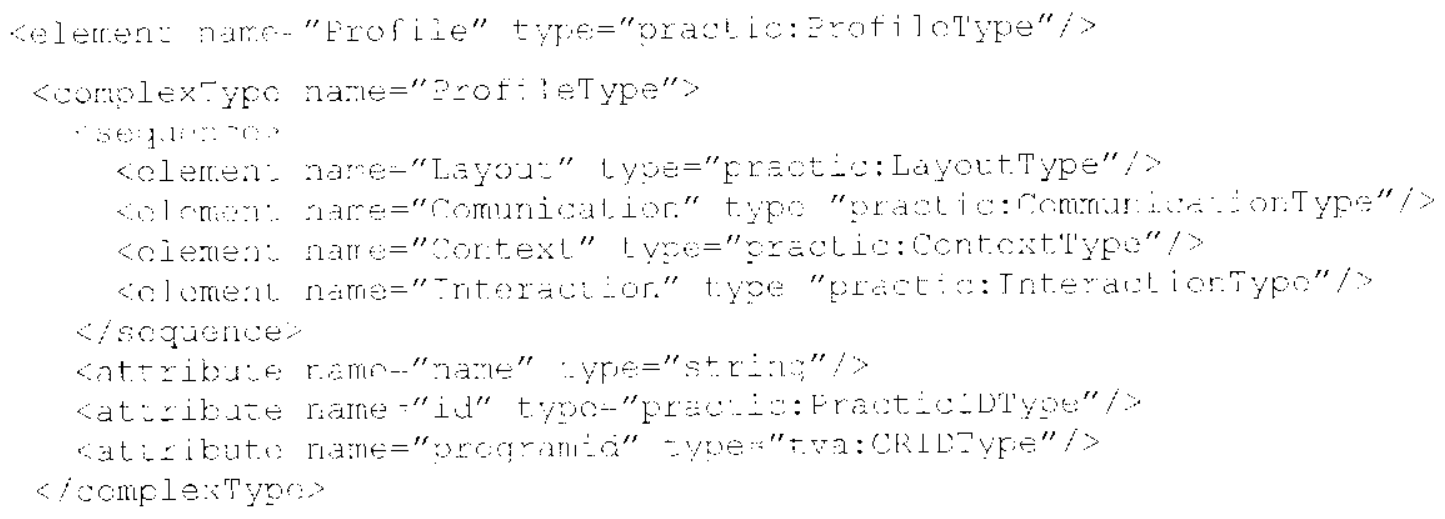

Figura 6.08 - Exemplo do Schema para o elemento profile

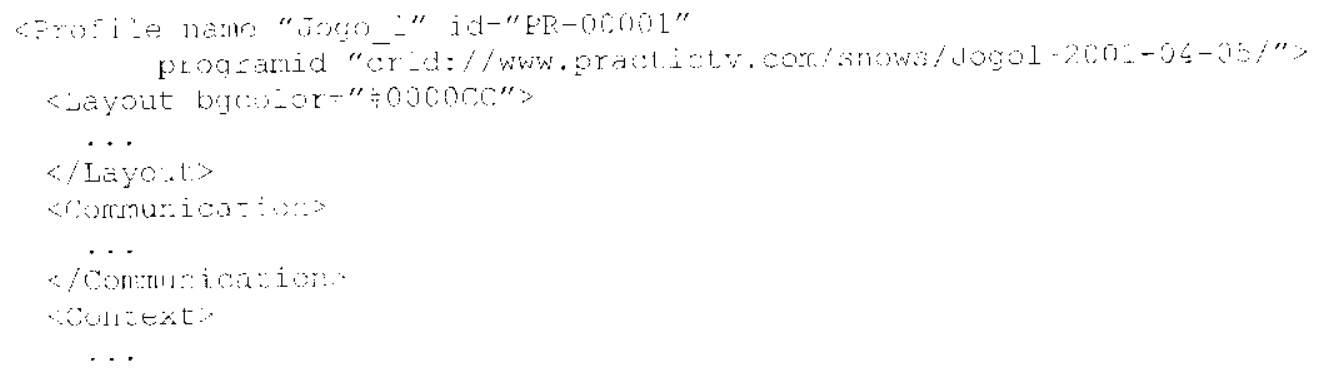




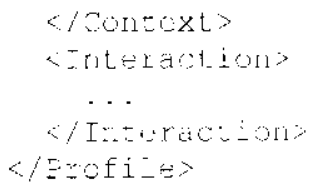

Figura 6.09 - Exemplo do cabeçal ho de um perfil de programa

Os aspectos de apresentação definidos, que fazem parte do elemento Layout, são relativos às cores de fundo, às fontes e posiçoes das mídias. Dentro do luyvut ainda, têm-se os controles de mídia possíveis para um determinado perfil, o tipo de menu e scu conteúdo. Uma versão simplificada do schema de descriçào do elemento Layout é apresentada na Figura 6.10 e a descrição de seus subelementos, na Tabela 6.06.

Tabela 6.06 - Subelementos de layout

\begin{tabular}{|c|c|}
\hline Nome & Definição \\
\hline Layout Type & i: um complextype que indica as características do layout do perfil \\
\hline bgcolor & Indica a cor de fundo padrăo. f́ do tipo hexadecimal \\
\hline object & $\begin{array}{l}\text { I. o elemento que indica um objeto na cena. Um objeto pode ser um } \\
\text { elemento de mídia ou uma descrição }\end{array}$ \\
\hline Id & Identificador único de objetos, sendo do tipo PracticIDType \\
\hline xposition & Indica a posiça horizontal do objeto \\
\hline yposition & Indica a posição vertical do objeto \\
\hline volume & Indica o volume do objeto \\
\hline effect & Indica o efeito sonoro aplicado àquele objeto. \\
\hline Button & Fsse é um elemento que apresenta um botão padrão na tela \\
\hline id & É um identificador do botão, sendo do tipo PracticIDType \\
\hline actiont & Indica a ação que deve ser disparada quando o botào é clicado \\
\hline xposition & Define a posição na lela da margem esquerda do botão \\
\hline yposition & Define a posição na tela da margem acima do botão \\
\hline Menu & $\begin{array}{l}\text { I: o elemento responsável pelo menu do programa, sendo do tipo } \\
\text { MenuType }\end{array}$ \\
\hline Control & $\begin{array}{l}\text { Säo os controles do programa (play, stop, rewind, forward, replay, } \\
\text { change subtitle, change language, dentre outros) }\end{array}$ \\
\hline name & $\begin{array}{l}\text { E o nome do comando, sendo de um tipo de dado MP'HG-7 que deve ser } \\
\text { retirado de MPEG7 ActionTypecs (ISO, } 2001 \mathrm{~g} \text { [seçäo 17.4.1.1.1]) }\end{array}$ \\
\hline id & É o identificador do comando \\
\hline Action & É a açào disparada guando o comando é executado \\
\hline MenuType & $\begin{array}{l}\text { F um complextype que define um tipo de menu disponivel para } \\
\text { aquale programa de TVI }\end{array}$ \\
\hline Selector & Ém tipo de menu, sendo do tipo Menuselector \\
\hline Poplip & É um lipo de menu, sendo do tipo Menupopup \\
\hline Bar & Ém tipo demenu, sendo do tipo MenuBar \\
\hline type & Identificador do lipo de menu (popup, selector, dentre outros) \\
\hline position & Indica a posiçao do menu (top, down, left, right) \\
\hline color & Indica a cor do menu. É do tipo hexadecimal \\
\hline
\end{tabular}




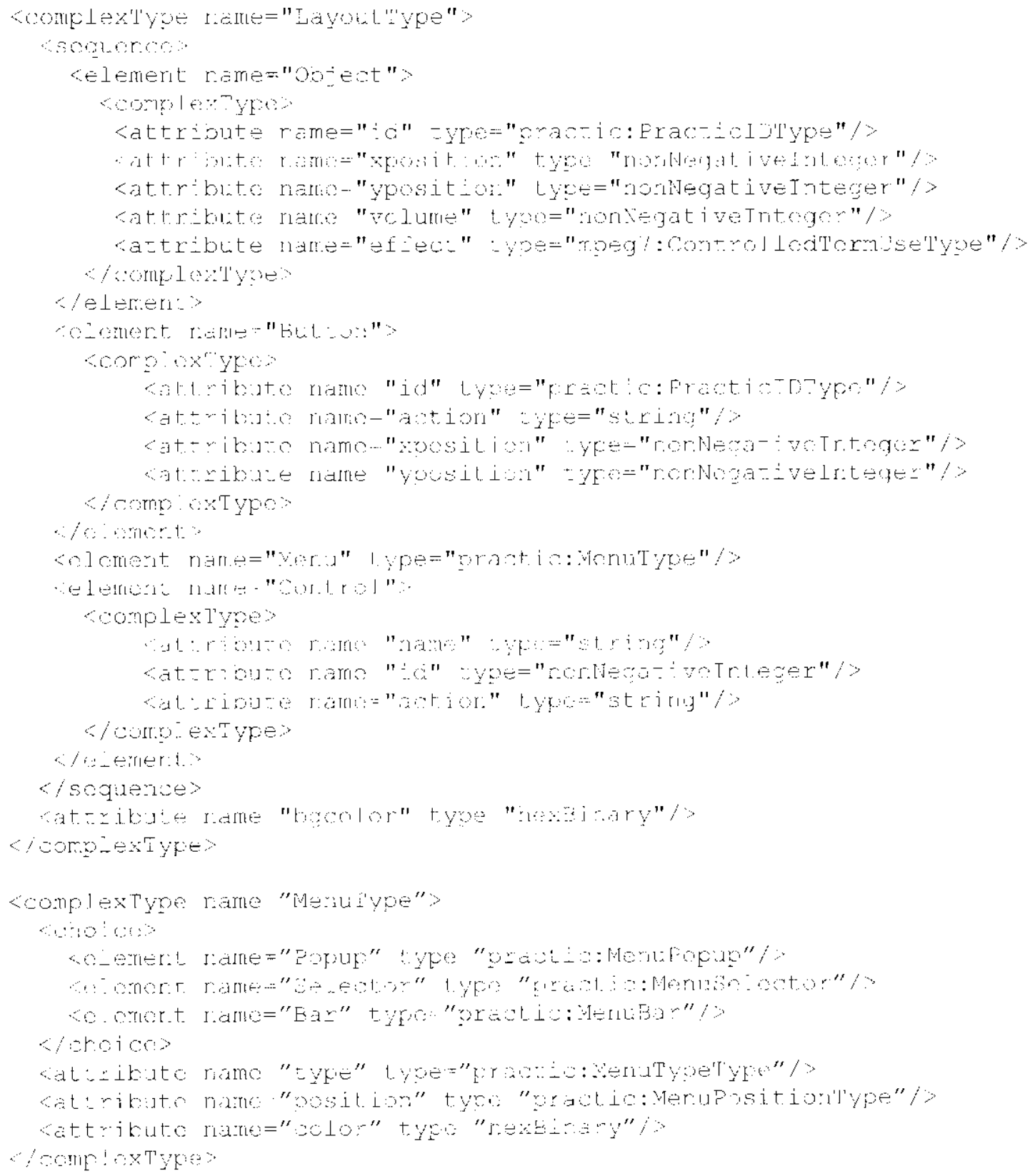

Figura 6.10 - Exemplo do Schena para o elemento layout

Os requisitos do perfil ficam especificados e armazenados dentro do elemento Communicution, onde estão os requisitos de comunicaçào de cada mídia, os decodificadores necessários para cada uma dessas mídias e requisitos técnicos da LRD. Na Tabela 6.07 são apresentados os subelementos do clemento Communication e na Figura 6.11 é apresentada uma versão simplificada do Schenta de descriçào do tipo Communication Typpe. 
'labela 6.07 - Subelementos de comunicaçào

\begin{tabular}{|l|l}
\hline Nome & Definição \\
\hline CommunicationType & $\begin{array}{l}\text { É um complexType que contém elementos que indicam as } \\
\text { características necessárias para a apresentação do perfil }\end{array}$ \\
\hline Commequirements & $\begin{array}{l}\text { E um complexType onde estão os requisitos de cada mídia } \\
\text { Quantidade de banda de rede necessária para a apresentação do } \\
\text { perfil }\end{array}$ \\
\hline Bandwidth & $\begin{array}{l}\text { Decodificatores e codificadores necessários para a apresentação } \\
\text { da mídia, sendo um tipo MPEG-7 que deve ser retirado de } \\
\text { MPEG7VideoCodingFormatCS (ISO, 2001g [seção 17.1.2.4.1]) ou } \\
\text { de MPEG7AudioCodingFormatCS (ISO, 2001g [seção 17.1.2.6.1]) }\end{array}$ \\
\hline
\end{tabular}

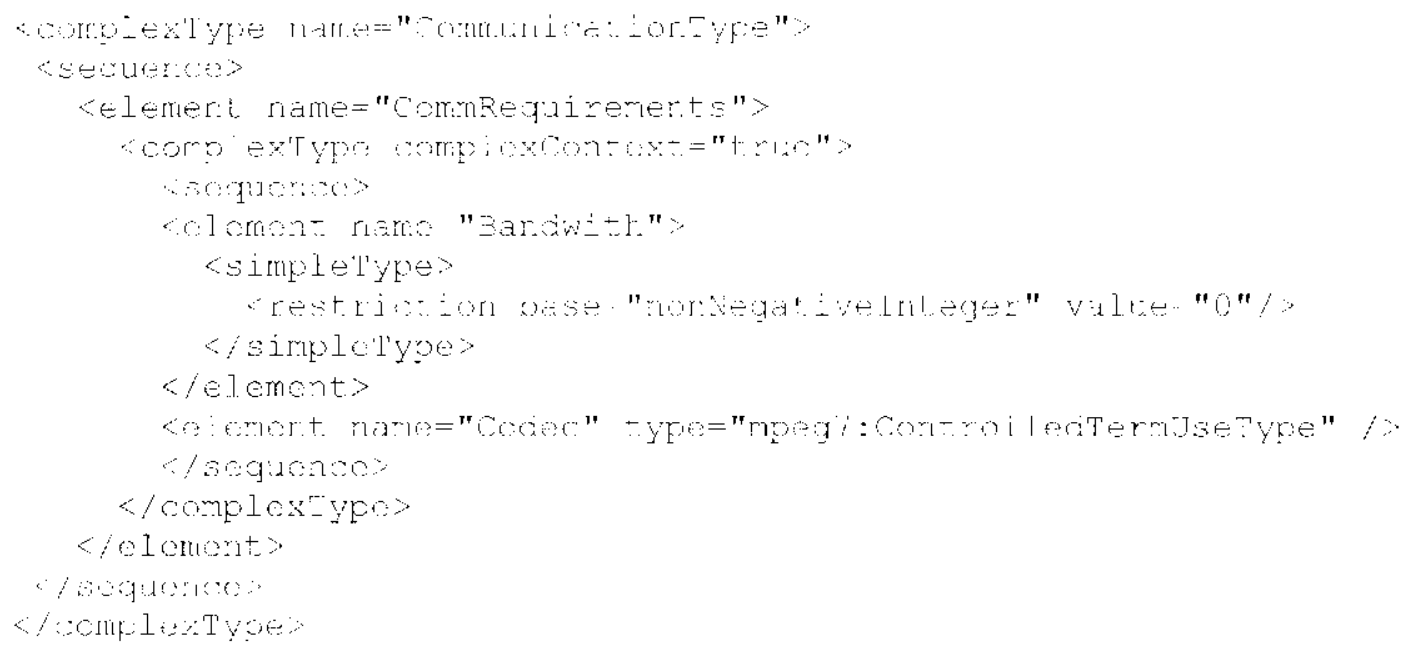

Figura 6.11 - Exemplo de Schema para o elemento Communication

Dentro do elemento Context, insere-se todo o tipo de informação de contexto que pode ser relevante para um determinado perfil. Esse elemento foi definido a partir de variaveis relevantes em consciência de contexto, tais como WHO, WHERE, WHFN e WHAT (Dey \& Abowd, 2000), e discutidas no Capítulo 4. Fsse elemento possui as açoes que devem ser realizadas em determinadas situações. $A$ Tabela 6.08 apresenta a descriçào desses elementos, e a Figura 6.12 apresenta um exemplo de como utilizar o Schemu para a contemplar consciência de contexto a partir do tipo Context Type.

Tabela 6.08 - Subelementos de consciência de contexto

\begin{tabular}{|l|l|}
$\begin{array}{l}\text { Nome } \\
\text { who }\end{array}$ & Definição \\
\hline RefId & $\begin{array}{l}\text { Elemento que indica quem (é utilizado para a ação dos agentes no } \\
\text { ambiente) e dependendo deste realizará uma ação }\end{array}$ \\
\hline Where & $\begin{array}{l}\text { Elentificador de who, sendo do tipo mpeg7 : User Identi fierType indica localização e dependendo desta realizará uma } \\
\text { aça }\end{array}$ \\
\hline
\end{tabular}




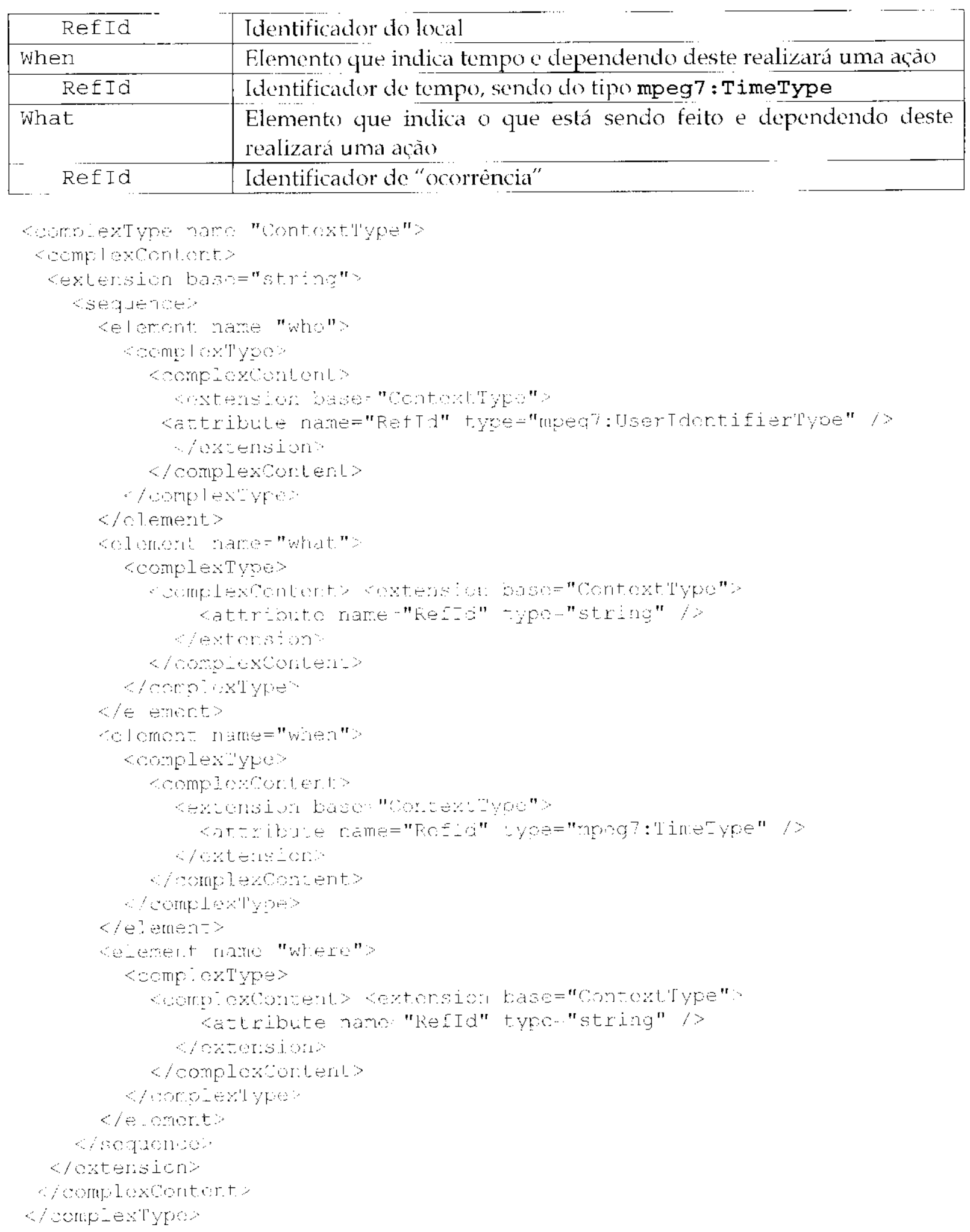

Figura 6.12 - Fxemplo de Schema para os elementos de consciência de contexto

A utilizaçáo dos subelementos do elemento context se dá através do aninhamento dos mesmos, de modo semelhante à utilização do "if-thentelse" em linguagens de programaşäo. 
Desse modo, é possivel associar açoes às situaçôes relevantes que acontecem no ambiente. Um exemplo é mostrado na Figura 6.13.

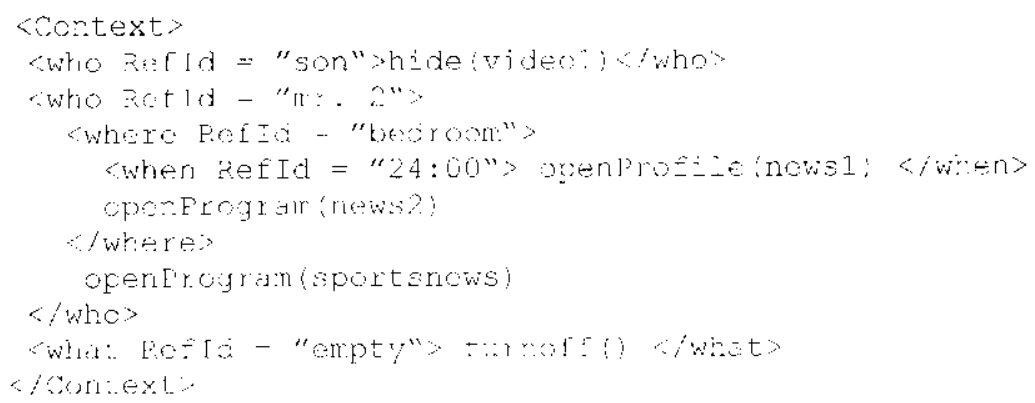

Figura 6.13 - Exemplo do uso dos elementos de consciência de contexto

No exemplo anterior, é mostrado o uso da consciência de contexto dentro de um perfil; no entanto, os elementos de consciência de contexto podem ser utilizados tanto no elemento <program> quanto no elemento userpreferences, indicando qual é o perfil mais adequado de. um programa para uma determinada pessoa. No elemento <userpreferences>, o elemento <context> é utilizado com a mesma sintaxe e, no caso do programa, ele será parte do Information Element, que representa uma contribuiçào deste trabalho.

O último importante elemento é o Inferaction, no qual encontram-se todas as açoes que podem ser realizadas para cada interaçào definida para um perfil. Essas interaçōes são descritas segundo a Tabela 6.09; na Figura 6.14 são mostrados os elementos de interação.

'labela 6.09 - Subelementos de interação

\begin{tabular}{|c|c|}
\hline Nome & Definição \\
\hline Interactiontype & $\begin{array}{l}\text { É um complextype, que possui a scqüência de interaçoes dadas } \\
\text { pelo elemento IT. }\end{array}$ \\
\hline IT & É o clemento necessário a cada interaçăo, sendo do lipo ITTYpe \\
\hline ITType & $\begin{array}{l}\text { É um complextype que descreve o que deve ser feito quando } \\
\text { uma açào é realizada }\end{array}$ \\
\hline On & $\begin{array}{l}\text { F́m atributo yue indica yue tipo de interasào foi feita (click, } \\
\text { move, double-click, dentre outros) }\end{array}$ \\
\hline Media & F́ um atributo que indica a mídia com a qual ocorreu a interação \\
\hline But ton & $\begin{array}{l}\text { F. um atributo que indica o botão (de um controle remoto) com o } \\
\text { qual ocorreu a interação }\end{array}$ \\
\hline action & É a açào que deve ocorrer (função que scrá chamada) \\
\hline \multicolumn{2}{|c|}{ 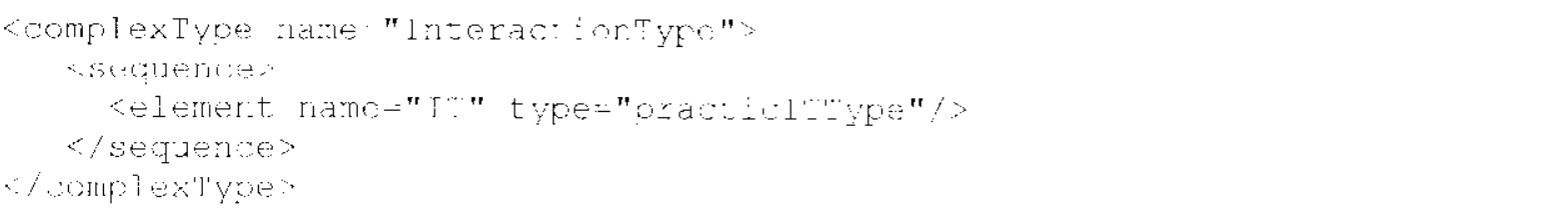 } \\
\hline
\end{tabular}




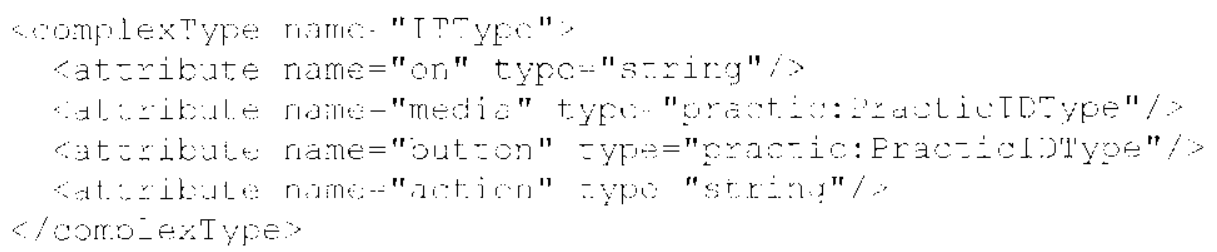

Figura 6.14 - Exemplo do Schema para os elementos de interaçäo

No exemplo da Figura 6.15, o alributo mơ' é uma descriçào MPEG-7, o atributo zideo3 foi apresentado no programa e descrito em MPEG-7 e a ação moxkMedin(ziden.3) representa um comando que será dado à URD para realizar a tarefa. É importante notar que esse comando depende do Sistema Operacional presente na LRD e das aplicaçóes que estào presentes no ambiente, tais como . MHP ou JavaTV (Sun, 2001).

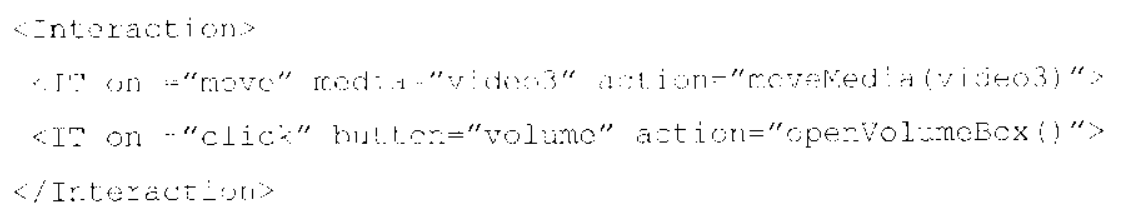

Figura 6.15 - Exemplo do uso dos elementos de interaçāo

Além dos elementos descritos, existe mais um elemento que segue a sintaxe dos perfis, denominado Userpreferences. O elemento Usipreferences, diferentemente dos outros elementos, fica armazenado na URD; nele estão armazenadas algumas personalizaçóes feitas pelos usuários para um determinado perfil de um programa. Os elementos de personalização do usuário são descritos na Tabela 6.10; o Sclk'ma é apresentado na Figura 6.16 e um exemplo do uso desses clementos é apresentado na Figura 6.17.

Tabela 6.10 - Elementos de personalizaçào do usuário

\begin{tabular}{|c|c|}
\hline Nome & Definição \\
\hline UserPreferences & $\begin{array}{l}\text { F. um elemento que armazenará as personalizações dos perfis e } \\
\text { programas }\end{array}$ \\
\hline UserPreferencestype & $\begin{array}{l}\mathrm{F} \text { um complexType onde serão armazenadas todas as } \\
\text { personalidaçoes de perfis, de programas e de hábitos para assistir } \\
\text { televisão }\end{array}$ \\
\hline user & $\begin{array}{l}\text { I.m atributo com o nome do usuário, sendo um tipo de dado } \\
\text { mpeg7 : UserIdentifierType }\end{array}$ \\
\hline Profile & $\begin{array}{l}\text { F " elemento yue contera as mudanças no perfil, sendo do tipo } \\
\text { ProfileType }\end{array}$ \\
\hline CustomPreferences & $\begin{array}{l}\text { É um elemento que informa outras personalizaçoes näo relativas } \\
\text { somente a um programa ou perfil, e sim relacionadas a situações ou, } \\
\text { entào, personalizaçoes validas para todos os perfis e/ou programas. }\end{array}$ \\
\hline
\end{tabular}




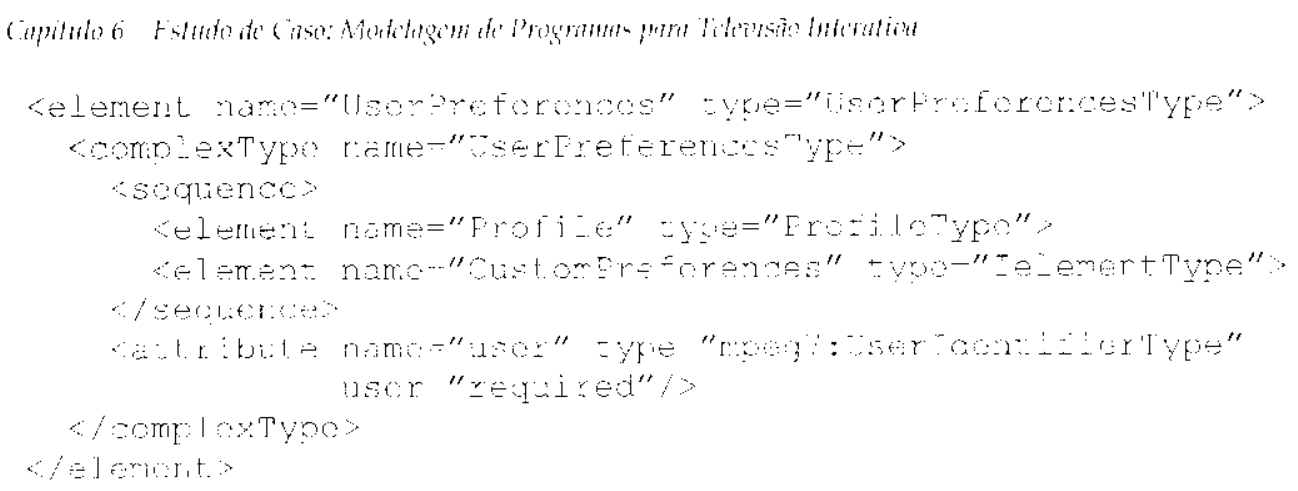

Figura 6.16 - Exemplo de Schoma para os elementos de preferências do usuário

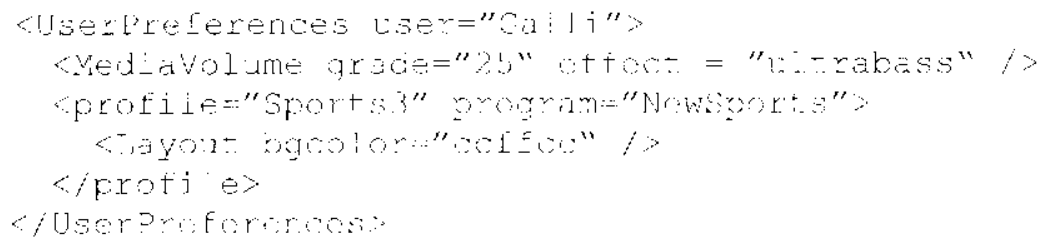

Figura 6.17 - Fxemplo do uso dos elementos de preferências do usuário

Com os elementos apresentados e utilizando as descriçōes do MI'EG-7 (1SO, 2001g; 1SO), 2001h) e do TV-Anytime Form (TVAF, 2001b; TVAF, 2001c), pode-se especificar um amplo conjunto de características singulares, além de personalizaçoes para os pertis e programas.

\subsection{Exemplos de programas de TV Interativa}

A linguagem visual para a TV Interativa deve ter características da linguagem já utilizada nos programas da televisào tradicional, da linguagem utilizada nos PDRs, e da linguagem presente em sites da WWW. Com isso, os programas adaptar-se-ão às novas funcionalidades disponiveis. A seguir, serăo apresentados alguns exemplos de programas da TV tradicional e algumas mudanças que serăo possíveis a partir da proposta aqui reportada.

Na parte visual em um evento, como um jogo de futebol, vôlei ou basquete, deve-se permitir a presença de múltiplas câmeras fornecendo vários ângulos da partida; na parte de áudio, a escolha da narração entre os vários narradores disponibilizados pela emissora do programa, ou o áudio original, se o programa for estrangeiro; na parte de dados relacionados, links para dados dos jogadores, dos limes, das partidas e dos campeonatos, sendo que alguns links podem ser exibidos em determinados momentos, como, por exemplo, após um gol em uma partida de futebol pode-se exibir links para replay, dados do jogador e da partida, dentre 
outros. Alguns dessess exemplos já estào disponívieis na tuhanced 'TV, porém de uma forma diferente e muito limitada.

No caso dos filmes, as possíveis mudanças são em direção a múltiplos ângulos, cenas alternativas e dados relacionados ao filme e aos atores. Fisse tipo de interaçáo já é possível e, em alguns casos, comum, como ocorre com os DVDs. Comandos como retroceder e avançar um filme, comuns nos PDRs, também podem ser disponibilizados pela emissora. Como complemento, as produtoras de filmes podem fazer um novo tipo de merchandising criando links aos seus produtos à medida que eles aparecem na tela, ou, entào, mudando os produtos de acordo com as caracteristicas do usuário.

Telejornais podem ler diversas "faces", ora privilegiando imagens, ora privilegiando noticias relacionadas, programas relacionados ou links na WWW relacionados com cada notícia. Cada notícia também pode ter uma versào expandida com maior duraçào que aquela mostrada no telejornal. O usuário, por sua vez, também pode personalizar seu telejornal a alguns assuntos de seu interesse.

Outro tipo dè programa tradicional que pode sofrer mudanças são os programas infantis, que podem incentivar a interação das crianças para a resposta de perguntas ou oferecerem mais informaçoes sobre objetos na tela, tornando-se, assim, educativos. Já existem programas infantis para a fulunced TV em transmissào nos ELA.

Um programa educativo pode utilizar as técnicas, já hastante estudadas, da educação por computador à distância e adaptá-las para a tela de TV c para os diferentes controles da TV Interativa. A TV pode ser uma interface mais interessante e acessivel às pessoas em geral, ao contrário do que ainda ocorre com o computador tradicional.

Programas de Home shopping podem sofrer uma melhoria significativa de qualidade e eficiência com a interaçà), uma ve\% que o consumidor pode obter informaçōes sobre o produto c comprá-lo. Além disso, é possivel personalizar o canal de Home Shopping, de modo a oferecer produtos atraentes, segundo o perfil do usuário. Os programas de Home Shopping podem ser adaptados para serem chamados a partir do link nos produtos em filmes, comerciais, notícias e outros programas de TV. 
Jogos Interativos também são uma parte motivadora da TV Interativa; os novos aparelhos, como o Xbox, I'layStation 2 e o Gamc Cube já têm características para jogos em redes e seus fabricantes pensam em adaptá-los para a TV Interativa. Gameshoưs são outros programas que podem ter um ganho bastante grande com a possibilidade de interação. Já existem programas interativos nos quais o usuário pode responder às perguntas ao mesmo tempo em que o participante do programa real e, no final do mês, o telespectador que mais acumular pontos ganha prêmios. Esses programas fazem uso dos recursos da Fnlanced Television e, para a interaçào (que á bastinte limitada), utilizam a linha telefonica. Considerando a TV Interativa com um canal dedicado, muitas outras características podem surgir, como a formaçào de equipes para compotir, auxilio da rede para o participante, dentre outras.

A propaganda para a TV Interativa deve ter um novo paradigma, uma vez que diversas novas variáveis serào introduzidas, como a propaganda direcionada (só alguns recebem a propaganda), a propaganda adaptável (dependendo de quem está assistindo, a propaganda é diferente) e a possibilidade de interação com o produto e, até mesmo, a compra via TV.

\subsection{Aplicação dos conceitos de programa e de perfil a um programa de evento esportivo}

Nesta seção, é apresentada uma proposta para um prograna esportioo que tenha como conteúdo uma partida de futebol, possibilitando a aplicação dos conceitos de perfis em um programa de televisào interativa. A siluaçào proposta para esse programa permite visualizar as novas formas de interação que o uso de perfis acrescenta à interaçào do usuário em TVI, evidenciando yue tanto o) usuario yuanto a própria aplicação interagem com a infra-estrutura descrita na Seção 6.4 .

Na exibição de um evento esportivo em TVI, alģumas características săo esperadas no contexto da interaçăo do usuário, dentre as quais pode-se deslacar: a) oferta de diferentes ângulos de câmeras; b) oferta de várias opçôes de áudio, tais como diferentes locutores e idiomas; c) acesso a informações estatísticas dos times que estăo jogando, do próprio jogo e dos jogadores; d) oferta de situações de replay, além do convencional; e) oferta de informaçòes sobre assuntos relacionados, como outros jogos simultaneos, por exemplo; f) acesso a informaçōes sobre o programa (sumário) e a programação; g) oferta de programas relacionados, como jogos do mesmo lime na programação do mês, por exemplo. 
Em termos de construção da aplicaçào, essas características devem ser implementadas e descritas segundo os elementos do programa e do perfil apresentados na Seção 6.7. Cada perfil pode possuir características únicas que devem ser especificadas. Nesse ponto, alguns exemplos de variáveis de um perfil podem ser como os seguintes:

- layout: aspectos de cor de fundo e das imagens/figuras; estilo dos botóes, estilo de menu, posiça do menu, posiçào das midias na interface do usuário (quando possivel); quais mídias devem ser apresentadas, quais mídias podem ter suas posições mudadas e quais podem ser as posiçōes finais;

- comminication: quais são os colecs necessários para cada mídia, hem como as taxas de laresura de banda necessárias para cada mídia;

- context: quais são os comandos de decisão que utilizam as variáveis de contexto, tais como que'm está usando, qual o horário de uso, quais outros aparelhos estão ligados e/ ou conectados, o que já foi visto até um delerminado momento;

- internction: quais sào as mudanças em relaçào às midias e ao layoul, por exemplo, a partir da interação do usuário com determinados grupos de botões/controles/menus associados a essas mídias e lmyout.

Vale ressaltar que a definiçào de uma instância de um programa, como é o caso de um erenlo esportico, nāo limita a aplicaçăo do conceito de perfis em TVI. Deve-se observar que tanto a infra-estrutura como os perfis podem ser aplicados, por exemplo, en ambientes interativos que contenham aplicaşoes diferentes da TVI, como é o caso da videoconferencia em um ambiente de ensino-aprendizagem.

\subsubsection{Definindo o programa}

Conforme apresentado, o programa é o elemento central de uma aplicação de T'VI, sendo responsável por agrupar os macro-elementos que descrevem a aplicação.

Para uma instância de programa, como é o caso do evento esportivo, observa-se que a definiçào dos elementos deve contemplar características especificas da aplicação, porém de forma associada aos elementos genéricos modelados. Os componentes do programa de evento esportivo sào apresentactos Tabela 6.11. 
Tabela 6.11 - Componentes do programa

\begin{tabular}{|c|c|}
\hline Objeto & Descrição \\
\hline Video_Principal & $\begin{array}{l}\text { Fi o strenm de vídeo principal da transmissão, semolhante a } \\
\text { transmissào atual de jogos de futebol. Composto por imagens de } \\
\text { diversas câmeras }\end{array}$ \\
\hline Video -I'opo & $\begin{array}{l}\text { E o strenm de video das imagens da câmera que fica acima do } \\
\text { estádio, em um dirigível. }\end{array}$ \\
\hline Video_GoL_esq & $\begin{array}{l}\text { E o stream de vídeo da imagem do gol da esquerda. Säo } \\
\text { utilizadas mais de uma câmera para esse stream de vídeo: uma } \\
\text { atrás da trave, uma acima da trave e uma lateralmente (para } \\
\text { escanteios e impedimentos) }\end{array}$ \\
\hline Video_Gol_dir & $\begin{array}{l}\text { É o stream de vídeo da imagem por trás da trave do gol da } \\
\text { direita; assim como o vídeo anterior, esse é composto por } \\
\text { imagens de mais de uma câmera }\end{array}$ \\
\hline Video_Amplo & $\begin{array}{l}\text { Apresenta a imagem do jogo de longe e é útil para examinar a } \\
\text { tática do jogo }\end{array}$ \\
\hline Video_zoom & $\begin{array}{l}\text { Apresenta a imagem do jogo de perto, focalizando jogactores e } \\
\text { jogadas }\end{array}$ \\
\hline Audio Principal & Canal de áudio principal com locução e comentários \\
\hline Audio_Locucao2 & Canal de áudio do locutor alternativo \\
\hline Audio_Banco_esq & $\begin{array}{l}\text { Canal de audio com o som do banco de reservas do lado } \\
\text { esquerdo }\end{array}$ \\
\hline Audio_Banco_dir & Canal de áudio com o som do banco de reservas do lado direito \\
\hline Audio Ambierte & Canal de áudio com o som ambiente da partida, sem locuçào \\
\hline estatistica timel & Dados e links referentes ao time 1 \\
\hline estatistica_time 2 & Dados e links referentes ao time 2 \\
\hline estatistica_jogo & Estatísticas do jogo \\
\hline Campeonato & Informagoes online de outros jogos do campeonato \\
\hline
\end{tabular}

\subsubsection{Descrevendo o programa}

A descriçâo MPEG-7 do programa de evento esportivo deve contemplar todos os elementos definidos no modelo de programa, a comecar pelo elemento sceme, a partir do qual é construída a árvore de elementos.

Uma vez descrito o elemento Scene, pode-se instanciar elementos de mídia, de interaçào, de timeline, de comunicaçào, de lnyout, c as elementos de composiçào, yue são o Summary e o Schedule. A Figura 6.18 apresenta a descriçào MPEG-7 para o programa de evento esportivo.

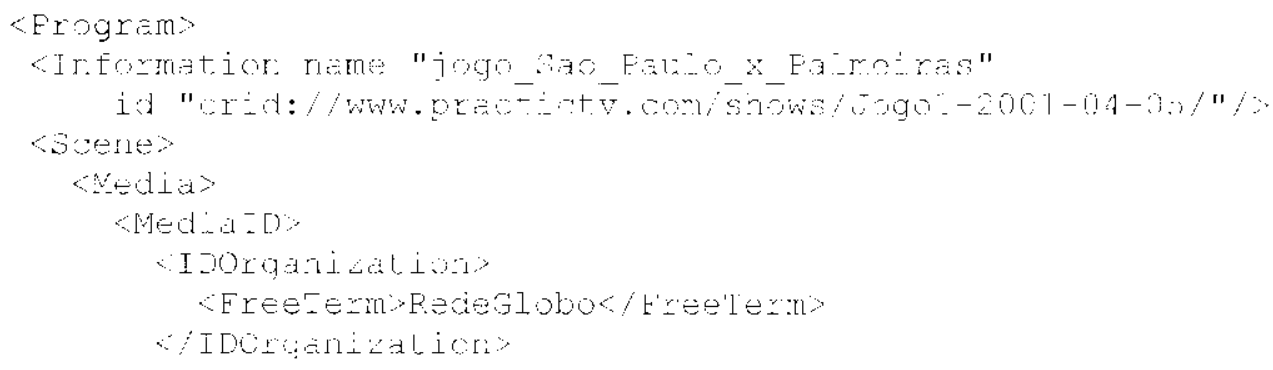




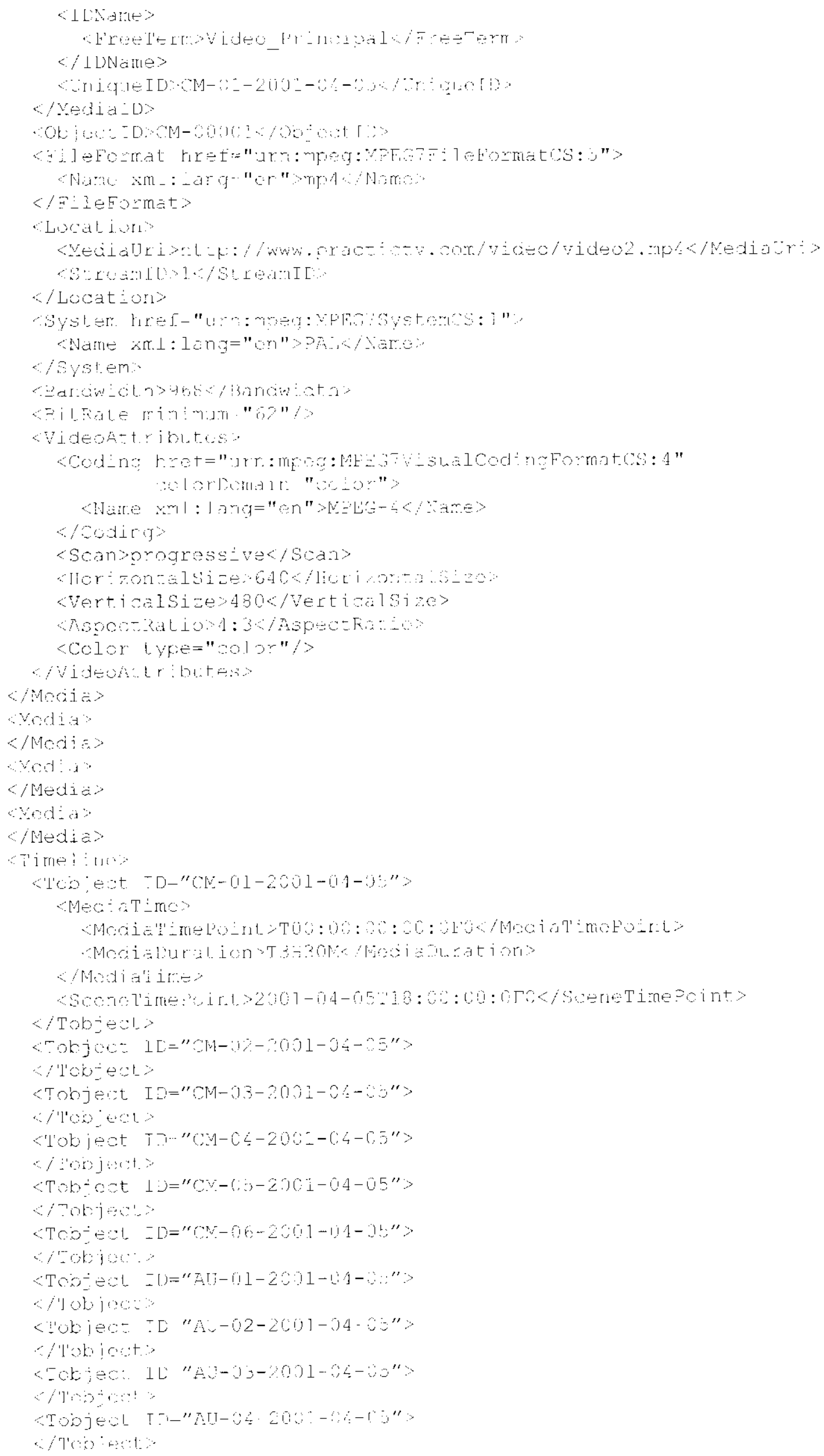




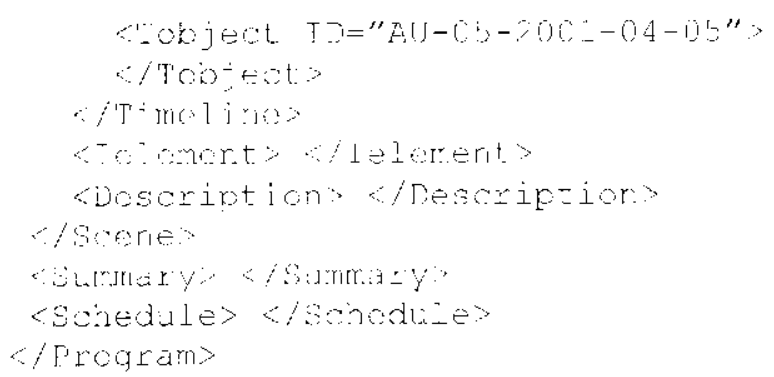

Figura 6.18 - Exemplo da descrição de um programa de evento esportivo

\subsubsection{Descrevendo os Perfis}

A partir do conteúdo disponibilizado pelo programa, foram definidos três perfis para o programa de evento esportivo. O primeiro é o perfil hásico, bastante semelhante à transmissão atual, com pequena possibilidade de interação. O segundo perfil contempla pequena possibilidade de interaçào e troca de imagens e sons, porém com grande ênfase ao acesso às informaçòes relacionadas ao evento. O terceiro perfil é o mais completo, com total possibilidade de intraçăo por parte do usuário e com muitas opções de imagens e de sons. A seguir, é apresentada, na Figura 6.19, a implementaçâo do primeiro perfil; a Figura 6.20 mostra o segundo perfil, enquanto a Figura 6.21 apresenta o terceiro e mais completo dos perfis especificados.

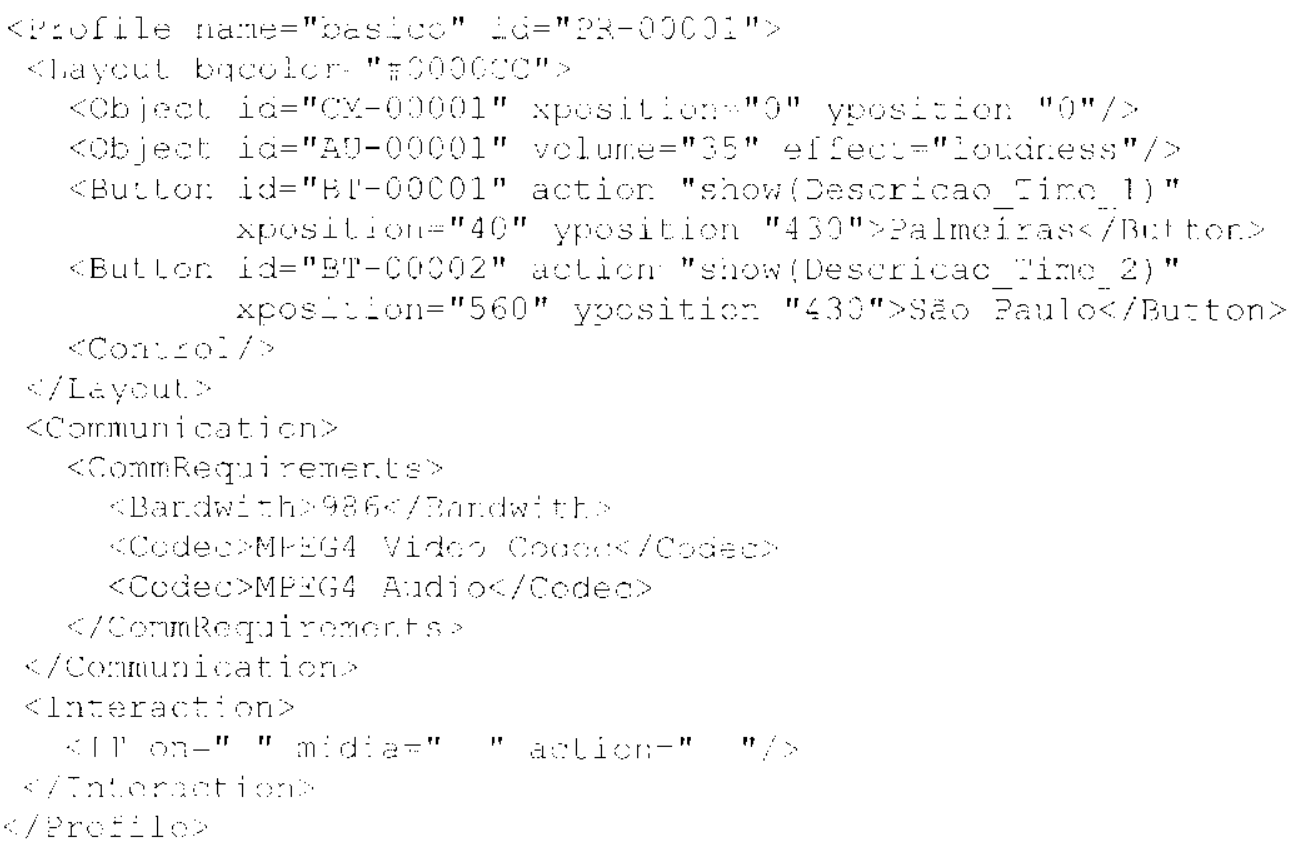

Figura 6.19 - Exemplo do perfil básico 
A seguir, será apresentado o seguundo perfil, que possui diversas características de interação, principalmente com conteúdo relacionado.

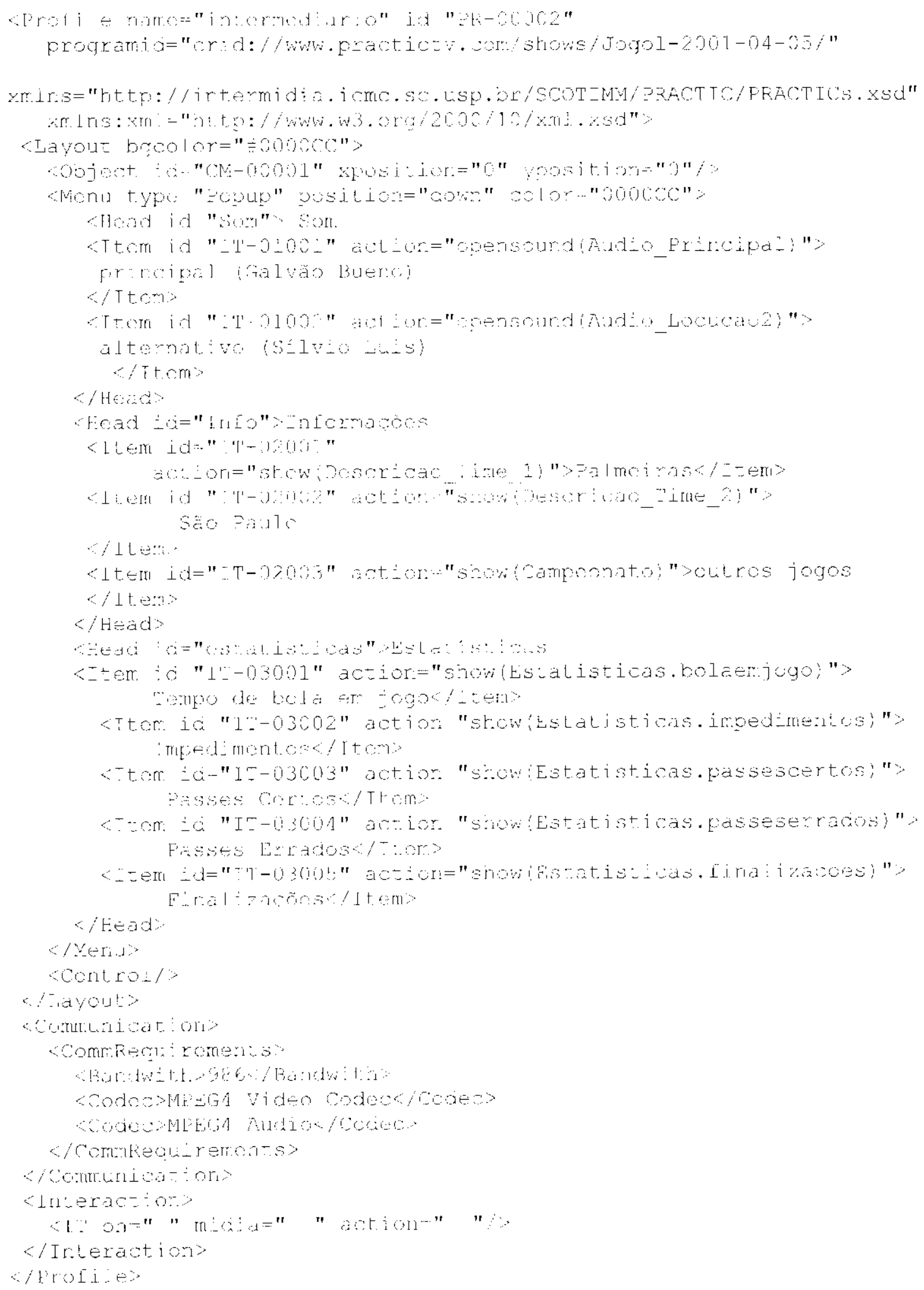

Figura 6.20 - Exemplo do perfil intermediário 
O tercuiro perfil é o avançado, possuindo como característica uma grande diversidade de imagens e sons.

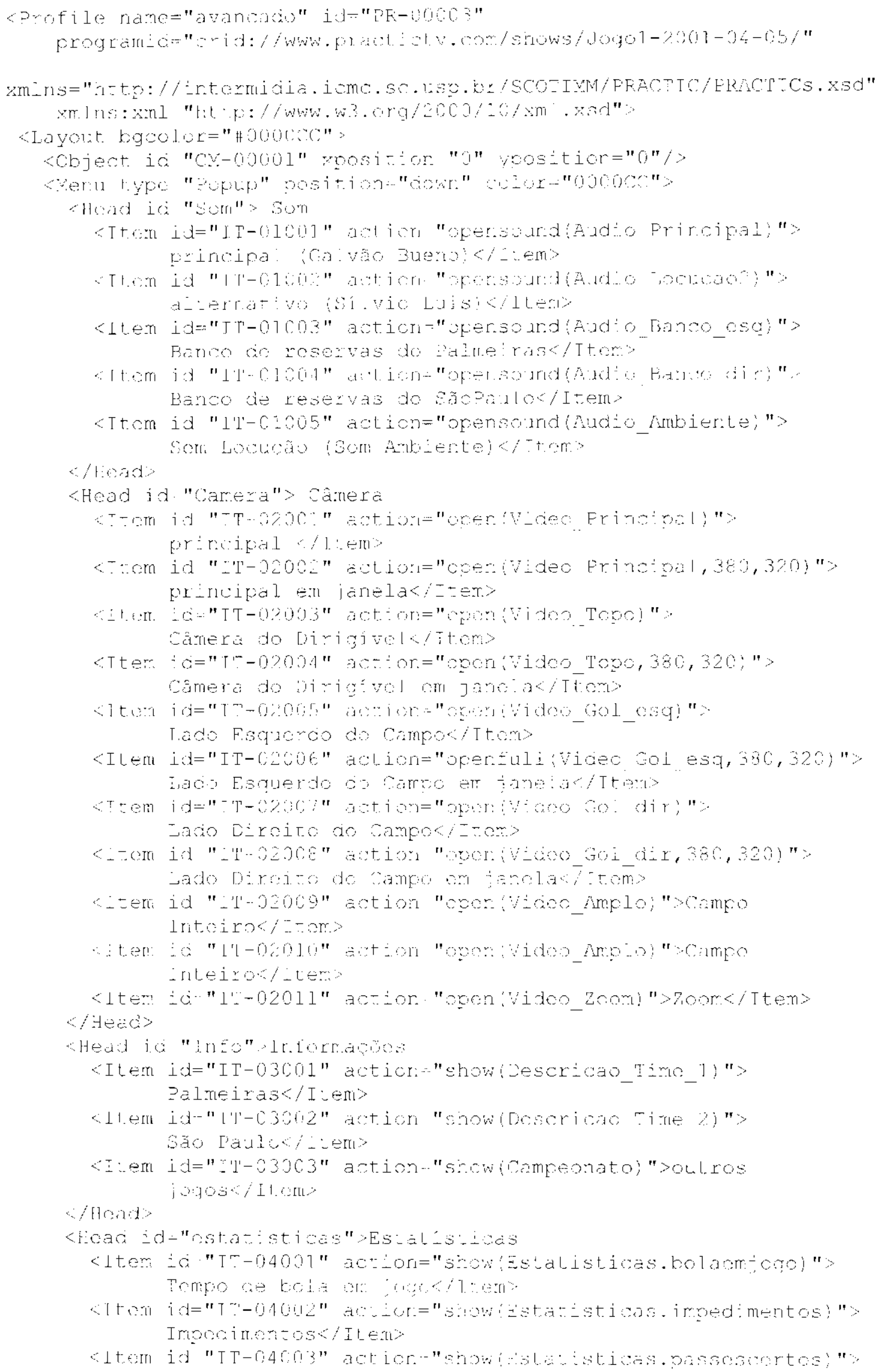




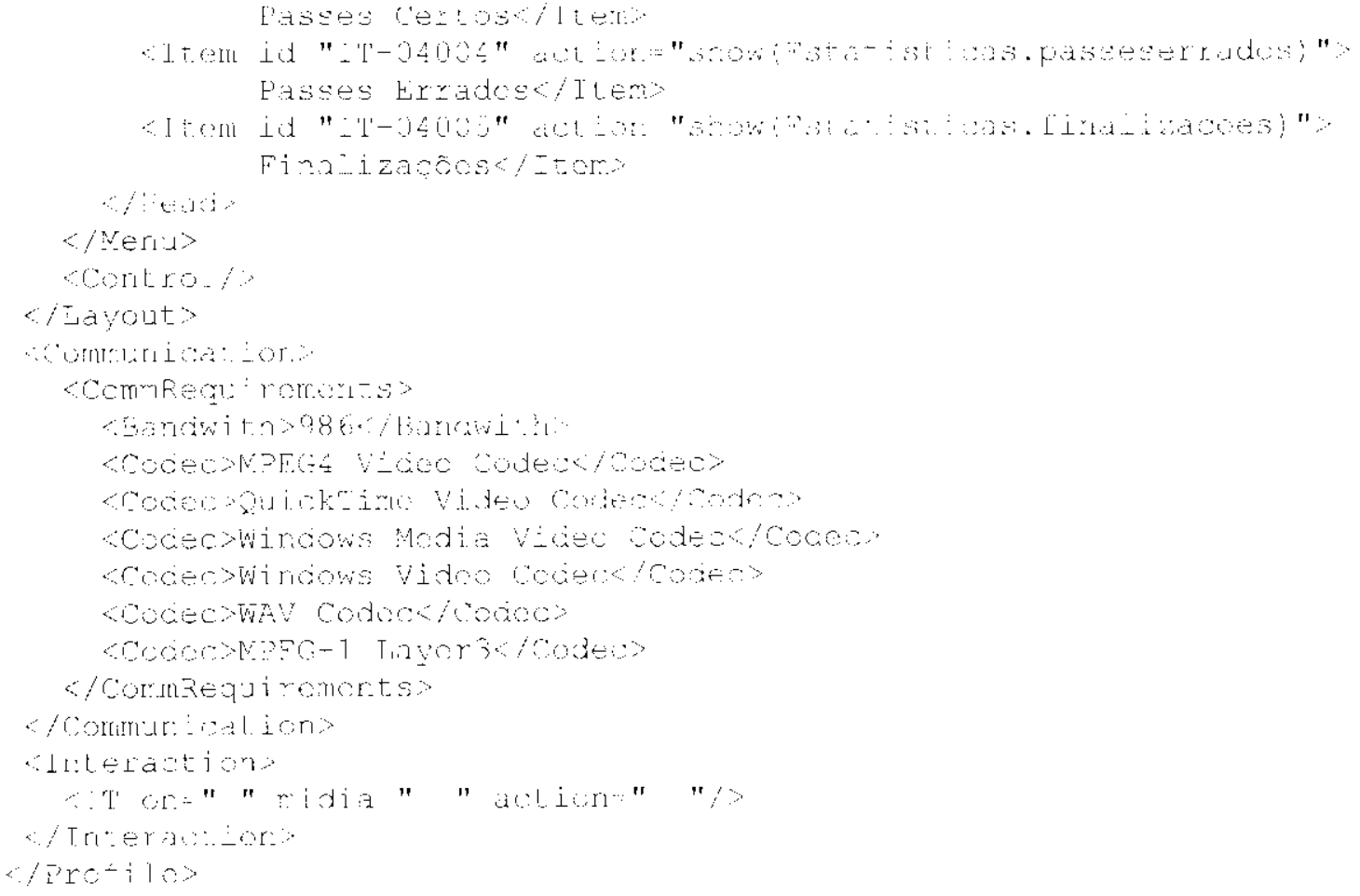

Figura 6.21 - Exemplo do perfil avançado

No terceiro exemplo de perfil, pode-se observar a utilizaçäo dos elementos de contexto que näo foram utilizados nos outros dois perfis. A utilizaçào desses elementos nào é obrigatória e, apesar de no exemplo terem sido usados para persuadir os usuários a comprarem produtos, esses elementos podem ser utilizados de modo a melhorar a interação do usuário com a televisão.

Observando os três exemplos, percebe-se que, utilizando os conceitos de programa e perfil, é possivel o reaproveitamento de conteudo para a apresentaçáo de diferentes programas, de um nodo relativamente simples. Esses conceitus também sào úteis na personalizaçào da TV e permitem a utilizaçào de consciência de contexto nesse ambiente.

\subsection{Considerações finais}

Quando se pensa na televisão interativa inserida cm um ambiente consciente de contexto, pode-se vislumbrar inúmeras novas aplicaçoes.

É possivel pensar que as redes de televisäo conseguirão lazer uma transmissão diferenciada para diferentes contextos; os anunciantess poderão transmitir suas propagandas somente para seu público-alvo; certas cenas poderăo ser excluídas em determinadas situaçõés (a presença 
de uma criança, por exemplo). No cntanto, deve-se observar que não só a transmissão mudará, mas também a apresentação passará por sensiveis mudanças.

Neste capitulo, foi apresentada, como estudo de caso, a modelagem completa de uma aplicaçào para TVI com base tecnológica centrada nos padrōes MPEG-4 e MPEG-7. Como contribuição, apresentou-se um modelo para composiçào de um programa interativo a partir dos conceitos de programa e perfil, também formalizados por este trabalho.

No próximo e último capítulo desta tese, são apresentadas e discutidas as conclusōes deste trabalho, bem como descritas as limitaçoes evidenciadas, yue permitem a identificaçào de trabalhos futuros e de um cenário para o desenvolvimento de novas pesquisas. 


\section{Conclusões}

\subsection{Considerações iniciais}

Conforme discutido neste trabalho, a evoluçăo e integraçăo dos sistemas digitais e o surgimento de novas e avançadas tecnologias multimídia têm oferecicto espaço para o desenvolvimento de novas e complexas aplicaçòes interativas.

Ao considerar o estado da arte representado pela evoluçào e convergência dos sistemas digntais (computadores, televisão, telefones e telefonia, infra-estrutura de comunicaçào de dados, PDAs - Personal Digital Assistant, dentre outros) e propor a utilizaçào dos padrões da família MPFG - MPEG-4, para representaçào de conteúdo multimídia na forma de objetos de mídia (ISO, 2001a); e MPFG-7, para descrição de informaçăo associada ao conteúdo multimidia (ISO, 2001b) - este trabalho ofereceu contribuiçoes sinģulares para o campo de modelagem de amlientes interativos conscientes de contexto, uma vez que ainda são poucos os trabalhos cientificos dessa natureza.

O foco deste trabalho é a proposta de uma modelagrem para ambientes interativos conscientes de contexto, especificando métodos para integração de tecnologias como MPEG4 (ISO, 2001a), MPEG-7 (ISO, 2001b), XMI. (Connoly, 1997), dentre outras, e apontando para modelos de desenvolvimento de aplicações interativas, tais como televisào interativa, videoconferência, vídeo-sob-demanda, dentre outras. A Figura 7.01 - que é uma reprodução da Iigura 1.01, apresentada no Capítulo 1 e recolocada aqui para auxiliar na compreensão do texto - apresenta a estrutura gráfica do escopo que foi coberto pela modelagem proposta, sendo importante relembrar os três modelos distintos que compóem a modelagem:

- NECTAR (Network Linironment with Context-Awareness Rules): cobre a infra-estrutura de comunicaçào necossária a aplicações interativas conscientes de contexto, principalmente em termos dos requisitos de rede;

- SPICE (Schemes for Internction on Context-Andart Environments): cobre os aspectos de modelagem que definem esquemas e criterios de interaçào para o modelo de interaçóes completas (complete' interaction $\rightarrow$ user-nctuork-application); 
PRAC'IIC (Profile for Context-Aware Interactive Applications): cobre o modelo da geração de perfis de aplicacoes interativas, sendo composto pelo PR ACTIC-E (PRACTIC Program Examples) - que cobre a especificaçào de perfis para instâncias de aplicaçōes interativas, como é o caso de programas de TVI - e pelo PRACTIC-S (PRACTIC Schema) - que cobre a especificação de esquemas de clescrição para aplicações interativas genéricas;

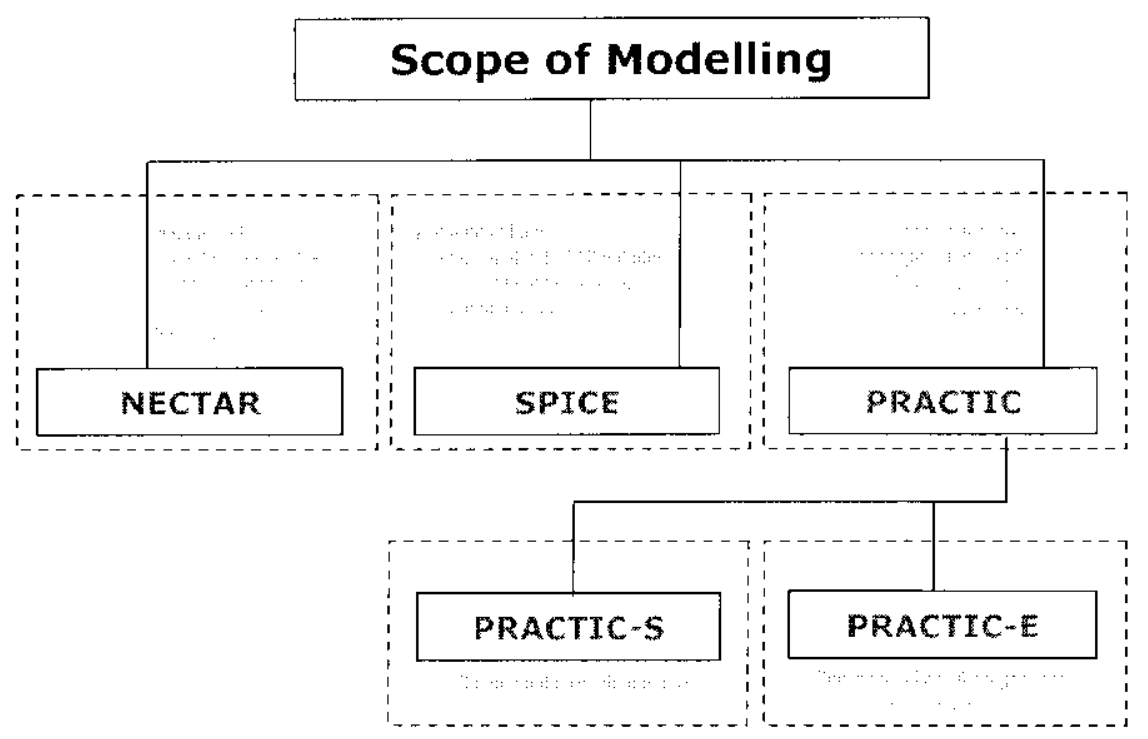

Figura 7.01: O escopo da modelagem - estrutura gráfica (Santos Jr. et al., 2001 b)

Nesta proposta, os agentes de software são vistos como componentes do ambiente e estão presentes nos três modelos propostos (NICTAR, SPICE a PRACTIC), servindo, portanto, como elemento integrador desses modelos. Neste sentido, a modelagem proposta explora os recursos da plataforma JADl: (Jara Agrents Dezelopment Framemork), que está rm desenvolvimento nos laboratórios TILAB (Bellefemine et al., 1999; Bellefemine et al., 2001). Portanto, no universo desta proposta, requisilos para o uso de agentes foram identificados e classificados, regulando as formas de provimento de informaçóes contextuais para os elementos que compõem as aplicaçoes interativas conscientes de contexto, yuer seja ao nivel da infra-estrutura de comunicação) (NECTAR), ao nível da interação usuário-ambiente (SPICE) ou ao nível da personalização do ambiente (PRACTIC).

Neste capítulo, são discutidas as contribuiçôes desta tese, o que ocorre na Seção 7.2. Lm seguida, na Seçào 7.3, são apontadas algumas das limitações do trabalho e, na Seçào 7.4, são descritos alguns dos trabalhos futuros. Na Seçào 7.5, são apresentadas alguns considerações finais. 


\subsection{Contribuições}

Ao longo da tese, observou-se que a principal contribuição oriģinal deste trabalho é a modelagem que visa definir e formalizar novos tipos de interaçăo gerados por uma aplicação inserida em um ambiente interativo consciente de contexto. Nesses ambientes, mecanismos tradicionais como VCR e STB (set-Iop Box) tendem a ser substituidos por dispositivos sensoriais, o que sinaliza para a interaçào usuário-ambiente ao invés da interaçào usuáriocomputador, simplesmente. A modelagem auxilia o desenvolvimento dessas aplicaçoes interativas por apresentar um conjunto bem definido das interaçóes geradas pela comunicação entre as entidades usuário, rede, aplicaçào e terminal (Santos Jr. et al., 2001a; Santos Jr. et al., 2001b). A modelagen, ao contemplar a consciência de contexto, apresenta avanços para o desenvolvimento de aplicaçōes complexas, como é o caso dos ambientes classificados como wearable computing e ubiquitons computing.

Os modelos NECIAR, SPICE a PRACTIC consideram as potencialidades dos padries MPLG-4 ? MPEG-7. Particularmente, o MPEG-7 é utilizado para oferecer suporte a personalização do ambiente através de esquemas de descrição das cenas multimídia.

As inovaçōes presentes neste trabalho estão concentradas no fato de que os padrōes, tecnologias e modelos, propostos até então, não consideram as interaçòes existentes entre a infra-estrutura de comunicaçào, a aplicaçào e os objetos de mídia que compoem uma ou mais cenas multimidia, uma ve\% que a representaçào das midias como objetos foi possível somente após a padronizaçáo do MPEG-4. Desta forma, os aspectos de consciencia de contexto são utilizados sempre ao nível da aplicação e não há preocupação em formalizar os critérios de interaçáo para uso da consciência de contexto e, nem mesmo, de formalizar a semântica dos elementos contextuais WHO, WIAT, WHERE e WHFN (Dey \& Abowd, 2000). Ao formalizar os aspectos de consciência de contexto, dentro do universo das aplicaçoes interativas, este trabalho representa um avanço na direção dos novos tipos de interação que sào esperados para a nova geração de aplicaçòes multimídia. Algumas funçòes tradicionais de controle remoto, por exemplo, tendem a desaparecer o outros tipos de mecanismos de controle devem surgir muito em breve, o que reforça a importancia da modelagem dos ambientes interativos conscientes de contexto, e não somente das aplicaçōes multimídia. 
Este trabalho também inovou na direçào da definiçào dos conceitos de perfil de aplicação interativa e de programa interativo, que sào apresentados de forma compativel com as tecnologias MPEG-4 e MPEG-7, gerando extensões a essas tecnologias de modo a possibilitar o uso inteģrado da aplicaçào com o ambiente.

A pesquisa realizada nesta tese abrangeu tópicos de diversas subáreas da Ciência da Computaçào e, portanto, as contribuiçôes são tratadas separadamente nas subseçôes seguintes.

\subsubsection{Contribuições para o campo da modelagem de sistemas multimídia}

No campo da modelagem de sistemas multimídia, a modelagem proposta estende o modelo proposto por Sauer e Fingels (Sauer e Engels, 2000), uma ve que considera aspectos de consciência de contexto explorar a codificação das mídias como objetos, através do suporte oferecido pelo padrão MPEG-4. Adicionalmente, a modelagem proposta também estende as categorias de interatividade e níveis de personalização propostas por Van Setten e seus colaboradores (Van Setten et al., 2001), especialmente através da proposta de formalização de consciência de contex to pela concepçâo das regras contextuais.

\subsubsection{Contribuições para o campo dos agentes de software}

No campo dos agentes de software, os requisitos para uso de agentes de software identificados nesta proposta impactam diretamente o desenvolvimento da plataforma JADE (farn Agents Derelopment Frnmerork), proposta por Bellefemine e seus colaboradores (Bellefemine et al., 2001). Novas API têm sido desenvolvidas para suportar consciência de contexto e a produçào de regras contextuais. Os requisitos aqui identificados têm sido incorporados à plataforma JADE através de aplicaçöes MPEG-J, conforme discutido no Capítulo 5.

\subsubsection{Contribuições para o campo da consciência de contexto}

No campo da consciência de contexto, o modelo SPICF estende o modelo proposto por Dey c Abowd (Dey \& Abowd, 1999) oferecendo suporte ao uso de informaçoes contextuais em todos os níveis (aplicação, infra-estrutura de comunicaçào, interaçào do usuário, mídias) da composiçào estrutural de um ambiente consciente de contexto. 


\subsubsection{Contribuições para o desenvolvimento de aplicações multimídia interativas}

Por último, no campo das aplicaçöes, mais precisamente da televisão interativa, a modelagem proposta especifica como produzir, distribuir c apresentar um programa de TVI, adicionando o conceito de profile interatizo a esse programa, o que caracteriza uma inovaçào no campo da Televisâo Interativa.

A modelaģem também agrega valor aos padroes MPEG-4 e MPEG-7, ao apresentar uma visão coerente sobre como integrar essas tecnologias no desenvolvimento de aplicaçóes interativas. Essa visão, haseada nos conceitos de programa e perfil, oferece esquemas eficientes para representação de conteúdo multimídia e meta-informação associada ao conteúcto, que sào objetos de trabalho para toda a cadeia produtiva de aplicações de TVl.

\subsubsection{Contribuiçōes para o estabelecimento de novos modelos de negócios}

O desenvolvimento das novas tecnologias de informaçâo é uma oportunidade estratégica para as organizaçoes que desejam aumentar sua competitividade na sociedade da informação. Freqüentemente, surgem notícias que demonstram o impacto estratégico dessas novas tecnologias, desde as mais inovadoras que permitem a compra de bilhetes de cinena a partir de dispositivos móveis de comunicaçào, à evoluçáo dos modelos de negócio mais tradicionais, como é o caso dos bancus, por exemplo. O comércio eletrônico (e-commerce) e os negócios eletrônicos (e-business) săo hoje a prova tangível de que empresas e setores da economia fazem parte de um ambiente competitivo baseado na utilização das novas tecnologias e da Internet (Amor, 2000).

O gestor daquela empresa que pretende ter sucesso num futuro próximo enfrenta assim novos desafios, e precisa compreender profundamente as estratégias que podem resultar da utilização das novas tecnologias.

Neste cenário, a modelagem aqui proposta, quando apresenta uma referencia para o desenvolvimente de aplicaçós inseridas em um ambiente interativo consciente de contexto e especifica as entidades (e seus comportamentos e relacionamentos) que formam ambientes dessa natureza, contribui ao oferecer os elementos necessários à compressão dessas novas tecnologias, especialmente em como integrá-las, considerando a evolução natural dos sistemas digitais. 
Observa-se que a apresentaço do MPEG-21 nesta tese sinaliza para o fato de que itens digitais universais poderào ser utilizades como elementos independentes, porém integrados, na construção de aplicaçōes, acrescentando novos requisitos tecnológicos. $O$ tratamento da informaçào poderá ser globalizado, criando novos cenários virtuais com maior grau de realismo, em relaçăo aos procedimentos que sào utilizados nos modelos de negócios já consolidados. Isto é um fato relevante, uma vez que muitas organizações ainda resistem ao uso das novas tecnologias quando encontram dificuldades em representar seus modelos tradicionais de negócios (muitas vezes de sucesso) em modelos digitais.

\subsection{Limitações}

Uma limitaçăo inicial está relacionada à escassez de ferramentas de autoria que permitam a implementaçào de todos os elementos e componentes propostos pela modelagem. No entanto, esta limitação é temporária, uma vez que há crescente interesse da indústria em produzir ferramentas para suportar os padrōes MPEG-4 e MPEG-7 (Envivio, 2001; Sinfonia, 2001).

Quanto à modelagem, especialmente no campo dos agentes, existem limitações na definiçăo de ontologias que validem por completo os diagramas use-ase discutidos no Capítulo 5. Observa-se que os requisitos identificados para o uso de agentes descrevem somente as primitivas fundamentais para suportar o uso desses agentes no fornecimento de informações contextuais e na personalização do ambiente interativo. Neste sentido, novas formas de uso de agentes poden ser necessárias em ambientes com novas complexidades, especialmente para que o uso de agentes seja compativel com as especificaşoes de padrões como o FIPA (Foundation for Intelligent Physical Agents).

Em relaçào à infra-estrutura de comunicação, o modelo NECTAR contempla os elementos fundamentais para prover informaçoes contextuais sobre a rede o sobre os dispositivos do ambiente. No entanto, é necessário expandir o conceito de personalização a tecnologias que contemplem maior grau de inteligência e não simplesmente o automatismo. Assim, a modelagem nào contempla especificaçōes de redes ations, por exemplo, o que limita os niveis de personalizaçào às informaçóes contextuais disponiveis.

\subsection{Trabalhos Futuros}

Considerando a modelagen desenvolvida e reportada ao longo dos capítulos desta tese, pode-se discutir a continuidade do trabalho aqui reportado, enfocando, assim como ocorreu 
nas contribuiçoess, as diversas subáreas da Ciência da Computaçào que podem ser impactadas por pesquisas futuras.

No campo da consciência de contexto, pode-se realizar extensōes no modelo SPICE, visando sua completitude em termos de criterios de interaçào. Em adição, extensòes podem ser feilas em termos da inserça de novos componentes estruturais nas classes contextuais, expandindo a cobertura dos elementos de contexto a partir dos formalismos das regras contextuais. Complementando, pode-se especificar novas descriçōes MPEG-7 que possam scr utilizadas como classes de critérios de interação.

Estendendo os critérios de interaçào, espera-se que novas contribuiçóes sejam dados no campo dos ambientes personalizados. Neste sentido, os conceitus de programa e perfil, definidos neste trabalho, podem ser estendidos para suportar novos elementos de personalização, especialmente aqueles que se relacionam $\mathrm{com}$ a infra-estrutura de comunicação, estabelecendo novas associaçòes entre os modelos NECTAR e PRACTIC. Nesle ponto, a investigação sobre propriedades das redes ativas pode acrescenlar novos itens de personalização e permitir a definição de niveis diferenciados de qualidade de serviço.

Observa-se, então, que no campo das redes de computadores e infra-estrutura de comunicação uma contribuição importante poderia ser a implementação de uma infraestrutura com suporte a redes ativas em ambiente multicasting, investigando novos niveis de interação entre a aplicaçào interativa e o ambiente em que essa aplicaçào está inserida. Tais contribuiçoes poderiam estender as funcionalidades previstas no modelo NECTAR.

No campo da hipermídia, muitos trabalhos de pesquisa podem ser definidos, indo desde a implementaçào de EPGs à criação de programas interativos, incluindo ferramentas de busca (searching tools) en vídeos que ulilizem MPEG-7 ou X.ML para a descrição de metainformaçao associada às cenas.

No campo dos agentes de software, espera-se que extensóes possam ser feitas para os requisitos de uso desses agentes. Ontologias podem ser definidas a partir do modelo proposto para interação com os agentes, e essas ontologias podem ser criadas para suportar níveis de automatismo em aplicaçoes que recomendam programas ao usuário, de acordo com suas preferencias e comportamento. 
No campo da interaçào usuário-ambiente, espera-se que extensōes sejam produzidas para os Sch'mn MPFG-7, de modo a suportar outros elementos de layout, tais como novos tipos de menu. Adicionalmente, tornam-se relevantes trabalhos que comparem o comportamento do usuário en um programa de TVI ao seu comportamento num sife na WWW $\mathrm{c} /$ ou assistindo a um programa da 'IV tradicional. Tais contribuiçoes podem ser significativas num cenário de emotionnt inlerfaces, por exemplo.

Por fim, no campo de banco de dados, pode-se trabalhar na estruturaçào de um modelo de banco de dados multimídia com suporte às novas tecnologias interativas, como é o caso do MPEG-4, oferecendo suporte ao armazenamento e recuperaçäo de objetos de midia. Trabalhos dessa natureza podem contribuir sobremancira para o desenvolvimento de aplicaçöes de comércio eletrònico, por exemplo.

\subsection{Considerações finais}

Neste capítulo foram apresentadas as conclusōes deste trabalho, ressaltando-se também alguns dos trabalhos que podem ser realizados como continuidade deste.

Quando se pensa em aplicações interativas inseridas em um ambiente consciente de contexto, pode-se vislumbrar inúmeras novas aplicaçòes. Ĺ possivel pensar, por exemplo, que as redes de televisào conseguirào fazer uma transmissão diferenciada para diferentes contextos; os anunciantes poderão transmitir suas propagandas somente para seu públicoalvo; certas cenas poderão ser excluídas em determinadas situaçōes (a presença de uma criança, por exemplo). No entanto, deve-se observar que não só a transmissão mudará, mas também a apresentação passará por sensíveis mudanças. Portanto, a modelagem de um ambiente completo é justificada pela necessidade de compreensão e formalização desse novo universo de potenciais aplicaçòes.

Por fim, a importância desse trabalho foi reconhecida na comunidade pela aceitaçào, no Brasil e no exterior, de cinco trabalhos científicos (Santos Jr. et al., 2001a; Santos Jr. et al., 2001b; Faria, Santos Jr., Moreira \& Goularte, 2001; Santos Jr. et al., 2002a; Santos Jr. et al., 2002b). 


\title{
Referências Bibliográficas
}

\author{
(Abert, 2000) \\ ABFRT. Teste's e'm Sistemus de Telerisaio Digital (Fevereiro de 2000) - [On Line] \\ http://www.anatel.gov.br/biblioteca/publicacao/relatorio_tvdigital_cp216.htm
}

(Abowd, 1999)

Abowd, G.D. (1999): Softeme Enginering Isste's for Ubirnitous Computing. Proceedings of International Conference on Software Engincering (ICSE'99), pp.75-84, 1999-May.

(Amor, 2000)

Amor, D.: 'The e-Business (R) Evolution: Living and Working in na Interconnected World. 1st Edition. Upper Saddle River, NJ: Prentice Hall, 2000. p. 6.36.

(A'TEF, 1995)

Advanced Television Systems I - Digital Audio Compression Standard (AC-3) - (A/52) (Dezembro de 1995) - [On Line] - http://www.atscorg/Standards/A5̃2/A_52A.pdf

(A'T'VEF, 2000)

Advanced Television Enhancement Forum - Fnhanced Content Specification (2000) - [On I,ine] http://www.atvef.com/library/spec1 1 1a.html

(A'T'VEF, 2001)

Advanced Television Systems I - ATSC Digital Telerision Stundard (Revision A) - (A/53) (Abril de 2001) - [On Line] - http://www.atscorg/Standards/ $553 / a_{-} 52 . p d f$

(Anatel, 2001)

Agència Nacional de Telecomunicaçòes (ANATEL) - Relutório Integrator dos Aspectos lécricos '. Mercudoligicos da TV Diritul - icrsino 1.0 - $(28 / 03 / 2001)$ - [On Line] http://www.anatel.gov.br/eventos_publicos/Consulta/2001/consulta 291/Relatorio_Integrador.exe

(ARIB, 2000)

Association of Radio Industries and Businesses (ARIB). - IIU Document 6M/J2-E Operalional Guideline's of ARIB'S XMI-Insed Multimedin Coding Scheme(Ver.1.2) - (Setembro de 2000) - [On Line] - http:/ www.itu.int/itudoc/itu-r/sg6/docs/wp6m/2000-03/contrib/009e.html

(ATSC, 2001)

ATS (2001): Advanced Television Systems Committee: ATSC DICITAL TEIIVISION STANDARI) (Revision A) [2001-April] http:/ www atscorg/Standards/A53/. Available on 2001.

(Backer et al., 1998)

Backer, G.; Bennington, J.; Boltax, J.; Gage, K.; Garcia, M.; Richmond, M.; Vickers, M.; Watson, S.; Zigmond, D. - A Fromerwork for Interactive Television Based on Internet Standards Apresentado no Workshop Television and the Web - (Julho de 1998) - [On Line] htlp://www.atvef.com/library/9806_framework.html 
(Barbieri, 2001)

Barbieri, M.; Ceccarelli, M.; Mekenkamp, G.; Jesvadba, J. - $\Lambda$ Porsonal TV Receizer with Storage and Retrieval Conphilities - Proceedings of the 1 st Workshop on Personalization in Future TV. Sonthofen, Germany, (Julho de 2001). http://www.di.unito.it/ /iliana/LM01/harbieri.pdf

\section{(Bates \& Gregory, 1997)}

Bates, R. J. and Gregory, D. (1997): Voice and Data Commmanications Handhork. McGraw-Hill Series on Computer Communications, 1997.

(Battista et al., 1999)

Battista, S.; Casalino, F.; Lande, C. MPFG-4: A Multimedin Standand for the Third Milleminm, Part1 - IEEE Multimedia, págśs 74-83 (Outubro-Dezembro 1999).

(Bellifemine et al., 1999)

Bellifemine, F. et al. (1999): IADE A FIPA-complinnt ngent framerwork. Proceedings of PAAM'99. London, pp.97-108. 1999-August.

(Bellifemine et al., 2001)

Bellifemine, F. et al (2001): Dereloping mulli agent systems with a FIPA-complinul agent framezork. In: Software - Practice And Fxperience, N.31, pp.03-128. 2001- February.

(Berger, 1995)

Berger, D. (1995): Video-on-Lemend Metadatn Query Interfaces. Master Thesis. University of California at Berkeley, 1995.

(Bernes-Lee et al., 1994)

Berners-Lee, T.; Cailliau, R.; Luotonen, A.; Henrik, N. and Secret, A. (1994): 'The World Wide Web. Communications of the ACM, N.8, V.37, pp.76-82, 1994.

(Bernes-I.ee et al., 1998)

Berners-lee, T. et al. (1998): Uniforn Resonroe ldentifiers (LIRI): Generic Syntux. Internet RFC 2396. Available on 1998.

\section{(Blásquez, 1998)}

Blásquez, M. (1998): Building Ontologies at the Knowledge Lerel using Ontology Design Encironment. KAW'98, Canada. 1998.

\section{(Booch et al., 1996)}

Booch, G.; Rumbaugh, J.; Jacobson, I. - LIML: Unified Modelling Langunge for Object-Oriented Development Documentation set. Addendmm, Santa Clara, California, Rational Software Corp, July 1996.

\section{(Bray et al., 1997)}

Bray, T. et al. (1997): Fxtensible Markup Iangunge (XMI) - Principles, Tools and Techniques. World Wide Web Journal, V.2, N.4, pp.29-66, 1997.

(Buford, 1994)

Buford, J. (1994): Lses of Multimedia Infornution in Multimedin Systems. Addison-Wesley, 1994. 
(Buford et al., 1994)

Buford, J.; Rutledge, L. and Kesklin, C. (1994): Hy()ctane: a Hylime Engine for an MMIS. Multimedia Systems, N.4, V.1, pp.17.3-185, 1994.

(Calvert et al., 1998)

Calvert, K. I. et al. (1998): Directions in Actioe Networks. IEEt: Communications Magazine $36(10), \mathrm{pp} .72-78,1998$.

(Chiariglione, 1999)

Chiariglione, L.: MPEG-4 - The fusion of natural and synthetic audio and video. Spring Conference in Computer Graphics 99, Budmerice, May-1999.

(Chiariglione, 2001)

Chiariglione, L.: Standard technologies to develop the multimedia applications. MPEG-4 Conference, Paris, 2001.

\section{(Churchill, 1998)}

Churchill, E. F. and Snowdown, D. (1998): Collaboratoratioe Virlual Fnoironments: An Introductory Rezine' of Issme's and Systems. Virtual Reality, V.3, N.1, 1998.

(Comer, 1995)

Comer, D. E. (1995): Intementorking whit TCP/IP. 3rd Edition, Prentice-Hall, 1995.

(Connoly, 1997)

Connoly, D. (1997): XMI, Principles, Tools and Techniques. World Wide Web Journal. O'Reilly, V.2, Issue 4, 1997.

(Cooper, 1997)

Cooper, A. (1997): About fruce: 7he Fssential of User Inlerface Design. IDG Books, 1997.

(Cornell, 1997)

Cornell, G. and Horstmann, C.S. (1997): Core /AVA - Guia Autorizato da SUN Microsystems. Editora Makron Books, São Paulo, 1997.

(Coulouris et al., 1994)

Coulouris, G.; Dollimore, J. and Kindberg, T. (1994): Distributed Systems: Concepts and Desing. 2nd Edition, Addison-Wesley Publishing Company, 1994.

(Daubechies, 1990)

Daubechies, 1.: The wavelet transform, time-frequency localization and signal analysis. IFF.F. Transactions on Information Theory, 36(5):961-1005, September 1990.

(DeRose \& Durand, 1994)

DeRose, S. J.; Duran, D. G. Making Hypermedia Work: A User's Gitide to HyTime, Kluwer Academic Publishers, Massachusetts, 1994.

(Dey \& Abowd, 1999)

Dey, A. K and Abowd, G. D. (1999): Cyberllesk: The' Use of Perception in Context Arrare Compuling. 1st WorkShop on Perceplual Liser Interfaces, pp.26-27, 1999. 
(Dey \& Abowd, 2000)

Dey, A. K. and Abowd G.D. (2000): Tounds a Better Inderstanding of Context and ContextAwareness. CHII 2000 - Workshop on the What, Who, Where, When, and How of ContextAwareness. The Netherlands, 2000-April.

(DVB, 1999)

Digital Video Broadcasting (DVB) - ETSI EN 300744 , - Framing structure, channel coding and

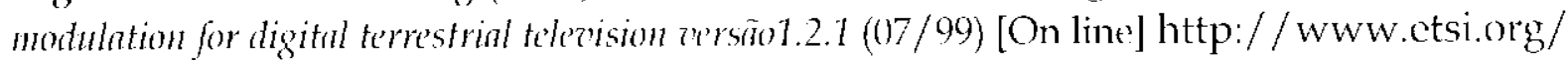

(DVB, 2000)

Digital Video Broadcasting (DVB) - FTSI TS 101 812, - Multimedia Home Platform (MHP) Specification 1.1 (Druft) [On I.ine] http:/ / www.mhp.org/

(Ebrahimi \& Horne, 2000)

Ebrahimi, T. and Horne, C. (2000): MPFG-4 Natumal Video Coding - an Ooeroiede. Signat Processing, Image Communication 15(4-5), pp.365-385. 2000.

(Engels, 2000)

Engels, G.: Object-Oriented Modelling of Multimedia-Applications. Handbook of Interaction on Multimedia Applications. 2000. [On-Iine] ftp:/Ls.pitledu/chang/handbork/54h.pedf

(Envivio, 2001)

The Envivio Tools for MIJ'G-4 Standard and Broadcast. The Envivio Corporation. [On-line] http://wwwenvivio.com

\section{(Evain, 1998)}

Evain, J. P. - The Multimedia Home Platform - an oceroiero - [On Line]

Extensible Markup Language (XMI) 1.0, W3C Recommendation, http://www.w3c.org February 1998.

(Faria, Santos Jr., Goularte \& Moreira, 2001)

Blengini, G. F., Junior, J. B. S., Goularte, R., Moreira, E. S.. Uso de Perfis em Aplicaçòes de Televisào Interativa Conscientes de Contexto. Anais do SBMidia 2001 - VII Simpósio Brasileiro de Sistemas Multimídia e Itipermídia, PP. 139-154. Florianópolis - SC., Brasil, outubro de 2001.(Impresso no Brasil - Eds: Roberto Willrich e Cesar Augusto Camilo Teixeira).

(Finseth, 1998)

Finseth, C.; Thomas, G.- Guilde to TV Bronlcast URLs- IOn Linel http://ietf.org/internetdrafts/draft-finseth-guide-01.txt

\section{(Fluckiger, 1995)}

Fluckiger, F. (1995): Understanding Neturorked Multimedia: Applications and Tedmology. Editora Prentice Hall, 1995.

\section{(Fröhlich, 1997)}

Fröhlich, P.; Wolfgang, N. A Database-Oriented Apprond to the Design of Eduational Hyperbooks, Proceedings of the Workshop "Intelligent Systems on the World Wide Web", 8th World Conference of the AIED society, Kobe, Japan, August 1997. 
(Galbreath, 1995)

Galbreath, J. (1995): Compressed I)igitnl Videconferencing. Educational Technology, pp.31-38, 1995.

(Garzotto et al., 1993)

Garzotto, F. et al. (1993): HDM: A Molel-balsed Appronch to Hypertext Application Design. The ACM Transactions on Information Systems, V.11, ‥2, pp.1-26, 1993-January.

(Goularte, 1998)

Goularte, R. - Utilizaģăo de Metadidos no Gerencinmento de Acesso a Servidores de Video (Fevereiro de 1998) - Dissertação de mestrado, ICMC/LSP, Sào Carlos 1998.

(Halasz, 1994)

Halaš, F. G. and Schwartz, M. (1994): The Dexter Hypertext Reference Motel. Communications of the ACM, V.37, N.2, pp.30-39, 1994-February.

\section{(Harrisson, 1996)}

Harrisson, M. (1996): 'The Essentials Ele'nents of Hypermedia. Academic Press, 1996.

\section{(Hashisuca, 1996)}

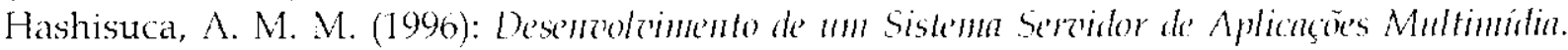
Dissertação (Mestrado), 1996. Instituto de Ciências Matemáticas e de Computação, Universidade de Sảo P’aulo.

\section{(Herwijnen, 1994)}

Herwijnen, E. van (1994): Practical SGMI.. Kluwer Academic Publishers, 2a Edition, 1994.

\section{(Isakovit $\angle$ et al., 1995)}

Isakovitz, T. et al. (1995): RMM: A Methodology for Structured Hypermedia Design. Communications of the ACM, V.38, N.8, pp.34-44, 1995-August.

(Isakovitz et al., 1998)

Isakowit\% T.; Kamis, A.A; Koufaris, M. The Extended RMM Metholology for Web, Publishing, Working paper, I S-98-18, Center for Research on Information Systems, 1998.

(ISO, 1986a)

International Organization for Standardization, ISO/IEC:1S-8879, Information Processing- Text and Office System-SCMI., 1986.

(ISO, 1986b)

1SO/IFC IS 8879. Information Processing - Text and Office Systemts - Standards Generalized Markup Language (SCML). Available on 1986.

(ISO, 1992)

International Organization for Standardization, ISO/IEC: 88744, Hypermedin/Time-Based Structuring Langhage (Hylime), 1992.

(ISO, 1994)

ISO/IEC 13818-3, Information Tedonology: Generic coding of Moning pictures and associated andio: Part 3 - Audio - (1994) 
(ISO, 1995)

International Organization for Standardization, ISO/IEC: 13522-1, Information Technology Coding of Multimedia and Hypermedia Information, Part. 5: MHEG, 1995.

(ISO, 1997a)

1SO/ILC IS 13818, MPEG-2: Creneric Coding of Moving Dictures and Audio Information. Available? on 1997.

(ISO, 1997b)

ISO/AEC JTCI/SC29/WCIT N1909, Oneniez: of the MPFG-4 Version 1 Standard. http://tilab.com/mpeg/public/w1909.htm. December-1997.

(ISO, 1997c)

ISO/IEC JTC1/SC29/NG11 N1921, Third Druft of MPEG-7 Rermirements. http://tilab.com/mpeg/public/w1921.htm. Available on December-1997.

(ISO, 1997d)

ISO/IEC 13818-7 - Information lechology: Generic coding of Mozing pictures and associaled andio: Part 7 - Adwanced Audio Coding (ANC) - (1997)

(ISO, 1997e)

ISO/IEC IS 13818 - MPLG-2; Generic coding of mozing pictures and audio information - (1997)

(ISO, 1998a)

ISO/IEC JTC1/SC29/WG11 N1902 - Generic Colding of Audio-Visual Objects: Part 2 - Visual (Novembro de 1998).

(ISO, 1998b)

ISO/IFC JTC1/SC29/WG11 N2460 - MPEG-7: Conlext and Objectioes (enersion - 10 Atlantic (ity) - (Outubro de 1998).

(ISO, 1999a)

[SO/IEC JIC1/SC29/WG11 N2725 - MPEG-4 Oiervieze - (Seonl Version) - (Març de 1999).

(ISO, 1999b)

ISO/MPFG N3201, DID, Working Draft 1.0, MPEG Systems subgroup. Maui, http://tilab.com/mpeg/public/mpeg-7_ddl.zip. December-1999.

(ISO, 1999c)

ISO/MPLG N3158, Onenieze of the MPFG-7 Standard, MPLG Requirements Group. Maui. http://tilab.com/mpeg/standards/mpeg-7/mpeg-7.htm. December-1999.

(ISO, 1999d)

ISO/MPEG N2739 ISO/IEC 14496-1/PDAM1 subpart 3 - MPEG-4 oersion 2 MPFG-) (Março de 1999)

(ISO, 2000a)

ISO/MPEG

orerriere

(iersion

$3.0)$.

http://tilab.com/mpeg/standards/mpeg-7/mpeg-7.htm. Available on 2000. 
(ISO, 2000b)

ISO/IEC JTC1/SC29/WG11 N35.37 - Nere MPEG-4 Profiles Under Considerntion - (Julho de $2000)$.

(ISO, 2001a)

ISO/MPEG N3536, MPEG-4 Oevolew (r.15 - beijing version).

http://tilab.com/mpeg/standards/mpeg-4/mpeg-4.htm. Available on 2001.

(ISO, 2001b)

ISO/MPEG N4001, ISO/IEC FCI) 15938-1 Information Terhnology - Multinedin Content Description Interface - Part 1 Systems, MI'EG Systems SubGroup, [Março de 2001]. http://www.cselt.it/mpeg/public/mpeg-7 systems fod.rip

(ISO, 2001c)

ISO/MPEG N4002, ISO/IEC FCD 15938-2 Information Technology - Multimidia Content Description Interficte - Part 2 Description Definition Langunge, MPEG Systems SubGroup, [15/01/2001]. http://www.cselt.it/mpeg/public/mpeg-7 ddl fod.zip

(ISO, 2001d)

ISO/MPEG N4062, ISO/IEC FCD 15938-3 Information Tedmology - Multimidin Content Description Inlerface - Parl 3 Visunl, MPEG Visual Ciroup, [Março de 2001]. http://www.cselt.it/mpeg/public/mpeg-7._visual fod.zip

(ISO, 2001e)

ISO/MPEG N4004, ISO/IEC ICD 15938-4 Information Technology - Multimilia Content Description Interfice - Part 4 Audio, MPEG Audio Group, [Março de 2001]. http://www.cselt.it/mpeg/public/mpeg-7_audio__fod.zip

(ISO, 2001f)

ISO/MPEG N3996, ISO/IEC FCD 15938-5 Information Technology - Multimedia Content Description Interface - Part 5 Mullimidia Description Schemes, Multimidia Description Schemes (MDS) Group [Março de 2001]. http://www.cselt.it/mpeg/public/mpeg7 mds_fcd.zip.

(ISO, 2001g)

ISO/MPEG N4006, ISO/IEC FCD 15938-6 Information Technology - Multimidia Content Description Interfuce - Part 6 Reference Softante, Implementation Studies Group [Março de 2001]. http://www.cselt.it/mpeg/public/mpeg-7 reference_software_fod.zip.

(ISO, 2001h)

ISO/MPEG N4031, Operileze of the MPEG-7 Standand (version 5.0), MPEG Requirements Group, ISO, Singapure. (Março de 2001). littp//www.cselt.it/mpeg/standards/mperg-7/mpeg7.hem. [5/13/01]

\section{(Jacobson et al., 1999)}

Jacobson, 1.; Booch, G. and Rumbaugh, J. (1999): The Unified Softuon Development Process. Addison-Wesley Object lechnology Series, 1999.

\section{(Jennings \& Wooldrige, 1995)}

Jennings, N. R. and Wooldrige, M. (1995): Agents Theories, Architecture's and Langruages: a Surce'y. Intelligent Agents, pp.55-67, 1995. 


\section{(Johnson, 1999)}

Johnson, M. (1999): XM1, for the Ahsolute Begimners. The JAVA World, 1999-April. Disponionel on-line (URL): http://www.javaworld.com/javaworld/jw-(14-1999/jw-04-xml-p.htmI

\section{(Kate, 1998)}

Kate, W.; Radha, H. - Bringing the Web to the TV: Conergence Scenarios - (julho de 1998) Apresentado no Workshop Television and the Web [On Line] http://www.w3.org/Architecture/1998/06/Workshop/paper38/

(Ketchpel \& Genesereth, 1994)

Ketchpel, S. and Genesereth, M. (1994): Softurare Agents. Communications of the $\Lambda$ CM, p.48$53,1994-J u l y$.

\section{(Koenen, 2001)}

Rob Koenen, Object-based MPEG offers flexibility, EE Times, 12 Vovember 2001, CMP http://www.eetimes.com/story/OEG2001111250042.

(Kurapati et al., 2001)

Kurapati, K.; Gutta, S.Schaffer, D.; Martino, I.; Zimmerman, J. - A multi-regent TV recommenter - Proceedings of the 1 st Workshop on Personalization in Future 'TV. Sonthofen, Germany, (Julho de 2001). [on-line] http://www.di.unito.it/ /iliana/UM01/kurapati.pdf

\section{(Lemair \& Shae, 1997)}

Lemair, M. H. W. and Shac, Z. Y. (1997): Vifeoconferencing ozer l'ackel-Pass d Networks. IEEE JSAC, V.15, N.1, 1997-August.

\section{(Li et al., 1998)}

Li, X. et al. (1998): Layered Video Multicast anith Retransmission (I.VMR): Fonluation of hiemrical rate control. IEEE INFOCOM'98, pp.1062-1072. 1998.

(Lie, 2000)

Lie, H. W., Bos, B. - Cascading Style Steets, levell- [On Line] http://www.w3.org/TR/1999/Rl:C-CSS1-19990111

\section{(Little \& Venkatesh, 1994)}

Little, T. D. C. and Venkatesh, D. (1994): Clint Seroer Metalutu Manage'ment for the Delecery of Movies in a Video-On-Demand System. 1st International Workshop on Services in Distributed and Netwoked Enviroments, P'rague, Czech Republic, 1994-June.

\section{(Maes, 1994)}

Maes, P. (1994): Agents that Rerluce Work and Information Overlond. Communications of the AC.M, pp.31-40, 1994-July.

\section{(Martins, 2001)}

Martins, L. Transmissian de Video Usando IPe6 e Multicasting e'm Redes de Nito Desempenho. Dissertação de Mestrado, ICMC/USP, 2001.

(McCanne et al., 1996)

McCanne, S. et al. (1996): Receizer-driven layered multicast. SIGCOMM'96. 1996.

\section{(Millet et al., 1996)}

Millet, J. R.; Schwabe, D.; I anzelote R. Autorin de Aplicaçöes Hipermídia Utilizanto un Banco de Dalos Orientado a Objefos, XI Simpósio Brasileiro de Banoo de Dados, Sào Carlos, 1996. 
(Moreira \& Walczowski, 1997)

Moreira, D. A. and Walczowski, L. 'l'. (1997): Using Software Agents to Generate VLSl Layouts. IIEFE Fxpert Intelligent Systems, pp.26-32. 1997-November.

(Moreira et al., 1995)

Moreira, F. S.; Nunes, M. G. V.; Pimentel, M. G. C. (1995): Design Issues for a Distributed Iypermedia-based Tutoring System (HyDTS). International Conference on Computer Application in Industry, Cairo, Egypt, 1995-December.

(Morse, 1998)

Morse, D.R., Ryan, N.S. \& Pascoe, J. (1998): Enhanced reality fieldwork using hand-held computers in the field. Life Scinans Falucational Commuting, 9(3): 18-20.

(MPIG-21, 2001)

MPEG-21: Requirements: From MPEG-1 to MPEG-21: Creating an Interoperable Multimedia Infrastructure. N4518. ISO/IFC. Pattaya, Thayland. December-2001.

(Nack \& Lindsay, 1999)

Nack, F. and Lindsay, A. T. (1999): Feerything You Wanted to Know Ahout MPLG-7: Part 1. IEEE Multimedia, pp.65-77.

(Nemet7, 1997)

Nemetz, F. Hypermedir Modelling Technique: An Object-Oriented Design Model for Hypermedia Applications, CHI 97, 1997.

(Pascoe et al., 1999)

Pascoe, J. et al. (1999): Issues in Dereloping Context-Awure Computing. In Gellersen, H. (ed.): Handheld and Lbiquitous Computing. Lecture Notes in Computer Science, V.1707. SpringerVerlag, Berlin Heindelberg New York, pp.208-221. 1999.

(Pereira \& Ebrahimi, 2002)

Pereira, F. \& Ebrahimi, T. (2002): The MPEG-4 Book. IMSC Press Multimedia Series. 2002.

(Perkins, 1997)

Perkins, C. (1997): Mobile Networking Throngh Motile IP. IEEE Internet Computing Online, 1997.

(Pimentel, Santos Jr. \& Fortes, 1998)

Pimentel, M. G. C.; Santos Jr., J. B. dos \& Fortes, R. P. M. (1998): Modelagem, Autoril e Apresentragono de Documentos Didaticos Fistruturados. Anais do IV Simpósio Brasileiro de Sistemas Multimídia e Hipermídia. Rio de Janeiro, V.1, p.211-224, maio de 1998.

(Practic, 2001a)

PRACTIC (2001a): PRACTIC Program Example [On line] http://www icmc.sc.usp.br/futuretv/practic.html. Available on 2001.

(Practic, 2001b)

[PRACTIC (2001b): PRACIIC Schema http://www icmc.sc.usp.br/futuretv/practic.html. Available on 2001. 
(Preece, 1994)

Preece, J. (1994): Human-computer Internction. Addison-Wesley, 1994.

(Pressman, 1995)

Pressman, R. S. (1995): Engenhmin de Softume. Makron Books, 1995.

(Rodrigues, 1998)

Rodrigues, P.; Gafsi, J.; Nonnenmancher, J. - A More Attractioe and Inleractioe TV - (Julho de 1998) - Apresentado no Workshop Television and the Web [On Line] http://www.w3.org/Architecture/1998/06/Workshop/paper08

(Rossi et al., 1995)

Rossi G.; Garrido A.; Carvalho S. Object-Oriented Patterns for Hypermedin Applications, Proceedings of Patterns Languages of Programs (PLOP'95), 1995.

(Rumbaugh, 1991)

Rumbaugh, J. et al. Object-Oriented Motelling and Design, Prentice-Hall, 1991.

(Salber, 1999)

Salber, D. et al. (1999): The Context Toolkit: Niting the Development of context-Enabled Applications. In proceedings of C HI'99, pp.434-441. April-1999.

(Santos Jr. et al., 2001a)

Santos Jr., J.B. dos; Goularte, R.; Faria, G.; Moreira, E.S.: Modelling of User Interaction in Context-Aware Interactive Television Application on Distributed Environments.

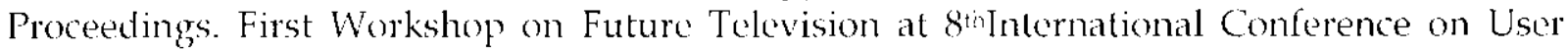
Modelling (UM2001). Sonthofen, Germany. July-2001. LNAI 2001 Springer Verlag, N1, V2, pp.49-56. (Printed in Germany).

\section{(Santos Jr. et al., 2001b)}

Santos Jr., J.B. dos; Goularte, R.; Moreira, E. S.; Faria, G. B.:The Modelling of Structured Context-Aware Interactive Environments. SDPS Journal. Transactions of the SDPS. Issue 5, Number 4, pp. 77-93. December-2001. (Printed in USA).

(Santos Jr. et al., 2002a)

Santos Jr., J.B. dos; Guglielmo, M.; Ie Petris, G.; Moreira, E. S.; Goularte, R.; Faria, G. B.; Cordara, G.; Laia, A. C.: Production, Distribution and Presentation of Educational Multimedia Content in Personalized Environments Lsing the New Standards of the MPEC, Fanily. Proceedings of IDPT $2002-6^{\text {th }}$ International Conference on Integrated Design and Process Technology. Pasadena, USA, June-2002. (Printed in USA).

(Santos Jr. et al., 2002b)

Santos Jr., J.B. dos; Moreira, E. S.; Goularte, R.; Faria, G. B.; Guglielmo, M.; De Petris, G.: Describing a Scenario and Technologies for Building Context-Aware Interactive Environments: Towards to Definition of New Interaction Criteria. To appear in Proceedings of CLEI'2002 - XXVIII Conferencia Internacional di Ingeneria Informatica. Montevideo, Liuguay, November-2002.

\section{(Sauer \& lingels, 1999)}

Sauer, S. \& Engles, G.: Extending U.ML for modelling of multimedia applications. In P. Mussio M. Hirakawa, editor, Proc. IEEE Symposium on Visual Languages (VL'99), Tokyo, 
Japan

http://computer.org/proceedings/ $1 / 0216 / 02160(180$ abs.htm

(Schmidt, 2000)

Schmidt, A. (2000): Implicit Human Computer Intenction Through Context. Personal Technologies Volume 4 (2\&3), pp.191-199, June-2000.

(Schwabe, 1995)

Schwabe D.; Rossi G. The Object-Oriented Hypermedin Design Model, Communications ACM, Vol 38, August 1995.

(Shneiderman, 1998)

Shneiderman, B. (1998): Design the User Interfice: Strategies for Lffective Human-computer Interaction. Addison-Wesley, 3rd Fdition, 1998.

\section{(Sinfonia, 2001)}

The Sinfonia Tools for MPEG-4 Standard. Mullimedia Division of TILAB - Telecom Italia Lab. 2001. [On-line] http://www.tilab.com

(Soares et al., 1995)

Soares, L. F G.; I emos, G.; Colches, S. Redes de Compuladores: das LANs, MANs e WANs às Redes ATM. 2a. Ed. Rio de Janeiro: Campus, 1995.

(Sowa, 2000)

Sowa, J. F. (2000): Ontology, metadatn and semiotics. Springer-Verlag, Berlin, pp.55-81. 2000June.

(SUN, 1999)

SLN (1999): IA VA Tutorinl. Disponivel on-line (URL): http://www.sun.com. Available on 1999.

(SUN, 2000)

SLN (2000): /AVA Serrlets Tutorial. Disponivel on-line (URL): htlp://www.sun.com. Available on 2000 .

\section{(SUN, 2001)}

SUN (2001): The Sun Microsystems Jazd I'V APl 1.0 specification. [On line] http://java.sun.com/products/javatv/. Available on 2001.

\section{(Takahashi et al., 1997)}

Takahashi, K; Liang, E. Anolysis amb Design of Well-based Information Systems, procecdings of the Sixth International World Wide Web Conference, 1997.

(Tanenbaun, 1996)

Tanembaun, A.S. (1996): Distributed Operating Systems. P'rentice Hall, 1996.

\section{(Tanenbaun, 1998)}

Tanembaun, A. S. (1998): Computer Networks. Prentice-H lall, 1998.

\section{(Tennenhouse \& Wetherall, 1996)}

Tennenhouse, D. L. and Wetherall, D. J. (1996): Toubards an Actioe Netcrork Architecture. Multimedia Computing and Networking (MMCN '96), San Jose, CA, 1996. 
(Turine et al., 1997)

Turine, M., A, S.; Oliveira, M. C. F.; Masiero, P. C. Hypertext Model Brased on Stalchlarts, Proceedings of the 8th ACM Conference on Hypertext (Hypertext'97), Southampton, UK, Abril 6-11, 1997, pp.102-111,1997.

(TVAF, 2000a)

TV Anytime Forum. - Rernuirements Series:R1 : The TV-Anyfine Fnoiromment (Informatioe)(Agosto de 2000) -[On Line] - Itp://tva:tva(t)ftp.blc.co.uk/pub/Plenary/lV035r6.zip

(IVAF, 2000b)

TV Anytime Forum. - Re'nuirements Series:R2: The System Description (Informatioe)- (Abril de 2000) -[On Line] - ftp://tva:tva(oftp.lbc.co.uk/pub/Plenary/lV036r2.zip

(IVAF, 2000c)

TV Anytime Forum. - Requirements Series:R3 : Metndata Requirements (Normatioe) - (Abril de 2000) -[On I ine] - ftp://tva:tva@ftp.bbc.co.uk/pub/Pleslary/TV037r3.zip

('I'VAF, 2001a)

TV Anytime Forum. - Specification Series:S1 on Phase 1 - Benchunark Applicalions (Informution)(Fevereiro de 2001) -[On Line] - ftp://tva:tva(i)tp.bbcco.uk/pub/Specifications/SP001v10.zip

(TVAF, 2001b)

TV Anytime Forum. - Specification Series:S2 on System Description (Informative)- (Junho de 2001) -[On I.ine] - ftp://tva:tva@ftp.bbc.co.uk/pub/Specifications/SP002v11.zip

(TVAl; 2001c)

TV Anytime Forum. - Specification Series:S3 on Metadata (Nomatize)- (Abril de 2001) -[On Line] - ftp://tva:tvartftp.bbc.co.uh/pub/Specifications/Spo03v10r1.rip

(TVAF, 2001d)

TV Anytime Forum. - specificalion Series:S4: Contem Referencing (Normatioe)- (Abril de 2001) -[On Line] - ftp://tva:tva@ftp.bbc.co.uk/pub/Specifications/SP004v11.zip

(Van Setten, 2001)

Van Setten, M. et al.: Gigaport: Personalized Information Systems. PhD Thesis. Telematica Institute. The Netherlands. June-2001.

(Van Setten et al., 2001)

Van Setten, M.; Tokmakoff, A.; van Vliet, I I.: Designing Personalized Information Systems. Proceedings. First Workshop on Future Television at $8^{\text {th }}$ International Conference on User Modelling (UM'2001). Sonthofen, Germany. July-2001. LNAI 2001 Springer Verlag, N1, V2 (Printed in Germany).

(Vickres, 2000)

Vickres, M; 7igmond, I)- Uniform Resonrce hientifiers for Telerision Brouldasts (21 de Fevereiro de 2000 ).

(VRML, 1997)

The Virtual Reality Modelling Language (1997): ISO/IIC 14772:1997. [on-line] http://www.vrml.org/technicalinfo/specifications/vrml97. 
(W3C, 1998)

W3C Working, Draft - symchronized Multimedia Integration language (SMIL) 1.0 Specification (15 de Junho de 1998) - [On I.ine] - http://www.w.3.org/TR/1998/RIC-smil-19980615

(W3C, 2000)

W3C Working Draft - Document Object Model (DOM) Le'el 1 Specification (Second Fdition) Versão 1.0 (29 de Dezembro de 2000) - [On Line] - http://www.w3.org/TR/2000/WDDOM-Level-1-20000929

(W3C, 2001a)

W3C Recommendation - XMI Schena Part 0: Primer (2 de Maio de 2001) - [On Line] http://www.w3.org/T'R/2001/RFC-xmlschema-0-20010502/

(W3C, 2001b)

W3C Recommendation - XMI. Sclemm Part 1: Structure (2 de Maio de 2001) - [On Line] http://www.w3.org/1R/2001/RLC-xmlschema-1-20010502/

(W3C, 2001c)

W3C Recommendation - XML Schema Parl 2: Data Types (2 de: Maio de 2001) - [On Line] http://www.w3.org/TR/2001/REC-xmlschema-2-20010501/

\section{(Wetherall et al., 1998)}

Wetherall, J. et al (1998): AN'SS: A Toolkit for Building and Dymanically Deploying Netwoork Protocols. Proc. IEEE OpenArch'98, San Francisco, CA, 1998.

(Wu et al., 1997)

Wu, L. et al. (1997): Thinstreams: An Architecture for Multicasting Layered Video. NOSSDAV'97, 1997. 


\section{Identification of the Interaction Criteria and Tools Suitable to Provide the most Efficient Use of Multimedia Educational Material and Implementation of a Telelearning Application over a Multicast/Broadcast Scenario ${ }^{1}$}

Final Report of the Research Activities Author: João Benedito dos Santos Junior (numed Visiting Researcher in this docmment)

Local: TILAB - Telecom Italia Laboratory

City: Turin, Italy

Division: Advanced Multimedia Boss: I eonardo Chiariglione Supervisor: Mario Guglielmo Project Manager: Gianluca De Petris Project: Telelearning System Period of Research: June- $1^{\text {st }}$ to November-30th Date of Writing: November- $05^{\text {th }}$ to $12^{\text {th }}, 2001$ 


\section{The TILAB research proposal}

The proposal for 06 (six) months of research activity at TILAB has been presented by Mario Guglielmo and Gianluca De Petris on April 2001, after a period of talking with Joào Benedito dos Santos Junior - the visiting researcher. This proposal has been elaborated also for contributing with Joào Benedito dos Santos Junior in his PhD thesis at the Institute of Mathematics and Computing, at University of Sao Paulo, Brazil [1], as ilustraded in the Table 01.

The title of the research has been defined "Identification of the interaction criteria and tools suitable to provide the most efficient use of multimedia educational material and implementation of a telelearning application over a multicast/broadcast scenario", having the "Distance Learning" like area of application.

The technologies avaitable for using in the project were the following: a) MPEG-4 object coding; b) scene control; c) user interaction; d) content description and identification; e) transport of MPEG-4 over IP and MPEG-2 TS. Furthermore, the available results were the following: a) skills on MPEG-4 technologies (mainly object coding and Systems); b) knowledge about the architecture of a prototypical telelearning platform; c) software for integration with commercial systems to send lessons; d) software to receive and handle lessons from the satellite.

In general lines, the research description was the following:

'IILAB is using MPEG-4 technology to huild applications to be used in real environments [6]. One of these applications allows a teacher to send real-time lessons to this/ her students or to record them. The Tele-learning system under development at TILAB includes:

- on the teacher side: a recording workstation with two cameras, microphone, specific MPEG-4 software;

- an IP network or an MP'HG-2 TS satellite link;

- on the student side: a PC with special MPEG-4/2 software and special boards, or a Set Top Box.

The research work would focus on the broadcast scenario where a satellite board is used in a PC or on an MHP set top box. 'The aim of this work is to send the lesson even to a student that is not connected to the intranet, using a satellite link, either over IP embedded in the 
MPEG-2 IS or directly over MPEG-2 I'S. For the security part it may be necessary to have a low-hand return channel implemented e.g. through a mobile phone.

The satellite environment may require the redesign of the User Interface and the retargeting of the elementary streams parameters in order to match specific requirements and features of the medium. The Figure 01 shows the architeclure of the Telelearning system and presents the scenario that is expected when this research has been started [5].

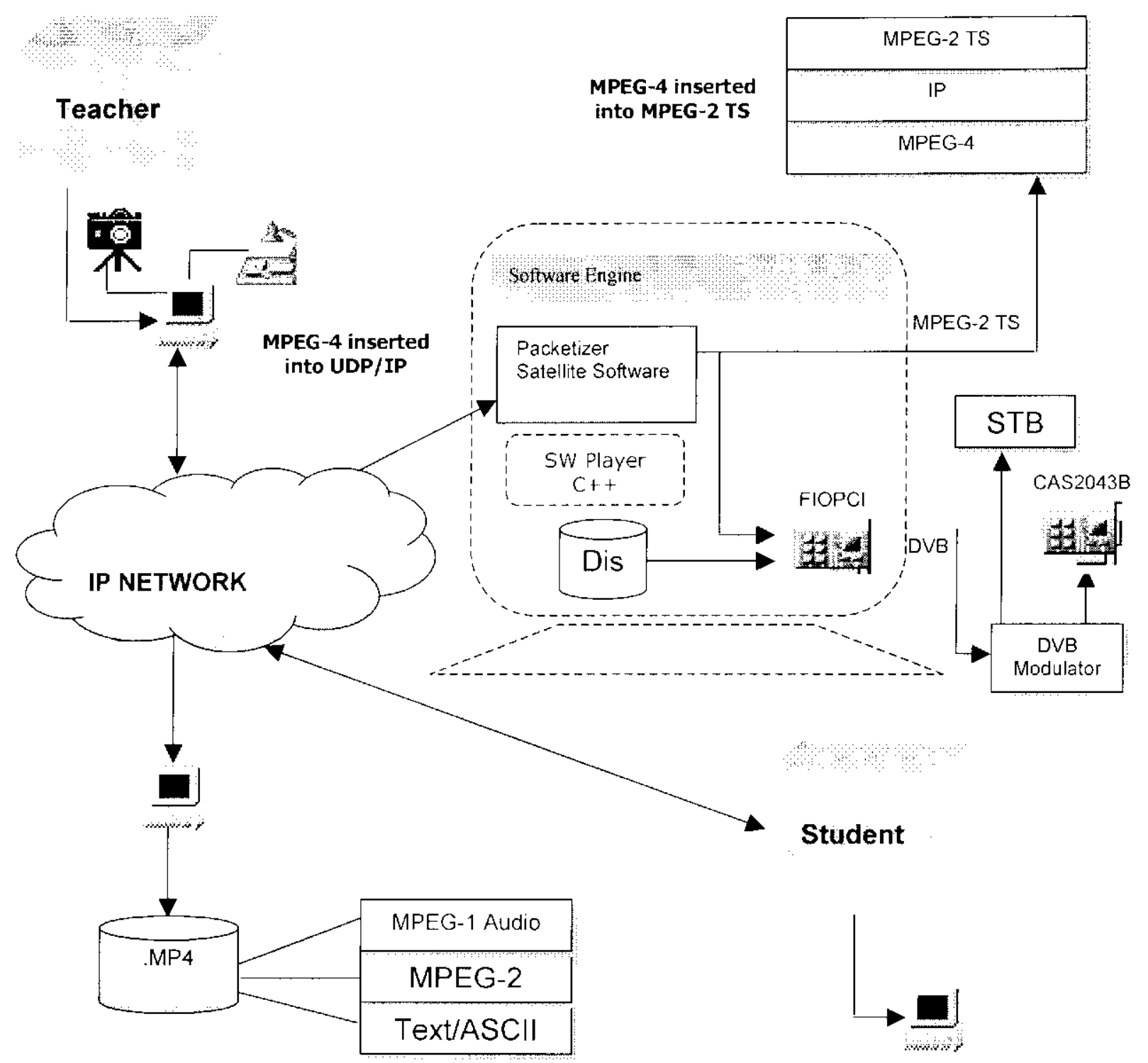

Figure 01: 'The 'T'elelearning Architecture

The satellite environment may require the redesign of the User Interface and the retargeting of the elementary streams paraneters in order to match specific requirements and features of the medium. 
I'able 01: Research Activities - 1't June-2001 to $30^{\text {th }}$ November-2001

\begin{tabular}{|l|l|}
\hline Month & Activity \\
\hline June & $\begin{array}{l}\text { 1. Study of the DVB, MPEG-2 and DSMCC specilications } \\
\text { 2. Study of resources of the Microsoft foundation Classes }\end{array}$ \\
3. Experiment of the resources of the Microsoft C++ Integrated \\
July Development Environment Version 6.0
\end{tabular}

\section{The development of software applications}

The activities of development of software applications have been divided into three phases: a) in the first phase, during July, it has been developed a player for MPEG-2 TS files; $b$ ) in the second phase, during August and September, it have been developed new interaction criteria and chat tools for the Telelearning scenario; c) in the last phase, during October and November, it have been implemented some mechanisms for providing support to transmission of MPEG-4 streams over MPEG-2 TS using DVB standard. 


\section{The additional contributions for TILAB researches}

As described in the Section 3.3, when the teacher chat application is turned active, is also trigged a subprocess for recording all actions realized by teacher. This record is generated through an XMI-compliant model, as show the schema of the Figure 02.

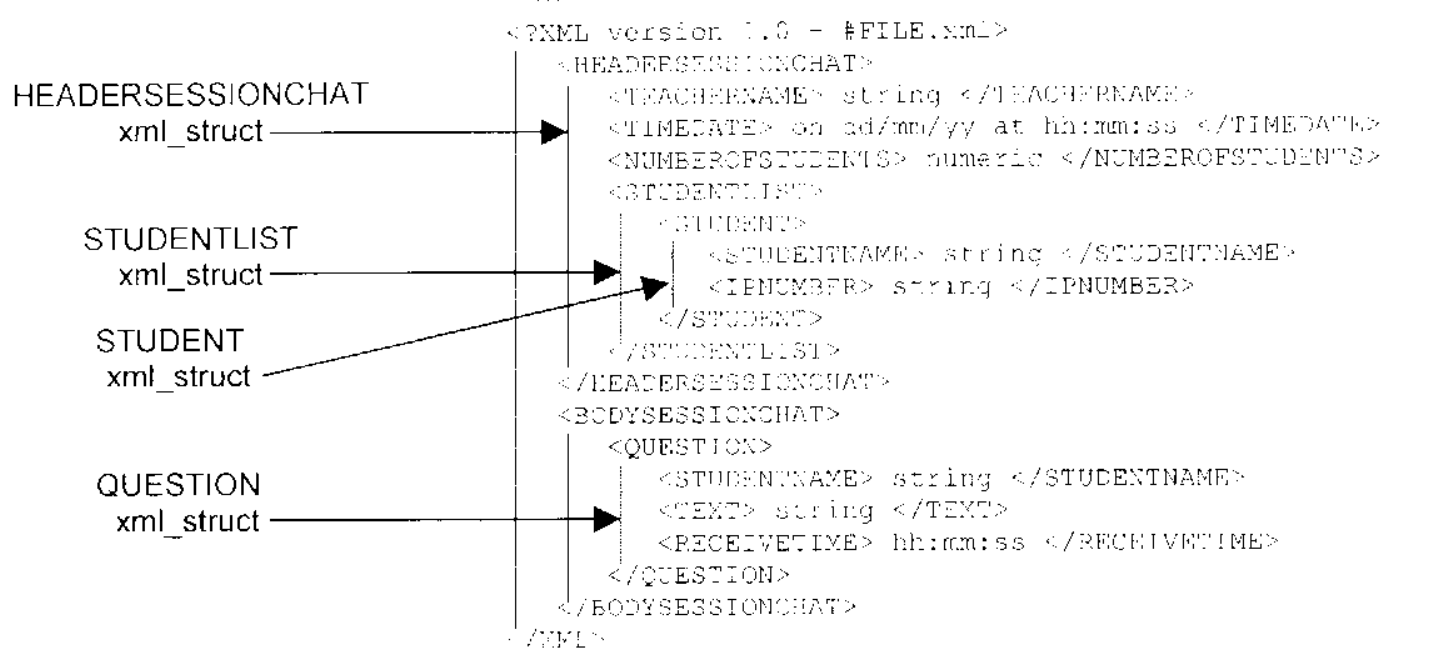

Figure 02: 'The XML-compliant model for integration of chat application at Telelearning architecture

At the level of implementation, the field <TIMEDATE> of the HEADERSESSIONCHAT $\mathrm{xml}$ struct can be divided into sub fields, allowing more granularity in the synchronization processes with the MPEG-4 elementary streams. For example, a suggestion is the specification of the following fields: $\langle$ day $\rangle,\langle$ month $\rangle,\langle y e a r\rangle,\langle$ hour $\rangle,\langle$ minute $\rangle$ and $<$ second $>$.

As described, TILAB is using MPEG-4 technology in the Telelearning project. In this context, the technologies available allowing the MPEG-4 object coding, the scene control and user interaction and transport of MPEG-4 over IP and MPEG-2 TS. This additional contribution presents a proposal for content description and personalization of the l'elelearning environment.

Considering the log files of the Teacher Chat Application is possible to integrate the data with DBMS (I)atakirse Mamiggment system) and providing new controls for the both student 
and teacher interfaces. The Figures 03 and 04 present examples of XML files generated by chat application.

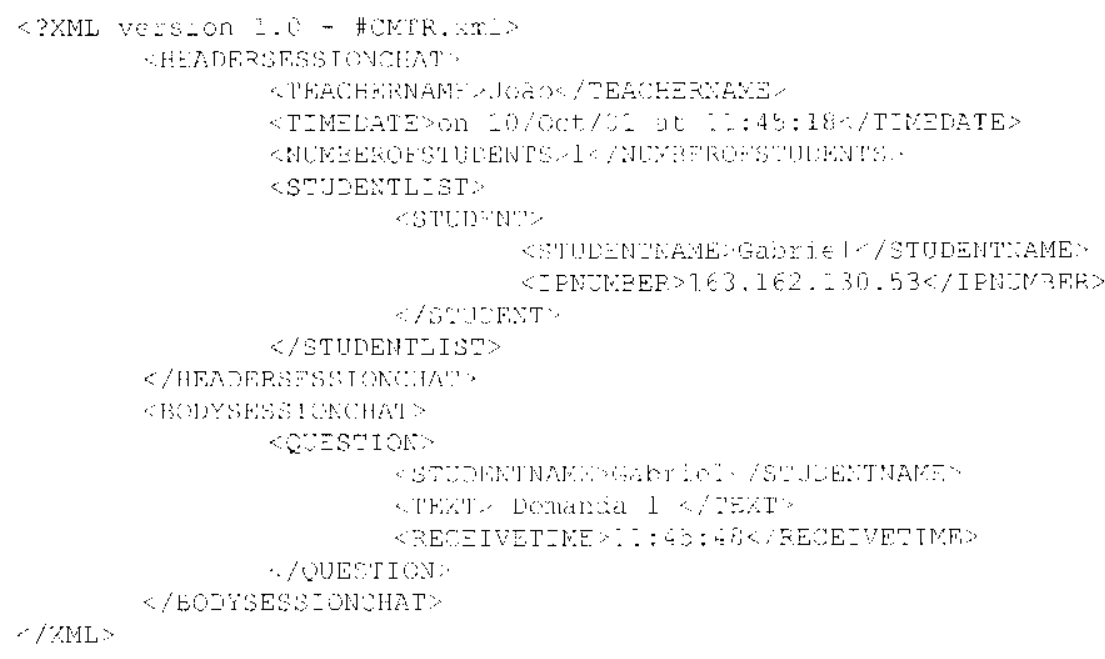

Figure 03: An example of XML file generated for Teacher Chat Application

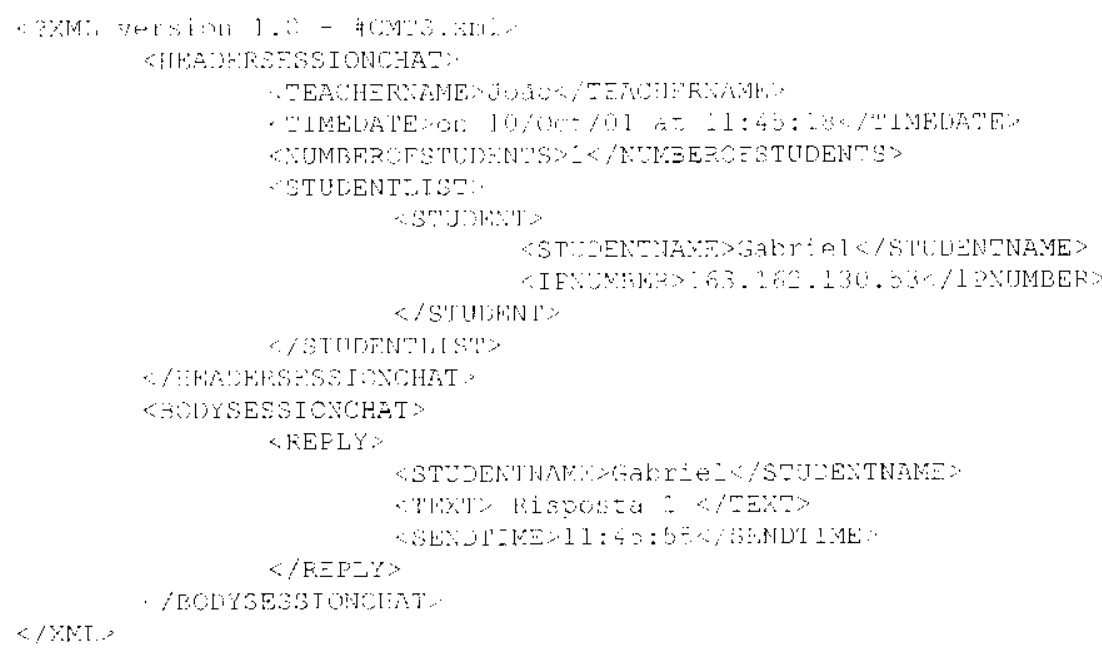

Figure 04: An example of XML file generated for Teacher Chat Application

The Figure 05 shows the basic graphic interface of the student side in the felelearning project. Each graphic object is a representation of each MPEG-4 elementary stream. The chat application can be inserted as an external application, but triggered by a special control inserted into a MPEG-4 stream. In this context, a synchronization process can be implemented for providing advanced controller for the user. 


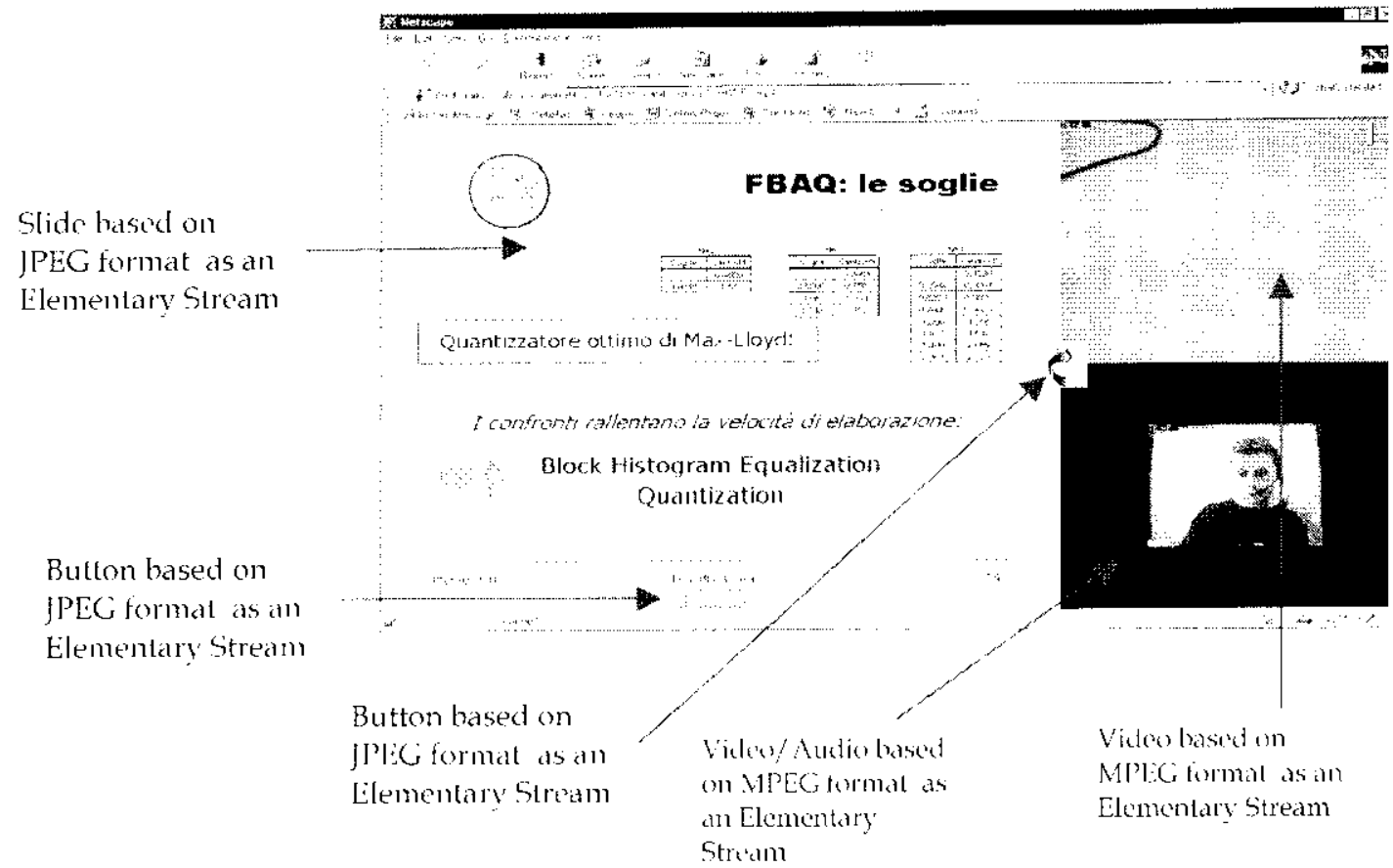

Figure 05: An example of XML file generated for Teacher Chat Application

As a concrete example, the XMI. structure, generated by chat teacher application, can be used for synchronizing the MPEG-4 objects with the questions that have been formulated by the students during the lesson. Thus, a publisher process can be used for presenting statistics about the lesson, considering the temporal relations described by chat time parameters and time stamp of the MPEG-4 objects, as illustrated in the Figure 06.

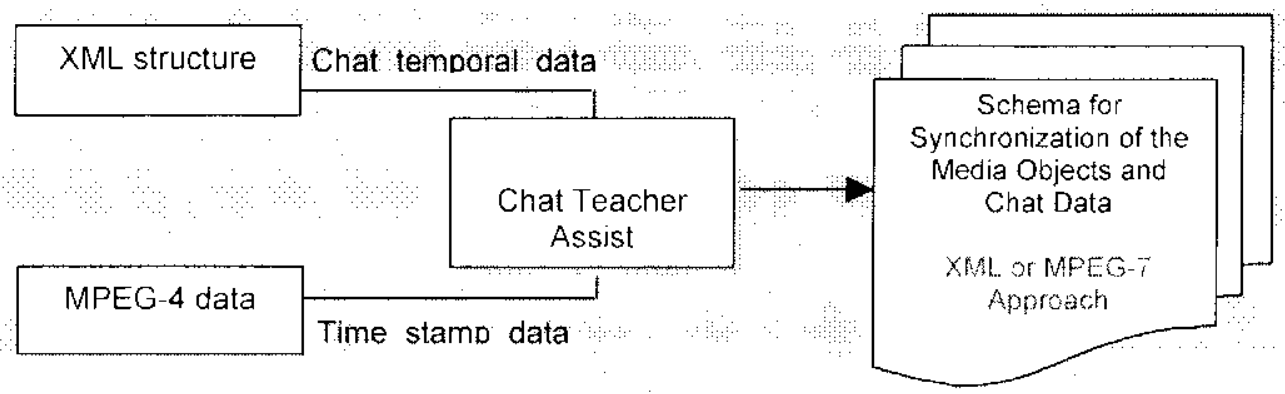

Figure 06: Basic scenario for integration of the new interaction criteria

Furthermore, MPEG-7 scenc descriptions can be used for adding new personalization levels to the Telelearning environment [7]. This is one point that will be explored by the visiting researcher in his PhD T'hesis and the results will be reported to TILAB [8]. 
Allinthir'A

\section{The skills for the visiting researcher}

TILAB - Telecom Italia Lab - is using MPEG-4 technology to build applications to be used in real environments. One of these applications allows a teacher to send real-time lessons to this/her students or to record them. The Tele-learning system under development at TIL $\triangle B$ includes:

The technologies available for using in the project were the following: a) MPEG-4 object coding; b) scene control; c) user interaction; d) content description and identification; e) transport of MPFG-4 over IP and MPEG-2 TS. Furthermore, the available results were the following: a) skills on MPEG-4 technologies (mainly object coding and Systems); b) knowledge about the architecture of a prototypical l'elelearning platform; c) software for integration with commercial systems to send lessons; d) software to receive and handle lessons from the satellite.

Joào Benedito dos Santos Junior (Gamoicmc.sciusp.br) is a PhD Researcher, advising by Prof. Dr. Edson dos Santos Moreira (edsonoicmc.sc.usp.hr, PhD at Manchester University, UK), at Institute of Mathematics and Computing at University of Sao Paulo, Brazil.

In his PhD Thesis - "Modelling of Conlext-Aanmen'ss Interactive Enviromments: An Approach Based on Ne'a Standards of the MPtG fimily", started in 1998, he is working with MPT:G-4 and MPEG-7 standards, as shows the following abstract [1]:

The possibility of using multimedia objects in modern applications Ias proven to be a bonus. We zant to prozide ways in which the user an interact arith multimedia objects as they are presented with fentures that go beyond the regular controls of a VCR. Furthermore, the presentation of the vileo can be modified by ene'nts laspening in the surrounding enoironment. This research presents a motelling for ContextAware Interactioe Telerision Applications as a proposal for producing, distributing and presenting multinedin at the use't, considering the actions from contextual information, in a way 10 ense its interaction with context-andare interaction applications. MPEG-4 and MPEG-7 slandands are being used for prociding the tednological support for producing multimedir content and media description, respectioely. The zoork also discrsses howe and which kind of contextual information

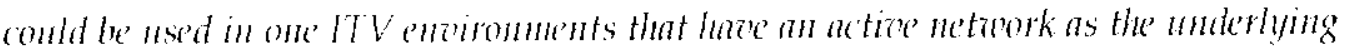


infrastructure. The concept of profile applied to ITV is presented and methods for using profiles in lTV programs are discussed.

In this context, the period of six months at $\Gamma I L A B$ has provided to Joano the possibilities for to know better the MPEG-4 and MPEG-7 standards and to evaluate the application of these standards to his PhD Thesis. Furthermore, the visiting rescarcher has used the tools that compound the TILAB MPEG Solutions for carrying out experiments suitable to the purposes of his research work.

According to PhD Program Timetable of the visiting researcher, he must finish his Thesis in March-2002, reporting the main results at the TIL $A B$, through Dr. Mario Guglielmo.

\section{Perspectives and future works}

IILAB - Telecom Italia Lab - is using MPLG-4 technology to build applications to be used in real environments. One of these applications allows a teacher to send real-time lessons to this/her students or to record them. The Tele-Learning system under development at TILAB includes:

- on the teacher side: a recording workstation with two cameras, microphone, specific MPEG-4 software;

- an IP network or an MPFG-2 TS satellite link;

- on the student side: a PC with special MPEG-4/2 software and special boards, or a Set Top Box.

Table 02: Timetable for the experiment

\begin{tabular}{|c|c|}
\hline Activity & Period \\
\hline $\begin{array}{l}\text { Visit of TILAB Researchers in Brazil, specially to Catholic } \\
\text { University of Minas Gerais (where the anthor is lecturer and resenther } \\
\text { in commuting) }\end{array}$ & September-2002 \\
\hline Providing of the IIILAB-BR infrastructure & January-2003 \\
\hline Event for starting the experiment & First week of February-2003 \\
\hline $\begin{array}{l}\text { Production of the Multimedia Content Compliant to Tele-l edming } \\
\text { Platform }\end{array}$ & February and March-2003 \\
\hline lxperiment & March, April and May-2003 \\
\hline Fivaluation & June-2003 \\
\hline
\end{tabular}

In this context, TILAB has interest on carry out an experiment in Brazil for evaluating the capabilities of the Tele-Learning, Platform in the Brazilian Distance Learning, Scenario. The Table 02 presents a suggested timetable for the experiment, starting on February-2003 and 
ending on June-2003. Furthermore, the visiling researcher has submitted an abstract to IDPT'2002 - International Conference on Integrated Design and Process 'Technology Session on Modelling and Development of Multimedia Systems (June 23-27, 2002, Pasadena, USA), as presented in the following.

Mario Guglielmo, Gianluca De Petris, Alessandro Costa Laia and Giovanni Cordara are coauthors of the follow abstract.

This abstract has been accepted and the authors must write the full paper by $15^{\text {th }}$ January2002. Thus, a specific timetable will be defined and the authors will work in the paper via Internet.

\title{
Using MPEG-4 and MPEG-7 for Production, Distribution and Presentation of Educational Multimedia on Personalized Environments
}

\author{
Joảo Benedito dos Santos Junior' ${ }^{1}$, Gianluca De Petris², Mario Guglielmo², \\ Edson dos Santos Moreira 1, Rudinei Goularte ?, \\ Alessandro Costa Laia² and Giovanni Cordara ${ }^{2}$ \\ joao, edson, rudinei\}oicme.sc.usp.hr \\ \{gianluca.depetris, mario.guglielmo, alessandro.costalaia, giovanui.cordaráatilab.com\} \\ Institute of Wathematics and Computing - ICMC \\ University of Sao Paulo - USP \\ ['. Box 668 - Sao Carlos - SP-Brazil \\ Phone: $+55162739668 \quad \mathrm{FAX}:+55162739751$ \\ zHLAB - Trlciom laalia Lab \\ Multimedia Division - Advanced Application Development \\ Via G. Reiss Romoli, 274 \\ $10118-$ Turin - Italy \\ Phone: +390112286115 FAX: +390112286299
}

\begin{abstract}
TILAB is using MPEG-4 techology to build applications to be used in real enviroments. One of these applications allows it teacher to send real-time lessons to this/her students or to record them. The Tele-Learning System under development at Jll.AB infudes: a) on the teacher side: a recording workstation with two ameras, microphone, specific .MPEG-4 software; b) an IP network or an MPEG-2 TS satellite link; c) on the student side: a PC with special NilP: $C_{-4}-4 / 2$ software and special hoards, or a Set Top Box. This research presents a focus on the broadcast scenario where a satellite board is used in a PC or on an .MIHI' set top box. The aim of this work is to send the lesson even to a sludent that is not comnected to the intranet, using a satellite link, either over II embedded in the MPEG-2 IS or directly over MPFG-2 IS. For the security part it may be necessary to have a low-band return channel implemented, for example, through a mobile phone. 'the satellite environment may require the redesign of the User Interface and the retargeting of the clementary streams parameters in order to match specific recuirements and features of the medium. At this point, new interaction criteria have been established from distribution of MPEG-4 media objects and MPLG-7 scene descriptions on network emviromments. Furthermort, context-awareness aspects are heing added for providing personalization on the teathing, learning, onvironment.
\end{abstract}




\section{Conclusions}

MPEG-4 is a standard that builds on the successes of MPEG-1 and MPEG-2, two standards that have changed the audio-visual landscape. MPEG-4 has been developed by the best experts provided by all industries with a stake in multimedia.

It is a powerful standard, rich in functionality, encompassing other successful standards. It can be customized to serve the needs of specific industries while preserving a high level of interoperability across applications of different industries.

It is a living standard in the sense that now features are being added preserving compatibility with existing applications to respond to the demands of the application world and supported by the expanding possibilities of technology.

In this context, the period of six months at TIIAB has provided to visiting researcher the possibilities for knowing better the MPEG-4 and MPFG-7 standards and to evaluate the application of these standards to his PhD Thesis. Furthermore, the visiting researcher has used the tools that compound the TILAB MPFG Solutions for carrying out experiments suitable to the purposes of his research work. At this point, the visiting rescarcher is able to help TILAB for providing technological solutions based on MPEG-4 in the both brazilian academic and industry market.

\section{Acknowledgments}

I would like to thank Leonardo Chiariglione for allowing the carrying of part of my l'hl) research at TILAB.

I am very thankful to Mario Guglielmo by the organization of the visit, advising of the research and by the friendship. Thanks also to Dr. Edson dos Santos Moreira (USP, Brazil) for his supervision and for the freedom he allowed me in conducing my research.

I also would like to thank Gianluca De Petris for his technical advising during the research activities and for providing the sufficient environment for experiments. Special thanks to Alessandro Costa Laia and Giovanni Cordara for the both technical support and friendship, what became more pleasant my stay in I urin. 
Aprotitice it

I would like to thank my colleagues at the Multimedia Division of TILAB for providing a very pleasant integration and excellent work environment, especially to Barbara Silano, Diego Gibellino, Filippo Chiariglione, Barbara Negro, Stefano Dal Lago and Iiziana Trucco. Finally, I would like to express my gratitude to III.AB for the financial support for this work.

\section{References}

[1] Santos Jr., J. B. dos; Goularte, R.; Faria, G. B.; Morcira, E. S.: Modelling of user interac

[2] Digyital Video Broadcasting (DVB). DVB Specification for Data Broadcasting. EN 301192.1999.

[3] Information Technology - Generic Coding of Moving Pictures and Associated Audio Information - Part 6: Extensions for DSM-CC. ISO/ILC 13818-6.

[4] Information Technology - Generic Coding of Moving Pictures and Associated Audio. MPEG-2 Systems. 1994.

[5] 'The Telelearning Architecture. TILAB reports.

[6] Information Technology - Coding of Audio-visual Objects. MPEG-4 Systems. 2000.

[7] Overview of the MIJGG-7 Standard (version 5.0). 2001.

[8] Santos Jr., J. B. dos: Modelling of Context-Aware Interactive Environments: An Approach Based on New Standards of the MPEG Family. PhD Thesis at the Institute of Mathematics and Computing at University of Sao Paulo, Brazil. 


\section{Apêndice B}

Resumo e Abstracts dos Artigos Publicados

\section{Artigos Publicados}

Paper 01 - Proceedings of International Conference (July, 2001)

UM'2001 - $8^{\text {th }}$ International Conference on User Modelling

$1^{\text {st }}$ Worshop on Personalization in Future TV

Santos Jr., J.B. dos; Goularte, R.; Raria, G.; Moreira, E.S.: Modelling of Lser Interaction in Context-Aware Interactive Television Application on Distributed Environments.

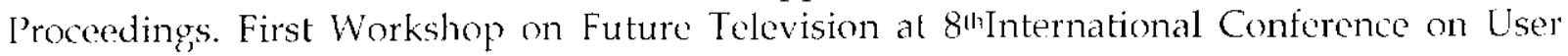
Modelling (UM'2001). Sonthofen, Germany. July-2001. L.VAl 2001 Springer Verlag, V1, V2, pp.49-56. (Printed in Germany).

Disponivel on-line: http://www.di.unito.it/ /iliana/LM2001/

Paper 02 - Anais de Congresso no Brasil (Outubro, 2001)

SBMidia'2001 - Simpósio Brasileiro de Sistemas Multimídia e Hipermídia

Blengini, G. F., Junior, J. B. S., Goularte, R., Moreira, E. S.. Uso de P'erfis em $\Lambda$ plicaçoes de Televisão Interativa Conscientes de Contexto. Anais do SBMidia 2001 - VII Simpósio Brasileiro de Sistemas Multimídia e llipermidia, pp. 139-154. Florianópolis - SC, Brasil, outubro de 2001.(1mpresso no Brasil - Eds: Roberto Willrich e Cesar Augusto Camilo Teixeira).

Paper 03 - International Journal (December, 2001)

SDPS Journal - Society for Design and Process Science

Santos Jr., J.B. dos; Goularte, R.; Moreira, E. S.; Faria, G. B.:The Modelling of Structured Context-Aware Interactive Environments. SDIS Journal. 'Transactions of the SDPS. Issue 5, Number 4, pp. 77-93. December-2001. (Printed in USA).

Disponivel on-line: htlp://www.sdpsnetorg/vol5-4.htm

Paper 04 - Proceedings of International Conference (June, 2002)

IDP'I'2002 - International Conference on Integrated Design and Process Technology

Santos Jr., J.B. dos; Guglielmo, M.; De Petris, G.; Moreira, F. S.; Goularte, R.; Faria, G. B.; Cordara, G.; Laia, A. C.: Production, Distribution and Presentation of Educational Multimedia Content in Personalized Environments Using the New Standards of the MPEG Family. Proceedings of IDPT'2002 - $6^{\text {th }}$ International Conference on Integrated Design and Process Technology. Pasadena, USA, June-2002. (Printed in USA).

Paper 05 - Proceedings of International Conference (November, 2002) CI.EI'2002 - XXVIII Conferencia Internacional di Ingeneria Informatica

Santos Jr., J.B. Aos; Moreira, E. S.; Goularte, R.; Faria, G. B.; Guglielmo, M.; De l'etris, G.: Describing a Scenario and Technologies for Building Contexl-Aware Interactive Environments: Towards to Definition of New Interaction Criteria. To appear in Proceedings of CLLI'2002 - XXVIII Conferencia Internacional di Ingeneria Informatica. Montevideo, Uruguay, November-2002. 
Proceedings of International Conference (July, 2001)

UM'2001 - $8^{\text {th }}$ International Conference on User Modelling

$1^{\text {st }}$ Worshop on Personalization in Future IV

Santos Jr., J.B. dos; Goularte, R.; Faria, G.; Moreira, E.S.: Modelling of User Interaction in Context-Aware Interactive Television Application on Distributed Environments.

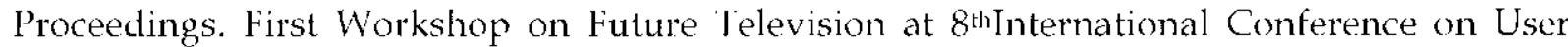
Modelling (UM2001). Sonthofen, Germany. July-2001. I.NAI 2001 Springer Vorlag, N1, V2, pp.49-56. (Printed in Germany).

Disponivel on-line: http://www.di.unito.it/ liliana/UM2001/

\title{
Modelling of User Interaction in Context-Aware Interactive Television Application on Distributed Environments
}

\author{
Joào B. dos Santos Jr, Rudinei Goularte, \\ Gustavo B. Faria and Edson dos S. Moreira \\ \{joao, rudinei, gusfaria, edson\}@icmc.sc.usp.br \\ Instilute of Mathematics and Computing - ICMC \\ University of Sao Paulo - USP \\ 13566-570, São Carlos-SP, Brazil, PO Bux 668
}

\begin{abstract}
The possibility of using multimedia objects in modern applications has proven to be a bonus. We want to provide ways in which the user can interact with multimedia objects while it is been presented with features that go beyond the regular controls of a VCR. Furthermore, the presentation of the video can be modified by events happening in the surrounding environment. 'l'his paper presents a proposal to model the user actions from contextual information, in a way to ease its interaction with context-aware interactive applications like Interactive TV (ITV). The paper also discusses how and which kind of contextual information could be used in one ITV environments that have an active network as the underlying infrastructure.
\end{abstract}


Anais de Congresso no Brasil (Outubro, 2001)

SBMidia'2001 - Simpósio Brasileiro de Sistemas Multimídia e Hipermídia

Blengini, G. F., Junior, J. B. S., Goularte, R., Moreira, E. S.. Uso de Perfis em Aplicaçóes de Televisão Interativa Conscientes de Contexto. Anais do SBMidia 2001 - VII Simpósio Brasileiro de Sistemas Multimidia e Hipermidia, pp. 139-154. Florianópolis - SC, Brasil, outubro de 2001.(Impresso no Brasil - Fds: Roherto Willrich e Cesar Augusto Camilo Teixcira).

\title{
Uso de Perfis em Aplicações de Televisão Interativa Conscientes de Contexto
}

\author{
Gustavo Blengini Faria, João Benedito dos Santos Junior, \\ Rudinei Goularte e Fdson dos Santos Moreira \\ \{gusfaria, joao, rudinei, edson\};icmc.sc.usp.hr \\ Universidade de São Paulo - USP \\ Instituto de Ciências Matemáticas e de Computação - ICMC \\ 1.3566-570, Săo Carlos, Brasil, Cx. Pustal 668
}

\begin{abstract}
Resumo. A TV Interativa é uma aplicação multimídia com características peculiares, tais como interaçòes em um ambiente anteriormente não interativo. Diversas tecnologias podem ser utilizadas em sua implementação e, devido ao crescente interesse da indústria, diversos esforcos säo feitos para sua padronizacao. Este artigo apresenta um novo conceito para programas interativos que provê uma melhor adaptação dos programas às necessidades ou expectativas dos usuários, utilizando os padröes e tecnologias para a TV Interativa e estendendo-os para o uso em ambientes conscientes de contexto.
\end{abstract}

\begin{abstract}
The Interactive TV is a multimedia application with peculiar characteristics like interactions in an environment where interactions were not possible previously. A number of technologies can be used on its implementation and there are some efforts to build standards. This paper presents a new concept to interactive programs that provides a better adaptation of the programs to the viewers using Interactive TV standards and technologies and extending them to the use on context aware environments.
\end{abstract}

Palavras-chave. Televisão Interativa, Interaçào do Usuário, Consciência de Contexto. MPFG4, MPEG-7.

Áreas de Adequaçäo. Interaçào do usuário com aplicaçōes multimídia e hipermídia. Ferramentas, ambientes e infra-estrutura para sistemas multimídia c hipermídia. 
International Journal (December, 2001)

SDPS Journal - Society for Design and Process Science

Santos Jr., J.B. dos; Goularte, R.; Moreira, E. S.; Faria, G. B.:The Modelling of Structured Context-Aware Interactive Enviromments. SDPS Journal. Transactions of the SDPS. Issue 5, Number 4, pp. 77-93. December-2001. (Printed in USA).

Disponivel on-line: http://www.sdpsnet.org/volj-4.htm

\title{
The Modelling of Structured Context- $\Lambda$ ware Interactive Environments
}

\section{Joào Benedito dos Santos Junior, Rudinei Goularte, lidson dos Santos Moreira and Gustavo Blengini Faria}

\author{
Institute of Mathematics and Computing \\ University of São Paulo - LSP \\ P.O.BOX 668 - Sá Carlos - SP - Brazil \\ $\{j o a o$, rudinei, edson, gusfaria\}@icmc.sc.usp.br
}

\begin{abstract}
Using multimedia video objects in building rich, interactive and distributed environments is complex. We want to provide ways in which the user can interact freely with those oljects. As a result, the quality of the applications is not only ruled by the presentation machine and its neighborhood but by the traffic conditions and the status of the server as well. As a good practice of design, modelling is essential, as woll as the observation of standards. This paper presents a proposal for modelling Structured Context-Aware Interactive Environments, as an approach for covering the user-network-application interactions that occur in an interactive environment. In this scenario, the work discusses matinly which type of contextual information (both at the terminal and the network) could be used in an interactive environment and how it should be manipulated. The concept of program profile is also presented and methods for using profiles in interactive video are discussed. Interactive Television (ITV) programs are presented as an example of application that can use our modelling.
\end{abstract}


Paper 04 - Proceedings of International Conference (June, 2002)

IDPT'2002 - International Conference on Integrated Design and Process 'Iechnology

Santos Jr., J.B. dos; Guglielmo, M.; De Petris, G.; Moreira, E. S.; Goularte, R.; Faria, G. B.; Cordara, G.; Laia, A. C.: Production, Distribution and Presentation of Educational Multimedia Content in P'ersonalized Environments Using the New Standards of the MPEG Family. Proceedings of IDI'I"2002 - $6^{\text {th }}$ International Conference on Integrated Design and Process Technology. Pasadena, USA, June-2002. (Printed in USA).

Production, Distribution and Presentation of Educational Multimedia Content in
Personalized Environments Using the New Standards of the MPEG Family

João Benedito dos Santos Junior ${ }^{1}$, Mario Guglielmo², Gianluca De Petris², Edson dos Santos Moreira', Rudinei Goularte', Gustavo Blengini Faria ${ }^{3}$,

Alessandro Costa Laia ${ }^{2}$, Giovanni Cordara ${ }^{2}$

\{joao, edson, rudinei, gusfaria\} $\omega_{i c m c}$.sc.usp.br

\{mario.guglielmo, gianluca.depetris, alessandro.costalaia, giovanni.cordara\}otilab.com

1.3 University of Sao Paulo - USI'

Institute of Mathematics and Computing - ICMC

P.O.Box 668 - Sao Carlos - SP - Brazil

Phone: $+55162739668 \quad$ FAX: +55162739751

2 TILAB - Telecom Ilalia Iab

Multimedia Division - Advanced Application Development

Via G. Reiss Romoli, 274 - 10148 - 'Turin - Italy

Phone: $+390112286115 \quad$ FAX: +390112286299

\begin{abstract}
TIL $\triangle B$ is using MPEG-4 technology to build applications to be used in real environments. One of these applications allows a teacher to send real-time lessons to this/ her students or to record them. The Tele-Lcarning System under development includes: a) on the teacher side: a recording workstation with two cameras, microphone, specific MPEG-4 software; $b$ ) an IP network or an MI'EG-2 TS satellite link; c) on the student side: a PC with special MPEG software, and a special board if receiving from satellite. This research focuses on the broadcast scenario where a satellite board is used in a PC. Thus, the work covers how to send the lesson even to a student that is not connecled to the intranet, using a satellite link, either over IP embedded in the MPEG-2 TS or directly over MI'EG-2 'IS. For the security part it may be necessary to have a low-band return channel implemented, for example, through a mobile phone. 'The satellite environment may reyuire the redesign of the User Interface and the retargeting of the elementary streams parameters in order to match specific requirements and features of the medium. At this point, new interaction criteria have been established from distribution of MPEG-4 media objects and MPEG-7 scene descriptions on network environments. Furthermore, context-awareness aspects are being added for providing personalization on the teaching-learning environment and MPEG-21 is being studied for applying to new multimedia requirements.
\end{abstract}


Paper 05 - Proceedings of International Conference (November, 2002)

CI.LI'2002 - XXVIII Conferencia Internacional di Ingeneria Informatica

Santos Jr., J.B. dos; Moreira, E. S.; Goularte, R.; Faria, G. B.; Guglielmo, M.; De Petris, G.: Describing a Scenario and Tochnologies for Building Context-Aware Interactive Enviromments: Towards to Definition of New Interaction Criteria. I'o appear in Proceedings of CLEI'2002 - XXVIII Conferencia Internacional di Ingeneria Informatica. Montevideo, Uruguay, November-2002.

\title{
Describing a Scenario and Technologies for Building Context-Aware Interactive Environments: Towards to Definition of New Interaction Criteria
}

\author{
Joào Benedito dos Santos Junior ${ }^{1}$ \\ Catholic University of Minas Gerais - I'LC Minas \\ Department of Computer Science \\ Poços de Caldias - MG - Brazil \\ Phone (voice) $:+55.353697 .3027 \quad$ FAX: +55353697.3001 \\ joaropucpcaldas.br \\ Edson dos Santos Moreira' ${ }^{2}$ Rudinei Goularte ${ }^{2}$, Gustavo Blengini Faria ${ }^{2}$ \\ University of Sào Paulo - LSP \\ Institute of Mathematics and Computing - ICMC \\ P.O.Box 668 - São Carlos - SP - Brazil \\ Phone (voice): $+55162739668 \quad$ FAX: +55162739751 \\ Mario Guglielmo 3 , Gianluca De Petris ${ }^{3}$ \\ [1] AB - Telecom Italia Lab \\ Multimedia Division - Advanced Application Development \\ Via Guglielmo Reiss Romoli, 274 - Turin - Italy \\ I'hone (voice): $+390112286115 \quad$ FAX: +390112286299
}

\begin{abstract}
As the interactive video technology has been disseminated, new forms of interaction became possible. A number of new techniques and standards have been produced in order to allow for the development of new applications; however, some potential new interaction forms are still unexplored. 'This paper describes a scenario for interactive applications, based on the emerging MPLG-4 and MPEG-7 standards, that uses the context-awareness concepts in order to provide the necessary support to the development of more interactive and useful systems. In this scenario, the environment may require the redesign of the user interface and the retargeting of the elementary streams parameters in order to makh specific requirements and features of the environment (applicition, media, network, terminal). At this point, new interaction criteria can be established from distribution of MPEG-4 media objects and MPEG7 scene descriptions on network environments. Context-awareness aspects are being added for providing personalization on the interactive environment.
\end{abstract}

Keywords: Human-computer Interaction; Human-environment Interaction; Lbiquitous Computing; Context-awareness; Distributed Interactive Applications; Multimedia Standards. 